\author{
UNIVERSIDADE DE SÃO PAULO \\ FACULDADE DE FILOSOFIA, LETRAS E CIÊNCIAS HUMANAS \\ DEPARTAMENTO DE ANTROPOLOGIA \\ PROGRAMA DE PÓS-GRADUAÇÃO EM ANTROPOLOGIA SOCIAL
}

DIEGO ROSA PEDROSO

O que faz um nome: etnografia dos Kubeo do alto Uaupés (AM)

Versão Corrigida

São Paulo

2019 


\author{
UNIVERSIDADE DE SÃO PAULO \\ FACULDADE DE FILOSOFIA, LETRAS E CIÊNCIAS HUMANAS \\ DEPARTAMENTO DE ANTROPOLOGIA \\ PROGRAMA DE PÓS-GRADUAÇÃO EM ANTROPOLOGIA SOCIAL
}

\title{
O que faz um nome: etnografia dos Kubeo do alto Uaupés (AM) \\ (Versão Corrigida)
}

\begin{abstract}
Diego Rosa Pedroso
Tese de Doutorado apresentada ao Programa de Pós-Graduação em Antropologia Social do Departamento de Antropologia da Faculdade de Filosofia, Letras e Ciências Humanas da Universidade de São Paulo, como parte dos requisitos para obtenção do título de Doutor em Antropologia Social.
\end{abstract}

Orientador: Prof. Dr. Renato Sztutman

São Paulo 
Autorizo a reprodução e divulgação total ou parcial deste trabalho, por qualquer meio convencional ou eletrônico, para fins de estudo e pesquisa, desde que citada a fonte.

Catalogação na Publicação Serviço de Biblioteca e Documentaçào

Faculdade de Filosofia, Letras e Ciências Humanas da Universidade de São Paulo

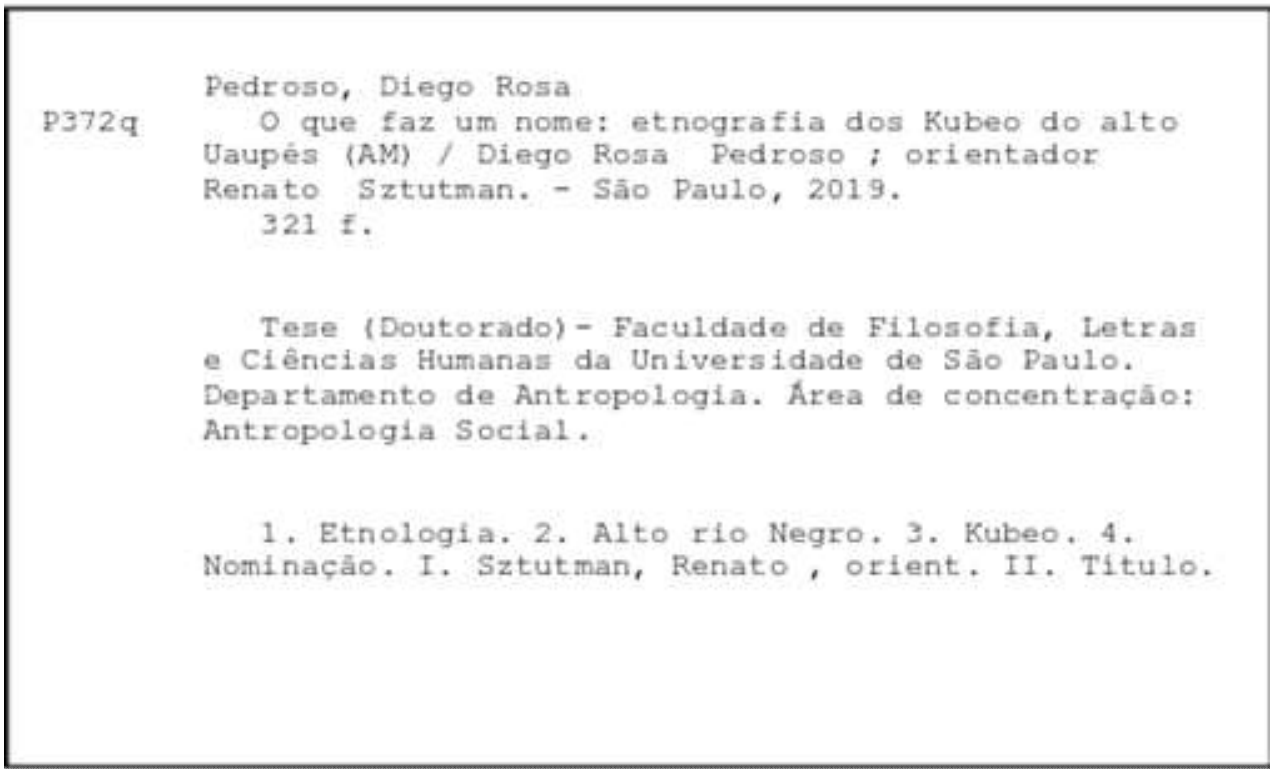




\section{ENTREGA DO EXEMPLAR CORRIGIDO DA DISSERTAÇÃO/TESE Termo de Ciência e Concordância do (a) orientador (a)}

Nome do (a) aluno (a): DiEgo ros A $P E D$ Roso

Data da defesa: $26,04,2019$

Nome do Prof. (a) orientador (a): RENA TO JZTUTMAN

Nos termos da legislação vigente, declaro ESTAR CIENTE do conteúdo deste EXEMPLAR CORRIGIDO elaborado em atenção às sugestões dos membros da comissão Julgadora na sessão de defesa do trabalho, manifestando-me plenamente favorável ao seu encaminhamento e publicação no Portal Digital de Teses da USP.

São Paulo, $19,06,2019$

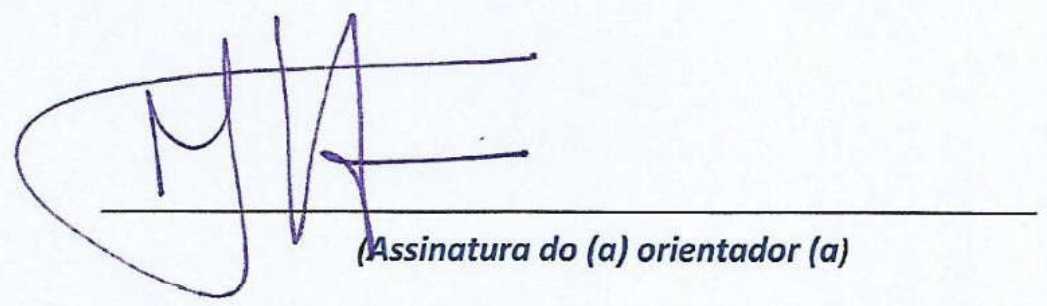


À família de Luiz Gilberto Gomes Rodrigues 


\section{RESUMO}

PEDROSO, Diego Rosa. O que faz um nome: etnografia dos Kubeo do alto Uaupés (AM). 2019. 321f. Tese (Doutorado em Antropologia Social) - Faculdade de Filosofia, Letras e Ciências Humanas, Universidade de São Paulo, São Paulo, 2019.

Esta pesquisa é uma etnografia dos Kubeo, mais especificamente, dos Yuremawa e Yúriwawa, grupos que habitam, respectivamente, as comunidades de Querari e Açaí no alto rio Uaupés, noroeste da Amazônia brasileira. Proponho uma descrição do regime de nominação kubeo, isto é, suas práticas e contextos de atribuição de nomes de pessoas, coletivos e lugares. A tese desenvolve a questão: o que é e o que pode fazer um nome?

Tomando o tema dos nomes como fio condutor, a etnografia atenta para o mundo vivido kubeo, suas descrições, seus idiomas, sem insistir em modelos e categorias tipológicas; pretendo, assim, num plano mais amplo, contribuir para uma apreensão mais adequada da criatividade e da vida social kubeo.

Palavras-chave: Rio Uaupés; Kubeo; Nome; Pessoa; Grupo; Lugar. 


\begin{abstract}
PEDROSO, Diego Rosa. What makes a name: Ethnography of the Kubeo in the upper Uaupés (AM). 2019. 321f. Tese (Doutorado em Antropologia Social) - Faculdade de Filosofia, Letras e Ciências Humanas, Universidade de São Paulo, São Paulo, 2019.

This is an ethnography of the Kubeo groups Yuremawa and Yúriwawa that inhabit, respectively, the communities of Querari and Açaí at the Uaupés river in the Northwest region of the Brazilian Amazon. I propose a description of the kubeo naming regime, that is, the practices and contexts of naming people, collectives, and places. The dissertation develops the questions: what is and what can make a name?

Taking the topic of names as a guiding thread, this ethnography stresses the kubeo living world, its descriptions and languages without aiming to create models or typological categories. In a broader perspective, therefore, I intent to contribute to a more adequate understanding of the kubeo creativity and social life.
\end{abstract}

Keywords: Uaupés river; Kubeo; Name; Person; Group; Place. 


\section{AGRADECIMENTOS}

Ao Conselho Nacional de Desenvolvimento Científico e Tecnológico (CNPq), pela bolsa de doutorado concedida.

À Fundação de Amparo à Pesquisa do Estado de São Paulo (FAPESP), pelo apoio com recursos para viagem de campo durante minha participação em dois projetos de auxílio à pesquisa.

Ao Instituto Socioambiental (ISA), pelo apoio logístico durante meus períodos de campo.

À FUNAI de São Gabriel da Cachoeira, na pessoa do então diretor regional Domingos Barreto.

À Federação das Organizações Indígenas do Rio Negro - FOIRN pelo apoio durante os períodos de campo.

A Rosilene Pereira e Maurício, pela amizade e hospitalidade em São Gabriel da Cachoeira.

A Vicenta e sua família, que tive o privilégio de conhecer em minhas passagens por Mitú, na Colômbia.

Aos amigos e interlocutores André Drago, Ana Yano, Larissa Barcellos, Emmanuel Richard, Patrícia Veiga, Raphael Rodrigues, Melissa Oliveria, Danilo Ramos, Renato Soares, Anggie Marcela López, Clarissa Maria, Angélica Maia, Fábio Marques, Fernando da Silva, Alexandre Cardoso e Rivelino Barreto.

A Duane Mota, pela amizade e auxílio na elaboração de desenho com representação de grafismo para meu trabalho.

A Igor Richwin, pelos mapas da região do alto Uaupés onde vivem os Kubeo.

A Thiago Chacon, pela amizade e confiança depositada ao me introduzir nas comunidades kubeo do alto Uaupés brasileiro, bem como ao estímulo e apoio constante.

Ao professor Geraldo Andrello, que sempre foi um interlocutor e importante incentivador de minha pesquisa no alto rio Negro.

Ao orientador Renato Sztutman, interlocutor desde meu mestrado, um agradecimento especial, pela orientação, amizade, pelas leituras sempre críticas e positivas e pelo constante estímulo intelectual. 
Aos Kubeo que me acompanharam durante toda a pesquisa, e graças aos quais esse trabalho foi possível, particularmente: Luiz Gilberto, Marci, Martins e Letícia. Ao Edson e Maria, Osvaldo e Marcela, Bernardo e Josefina, Amós, Gabriel Saldanha e toda sua família.

Aos Yuremawa e Yúriwawa que vivem em São Gabriel da Cachoeira: Manuel e toda sua família; Márcio Silva; a família Espitia: Maria Cristina, João, Pedro, Paulo, Jairo, Reinaldo, Simão e Josefina.

À minha família. 


\section{LISTA DE FIGURAS}

Figura 1: Mapa da região do alto rio Negro

Figura 2: Mapa de comunidades Kubeo no alto rio Uaupés com principais igarapés

Figura 3: Vista aérea de Querari, com destaque para o $2^{\circ} \mathrm{PEF}$

Figura 4: Coluna de antiga moradia kubeo no Yawakari Tawa

Figura 5: Vista de parte da comunidade de Açaí

Figura 6: Lista de divisões Yuremawa formulada por José Bernardo

Figura 7: Lista de divisões Yuremawa formulada por Graciliano Rodrigues

Figura 8: Lista de divisões Yuremawa enunciada por Henrique Rodrigues

Figura 9: Lista de divisões Yuremawa citada por Simão

Figura 10: Lista de divisões Yuremawa de Luiz Gilberto

Figura 11: Gráfico de casamentos kubeo

Figura 12: Divisões Betowa

Figura 13: Pintura corporal para proteção

Figura 14: Serra de Abuhuñami

Figura 15: Representação do mundo em camadas

Figura 16: Mapa como representação kubeo de usos e recursos da região

Figura 17: Maloca da comunidade de Açaí

Figura 18: Desenho dos bairros de Querari

Figura 19: Oficina de elaboração de etnomapas

Figura 20: Wakaipani, maloca ancestral kubeo

Figura 21: Marcas da surra no Marãkãriku durante o Jurupari

Figura 22: Mapa mental do trecho de Querari (Kubeo) até Taína (Kotiria)

\section{LISTA DE TABELAS}

Tabela 1: Povos indígenas do alto rio Negro

Tabela 2: Dados populacionais

Tabela 3: Imagens da hierarquia no Uaupés

Tabela 4: Casamentos proibidos

Tabela 5: Grupo das mulheres de Querari e Açaí

Tabela 6: Lista de clãs kubeo de Nimuendajú

Tabela 7: Lista de clãs kubeo de Goldman

Tabela 8: Lista de clãs kubeo de Bruzzi Alves da Silva 
Tabela 9: Equivalência entre nomes de grupos kubeo

Tabela 10: Pupui amiya Yuremawa masculinos

Tabela 11: Pupui amiya Yuremawa femininos

Tabela 12: Pupui amiya Yúriwawa masculinos

Tabela 13: Pupui amiya Yúriwawa femininos

Tabela 14: Apelidos de nomes de brancos kubeo

Tabela 15: Nomes de igarapés

\section{LISTA DE SIGLAS}

BEF - Batalhão Especial de Fronteira

CASAI - Casa do Índio

CEF - Companhia Especial de Fronteira

CEF - Comando Especial de Fronteira

CFRN - Comando de Fronteira Rio Negro

COMARA - Comissão de Aeroportos da Região Amazônica

CPF - Cadastro de Pessoas Físicas

DSEI/RN - Distrito Sanitário Especial Indígena do Rio Negro

FOIRN - Federação das Organizações Indígenas do Rio Negro

FUNAI - Fundação Nacional do Índio

IFAM - Instituto Federal do Amazonas

ISA - Instituto Socioambiental

MEC - Ministério da Educação

MinC - Ministério da Cultura

NEAI - Núcleo de Estudos da Amazônia Indígena

PDPI - Projeto Demonstrativo dos Povos Indígenas

PEF - Pelotão Especial de Fronteira

PRN - Programa Rio Negro

PGTA - Plano de Gestão Territorial e Ambiental

PNGATI - Política Nacional de Gestão Ambiental e Territorial em Terras Indígenas

$\mathrm{RG}$ - Registro Geral

SEMEC - Secretaria Municipal de Educação

SIGEAM - Sistema Integrado de Gestão Educacional do Amazonas

SIL - Summer Institute of Linguistics 
SPI - Serviço de Proteção ao Índio

TI - Terra Indígena

UEA - Universidade do Estado do Amazonas

UFAM - Universidade Federal do Amazonas 
PRIMEIRA PARTE - OS YÚRI PARÃMENA CHEGAM AO UAUPÉS

CAPÍTULO 1 - OS YÚRI PARÃMENA NO ALTO UAUPÉS. 43

Quem são os Kubeo?

Os Kubeo no alto rio Uaupés

CAPÍTULO 2 - EXISTEM GRUPOS NO ALTO UAUPÉS?

O modelo de Irving Goldman revisitado

Os Yúri Parãmena

As relações de parentesco contadas nas narrativas de origem

Nomes de grupos

SEGUNDA PARTE - A PESSOA E SEUS NOMES

CAPÍTLO 3 - PUPUI AMIYA COMO MANEJO DE UMÉ

O nascimento

A primeira menstruação

O Jurupari

A morte

CAPÍTULO 4 - PUPUI AMIYA: METAFÍSICA E ESQUECIMENTO 170

Pupui amiya e produção da pessoa

CAPÍTULO 5 - OS NOMES ESCRITOS: EQUÍVOCOS CONTROLADOS? .198

Os termos de parentesco

Escrevendo o pupui amiya

Recebendo nome de branco 
O yahui amiya kubeo

Nomes de animais

Origens dos yahui amiya

Manejando vitalidade: as brincadeiras em festas de caxiri

Quando a brincadeira vira zombaria

Os apelidos de nomes de brancos entre os Yúri Parãmena

TERCEIRA PARTE - OS NOMES NOS LUGARES.

260

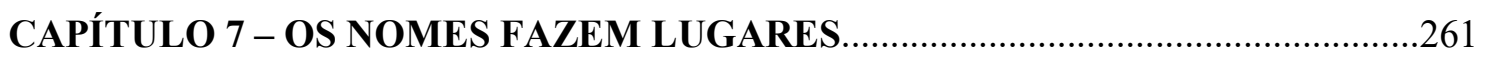

As categorias kubeo de espaço

Episódio da viagem ao Wakaipani

Produzir consenso com nomes no papel: os Yúri Parãmena fazem planos de gestão ambiental e territorial

CONSIDERAÇÕES FINAIS.

.308

REFERÊNCIAS 


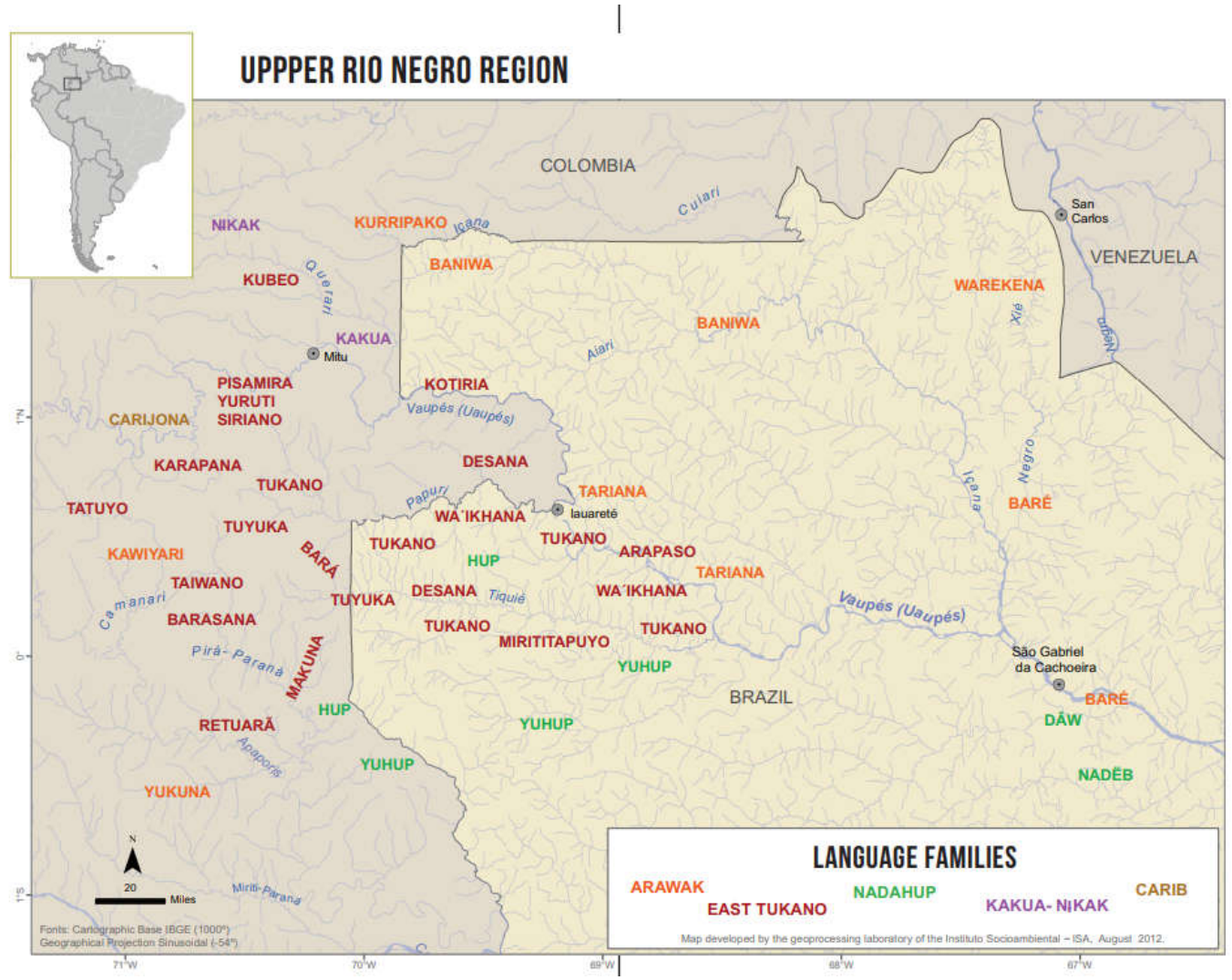

Figura 1: Mapa da região do alto rio Negro (fonte: EPPS \& STENZEL, 2013, p. 10-11) 


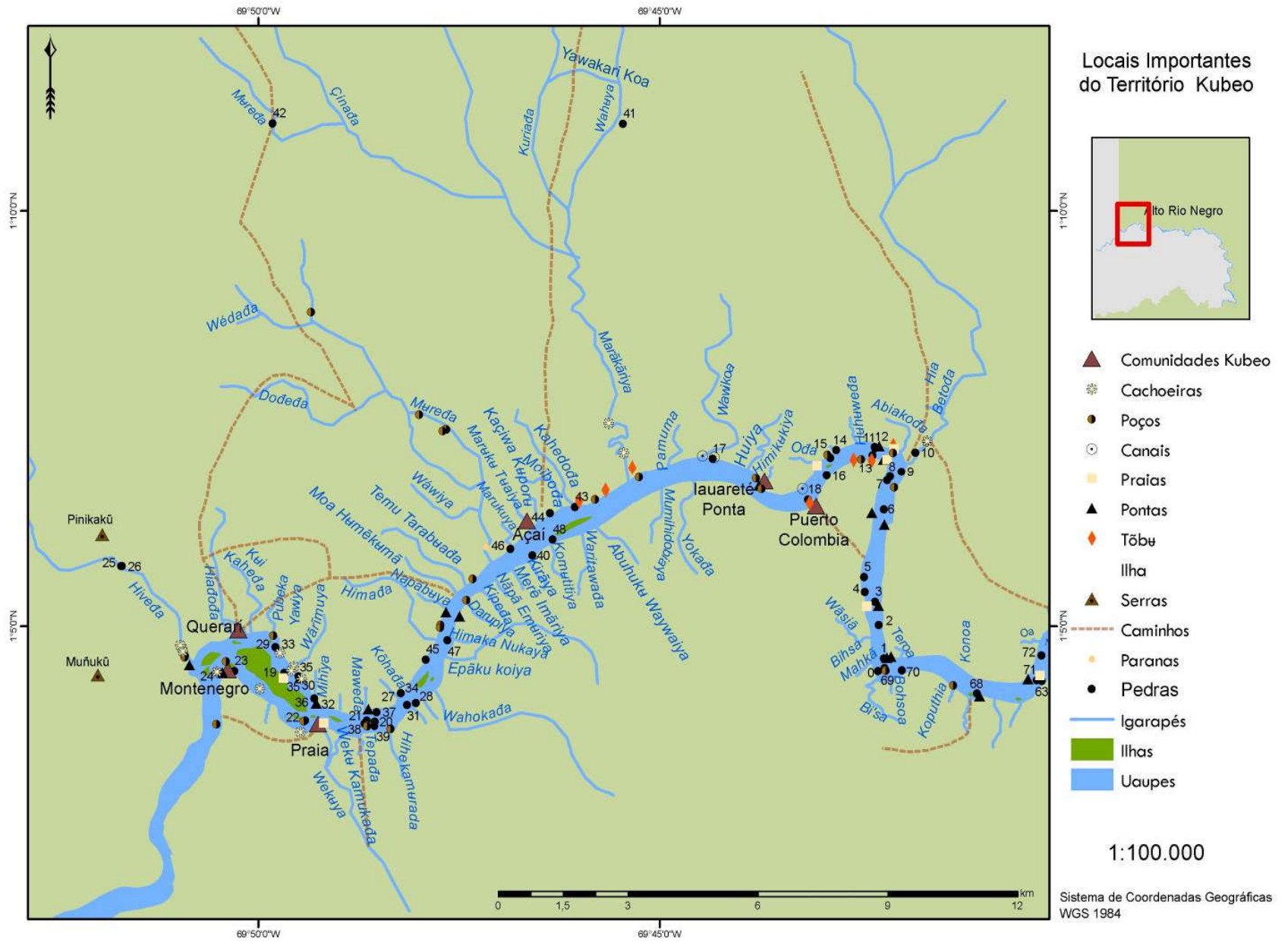

Figura 2: Mapa de comunidades Kubeo no alto rio Uaupés com principais igarapés (elaboração: Igor

Richwin, 2019) 


\section{INTRODUÇÃO}

De modo geral, creio que essa é uma velha lição da antropologia, que ainda deve ser repetida: contra as eventuais abstrações a que por vezes somos tentados, o remédio é uma dose maior de etnografia.

Márnio Teixeira-Pinto (2018)

Este trabalho é uma etnografia dos Kubeo, mais especificamente, dos Yuremawa e Yúriwawa que habitam o alto rio Uaupés, na fronteira do Brasil com a Colômbia, noroeste amazônico. Proponho uma descrição do regime de nominação, isto é, práticas e contextos de atribuição de nomes de pessoas, grupos, lugares. A questão que orienta e atravessa minha pesquisa pode ser formulada nestes termos: o que pode fazer um nome?

Quando nos defrontamos com o material etnográfico acerca dos nomes no noroeste amazônico notamos que há ainda poucos trabalhos que oferecem um tratamento sistemático do tema. Os dados, em sua maior parte, estão dispersos nas etnografias. O primeiro trabalho a lançar um olhar mais detido sobre esses dados foi escrito por Stephen Hugh-Jones (2002), a partir de material dos grupos Tukano orientais.

Segundo Stephen Hugh-Jones, o sistema de nomes e nominação no noroeste amazônico tem como centrais os nomes pessoais e os nomes de grupos e clãs exogâmicos (2002, p. 47). Para os grupos, o autor afirma que estão divididos em um ou mais “conjuntos de clãs hierarquizados, cujos ancestrais são os filhos da cobra ancestral original, classificados por sua ordem de nascimento. Cada clã tem um ou mais nomes sagrados" (2002, p. 48-49), os quais "encarnam a potência e a essência do clã" (p. 49) e cuja complexa elaboração "é um traço marcante da cultura tukano [...] e cercada de muito sigilo e de interpretações políticas e rivais" (ibidem).

No caso da pessoa, cada uma tem três tipos de nomes: nomes de espírito, apelidos e nomes de estrangeiro. Assim, “cada grupo exogâmico possui um conjunto particular de nomes de espírito específicos quanto ao gênero" (2002, p. 50). Uma criança, algum tempo depois de seu nascimento (ou no momento do nascimento, em alguns casos) recebe um nome pertencente a esse repertório e "que foi previamente portado por uma pessoa morta do mesmo grupo, da segunda geração ascendente, um pai do pai (FF) real ou classificatório para 
meninos e uma irmã do pai do pai (FFZ) para meninas" (2002, p. 50-51). Esse conjunto de nomes é restrito, o que fará com que dois ou mais indivíduos frequentemente tenham o mesmo nome.

Além do nome de espírito, as pessoas têm regularmente pelo menos um apelido, os quais podem ser de dois tipos: "em uma extremidade estão os nomes jocosos verdadeiros, a maioria dos quais se refere ao mundo dos mamíferos, pássaros e peixes [...]. Outros apelidos têm alguma referência direta ou oblíqua à vida, aos hábitos, à aparência física ou caráter do portador" (ibidem, p. 52). Na outra extremidade estão os nomes comuns "veneráveis, semisagrados, cujo conteúdo semântico é semelhante aos dos verdadeiros nomes jocosos dos quais, suspeito, eles podem derivar, mas que agora formam par com nomes de espírito e são transmitidos com eles" (ibid.).

Por fim, temos os nomes de estrangeiro, "a maioria nomes cristãos colombianos ou brasileiros que são, em geral, abreviados e modificados tanto de acordo com as demandas da fonologia das diferentes línguas tukano, quanto com o capricho individual” (ibid., p. 52-53). Eis, em linhas gerais, o sistema de nomes do noroeste amazônico tal como apresentado por Hugh-Jones.

Encontramos outro esforço de investigação acerca dos nomes na leitura que Pedro Rocha (2007) faz da literatura etnográfica sobre os Kotiria do rio Uaupés, trabalho centrado na análise do sistema de parentesco e na onomástica kotiria, entendendo que "os nomes cumprem um papel de proteção e de provimento de vida aos seus portadores, e os insere em uma cadeia hierárquica de papéis e em uma ordem social que surgiu junto com a humanidade, ou até mesmo antes" (ROCHA, 2007, p. 3).

Flora Cabalzar, por sua vez, dedicou sua pesquisa de doutorado aos Tuyuka de São Pedro, no Tiquié, com o propósito de fazer "uma etnografia das redes de circulação de saberes e de suas transformações", e analisar os "processos em curso de vivência e percepção da geração e transformação dos saberes considerados de maior valor (niromakañe)" e “compreender o modo como são percebidos os conhecedores (masirã), hoje dispersos entre o alto Tiquié e a cidade de São Gabriel da Cachoeira” (CABALZAR, 2010, p. 1). Dentre esses saberes inclui-se o conjunto dos nomes de cada grupo.

Mais recentemente, o antropólogo Geraldo Andrello (2016) reafirmou o interesse e possível rendimento para a etnologia do alto rio Negro de uma investigação centrada em nomes e nominação em artigo no qual "explora um aspecto marcante da vida social dos povos indígenas rionegrinos: a grande quantidade de categorias de que lançam mãos os atores locais, hoje e no passado, para designar grupos e subgrupos" e avança a hipótese "de que a dinâmica 
entre nomes e apelidos mais ou menos englobantes e as formas de tratamento que implicam são instrumentos fundamentais na conceituação de diferenças internas a esse grande conjunto multiétnico e multilinguístico" (ANDRELLO, 2016, p. 59). Diante de tal quadro de investigações, minha pesquisa pretende contribuir para um adensamento do debate ainda incipiente sobre nomes no alto rio Negro a partir de um retorno aos Kubeo, população indígena que desde as monografias de Irving Goldman $(1963 ; 2004)$ foi pouco revisitada pela etnologia.

Minha etnografia, portanto, toma como eixo condutor a análise dos nomes, particularmente nomes pessoais, mas também de lugares e coletivos. Tal eleição deve-se, em primeiro lugar, à uma intuição - assentada na leitura da literatura etnográfica regional e na interlocução em campo -, de que tal tema é chave que permite um entendimento mais apurado da vida social kubeo. Ao mesmo tempo, essa escolha, devo alertar o leitor, é também estratégica, isto é, por meio dela ofereço uma descrição mais ampla dos Kubeo no alto Uaupés brasileiro. Aqui, convém lembrar o tanto de aposta que há na escolha de um aspecto a ser perseguido, o qual não deve ser tomado como se fosse questão central para aqueles com quem se trabalha, a despeito de todo o interesse que possam ter no assunto. Tal orientação remete à crítica de Paul Veyne, lembrada por Marcio Goldman em seu estudo da política em Ilhéus, a saber, trata-se de evitar o que esse historiador francês

denunciou como o absurdo pressuposto do "monolitismo monoideísta" dos homens, sua inverossímil "monomania": como se cada grupo social, ou cada época histórica, pudesse se encontrar obcecado por uma questão "central" bruxaria, gado, vingança, parentesco, relações pessoais, honra, igualdade, dinheiro, religião, ou seja lá o que for (GOLDMAN, 2006a, p. 20).

A tese que apresento busca também observar outra orientação ainda de Márcio Goldman (2006a) de uma etnografia atenta ao vivido, com "carne e sangue", algo que algumas das monografias clássicas do noroeste amazônico, isto é, aquelas elaboradas na segunda metade do século XX, parecem não atentar, com suas análises tipológicas, preocupadas com a elaboração de modelos e categorias. Nesse sentido, aproximo-me da posição de Peter Gow (2001), segundo a qual a etnografia deve atentar para o "mundo vivido" nativo (lived world) ${ }^{1}$, suas descrições, seus idiomas e conceitos. Em se tratando de uma

\footnotetext{
${ }^{1}$ Pode-se encontrar alguns comentários sobre essa importante categoria analítica proposta por Peter Gow (2001) em Lima (2002), e Queiroz (2004). Esse último autor, por exemplo, nos diz: “Tal noção aponta para um projeto etnográfico voltado para elucidar uma situação vivida e percebida num determinado período de tempo, sobre o qual e somente ao qual é permitido ao etnógrafo debruçar o seu olhar" (2004, p. 4); mais adiante cita Gow: " $A$ lived world is necessarily someone's lived world, and the analytical concept focuses attention on the
} 
pesquisa que lidou com muitos interlocutores falantes de português ${ }^{2}$, foi preciso prestar atenção, seguindo uma lição de Beatriz Perrone-Moisés (2015), ao "português dos índios"3, isto é, a linguagem em português manejada pelos indígenas, seus esforços tradutórios, as formulações, termos e os mundos conceituais que tal vocabulário supõe e projeta. Segue, portanto, uma tentativa de descrever falas e práticas kubeo, atenta aos perigos da generalização (ABU-LUGHOD, 2018, p. 206-214), uma reflexão etnograficamente fundamentada sobre os nomes, uma tentativa de deixar "de lado especulações abstratas e

concreteness of that other person or of thoses other persons" (GOW, 2001, p. 26 apud QUEIROZ, 2004, p. 4, itálico meu).

${ }^{2}$ Sairá em breve uma publicação com dados detalhados sobre a situação sociolinguísta das comunidades kubeo do alto Uaupés (PEDROSO et ali, no prelo). Aqui, quero insistir na forte presença do português, falado por todos os Kubeo da região foco de minha pesquisa e ensinado como língua exclusiva a muitas crianças, sobretudo em Querari. Além disso, merece destaque a intensa circulação entre comunidade e cidade, sobretudo de professores que frequentam cursos de formação, licenciaturas indígenas e graduação. O ano de 2019 foi marcado pelo ingresso de dois jovens Kubeo na graduação da Unicamp e outro na UFSCar, por meio do vestibular indígena; movimento que, penso, deve se intensificar.

${ }^{3}$ A formulação de Beatriz Perrone-Moisés (2015), verdadeira lição sobre a condução da investição etnográfica, é a seguinte: “A tradição de desconsiderar as traduções propostas pelos índios na língua do antropólogo, diga-se de passagem, é antiga e parece obviamente mais um empecilho do que uma garantia de conhecimento. Com efeito, Goldman (1975), em seu livro dedicado aos Kwakiutl, aponta diversas traduções registradas por Boas que diferem daquelas propostas por James Hunt, o etnógrafo nativo, treinado por ele justamente para isso. E num livro que declara

start from the Boasian position that we should first know how the native thinks [...] Then, and later, we [as scientists] can say if we wish: This is how the culture and its institutions would appear in current theory (Goldman 1975:14),

graças ao cuidadoso trabalho de cotejo realizado por Goldman entre as notas originais de Hunt e os textos publicados por Boas, ficamos sabendo que Boas desconsidera traduções como 'tribe', propostas por seu assistente kwakiutl, porque não correspondiam ao que ele, Boas, seguindo a 'conventional sociological tradition', entendia pelo termo, e que o aplica a uma categoria nativa que significa 'fellow inhabitants of the houses', a qual, na verdade - e Boas o reconhece -, mais bem designaria 'village' (Goldman 1975:31). Ao longo do texto somos apresentados a várias 'retraduções' de Boas, todas produtoras de imbroglios analíticos, entre as quais uma chama especialmente a atenção, tendo em vista o tema deste ensaio. Trata-se da recorrente substituição por Boas, nas obras acerca dos Kwakiutl, do verbo 'dizer' pelo verbo 'cantar', este último empregado por Hunt para falar das performances de nobres em que se rememoravam histórias de famílias. Boas achou por bem fazer de cantos discursos. Perde-se aí algo fundamental.

Nesse sentido, o movimento empreendido aqui é o de se aproximar do "native thinks" partindo da premissa de que, ao cabo de um esforço contínuo de tradução, por sucessivas gerações de indígenas vivendo em território brasileiro, está na hora de levar a sério o 'português dos índios'. Não parece cabido supor que pessoas em contato com a língua portuguesa, muitas vezes diário ao longo de sua vida, algumas das quais nasceram ouvindo português, outras que viveram anos em cidades brasileiras, tenham menos proficiência na língua do antropólogo e/ou menor capacidade de tradução que um etnólogo com talento e disciplina para o aprendizado de línguas indígenas." (2015, p. 18-19). 
meramente formais, e indo ao encontro dos regimes simbólicos e os esquemas conceituais que podem nos fazer perceber o sentido de certas práticas" (TEIXEIRA-PINTO, 2018, p. 250).

Aqui, que o leitor não veja um elogio da empiria concomitante a um desinteresse pela formulação teórica. Em primeiro lugar, essas duas dimensões do trabalho investigativo não se separam, como já explicitou Irving Goldman: "Ethnography is itself sufficiently theoretical" (2004, p. 8). Minha crítica se dirige antes ao aferro a certas categorias e generalizações que muitas vezes pouco acrescentam ao entendimento do mundo vivido nativo. O que proponho ressoa certa observação de Teixeira-Pinto (2018), formulada a partir de lição extraída da leitura de um ensaio de Vernant. Assim, esse helenista francês, ao escrever sobre a noção de "alteridade" na Grécia clássica, diz:

Alteridade, noção vaga e excessivamente ampla, mas que não reputo anacrônica, na medida em que os gregos a conheceram e utilizaram. Assim é que Platão opõe a categoria do Mesmo à do Outro em geral, tò héteron. Não se falará, naturalmente, de alteridade pura e simples, antes distinguindo e definindo a cada oportunidade tipos precisos de alteridade (...) (VERNANT apud TEIXEIRA-PINTO, 2018, p. 249, itálico do autor).

Desse modo, o que segue é uma análise detida e detalhada dos nomes kubeo, ou seja, parafraseando Vernant, não se falará de nome puro e simples, antes distinguindo e definindo a cada oportunidade tipos precisos de nomes, o que eles fazem e as relações que supõem ou implicam.

Tal postura significa também reconhecer as diferenças pessoais, a criatividade de meus interlocutores, isto é, não se falará em "Kubeo" ideal, ou em "pensamento kubeo" de modo genérico e monolítico; não se pretende buscar um modelo geral. Trata-se antes de reconhecer que as práticas e as formulações que apresento são feitas por certos interlocutores, em determinados contextos; isso nos ajuda, penso eu, a evitar muitas imprecisões etnográficas, ainda que, como é sabido, seja problemático distinguir entre pessoal e coletivo ${ }^{4}$.

Como a literatura etnológica regional tem mostrado, o alto rio Negro é uma região onde a discordância e o conflito têm lugar central, e buscar um modo de traduzir tal

\footnotetext{
${ }^{4}$ Lembro aqui um trecho de entrevista de Marcio Goldman, onde ele conta o seguinte episódio: "Há algum tempo convidei um dos meus amigos de Ilhéus, Jaco Galdino (que na verdade é de Caravelas, no extremo sul baiano, mas morou por muito tempo em Ilhéus antes de voltar, há pouco, para Caravelas), para falar em um dos nossos encontros das sextas na Quinta. Depois da apresentação, alguém perguntou a ele se o que ele estava dizendo eram ideias compartilhadas por todos os membros do movimento cultural de Caravelas ou se eram ideias dele. A resposta foi interessante e profunda. Primeiro, Jaco disse que 'claro que essas ideias são minhas, sou eu que estou falando'. Depois pensou um pouco e completou: 'não, na verdade acho que de algum modo são ideias de todos porque a gente conversa muito sobre isso'. Em toda parte as pessoas obviamente concordam e discordam, mas concordância ou discordância já são relações que devem fazer parte da etnografia" (GARCIA NOGUEIRA \& FERREIRA PIRES, 2012, p. 103-104, itálico meu).
} 
característica na escrita etnográfica, explicitando as controvérsias, não "purificando" ou "positivando" os dados, parece-me um desafio de todo aquele que almeja uma apreensão mais profunda da vida social rionegrina. Desse modo, a pesquisa não pretende apresentar uma teoria ou filosofia kubeo do nome, mas mostrar que eles têm entendimentos diversos e muitas vezes conflitantes sobre o que é e o que faz um nome, e somente a partir da consideração desses diversos entendimentos podemos divisar alguma compreensão da onomástica Yuremawa e Yúriwawa.

Irving Goldman, em sua primeira monografia sobre os Kubeo (1963), escreveu que falava a partir do ponto de vista Bahúkiwa, e depois, no segundo trabalho, da perspectiva Hehénewa $(2004)^{5}$, ainda que ressaltando o caráter compósito de tais perspectivas. Penso que é preciso ir mais longe, e explicitar que se fala do ponto de vista desta e daquela família, desta e daquela pessoa, num movimento análogo ao descrito por Lévi-Strauss (1962) ao falar das passagens da universalização a particularização, e vice-versa. Assim, durante o trabalho de campo, embora tentasse circular por toda a comunidade, tive alguns interlocutores privilegiados, que me ensinaram sobre práticas e conhecimentos dos Yuremawa e Yúriwawa, e forneceram sua maneira própria de entender tais práticas e conhecimentos. Sem querer ser injusto, destaco alguns desses interlocutores: Luiz Gilberto $^{6}$ e sua família: Marci (esposa), Letícia (mãe), Martins Gomes (pai); Geraldo Edson Farnela e José Bernardo ${ }^{7}$.

Luiz Gilberto é Yuremawa, nasceu em 1982, em Açaí, e ainda criança foi morar em Mitú, onde fez a maior parte de seus estudos. Já adolescente, no final dos anos 1990, por conta do acirramento do conflito entre FARC e exército colombiano, voltou ao Brasil, morando inicialmente em Açaí, e depois em Querari, onde vive até hoje, casado com Marci, Yúriwako de Açaí, também ela importante interlocutora em campo, com elaboradas

\footnotetext{
${ }^{5}$ Bahúkiwa e Hehénewa, como será desenvolvido em outros momentos, são os nomes de dois grupos, ou clãs, para usar a terminologia do autor, estudados por Irving Goldman; o primeiro grupo foi objeto de seu primeiro livro (1963); o segundo resultou no livro (2004) postumamente publicado por Peter J. Wilson, amigo de Goldman.

${ }^{6}$ Destaco também que luiz Gilberto esteve por um mês na Universidade de Brasília no ano de 2017, a convite do linguista Thiago Chacon, para avançar estudos de língua kubeo e também como palestrante e debatedor em eventos com alunos da universidade. Em 2018 veio a São Paulo como palestrante no evento "Lições de Fala", promovido pelo CEstA, o Projeto Fapesp "Diplomacias Cosmopolíticas nas Terras Baixas Sulamericanas” e a CAPES.

${ }^{7}$ Apesar da expressa decisão de citar meus interlocutores, o etnólogo em campo muitas vezes se vê em situações delicadas, no meio de conflitos ou disputas familiares e comunitárias. Para evitar uma exposição possivelmente negativa de pessoas e situações, sempre que me referir a um contexto ou fala que julgue delicada e digna de discrição evitarei citar os nomes, usando antes designações gerais como "um Yuremawa", "um Yúriwawa" etc.
} 
observações, e sempre manifestando apreensão com o modo como as mulheres mais jovens observam certas práticas e cuidados indicados pelos velhos. Luiz Gilberto é filho de Letícia Rodrigues, Yuriwakó, senhora com vasto conhecimento, falante de muitas línguas, filha de antigo morador de Açaí, Marcelino Rodrigues. Geraldo Edson é Yuremawa também, nasceu em 1980 na antiga Pacú-Cachoeira ${ }^{8}$, onde viveu parte de sua vida. Com a mudança das famílias para Querari, após a instalação do 2 Pelotão Especial de Fronteira ( $2^{\circ} \mathrm{PEF}$ ) no final dos anos 1980, ele e seus pais foram das últimas pessoas a deixar Pacú-Cachoeira. Vive atualmente em Querari, casado com Maria, Kotiria de Jutica. José Bernardo, Yúriwawa, nasceu em 1952, em antiga moradia próxima ao igarapé Muređa, localizada em lugar conhecido como Oribt. Ao longo da vida, conheceu muitos lugares, viajando sobretudo a trabalho com seu pai pelos rios Uaupés, Aiary, Pirá-Paraná. Mora em Açaí, com Josefina, Tarabuwakó de Santa Maria, no rio Querari.

Além dos laços de amizade, compartilhei muitos interesses em comum com tais pessoas, sempre muito generosas em me oferecer explicações sobre ideias e práticas, bem como em me dirigir perguntas sobre os brancos, relacionadas a questões que iam desde temas políticos e de história do país, a questões de parentesco e práticas de casamento 9 .

Destacar essa interlocução, e o aspecto colaborativo da etnografia que construí é importante sobretudo no contexto do alto rio Negro, marcado pelo trabalho colaborativo, ainda que em certa literatura pretérita tal colaboração seja timidamente expressa em notas de página ou nos capítulos introdutórios, como vemos, para citar alguns casos, na relação fundamental e pouco explicitada entre Stradelli e seu companheiro indígena Maximiniano José Roberto (CASCUDO, 2001), ou na introdução de Reichel-Dolmatoff a sua etnografia sobre os Desana (1971), toda ela escrita a partir de conversas tidas nos arredores da Universidad de los Andes, em Bogotá, com um indígena desana, Antonio Guzmán. Com efeito, diz Reichel-Dolmatoff:

The present volume is the result of an ethnographic study carried out under rather unusual conditions. In fact, the chapters that follow and contain a description of the religious symbolism of a small group of tropical rain forest Indians are based upon conversations held with a single informant

\footnotetext{
${ }^{8}$ Antiga comunidade yuremawa, próxima a atual comunidade de Querari, no rio Uaupés, como será detalhado mais adiante.

${ }^{9}$ Penso que a relação que estabeleci com esses interlocutores remete à aspectos daquilo que Cayón (2018) chama de "etnografia compartida", e que me parece um caminho bastante promissor, e talvez o mais adequado, para a prática etnográfica de modo geral.
} 
and were written before I had personally visited the tribal territory that is his original home (p. xi, itálico meu).

Berta Ribeiro, em sua etnografia também sobre os Desana, destaca no capítulo introdutório a importância e lugar de seus interlocutores para a construção do trabalho. Assim, a antropóloga nos diz:

Contudo, este livro deve mais a Tolamãn Kenhíri. Talvez devesse ser assinado também por ele. Na verdade, todas as informações de campo - ou quase todas - são de sua autoria. Desde 1978, quando o encontrei na Missão Salesiana Pari-Cachoeira e lhe falei do meu projeto, nada mais fiz do que escrever, em forma possivel de leitura, os dados que me ia passando (RIBEIRO, 1995, p. 14-15, itálico meu).

Irving Goldman, na monografia que estava preparando sobre os Hehénewa, também insiste no papel da interlocução:

Unlike my first work, is in the "participant-observer" mode, this book relies largely upon older methods of formal interrogation. Interviews were spoken in Spanish and mediated by translators into and from Cubean. The informants, selected elders whom I had known from my first trip, were proficient enough in Spanish to correct a rendition. The translators were younger men, graduates of the Catholic mission school at Mitú, who were equally proficient in Spanish and Cubean. One was Hehénewa and the other Bahúkiwa, and each was either a son or a nephew of the informants. The informants were, of course, "acculturated natives" [...]. They are also true ethnic Pamí'wa (2004, p. 4-5, itálico meu).

Algumas páginas adiante, Goldman diz:

In 1979, I started, in imitation of Franz Boas's most prodigious field correspondences with George Hunt, a modest exchange of letters of my own with the two Cubeans who had been my interpreters and intellectual guides on the Cuduiarí. The correspondence, consisting of five substantial questionnaires, ended in 1981. Both correspondents worked as a field anthropologist would, by interviewing elders in their own language. My questions were relatively open ended but were directed, nevertheless, to specifics. [...] Portions of several chapters in the book are, in fact, direct translations of their observations and I identify them as such. Since they represent an indigenous contribution, I have not enveloped them in my own style of analysis. They are set off in the text as quotations (2004, p. 6-7, itálico meu).

Goldman destaca o trabalho colaborativo, "This book is, therefore, a product of collaboration at various intellectual levels, which is, of course, the standard methodology of 
ethnography" (2004, p. 7), e é bastante otimista em relação a ele, "we are in the presence now of genuine collaboration", e sentencia "this is a new and exciting development, for it portends an increasing shift from academic to native versions of ethnography" (ibid., p. 7).

Mais recentemente, vemos tal dimensão constituinte do trabalho etnográfico rio negrino levada adiante em investigações como a conduzida por Raphael Rodrigues (2012) em colaboração com Maximiliano Menezes, com o propósito de produzir um registro escrito da trajetória e posicionamento hierárquico dos Inapé-porã, um dos clãs tukano. No trabalho conjunto de Cayón, Arhem, Gladys Angulo e Maximiliano Garcia (2004) sobre os Makuna ${ }^{10}$; e, mais recente, a publicação de artigo em co-autoria de Andrello e Arlindo Maia (2018), resultado de um longo processo de registro e reflexão sobre os nomes de grupos e subgrupos Tukano.

Neste breve apanhado acerca do trabalho colaborativo no alto rio Negro, não poderia deixar de mencionar as pesquisas conduzidas pelos próprios indígenas da região, então reunidos no Núcleo de Estudos da Amazônia Indígena - NEAI ${ }^{11}$, como, para citar alguns, João Paulo Barreto (2013), Dagoberto Azevedo (2013), Gabriel Maia (2016), Jaime Diakara (2018) e Rivelino Barreto (2012). Desses trabalhos, Rivelino Barreto tem importantes formulações sobre o tema dos nomes, as quais analisarei no momento oportuno. Meu trabalho, em suma, é devedor das lições dessa tradição colaborativa que paulatinamente se cristaliza no alto rio Negro.

Numa escala mais ampla, essa pesquisa busca levar adiante o trabalho de crítica etnográfica dos modelos elaborados para o alto rio Negro, os quais operam muitas vezes com tipologias e categorias fixas que têm se mostrado de pouco rendimento explicativo e analítico. Andrello oferece uma precisa formulação dessa tarefa:

Tais fatos são, a meu ver, suficientes para ponderar em que medida os traços via de regra acionados para produzir uma imagem-tipo dessas sociedades -

\footnotetext{
${ }^{10}$ Pode-se encontrar comentários sobre o projeto colaborativo que resultou neste livro, bem como reflexões sobre o que o autor chama de "etnografia compartida", em Cayón (2018).

${ }^{11}$ O Núcleo de Estudos da Amazônia Indígena (NEAI) é um grupo de pesquisa vinculado ao Programa de PósGraduação em Antropologia Social (PPGAS) e ao Departamento de Antropologia da Universidade Federal do Amazonas (UFAM).
} 
patrilinearidade associada à exogamia e hierarquia clânicas - não seriam efeitos de um certo estilo descritivo adotado pela etnografia regional desde seu início, e em alguma medida tomado como não problemático em trabalhos mais recentes (2013, p. 2-3).

Trata-se, portanto, de levar adiante um esforço para apreender a vida social indígena, sempre complexa, explicitando os conhecimentos fragmentários, compartilhados por certo número de pessoas, os desencontros nas formulações e pensamentos, e os diferentes modos de formular certas práticas. Nessa empresa, não suponho uma comensurabilidade entre a complexidade da vida social e a descrição, risco já advertido por Marilyn Strathern (2006, p. 29 e ss.), mas busco antes colocar em xeque a própria linguagem analítica da antropologia rionegrina.

As categorias de clã, sib, fratria, grupo exogâmico e hierarquia receberam diversas formulações no corpus etnológico regional ${ }^{12}$. O historiador da filosofia Gerard Lebrun, num ensaio sobre o termo "poder", e citando Nietzsche, diz que as palavras abstratas "são como alforzes, nas quais as épocas e as filosofias teriam acumulado as coisas mais heteróclitas. E assim a palavra acaba tornando-se um tal entrecruzamento de 'marcas' que embaralha todas as pistas" (1981, p. 8). Penso que tal observação é adequada ao complexo de categorias abstratas formuladas e reformuladas ao longo dos mais de 50 anos de etnologia dos povos do noroeste amazônico. Sendo assim, cabe ao pesquisador duas orientações: primeiro, um cuidado de genealogista ao empregar os termos, distinguindo suas várias camadas semânticas; segundo e já explicitado, atenção ao "português dos índios” (PERRONE-MOISÉS, 2015), suas traduções, buscando distinguir os pressupostos e implicações que tais usos idiomáticos indicam.

Atento a essa orientação, adianto ao leitor que a tese fará uso constante dos termos "grupo" e "subgrupo" para referir-se aos arranjos sociais de modo geral, explicitando sempre as diferentes escalas nas quais coletividades são elicitadas (WAGNER, 2010, p. 247). Embora não satisfatório, ainda não dispomos de um vocabulário analítico adequado, quadro que aponta para uma revolução, dado a cristalização recente sobretudo de investimentos etnográficos e teóricos por indígenas-antropólogos rionegrinos, como já destacado.

Por fim, se começo a apresentação dessa pesquisa formulando o problema e explicitando minha posição, cabe citar outro cuidado que busco observar, a saber, evito sempre que possível certo uso desagradável (e tão comum na escrita antropológica) das aspas,

\footnotetext{
${ }^{12}$ Para uma exposição detalhada acerca dos modelos e categorias já elaborados para os povos do alto rio Negro, ver os trabalhos de Cabalzar (2009), Pedroso (2013).
} 
esse signo de pontuação que na intenção positiva de suspender o uso corrente ou tradicional de determinada categoria, termina quase sempre por manter o pensamento preso à essas mesmas categorias das quais pretendia livrar-se; nesse aspecto, estou de acordo com Agamben, quando diz que as aspas "representam os muros - finos, mas intransponíveis - da nossa prisão na palavra. No círculo que as aspas fecham à volta do vocábulo permaneceu fechado também o falante" (AGAMBEN, 2012, p. 100) ${ }^{13}$. Aspas serão usadas par indicar citação de fala dos meus interlocutores ou termos referenciados na literatura etnológica regional. Passemos a uma contextualização mais precisa da região de minha pesquisa, dos percursos da mesma e dos Kubeo Yuremawa e Yúriwawa.

\section{Situando o campo}

Os Kubeo estão localizados na região conhecida na literatura etnológica como noroeste amazônico. Para entender isso, lembremos que, com a publicação do Handbook of South American Indians entre os anos de 1946 e 1950, Steward propôs, com o objetivo de organizar a diversidade de povos e culturas do continente sul-americano, um modelo baseado em quatro grandes tipos hierarquizados em função de seus respectivos níveis de complexidade. A essa tipologia corresponderia uma determinada distribuição geográfica. Assim, teríamos: a) os povos marginais; b) as tribos da floresta tropical; c) os povos da região circuncaribenha; d) os povos dos Andes Centrais (STEWARD, 1949).

Dentro dessa tipologia, a região do noroeste amazônico insere-se na área designada como floresta tropical, ocupada por grupos horticultores de "estrutura produtiva mais eficiente e tecnologicamente mais avançados [...] cujas unidades, maiores, mais densas e estáveis, conquanto ainda internamente dominadas por distinção de parentesco, sexo e idade, haviam infundido, por recurso à ficção de uma descendência comum, grupos antes irrelatos, dotando-se de uma constituição comunitária que se estendia para além do parentesco prosaico e no qual o chefe e o xamã podiam dar-se as mãos e exercer controles sociopoliticos mais convencionais" (DRAGO, 2012, p. 16, itálico do autor). Essa subárea será caracterizada e delimitada por Goldman (1948) em artigo para o terceiro volume do Handbook. Vejamos.

Goldman circunscreve por meio de referentes hidrográficos o noroeste amazônico como subárea da floresta tropical, considerada uma "província cultural" (1948, p. 763-64): ao norte, limita-se pelo rio Guaviare; a leste pelos rios Negro e seu afluente Guainia; ao sul pelo

\footnotetext{
${ }^{13}$ Agamben é ainda mais duro com o uso irresponsável de aspas nos escritos, afirmando: "uma humanidade que pudesse falar somente entre aspas seria uma humanidade infeliz, que teria perdido, à força do pensar, a capacidade de levar a cumprimento o pensamento" (AGAMBEN, 2012, p. 100). Eis aí algo que muitos antropólogos, tão íntimos das aspas, deveriam considerar.
} 
rio Caquetá-Japurá; e a oeste pelos Andes (1948, p. 763-64). Essa região é habitada por diferentes grupos étnicos das famílias linguísticas Tukano Oriental, Arawak e Makú ${ }^{14}$. Os “traços” característicos dessa área cultural seriam:

Primary emphasis upon bitter manioc cultivation and fishing, with hunting of secondary importance; the use of large multifamily houses, each constituting a local kinship group, rather than villages; a complex of men's rites associated with an ancestor cult, inadequately referred to in the literature as yurupari; the existence of patrilineal sibs; painted bark-cloth masks, unevenly distributed in the area; frequent and prolonged chichi drinking, with intoxication common; chewing of powdered coca mixed with leaf ash and use of vision-inducing lianas; shamanism associated with the jaguar; and striking emphasis upon sorcery. Tribal organization is either weak or absent, with authority vested in the leader of the sib or local kin group. Cannibalism has been attributed to most of the tribes in the area (ibid., p. 763-64).

Além de Goldman, outras gerações de pesquisadores que se dirigiram à região na segunda metade do século XX insistiram numa delimitação regional e cultural, evocando a ideia de uma unidade social mais vasta. Assim, Stephen Hugh-Jones, retomando a noção de "sistema regional aberto" (“an open-ended regional system”) apresentado por Christine HughJones (1979), afirmará

I am convinced that a proper understanding of the Indian societies of Northwest Amazonia will only come when the different socio-linguistic groups or "tribes" are seen as forming an open-ended regional system that spreads across cultural and linguistic boundaries and when their cultural differences are seen as variations on a common theme (1979, p. 241, itálico meu).

Na década de 1990, muito mais tarde, portanto, Berta Ribeiro, a partir da constatação de semelhanças em termos de estrutura social e cultura, afirma acerca da "área cultural do Alto Rio Negro" que "o sistema de troca de bens e a especialização artesanal funcionam como mecanismos de homogeneização cultural e criação de laços de dependência recíproca" (RIBEIRO apud LASMAR, 2005, p. 27, itálico meu). Muitos outros etnólogos falam em um vasto "sistema social formado por vários grupos lingüísticos que, interseccionando-se,

\footnotetext{
${ }^{14}$ Essa é a categoria usada por Goldman e alguns outros antropólogos citados. Recentemente, ela tem sido alvo de uma reavaliação crítica por etnólogos, linguístas e pelos próprios povos que estariam nela incluídos, como os Hupd'äh e Yuhupdeh. Para uma exposição sobre os diversos sentidos desse termo, veja Lolli (2016) e Ramos (2014).
} 
partilham uma cultura bastante homogênea em vários aspectos" (CABALZAR, 2009, p. 37, itálico meu). Com efeito, esses autores têm mostrado a importância de uma perspectiva regional, visto que as "sociedades indígenas do Noroeste [Amazônico] são interligadas por uma rede de vínculos sociais, comerciais, políticos e religiosos que desafia qualquer tentativa de definir sociedades individuais como entidades distintas e autônomas. [...] o que tem sido descrito como um sistema 'aberto' e 'fluido' de interdependência regional' (WRIGHT, 1992, p. 263, itálico meu).

Aqui, gostaria de chamar a atenção para um aspecto dessa insistência na ideia de "sistema social regional". Com efeito, o alto rio Negro constitui um vasto mosaico de povos indígenas, com distintas línguas, práticas sociais e rituais, e sobretudo distintas narrativas de origem do mundo e da humanidade, mas ao mesmo tempo com muitos vínculos "sociais, comerciais, políticos e religiosos" (ibid.), e tradições narrativas compartilhadas. Contudo, é preciso lembrar a lição de Marilyn Strathern quando nos adverte para não tomar por objeto o que seria método (STRATHERN, 2006), isto é, parece-me que pensar o alto rio Negro como um sistema social aberto seria antes uma estratégia metodológica. É preciso manter-se vigilante para não tomar certas ideias e práticas como traços gerais do "sistema social regional", não subsumir o mosaico de ideias e práticas de povos Tukano, Arawak, Naduhup em determinadas categorias e definições. É preciso, em suma, evitar essa naturalização e simplificação tendenciosa da realidade etnográfica da região. Avancemos.

Entre os anos de 1922 e 1927 o etnólogo Curt Nimuendajú (1982[1927]) realizou, a pedido do Serviço de Proteção aos Índios/SPI, uma expedição de reconhecimento pela região do noroeste amazônico, mais especificamente, pelos rios Içana, Ayari e Uaupés, se limitando, contudo, a região brasileira do Amazonas e Acre. No relatório de Nimuendajú, além da descrição propriamente dita da viagem, encontramos dados estatísticos, linguísticos e sobre a situação dos indígenas diante do Estado brasileiro. É dentro desse quadro de informações que Nimuendajú, recuperando algumas formulações de Koch-Grünberg, apresenta uma "teoria dos estratos de cultura"; trata-se, veremos, de uma teoria acerca da formação e povoamento da região do noroeste amazônico.

Segundo Nimuendajú, é possível distinguir nesta região três camadas de "civilização indígenas" (1982[1927], p. 168), correspondendo cada uma a determinadas famílias linguísticas e representando três fases da história desta região (ibid., p. 168-169). A primeira camada diria respeito a uma população "extremamente rudimentar, desconhecendo a princípio a cerâmica, a arte têxtil, a navegação, a lavoura e as construções permanentes, levando uma vida errante pelos centros da mata" (1982[1927], p. 169). A essa população 
primeva Nimuendajú identifica como atuais representantes os ditos povos Makú. O segundo estrato, ao contrário do primeiro, seria formado "de tribus portadoras de uma das culturas mais adeantadas desenvolvidas por índios da região da mata tropical” (1982[1927], p. 169). Essa população se caracterizaria pelo

alto desenvolvimento da arte cerâmica, da lavoura, especialmente da mandioca, e da architectura das malocas, consequências estas de uma vida sedentária, pelos usos das ubás, das carauatánas, dos escudos e das redes de fibras de tucum [...] eram divididas em clans exogamicos com sucessão em lina paterna, professam o culto do Kaái-Yurupari [...] (ibidem).

Essas tribos chegaram à região do rio Negro por ondas migratórias vindas sucessivamente em sentidos diversos. A primeira onda, vinda do norte, era formada por tribos Arawak; a segunda, vinda do oeste, era formada por tribos da família linguística Tukano Oriental. Nimuendajú também explicita uma segunda onda migratória dos Arawak para o rio Uaupés já em tempos "relativamente modernos" (ibid., p. 170): a invasão dos Tariana. Segundo o etnólogo, as tribos da família tukano e os Tariana exerceriam forte influência sobre a cultura dos ditos Makú da bacia do Uaupés. Por fim, a terceira camada de cultura é "um produto hybrido, formado pelo contacto da cultura do segundo estrato com a civilidade europeia desde o século XVIII para cá” (ibid., p. 171). Essa camada, portanto, teria adotado certos traços dos "civilizados", como as roupas, as ferramentas, as armas e o uso da língua geral; ao mesmo tempo teriam conservado traços próprios das culturas locais, como o culto koai-Yurupari, os dabucuris e numerosas pequenas indústrias caseiras (ibidem). Dito isso, passemos ao contexto regional atual.

Como vimos, a região é caracterizada por um grande conjunto multiétnico e multilinguístico, apontada por Goldman como cosmopolita,

In general the region of the Vaupés, the only part of the Northwest Amazon that I can speak of from personal knowledge, exhibits a high degree of cultural cosmopolitanism. Many Indians are multilingual because of the frequency of intermarriage with other linguistic groups and the love of the Indians for travel and intertribal trade (1963, p. 15).

O alto rio Negro é habitado atualmente por cerca de vinte e dois grupos linguísticos das famílias Tukano Oriental, Arawak e Naduhup (número para população no Brasil; vinte e 
sete se se considera os grupos na Colômbia). Segundo dados disponibilizados pelo Instituto Socioambiental - ISA ${ }^{15}$, temos a seguinte configuração:

\section{Etnias do Rio Uaupés}

Arapaso, Bará, Barasana, Desana, Karapanã, Kubeo, Makuna, Mirity-tapuya, Pira-tapuya, Siriano, Tariana, Tukano, Tuyuca, Kotiria, Tatuyo, Taiwano, Yuruti (as três últimas habitam só na Colômbia)

\section{Etnias do Rio Içana}

Baniwa e Coripaco

\section{Etnias Naduhup}

Hupda, Yuhupde, Dow, Nadöb, Kakwa, Nukak (as duas últimas habitam só na Colômbia)

\section{Etnias do Rio Xié}

Baré e Warekena

Tabela 1: povos indígenas do alto rio Negro.

Nesse contexto regional e sociocultural inserem-se os Kubeo Yuremawa e Yúriwawa. Passemos a eles.

\section{As comunidades kubeo do alto Uaupés}

Os Kubeo estão distribuídos em comunidades ao longo dos rios Uaupés, Querari e Cuduiarí, sendo esses dois últimos completamente em território colombiano. São duas comunidades kubeo do lado brasileiro e mais um sítio.

Yauaretê-Ponta, o primeiro assentamento kubeo subindo o Uaupés, foi uma comunidade habitada pelos Betowa que, segundo relatos de antigos moradores, contou com mais de vinte famílias nas décadas de 1980 e 1990, mas depois sofreu um esvaziamento progressivo, com parte dos moradores indo para as comunidades de Querari e PuertoColombia, e a maior parte para a cidade de São Gabriel da Cachoeira. Em minha última viagem a campo, em 2017, viviam nesse lugar duas pessoas apenas: uma mãe e seu filho.

\footnotetext{
${ }^{15} \mathrm{O}$ site do ISA possui um acervo de informações atualizadas sobre os povos do alto rio negro. Tais informações podem ser consultadas em: https://pib.socioambiental.org/pt/Povo:Etnias do Rio Negro
} 
Ainda há casas que são usadas por alguns antigos moradores temporariamente, para trabalho na roça, pesca ou simplesmente, como faz Abelardo, atual morador de Querari e ex-morador de Yauaretê-Ponta, para descansar. É considerada, portanto, um sítio.

Na comunidade de Açaí, logo acima de Yauaretê-Ponta, vivem os Kubeo Yúriwawa. Em conversas com alguns velhos moradores de Açaí, soube que antigamente os Yúriwawa viviam em malocas próximas a determinados igarapés, mais para o interior da mata, afastados do Uaupés. Com o tempo, por conta da chegada e do esforço missionário salesiano para reunir esses indígenas em casas próximas ao rio Uaupés, passaram a viver no lugar onde hoje é Açaí ${ }^{16}$.

Tal como aconteceu com Yauaretê-Ponta, Açaí também foi uma comunidade grande nos anos 1980 e 1990. Mas iniciou um processo de esvaziamento nos anos 2000, e hoje conta com apenas oito famílias. Ela tem uma igreja católica, e uma escola da prefeitura de São Gabriel da Cachoeira que atende os filhos de moradores de Açaí e alguns da comunidade de Puerto-Colombia, próxima de Açaí, do lado colombiano do Uaupés. Além disso, a comunidade tem também uma maloca, onde os moradores se reúnem para o café da manhã, reuniões e festas de caxiri. Segundo alguns ex-moradores de Açaí, muitas famílias foram viver em São Gabriel da Cachoeira por conta de conflitos envolvendo, sobretudo a administração da escola e rivalidades familiares.

A comunidade de Querari, a maior, com cerca de 24 famílias, é composta na maior parte de indígenas Yuremawa, e faz vizinhança com o $2^{\circ}$ Pelotão Especial de Fronteira do Exército brasileiro (2. PEF). Essa comunidade conta com igreja católica, escolas estadual e municipal, uma pista de pouso para aviões de pequeno porte, e algum apoio disponibilizado pelo 2. PEF, como atendimento médico, odontológico e socorro em situações de emergência que necessitam de remoção para os hospitais de São Gabriel da Cachoeira ou Manaus. Querari divide-se em sete "bairros" ou "vilas": São João, Bairro da Paz, São Sebastião, Aparecida, São José, Imaculada Conceição e Vila Poupex (conjunto de casas onde vivem os militares de outras regiões); divisão que parece emular a organização administrativa de Iauaretê e São Gabriel da Cachoeira, uma espécie de "modelo reduzido".

Além das duas escolas (estadual e municipal) e da igreja, a comunidade conta com um centro comunitário, onde acontecem reuniões e também grandes festas. Alguns dos bairros têm palhoças particulares, como os bairros São José e Imaculada Conceição, onde acontecem

\footnotetext{
${ }^{16}$ Essa história, bem como a história da comunidade de Querari, será detalhada no primeiro capítulo desta tese.
} 
festas menores, como aniversários ou confraternizações após trabalhos coletivos, para citar alguns exemplos.

A escola desempenha papel importante na comunidade, constituindo, entre outros fatores, a principal fonte de renda de parte significativa de seus moradores. Além disso, ela recebe estudantes de outras comunidades, brasileiras e colombianas. Muitas famílias mudam de comunidade e passam a viver temporariamente em Querari apenas por conta da escola para seus filhos. Muitas das festas de caxiri que movimentam a comunidade acontecem segundo o calendário de eventos escolares; nos períodos de férias escolares as festas ficam escassas, e a comunidade esvaziada. Por fim, a administração da escola e seu funcionamento, cursos de formação escolar e encaminhamentos de documentação relativa a escola constitui um dos principais motivos das viagens dos Kubeo para São Gabriel da Cachoeira.

No lado colombiano da fronteira, próximas a Querari e Açaí, existem as comunidades de Puerto-Colombia (Betowa), próxima de Açaí; Puerto-Playa e Montenegro (ambas Yuremawa), próximas a Querari. As outras comunidades kubeo estão distribuídas ao longo do rio Querari. O Uaupés segue com comunidades predominantemente kotiria até Mitú, capital do Vaupés, considerada de maioria Kubeo. O rio Cuduiarí, cuja foz fica próxima de Mitú, é todo ele ocupado por comunidades kubeo.

Como se pode concluir da breve descrição acima, são três os grupos que habitam as comunidades onde desenvolvi minha pesquisa: Yuremawa, Yúriwawa e Betowa ${ }^{17}$. Os Yúriwawa, até meados dos anos 2000, viviam todos em Açaí (hoje um grande número de famílias vive em São Gabriel da Cachoeira). Os Yuremawa vivem nas comunidades de Querari, Puerto-Playa, Montenegro, e na maioria das comunidades do rio Querari. Yúriwawa compartilha com os Yuremawa uma mesma tradição de origem. Diz-se que no passado compunham um mesmo grupo, os Yúri Parãmena, que em certo momento se dividiu por conta de um conflito. Os Betowa viviam em Iauaretê-Ponta. Hoje vivem em Querari e PuertoColombia, sendo essa última habitada por Betowa originários de Yauaretê-Ponta e também da comunidade de Birabaçu, no igarapé Abiú (pouco acima de Mitú, na Colômbia), e da comunidade de Santa Rita, no rio Querari.

Apresento a seguir um gráfico com dados populacionais dessas comunidades segundo levantamento feito em 2014:

\footnotetext{
${ }^{17}$ Como se verá ao longo da tese, minha pesquisa se deu exclusivamente junto aos Yuremawa e Yúriwawa. Em alguns momentos da tese examino falas e práticas Betowa, sobretudo algumas cenas de disputas entre esse grupo e os Yúri Parãmena, mas sem avançar em descrições etnográficas mais detalhadas e detidas. Como é sabido, as relações que constituímos em campo muitas vezes exigem de nós certas escolhas e aproximação a determinados pontos de vista.
} 


\begin{tabular}{|c|c|c|}
\hline Comunidade & Número de famílias & População \\
\hline Yauaretê-Ponta & 1 família & 2 pessoas \\
\hline Açaí & 8 famílias & 42 pessoas \\
\hline Puerto-Colombia $^{18}$ & 7 famílias & 30 pessoas \\
\hline Querari & 24 famílias & 190 pessoas ${ }^{19}$ \\
\hline
\end{tabular}

Tabela 2: Dados populacionais.

\section{Os Kubeo na literatura etnológica}

"No region of the South American tropical Forest can claim greater anthropological interest than any other. The entire area of the two great river basins, the Orinoco and the Amazon, is still an anthropological terra incognita" (GOLDMAN, 1963, p. 1, itálico meu). Com essas palavras, Irving Goldman abre a introdução de sua monografia pioneira sobre os Kubeo. De fato, é apenas a partir de meados da década de 70 que a etnologia da Amazônia indígena inicia um crescimento "sem precedentes" (VIVEIROS DE CASTRO, 2002, p. 319); é somente a partir desse momento que "muitas sociedades foram pela primeira vez descritas segundo padrões técnicos aceitáveis" e que "algumas delas foram estudadas por sucessivas levas de pesquisadores, oriundos de diferentes tradições teóricas" (ibidem). Antes disso, a região era "an anthropological terra incognita" 20.

O histórico de contato dos indígenas dessa região com os brancos remonta ao século XVI. Goldman (1948, p. 768-69) indica que as primeiras referências ao rio Uaupés, sem descrição dos povos que o habitavam, encontram-se em Hernán Pérez de Quesada (em 1538) e Phillip von Hutten (em 1571). O estabelecimento das primeiras missões religiosas na região data do século XVII. Contudo, é a partir de meados do século XIX e início do XX que vários

\footnotetext{
${ }^{18}$ Incluo Puerto-Colombia pois, embora não tenha desenvolvido pesquisa de campo nessa comunidade, como dito na nota anterior, muitos de seus moradores foram interlocutores durante minhas estadias, e certas descrições de discussões que se farão nesta tese dizem respeito aos Betowa dessa comunidade.

${ }^{19}$ Neste cômputo não estão incluídos os militares que vivem em alojamento dentro do $2^{\circ}$ Pelotão Especial de Fronteira de Querari.

${ }^{20}$ O leitor interessado num histórico das pesquisas antropológicas no rio Uaupés pode consultar com proveito Pedroso \& Ramos (2014).
} 
viajantes, destacando-se naturalistas e etnógrafos, passaram pela região do Uaupés; os relatos e estudos legados por esses estudiosos constituem um conjunto de fontes bastante heterogêneo,

\begin{abstract}
Abarcando desde os autores que permaneceram por pouco tempo até os que se internaram durante anos na região, desde aqueles sem nenhum preparo para a observação etnográfica até os grandes investigadores, que primaram pela perspicácia na análise e pelo cuidado nas descrições (CABALZAR, 2009, p. 69).
\end{abstract}

Dentre esses estudiosos, os trabalhos mais conhecidos são os de Alfred Russel Wallace (1870), considerado por Goldman como o autor da "earliest detailed account of Indians of the Rio Negro and Vaupés river" (1948, p. 768); os trabalhos de Theodor KochGrünberg (2005), "the best and most detailed published accounts of Northwest Amazon culture" (GOLDMAN, 1948, p. 769); e, por fim, Curt Nimuendajú (1982[1927]). Entretanto, esses etnógrafos/naturalistas não produziram "análises sistemáticas da organização social dos grupos habitantes" (CABALZAR, 2009, p. 69). Irving Goldman, que realizou sua pesquisa de campo em 1939-1940, foi o primeiro a levar tal empresa a cabo, estudando os Kubeo Bahúkiwa do Cuduiarí e, nesse sentido, foi um pesquisador pioneiro, autor da "primeira síntese mais exaustiva da organização social de um grupo lingüístico do Uaupés" (CABALZAR, 2009, p. 77). A primeira pesquisa de Goldman se deu em uma comunidade kubeo do rio Cuduiari onde viviam os Bahúkiwa ${ }^{21}$. Em 1969-70, e 1979, depois de pesquisas sobre sociedades da Polinésia e os Kwakiutl da Columbia Britânica, Goldman retoma seus trabalhos junto aos Kubeo, dessa vez com os Hehénewa, também no rio Cuduiarí.

Além das duas monografias e de artigos produzidos por Goldman (1940; 1948; 1963; 1976; 1977; 1993; 2004), há material que foi publicado pelos missionários do Summer Institute of Linguistics - SIL e outros pesquisadores, compondo-se em sua maior parte de estudos da língua kubeo (SALSER, 1971; ZAPATA, 1982), e algumas publicações gerais sobre a cultura kubeo (HOLGUIN, 1972; SEPULVEDA, 1975; SALSER, 1978; MORSE, 1985).

Tive acesso também a uma compilação de narrativas de origem kubeo feita por François Correa (1997); e trabalhos de dois indígenas kubeo de Mitú: uma monografia de Restrepo (2001) sobre os Hehénewa do Cuduiarí, e outra de Simon Valencia (s/d) sobre os

\footnotetext{
${ }^{21}$ Para um histórico da trajetória de Irving Goldman, cf. Pedroso (2016).
} 
Yuremawa do Uaupés. Juan Carlos Marquéz (2008) escreveu uma tese sobre a presença dos Kubeo em Mitú, onde encontramos algumas informações acerca desses indígenas.

No que diz respeito aos Kubeo das comunidades localizadas no Uaupés brasileiro, nota-se a quase ausência de pesquisas. O linguista Thiago Chacon $(2012 ; 2013)$ fez pesquisas nas comunidades de Açaí e Querari entre os anos de 2008 e 2011 sobre a língua desse povo, com especial interesse nos aspectos fonológicos. Mais recentemente, João Veiga (2014) fez uma monografia acerca do lugar de transformação dos Yúri Parãmena, o Wakaipani, acompanhando uma expedição feita com velhos conhecedores yuremawa e yúriwawa que percorreu parte do igarapé Marãkãriya em 2013. Como se depreende a partir dessa síntese, a literatura acerca dos Kubeo não é muito extensa, sendo bastante exígua no que diz respeito às comunidades do lado brasileiro da fronteira ${ }^{22}$.

\section{Os percursos da pesquisa}

"Não há inferno para os que viajam pelas cachoeiras!"; eis um provérbio amazônico recuperado por Theodor Koch-Grünberg quando escreve sobre suas viagens pelas cachoeiras do Uaupés nos anos 1903-1905. Cortado por inúmeras cachoeiras e corredeiras, o Uaupés exige daqueles que navegam por ele grande habilidade no manejo das canoas e barcos, além de resistência física e um conhecimento preciso do rio. Foram muitas dessas cachoeiras que atravessei pela primeira vez em 2013, ano de minha primeira viagem ao alto Uaupés.

$\mathrm{Na}$ época, estava terminando minha dissertação de mestrado (PEDROSO, 2013), uma investigação conduzida a partir de análises de parte da literatura etnológica sobre alguns grupos Tukano Orientais do noroeste amazônico, tendo como fio condutor a categoria de hierarquia tal como formulada e operacionalizada em tal literatura. Tentei sistematizar essas formulações, bem como explicitar alguns dos problemas propriamente nativos que tal ideia recobre. Por fim, esforços foram dirigidos para testar o interesse etnográfico para a região do alto rio Negro da teoria da hierarquia indiana elaborada por Louis Dumont. Foi durante tal pesquisa que o interesse pelos Kubeo, gestado na leitura das etnografias de Irving Goldman, surgiu; ganhou forma quando fui aceito como assessor de um projeto do Museu do Índio, coordenado por Thiago Chacon, então linguista estudioso da língua kubeo, e que visava

\footnotetext{
${ }^{22}$ Vale notar: refiro-me a literatura a qual tive conhecimento e acesso; embora com pretensão de ser exaustivo, uma ou outra referência pode ter ficado fora de meu conhecimento. Contudo, isso não altera o quadro geral de poucos estudos sobre os Kubeo.
} 
registrar histórias relacionadas aos lugares de transformação indicados nas narrativas de origem dos Yúri Parãmena. Foi uma viagem curta, de cerca de um mês ${ }^{23}$.

Consolidado o interesse em iniciar uma pesquisa etnográfica com os Kubeo do alto Uaupés brasileiro, voltei a campo pela segunda vez em julho de 2014, dessa vez como assessor de um projeto visando a elaboração de Plano de Gestão Territorial e Ambiental PGTA para os Kubeo e Kotiria ${ }^{24}$ (povo vizinho), e como doutorando com interesse inicial em apreender e descrever a dinâmica de constituição, atualização e transformação das unidades e subunidades kubeo, tendo como foco da pesquisa as comunidades de Querari e Açaí, e os grupos yuremawa e yúriwawa. Um tema geral, portanto, sem contornos muito definidos.

Permaneci em campo até final de janeiro de 2015. No mês de novembro, por conta de meu envolvimento com a elaboração do PGTA, além de visitar as comundiades kotiria do alto Uaupés e uma breve estadia na comunidade de Caruru-Cachoeira, participei da V Canoita, na comunidade de São Pedro, no rio Tiquié25. Esse encontro reuniu povos indígenas do rio Tiquié, do baixo, médio e alto Uaupés, e do rio Pirá-Paraná na Colômbia, e tinha por finalidade discutir planos de gestão do território em terras indígenas, incluindo discussões sobre os relatos de origens dos povos do noroeste amazônico, com foco no tema do "manejo do mundo" (CABALZAR, 2010), e que foram de importância para o desenvolvimento de minha pesquisa.

Novamente, por conta do plano de gestão, me vi às voltas com o trabalho de visitar os lugares considerados importantes nas narrativas de origem, registrar os nomes nativos, as histórias, bem como todo o complexo de práticas e restrições relacionado aos diferentes espaços. Paralelo a esse trabalho, tentei avançar na investigação do tema dos grupos kubeo, isto é, busquei respostas para questões como: o que significa ser Kubeo ou Pamiwa? Por que constantemente os Yuremawa e Yúriwawa se referiam aos Hehénewa como os "Kubeo verdadeiros", "puros", e se atribuíam o qualificativo de "não-verdadeiros"? Que tipos de relações há entre esses grupos? Como se faz ou desfaz um grupo kubeo? "Puro", "imitação",

\footnotetext{
${ }^{23}$ As oficinas de elaboração de mapas e a viagem ao lugar de transformação foram analisadas por João Pimenta da Veiga (2014).

${ }^{24}$ O Plano de Gestão Territorial e Ambiental Kotiria e Kubeo foi elaborado ao longo dos anos de 2014 e 2015 , contando com recursos do então PDPI, programa do Ministério do meio Ambiente. A publicação resultante desse trabalho deve sair no segundo semestre de 2019.

${ }^{25}$ Aqui, vale mencionar uma nota de Andrello, que aponta para o lugar das viagens a outros contextos durante o trabalho de campo: "Mas alguma coisa a mais deveria ser contabilizada como trabalho de campo" (2006, p. 44, nota 12). Estou de acordo com o autor; parece-me que viagens a outras comunidades, além de permitir um conhecimento mais amplo da região, permite também o desenvolvimento de um olhar comparativo mais sensível.
} 
pertencimento a um "grupo" e "lugar" são ideias que ganharam corpo nesse momento de pesquisa e que tentei avançar um pouco nas minhas conversações.

Tais questões levaram-me a perceber que uma investigação acerca do tema da constituição e dissolução dos grupos é indissociável da consideração das narrativas de origem, as quais falam das condições de surgimento dos grupos e fundamentam as atuais relações que os constituem. Essa problemática, por sua vez, remete aquela do complexo de nomes - nomes pessoais, como os nomes de benzimento, de branco e apelidos, nomes de grupo, e sobretudo nomes de lugares -, mobilizado sempre que se trata de levar adiante discussões relativas aos grupos, sua constituição e relação com o lugar. Constituição de grupos, narrativas de origem, economia dos nomes, e uma reflexão acerca da noção nativa de lugar mostraram-se, portanto, constituir um novelo de problemas impossíveis de serem perseguidos sem que se considere toda sua trama.

Devo mencionar que o interesse no nome, embora tenha ganhado substância após as viagens a campo, despontou ainda durante a pesquisa de mestrado pois, como certa literatura têm mostrado, aquilo que se chama de hierarquia é indissociável dos nomes de pessoas e grupos. Basta lembrarmos da monografia de Janet Chernela (1993), trabalho que toma por tema o que a antropóloga chama de "sistema de ranks", onde ela nos diz, por exemplo, "Social distinctions within the Wanano language group are maintained and reproduced through a naming system in which each Wanano sibs owns a set of exclusive ancestral names" (ibid., p. 6). Assim, minha pesquisa no mestrado sobre a categoria de hierarquia já apresentava pistas sobre o interesse dos nomes. Mas apenas fui dar a devida atenção ao tema após prolongado trabalho de campo e com a leitura de artigo de Andrello (2016), já citado no início dessa introdução, onde é explicitado o rendimento de um estudo centrado no tema dos nomes.

Com esse conjunto de ideias em mente, em junho de 2017 retornei a campo, permanecendo até novembro. Investi esse tempo na investigação dos nomes de benzimento (ou nomes de espírito, como usa Hugh-Jones, 2002), dos apelidos, seus sentidos e contextos de atribuição, e registrando conversas sobre cuidados com a pessoa e narrativas de origem.

Esse percurso de uma questão mais ampla e sem contornos precisos - aquela dos arranjos sociais kubeo com suas unidades e subunidades - para um recorte mais específico, os nomes de pessoa, contextos e práticas de nominação, também foi propiciado pela minha participação em dois projetos de pesquisa coletivos: o projeto "Diplomacias cosmopolíticas nas terras baixas sul-americanas: Exercícios de comparação etnográfica”, iniciado em 2016, e que centralizou seus debates em torno da questão da linguagem e das formas de expressão 
ameríndias $^{26}$. Nesse mesmo ano, também auxiliei na elaboração e participei como pesquisador do projeto "Nominações: pessoas, objetos, hierarquia e parentesco no Alto Rio Negro $(\mathrm{AM})^{27}$, que reuniu pesquisadores da região do rio Negro com interesse no tema dos nomes. Um olhar retrospectivo para esses projetos mostra certa amarração na minha trajetória de pesquisa, pois o tema do nome, que por sua vez insere-se numa discussão mais ampla sobre linguagem, com efeito constitui o objeto das análises do trabalho que ora apresento.

Diante desse quadro, propõe-se aqui explorar a trama apontada acima a partir da etnografia das comunidades kubeo de Açaí e Querari. Tal trabalho pretende levar adiante certas discussões já em curso na etnologia amazônica. A economia de nomes constitui tema para o qual recentemente tem-se chamado a atenção, como destacamos no início dessa introdução, e como se pode ver nos trabalhos de Andrello $(2006 ; 2013 ; 2016)$ para o alto rio Negro e, numa escala mais ampla, nas sugestões feitas por Oscar Saez (2013) num texto propositivo e que constitui um convite ao desenvolvimento de reflexões acerca dos nomes e etnônimos indígenas, bem como, tendo no horizonte as formulações de Roy Wagner (WAGNER, 2010), acerca dos processos de nominação como constitutivos da base para os processos de produção de agrupamentos ${ }^{28}$. Aqui, lembremos que Lévi-Strauss foi autor de

\footnotetext{
${ }^{26}$ Projeto financiado pela FAPESP e coordenado por Renato Sztutman (USP), que se desenvolveu entre os anos de 2016 e 2018. Em sua primeira proposta, ele foi assim formulado: "Este projeto propõe um estudo comparativo de 'eventos diplomáticos cosmopolíticos' indígenas. Tomamos de empréstimo a expressão 'diplomacia cosmopolítica' dos Sciences Studies - em especial, dos escritos de Stengers e Latour -, de modo a testar uma conexão parcial, no sentido proposto por Strathern, entre estes estudos e a etnologia americanista. O que nos conduz a tanto é o problema, enfrentado de modo diverso por ambas áreas do conhecimento, do 'pluralismo ontológico' e sua incidência numa reflexão sobre a política, isto é, sobre a composição (e a dissolução) de coletivos e sua articulação em 'mundos comuns' ou 'redes'. Ao tratar de 'eventos cosmopolíticos' por meio da etnografia e do trabalho comparativo - jamais dissociados -, centraremos nosso foco na dimensão estética e nas formas de expressão pelas quais personagens e coletivos são 'feitos aparecer'. Se a maior parte dos casos aqui tratados advém do mundo ameríndio, incluímos também como contraponto um estudo de um coletivo afro-amazônico, significativamente inserido em redes ameríndias" (SZTUTMAN, 2016).
}

27 Este projeto também recebeu apoio da FAPESP, foi iniciado em 2016, sob coordenação dos professores Geraldo Andrello (UFSCar) e Pedro Lolli (UFSCar), com finalização prevista para primeiro semestre de 2019. Segue a proposta do projeto: "O projeto se propõe a descrever e analisar os contextos nos quais nomes e apelidos são atribuídos e ativados entre os povos indígenas que habitam a região do Alto Rio Negro, de forma a problematizar a separação radical entre esfera doméstica e a esfera político-ritual. A hipótese a elaborar é a de que os processos de nominação constituem a base para os processos de produção de agrupamentos e determinam a forma variável desses coletivos. O caráter da reflexão é sobretudo comparativo, na medida em que o projeto integra uma equipe de pesquisadores. Com isso pretende-se dar continuidade a investigações anteriores acerca da vida social dos povos indígenas, cuja questão mais geral é o problema da dinâmica de constituição, atualização e transformação das unidades e subunidades que conformam o extenso sistema social regional, isto é, a produção contínua de diferenças internas em um grande conjunto multiétnico e multilinguístico. Entre os temas a se destacar está a íntima relação dessa grande variabilidade com os processos de nominação, sobretudo através da repetição de nomes cerimoniais e da proliferação de apelidos que, em combinação, permitem a existência de pessoas e de grupos extremamente heterogêneas entre si” (ANDRELLO \& LOLLI, 2016).

28 Tal proposição conduziu a realização de um seminário para discutir o tema da etnonímia, que resultou em publicação do dossiê “A serpente do corpo cheio de nomes: Etnonímia na Amazônia”, na Revista Ilha (2016). 
importantes elaborações sobre os nomes em La Pensée Sauvage (1962), explorando os aspectos classificatórios e individualizantes dos nomes. Além de ter no horizonte suas formulações, pretendo desenvolver nesta pesquisa outro aspecto, a saber, as capacidades agentivas do nome, o nome enquanto produtor de qualidades, atributos, afecções da pessoa e do corpo.

Discussões sobre nomes de pessoas, lugares e grupos atualizam-se e se fazem presentes de diversas maneiras na vida social kubeo. São patentes, por exemplo, nas birncaderias do cotidiano e nas festas de caxiri, e em discussões sobre o registro escrito de nomes em documentos; aparecem também em discussões acerca do uso dos lugares, que por sua vez se assentam em confrontos de diferentes versões das narrativas de origem, o pertencimento ou não de determinado grupo a determinado local, e a senioridade dos grupos explicitada nessas narrativas. Assim, há toda uma política (ou cosmopolítica) onomástica a ser explorada.

A guisa de conclusão, diria que, próximo ao que tem enunciado Andrello em alguns de seus trabalhos $(2013 ; 2016)$, a tese que se segue consiste na ideia de que é preciso apreender o movimento que opera sob o caráter à primeira vista fixo das categorias descritivas que temos usado para descrever a socialidade rionegrina, como fratrias, grupos exogâmicos simples e compostos e sibs ou clãs (ANDRELLO, 2016, p. 60); é preciso submeter, em suma, as categorias da etnologia regional a uma crítica etnográfica. E como levar tal empresa a cabo? Proponho descrever o uso que os atores locais fazem de termos para designarem a si mesmo e a outrem, tentar responder às seguintes questões: “Quais princípios subjazem ao manejo das categorias recíprocas acionadas pelos atores locais? O que eles nos ensinam sobre a própria natureza das unidades sociais rionegrinas?” (ANDRELLO, 2016, p. 60) e, finalmente, o que é e o que faz um nome?

\section{A estrutura da pesquisa}

Esta tese está organizada em sete capítulos, centrados no tema do nome e das práticas de nominação kubeo. O foco primeiro de interesse são os nomes de pessoa. Contudo, tais nomes não podem ser entendidos sem que se pense também os nomes de grupos e de lugares. Como disse certa vez Luiz Gilberto: "Nas conversas com cigarro [conversas longas] se começa perguntando: 'quem é você?', e 'de onde você é?", ou seja, as coordenadas que definem uma pessoa passam pelo grupo (“quem é você?”) e pelo lugar (“de onde você é?”). Tal fala de Luiz Gilberto estrutura e orienta minha tese. 
O primeiro capítulo, "Os Yúri Parãmena no alto Uaupés" explicita os sentidos do nome "Kubeo", recuperando suas formulações na literatura etnológica bem como as conversas em campo com os Yuremawa e Yúriwawa acerca desse nome; num segundo momento, apresenta um histórico da presença dessa população no alto Uaupés, escrito segundo as falas e memórias dos próprios Yúri Parãmena.

O segundo capítulo, “Existem grupos no alto Uaupés?”, inicialmente recupera o modelo de Irving Goldman, fonte das categorias manejadas quando se trata de pensar os arranjos sociais no noroeste amazônico e, a partir das formulações dos Yúri Parãmena sobre grupos e relações de parentesco contadas nas narrativas de origem, explora os nomes de grupos, com especial interesse nos nomes Yuremawa e Yúriwawa.

O terceiro capítulo, "Pupui amiya como manejo do umé", analisa a noção de pupui amiya (traduzida na região como "nome de benzimento") e pretende mostrar como ela é parte de um complexo de práticas relacionadas à produção da pessoa. Para isso, expõe os cuidados kubeo no nascimento, na primeira menstruação, o Jurupari e a morte.

O capítulo quatro, "Pupui amiya: metafísica e esquecimento", investe no exame de listas de nomes pessoais (pupui amiya), com o propósito de entender seus significados e usos. Busca mostrar como o cálculo feito no momento da escolha do nome supõe certa metafísica segundo a qual os nomes afetam as pessoas e seus corpos, ao mesmo tempo que analisa um aparente esquecimento dos nomes visível em campo, duramente criticado pelos mais velhos e interessados nas práticas e "conhecimentos tradicionais", tema esse que é avançado no capítulo seguinte.

Em “Os nomes escritos: equívocos controlados?”, busco analisar o tema da escrita dos pupui amiya, com o propósito de apresentar ao leitor algumas hipóteses acerca do manejo dos nomes no momento de seu registro em papel. O capítulo também apresenta o modo como os Kubeo usam o nome de branco.

O capítulo seis - "Brincando com nomes" - analisa o yahui amiya (apelido) kubeo, e foca seu contexto por excelência, as festas de caxiri; mostra como as brincadeiras em festas são importantes para a produção de vitalidade. Apresento também alguns apelidos de nomes de brancos entre os Yúri Parãmena, matizando algumas formulações feitas por Stephen Hugh-Jones (2002).

O último capítulo da tese se volta para a análise das categorias kubeo de espaço, a relação entre nomes e lugares, e explora dois episódios que envolvem disputa por nomes e lugares: uma viagem ao Wakaipani, lugar de transformação dos Yúri Parãmena, e o envolvimento recente dos Kubeo com planos de gestão ambiental e territorial (os PGTAs). 
PRIMEIRA PARTE - OS YÚRI PARÃMENA CHEGAM AO UAUPÉS 


\section{CAPÍTULO 1 - OS YÚRI PAR ÃMENA NO ALTO UAUPÉS}

Nas comunidades de Querari e Açaí, no alto Uaupés brasileiro, vivem indígenas kubeo de dois grupos, respectivamente, Yuremawa e Yúriwawa, sendo que ambos se reconhecem como tendo uma origem comum, isto é, como provenientes de um mesmo agrupamento passado: os Yúri Parãmena ("Netos de Yúri”). Yuremawa e Yúriwawa possuem uma longa história de presença na região. Neste capítulo, além de recuperar parte da história kubeo, também tento responder à questão: quem são os Kubeo? Para isso, retomo algumas das imagens que foram apresentadas acerca desse povo na literatura etnográfica disponível, seus sentidos e usos $^{29}$.

\section{Quem são os Kubeo?}

O termo "Kubeo" cobre uma vasta nuvem de grupos e comunidades distribuídas pelos rios Uaupés, Querari e Cuduiarí. Na literatura etnográfica encontramos algumas imagens que se construíram em torno desse termo. Comecemos por entender o que os próprios Yúri Parãmena dizem.

Os Yuremawa de Querari me explicaram que usam o termo Pamiwa para referir-se aos indígenas de modo geral, por oposição à ñaradawi, termo para "branco". Mas Pamiwa tem também um segundo sentido, mais específico e contextual, que ora é usado para designar o conjunto de grupos falantes da língua kubeo, e nesse sentido Pamiwa e Kubeo se sobrepõem, ora numa escala menor, apontando para aqueles falantes de Kubeo que vivem em Santa Cruz (comunidade no alto Uaupés colombiano), e no rio Cuduiarí, como os Hehénewa, e que são designados como "Kubeo puros", ou ainda "Kubeo verdadeiros", Pamiwa, por oposição aqueles que seriam "cópia” ou "imitação", caso dos Yuremawa e Yúriwawa, que recebem esse qualificativo por falarem uma língua que não a da origem, mas antes apropriada, o Kubeo. Notamos, assim, certa plasticidade no manejo do nome Pamiwa, uma variação de escala na qual é usado. Voltarei a esse ponto em outro momento da tese. Agora, vamos recuar na literatura e retraçar os sentidos e imagens do termo "Kubeo".

Alfred Russel Wallace (1870), que viajou pelo Uaupés em 1853, e sempre citado em monografias por ser um dos primeiros a fornecer informações sobre as populações indígenas do Uaupés, chegou até a boca do rio Cuduiarí e, embora encontremos em sua narrativa

\footnotetext{
${ }^{29}$ Num procedimento semelhante ao de Pedro Lolli para o termo "Makú" (LOLLI, 2016).
} 
algumas informações etnográficas sobre os Kubeo, como a ideia de um suposto canibalismo funerário praticado por esses indígenas, não encontramos nada acerca do termo "kubeo" propriamente.

Theodor Koch-Grünberg, etnógrafo que viajou pelo noroeste do Brasil entre 1903 e 1905, esteve por algumas semanas entre os Hehénewa do Cuduiarí. Esse etnógrafo fez a seguinte observação acerca dos Kubeo:

A tribo dos Kobéua ou Hähnaua, como eles se denominam a si mesmos, divide-se em um número de subdivisões de hordas com nomes diferentes e em parte de origens bem diferentes. Como autênticos Hähuaua valem somente os habitantes de Namocolíba e duma maloca acima dela, e mais doutra maloca abaixo dela (...). São descendentes dos Tukáno, que antigamente imigraram para cá do Papurý, como indica seu nome, e aqui se converteram em Kobéua. Eles não podem negar sua origem (...). Na região das nascentes do Querarý há uma tribo pequena, chamada Abóxöhähänaua. Os kobéua do Uaracapurý chamam-se Ólobahähänaua, e os Kobéua acima desta chachoeira são Ulaliua (KOCH-GRÜNBERG, 2005, p. 438, itálico meu).

Nesse trecho alguns pontos merecem atenção. Em primeiro lugar, o vocabulário: Koch-Grünberg usa o termo "tribo" para o grupo de maior inclusão, e "horda" para as subdivisões; como veremos mais adiante, apenas com a etnografia de Irving Goldman (1963) se consolidará um vocabulário analítico para tratar a organização social dos povos do noroeste amazônico ${ }^{30}$. Em segundo lugar, o autor ao dizer "a tribo dos Kobéua ou Hähnaua, como eles se denominam a si mesmos" identifica os Kubeo (Kobéua) aos Hehénewa (Hähnaua, ou, mais adiante, Hähuaua). Depois, elenca mais algumas "tribos" também kubeo $^{31}$ : Abóxöhähänaua, na região das nascentes do Querari; Ólobahähänaua, como se chamam os Kubeo da cachoeira de Uaracapuri (onde atualmente está a comunidade de Santa Cruz); e os Ulaliua, que seriam os Kubeo acima desta cachoeira. Essa identificação entre Kubeo e Hehénewa será apontada como errônea por Nimuendajú.

\footnotetext{
${ }^{30}$ Remeto o leitor a introdução de minha dissertação de mestrado (PEDROSO, 2013), onde apresento uma discussão detalhada das categorias para arranjos sociais elaboradas pela literatura do alto rio Negro.

${ }^{31}$ Koch-Grünberg não é preciso no manejo desses termos, como podemos ver no momento que o etnógrafo alemão usa "tribo" para se referir aos "Abóxöhähänaua" (uma subdivisão kubeo, segundo o autor), e não "horda".
} 
Além disso, temos uma hipótese acerca da origem dos Kubeo de Namocolíba e das duas comunidades adjacentes (acima e abaixo) - os "autênticos Hähuaua" - que, segundo Koch-Grünberg, seriam antigos Tukano vindos do rio Papuri que se "converteram" em Kubeo. Aqui, o etnógrafo alemão não fornece esclarecimentos acerca da atribuição do qualificativo "autênticos Hähuaua"; somos levados a pensar que tal afirmação se deve à origem tukano dos grupos, mas porque receberam esse qualificativo? Em outro momento, apresentarei alguns dados de meu campo sobre como os Yúri Parãmena se pensam em relação aos Hehénewa nessa chave da "cópia" por oposição à "autenticidade", que permitirá recuperar e oferecer uma hipótese interpretativa para esse dado de Koch-Grünberg. Por fim, é importante destacar a suposição da origem Tukano, pois mais tarde, quando Goldman descreve os Bahúkiwa também do rio Cuduiarí, encontraremos a conjectura de origem makú desse grupo, dados esses que apontam para a questão da hierarquia entre os Kubeo, visto serem os Bahúkiwa ditos de "baixa hierarquia", e os Hehénewa de "alta hierarquia", sendo estes indicados como de origem tukano, e aqueles de origem makú. Voltarei a esse ponto.

Acerca do nome "Kobéua", Koch-Grünberg diz que:

O nome "Kobéua", sem dúvida, inicialmente era um apelido de zombaria, dado-lhes pelos vizinhos, provavelmente pelos seus inimigos antigos, tribos Aruak, de modo semelhante ao que foram dados os apelidos de "Karútana" ou "Korekarú" aos habitantes do baixo Içana, por causa do costume acentuado destes indígenas de repetir muito frequentemente a palavra de negação "köbuö" ("não"), na língua deles (KOCH-GRUNBERG, 2005, p. 438 , itálico meu).

Aqui, Koch-Grünberg sugere a hipótese da origem do termo "Kobéua" como um apelido de zombaria atribuído pelos vizinhos aruak. Mais tarde, essa hipótese será lembrada e citada por Nimuendajú (1950) e pelo padre Alcionilio Bruzzi (1962); também Irving Goldman falará do nome Kubeo como um "jest name” (1963, p. 25), como veremos. Contudo, em meu trabalho de campo, durante as conversas acerca de nomes de grupos, não ouvi qualquer menção a ideia do nome "Kubeo" como apelido de zombaria. Isso chama mais a atenção na medida em que, como sabemos, tal atribuição de apelidos à grupos é comum entre os povos tukano, como mostra Andrello (2016) ao falar do termo Tukano: 
Como designação externa, Tukano seria um epíteto atribuído por outros, de uso corrente, sobretudo, entre seus cunhados próximos, os Desana, Tariano, Pira-Tapuia e outros. Mais especificamente, trata-se de um apelido a eles atribuídos por seus cônjuges potenciais pertencentes a esses outros grupos. Segundo elas, esses homens que andam em bandos, sempre muito ávidos por comida e prontos a agarrá-las, se parecem com tucano, isto é, com a ave cujos hábitos ofereceriam uma perfeita comparação com os modos desses comilões mulherengos (ANDRELLO, 2016, p. 79).

Alguns anos depois das viagens de Koch-Grünberg, a região foi visitada pelo etnógrafo Curt Nimuendajú, que apresentou ao Serviço de Proteção ao Índio - SPI do Amazonas e Acre um relatório de suas viagens pelos rios Içana, Aiary e Uaupés em 1927. Em sua viagem, subiu o Içana, entrou no Ayari, foi até o alto Ayari, retornou, e percorreu a trilha (um "varadouro", como se diz no português local) até a comunidade de Jutica, no Uaupés. Depois, seguiu até o rio Querari, pernoitando em Pacú-Cachoeira (comunidade kubeo); retornou para Jutica e, após alguns dias nessa comunidade, desceu o Uaupés, entrou no rio Negro e chegou em 1 de junho a São Gabriel. Dado que, como se pode ver pelo percurso de Nimuendajú, ele esteve em muitas comunidades kubeo, encontramos nesse relatório importantes dados sobre essa população indígena.

Com efeito, Nimuendajú nos informa que a "tribo" dos "Cobéuas" do alto Uaupés está dividida em 24 “clãs" (termos usados em sentidos próximos ao de Koch-Grünberg, quando falava em "tribo" e "hordas", respectivamente):

[...] a família Tucána, representada pelas tribus seguintes: os Cobéuas do Alto Uaupés, divididos em 24 clans. No Querari, os Dyuremawa, Dyaniwa, Koaitarabewi, Biówa, Tóliawi, e Kawikuliwa. No Uaupés entre a boca do Querari e a do Cuduyari os Walaliwa, Crabawa, e Miaráwa. No Cuduyarí os Ambomamára, Pialawa, Ilheadówa, Kalówa, Hehénawa e Bahúkiwa, Pedikwawi, Piándokawi, Heliwa e Aweea. No Uaupés acima do Cuduyari os Ucuwaiwa, Kohakolobewa, Papiwa, Buóibowa, e Hulélaliwa. O seu número total pode montar numas 500 cabeças, das quaes só umas 120 pertencem especialmente ao clan Dyurémaua (Yiboya-Tapuya), habitam em territorio brasileiro, ocupando o Alto Ayari, e a margem esquerda do Querari. Abaixo dos Cobeua habitam no Uaupés os Uanána (NIMUENDAJÚ, 1950, p. 165).

Mais adiante no relatório, Nimuendajú apresenta uma hipótese segundo a qual os grupos ("clá") kubeo do rio Querari seriam antigos Baniwa, que em certo momento adotaram 
a língua kubeo; assim, os Yuremawa ("Dyuremawa") constituem um grupo que adotou a cultura dos grupos tukano (foi "tucanisado"). Nas palavras do etnógrafo:

A tradição designa ainda como «Baníua» as clans do Rio Querari que hoje só falam a lingua Cobeua, e foi já linguisticamente e culturalmente tucanisado o clan Dyuremawa (Yiboya-Tapuya) estabelecido ainda em 1904 integralmente no Querari, emigrante para o Alto Ayari, com excepção de uma maloca (NIMUENDAJÚ, 1950, p. 165).

Mais adiante, ele continua com a hipótese da origem baniwa:

Nâo só ali como em todas as fronteiras vemos a lingua «Baniua» em regresso. Ainda hoje são tidos como antigos «Baniua» os clans dos Querari que só falam atualmente a lingua Cobeua. De 1903 para cá, estes índios invadiram o Alto Ayari estendendo assim o dominio da lingua Cobeua para dentro da bacia do Içana. Daquela mesma data para cá efetuou-se o abandono do Papunáua pelos Coati-Tapuya e pelo Baixo Içana está se estendendo o uso da lingua geral (NIMUENDAJÚ, 1950, p. 169).

Além disso, apresenta também a conjectura de que alguns dos grupos kubeo seriam de origem makú (suposição que será retomada mais tarde por Goldman, como já apontei): "Diversos clans dos Cobeuas são aportados com descendentes dos Macús, e o nome de um deles, Okódyboroa, segundo Koch-Gruenberg, significa Macú (Borówa) dos Uanána (Okódyiwa)" (NIMUENDAJÚ, 1950, p. 165).

A respeito da língua e do nome "Kubeo", Nimuendajú nos diz:

A lingua Cobéua que é a mais divergente, falada em territorio brasileiro pelos habitantes da margem esquerda do Querari e do Alto Ayari, pertencentes aos clans Dyurémawa (Yiboya-Tapuya), Dyániwa, Koaitarabewi, Biówa, Kawikuliwa, antigos Baníuas, tucanisados há muito tempo.

O nome Cobéua vem da negaçâo "kebeu " desta lingua; eles mesmos se chamam Kaniwa na sua totalidade, e nâo Hehénawa, como supoz KochGruenberg que tornou o nome de um dos seus clans, estabelecidos no Rio Cuduyari pelo nome da tribu toda. A lingua Cobéua não chegou a formar dialetos conforme verifiquei tomando vocabularios dentro de seus 24 clans (Dyurémawa, Hehénawa e Bahukiwa) (NIMUENDAJÚ, 1950, p. 170, itálico meu). 
No trecho acima, Nimuendajú oferece uma explicação para o nome "Kubeo", recuperando Koch-Grünberg: “O nome Cobéua vem da negaçâo «kebeu» desta lingua”. Em seguida, apresenta o que seria a autodesignação kubeo: "eles mesmos se chamam Kaniwa na sua totalidade", corrigindo, ao mesmo tempo, a identificação que Koch-Grünberg fez entre a totalidade dos Kubeo e o que seria uma de suas subdivisões, os Hehénewa do rio Cuduiarí; opera, portanto, um reposicionamento da escala do nome Hehénewa. Sobre o termo segundo Nimuendajú usado como autodesignação - "Kaniwa", não encontrei nenhum registro na literatura, nem os Kubeo a quem durante meu trabalho de campo interroguei sobre o sentido desse termo souberam me dizer do que se tratava. Minha hipótese é que se trata de um registro foneticamente equivocado de Nimuendajú, dado que os Kubeo usam comumente "Pamiwa" como autodesignação.

Em outra passagem, Nimuendajú fala que o rio Ayari foi por um período da história refúgio natural dos Kubeo do rio Querari, fugindo dos colombianos. Nesse trecho, encontramos referência aos "Yiboya-Tapuya", isto é, os Yuremawa ("Dyuremawa"), que seriam habitantes do rio Querari e teriam aberto sítio no alto Ayari, para onde todo o "clan" teria se mudado. Segue:

Outra providencia que se impõe com maior urgencia que a fundaçâo de um estabelecimento de maior culto em Yauareté, séria a fiscalisaçâo do Alto Uaupés e do Ayari-Içana, especialmente da regiâo compreendida entre os povoados de Yutica, Caruru, Uapui-Cachoeira e os sitios dos YiboyaTapuya do Alto Ayari. Este último rio constitue o refugio natural dos Cobéua do Querari quando acossados pelos colombianos. Já mudou-se para là todo o clan dos Yibóya-Tapuya com excepção de uma única maloca, vivendo agora tranquilamente no Ayari. É preciso que eles não sejam tambem perseguidos pelos cobradores de contas arrumadas com os índios já caraterisados (NIMUENDAJÚ, 1950, p. 178).

Já o padre Alcionilio Bruzzi Alves da Silva (1962), sobre o nome "Kubeo", nos diz o seguinte:

PAMIWA OU KUBEWÃNA - Opina Koch Krunberg [...] que o nome Kobéua seja apenas uma alcunha dada pelos seus antigos inimigos, os Arwake, pelo uso frequente da palavra köbäü̈, nada, não. No idioma Tukano são denominados Poteri-khãra que significa "gente ou habitantes das cabeceiras dos rios" [...]. Eles, porém, a si mesmos se denominam 
Pamiwa sing. M. pamikö, F. pamiko). Curt Nimuendajú e Kock registram Hehénawa como nome da tribo. Os Hehénawa constituem apenas um grupo principal dos Kubewana, que koch encontrou na maloca de Namakoliba [...] (ALVES DA SILVA, 1962, p. 103, sublinhado meu).

O padre salesiano recupera a suposição do nome "Kobéua" como alcunha dada por grupos Arawak; diz também que os Kubeo se autodesignam Pamiwa ${ }^{32}$. Contudo, atribui a Nimuendajú e Koch-Grünberg a identificação entre Kubeo e Hehénewa, atribuição essa que precisamos corrigir pois, como vimos, Nimuendajú já apontava o equívoco de tal identificação em Koch-Grünberg. Outro dado importante apresentado por Alves da Silva é a denominação que os Tukano dão aos Kubeo: "poteri-khãra", isto é, na tradução do padre, "gente ou habitantes das cabeceiras dos rios". Esse dado merece mais algumas considerações. Vejamos.

Em seu estudo "Crenças e lendas do Uaupés", Alves da Silva, em certo momento da narrativa da história de Yapirikuri $^{33}$ contada para ele em 1947 por um indígena tariano de Periquito (no rio Uaupés), faz referência aos Coivana, motivado pela citação do termo no seguinte trecho da narrativa: "Começaram a aparecer os Brancos. Os dois casais de Tariana vieram baixando junto com os Brancos até Iauaretê. Ai mesmo tinha outra tribo de gente que se chamava Coivana" (1994, p. 258, itálico meu), e, em nota, nos diz que:

Coivana é provável adulteração de Kubewana ou Kubewa, tribo da família linguística Tukano que, antes da colonização do Estado do Amazonas pelos Portugueses, se localizava no alto Uaupés brasileiro e nos rios Querari e Cuduiarí. Os Kobewa, no próprio idioma chamam-se Hipômua (1994, p. 258, itálico meu).

\footnotetext{
32 Pamiwa é o termo para coletividade; pamiku é a forma singular masculina, e pamikó a forma singular feminina.

${ }^{33}$ Essa narrativa conta parte da origem dos Tariano, dos brancos, e também o episódio conhecido como "revolta dos juruparis" (ALVES DA SILVA, 1962, p. 259-260), quando alguns padres exibiram, numa capela em Ipanoré, no rio Uaupés, as flautas sagradas de jurupari para mulheres que, como sabemos, não podem ver tais objetos.
} 
Aqui encontramos uma outra suposta autodesignação dos Kubeo: Hipômua ${ }^{34}$. Contudo, perguntei à algumas pessoas das comunidades de Querari e Açaí acerca do sentido dessa palavra. Luiz Gilberto me disse inicialmente que esse termo podia ser traduzido como "cabeças achatadas", e nesse caso a grafia correta seria hipomuã. Afonso, sogro de Gilberto e que estava acompanhando a conversa, lembrou que o termo era usado também para designar “pessoas que vivem nas cabeceiras de rios ou igarapés". Diante dos dois sentidos apresentados, não tenho dados suficientes para estabelecer em qual deles o termo hipômua foi apresentado a Bruzzi; tendo a pensar que o segundo sentido seja mais apropriado, sobretudo porque no primeiro estudo citado acima do padre salesiano, lemos que "no idioma Tukano são denominados Poteri-khãra que significa 'gente ou habitantes das cabeceiras dos rios"”, ou seja, o termo usado em Tukano ("Poteri-khãra") tem o mesmo sentido do termo em Kubeo (“hipômua"). Mas minha interpretação permanece hipotética. De qualquer modo, a partir das traduções oferecidas podemos entender que não se trata de autodesignação, como pensou o padre salesiano.

Irving Goldman chegou ao rio Cuduiarí em 1939 para pesquisa de campo onde permanecerá até 1940. Em seu primeiro artigo sobre os Kubeo (1940), ainda apresentando algumas elaborações preliminares do material de campo que apenas viria a ser publicado em sua monografia mais de 20 anos depois, quando trata do nome "Cubeo", ele diz apenas que "The Cubeo Indians refer to themselves as pámiwa 'first people"” (ibid., p. 242).

Já em sua monografia (1963), ao falar dos “Cubeo", o antropólogo norte-americano inicialmente apresenta a multiplicidade de pontos de vista subsumidos nesse nome, e os problemas que isso coloca para a pesquisa:

The reader, however, will understand that this study has a special perspective. Although I have made some effort to present "Cubeo", the point of view is unavoidably that of the Bahúkiwa, a low-ranking sib and perhaps even an alien sib of probable Macú ancestry. Strictly speaking, a Cubeo perspective can be only an artificial composite pieced together and generalized from the distinctive perspectives of each of its principal sibs. I would imagine that the Cubeo presented from the point of view of the Hehénewa, a high-ranking sib, would bring out somewhat more emphasis upom social status and upon the authority of the headman (1963, p. 23, sublinhado meu).

\footnotetext{
${ }^{34}$ Vale notar que Alves da Silva parece esquecer que em estudo anterior (1962) já havia indicado o termo "Pamiwa" como autodesignação dos Kubeo, oferecendo aqui outro termo, sem nenhuma menção ao primeiro.
} 
Cada sib, portanto, apresenta uma perspectiva distinta, sendo o que chamamos de "Cubeo" um compósito artificial de diferentes perspectivas dos sibs. Essa afirmação de Goldman me parece fundamental para se entender os Kubeo, e os povos rionegrinos de modo geral. Voltarei a ela em outro momento. Sigamos com nossa reconstituição dos sentidos do termo Kubeo.

Ainda nessa monografia, Goldman nos diz que "Cubeo" é uma europeização da palavra tukano kebéwa, a qual pode ser traduzida literalmente, segundo o antropólogo, como "the people that are not" (GOLDMAN, 1963, p. 25). E continua "it is a jest name applied to them by some other Tucanoan-speaking tribe. Most Indians were not aware that they were called 'Cubeos', while those who understand what it meant did not like the name. Strictly speaking, there is no tribal name" (ibidem, itálico meu). "Cubeo" seria, portanto, um nome de brincadeira, um apelido dado pelos Tukano. Esse agrupamento compósito dito "Cubeo", estritamente falando, não teria um "tribal name". Encontraremos essa explicação também na monografia dedicada aos Hehénewa, publicada após sua morte, onde Goldman diz:

The term "Cubeo" or "kubéwa" is not a self-designation by the members of the tribe in question, but a rather accidental naming of the sort that happens to native peoples who often persist as creations of their discoverers, interpreters, and, in other respects, masters. The name "Cubeo" appears in the earliest literature of the Vaupés region and has persisted on maps, official records, and ethnographic writings, including my own. The Cubeo, however, share some of the blame for the false appellation because of their remarkable reticence in correcting others. Even now, in a period of native activism, they list themselves as Cubeos within an official organization of Vaupés tribes (2004, p. 1, sublinhado meu).

Vemos no trecho destacado que Goldman retoma a ideia segundo a qual "Cubeo" não é autodesignação; mas ao contrário de Koch-Grünberg (seguido por Alcionilio Bruzzi da Silva), não avança nenhuma hipótese sobre a origem do termo, se mantendo apenas numa formulação geral, dizendo que "Cubeo" é um "accidental naming of the sort that happens to native peoples who often persist as creations of their discoverers, interpreters, and, in other respects, masters". Mais adiante, o antropólogo nos fala do termo usado como autodesignação: 
In truth, they call themselves "Pamí'wa", a term for which I have no authentic translation. It was explained as the name for the first people, whose original speech, pamyéne, was the "language of the Pamí'wa". Among Cubeo, "Pamí'wa" is an occult term used in conversations about traditional history, but it is not heard in vernacular conversations anywhere within the region to my knowledge. Asked who they are, they may judge the interlocutor as incompetent on such matters and reply, "We are Cubeo". With-holding their true identity is a matter of regard for the sanctity of a name according to tenets that view ignorance as form of disrespect (2004, p. 1, sublinhado meu).

A autodesignação, portanto, é "Pamí wa", termo de difícil tradução; esse termo seria de uso restrito aos contextos de conversações sobre a história tradicional, na formulação acima. Por esse motivo, é mais comum os Kubeo usarem os nomes de sibs, como afirma Goldman:

The name that is in most active use among any group of Cubeo is always that of the local group of agnates or, as I call it, the "sib". But even though the sib name is known to all fellow natives, it is not mentioned to outsiders [...] (ibid., p. 1).

Aqui, vemos uma distinção entre dois usos de nomes; um uso restrito (caso de Pami'wa), e outro uso mais comum, o nome de sib; um nome que deve ser ocultado e outro que pode ser dito, mostrado. Veremos mais adiante essa lógica do ocultamento e não ocultamento operando no que diz respeito aos nomes de pessoas. Além disso, tais usos já nos deixam entrever certa metafísica onomástica kubeo, pois, com efeito, por que certos nomes não são de uso comum ao passo que outros são? Deixemos essa questão em suspenso, aguardando o momento oportuno de ser desenvolvida, e voltemos à tarefa de reconstituição dos usos do termo Kubeo.

A questão do nome "Kubeo" e da ausência de um etnônimo definitivo para essa população foi sintetizada mais recentemente por Thiago Chacon, linguista estudioso da língua kubeo: "Different from most ethnic groups in the Vaupés, the Kubeos lack of a definite ethnonym [...], which can be taken as evidence of their ethnic pluralism" (CHACON, 2012, p. 
2). E segue afirmando tratar-se de um termo dado por estrangeiros ao conjunto da população falante de Kubeo:

The term "Kubeo" is a name given by outsiders to the whole Kubeospeaking population. The Kubeos also use that name in relating to the outside world. Among themselves and among whoever they think is aware of their internal social organization, the Kubeos use names relatives to their sibs (clans). In their language, as Koch-Grünberg (2005 [1909]) suggests, "Kubeo" might come from ki-bewi (exist-NEG-3.IN) 'there is not' - a phrase that was probably often repeated to the Portuguese violent traders and nativized in local Lingua Geral and from there later in Portuguese and Spanish as "Kubeo". Another common ethnonym is pamiwa, which, in a more restricted sense, refers only to the sibs in Phratry-I [...]. Pamiwa may also refer to all Kubeo-speaking peoples (the people that speak pamie or pami kamu 'Kubeo language'), in contrast with non-Kubeo-speaking indigenous people. Or it can be used even in a more general sense as related to anything that is indigenous (or non-white) (CHACON, 2012, p. 2, sublinhado meu).

A partir desses dados disponíveis na literatura, vemos que o termo "Kubeo" é de origem externa, atribuído aos falantes da língua kubeo, e sem um sentido definido. Pamiwa, termo nativo, é tomado em parte da literatura como autodesignação; contudo, vimos que ele também é um termo geral, usado tanto para designar o conjunto dos indígenas, por oposição aos brancos, como num sentido mais restrito para designar determinado conjunto dos falantes do pamie; trata-se, portanto, de um uso contextual, manejado em diferentes escalas ${ }^{35}$. Em suma, "Kubeo" abarca um conjunto de grupos com lugares e tradições de origens distintos. Essa tese se debruça sobre dois deles: Yuremawa e Yúriwawa.

\section{Os Kubeo no alto rio Uaupés}

O noroeste amazônico tem sido objeto de recentes pesquisas históricas, que tentam reconstruir as trajetórias do vasto mosaico de populações indígenas que ocupavam essa região desde antes da chegada dos europeus e suas modalidades de relações. Para citar alguns trabalhos de grande relevância temos Stephen Hugh-Jones (1981), Andrello (2006), Márcio Meira (2017) e Robin Wright (2005). Não farei aqui uma narrativa dessa história, que não

\footnotetext{
${ }^{35} \mathrm{O}$ problema da escala, pouco problematizado pelos estudiosos do alto rio Negro - embora Goldman já tenha chamado a atenção para ele nos anos 1960, e Stephen Hugh-Jones voltado a ele por meio da noção de "pessoa fractal" de Roy Wagner -, parece-me constituir questão central para apreender as configurações sociocosmológicas da região. Insistirei nisso ao longo da tese.
} 
passaria de uma síntese das exposições feitas nos citados trabalhos. O que proponho é a história dos Kubeo no alto Uaupés tal como contada por eles próprios.

Os Kubeo possuem uma longa história de presença no noroeste amazônico, história essa contada nas narrativas de origem e presente nas memórias dos mais velhos. Antes de mais nada, cabe esclarecer os usos que faço da história em minha etnografia. Adoto aqui a posição de Peter Gow no entendimento da história, isto é, trata-se de uma "história de dentro da cultura dos povos nativos" (1991, p. 3), ou seja, o que me interessa é a história contada pelos Kubeo, e referida aos seus próprios valores. Dado que evoquei a posição de Gow no entendimento da história, vejamos mais de perto como esse antropólogo formula seu argumento.

Partindo de suas dificuldades iniciais quando de seu trabalho de campo junto aos Piro do Baixo Urubamba, povo que à primeira vista apresentava uma situação que parecia se encaixar no que a literatura antropológica amazônica então chamava de "aculturação", Gow aponta os limites dos modelos então disponíveis para pensar os ditos povos amazônicos aculturados. Segundo o autor, "All founder when attempting to relate history and ethnography, and in particular the meaning of history for Native Amazonian peoples" (1991, p. 9-10). Mais adiante, Gow indica uma possível solução, a qual vai de encontro à posição que adoto aqui:

\begin{abstract}
Thus one solution to the analytical problems of understanding the native communities of the Bajo Urubamba, and the solution I follow here, is to explore the local discourses of identity, of culture, and of history. Instead of attempting to identify a baseline "traditional" culture in historical documents, one can ask one's informants what they hold to have been the culture of the 'ancient people'. Similarly, instead of trying to identify each person on the Bajo Urubamba as the bearer of a particular culture, as the member of a particular tribal or national society or a particular ethnic group, one can explore the salient categories of identity used by local people themselves. Further, instead of trying to fit the history of the Bajo Urubamba into the schemata of either acculturation studies or contact studies, one can ask local people what they think are the significant processes and events of their history (1991, p. 15, itálico meu).
\end{abstract}

Portanto, interessa-me "apreender as premissas sociocosmológicas com base nas quais alguns grupos indígenas do rio Uaupés descrevem e vivenciam as transformações sociais que se processaram na região" (ANDRELLO, 2006, p. 17). Sendo assim, trata-se não de verificar 
a "objetividade" desta ou daquela afirmação ou evento, isto é, a "história dos historiadores" (SZTUTMAN, 2012, p. 109), mas antes levar à sério o que os Kubeo me disseram, e pensar sobre os motivos pelos quais eles disseram tais coisas. Como nos sugere Marilyn Strathern, em seu estudo da noção de aldeia na Inglaterra rural, "When Elmdoners say, then, that so-anso is a real village person, or a newcomer declares that the real Elmdon families have been there for generations, we should not ask so much whether it is true, but why it matters" (STRATHERN apud GOW, 1991, p. 16).

Segundo uma versão da narrativa de origem contada pelo mais antigo morador de Querari, o senhor Henrique Rodrigues, os Yúri Parãmena surgem em Hípana (também designada Cachoeira de Hapuí), no rio Ayari. Depois de uma longa jornada em busca de um lugar para se estabelecer pelos rios Içana, Negro e Uaupés, os Yúri Parãmena chegam ao Wakaipani, lugar próximo ao igarapé Marãkãriya, no rio Uaupés, e realizam uma festa de Jurupari. Contudo, o lugar onde os Yúri Parãmena pararam já tinha dono, pertencia aos Kotiria; quando Marãkãriku, um dos chefes kotiria, escuta o som da festa no Wakaipani, ele vai até lá. Depois de conversações, Marãkãriku permite que os Yúri Parãmena se estabeleçam na região. É também durante essa festa que, por conta de uma discussão, os Yúri Parãmena separam-se em dois grupos: os Yuremawa e os Yúriwawa. Esses grupos, então, seguem trajetórias distintas que culminam no seu estabelecimento em diferentes localidades. Vejamos.

\section{Pacú-Cachoeira e Querari}

A primeira comunidade yuremawa no Brasil foi em Pacú-Cachoeira, no rio Uaupés, que recebeu esse nome por conta da cachoeira localizada diante da antiga comunidade. Infelizmente, não disponho de dados censitários acerca de Pacú-Cachoeira, mas contam alguns Kubeo mais velhos que foi uma comunidade grande, com muitas famílias, uma igreja católica - construída pelos padres salesianos, que chegaram à região por volta do ano de 1934 -, e uma escola. Hoje, Pacú-Cachoeira não é mais que um descampado às margens do rio Uaupés, sem nenhum morador. Próximo a essa comunidade existia um antigo posto do 
Serviço de Proteção ao Índio - SPI. Chegaram até nós alguns relatórios do SPI com dados sobre os Kubeo dessa região na época. Vejamos.

O Posto de Vigilância da foz do rio Querari foi fundado em 1929 (MELO, 2007, p. 187). Segundo relatório do inspetor Bento de Lemos de 1930-1931, o posto de Querari tinha a seguinte configuração:

Possui um bom barracão, coberto de palha e assoalhado de paxiúba, com as paredes de casca de pau, tendo sentina e galinheiro, afora uma barraca para hospedagem de índios e passageiros que por lá aparecem, subindo o alto Uaupés. Por trás do posto há uma pequena maloca, com 7 indígenas, sendo 5 da tribo Uaná e 2 Cobéus; e, acima, uma barraca, com 3 índios Uanána [...] Graças ao zelo e dedicação do respectivo encarregado, este posto vai preenchendo o fim a que é destinado. Os índios a que assiste, naquela recuada zona, têm estado algo mais acobertados das violências que lhe eram cruamente infligidas pelos colombianos que habitam a fronteira e se empregam no comércio da balata. Existem algumas malocas nos igarapés Patariá, Umirapára, Carapanã, Assai e Cumã, sendo as quatro primeiras habitadas por índios Cobéus e a última por Uanánas, todas no território do Brasil [...] Os aborígenes do Querarí dizem claramente que, antes da fundação do posto, "dormiam sobressaltados e algumas vezes refugiados de suas malocas", temendo serem, de momento a momento, agredidos por balateiros colombianos, que costumavam carregar suas filhas para criadas ou concubinas, não respeitando suas famílias, propriedades e criações, enquanto que, na atualidade, graças ao S.P.I., vivem tranqüilos, fazendo seus caxirís, suas roças, suas pescarias, sem a menor turbação (LEMOS apud MELO, 2007, p. 187-188).

Lemos faz referência a existência de uma maloca com indígenas Kubeo e Kotiria vivendo nela. Cita também alguns igarapés próximos onde hoje está a comunidade de Açaí, onde se encontravam outras malocas Kubeo.

José Bernardo ${ }^{36}$, Yúriwawa de Açaí, nas muitas conversas que tive sobre a história da região, disse-e que em Querari vivia um português, um senhor chamado Adriano Godinho (já falecido), representante do governo brasileiro na fronteira. Muito depois, a já FUNAI ${ }^{37}$ enviou um funcionário para a região. Carlinhos, outro Yúriwawa de Açaí e que vive

\footnotetext{
36 José Bernardo, como se verá pel abundância de referências a ele nessa tese, sempre mostrou em nossas conversas um interesse particular pela história, detalhando com abundância de detalhes episódios como o trabalho na borracha, a construção da pista de pouso de Querari, a presença missionária na região, e a construção das comunidades, para citar alguns dos episódios comumente rememorados e comentados.

${ }^{37}$ O Serviço de Proteção ao Índio e Localização dos Trabalhadores Nacionais - SPILTN (apenas SPI a partir de 1918), foi criado em 1910, e funcionou até 1967, quando é substituído pela FUNAI.
} 
atualmente em Querari, disse-me que na década de 1980 um senhor branco de nome Francisco foi funcionário da FUNAI em Querari, de quem ele foi ajudante, e substituiu a figura de Adriano Godinho como representante do estado na região. Depois dele, nos idos de 1984, se instalou o exército de fronteira brasileiro e a FUNAI deixou de existir. Portanto, foram três as figuras do estado brasileiro que se fizeram presentes nesse trecho de fronteira: Serviço de Proteção ao Índio, FUNAI e o exército de fronteira. Detalhemos um pouco a mais os relatos sobre a presença militar, que se segue até hoje em Querari.

Com a chegada dos militares brasileiros na região em meados dos anos 1970 , tentouse inicialmente construir um posto do exército em Pacú-Cachoeira onde viviam os Yuremawa; mas por conta das dificuldades oferecidas pelo terreno, que impossibilitava a construção de uma pista de pouso - José Bernardo explicou que a pista de pouso em Pacú-Cachoeira foi impossibilitada pela existência de um igarapé que cortava o terreno -, os militares desistiram e mudaram-se para onde se localiza a atual comunidade de Querari, próximo a foz do rio de mesmo nome. José Bernardo também conta que foram os indígenas que trabalharam na abertura da pista em Querari, dado que os soldados militares ainda não haviam chegado, apenas os superiores, para dar instruções de como se devia proceder na construção do pelotão. Essa história, bem como um relato mais extenso da constituição da comunidade de Querari, está registrada e contada em documento depositado no $2^{\circ}$ Pelotão Especial de Fronteira, escrito pelo Yuremawa Amós, antigo morador de Pacú-Cachoeira e que vive atualmente em Querari:

Em primeiro lugar QUERARI Significa rio de sangue, antigamente os tribos kubeos eram guerreiros brigavam com outras tribos, e derramavam muito sangue por isso recebeu esse nome. $\mathrm{O}$ morador de querari, chamado FRANCISCO RODRIGUES era tribos kubeos, e também conhecido como chefe do tribo mais conhecido. Eles viviam com suas tradições e demonstravam a sua cultura, com isso mostravam ser puro índio. Moravam numa maloca com suas familiares com maior tranqüilidade. A decorrer dos anos os familiares do senhor Francisco Rodrigues "TUCHAUA" foram aumentando cada vez ao decorrer dos anos.

Em 1912 nasceu senhor Francisco Rodrigues e faleceu em 1972 com 60 anos de idade, foi sepultado no antigo posto. Em 1972 á 1993 foi substituído no lugar do pai seu $1^{\text {a }}$ filho Senhor Henrique Rodrigues, como chefe do tribo.

Tribos Yuremavã de etnia kubeos viviam a vida confortável com outras etnias ajudavam uns aos outros, tantos na atividade materiais e espirituais. Os anos passaram cada vez mais surgiram o progresso, no ano de 1934 chegaram os primeiros missionários no alto rio vaupes e até chegaram aqui 
em querari, para visitar as comunidades ribeirinhas, e estes missionários levavam os filhos do tribos até no colégio para estudar e davam maior apoio.

Em 1976 à 1979 foi construída pista de pouso de querari com convênio $7^{\circ}$ COMAR de Belém o responsável da obra era senhor SANTANA "PARAENSE", TINHAM 40 Homens civis mais 40 homens de fora, o trabalhos foram mãos de obras não tinha ainda as maquinarias. Pouco a pouco foram chegando, a pista foi inaugurada em 1979 o primeiro avião que pousou no solo de querari foi cata Lina "DEVAGAR MAIS CHEGO LA".

Em 1973 à 1989 a escolinha de querari foi fundada, o nome da escolinha era general Rondon, administrada pela prefeitura de São Gabriel da Cachoeira.

Es Professores: 1973 à 1978, Professor Pedro Fontoura, da região $\mathrm{PROF}^{\circ}$ João Batista Cruz Ferreira. 1984 à 1989 os professores foram: Geraldo Lozano Marques, Marina Gonçalves Rodrigues, Hilário Sodré Maia.

Em 1990 à 1993 a escolinha General Rondon passou a ser para Estado com convênio do CMA e SEDUC. Foi transferido com nome da ESCOLA "NOSSA SENHORA DA IMACULADA CONCEIÇÃO", devido da padroeira da comunidade de querari. Recebemos um pavilhão comunitário onde funcionou com 02 salas de aula 01 sala de diretoria 01 sala de secretaria 01 apartamento dos professores 02 banheiros. Os professores que trabalharam nessa época; Elvia, Gaudêncio, Lucia, Manoel, Marlene Responsável Geraldo Lozano Marques, Secretario Bernardo Salgado Rodrigues.

Em 1993 á 1978 funcionou Alfa 3a série, 1979 à 1990 funcionou Alfa e $4^{\mathrm{a}}$ serie, 1991 à 1993 Alfa 5a, 6 Série e 1993 à 1995 funcionou $7^{\mathrm{a}}, 8^{\mathrm{a}}$ Série onde formaram $1^{\mathrm{a}}$ turma.

Em 1982 à 1987 chegaram Exército Brasileiro aqui em comunidade de Querari com 20 efetivos, $01 \mathrm{CMT}$ do Destacamento era $1^{\circ}$ Sgt Andes do $1^{\circ}$ Bis - Manaus. A Missão dele era para a guarda de Fronteira e ajudar população indígena e permanecia 30 dias no destacamento depois de 30 dias era substituído, chegavam outra turma e assim seguia sucessivamente. Trazia radiofonia, um gerador que trabalhava com óleo diesel. Junto com ele vinha um enfermeiro que atendia $15 \mathrm{em} 15$ dias faziam patrulhamento até na comunidade de Caruru se encontravam alguns pacientes com problemas de doenças eram encaminhados para São Gabriel da Cachoeira para tratar. Recebemos esse apoio pelo Exército Brasileiro, nem outra órgão fazia esse apoio, não existia FUNAI até agora.

Em 1988 à 1993 o destacamento passou a ser $2^{\circ}$ Pelotão Especial de Fronteira foram construídas várias casas. Os materiais de construção foi transportada pela FAB.

No início do ano 1989 começaram chegar militares com suas famílias. $1^{\circ} \mathrm{CMT}$ do $2^{\circ} \mathrm{PEF}$ foi $1^{\circ}$ TEM. Ricardo(cavalaria) com sua esposa Senhora Paula. Ex comadante TEN. Almeida Ten. Figueredo Ten. Pacheco Ten. Assis Ten. Daniel etc... Atual Ten. Tossetto. Em 1991 à 1992 chegaram as 'pessoas da pequena Mini Usina Elétrica. Toda comunidade cooperaram no trabalho ao levantamento da barragem, carregaram areia e pedra. A comunidade recebeu rede externo e cada casa recebeu um pingo de luz. Até alguma Família já tem televisão e geladeira pela vista que nos vimos é grande progresso, ao mesmo Tempo é grande Apoio nos deram como energia, medico, escola. 
Os Kubeo Yuremawa, como dito, em meados do século XX viviam na comunidade de Pacú-Cachoeira. Em 1976 inicia-se, segundo o relato acima citado, a construção da pista de pouso do posto do exército de fronteira, que posteriormente será designado 2 Pelotão Especial de Fronteira (2. PEF) ${ }^{38}$; tal atividade fez a comunidade se deslocar. Inicialmente, apenas Henrique Rodrigues morava próximo a foz do Querari, como responsável por guardar o material do exército que chegava para a construção do pelotão. Com o tempo, dado que o senhor Henrique era chefe - "tuchaua", "primeiro filho" de Franscico Rodrigues e, portanto, aquele que o substituiu na chefia - como nos lembra o texto, e gozava de "consideração" e "respeito" junto à comunidade, como me disseram alguns, as famílias foram pouco a pouco se deslocando para a atualmente designada comunidade de Querari. O pai de Henrique, senhor Francisco, era "chefe" de Pacú-Cachoeira; Henrique foi o primeiro "chefe" de Querari. Aqui, devo salientar o uso que o texto apresentado acima faz do termo "tuchaua" que, como sabemos, é o termo que em meados do século XVIII passou a substituir o de "principal", o qual, por sua vez, diz respeito a categoria criada pelo sistema administrativo da época para designar "líderes indígenas que passavam a ser reconhecidos como tais pelas autoridades" (ANDRELLO, 2006, p. 84); como nos explica o citado antropólogo:

Um dos expedientes de que os diretores de índios parecem ter lançado mão em seus negócios com os índios foi direcionar a distribuição das chamadas "carta-patentes" a pessoas de sua confiança. Tais documentos eram expedidos pelos militares ou pelo próprio presidente da província para nomear "principais" (ibidem, p. 84).

\footnotetext{
${ }^{38} \mathrm{O}$ documento citado acima faz referência à organização do exército e suas distinções em patentes; dado que poucos leitores devem estar familiarizados com tal organização, segue uma síntese para orientação: o exército brasileiro conta com sete comandos militares, distribuídos pelo país. Na Amazônia, temos o Comando Militar da Amazônia (CMA), sediado em Manaus. O Comando Militar da Amazônia tem jurisdição sobre os territórios da 8a Região Militar/ 8a Divisão de Exército, com sede em Belém, e da 12a Região Militar, com sede em Manaus, e sua área de responsabilidade abrange os Estados do Acre, Amapá, Amazonas, Pará, Rondônia, Roraima e partes do Tocantins e Maranhão. O Comando Militar da Amazônia é composto por cinco unidades operacionais, as Brigadas de Infantaria de Selva, sendo que em São Gabriel da Cachoeira está localizada a 2a Brigada de Infantaria de Selva. O exército conta também, nas áreas de fronteira, com as unidades dos Batalhões de Infantaria de Selva (BIS) e os Pelotões Especiais de Fronteira (PEF) (MARQUES, 2007, p. 77-87). No caso da Força Aérea Brasileira, esta se constitui de sete Comandos Aéreos Regionais (COMAR); São Gabriel da Cachoeira está incluída no 7a COMAR (criado em 1983), sediado em Manaus, Comando esse com jurisdição sobre os estados do Amazonas, Roraima, Acre e Rondônia (ibid., p. 125-128).

Na região conhecida como "Cabeça do Cachorro", o exército brasileiro possui atualmente sete pelotões ao longo da fronteira: 1. PEF do distrito de Iauaretê, 2. PEF de Querari, 3. PEF de São Joaquim, 4. PEF de Cucuí, 5. PEF de Maturacá, 6. PEF de Pari-Cachoeira e 7. PEF de Tunuí.
} 
Luiz Gilberto contou-me em uma de nossas conversas sobre história das comunidades que na época o senhor Francisco, então considerado "tuchaua", recebeu do exército uma espada como reconhecimento pelos serviços prestados e também pela sua posição de chefe, mas alguns anos depois vieram outros militares e a levaram. Essa espada devia ter permanecido na comunidade, disse Luiz Gilberto, ser "bastão de mando" do capitão, e passar de capitão para capitão. Aqui, alguns comentários.

Primeiro, notamos que os militares atribuem um tipo de reconhecimento ao papel de "chefe" de Francisco, e posteriormente de Henrique, algo que remete ao texto de Andrello citado acerca das "carta-patentes"; aqui, contudo, não se tratava de uma "carta", mas antes de uma "espada". Em segundo lugar, Luiz Gilberto lamenta que a espada tenha sido levada de volta pelos mesmos militares, pois devia ter permanecido na comunidade, mas não como "espada", um objeto dos militares - dos brancos, portanto -, e sim como "bastão de mando", artefato kubeo, pertencente ao chefe, e como tal, deveria ser transmitido de chefe para chefe.

O documento nos informa também que a partir do ano de 1934 chegaram os primeiros missionários salesianos na região do alto Uaupés. Como sabemos, esses missionários estavam presentes no rio Negro desde o início do século XX, mais especificamente, a primeira missão salesiana na região foi fundada em 1914, em São Gabriel da Cachoeira (ANDRELLO, 2006, p. 105). A partir desse momento, deu-se o processo de constituição da infraestrutura missionária no rio Negro:

Além de São Gabriel da Cachoeira, instalaram-se outras duas missões em pontos estratégicos do rio Uaupés na década de 1920: Taracuá em 1923 e Iauaretê em 1929. A partir dos anos 1940, outras surgiram: em 1940, PariCachoeira, no alto rio Tiquié; em 1942, Santa Isabel, no médio rio Negro; e, em 1952, Assunção do Içana, no rio Içana (ANDRELLO, 2006, p. 105).

Segundo os relatos que ouvi entre os Kubeo, esses missionários foram responsáveis pela construção da igreja de Pacú-Cachoeira. Eduardo, Yuremawa filho do velho senhor Henrique Rodrigues, contou-me que a comunidade foi toda organizada pelos padres salesianos, e depois o mesmo se deu em Querari. Os missionários iniciaram trabalhos de catequização nas então recém-constituídas comunidades, ao mesmo tempo que conduziam muitos dos filhos dos indígenas para estudar no colégio de Iauaretê. 
Além da mudança do senhor Henrique Rodrigues por conta do exército e da construção do PEF, outra importante razão para o deslocamento gradual das famílias de PacúCachoeira para Querari diz respeito à escola.

A escola de Querari, chamada "Nossa Senhora da Imaculada Conceição", foi criada em 1990, substituindo a Escola General Rondon, de 1973. A escola, contam os Kubeo, inicialmente funcionava dentro do PEF, mas por conta do incômodo causado a alguns superiores pela circulação de civis dentro do espaço militar, decidiu-se deslocá-la para onde está instalada atualmente: uma construção que tinha servido de moradia do pessol da COMARA (organização militar responsável por projetar, construir e equipar aeroportos na região Norte do Brasil), durante o trabalho de construção da pista de pouso, já fora dos limites do PEF. Passados quase duas décadas, a escola continua instalada no mesmo lugar, com estrutura já em estado precário, situação que constitui assunto constante de conversações e reclamaçãoes na comunidade e junto a autoridades que ocasionalmente visitam Querari ou em São Gabriel da Cachoeira.

Outro evento comumente destacado pelos Kubeo quando falam de sua história se refere a construção de pequena usina hidrelétrica no igarapé Hiađoya ("Loiro-Igarapé"), que teve lugar durante a instalação do 2. PEF. O propósito da usina era aproveitar a configuração natural do igarapé, com cachoeiras e quedas d'água acentuadas, para gerar energia para o PEF e a comunidade ${ }^{39}$. Como também enfatizou José Bernardo para mim, a construção da usina foi também resultado de trabalho sobretudo indígena.

O mesmo José Bernardo em seus relatos sobre o passado da região insistia também na presença de outro personagem: antes da instalação do exército de fronteira, segundo ele, era comum a circulação de comerciantes e regatões colombianos pela região, que procuravam os Kubeo oferecendo itens como roupas, alimentos, instrumentos de trabalho (machados, terçados) em troca da disponibilidade desses indígenas para o trabalho nas produções de borracha. Essa relação de indígenas kubeo com colombianos no Uaupés nos remete ao sistema de aviamento que operou na região amazônica entre os séculos XIX e XX, isto é, um modelo de trocas comerciais baseado no escambo e na dívida (MEIRA, 2017, p. 24). Márcio Meira define o sistema de aviamento nos seguintes termos:

\footnotetext{
39 É relevante lembrar que as relações estabelecidas entre militares e comunidades indígenas em região de fronteira seguem orientações ditas "estratégias de presença"; como nos diz Marques: "A consecução da estratégia da presença exige das forças armadas a execução de tarefas que não são de natureza militar, mas às quais se atribui um valor militar quando realizadas no âmbito da estratégia" (2007, p. 89-90).
} 
Como forma de pagamento pelas mercadorias adiantadas pelos mercadores externos, alguns povos nativos entregavam-lhes cativos e especiarias, ou seja, estabeleciam vínculos de comércio a crédito. O sistema de aviamento constituiu-se na Amazônia como um modelo que implica a formação de uma cadeia de escambo entre, de um lado, comerciantes/patrões e, de outro, produtores/fregueses, ambos situados, respectivamente, como elos de uma corrente, entre dois pólos sociopolíticos hierárquicos, marcados por relações de dominação e dependência em função da dívida estabelecida (MEIRA, 2017, p. 24).

Devo destacar que um dos motivos de muitos indígenas kubeo viverem afastados do rio Uaupés, no interior da mata, como veremos na descrição sobre Açaí a seguir, devia-se à tentativa de fuga do contato com esses comerciantes que buscavam mão-de-obra seja, num primeiro momento, para o trabalho na borracha - na "caucheria" como se diz na região -, seja, num segundo momento, para o trabalho de cultivo da coca. Aqui, vale uma breve menção a diferença do Uaupés em relação a outras regiões do noroeste amazônico, sobretudo o Pirá-Paraná, por configurar uma situação oposta. Se no Uaupés as populações indígenas foram levadas a se refugiar no interior das matas, dada a presença mais intensa dos colombianos, no caso do Pirá-Paraná foi o próprio rio que se constituiu em lugar de refúgio, o que se explica pela dificuldade de acesso à região (C. HUGH-JONES, 1979; ARHEM, 1981; CAYÓN, 2010).

O movimento de comerciantes colombianos na região parou com a instalação do 2 . PEF que, além da construção da pequena usina hidrelétrica que fornece energia para a comunidade, instaurou novas relações: nota-se casos de casamento de militares com mulheres indígenas da comunidade, que muitas vezes vão morar em outras cidades acompanhando o marido; quando há brigas na comunidade costumam recorrer aos militares para mediar e solucionar o conflito (sobretudo no caso de conflitos muito violentos, envolvendo ferimentos graves); por conta dos militares terem remuneração e acesso mais fácil a produtos industrializados (há uma aeronave militar que mensalmente abastace o pelotão com itens de São Gabriel da Cachoeira), são muito procurados pelas comunidades próximas para vender e trocar produtos; a aeronave que abastece o PEF carrega mercadorias dos moradores, bem como oferece vagas para viagem de civis no percurso entre a comunidade e São Gabriel da Cachoeira; o exército procura as comunidades para comprar alimentos: peixe, caça, farinha, beijú e frutas. $\mathrm{O}$ exército disponibiliza atendimento médico e odontológico à comunidade de 
Querari e do entorno, bem como auxílio no caso da necessidade de resgates emergenciais. Cabe lugar de destaque nessa teia de relações o fornecimento de combustível para viagens, pois dada a localização da comunidade, conseguir combustível para viajar é uma das principais dificuldades. Passemos aos relatos sobre Açaí, comunidade dos Yúriwawa.

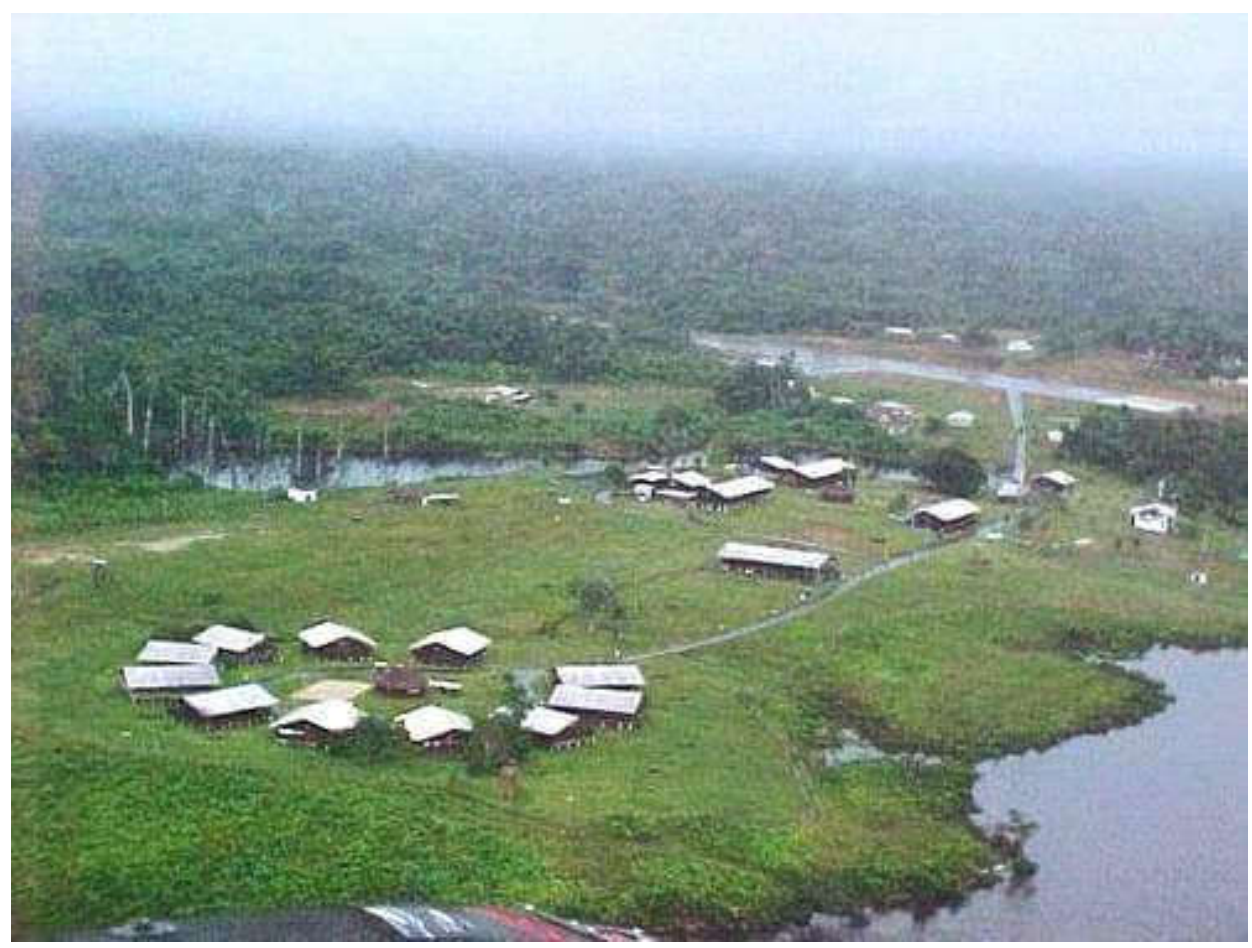

Figura 3: vista aérea de Querari, com destaque para o $2^{\circ} \mathrm{PEF}$ (fotografia de Márcio Silva)

\section{Açaí}

No caso da comunidade de Açaí, contam que os antigos moradores yúriwawa viviam nos igarapés, no interior da floresta. Com a chegada dos missionários salesianos, vieram para próximo do Uaupés morar segundo o padrão de comunidades, e não mais dispersos no interior da mata. A história de Açaí é contada da seguinte maneira ${ }^{40}$ :

No começo, os Yuriwawa viviam na boca do igarapé Jacundá numa única maloca. No entanto, o vovô Paulino fez sua própria casa separada um pouco

\footnotetext{
${ }^{40}$ Esse relato foi contado por Trino da Silva Hernandes, em 2014, no contexto de oficinas para elaboração do Plano de Gestão Territorial e Ambiental Kubeo e Kotiria.
} 
menor. E assim passaram a ter duas malocas: a casa do Huré, a grande, e a casa do Paulino. Moraram lá por muito tempo. O falecido Vicente se separou deles, vindo morar no lugar chamado "Volta da Sardinha" (Wãrika Hurt, no igarapé Mureða "Carapanã"). Não viveram por muito tempo lá e vieram para o lugar chamado "Lugar de Sofrimento" Ihidi Tawa. Ali viveram por muito tempo.

Os outros foram para o lugar chamado Yawakari Tawa, na cabeceira do igarapé Açaí. Foi o José quem fez a casa lá. No entanto, vendo as crianças crescendo, pescando no igarapé, o avô deles, Vicente, falou: "estão se pondo em perigo, podem tomar picada de cobra" disse. "Se morássemos no rio grande seria melhor". Dizendo isso, vieram para onde seria fundado Açaí e começaram a abrir a área. $\mathrm{O}$ Vicente foi o que primeiro abriu esta área. Ele viveu pouco, porém, e faleceu. Depois disso, ficaram os três filhos: o José, o Raul e o Roque. Aqui em Açaí, já ficaram vivendo em casas separadas. Depois de um longo tempo, chegaram os padres.

Enquanto isso, os filhos do Huré, depois do falecimento do pai, vieram morar no lugar chamado Küruriktt. Seguindo os demais, os que já viviam aqui, chegaram para morar em Açaí. Enquanto isso, o grupo do finado Çiriaku vivia num lugar chamado Oribu "de Lágrimas". Eles sempre moraram lá mesmo, nunca haviam se mudado. Eles também viram o grupo se juntando e chegaram para viver aqui. Sendo assim, os padres chegaram em 1960 e deram o nome para essa que viria ser a comunidade. Assim surgiu a comunidade de Açaí.

Nessa versão, os Yúriwawa viviam inicialmente em uma única maloca próximos ao igarapé Jacundá. Em certo momento, Paulino decide fazer uma moradia separada, uma segunda maloca. Mais adiante, é Vicente, irmão dos citados Paulino e Huré, que passa a morar separado numa terceira maloca, no igarapé Mureða (Igarapé Carapanã). José, filho mais velho de Vicente, por sua vez, muda-se para o Yawakari Tawa, na cabeceira do igarapé Açaí (Marãkãriya). Vendo os perigos que as crianças corriam na mata, segundo o relato de Trino, o velho Vicente convida seus filhos José, Raul e Roque a construírem moradia próximo ao rio Uaupés (“o rio grande”). Posteriormente, outros Yúriwawa que ainda moravam próximos aos igarapés no interior da mata se juntaram na comunidade que veio a se chamar Açaí, denominação dada pelos missionários salesianos que passaram pela região.

José Bernardo, um dos moradores mais antigos de Açaí, e que nasceu no lugar chamado Oribu, completa essa versão contando que "antigamente as famílias viviam nos igarapés. Cada família longe uma da outra; quando tinha festa, se reuniam todos, e depois separava de novo". O velho José (irmão de Raul e Roque) - que de acordo com José Bernardo era chefe -, convidou as famílias a irem para as margens do rio Uaupés (onde hoje é Açaí) na década de 1950. Estabeleceram-se próximo ao rio Uaupés, numa grande casa com todas as 
famílias. Contudo, detalha José Bernardo, a casa queimou num incêndio acidental, e depois disso passaram a fazer casas separadas.

José Bernardo lembra que na década de 1960 chegaram os missionários salesianos. Ao mesmo tempo que levavam crianças para estudar em Iauaretê, esses missionários tentaram organizar os Yúriwawa em comunidade, segundo projeto de catequização. Essa ação missionária junto aos Yúriwawa de imposição de um modelo de comunidade insere-se num amplo movimento de ação salesiana na região; assim, como destaca Meira, "No Brasil, desde 1914, sob a influência dos missionários salesianos, as malocas foram substituídas por casas monofamiliares, cujo conjunto compõe a 'comunidade', impondo o novo padrão de organização: casas enfileiradas, escola, capela e centro comunitário” (MEIRA, 2017, p. 53).

Com efeito, os Yúriwawa passaram então a morar em casas, segundo organização dos padres: casas enfileiradas próximo ao igarapé Katiwaya, com uma igreja em posição central em relação ao conjunto das casas. José Bernardo conta que a antiga Açaí era um conjunto de casas feitas de barro próximo ao igarapé, dos dois lados, pintadas, com capela e ponte sobre o igarapé ligando as duas fileiras de casas. Com a subida no nível do igarapé Katiwaya em 1984, numa época de cheia dos rios, as casas foram inundadas, e então os moradores se dispersaram, construindo casas em outros lugares, e distantes umas das outras, fazendo com que a comunidade se separasse novamente. Acerca do nome da comunidade, Bernardo disse que foi dado pelo "delegado" que morava no então posto do SPI próximo à Pacú-Cachoeira, e depois confirmado pelos padres missionários, versão que difere da contada acima por Trino, segundo a qual teriam sido os padres que atribuíram nome a comunidade.

Como já destacado anteriormente, a presença colombiana na região era muito comum antes da instalação do exército brasileiro; presença sobretudo de comerciantes regatões, que comercializam produtos em troca de trabalho. José Bernardo conta que esses colombianos viajavam pelo rio levando mercadorias (rádio, roupa, terçado, comida etc.), e trocavam com os indígenas que, como pagamento, muitas vezes iam trabalhar no caucho na Colômbia. José Bernardo lembra que seu próprio pai trabalhou na caucheria, assim como muitos outros Kubeo yúriwawa de Açaí, e que nos anos 1960 foi frequente esse intercâmbio de produtos industrializados por trabalho indígena nos seringais colombianos. Além do trabalho nos seringais, e já em anos subsequentes, na década de 1980, muitos Yúriwawa e Yuremawa foram trabalhar na produção da coca, também na Colômbia. Quando termina esse arregimentamento de indígenas para a caucheria e posteriormente para as plantações de coca, 
os comerciantes colombianos passam a direcionar seus interesses para a compra de artesanato das comunidades (compra ou troca por mercadorias), comércio só interrompido com a chegada de militares brasileiros na fronteira para instalação do pelotão; não apenas o comércio, mas a própria circulação de colombianos por essa região de fronteira cessa nesse momento, segundo relato de José Bernardo.

Em minha última viagem a Querari, no ano de 2017, conversei com Letícia Rodrigues, mãe de Luiz Gilberto, sobre as antigas moradias das famílias que hoje vivem em Açaí. Ela contou-me que o nome do lugar onde nasceu José Bernardo, próximo ao Muređa, é Oribut Kurãtawa, e que os irmãos de Bernardo estão enterrados no lugar. Hoje, uma trilha para roça passa perto de Oribu Kurãtawa, uma pequena clareira próxima a trilha, onde podemos observar uma pequena garrafa de vidro no centro, meio enterrada, com a finalidade de recipiente para colocar flores. Disse que ali tinha antiga maloca. Também tinha maloca em outros lugares, como: Ihidi Tawa (onde vivia Vicente), Yawakari Tawa, onde nasceu Martins Gomes e onde vivia seu pai, Marcelino Rodrigues, sua mãe Ana Moreira (uma Tarabuakó originária das cabeceiras do rio Querari) e o cunhado deu seu pai. Letícia mesma nasceu em Açaí, mas seu pai e avô eram de Wawiya ${ }^{41}$.

${ }^{41}$ Em conversa com Afonso Rodrigues, irmão menor de Letícia, ouvi que Marcelino Rodrigues nasceu em Umiari, em igarapé pouco acima da comunidade de Santa Maria, no rio Querari. Duas versões distintas da origem, portanto. 


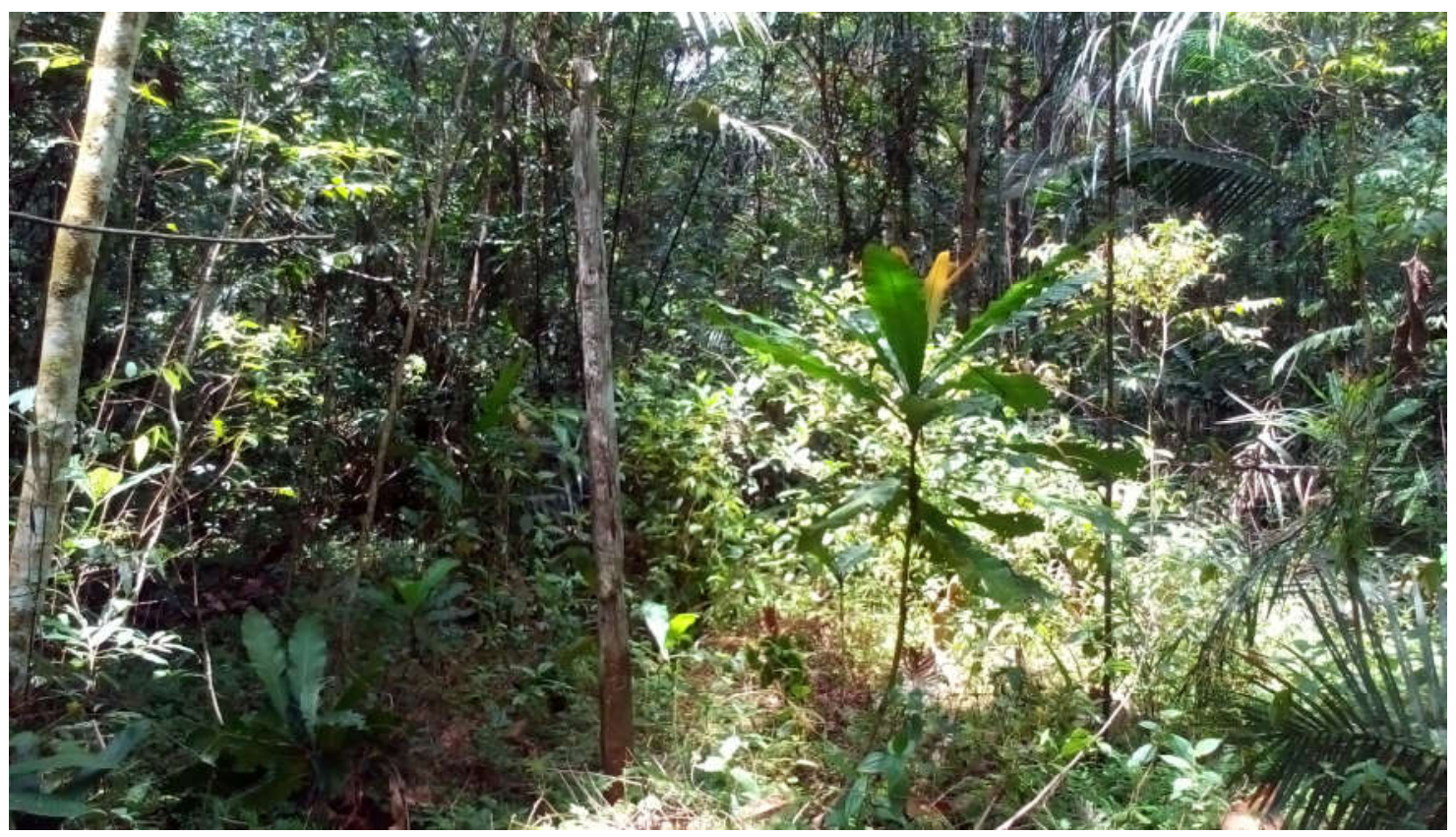

Figura 4: coluna de antiga moradia kubeo no Yawakari Tawa (fotografia do autor, 2017)

Os moradores atuais contam que Açaí foi uma comunidade grande, mas a partir de meados dos anos 2000 começou a esvaziar. Há muitas versões sobre os motivos do esvaziamento dessa comunidade, que vão de conflitos na condução da escola por parte de sua direção à acusações de "estrago". Os motivos principais sempre destacados pelos Yúriwawa foram a busca por educação e acesso aos programas do governo, sobretudo bolsa família e aposentadoria. Muitas pessoas com as quais conversei insistiram que se tivesse escola ${ }^{42}$ boa na comunidade ninguém iria embora, a comunidade não esvaziaria.

Luiz Gilberto que, embora vivendo atualmente em Querari, morou por algum tempo em Açaí, também lembra que antes havia muitas famílias. Ele destaca que em certo momento existiram muitos homens vivendo em Açaí, sinal de "força" da comunidade, pois "os homens constituem família na própria comunidade, diferente das mulheres, que vão embora com os

\footnotetext{
${ }^{42}$ Segundo relatos, a escola de Açaí começou a funcionar nos anos 1980, por iniciativa de Manoel Saldanha, filho do velho Raul (lembremos da história contada por Trino, um dos três irmãos a iniciar moradia próxima ao rio Uaupés), que havia estudado em Iauaretê e era professor.
} 
maridos". Por volta dos anos 2000, essas famílias foram progressivamente abandonando Açaí, de modo em 2014 - data de meu último censo - havia 8 famílias apenas, sendo que algumas delas já tinham o plano de sair de Açaí. Luiz Gilberto explica esse esvaziamento por motivo de brigas entre as famílias, sendo um dos motivos dessa briga o funcionamento da escola, a saber, as reclamações dos pais em relação à constante falta de aulas e atraso no cumprimento do calendário letivo escolar era transformada em brigas entre famílias, que durante as festas de caxiri conduziam à confusões e episódios de violência. Também havia discussões acerca do uso dos recursos que chegavam para a comunidade. A primeira família a sair de Açaí foi a de Simão (por volta de 1996-1997); depois saiu a família de Manoel Saldanha, e assim se seguiram outras famílias. Essas conversas e relatos apontam a centralidade da escola como força centrípeta (ou centrífuga, no caso de desentendimentos e conflitos) da comunidade.

A maior parte dos ex-moradores de Açaí vivem hoje na cidade de São Gabriel da Cachoeira, sobretudo na Vila Amazonino, comunidade localizada próxima a estrada que liga São Gabriel da Cachoeira ao aeroporto e ao porto de Camanaus, e para aonde se dirigiu toda a família de Simão, e também no bairro Thiago Montalvo, na região central da cidade.

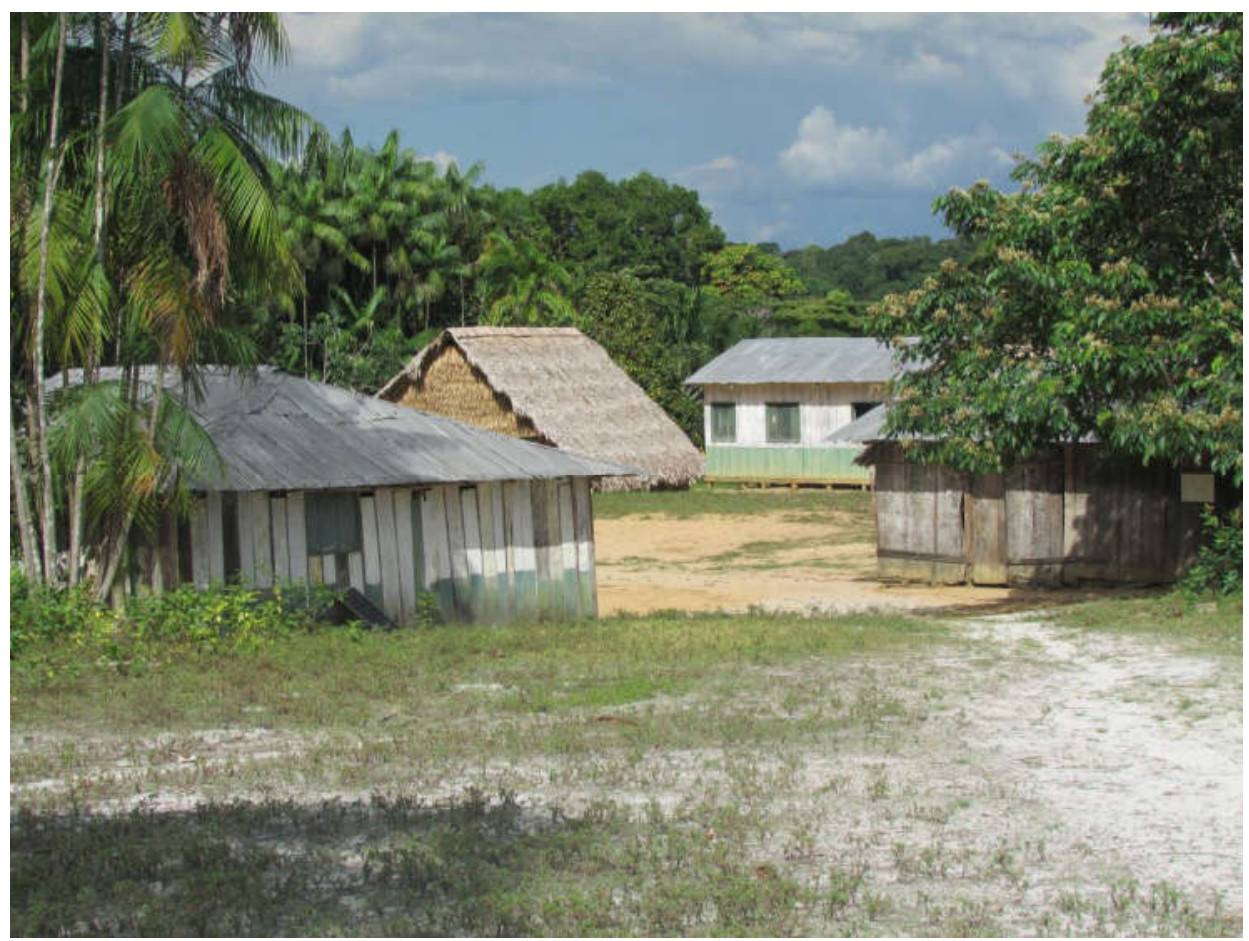

Figura 5: Vista de parte da comunidade de Açaí (fotografia do autor, 2014). 


\section{Yauaretê-Ponta}

Uma terceira comunidade kubeo $^{43}$ no Uaupés brasileiro era a de Yauaretê-Ponta, onde vivia um grupo Betowa. Essa comunidade foi criada pelo avô de José Abelardo ${ }^{44}$, o senhor Emiliano da Silva, cujos antepassados viviam antigamente "dentro do Marãkãriya, no Wakaipani”, segundo relatou o próprio José Abelardo em conversa. Seu avô viajou pela Colômbia, trabalhou com balateiro, e conseguiu uma esposa nesse mesmo país, uma mulher Kotiria, cuja família era de Puerto-Cólon (comunidade kotiria no rio Uaupés, logo acima da foz do rio Querari), e retornou ao Brasil por volta dos anos 1940, criando então a comunidade de Yauaretê-Ponta, logo abaixo de Açaí. O nome da comunidade, segundo José Abelardo, vem da "antiga origem", não foi dado por branco, e sim pelos próprios Betowa; desse modo, na língua a comunidade chama-se Yawibu ou Yawi Kapido.

José Abelardo conta que "antigamente tinha muita gente" em Yauaretê-Ponta. A comunidade também contava com igreja católica, instalada pelos padres salesianos, e escola, a qual, segundo lembrança de José Abelardo, foi criada em 1989, e atendia alunos da primeira até a quarta série. Mas nos anos 1990, a comunidade começou a esvaziar. A escola parou de funcionar por volta de 1992. Um primeiro conflito se deu entre algumas famílias, que culminou no deslocamento da família de Otávio (filho do senhor Emiliano) para o outro lado do rio Uaupés (lado colombiano), e na criação da comunidade de Puerto-Colombia, comunidade essa, portanto, onde vivem os filhos de Otávio, com suas respectivas famílias. Nesta comunidade, segundo dados censitários de 2014, vivem sete famílias. A história de Puerto-Colombia é contada pelo senhor Trino da Silva Hernandes da seguinte maneira:

Meu avô finado vivia em frente à Ponta Pimenta Derrameda. O nome dele era Emiliano. Ele veio de lá e chegou aqui, em Iauaretê Ponta. Depois de viver ali, foi para Paranã Jacundá. Então, o Otávio, meu pai, atravessou para este lugar (Porto Colômbia), onde hoje vivemos, depois que houve um problema com um parente nosso, envolvendo brigas de bebedeira. Nós vivemos ali apenas entre nós mesmos (uma única família).

\footnotetext{
${ }^{43}$ Veremos em outro momento desta tese que a consideração dos Betowa como Kubeo não é pacífica; é antes matéria de controvérsia e conflitos.

44 José Abelardo, Betowa, nasceu e viveu grande parte de sua vida em Yauaretê-Ponta, onde também foi catequista na igreja local. Com o esvaziamento da comunidade, foi morar em Querari com toda sua família. Ainda tem casa em Yauaretê-Ponta, onde se instala temporariamente para pescar, caçar, trabalhar na roça ou, como ele diz, "descansar, tirar férias".
} 
No ano de 2014 vivia em Yauaretê-Ponta apenas uma família, o betoku Moisés e sua mãe. O lugar é visto sobretudo como "sítio" da família Betowa de José Abelardo, que ocasionalmente passa um final de semana ou mais dias no lugar. Além de Yauaretê-Ponta e Puerto-Colombia, José Abelardo diz haver famílias betowa vivendo no igarapé Cubiú, acima de Mitú, na Colômbia, mas não tem certeza disso.

Segundo conversas que tive com Letícia Rodrigues e Martins Gomes, os relatos de José Abelardo são corretos. Segundo eles, Yauaretê-Ponta foi uma comunidade grande que por motivos de brigas constantes entres seus moradores foi esvaziando aos poucos. A própria criação de Puerto-Colombia por Otávio, confirmam Letícia e Martins, se deu porque ele brigou com seu irmão e por isso saiu de Yauaretê-Ponta. Já José Bernardo, ao falar sobre os Betowa, enfatizou que eles conformam outro grupo, "são outra tribo", diz ele, chegaram a região na época de seu pai, o senhor Angélico, e se estabeleceram onde hoje é YauaretêPonta. Seriam, portanto, “estrangeiros".

A relação dos Betowa com os Yúri Parãmena é por vezes conflituosa, como a fala de José Bernardo acima já deixa entrever. José Abelardo frequentemente me contava sobre a desconsideração que os Yuremawa e Yúriwawa têm com os Betowa. Voltarei ao tema do conflito entre Yúri Parãmena e Betowa em outros momentos. Agora, encerremos esse quadro geral da presença kubeo no alto Uaupés, e passemos a consideração dos nomes Yuremawa e Yúriwawa. 


\section{CAPÍTULO 2 - EXISTEM GRUPOS NO ALTO UAUPÉS?}

Sibs are named groups in a way that more inclusive units are not. In fact, the identity of a sib is so intimately bound up with the name that, in a sense, the name is the sib.

Christine Hugh-Jones (1979, p. 26)

Os termos são nomes, não são as coisas nomeadas.

Roy Wagner (2010, p. 246)

Este capítulo analisará os nomes de grupos - nomes daquilo que os Kubeo designam yahubo, comumente glosada pelos próprios Yuremawa e Yúriwawa como "grupo", "tribo" ou mesmo "etnia" -, e as relações de parentesco que são formuladas nas narrativas de origem. Mostrarei como o tema dos nomes de coletivos ocupa lugar importante nas falas sobre yahubo, e como um olhar atento às diversas escalas nas quais se insere o nome é importante para entender aquilo que a literatura regional tem referido como "organização social". Começo recuperando o modelo elaborado para os Kubeo por Irving Goldman - e que foi posteriormente ampliado, com modificações, para os grupos Tukano do Uaupés por outros antropólogos -, para em seguida, tendo tal modelo como pano de fundo, penetrar na análise dos dados Yuremawa e Yúriwawa. Antes, contudo, uma explicação sobre o uso dos termos "grupo", "subgrupo" e "coletivo".

Andrello abre seu artigo sobre o tema dos nomes de grupos no Uaupés com a seguinte epígrafe:

If recurse is made to Spanish to explain a hierarchical arrangement, an informant will say something like "Este grupo tiene três grupos". In Tukano he would say, "This group is threegroups: the Anteater people are threegroups: the $\mathrm{A}$ are at $\mathrm{X}$ rapids, the $\mathrm{B}$ are at $\mathrm{Y}$ stretch of the Papuri river, and the $\mathrm{C}$ are at $\mathrm{Z}$ mission village." (SORENSEN, 1967 apud ANDRELLO, 2016, p. 59).

Como se pode ver, o mesmo termo "grupo" é usado para referir-se a nomes com ordens de grandeza distintas; isso deve-se à ausência de termos específicos nas línguas tukano para aquilo que a etnologia regional formulou em termos de "sib", "clã" ou "grupo 
exogâmico". Voltarei a esse ponto. Por ora, explico que tal como o "informante" de Sorensen usa "grupo" em diferentes escalas, por falta de um vocabulário apropriado, também mantenho tal termo, usando em alguns momentos "coletivo" com o mesmo sentido, variando antes por uma questão de elegância na escrita, para evitar repetições excessivas de um mesmo termo, que por uma suposta distinção conceitual entre essas noções.

\section{O modelo de Irving Goldman revisitado}

Muitas foram as tentativas de formular uma linguagem analítica para dar conta dos arranjos sociais dos povos do noroeste amazônico. O primeiro esforço nesse sentido foi feito justamente a partir de dados kubeo, mais especificamente, dos Bahúkiwa do rio Cuduyari, na Colômbia, por Irving Goldman; vejamos em linhas gerais como esse modelo se apresenta ${ }^{45}$.

Em 1939, Irving Goldman, sob orientação de Franz Boas, desembarcava na região do Uaupés colombiano onde ficaria até 1940 para pesquisa de campo junto aos Kubeo (PEDROSO, 2016). De tal pesquisa resultará sua monografia “The Cubeo" (1963) que inaugura os estudos sobre organização social na região do Uaupés e introduz os temas que se tornaram recorrentes em trabalhos posteriores (CABALZAR, 2009, p. 70). Antes da publicação desta monografia, Goldman publicou dois artigos $(1940 ; 1948)$ onde apresenta parte dos dados coletados durante os 10 meses em que permaneceu na região e que depois serão publicados de modo mais detalhado e sistemático em sua monografia.

Com efeito, a primeira exposição de dados relativos ao arranjo social kubeo encontrase no artigo de 1940, onde o antropólogo oferece uma breve síntese de parte de seu material acerca do universo cosmológico desse povo: a narrativa de origem, a teoria da vida pós-morte e a relação com os seres que habitam as florestas e os rios. No que diz respeito à dita organização social, encontramos uma breve referência no seguinte trecho

Some thirty gentes, grouped into three exogamous unnamed phratries comprise the tribe. The Cubeo Indians refer to themselves as pámiwa "first people". The gens is the local group, and for the most part members of the same gens occupy the same long house. Gentes of the same phratry tend to occupy adjacent sites along the river. The principles of gens and phratric organization condition Cubeo cosmological beliefs. (...) The Cubeo are a river people, and according to their traditions their ancestors first emerged from the rocks at river rapids; thereafter all Cubeo lived along the rivers (GOLDMAN, 1940, p. 242, itálico meu).

\footnotetext{
${ }^{45}$ Esclareço ao leitor que retomo, nesse trecho de apresentação do modelo de Goldman, o texto de minha dissertação de mestrado (PEDROSO, 2013, p. 35-39), melhorado e mais sintético. Para uma apresentação detalhada do modelo de Goldman e de outros antropólogos que trabalharam na região, sugiro a leitura da introdução da referida dissertação.
} 
Nesse trecho, Goldman apresenta os Kubeo como uma "tribo" composta de trinta "gentes" 46 agrupados em três grupos exogâmicos não nomeados, as fratrias. Também afirma o pertencimento dos "gentes" de mesma fratria a lugares adjacentes ao longo do rio. Nessa breve formulação, gostaria de chamar a atenção para o uso que o autor faz da noção de "gens" para se referir aos grupos locais que compõem a fratria, num esforço vocabular que já o afasta dos usos gerais de "tribo" ou "horda", tal como vimos em Koch-Grünberg e Nimuendajú. Em trabalhos posteriores, contudo, a noção de "gens" será substituída pela de "sib", que é introduzida em 1948, no artigo para o Handbook of South American Indians (1948), e se tornará de grande relevância para a etnologia regional. Avancemos.

Em 1948 é publicado o artigo Tribes of Uaupés-Caquetá. Aqui, embora seja o propósito de Goldman tratar sumariamente dos povos que habitam a região que ele denomina "Uaupés-Caquetá", seu foco recai novamente sobre os dados etnográficos a respeito dos Kubeo, num apanhado que apresenta dados sobre a organização das comunidades e das malocas, ornamentos, ciclo de vida, xamanismo, mitologia e aspectos da economia e política desse povo. Goldman oferece uma caracterização da área do noroeste amazônico, e faz isso mediante a listagem daquilo que considera serem traços ou características compartilhadas pelos povos que habitam a citada região. Quando fala da "organização social", apresenta a seguinte formulação: "Tribal organization is either weak or absent, with authority vested in the leader of the sib or local kin group" (ibid., p. 763-64, itálico meu). Eis que o antropólogo nos coloca diante de uma formulação vaga e obscura, afinal, o que significa dizer que a “organização tribal é fraca ou ausente”?

Mesmo afirmando que a "tribal organization is either weak or absent", Goldman avança uma descrição da organização social kubeo. Assim, encontramos a seguinte formulação

Investigations by the present author in 1940 among the Cubeo of the Cuduiarí River disclosed a social organization based upon patrilineal sibs. [...] The patrilineal sib among the Cubeo is basically a local group, all its male members and their wives inhabiting one or more multifamily houses, each divided into 8,10 or 12 "apartments". [...] Cubeo sibs are further grouped into three unnamed exogamous phratries, each occupying a more or less continuous territory, so that in some cases marriage would be with

\footnotetext{
${ }^{46}$ Gens é uma noção que fez parte do vocabulário antropológico para falar de organização social e parentesco nos fins do século XIX e início do XX; desse modo, para citar um exemplo, encontramos longas formulações dessa categoria em Morgan (1936). Tal noção caiu em desuso; contudo, encontramos esse registro de uso em Goldman, que não mais voltará a ela, como mostro logo adiante.
} 
someone at a considerable distance (GOLDMAN, 1948, p. 780, sublinhado meu).

De modo geral, nenhum avanço em relação ao primeiro artigo (1940), exceto pela introdução da noção de "sib" para designar os grupos locais patrilineares que compõem as fratrias kubeo, noção essa proveniente de Lowie $(1920)^{47}$. Além disso, encontramos também nesse artigo dados a respeito das narrativas de origem e a disposição dos sibs e fratrias de acordo com essas narrativas. O modelo de organização social kubeo, esboçado nesses dois artigos, será sistematizado e aprofundado na monografia de 1963.

Com efeito, em seu modelo Goldman adota como categoria mais inclusiva aquela de "tribo"; sendo assim, os Kubeo seriam uma tribo que "consists of some 30 or more patrilineal, exogamous sibs that are grouped into three unnamed confederations or phratries of unequal size that are also exogamous" (GOLDMAN, 1963, p. 24, itálico meu); sendo a língua o critério que permite subsumir os grupos na categoria "tribo". Os arranjos dos sibs e das fratrias dos Kubeo, como já observamos, são formulados em longos relatos: trata-se das narrativas de origem e formação da humanidade, as quais, segundo a ordem de surgimento dos ancestrais de cada sib, estabelecem a disposição que esses sibs ocupam no conjunto da configuração social desse grupo indígena.

O segmento básico da organização social kubeo, portanto, é o sib. Goldman o define nos seguintes termos:

The Cubeo sib is a unilineal descent group whose members regard themselves as being descended from common ancestors but cannot establish an actual genealogical relationship. Sibs are named, normally localized, exogamic, patrilineal, and patrilocal (1963, p. 90, itálico meu).

Os sibs estão arranjados em unidades maiores, as fratrias, três ao todo, não nomeadas e exogâmicas, dentro das quais os sibs "occupy an order of rank that expresses the sequence in which they emerged during their mythical first emergence" (1963, p. 90, itálico meu). Os membros de cada sib, por sua vez, como Goldman observou, afirmam serem descendentes do homem que compunha o par ancestral de irmãos (homem e mulher), e são identificados pelo nome do sib. O sib, portanto, nos termos de Goldman, é o centro da estrutura social kubeo.

\footnotetext{
${ }^{47}$ Em Goldman e em outros pesquisadores encontramos um uso variável dos termos "sib" e "clã", contudo, com o mesmo sentido. O próprio Lowie, fonte da noção em Goldman, ao falar em "sib", destaca que alguns antropólogos americanos e britânicos usam "clã" (LOWIE, 1920, p. 111). Vale notar que a edição francesa do citado livro, Traité de Sociologie Primitive (1936), traduz o capítulo "The Sib" por "Le Clan", o que reforça tratar-se de dois termos com mesmo sentido. Novamente, para mais detalhes cf. Pedroso (2013).
} 
Como vimos, os sibs e as fratrias são exogâmicos; esse aspecto merece algumas considerações. Segundo Goldman

The rule in marriage is that a wife can not be taken from within the sib or phratry. She may be taken from another tribe and, of course, from any of the other two phratries (1963, p. 136).

Apesar da exogamia das fratrias, como se nota nessa observação de Goldman, há casamentos dentro da "tribo" entre membros de diferentes fratrias; portanto, a "tribo" kubeo permitiria, dessa forma, a endogamia, constituindo uma exceção ao padrão de grupos lingüísticos exogâmicos atestado pela literatura etnográfica como generalizado na região. Os Kubeo manteriam a preferência pelo casamento com alguém distante da comunidade e também teriam um padrão de casamento de primo cruzado, o qual criaria uma aproximação e fortalecimento dos laços entre os sibs paternos e maternos (ibid., p. 137). Tomando o sib Bahúkiwa, Goldman faz uma contagem dos casamentos desse grupo mostrando que, embora se verifique alguns poucos casamentos com membros de outros grupos lingüísticos, como Wanano e Karapana, os casamentos se dão predominantemente entre os sibs kubeo, provando assim a exceção desse grupo indígena à "regra" da exogamia lingüística do Uaupés apontada por pesquisadores como, entre outros, Sorensen (1967) e Christine Hugh-Jones (1979). Voltarei a esse tema ainda neste capítulo.

Portanto, com Goldman temos a primeira sistematização e proposição de um modelo, ponto de partida de toda uma geração de antropólogos do noroeste amazônico; antes desse antropólogo, como vimos, fazia-se um uso vago de noções como "clãs" e "tribos". Contudo, o vocabulário proposto pelo autor não deixa de apresentar dificuldades.

A categoria de fratria ${ }^{48}$, por exemplo, é problemática: com base em quais listas de nomes, e a partir de qual ponto de vista se pode circunscrever fratrias? Goldman também formula a fratria como unidade inclusiva não nomeada: como pode ser algo sem nome no alto rio Negro onde tudo que é conhecido tem nome? ${ }^{49}$ Como mostra a etnografia regional, parece haver certa indissociabilidade entre ter nome e ter existência, ser reconhecido. Essa noção de "fratria" parece, portanto, extremamente artificial, antes fruto da busca do antropólogo por

\footnotetext{
${ }^{48}$ Lembremos que o sentido usado por Goldman é diferente daquele usado por outros pesquisadores da região, como Christine Hugh-Jones (1979).

${ }^{49}$ Como bem nota Aline Iubel: "Ter um nome é condição existencial primordial tanto nos sistemas Tukano quanto Arawak do alto rio Negro, constituindo a ordem primeira de pertencimento ao mundo social" (2015, p 25).
} 
arranjos sociais abstratos, os "grupos", contrariando mesmo certa filosofia onomástica rionegrina segundo a qual tudo que é conhecido tem nome. Retornarei a essa questão.

No "português nativo" dos Kubeo, ouvi muitas vezes as palavras "grupos", "tribos", e também "etnia". Essas expressões traduzem o termo kubeo yahubo ("conjunto de coisas/elementos"); em Tukano, como me explicou Letícia certa vez, se diz kurua, assim mahsã kurua, "conjunto de pessoas" ${ }^{50}$. Não há, desse modo, um termo na língua nativa que traduza aquilo que a literatura chama de "sib" ou "clã", como já destacado. Andrello (2013, p. 1), quando fala dos Tukano, observa que:

Não há um termo nativo equivalente a "clã", ou seja, não há um conceito tukano exclusivo para definir esses coletivos. A expressão recorrentemente usada é mahsã kurua, ou simplesmente kurua (grupo ou conjunto de gente, ou simplesmente grupo).

Lembremos que Goldman quando fala de possíveis termos nativos para grupo, tribo e fratria, nos diz que

Strictly speaking, there is no tribal name. A man will always identify himself by his sib name, never by phratry and never by tribe. In the course of discussions with the ethnologist on native conceptions of "tribe" the Indians offered some self-designations. The most common was pamiwa (first people). They also offered pwanwa (people), and then referred to other tribes as apépwanwa (other people). The group of exogamous sibs that form a phratry are spoken of as kwináwü, únhiwü, or kwinánokauwü, all terms with the general meaning of "one kinfolk" or "the same kinfolk". However, I have also heard the expression nuhénokauwü (my own kinfolk) used to refer to both tribe and phratry (1963, p. 25-26, sublinhado meu).

Eis nos, portanto, diante de questões incontornáveis quando se pretende apreender os arranjos sociais kubeo. Vejamos como os Yúri Parãmena nos oferecem pistas e chaves de compreensão para tais interrogações.

\section{Os Yúri Parãmena}

Os Yuremawa e Yúriwawa, na origem, conformavam um único grupo: os Yúri Parãmena ("Netos de Yúri"), sendo seu lugar de origem a cachoeira de Hapuí, no rio Ayari. Em conversa com José Bernardo, ouvi a seguinte descrição desse lugar:

\footnotetext{
50 Janet Chernela diz para os Wanano: "Each language group is in turn subdivided into units I call sibs. All of these organizational groupings, regardless of level or magnitude, are known by the same Wanano term - Kurua. The Wanano refer to themselves as being of one kurua and view themselves as a group defined primarily by their unique language, name, and distinct ancestral history" (1993, p. 47, sublinhado meu).
} 
Cachoeira de Hapuí é grande, uma caída alta, de 3 metros, mas o rio Ayari é pequeno; aí essa cachoeira Hapuí cai, e o lado da terra é uma pedra bem comprida, aí tem buraco grande, pequeno, no porto deles. As pessoas daí me explicaram que esses buracos não são de onde saíram as pessoas, são para fazer mentira; "o nosso buraco, de onde nascemos, nosso próprio buraco, é no meio do rio, onde cai essa água", eles disseram; no meio do rio, ela cai assim dessa altura, 3 metros; quando é verão aparece como uma vidraça, só pequena água cai, bem fininha; aí a gente tem que entrar; é uma casa, entra, aí tem buraco, bem brilhante; "esse é segredo, não é para todo mundo", eles falaram. Esse buraco parece caracol, não tem fim, eles falaram; "não é para olhar muito tempo; se você olhar muito tempo aparece gente, o resto que ficou á'”, eles falam. Quando o rio cresce não é para entrar, é cachoeira muito perigosa, "no verão vocês podem vir para cá para conhecer essas coisas", eles falaram.

Com efeito, nessa cachoeira, ou "casa", como nos disse José Bernardo, localiza-se o buraco da criação não apenas dos Yúri Parãmena, mas de muitos povos Arawak como os Baniwa e Kuripako, conhecido como Hipana (WRIGHT, 2017) ${ }^{51}$. José Bernardo conta a origem dos grupos Yuremawa e Yúriwawa da seguinte maneira:

Quem cria é Yúri. Huredanaçu é dos Yuremawa, é avó dos Yuremawa. Os Yuremawa foram criados por Yúri. No Wakaipani que divide; só um grupo que vieram para cá, procurando a terra prometida; aí, no Wakaipani, quando chegaram, era uma maloca bem bonita, aí eles ficaram; "bora ficar", disseram. Aí eles ficaram, o chefe estava benzendo aquele... quando dança com Jurupari ele bate... isso ele estava benzendo, aí antes de terminar eles já começaram uma briga; Piađa e Kuenomo, aí ele falou "deixa de bater entre vocês, ainda estou terminando de benzer". Eles não escutaram. Só o chefe, esse Kuenomo, chefe dos Yuremawa, não deixou Piađa bater nele; aí Piađa também respondeu para ele. Quando acabaram esse cipó deles, aí ficaram batendo com as mãos. O chefe mandou parar e nada, ele não conseguiu. Eles brigaram até ficar... assim algum deles morto mesmo... assim... ficar caído. Aí ele, nosso chefe falou: "você era único tribo, parente mesmo entre vocês; com vocês não tem cunhado; agora vou separar vocês; agora esse Yuremawa vai ser cunhado de vocês, e Yúriwawa também vai ser cunhado de vocês"; aí ele separou. Aqui mesmo eles ficaram. Tem muito Yuremawa aqui, esse

51 “Hipana é considerado o 'centro do universo' (Hekwapi pamudzua), tanto no sentido vertical quanto horizontal, por vários povos aruaque setentrionais. Verticalmente, está situado entre o mundo superior dos grandes espíritos, o Criador e o mundo inferior dos ossos dos mortos, com uma variedade de espíritos-entidades (...). É o 'umbigo do universo', no sentido de uma conexão entre a fonte de vida no mundo superior do Sol, a origem da vida, e este mundo, a Terra e seus povos. Horizontalmente, é desse local central que 'este mundo' cresceu para fora, até seus limites sociais e geográficos" (WRIGHT, 2017, p. 626, sublinhado meu); em outro momento, no mesmo texto, Wright esclarece que "O nome do lugar Hipana (pron.: Hee -pana), dizem os Baniwa, se refere ao barulho que a cachoeira faz quando as correntezas passam por cima dos buracos nas pedras do centro. A palavra pana significa 'casa de'; a palavra 'Hee' se refere ao som da maior flauta sagrada, chamada 'Osso de Jaguar', que é do ‘tórax de Kuwai'” (ibid., p. 644). 
Yuremawa do rio Uaupés são daqui mesmo, onde os pais e avôs deles ficaram; e esses Yuremawa que estão no rio Querari, eles também ficaram aí, até agora, os filhos, os netos, eles ficaram.

Como vemos, os Yúri Parãmena surgem em Hapuí e, após uma série de viagens pelos rios "procurando a terra prometida", na analogia bíblica de José Bernardo, param no lugar chamado Wakaipani. Uma vez lá, fazem uma festa de Jurupari. Em dado momento, começa uma briga entre Piađa e Kuenomo, o que ocasiona a separação dos Yúri Parãmena em Yuremawa e Yúriwawa.

José Bernardo ao citar na narrativa a fala do chefe dos Yúri Parãmena usa o termo "tribo" para designar esse coletivo. Desse modo, ele cita a fala do chefe "você era único tribo, parente mesmo entre vocês; com vocês não tem cunhado; agora vou separar vocês; agora esse Yuremawa vai ser cunhado de vocês, e Yúriwawa também vai ser cunhado de vocês". Aqui, cabe lembrar a interpretação do Jurupari elaborada por Stephen Hugh-Jones (1993) onde tal "ritualização", para usar um termo comum entre os Yuremawa e Yúriwawa para referir-se a esse evento, se dá apenas dentro do grupo ou sib, sem a presença da figura feminina e afins:

He House is the very antithesis of Food-giving House. The latter is a cooperative, egalitarian and inter-group affair; the former (ideally) brings together the whole sib, a single, male-only unit with its own particular interests, asserting its independence as it presents its painted face to the world. It is vertically oriented towards the ancestors and also intrinsically hierarchical, employing a number of ritual devices to mark out the relative standing of the people involved. The ethos of complementary nurturing which characterises Foodgiving-House is likewise far removed from that of he House. No fires must be lit, no beer is served, and no food of any kind enters the maloca. The aftermath of the rite is characterised by a two-month long fast during which time the men avoid all contact with women. The fast is broken by a dance called The House of Manioc Bread (dähu kitiria wii) at which the missing female element is restored. Neighbouring affines are invited, the men dance with the women, and huge amounts of snowy-white bread made from pure manioc starch are distributed. People throw bits of this bread, tied together with strips of bast, up into the rafters of the house till the interior is festooned in white. If the men of the sib are the bones and framework of the house, their wives and affines provide substance, restoring its flesh in the bread they throw. This rite marks the end of the men's food taboos and the resumption of normal meals, a return to the consanguineal mode of daily life (ibid., p. 111). 
O encerramento do Jurupari é marcado com a reintrodução do elemento feminino e de convidados afins de comunidades próximas. Tal interpretação não deixa se mostrar adequada para nossa inteligibilidade do episódio narrado por José Bernardo: o rompimento da festa de Jurupari se dá com a divisão Yuremawa e Yúriwawa, com a chegada dos afins.

Mais adiante, na mesma narrativa, José Bernardo dirá que os Yuremawa possuem outras divisões internas:

Esse Tarabuawz também foram para... [rio Querari] e ficaram por lá. Tarabuwz já separam no Hapuí mesmo, para nós, aí mesmo eles ficaram assim separados, até eles nasceram assim já cunhados; esses Yuremawa que separaram aqui no Wakaipani. Em Santa Maria, Santa Luzia [no rio Querari], são comunidades Tarabuwzt. Lá em Tapuruquara, na cabeceira do rio Querari, tem muitas tribos, tem Yuremawa, tem Piađawa... já são outro grupo, são cunhados dos Yuremawa e Tarabuwt... tem Biowa, aí já vem Toriawz, Yokakebewz, muitas tribos vivem aí. Agora entre cunhados, já vivem Tukano, Desano... não sei que... misturado... até caboclo existe, misturado. As filhas deles encontraram... andando aí na cidade... mãe solteira. Yuremawa e Yúriwawa são todos iguais; Tarabuawz é maior dos Yuremawa. Yuremakt maior só esse sogro do Osvaldo [Jaime Gomes], ele é Kapuareda. Esses Yuremawa têm muitas tribos. Esse Kapuareda é maior dessas tribos. Depois vem outras tribos menor, depois vem outras tribos, também Yuremawa, menor... já vem quarta tribos, Yuremawa, menores... quinta... e assim. Yaniwa é o menor. Yúriwawa é uma só tribo.

Com efeito, Bernardo afirma "Esses Yuremawa tem muitas tribos", ao passo que "Yúriwawa é uma só tribo". Aqui, não pedemos deixar de lembrar Sorensen (apud ANDRELLO, 2016, p. 59), ao falar da dificuldade vocabular para falar dos arranjos sociais. Com efeito, a "tribo" Yuremawa é composta de "muitas tribos". Avancemos na narrativa de José Bernardo:

Essa parte é dos Wanano, que se chamava Marakarikt; esse Marakarikt, Wanano, é chefe de tudo wanano. Ele que tinha essa canoa grande, onde ele tinha todas as tribos. Aí, não sei para onde começou... falam no Rio de Janeiro... ele trouxe essa canoa, ele veio deixando todas as tribo... Tukano... esse que fala a mesma língua, como chama... Pira-Tapuya parece... essa parte onde está esse Wanano, ele deixou Wanano. Ele deixou até Vila Fátima, Tucunaré, Itaiaçu, Wirawaçu; aí que ele encontrou outro tribo que estava aí... esse... como chama esse... Hehénewa. Aí encontrou essas tribos aí, era guerreiro mesmo eles; então atacaram para ele, para não passar mais por alí. Então ele ficou aí e deixou, voltou. Deixou todos esses Wanano que 
estão aí. Voltou e ficou nessa ilha, que é casa dele; Marakari hiawz, é o nome dele mesmo, "ilha de Marakari". Aí ele ficou morando, esperando as tribos que ele deixou. Então nossa tribo chegou em Wakaipani; ele escutou som de Jurupari; ele falou: "quem está fazendo som de jurupari no mato? bora ver", ele falou para o secretário dele. Aí foi que ele entrou nesse Marãkãriya, por isso que tem o nome dele mesmo. Foi até chegar onde eles estavam. Então nossos guardas saíram de encontro a ele para matar ele. Marakariku falou: "não, deixa eu ir, quero falar com o chefe de vocês". Então nosso chefe disse, "pare, o que ele veio falar comigo?". Então ele foi, e falou: "essa parte da terra onde tu estás é minha terra; onde tu vem eu estou vivendo; agora você vai ser meu amigo, meu parente mesmo; essa parte é minha terra, mas essa parte ninguém vive; agora você tem que descer e viver na beira do rio, porque eu vou deixar você aqui". Nossos pais falavam essas coisas, "a história começa assim", eles falavam; aí que eles disseram pakomá para nós [Yúriwawa], considerado primos-irmãos; Yuremawa são cunhados dos Wanano. Ele também deixou para eles aqui, os Yuremawa. Esse pessoal de Puerto-Playa, de Montenegro são antigos povos dele também, vivia nesse rio mesmo; e esse povo Yuremawa que vive no Querari são de aí mesmo [...]. Esse pessoal que está em Querari, antigamente, os pais não viviam aqui; eles são de rio Querari, lá de Tapuruquara. Aí cada festa eles fizeram brigas entre eles, aí foram expulsos; então vieram para cá, e ficaram em Pacú, ficou para sempre mesmo aí. Ficaram aí até que foram com exército; moravam em Pacú. [...] Antes de chegar a COMARA, o Chico, pai de Henrique, morreu; então ficou capitão Henrique, o filho. Aí, ele, depois de terminar a pista, disseram "quem vai ficar responsável por essa pista? O capitão pode ficar como responsável"; então levaram ele, e deixaram lá para cuidar dessa pista. Ele foi e ficou, depois filho dele, depois todos parentes dele; único que ainda ficou em Pacú foi Pedro, irmão do Henrique, aquele pai do Amós; ele ficou ainda muito tempo sozinho, com a mulher, com os filhos. Por fim, ele também foi embora para Querari.

José Bernardo narra a chegada dos Yúri Parãmena a Wakaipani, onde eles se dividem durante uma festa de Jurupari, e o encontro com Marakariku, chefe Wanano "dono" da região, que permite que os Yúri Parãmena se estabeleçam neste lugar. Mais acima, vimos José Bernardo falar "esses Yuremawa têm muitas tribos. Esse Kapuareda é maior dessas tribos. Depois vem outras tribos menor, depois vem outras tribos, também Yuremawa, menor... já vem quarta tribos, Yuremawa, menores... quinta... e assim. Yaniwa é o menor". Tal formulação remete à uma conversa com Luiz Gilberto, logo no início de meu primeiro trabalho de campo em 2014, que me explicou que "dentro do grupo Yuremawa tem graus de irmão maior e menor"; acrescentou que um irmão menor deve "respeitar" o irmão maior e, ao mesmo tempo, lamentou que muitos jovens de hoje não se interessem pela história de seu grupo, o que implica, por desconhecimento, na ausência de práticas de "respeito" entre irmão menor e irmão maior. Em situações consideradas mais graves, um jovem pode vir a se interessar em ter relações com uma mulher de mesmo grupo, fruto da falta de respeito e 
consideração. Esse conhecimento que uma pessoa tem de seu "grau" na escala de irmãos maiores e menores, ainda segundo Luiz Gilberto, é dado desde o momento que a pessoa nasce, e passa de pai para filho. Avancemos neste tema das diferenciações internas Yuremawa.

Em outro momento, José Bernardo comenta a divisão interna dos Yuremawa da seguinte maneira:

O maior dos Yuremawa é Jaime, o sogro do Osvaldo, mas Yuremawa tem muitas tribos, maiores tribos, depois segue menores tribos; dentro deles tem maior, menor, assim [...]. Acho que tem muitas tribos, eu sei tribo de Jaime, outro lado; do Jaime é Kapuareda; o pessoal de Montenegro, de Henrique, eles falam que tem o mesmo nome. Depois segue benawikawa, depois segue Yaniwa, e assim; Yaniwa quer dizer "última tribo dos Yuremawa".

Assim, José Bernardo fala em "tribos" Yuremawa diferenciadas pelas noções de "maiores tribos" e "menores tribos", ao passo que, ainda segundo José Bernardo, "os Yúriwawa eram como uma família", sem divisões internas (apenas consideração entre irmãos maiores e menores). Vejamos um diagrama que representa a divisão Yuremawa enunciada por José Bernardo, com indicação das comunidades onde vivem os citados grupos:

Irmão Maior

Irmão Menor

$\begin{array}{llll}\text { Kapuareda } & \text { Wianawa } & \text { Benawikawa } & \text { Yaniwa } \\ \text { Jaburu (rio Querari) } & \text { Montenegro } & \text { Querari (rio Uaupés) } & \text { Tolima, Santa Maria, Mauá (rio Querari) }\end{array}$

Figura 6: Lista de divisões Yuremawa formulada por José Bernardo (elaboração própria). 
Além de José Bernardo, tive a oportunidade de conversar com outros conhecedores acerca da diferenciação pretérita a partir dos Yúri Parãmena. Graciliano Rodrigues, velho Yuremawa de Querari, irmão do senhor Henrique Rodrigues, listou as seguintes "tribos" dos Yuremawa:

São muitos nomes, muitos tribos. Primeiro, Yokakubekt... ele que sabe, o grupo que sabe; outro, Kapuareda, aquele de Jaime. Outro, de outro lado, de Rafael, é Makawene, é Yuremawa também, tribo, assim; outro é eu, yuremakt, Wiana Mamakt; Kaiwarida, outro tribo; aí embaixo, tem aquele yuriwakt; depois, Bedebo Paramekt; só isso mesmo (sublinhado meu).

Se representarmos em diagrama a lista de Graciliano Rodrigues, teremos o seguinte:

Irmão Maior

Irmão Menor

Yokakubekt

Kapuareda

Makawene

Wiana mamak甘

Kaiwarida

bedebo paramekt

Figura 7: Lista de divisões Yuremawa formulada por Graciliano Rodrigues (elaboração própria).

Em conversa com os velhos Henrique Rodrigues e Pedro Rodrigues, velhos conhecedores Yuremawa de Querari e irmãos de Graciliano, ouvi o seguinte:

Meçiwida, o primeiro... Kahe, outro... Mandawa... Kapuareda... Wiana... Kaiwarida... esses Yaniwa são os que moram em Tolima, Vila Maria... eles são Yaniwa... esses Bedebo são aqueles que moram lá para cima, mais acima de Tapuruquara, no rio Querari. Bedebo é último. Meçiwida, depois vem Kahe, em seguida Mandawa, esses já não existem mais, já acabaram, foram nossos irmãos maiores; aí começa Kapuareda, depois segue Wiana, são esses que moram aqui em Querari, que moram lá em Tapuruquara são Wiana também, lá são Yuremawa também, é um grupo Yuremawa. Kapuareda são de Jaburu; depois vem Kaiwarida, moram lá em Tapuruquara mesmo... Bedebo mora lá em Santa Rita...é o último. Yaniwa está em Tolima, Puerto-Ormiga, Vila Maria, Puerto-Mauá, alí todos são Yaniwa. Tem uma família Yaniwa que mora em Jaburu, família Garcia. 
Segue uma representação diagramática da lista de Henrique Rodrigues:

Irmão Maior

Irmão Menor

$\underbrace{\text { Kaçiwida Mandawa Kapuareda Wiana Kaiwarida Yaniwa Bedebo }}_{\text {Não existem mais }}$

Figura 8: Lista de divisões Yuremawa enunciada por Henrique Rodrigues (elaboração própria).

Nessa conversa com os irmãos Henrique Rodrigues e Pedro Rodrigues contei com o auxílio de Jaime Gomes, velho Yuremawa, que traduzia e explicava com português falas que eu não compreendia em Kubeo. No esforço tradutório para explicar a narrativa de Henrique e Pedro, Jaime se serviu do termo "classe"; assim, os Yuremawa são divididos em "classes baixa, média e alta".

Já Simão, velho Yúriwawa ex-morador de Açaí que atualmente vive com a família em São Gabriel da Cachoeira, contou a seguinte história:

Piađa é chefe da surra; no tempo das festividades... eles estavam fazendo festa de Jurupari lá no Wakaipani, de repente surgiu uma canção diferente da que eles tocavam... então eles se dividiram... "vocês tocam diferente, tem um som diferente, acho que vocês são de outra tribo", aí começaram a discutir. [...] Piađa é chefe da surra, ele surrou um da tribo yuremakt, e venceu ele na surra. Aí eles se separam... lá no Wakaipani, aí Piađa surge, da tribo dos Yuriwawa. Aí, do Yuremaku surge essa cobra, yurema ainkt. Aí de repente ele se afunda lá embaixo, onde a gente não consegue puxar essa pessoa, é uma forma de mulher. Aí que começa essa divisão das tribos dos Yuremawa. Aí, nós, Yúriwawa não temos essa divisão de tribos, das classes baixa, média... não temos isso, somos apenas Yúriwawa; eles não, eles têm, acima, abaixo, vem descendo, os Yuremawa. [...] Makawane, que é cabeça deles, dos Yuremawa; depois vem Kahetariapi, que é segunda... vem descendo a classe... depois vem Meçiwida, o terceiro; depois vem quarto lugar, Dareakuni; aí por último fica esse Karemuwa. Aí termina a classe. Depois vem Torewt... que já são classes não consideradas... são Yuremawa também... mas eles não são considerados na classe de baixo... só são só... o que eles mais valorizam são cinco só, da classe yuremawa [...]. Do nada surgiu esse yurema ainkt, essa cobra, lá no Wakaipani; só que ele afundou, 
foi lá para baixo, aí já pra separar essas classes, o chefe chamou para puxar eles [...], o nome do chefe era Kapuare makawane. Aí eles vieram, tentaram puxar, só que o braço deles era curto... outros suaram... aí foram dando nomes já, por causa disso... e foi dando nomes... puxando, puxando... aí esse que puxou a cobra para fora ficou como cabeça da tribo Yuremawa, Wiana Paramekt que conseguiu puxar. Dessa tribo que mora lá em Querari, são Wiana Parãmena, assim que foi, as divisões de classe... ele puxou ela para fora, em forma de cobra para cá e mulher para baixo. (Sublinhado meu)

Notamos que o termo usado em português para yahubo foi "classe", sugerido por Pedro Espitia, filho de Simão e que acompanhava essa conversa, usado na narrativa como sinônimo de "tribo". Em diagrama, temos o seguinte:

\begin{tabular}{|l|l|l|l} 
Irmão Maior & Irmão Menor \\
Makawane & Meçiwida & Dareakuni & Karemuwa \\
Classes consideradas & $\begin{array}{c}\text { Classe não- } \\
\text { considerada }\end{array}$
\end{tabular}

Figura 9: Lista de divisões Yuremawa citada por Simão (elaboração própria).

Mas essas listas não param aí. Geraldo Edson, Yuremawa de Querari, conta o seguinte:

Biowa já tem outra história, não vem do Hapuí. Tarabuawz vem do Hapuí. $\mathrm{Na}$ origem vão saindo de um buraco, aí começando de acordo com essa carreira, primeiro vai saindo irmão maior, depois menor, assim vai seguindo. A partir dali foram dividindo em cada grupo, o grupo desse Tarabuawt... desse... vários clãs de etnias aí. Viram que estava saindo muitos, dizem que Aviá [sol] fechou esse buraco original, conta a história. Dali foram divididos, e cada um foram para o lugar onde podiam ficar, foram expandindo, por causa do território, foram procurar diversos lugares, cada um foi para um canto; dessa forma que tiveram que dispersar do lugar de origem própria deles. Exceto que se eles ficassem originários do mesmo lugar, ia encher muita gente, não tinha como, então cada um tinha que ocupar o lugar diferente dele, que seja mesmo grupo; por isso que ele foi classificado de modo geral com primeiro grupo, segundo grupo, com irmão maior, menor, 
assim vai. Já também visando que cada grupo tinha que ter seu cunhado, para casar, por isso que foi dividido os grupos já aí. Yuremawa não pode casar com Tarabuawz, é irmão (amiyo) próximo deles; no caso, Tarabuawz são irmão maior nosso. Do Tarabuawu, irmão maior são esse Kapureda, subindo assim, maior deles, primeiro irmão, desse grupo aí, falante de Yuremawa. Mesma coisa também falante de Wanano, tem um grupo que é irmão maior deles, esse de Jutica, Ñahori, o maior deles; depois vão classificando para outro nível, mesma coisa. Esses Hupd'äh também têm sua classificação aí.

Geraldo Edson, casado com uma mulher kotiria, faz nessa fala uma analogia da divisão em "grupos" - termo que ele mesmo usa, falando em "primeiro grupo, segundo grupo" e "irmão maior, menor" - dos Yuremawa e aquela dos Wanano de Jutica, quem têm como irmão maior $\tilde{N} a h o r i{ }^{52}$; e lembra que os Hupd'äh também "têm sua classificação", num esforço comparativo mais amplo. Essa fala de Geraldo Edson, além de narrar a origem dos grupos, oferece ao mesmo tempo uma interpretação bastante pessoal aos eventos narrados. Segundo Geraldo Edson, são dois os motivos da diferenciação entre grupos e sua posterior expansão: em primeiro lugar, uma razão demográfica, a saber, a impossibilidade de uma concentração muito densa de gente numa mesma porção de território, devido, suposição minha já, sobretudo a falta de recursos para atender toda essa gente que surgia. Em segundo lugar, a necessidade de grupo de ter com que se casar, "ter seu cunhado". Voltemos às listas dos Yúri Parãmena.

Luiz Gilberto, acompanhado de seu pai Martins Gomes, falou sobre as divisões, os "graus de irmão maior e menor": "antigamente, Yuremawa e Yúriwawa formavam apenas um grupo, os Yúri Parãmena; depois se separam"; ao passo que Yúriwawa constitui um grupo, sem subdivisões, os Yuremawa se subdividem, "como uma cobra: os irmãos mais velhos são a cabeça, os do meio o corpo, e os menores a cauda". Ofereceu o seguinte esquema onde subgrupo "é como uma parte do corpo da cobra, assim como a cobra tem divisões em seu corpo, os Yuremawa também têm":

\footnotetext{
${ }^{52}$ Com efeito, Pedro Rocha em sua tese de doutorado confirma esse dado segundo o qual os Nahori conformam um grupo de "alta hierarquia" ou, nos termos de Geraldo Edson, "irmão maior", para os Kotiria (ROCHA, 2012, p. 68).
} 


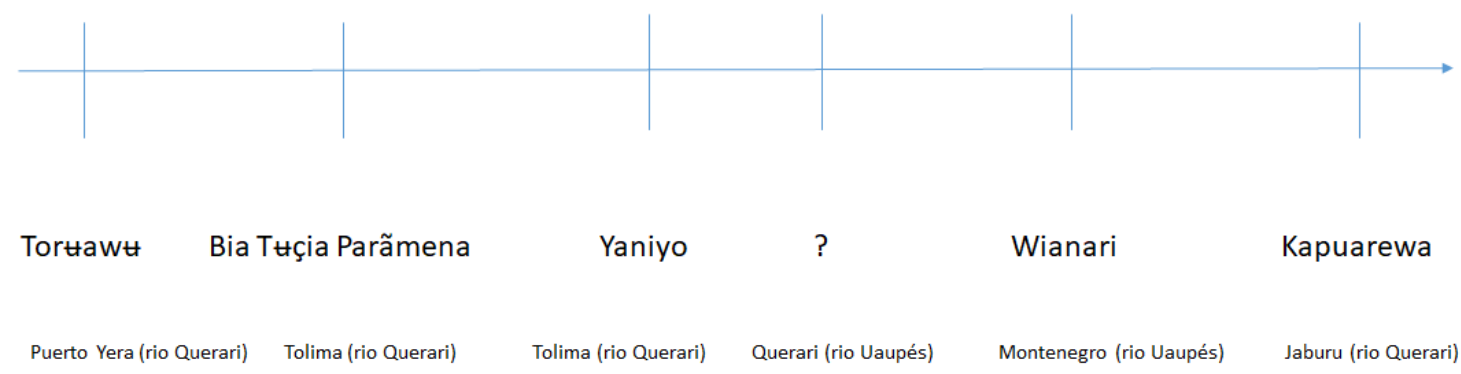

Figura 10: Lista de divisões Yuremawa de Luiz Gilberto (elaboração própria).

Nesse esquema, inseri junto com os nomes de cada subgrupo o nome da comunidade onde vivem atualmente a maior parte das pessoas do grupo. Luiz Gilberto explicou que dentro dos subgrupos existem "considerações" entre irmão maior e irmão menor, e que isso se dá tanto entre famílias como dentro das famílias, ou seja, em diferentes escalas; o pertencimento à um grupo ou subgrupo é dado pela linha do pai, não da mãe. $\mathrm{Na}$ mesma conversa, Luiz Gilberto ainda lamentou o fato dos jovens não conhecerem mais as histórias antigas e os pertencimentos; sugeriu mesmo que isso fosse ensinado na escola, pois com o desinteresse por essas considerações, perdem-se as relações de respeito com os irmãos maiores. Concluiu falando do sentimento de vergonha que alguns têm de falar de seu subgrupo, o que faz com que a pessoa assuma pertencer à um grupo que não é o seu, questão que veremos aparecer no caso do registro de nomes de benzimento (pupui amiya), a qual voltarei em outro momento.

O que podemos extrair em termos analíticos dessas listas de nomes de grupos e subgrupos? Em primeiro lugar, devemos notar a questão da escala, Yuremawa têm divisões e Yúriwawa não têm; Yuremawa, além das relações entre irmãos e famílias, é ordenado em “classes", "graus" ou "tribos", nas variantes terminológicas usadas por meus interlocutores. Yúriwawa, como disse José Bernardo, "é um só". Em segundo lugar, o vocabulário empregado para falar das coletividades: "classes", "grupos", "tribos" e "graus de irmão maior e menor". Tais categorias parecem apontar para uma ordenação de grupos com certa estabilidade, remetendo àquilo que Janet Chernela, entre outros, dizia: "rank positions are theoretically inherited and fixed" (1993, p. 135). Devemos ressaltar ainda que, acerca dessa questão das divisões internas, se nas listas acima elencadas podemos encontrar algumas diferenças sobre grupos citados ou não citados, vemos, contudo, que Kapureda e Yaniwa são 
destacados como o "irmão maior" e "último grupo", respectivamente, como na fala de José Bernardo, o que nos remete à formulação de Andrello, feita a partir da análise de dados Tukano, segundo a qual nessas listagens notamos flutuações e variações no meio, mas nos extremos parece haver certa estabilidade. Com efeito, segundo Andrello:

De acordo com os dados que disponho (fornecidos por homens de um clã de chefes), os Tukano correspondem a 47 clãs nomeados e agrupados em quatro blocos distintos, encadeados hierarquicamente de acordo com papéis rituais: 4 clãs compõem o bloco dos "irmãos maiores" (chefes), 18 clãs compõem o bloco dos "irmãos menores" (guerreiros), 14 clãs fazem parte de um terceiro bloco dividido entre especialistas em encantações xamânicas e cantos; por fim o último bloco é formado por 11 clãs designados como "preparadores de cigarros", isto é, os servidores. Há alguma controvérsia quanto à ordem interna dos clãs nos blocos intermediários (segundo e terceiro blocos), casos em que não é incomum que as pessoas expressem dúvidas sobre a posição correta ou o nome verdadeiro de seu grupo (2013, p. $3)$.

Mais adiante no mesmo texto Andrello sustenta que:

Porém, ainda que a ordem e composição daquilo que se passa na região intermediária dessa escala, em geral mais extensa, tenda a flutuar, variando de acordo com a posição e o conhecimento daquele que fala, há, por outro lado, um alto grau de consenso quanto aos nomes dos clãs que figuram nas regiões superior e inferior da escala hierárquica. Se o que se passa na zona intermediária dessa escala suscita frequentemente questionamentos, o que se passa em suas pontas superior e inferior não parece ser objeto de versões divergentes (ibid., p. 4).

Assim, lembremos novamente Janet Chernela, autora que avançou importantes análises acerca da categoria de hierarquia - e que não foi, parece-me, devidamente reconhecida pela literatura regional -, que já falava sobre uma suposta fixidez da ordem dos grupos, mas reconhecia a possibilidade de manipulação dessa ordem. Ao analisar o caso do conflito entre três grupos envolvendo o direito de uso dos recursos da comunidade de Bucacopa $^{53}$, essa antropóloga nos diz:

\footnotetext{
${ }^{53}$ Esse episódio descrito por Chernela (1993, p. 135-147) será retomado em detalhes mais adiante.
} 
Relative claims of the disputants aside, the Bucacopa situation exemplifies the wider contemporary problem of social disintegration among traditional tribal hierarchies. The disputing parties seek to manipulate sib order, but ideology dictates that sib order is fixed (1993, p. 141, itálico meu).

Desse modo, penso que tema da ordenação interna dos Kubeo na chave da hierarquia merece mais atenção. Antes de avançar, porém, o que tem sido chamado de hierarquia? ${ }^{54}$

A categoria de hierarquia tem mobilizado esforços de pesquisadores da região do noroeste amazônico. Com efeito, como foi formulado de modo preciso por Cabalzar, "a hierarquia é o principal mecanismo de produção de relações sociais, de geração de diferenças em todas as esferas da vida social; repercutindo em espaços, coisas, modos, pessoas. Como pensada e falada no noroeste amazônico tem inúmeras associações socioespaciais e sociocosmológicas" (2009, p. 337-338). A partir de discussões avançadas por parte ${ }^{55}$ da literatura etnológica regional, que sentidos foram atribuídos a essa categoria?

Em primeiro lugar, o corpus etnográfico considerado equaciona hierarquia com ordem de senioridade (ordem de emergência ou nascimento dos ancestrais dos grupos sociais). A partir disso, no caso de Goldman (1963; 1993), encontramos num primeiro momento uma imagem da hierarquia associada às noções de centralidade política e desigualdade na distribuição de recursos materiais e econômicos, imagem essa que leva esse antropólogo a afirmar que a vida social kubeo é constituída, em parte, de relações "fracamente hierarquizadas" (1963), ou então que os Kubeo, dada a ausência de centralização política e controle dos recursos econômicos, possuem uma "hierarquia elementar", isto é, "pré-política" e "pré-econômica", ou, outro termo usado por esse autor, uma "hierarquia ritual", dado tratarse de relações que se manifestam privilegiadamente em contextos rituais, sem grande

\footnotetext{
${ }^{54}$ Novamente, retomo brevemente minha dissertação de mestrado (PEDROSO, 2013) à qual remeto o leitor interessado numa discussão mais detida da categoria de hierarquia tal como operacionalizada na literatura etnográfica regional.

55 Digo "parte da literatura", pois meu material da pesquisa de mestrado consistiu sobretudo naquele referente aos povos tukano orientais. Uma síntese exaustiva da categoria de hierarquia operacionalizada na literatura acerca dos povos do noroeste amazônico, a saber, não apenas Tukano orientais, mas Arawak e grupos Naduhup, ainda está por ser feita.
} 
significação no cotidiano kubeo (GOLDMAN, 1993). É, em suma, por meio dessas formulações que Goldman resolve a aparente contradição entre a imagem herdada das tipologias do Handbook of South American Indians - segundo a qual na floresta tropical teríamos sociedades igualitárias (a hierarquia sendo uma característica própria das sociedades andinas) -, e uma aparente hierarquia kubeo observada em campo.

Contudo, é preciso ficar atento aos deslocamentos conceituais feitos nas etnografias de Goldman, visto que esse antropólogo opera uma reformulação da noção de hierarquia a partir de seu campo junto aos Hehénewa. Com efeito, na segunda monografia (2004) o autor tenta avançar uma teoria etnográfica ${ }^{56}$ da hierarquia, a qual parece ser entendida pelos Hehénewa como fundamentada numa "teoria das forças ancestrais" (teoria nativa do umé), e vista como relação que opera no nível das fratrias, sendo as relações entre sibs igualitárias; mas ainda aqui permanece a tese da pouca significação da hierarquia no cotidiano kubeo.

Essa imagem da hierarquia como baseada na ordem de senioridade é compartilhada, de modo geral, por Christine Hugh-Jones (1979) e, nessa linha, podemos colocar também os trabalhos de Stephen Hugh-Jones (1976; 1979; 1993), Jean Jackson (1983) e Kaj Arhem (1981). Também Dominique Buchillet (1983) parece pensar a hierarquia como relação própria aos contextos cerimoniais/rituais; assim, ao falar da especialização funcional e da ordem de nascimento/senioridade como os dois traços principais do "clã" ou "sib", essa autora afirma que

cette classification des clans selon l'ordre de naissance et une fonction espécialisée, ne semblait avoir de sens qu'au moment des rituels ou les membres de chaque clan devaint remplir pour les autres, le rôle qui leur était

\footnotetext{
${ }^{56}$ Uso o termo no sentido proposto por Marcio Goldman: "Uma teoria etnográfica não se confunde nem com uma teoria nativa (sempre cheia de vida, mas por demais presa às vicissitudes cotidianas, às necessidades de justificar e racionalizar o mundo tal qual ele parece ser, sempre difícil de transplantar para outro contexto), nem com uma teoria científica (cuja imponência e alcance, ao menos na antropologia, só encontram paralelo em seu caráter anêmico e, em geral, pouco informativo). Evitando os riscos do subjetivismo e da parcialidade, por um lado, do objetivismo e da arrogância, por outro, trata-se de encontrar o que Milan Kundera (1991: 78) chama de 'o soberbo ponto mediano, o centro. Não o centro, ponto pusilânime que detesta os extremos, mas o centro sólido que sustenta os dois extremos num notável equilíbrio’.

Mas é muito importante não se equivocar aqui. A diferença entre teorias nativas, etnográficas e científicas não repousa sobre uma repartição de erros e verdades, nem sobre uma suposta maior abrangência das últimas, mas sobre diferenças de recortes e escalas, de programas de verdade, como diz o historiador francês Paul Veyne. Que, aliás, também sugeriu que talvez não haja mesmo jeito e que é preciso escolher entre dar conta de pouca coisa muito bem - como fazem as ciências propriamente ditas — e dar conta não muito bem de muita coisa que é o que, afinal de contas, nós fazemos. Ou seja, uma escolha entre 'explicar muito, porém mal, ou explicar pouca coisa, porém muito bem' (Veyne 1978: 118), entre a explicação histórica ou humana ('sublunar', nas palavras de Veyne), que é na verdade uma explicitação, e a científica ou praxeológica. O máximo a que uma teoria etnográfica pode pois aspirar é explicar razoavelmente (no sentido de explicitar) um número relativamente grande de coisas. Em outros termos, seu objetivo central é a elaboração de modelos de compreensão de um objeto social qualquer que, mesmo produzido em e para um contexto particular, possa funcionar como matriz de inteligibilidade em e para outros contextos" (2006b, p. 170-171).
} 
imparti du fait de leur appartenance à tel ou tel clan. En d'autres termes, l'organisation fonctionnelle de cet ensemble de clans n'avait de sens qu'au moment de la vie cérémonielle ou rituelle, les clans ne fonctionnant de façon interdépendante que pendant celle-ci" (BUCHILLET, 1983, p. 76, itálico meu).

E prossegue dizendo:

L'appartenance à un clan de chef ou de serviteur, pour prendre les deux positions les plus extremes, ne se traduisait pas, dans la vie quotidienne, par un mode de vie différent des individus [...]. Le standard de vie entre clans de niveaux différents est identique en dehors du fait, néanmoins, que les clans de têtes occupaient l'aval de rivières repute comme plus prestigieux (ibidem).

A despeito das diferenças de orientação teórica subjacente aos trabalhos desses antropólogos, eles concordam na questão da relativa ausência de significações sociais de tais relações ditas hierárquicas que se manifestariam apenas em contextos rituais ${ }^{57}$.

Cito aqui alguns de meus dados de campo que mostram como tal imagem é questionável e como a ideia de senioridade manifesta na díade irmão maior e irmão menor está imbricada em práticas e falas do cotidiano. Certa vez, durante uma bebedeira de caxiri, conversava com Gabriel, Yúriwawa de Açaí. Em certo momento da conversa, já um pouco embriagado, ele falou de sua preocupação com o futuro da comunidade de Açaí, pois notava com apreensão a saída das famílias, e o consequente esvaziamento da comunidade. Afirmou que queria fazer algo para ajudar, para fazer a "comunidade crescer", mas como "Yúriwawa de último grau" não podia fazer muito. Falou que estava insatisfeito com "irmãos maiores", que não estavam fazendo tudo que podiam pela comunidade. Lembro que na noite anterior, enquanto bebíamos, Gabriel também enfatizara sua condição de "irmão menor", do "último grau" ou "última classe". O que tal fala nos mostra é uma compreensão segundo a qual a iniciativa de fazer algo em direção a uma melhoria da comunidade cabe antes aos "irmãos maiores", o que remete também ao fato bastante documentado na literatura etnográfica regional do chefe ser o irmão maior, ocupar posição de "alta hierarquia”. Lembremos, para citar mais um caso que, em Querari, na época da criação dessa comunidade, o lugar de chefe foi ocupado por alguém dito de alta hierarquia: Henrique Rodrigues, primeiro morador de

\footnotetext{
57 Stephen Hugh-Jones (1993), em artigo onde revisa o problema da organização social tukano e propõe uma nova categoria analítica para pensá-lo, a categoria lévi-straussiana de Casa, embora coloque hierarquia e igualitarismo em novos termos, não mais pensada como oposição, mas antes relações complementares, ainda insistirá na tese segundo a qual relações hierárquicas são da ordem dos rituais, e relações igualitárias da ordem do cotidiano.
} 
Querari, e filho mais velho de Francisco Rodrigues, que substitui o pai na chefia. Quando cheguei em Querari no ano de 2014 o capitão era Francisco, filho de Henrique ${ }^{58}$ e neto de Francisco Rodrigues, numa clara linha sucessória de chefia. Dito isso, retorno à reconstituição das imagens da hierarquia no Uaupés.

Além dessa primeira imagem geral da hierarquia (com os matizes que apontei), de outro lado, temos a imagem delineada por Janet Chernela (1993) que contestará a concepção da hierarquia enquanto modalidade de relação assimétrica atualizada apenas em contextos rituais, sem consequências de ordem sociológica e econômica.

Com efeito, Chernela argumenta que as relações hierarquizadas resultam em desigualdade no acesso a certos recursos, sendo aqueles grupos ditos de alta hierarquia os que teriam acesso a regiões ecologicamente mais ricas, mais "suculentas" (succulence) ${ }^{59}$, para usar o termo proposta pela autora. Contudo, Chernela, preocupada com a chave da oposição hierarquia/igualitarismo, mostra que tal desigualdade no acesso aos recursos não implica desigualdades de ordem social-material, isto é, essa desigualdade no acesso aos recursos é contrabalanceada pela distribuição dos recursos alimentares nas festas de troca, os dabucuris, que impede que se cristalizem desigualdades de ordem material e social. Assim, salva-se o velho topos do Handbook of South American Indians (1948) do igualitarismo das sociedades de floresta tropical sem recusar a existência de relações assimétricas subsumidas na categoria da hierarquia. Teríamos, de modo geral, duas imagens da hierarquia no Uaupés (como também aponta NEVES, 1998, p. 138-39).

Num quadro síntese, poderíamos representar graficamente as concepções de hierarquia do seguinte modo:

\footnotetext{
${ }^{58}$ Em minhas últimas viagens a campo observei um quadro oposto ao descrito acima que aguarda tratamento adequado; fica aqui o registro: em eleição realizada por volta de 2012, foi escolhido um Desano que não falava a língua kubeo, conhecia muito pouco das práticas e saberes kubeo e tinha mais familiaridade com espanhol do que com o português. Uma não Kubeo, portanto, foi escolhido para ocupar a posição que seguia até então uma linha clara: Francisco Rodrigues, Henrique Rodrigues e Francisco (filho de Henrique e neto do primeiro Francisco Rodrigues). A escolha do "capitão" ou "líder" - como se fala no português local - mediante eleição, difere daquela do chefe, ressoando uma distinção que Goldman (1963) formulou em sua etnografia entre habóku ("líder", "capitão") e kenámi upáku ("cabeça de maloca", figura associada a ideia de "chefe tradicional"). Pode-se encontrar uma qualificada discussão sobre as noções de "líder" e "liderança" no alto rio Negro em Iubel (2015).

${ }^{59}$ Voltarei a essa noção no capítulo final, ao tratar do tema dos nomes de lugares.
} 


\begin{tabular}{|c|l|l|}
\hline \multirow{2}{*}{$\begin{array}{c}\text { Hierarquia = ordem de } \\
\text { senioridade }\end{array}$} & $\begin{array}{l}\text { Hierarquia = modalidades de } \\
\text { relações assimétricas que se } \\
\text { manifestam, sobretudo, em } \\
\text { contextos rituais }\end{array}$ & $\begin{array}{l}\text { Irving Goldman (1963; 1993; } \\
(1979)^{60}\end{array}$ \\
\cline { 2 - 3 } & $\begin{array}{l}\text { Hierarquia = modalidades de } \\
\text { relações assimétricas que } \\
\text { implicam acesso privilegiado } \\
\text { a recursos econômicos }\end{array}$ & Janet Chernela (1993) \\
\hline
\end{tabular}

Tabela 3: imagens da hierarquia no Uaupés (elaboração própria).

Em suma, o que tentei mostrar na argumentação de minha dissertação (2013) é a resistência dos dados etnográficos uaupesianos ao serem subsumidos na categoria de hierarquia quando a mesma é entendida a partir de determinados pressupostos que podem ser localizados, ao menos, desde a publicação do Handbook of South American Indians (1948). Se essa categoria engloba um conjunto de relações assimétricas, tais relações necessitam ser explicitadas e conceitualizadas, e a própria noção de assimetria elaborada. A categoria de hierarquia, tal como aponta Márnio Teixeira-Pinto (2018) para a noção de alteridade, aguarda um tratamento analítico rigoroso das relações concretas que subsume. Voltemos às formulações dos Yúri Parãmena.

\section{As relações de parentesco contadas nas narrativas de origem}

Em texto sobre o parentesco tukano, Andrello questiona a imagem tradicional dos povos do Uaupés sustentada na literatura etnológica regional; assim, nos diz "tais fatos são, a meu ver, suficientes para ponderar em que medida os traços via de regra acionados para produzir uma imagem-tipo dessas sociedades - patrilinearidade associada à exogamia $e$ hierarquia clânicas - não seriam efeitos de um certo estilo descritivo adotado pela etnografia regional desde seu início, e em alguma medida tomado como não problemático em trabalhos mais recentes" (2013, p. 3, itálico meu), e propõe como alternativa "identificar a linguagem específica empregada em narrativas míticas para tratar dessas mesmas relações, buscando assim apreender outras imagens" (2013, p. 3). Essa proposta parte da seguinte hipótese:

\footnotetext{
${ }^{60}$ Indico aqui apenas os trabalhos de Goldman e Christine Hugh-Jones por serem os autores dos modelos mais influentes na etnologia do noroeste amazônico, mas poderíamos incluir também, como já apontei, Jean Jackson (1983), Buchillet (1983) e Arhem (1981).
} 
A hipótese que subjaz a esse experimento é a de que a gênese do parentesco humano é o problema central dessas narrativas, e que, de modo correlato, os processos internos a essa grande nuvem de relações sociais que cobre até hoje a extensa zona do médio Uaupés e seus afluentes Papuri e Tiquié, podem ser definidos como uma forma de mitopráxis (Sahlins, 1990) - ou talvez, eis o ponto, como uma cosmopolítica (ibidem, itálico meu).

Tal como sustenta Andrello, as narrativas de origem fornecem o idioma das relações de parentesco e entre os grupos; se Andrello sugere que "os processos internos a essa grande nuvem de relações sociais que cobre até hoje a extensa zona do médio Uaupés e seus afluentes Papuri e Tiquié, podem ser definidos como uma forma de mitopráxis (Sahlins, 1990) - ou talvez, eis o ponto, como uma cosmopolítica”, proponho ampliar essa hipótese para o alto Uaupés. Assim, devemos analisar primeiramente como a narrativa de origem kubeo, isto é, a versão contada pelos Yúri Parãmena, fornece esse idioma de parentesco. José Bernardo narra o seguinte:

Tem muito assim, entre os parentes [...]. Yuremawa são separados dos Yúriwawa, mas são parentes-cunhados; antigamente era um só, depois separou, até agora, ficaram cunhados, eles podem casar com nossas parentas e também nós a elas. Wanano também antigamente era primo-irmão para nós, os Yúriwawa, mas agora já deixaram de ser assim, mas alguns, não muitos, só que o Gabi ficou casado com Wanano, é o primeiro que fez essas coisas aí, mas não podia. Só que nosso cunhado era Yuremawa e Tarabuwz, só eles; com esses pode casar, eles também podem casar com os Yúriwawa. Tarabuwz e Yuremawa são irmãos entre eles, só que fica mudado o nome deles; Tarabuwz é irmão maior. Ele [Yuremawa] sempre chama de irmão maior para ele. Yuremawa não pode casar então com Tarabuwz; falam tios, primos-irmãos entre eles, irmã, irmão, é assim. Biowa são outra tribo, outro grupo. Yuremawa e Tarabuwz pode casar com eles, não tem problema, já são considerados como cunhados, outros tribos. Wanano com Yuremawa também não tem problema, são cunhados, desde o princípio até agora. Hehénewa para o [...] Yuremawa, podem casar entre eles. Mas esse Hehénewa para nós diz pakomá, assim considerando como parente. Já são outro grupo, tem outra origem, mas fala o mesmo Kubeo, mas já são outros; tem origem em Santa Cruz, no Waracapuri. Sobre a origem dos Yuremawa e Yúriwawa] origem é no Hapui, Tarabuwz, esse Kuripako, Baniwa, também saíram daí, mesmo lugar.

Segundo José Bernardo, "Yuremawa são separados dos Yúriwawa, mas são parentescunhados"; já os Wanano são "primo-irmãos” dos Yúriwawa. Tarabuwz e Yuremawa são 
irmãos entre ele, não podem se casar, portanto, mas podem se casar com Biowa, "outro grupo". Sobre os Hehénewa, diz que eles usam pakomá para se dirigir aos Yúriwawa. Aqui, um comentário. Os Kubeo comumente usam o termo pakomá para o que traduzem como "parente" ou "primo-irmão", isto é, aquele com quem não se casa. Certa vez, para citar ao leitor uma cena onde tal termo foi usado, na casa de Martins, chegaram José Bernardo e logo depois José, um velho Wanano de Jutica, num dia de bebida de caxiri. Notei que Bernardo, quando se dirigia a José, o chamava pelo termo pakomá. Para aqueles com quem se pode casar os Kubeo usam çima.

Em outra conversa, ainda a respeito das relações de parentesco explicitadas nas narrativas de origem, Geraldo Edson diz o seguinte:

[...] Yúriwawa não pode casar com Wanano; no caso Tariano também não pode casar com Wanano, são irmãos, no português chama de Tukano Orientais. Agora já é diferente, agora o Kubeo casa com Tukano e com Wanano, tem essa diferença de novo. Yuremawa pode casar com Yuriwakt também, na origem já viram que esse Yúriwaku com Yuremawa podia ser cunhado ("meu cunhado", hikoyzma), não tem erro esse aí. […] Em consideração, no caso, a consideração do irmão... esse... vem também daquele... como é.... a linhagem da mãe ou do pai, as vezes ele considera aquele grupo como irmão dele, ou como irmão maior ou irmão menor dele... dessa forma que não pode casar. Tem outros grupos que são... assim, como outros grupos já... então pode casar. No caso esse... do Cristo (Tariano), ele casou com a irmã maior dele, do grupo, de consideração deles, que é Wanano... então ele casou com própria linhagem dele, família... muitas vezes acontece assim... não podia, assim, vendo na origem já; muita gente tem essa forma mesmo, casa com próprio parente já, ninguém mais vê nessa linhagem do antigo, vai para questão do branco nessa parte, não segue mais. [...] A história de origem explica tudo, os lugares, onde estabeleceram... cada grupo... Henrique sabe tudo. Na história de origem explica... eles... esses grupos, já vieram junto com cunhados, na origem.

Aqui, Geraldo Edson elenca alguns casos de interdições de casamento com críticas dirigidas a certas práticas recentes que não observam essas interdições e as "considerações" devidas a cada grupo, e conclui apresentando uma afirmação que vai de encontro à hipótese de Andrello citada anteriormente: "A história de origem explica tudo, os lugares, onde estabeleceram... cada grupo", diz Geraldo Edson, "Na história de origem explica... eles... esses grupos, já vieram junto com cunhados, na origem".

Se representarmos as proibições de casamento elencadas até o momento por José Bernardo e Geraldo Edson em uma tabela, temos o seguinte: 


\begin{tabular}{|l|l|}
\hline Grupo kubeo & Casamentos proibidos \\
\hline Yuremawa & Tarabuwt, Desana \\
\hline Yúriwawa & \\
& Wanano, Hehénewa, Biowa \\
\hline
\end{tabular}

Tabela 4: Casamentos proibidos (elaboração própria).

Esses relatos sobre as relações de parentesco que se estabeleceram no passado e as interdições de casamento nos remetem a outra afirmação de Andrello (2013) segundo a qual:

Se há uma regra que pode ser considerada preferencial de casamento, dada, por sua vez, pela terminologia de parentesco de tipo dravidiano e pela regra de residência virilocal (um homem casa com frequência com uma prima cruzada patrilateral oriunda, idealmente, do mesmo grupo de origem da mãe), parece preponderar, sobretudo, uma regra negativa, que interdita o casamento com esposas pertencentes a grupos específicos. Os Tukano não se casam, por exemplo, com mulheres wanano, grupo com o qual mantêm uma relação considerada de consanguinidade (filhos de mãe). Afora isso, $o$ campo de opções matrimoniais é notoriamente extenso, permitindo a expansão de alianças, e, assim, uma inserção territorial ampliada (ibid., p. 2 , itálico meu).

Os casos de casamento que não observam as interdições e ordens de "consideração" dadas nas narrativas de origem são apontados pelos Kubeo como casamentos “errados”. Deste modo, José Bernardo, como vimos, dizia que "Wanano também antigamente era primo-irmão para nós, os Yúriwawa, mas agora já deixaram de ser assim, mas alguns, não muitos, só que o Gabi ficou casado com Wanano, é o primeiro que fez essas coisas aí, mas não podia”, e também Geraldo Edson destacou "No caso esse... do Cristo (Tariano), ele casou com a irmã maior dele, do grupo, de consideração deles, que é Wanano... então ele casou com própria 
linhagem dele, família... muitas vezes acontece assim... não podia, assim, vendo na origem já; muita gente tem essa forma mesmo, casa com próprio parente já, ninguém mais vê nessa linhagem do antigo, vai para questão do branco nessa parte, não segue mais”. Luiz Gilberto explicou:

[...] isso vai ser uma coisa humilhante, até agora... aí eu sempre digo para eles... de uma forma indireta, "mas como vocês vão educar seus filhos?"; até que educar a gente pode educar, do nosso jeito, mas como vamos educar e entrar no assunto de consideração de parentesco se a gente cometer esse erro? Como vamos usar uma estratégia... porque pelo que sei, para você ser educador você tem que ser exemplar primeiro, um exemplo real; então se tu já cometeu um grave erro, e não conseguiu ser exemplar, como você vai ensinar os outros? Mesmo que você pressione, seja... mas não... quanto mais ele for crescendo, um dia ele vai te dizer "como eu vou te ouvir, se próprio você faz isso? Só pega pesado, mas e você que fez isso, que anda fazendo isso?", daí que vem "ele também faz, por que a gente não fazer?". Isso... é assim que acontece. Então para reclamar, ou para tu ensinar, tem que ser exemplar. É isso que está acontecendo aqui na escola, se o professor bebe, o aluno também bebe. Se o professor reclamar, "não, os alunos não podem beber, não podem fazer isso", você vai se tornar um palhaço na cara deles; "ele que bebe", ele está falando a vergonha dele só, nem todos os alunos fazem a vergonha do professor... você se torna um palhaço só, não adianta reclamar de outra pessoa... "Por que você vem me falar disso? Por que não permite que eu saia com ela, tem problema?", o pai pode falar, "está errado, é sua prima", aí o filho, "e o senhor, ela não foi sua prima, qual o problema agora?". Então são coisas delicadas... há muitos casos assim... milhares... é aquela coisa que eu disse, hereditariedade, se o pai fez, alguém da família vai continuar com isso, nem todos... mas sempre um... aí disseram que o [cita um jovem yúriwawa] já fez o mesmo comportamento que o pai dele, foi chamado a atenção de modo indireto, não pelo pai, mas pelos outros. Aí o pai dele tinha me dito uma vez, "ele sempre responde: se você fez isso por que eu também não posso fazer? Eu gosto dela, ela gosta de mim; isso é problema nosso, não do senhor". Nesse caso, fazer o que? Se pressionar mais é briga; para pressionar você tem que ser limpo, tem que ver sua pessoa... antes de falar alguma coisa, você tem que ver a sua pessoa... ou não dá certo; mas disseram que já aconteceu isso, ele brigava com pai, quando chamava a atenção... "eu já cometi esse erro, eu assumo, mas você não pode continuar", o pai dizia... mas eles sempre brigavam, meu tio que conta isso... aí essa família sempre está assim.

Podemos ver essa questão do "casamento errado" no caso citado por Luiz Gilberto (que é o mesmo caso referido por José Bernardo anteriormente) no seguinte diagrama: 


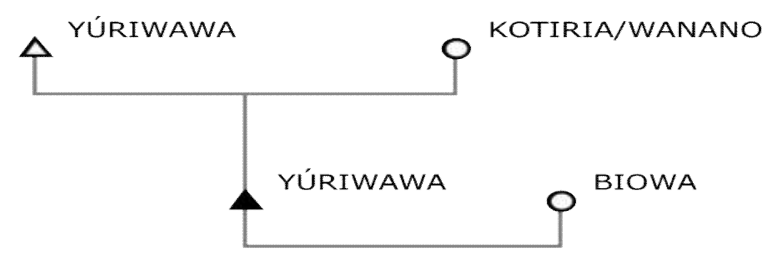

Trata-se de "casamento errado" em duas gerações, o pai yúriwawa que se casou com uma prima-irmã, Wanano, e o filho yúriwawa que se casou com uma Biowa, dois casamentos não permitidos segundo o idioma de parentesco das narrativas de origem Yúri Parãmena. Segundo Luiz Gilberto, o "casamento errado" é resultado de "desobediência ou desconhecimento das regras", as quais, como vimos, estão explicitadas nas narrativas de origem; é uma das principais causas de brigas e desentendimentos na família.

O dito "casamento errado" parece ter muitas implicações, uma delas, muito comentada e motivo de preocupação de muitos de meus interlocutores, é o não crescimento da pessoa. Crescer é fundamental para ser uma pessoa "saudável", "forte", dotada de vitalidade, "força", "energia". Não apenas os Yuremawa e Yúriwawa compartilham essas ideias sobre a centralidade do crescimento; já Goldman havia notado para os Bahúkiwa e os Hehénewa a importância de tal noção, a ponto de formular que haveria mesmo um conceito de crescimento (concept of Growth) subjacente a boa parte das práticas e falas bahúkiwa (1963, p. $277-278)^{61}$ e Hehénewa, como aquela da atribuição de nomes pessoais, assunto do próximo capítulo.

Segundo levantamento feito em 2014 nas comunidades de Querari e Açaí, obtive a seguinte configuração de casamentos:

61 Goldman destaca a centralidade para os Bahúkiwa da noção de crescimento, seja da pessoa, seja da comunidade, embora esse antropólogo afirme ser o crescimento corporal mais importante. Tal noção parece ser central para os Yuremawa e Yúriwawa também, em suas duas dimensões, como ficará claro ao longo de minha tese. A despeito de seu interesse, tal noção, salvo desconhecimento meu, quase não recebeu atenção da literatura etnográfica regional. Mais recentemente, Andrello propôs em projeto de pesquisa coletivo (2012, p. 15-17) voltar a essa ideia e explorar seu rendimento para entender as configurações sociais da bacia do Uaupés. Juntome a esse autor na ideia de que tal noção merece mais atenção, como insistirei ao longo de minhas descrições e análises. 


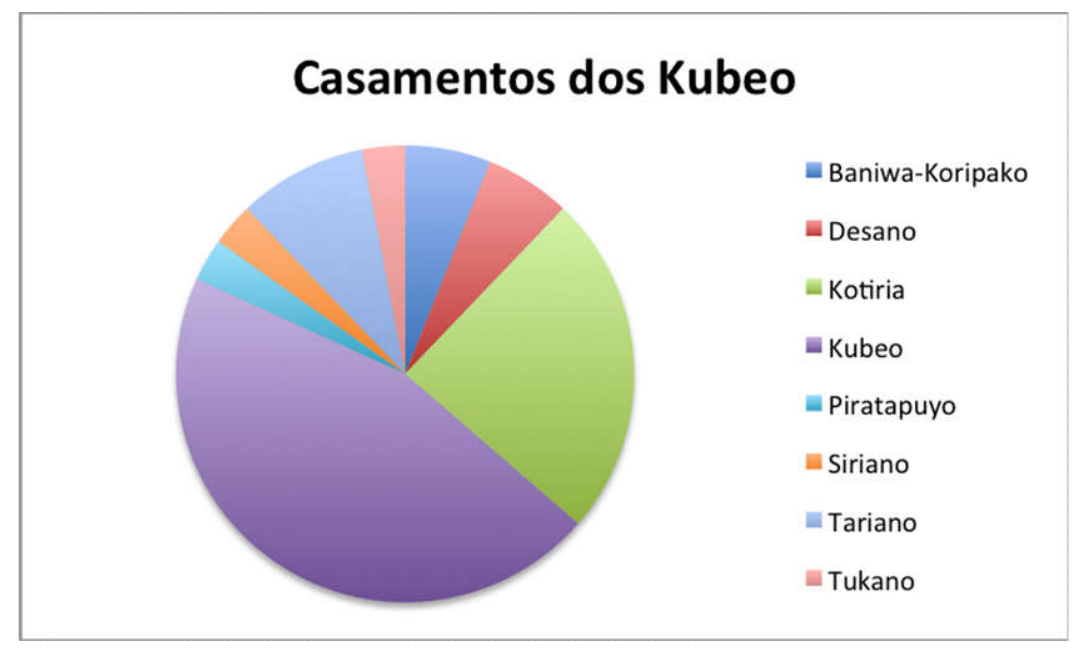

Figura 11: gráfico de casamentos kubeo (elaboração própria).

Nesse gráfico notamos que a maior parte dos casamentos se dá com outras mulheres kubeo pertencentes a grupos distintos. De um total de 33 casamentos, 15 foram realizados entre homens e mulheres falantes de Kubeo. Em seguida, vêm as mulheres Kotiria, com 8 casamentos; depois as Tariana, com 3 casamentos, Desana e Baniwa com 2 casamentos cada. Com um casamento apenas temos uma mulher Siriana e uma Piratapuya.

Uma representação separada por comunidade com uma lista dos principais grupos aos quais pertencem as mulheres com as quais os Kubeo de Açaí e Querari se casam, nos mostra o seguinte quadro:

\begin{tabular}{|l|l|}
\hline Açaí & Querari \\
\hline Baniwa & Baniwa \\
\hline Kotiria & Desano \\
\hline Kubeo (Tarabtawzt) & Kotiria \\
\hline Kubeo (Yuremawa) & Kubeo (Yuriwawa) \\
\hline Siriano & Kuripako \\
\hline Tariano & Pira-tapuyo \\
\hline
\end{tabular}




\section{Tariano}

Tabela 5: grupo das mulheres de Querari e Açaí (elaboração própria).

Importante destacar que não registrei nenhum caso de casamento dentro do grupo, isto é, os casamentos ditos "errados" dizem respeito ao rompimento da interdição de casamento com grupos considerados "primos-irmãos", mas não se casa com aqueles que compartilham o mesmo nome de grupo; não há casamento de Yuremawa com Yuremawa, ou Yúriwawa com Yúriwawa.

Voltemos nossa atenção agora para certa sobreposição que encontramos na literatura, problemática quando consideramos o caso dos Yúri Parãmena: penso na identificação que comumente se faz entre grupo e língua. Como mostram Chacon e Cayón (2013), há uma visão canônica na literatura etnográfica regional que reforça a sobreposição "língua-povo" e pode ser encontrada no trabalho de Sorensen (1967), retomada nas etnografias de Jean Jackson (1983) e Janet Chernela (1993) ${ }^{62}$. Com efeito, Meira (2017), para citar uma formulação recente e enfática de tal visão, afirma a sobreposição grupo e língua, dizendo:

Ou seja, a língua proporciona a base da identidade e as diferenças linguísticas as possibilidades matrimoniais: casa-se somente com alguém que "fala diferente". Unidades linguística e exogâmica, portanto, são coincidentes (2017, p. 39).

\footnotetext{
62 “A expressão máxima da relação entre língua e identidade no Noroeste Amazônico foi classicamente definida por Sorensen (1967) para as línguas Tukáno Oriental. Ele analisa a língua como um elemento co-extensivo da associação de um indivíduo a uma linhagem patrilinear. Todo indivíduo, nessa Região, pertence a uma unidade de filiação patrilinear que está estruturada desde as famílias nucleares até um clã nomeado. Um conjunto de clãs formam uma unidade social mais ampla, a qual chamamos de grupo étnico. Os grupos étnicos também são nomeados, por exemplo, os Desáno, Tukáno, PiraTapuya, etc., os quais foram chamados de tribos por Sorensen. Cada grupo étnico possui um ancestral mítico em comum, um território, uma língua, bens rituais, uma maloca particular de nascimento mítico, cultivares e conhecimentos xamânicos próprios, entre outros, assim como um conjunto de mitos e etnohistórias que são compartilhados entre os diferentes clãs. Um conjunto de grupos étnicos constitui uma fratria, não nomeada, a partir de ancestrais míticos relacionados por consanguinidade, e estão agrupados de forma hierárquica em ordem de senioridade (irmão mais velho, irmão mais novo, etc.) Sorensen (1967, assim como Brüzzi 1977) aponta que o denominador comum de um grupo étnico é que os indivíduos desse grupo não casam entre si, ou seja, cada grupo étnico é uma unidade exogâmica. Isso enquadrase em uma visão mítica nativa em que os diferentes clãs do grupo possuem um ancestral em comum, fato que os coloca como 'irmãos'. Um outro elemento apontado por Sorensen é o fato de cada grupo étnico ter sua língua própria. Por essa razão, as famílias nucleares são - pelo menos - bilíngues, pois esposo e esposa falam necessariamente línguas diferentes. É esse tipo de associação 'língua-grupo étnico' que está na base da noção de exogamia linguística. Jackson (1983) aprofunda essa relação ‘uma língua - um povo' e reformula a ideia de tribo de Sorensen, para então se referir a language group ('grupo linguístico') para a unidade social que neste artigo são chamados de grupo étnico" (CHACON \& CAYÓN, 2013, p. 9-10).
} 
Contudo, se é assim como fica o caso dos Kubeo? Nesse encontro entre "Unidades linguística e exogâmica", apresentado como "regra", os Kubeo configurariam a "exceção". Ora, será esse par "regra/exceção" apropriado para entendermos o problema dos casamentos e da relação entre noções de língua e grupo? Se tomarmos a sério o que dizem os indígenas a resposta é negativa. Os Kubeo se casam entre si, mas trata-se, como vimos, de grupos distintos, que têm em comum a língua e, no caso de alguns grupos, uma mesma tradição narrativa de origem. Assim, se encontramos formulações na literatura sobre os Kubeo como “exceção", "atípicos" etc., podemos afirmar que os Kubeo não se pensam assim; com efeito, "exceção" para quem? Quem determina a "regra" e a "exceção"? Como vimos, o casamento entre os grupos kubeo é dado pelo idioma do parentesco fornecido pelas narrativas de origem, e o que importa, do ponto de vista Yúri Parãmena, é a atenção dada a esse idioma explicitado nessas narrativas, é a observância das interdições ou seu desrespeito por meio do "casamento errado" que resultará em crescimento - ou não - da pessoa e da comunidade. A exogamia kubeo não é linguística, tal como parece ser o caso para outros grupos tukano; eis, portanto, que essa sobreposição entre grupo, língua e exogamia não pode ser generalizada como "regra" ou "padrão" no alto rio Negro.

Disse acima que os diversos grupos kubeo compartilham uma mesma língua. Mas até mesmo essa ideia de uma "língua comum" precisa ser revista pois, como veremos, os Yúri Parãmena falam uma língua que não seria a deles propriamente dita, e apresentaria diferenças em relação a falada por seus portadores originais, os "Kubeo puros", "verdadeiros". Vejamos em mais detalhes esse tema.

Sobre o casamento entre pessoas que falam a mesma língua, Geraldo Edson oferece uma leitura que merece nossa atenção:

Kapureda, Meçiwida... tem vários grupos... dentro de Kapureda tem vários grupos... divide. Wiana Parameno... tem vários grupos Yuremawa... tem Piađawa também... último grupo dos Yuremawa... tem vários grupos. Acho que não tem diferença, só muda... como se diz... vamos dizer, uma árvore genealógica, essa linhagem deles, esses falantes aí... mas são falantes de mesma língua, não tem diferença não, a mesma origem [...]. Nosso grupo é Meçiwida. De Jaime é Kapureda, são lá de Jaburu, são de lá, esse grupo vive lá; eles são misturados também, poucas pessoas são Kapureda, poucos são outras línguas também, casaram com mulheres de lá também, aí vieram e ficaram com eles, então vêm outros falantes de língua também; no caso, agora, os filhos casam com Karapanã, com Tatuyo... já vão modificando o grupo... vai mudando... aí deles já falam a língua da mulher, a mulher fala língua do marido... vai mudando.... [...]. Por isso que antigamente um grupo podia casar só com falante daquele grupo mesmo, para não perder a 
linguagem, a fala deles; no caso, esse Tukano, tem outros grupos tukano maiores, e menores dele, então podia casar com falante de tukano também, não podia perder a língua deles. Agora não... casa com falante de outra língua... vai mudando. Acho que era como uma ditadura nesse tempo, não podia casar com outra... hoje está todo mundo mudado... mesma coisa, esse falante de Wanano, ele podia casar com aquele que fala wanano; acho que os velhos queriam manter a tradição, tanto a língua, tanto o costume, queriam manter acho; por isso que tinham essa forma de tratar entre eles. Wanano casavam entre eles antigamente, mas de outro grupo, falante de Wanano, sem ser o parente próximo deles, tem que ser outros grupos, falante da mesma língua. Mesma coisa esse pessoal dos Yúriwawa, Kubeo pode casar com pessoal dos Yúriwawa, eles são falantes da mesma língua, mas já vieram como cunhados, dessa forma outros grupos também... com isso mantinham suas línguas, os filhos já vinham falando essa língua dele. Não podiam perder essa fala deles. Hoje a gente perde muito a língua, outro fala a língua da mãe, outro deixa de falar língua do pai, outro deixa de falar língua da mãe... para evitar isso, eles inventaram essa forma de ter como cunhado deles [...]. Agora aquele que cresce com o pai e fala só uma língua dentro de casa, ele fala bem, pode ver, nessas comunidades distantes, ele fala bem a língua dele, tanto do pai, da mãe. O que influencia mais agora é a questão da televisão, fala mais já na cópia do português. Tem o adulto que tem vergonha de falar a língua dele, não quer mais falar a língua dele... mesma coisa a menina, ela fala bem, mas não quer falar.

$\mathrm{Na}$ fala de Geraldo Edson, vemos a tese segundo a qual antigamente se casava no mesmo grupo com o propósito sobretudo de manter a língua, a diferença se dava por subdivisões no interior do grupo. Geraldo Edson parece formular uma espécie de endogamia generalizada pretérita, que em certo momento muda com a realização de casamentos entre falantes de línguas distintas. Tal mudança resultou, segundo esse yuremaku, na situação atual onde muitos não falam mais a língua do pai, e em alguns casos nem a da mãe, falando apenas o português. Fica também explícita nessa fala de Geraldo Edson a centralidade da língua como operador de diferenciação.

Quando se trata de pensar diferenças entre grupos kubeo há algumas noções que são manejadas pelos Yúri Parãmena. Uma delas, muito frequente, é aquela que opõe a ideia de "Kubeo puro" ou "próprio Kubeo" aquela de "imitação", distinção essa recorrente nas falas kubeo. Assim, os Yúri Parãmena se dizem "cópia” ou "imitação" de outros grupos kubeo, como os Hehénewa, tidos como "Kubeo puro". Essa oposição se baseia sobretudo na língua, elemento, como vimos na fala de Geraldo Edson, de diferenciação. É esse mesmo yuremaku que explica a ideia de "Kubeo próprio" ou "puro": 
Kubeo próprio, originário, são esses de cima aqui. No caso, nossa língua é essa de Baniwa e Kuripako; mas como tiveram essa viagem feita por causa da terra, do território, então eles vieram para cá, desceram esse rio, tiveram que adotar essa outra língua que a gente fala atualmente. Quando a gente morava para lá, Ayari, nosso território mesmo, a gente falava outra língua, o Kuripako; aqui estamos vivendo emprestado, essa terra é dos Wanano, eles emprestaram essa terra para os Yuremawa, ele viu que a gente não tinha nada, então fez questão de emprestar; por isso que tem um pedaço falante de Kubeo, e outra falante de Wanano. Agora nosso mesmo é nesse rio Ayari. Eles [kubeo da Colômbia] falam o Kubeo próprio, língua originária deles, não adotaram outra língua. Agora nosso não, a gente falava esse Kuripako misturado com Baniwa, e chega até aqui, adotamos essa língua deles já, ou seja, eles casaram com originário falantes dessa língua, e tiveram modificações na língua já, como agora tá acontecendo, a gente casa com Wanano, com Tukano, então a gente fala mais dotado a língua da mulher já, vai deixando o lado do pai, assim que acontece nesse território para cá. Por isso que tem várias pronúncias, original mesmo tem outra pronúncia, na Colômbia é diferente, idioma deles é diferente; aqui a gente fala mais especificando... e tem palavras diferentes também [...]. Era um grupo só antes, viram que tinham que ter cunhado, Yuremawa e Yúriwawa viram que não tinham cunhado, tiveram que negociar, dar a mulher e vice-versa, para ser chamado de cunhado [...]. No rio Querari tem mistura, tem Biowa, tem Tarabuawz, tem Yuremawa, tem Wanano também, tudo misturado aí, não é só um clã; uns casaram com outras etnias, aí já vem falante dessa língua, outro já casa com falante de outra língua, já vão modificando a língua deles aí.

Desse modo, os Kubeo contam que a língua falada atualmente não é a língua original. "Kubeo próprio, originário, são esses de cima aqui", diz Geraldo Edson se referindo aos Kubeo do alto Uaupés colombiano, sobretudo os Hehénewa. "No caso, nossa língua é essa de Baniwa e Kuripako", emenda. É uma ideia constantemente afirmada essa de que a língua original seria uma variação do Baniwa ou Kuripako. "Quando a gente morava para lá, Ayari, nosso território mesmo, a gente falava outra língua, o Kuripako”. Na sequência de sua fala, relembra que o território onde vivem atualmente não é próprio dos Yuremawa, foi antes emprestado pelos Wanano, "aqui estamos vivendo emprestado, essa terra é dos Wanano, eles emprestaram essa terra para os Yuremawa, ele viu que a gente não tinha nada, então fez questão de emprestar". Tal como o lugar onde se vive - a "terra", o "território" - é "emprestado", a língua falada atualmente pelos Yuremawa (e Yúriwawa) não é própria, e sim "emprestada".

Há narrativas que contam como se deu essa perda da língua original. Eis uma narrativa de José Bernardo que explicita como isso aconteceu: 
Yuremawa e Yúriwawa falavam igual esse Baniwa, mas já... não como língua própria do Baniwa, algumas palavras saíam deles mesmos, outras eram diferentes. Aí essas tribos... Antigamente os brancos chegaram aqui, perseguiram eles, então foram embora para baixo, não sei para onde, aí eles deixaram um menino, de uma semana, muito pequeno, a mãe dele era Kubea. Aí eles deixaram, era menino. Foram embora, todo mundo, ninguém ficou aqui. Ele cresceu com o tio dele, e ficou falando com Kubeo, aí ele aprendeu a falar com Kubeo, nem sabia a língua do pai dele, aí esquecemos a língua. O único que ficou aqui cresceu com a mãe, tios, primos, assim. Ele começou a falar, aí o tio dele, quando já ficou com 14 ou 12 anos, ele já começou com a história deles, "vocês são eles, são yuriwakt, os pais, vovôs antigos são assim, vocês... eles foram embora, você era criança, você ficou com sua mãe"; ele contou tudo para ele. Ele cresceu, teve mulher dele, nasceram os filhos deles... aí eles vêm assim crescendo até agora. [...] diz que irmã de Horácio [ex-morador de Açaí] encontrou uma yuriwakó, tinha uma comunidade para baixo aí... lá no baixo... no rio Negro, abaixo de São Gabriel, rio Marié [...]. Esse grupo que foi embora fala a língua original.

Como vemos, a narrativa fala da partida do grupo falante da língua original, ficando apenas uma criança ainda com uma semana de vida, filho de uma mulher kubeo. Essa criança cresceu com a mãe, o tio e os primos, e aprendeu a falar o Kubeo. Quando tinha entre 12 e 14 anos o tio conta a ela sobre o grupo que foi embora, ao qual pertencia seu pai. Desse modo, deixou-se de falar a língua original.

A língua aprendida é dos Kubeo cujo lugar de origem é em Santa Cruz, na cachoeira de Waracapuri, no rio Uaupés, ou seja, é língua de grupo cuja tradição narrativa de origem é distinta. Sobre essa língua aprendida, Geraldo Edson diz o seguinte:

Já é outro grupo, tem a história deles; origem deles é em Santa Cruz [...]. No caso, esse pessoal lá do Cuduyari, eles são falantes desse Kubeo, eles são falantes originais, da língua própria, eles falam, já falam melhor que a gente a língua... esse Kubeo. [...] essas palavras [do benzimento] vem mais da questão do Baniwa e Kuripako, misturado, que era a língua original deles. Por isso que meu avô finado dizia, nós somos Makapãwã, Kuripako; deixamos nossa língua original e falamos essa língua agora, copiado desse de cima, esse Cuduyari. Outras línguas, a gente dá nome mais na questão do Kuripako mesmo, tanto no peixe, tanto do animal, a gente usa mais do Kuripako, não é mais do nome original do Kubeo, é língua original nossa que estamos dando nome. Não tem nem diferença o Tariano, ele fala a mesma língua desse Kuripako. Agora não sei língua própria dos Kubeo, como seria esses nomes... ninguém sabe também, a gente usa mais parte desse Kuripako. Por isso que referente a outros nomes, a gente tem muitos... muitos nomes diferentes em relação ao kuripako também, meio misturado do Tukano mesmo e esses Baniwa também, a gente usa. [...] meu avô finado falava bem o Kuripako [...]. Em Tapuruquara, vivia nosso avô finado, que era falante original do Baniwa mesmo, a gente sempre chegava lá, ele só comunicava com língua dele mesmo, Baniwa mesmo; em consideração dele, chamava ele de nori, cunhado dele, consideração cunhado dele. 
Como destaca Geraldo Edson, muitos dos nomes kubeo são em "língua antiga", que ele diz ser o Kuripako. Voltarei a essa afirmação de Geraldo Edson no próximo capítulo, quando examinarei os pupui amiya (nomes de benzimento) Yuremawa e Yúriwawa. Aqui, gostaria de insistir nessa chave de distinção que opõe "original" e "cópia", e seu caráter, ao meu ver, assimétrico.

A relação Yúri Parãmena e Hehénewa, como vimos, se coloca na chave "puro Kubeo" e "imitação", relação essa, em termos metafísicos, assimétrica. Digo em termos metafísicos pois a língua é considerada pelos Yúri Parãmena, e pelos Kubeo de modo geral (GOLDMAN, 2004, p. 345 e ss.), elemento importante da "força" ou "vitalidade" do grupo; deixar de falar a própria língua é, em certo sentido, diminuir sua "vitalidade"63.

Se os Yúri Parãmena se colocam como "imitação" dos "Kubeo verdadeiros" do rio Uaupés acima e Cuduiari, sendo o fato de falar uma língua emprestada o operador central dessa diferenciação, qual o lugar dos Betowa que, como já enuciamos mais de uma vez, são vizinhos dos Yuremawa e Yúriwawa, e se designam também como Kubeo?

A relação entre os Yúri Parãmena e os Betowa, parece-me, se coloca em outra chave. Não mais "Kubeo puro" e "imitação", mas antes "próprio do lugar" e "forasteiros". Além de serem considerados como moradores recentes da região, um grupo "de fora", "estrangeiros", provenientes do igarapé Abiú (acima de Mitú, na Colômbia) são também tidos como irmãos menores distantes na ordem de consideração ${ }^{64}$. Sobre os Betowa, José Bernardo conta:

Esses Betowa são de outro lugar; esse Betowa que está aqui não têm história deles, o avô deles cresceu com outras tribos, aí ele não sabe história deles; só que essas pessoas só pensam no Wakaipani, só que não nasceram aí, foram

${ }^{63}$ Desenvolverei com mais detalhes essa metafísica kubeo, assentada na noção de umé, nos próximos dois capítulos.

${ }^{64}$ Algumas versões das narrativas de origem, como examinarei no capítulo sete, ao tratar de conflitos envolvendo lugares, falam dos Betowa como "criancinhas", o que acentua a distância entre eles e os Yúri Parãmena. 
lá no alto Uaupés, acima de Mitú, lá tem outras tribos betowa, que são legitimamente eles; esses que estão aqui em Puerto-Colombia não são legítimos, são assim considerados como Betowa, menores, parentes deles. O que está para lá, no Upiaria (Wirawaçu) são legítimos Betowa, eles sabem toda a história deles. Essa língua é língua geral (Wirawaçu), antigamente a maioria falava língua geral aqui, o pessoal, brancos, aí todas essas que estão acima, cachoeiras etc. são em língua geral, como Macucu, Naná, Vila Fátima, Tucunaré, Itaiaçu, Santa Cruz, Tatú, Mitú também é com língua geral, até acima, até Yurupari. Aí chegaram os colombianos, aí perguntaram para os antigos indígenas como se chamavam, e eles disseram com língua geral, aí os colombianos aprenderam chamar com esse nome aí.

Vemos nessa fala a formulação de uma relação entre os grupos Betowa semelhante aquela entre Yúri Parãmena e outros grupos kubeo cuja origem é na cachoeira de Waracapuri, a saber, os grupos betowa do alto Uaupés colombiano são "legítimos", os que vivem em Querari e Puerto-Colombia "não são legítimos, são assim considerados como Betowa menores, parentes deles". A mesma chave de diferenciação, portanto: "verdadeiro" / "imitação" e "legímito" / "não legítimo". No caso Yúri Parãmena e Betowa, a chave é "do lugar" e "forasteiro". Avancemos.

Na mesma conversa com José Bernardo sobre os Betowa, ele emendou:

Eles ficaram aqui para sempre. Foram ficando. O meu pai finado falou que antes, quando éramos como esse meu filho Masá [jovem], eles não estavam, não tinha; "até quando eu fiquei já casado com minha mãe [de Bernardo], aí ele chegou", meu pai falou. Esse igarapé abaixo de Mitú... Cuduiari, aí que mãe dele levou, ele cresceu, e quando já era jovem ele veio para cá, chegou aí, fez casa e ficou. Ele falava "sou descendente dele". Depois ele teve 4 filhos: Simão, Otávio, Antônio, Gustavo, e uma mulher, que está em Taracuá, essa mulher do pajé, Sakú, ela é betokó. [...] fizeram comunidade em Yauaretê-Ponta. Aí Otávio ficou com crente, e pessoas desse lado bebiam caxiri, então ele deixou, e foi embora para outro lado, onde está agora os filhos dele; ele não tomava nada desse caxiri, nem fumava tabaco. Até... sendo crente mesmo, ele morreu. Os filhos dele que antigamente também não tomavam... depois, enquanto estavam os pais, os filhos deixaram de ser crentes e ficaram tomando, até agora [risos].

Aqui, José Bernardo narra episódio que já detalhamos no capítulo anterior: a criação de Yauaretê-Ponta e posterior conflito, resultando na divisão dos Betowa com a criação de Puerto-Colombia, no lado colombiano do rio Uaupés. O que merece atenção nessa narrativa é a insistência de José Bernardo em afirmar a chegada recente desses indígenas ao lugar onde 
então criaram Yauaretê-Ponta: "Eles ficaram aqui para sempre. Foram ficando. O meu pai finado falou que antes, quando éramos como esse meu filho Masá [jovem], eles não estavam, não tinha”. Jaime Gomes, velho Yuremawa, arrisca a seguinte explicação para a origem dos Betowa:

[...] Esse Betowa... não sei... não tem origem aqui... não sei como antigo avô deles... quando matava tudo, e tirava uma criança, trouxe esse yuremakt, aí ele criou, avô dele aqui mesmo, ele criou, aí ele casou aqui em Taracuá, aí formou família; ninguém sabe a origem dele. A língua deles é Kubeo. Meu pai que falava... eles criaram, esses Yuremawa, o avô deles...

Já outro interlocutor yuremawa contou o que se segue a respeito dos Betowa e que se aproxima da fala de José Bernardo:

Betowa? É uma questão... nós, historicamente, realmente, não temos nada a ver... talvez eles sejam dos Wanano, dizem... mas eles se originaram lá, acima de Mitú, lá que é o lugar deles... eles vieram de lá... são meio que perdidos... voaram muito alto, se perderam. O certo mesmo é que chegaram, se fizeram de mansinho, fizeram uma forma de convencer para não morrer, iam ser secretários, "eu vou trabalhar com vocês... deixa que eu faço", para ganhar confiança do grupo. Então se tornaram um escravo, na verdade se tornaram secretários, empregados, nosso grupo se tornou chefe deles, pediam para fazer alguma coisa, eles já faziam; mas fizeram isso só para não ser acabado com eles... então o grupo passou a valorizar eles, defender eles... "não, que esse aí é meu secretário", não significa que é parente... já é diferente. Então já isso... essa relação, para eles se tornou... eles colocaram uma afirmação dizendo "a gente é irmão deles", aí eles passaram a ter força dizendo "nós somos os últimos deles, eles são nossos irmãos maiores, somos os últimos"; então é uma história recente, não é da origem, já é uma nova história, um novo testamento. Por isso que eles consideram a gente irmão maior deles. Mas, tu pode fazer várias perguntas para eles, "onde surgiram os Betowa?", então o homem vai começar a contar lá, no alto Mitú, Uaupés, então por que eles surgiram lá? E por que os netos de Yúri não surgiram lá? Ou deixaram alguma coisa marcada lá, nesse local, fizeram uma volta lá, nesse local; com certeza eles não vão te explicar nada. Eles nunca vão chegar a uma resposta... você não vai conseguir um ponto compatível com o nosso. A nossa origem é lá no Hapuí, lá que a gente originou, e nessa história você nunca vai ouvir uma parte dos Betowa, não tem, a história nunca vai falar dos Betowa, não consta... não consta mesmo, muita gente não sabe disso. Mas eles dizem que são parte da gente, do nosso grupo, mas por que a gente não sabe então? Se fossem parte de nosso grupo, o ultimozinho de nosso grupo, a gente saberia; meu pai não sabe, meu avô não sabia, nunca me falou; mas ele sempre dizia "não, eles quiseram ser do nosso grupo, mas só porque eles tinham medo, não queriam ser 
arrebatados", fizeram o possível para se aproximar e ganhar confiança, porque senão a gente ia acabar com eles, a gente era um grupo doido, a gente não deixava se aproximar... um grupo dos bravos mesmos. A gente era assim... também eles estavam sendo exterminados por outros... mais grupo de Kuripako, associados com Baré, aliança deles... então estavam sendo exterminados, e procuraram um refúgio, a gente era o refúgio deles. Eles preferiram um muro para proteger eles, aí se sentiram mais à vontade, protegidos; muitos foram exterminados [...]. Então essas pessoas, realmente não fazem parte... mas eles não gostam de ouvir essa história, se a gente começar a falar, é briga [...].

Otávio mesmo... esse já era outro... Abelardo já era filho de outro... na verdade, o pai foi expulso, saiu deles, parece que era irmão maior. O pai do Abelardo preferiu sair, percebeu que não ia dar certo, separou deles, se tornou independente, do que morar junto. Eu acho que Abelardo teve mais ideia que o pai dele, preferiu já abrir espaço para ele, e para o futuro do filho dele. Eu vi que se Abelardo não segurasse a barra, era capaz de ser esquecido da história... porque na verdade, essa palavra "Betowa", na história dos Yuremawa, ela não está escrita, talvez ela pode ser esquecida... pior se ele não tivesse esse comportamento... ele não tá sendo considerado, até agora não tá ganhando nenhuma consideração... mas ele fica implicando "Betowa são assim... nós viemos de lá...", mas uma versão sem sentido; então se ele fala assim, está revelando que é outro grupo, outro grupo que não tem nada a ver, ele é só hóspede na área. É por isso que sempre dá isso, cada um fala sua história, ele também tem que falar a história dele, e como ele é hóspede, para ele é ofensivo dizer que "não, Yúri Parãmena é assim... assim... que nós é assim...", aí ele começa a falar a história dele também, "não, que nosso avô dizia que Yuremawa é assim...", por isso que pegam pesado com Abelardo, às vezes ficam chateado com ele, "ele está falando besteira aí", às vezes se mete na conversa dos velhos, atrapalha eles. Mas isso não vai ser só com velhos não, isso vai ser para sempre.

Essa fala manifesta um conflito latente entre os Yúri Parãmena e os Betowa. Meu interlocutor oferece uma versão explicativa de como se deu a chegada dos Betowa na região: inicialmente, se colocaram como "escravos", "empregados", postura adotada como estratégia para ganhar a confiança dos Yúri Parãmena. Dessa primeira aproximação passaram a se colocar como "irmão menor" dos Yúri Parãmena, o que, segundo meu interlocutor, concedeu a eles alguma "força". Mas essa história é "recente", não é da "origem”, dado que nas narrativas de origem, ainda segundo meu interlocutor, não há menção ao nome Betowa. É essa insistência betowa em particpar das narrativas Yúri Parãmena fonte de conflitos e desentendimentos, "às vezes ficam chateado com ele, 'ele está falando besteira aí', às vezes se mete na conversa dos velhos, atrapalha eles", diz meu interlocutor referindo-se a certo Betowa. Não é apenas a participação na narrativa de origem Yúri Parãmena que os Betowa reclamam. Afirmam também que, tal como os Yuremawa, apresentam uma configuração de subdivisões, ou "linhas de consideração", como me disseram, o que os aproximaria. Vejamos. 
Em visita a comunidade de Puerto-Colombia, o betoku Rafael (um dos filhos de Otávio, o fundador da comunidade) me falou que, tal como os Yuremawa, os Betowa também têm subdivisões, as quais podem ser representadas no seguinte diagrama:

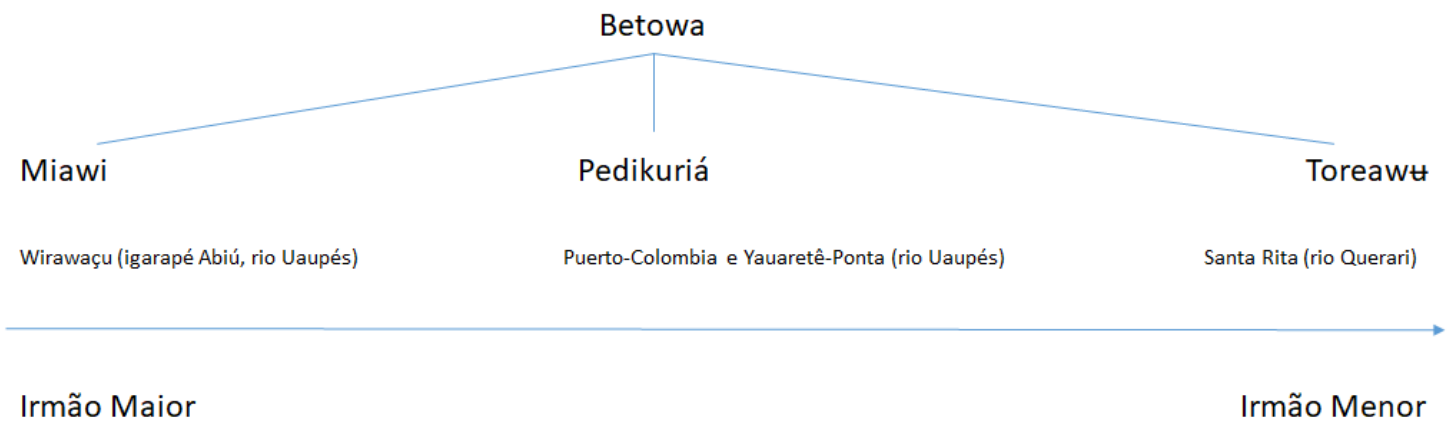

Figura 12: Divisões Betowa (elaboração própria).

José Abelardo disse-me que os Betowa são "várias tribos", como os Yuremawa, e listou: Miawi Betowa (irmão maior), Kuenomo Betowa, Tuiçikuriwa Betowa (irmão menor). Lista essa que, como podemos ver, difere em parte daquela de Rafael, mantendo apenas o nome Miawi em comum, nome do "irmão maior". Disse que sua "tribo" era Tuiçikuriwa Betowa (o mesmo da família de Otávio). Merece menção o uso insistente no português local do termo "tribo" para grupos, uma apropriação de um termo que a antropologia em certo momento operacionalizou, lembremos aqui o modelo de Goldman (1963), e depois abandonou $^{65}$, agora reapriado pelos próprios indígenas. Encerremos por ora essas considerações sobre os Betowa, às quais retornaremos em outros capítulos.

Que o leitor me permita algumas digressões. No esboço de análise das relações entre grupos kubeo delineado acima, vimos como a questão da origem é central. Parece-me que pensar esse tema das origens dos grupos kubeo é uma via adequada para se entender as

\footnotetext{
${ }^{65}$ Lembremos que já Arhem (1981) apresentou elaboradas críticas ao uso da categoria "tribo".
} 
relações entre os grupos e o caráter muitas vezes assimétrico delas, como a matriz apontada acima "imitação" e "verdadeiro/original/puro". Essa sugestão é corroborada também pela formulação que encontramos na literatura etnológica regional segundo a qual o modelo hierárquico das origens inflete nas atuais relações ditas hierárquicas. Os Bahúkiwa são apontados como um grupo kubeo originariamente "makú", são apresentados por Goldman como de "baixa hierarquia"; em seus termos: "The Bahúkiwa sibs of the Cubeo acknowledged Macú ancestry and may well have been, as Koch-Grünberg has claimed, one of the assimilited Macú groups" (1963, p. 7). Os Hehénewa seriam de origem tukano, vindos do Papuri; e são apresentados como ditos de "alta hierarquia". Os Yuremawa e Yúriwawa, por sua vez, são apontados como antigos grupos Baniwa-Kuripako na literatura; não são, como dizem, "próprio Kubeo".

Sobre as tradições de origem dos grupos kubeo, José Bernardo conta o seguinte:

Tarabuwz também é Yúri que criou. Biowa são outro, já tem história dele separado de nós; Hehénewa também. A história desse Hehénewa deve ser aí no Waracapuri [na comunidade de Santa Cruz, rio Uaupés], aí que eles nasceram, nessa cachoeira. Por isso que eles, quando construíram essa hidrelétrica, não mandaram fazer tudo, só um pedaço, porque no meio dessa cachoeira tem o sítio sagrado deles, onde nasceram. Aí por isso que eles não deixaram para o branco construir tudo, até outro lado, era uma hidrelétrica grande, aí proibiram para ele. Tem ali o sítio sagrado, onde nasceram, pedra sagrada. Para esconder essas coisas, não deixaram para eles. Aquele chefe indígena, todos se reuniram, falaram, e foram até falar com presidente, aí que não deixaram. No Hapuí é lugar de origem dos Yúriwawa, dos Yuremawa, Tarabuwz, Kuripako.

$\mathrm{Na}$ literatura etnográfica encontramos também formulações que apontam os Kubeo como "gente das cabeceiras" (hipomuã), como já mostrei. Tal afirmação pode ser relacionada à tese de Andrello (2016) sobre certo gradiente de personitude no alto rio Negro ${ }^{66}$; com efeito, a ideia de "gente da cabeceira" remete à ideia generalizada no rio Negro da distribuição de grupos segundo certo código hidrográfico que associa alto curso do rio a baixa hierarquia, e baixo curso a alta hierarquia.

\footnotetext{
${ }^{66}$ Nos termos de Andrello: "Precisamente por esse motivo, somos levados a pensar em termos de um gradiente de personitude decrescente, que se estende entre os seguintes polos: da jusante à montante, de leste a oeste, do lago de leite à beira do mundo - pontos extremos do mundo descrito nas narrativas míticas - com gente como os Tukano, Desana, Tariana, Cubeo, Wanana, Pira Tapuia, Tuyuka e Arapasso situando-se em uma zona intermediária" (2016, p. 72); mais adiante no mesmo texto afirma novamente a ideia de gradiente de personitude "[...] de acordo com o qual os clãs ou grupos maiores, i.e. 'mais velhos', situam-se idealmente à jusante chegaram antes - ao passo que os mais novos situam-se a montante, a 'gente das cabeceiras' - encontraram seus territórios mais tarde, quando os primeiros já possuiriam filhos e netos, motivo pelo qual são considerados seus avós' (ibidem, p. 81-82).
} 
Contudo, esse código hidrográfico precisa ser considerado com cuidado. Em primeiro lugar, pensar os Kubeo como "gente da cabeceira" é problemático dado que, como vimos, o termo abrange uma miríade de grupos diferentes e que têm relações distintas entre si. Em segundo lugar, não podemos deixar de considerar a possibilidade da disposição hidrográfica dos grupos obedecer a outros fatores. Luiz Gilberto, certa vez, apresentou uma chave muito original sobre a distribuição dos grupos ao longo dos rios, a saber: a disposição de grupos nos altos e baixos cursos dos igarapés como uma "estratégia de guerra"; isso significa que, segundo a explicação de Luiz Gilberto, muitos grupos, aqueles guerreiros, se estabeleciam na foz dos igarapés para defender seus chefes, que ficavam nas cabeceiras, protegidos. Vale lembrar que Janet Chernela (1993) também fala de grupos ditos de alta hierarquia nas cabeceiras, e grupos de baixa hierarquia na foz, contrariando o código hidrográfico aparentemente comum na região. Contudo, cito a interpretação de Luiz Gilberto sobre a relação dos Kubeo com a guerra no passado, e como isso explicaria a disposição territorial dos grupos apenas como uma hipótese, não tenho mais material para avançar na fundamentação de tal ideia. Mas ainda assim, tal sugestão de Luiz Gilberto é suficiente para exigir de nós uma reflexão mais lenta sobre o tema. Aqui, minhas considerações já tomam outro rumo e se distanciam do tema norteador dessa tese; faz-se necessário, portanto, realinhar minhas descrições. Passemos à análise das listas de nomes de grupos kubeo.

\section{Nomes de grupos}

A literatura nos legou muitas listas de nomes de grupos e de subgrupos kubeo. O que a análise de tais listas de nomes pode nos revelar? Vamos às listas:

\begin{tabular}{|l|l|l|l|}
\hline \multicolumn{5}{|c|}{ Nimuendajú (1950) } \\
\hline \multirow{2}{*}{ Tribo } & Clãs (24) & Localização & Outros termos \\
\hline & $\begin{array}{l}\text { Dyuremawa (também } \\
\text { Dyuremaua) }\end{array}$ & Querari & Yiboya-Tapuya \\
\hline \multirow{2}{*}{ Cobeuas } & Dyaniwa & Querari & \\
\hline & Koaitarabewi & Querari & \\
\hline & Biówa & Querari & \\
\hline & Tóliawi & Querari & \\
\hline & Kawikuliwa & Querari & \\
\hline
\end{tabular}




\begin{tabular}{|c|c|}
\hline Walaliwa & $\begin{array}{l}\text { No Uaupés entre a boca do } \\
\text { Querari e a do Cuduyari }\end{array}$ \\
\hline Crabawa & $\begin{array}{l}\text { No Uaupés entre a boca do } \\
\text { Querari e a do Cuduyari }\end{array}$ \\
\hline \multirow[t]{2}{*}{ Miaráwa } & $\begin{array}{l}\text { No Uaupés entre a boca do } \\
\text { Querari e a do Cuduyari }\end{array}$ \\
\hline & Cuduyari \\
\hline Ambomamára & Cuduyari \\
\hline Pialawa & Cuduyari \\
\hline Ilheadówa & Cuduyari \\
\hline Kalówa & Cuduyari \\
\hline Hehénawa & Cuduyari \\
\hline Bahúkiwa & Cuduyari \\
\hline Pedikwawi & Cuduyari \\
\hline Piándokawi & Cuduyari \\
\hline Heliwa & Cuduyari \\
\hline Aweea & Cuduyari \\
\hline Ucuwaiwa & Acima do Cuduyari \\
\hline Kohakolobewa & Acima do Cuduyari \\
\hline Papiwa & Acima do Cuduyari \\
\hline Buói- bowa & Acima do Cuduyari \\
\hline Hulélaliwa & Acima do Cuduyari \\
\hline
\end{tabular}

Tabela 6: Lista de clãs kubeo de Nimuendajú (elaboração própria). 


\begin{tabular}{|c|c|c|c|c|c|}
\hline \multicolumn{6}{|c|}{ Goldman (1963) } \\
\hline Tribo & Fratrias & $\begin{array}{l}\text { Sib (em ordem decrescente } \\
\text { de senioridade) }\end{array}$ & Sub-sib & Sub-sib & $\begin{array}{l}\text { Sibs não- } \\
\text { identificados }\end{array}$ \\
\hline \multirow{19}{*}{ Cubeo } & \multirow{19}{*}{ Fratria I } & Órobawa & & & Batóua \\
\hline & & Aúnbwawü & & & Ilhéadowa \\
\hline & & Hehenewa & $\begin{array}{l}\text { Byá- } \\
\text { Hehénewa }\end{array}$ & & Káua \\
\hline & & \multirow{5}{*}{ Bahúkiwa } & $\begin{array}{l}\text { Byá- } \\
\text { Wathariwa }\end{array}$ & & \\
\hline & & & Urérariwa & & \\
\hline & & & $\begin{array}{l}\text { Bahúküdja } \\
\text { uwü }\end{array}$ & & \\
\hline & & & & $\begin{array}{l}\text { Bahúku } \\
\text { onówa }\end{array}$ & \\
\hline & & & $\begin{array}{l}\text { Bahúkübw } \\
\text { auwü }\end{array}$ & & \\
\hline & & \multirow{2}{*}{ Pedikwa (sub-sib Hehénewa) } & $\begin{array}{l}\text { Kenánikau } \\
\text { wü }\end{array}$ & & \\
\hline & & & $\begin{array}{l}\text { Kenámbwa } \\
\text { wa }\end{array}$ & & \\
\hline & & Utcíwaiwa & & & \\
\hline & & Baryáwatiwaiwa & & & \\
\hline & & Piaráwa & & & \\
\hline & & Pyéndo-Hehénewa & & & \\
\hline & & $\begin{array}{l}\text { Hwáni-Hehénewa (sub-sib } \\
\text { Hehénewa) }\end{array}$ & & & \\
\hline & & $\begin{array}{l}\text { Aúnwewa (sub-sib } \\
\text { Aúnbwawü) }\end{array}$ & & & \\
\hline & & Kompaínyewa & & & \\
\hline & & Abóxo-Hehénewa & & & \\
\hline & & Ambomamára & & & \\
\hline
\end{tabular}




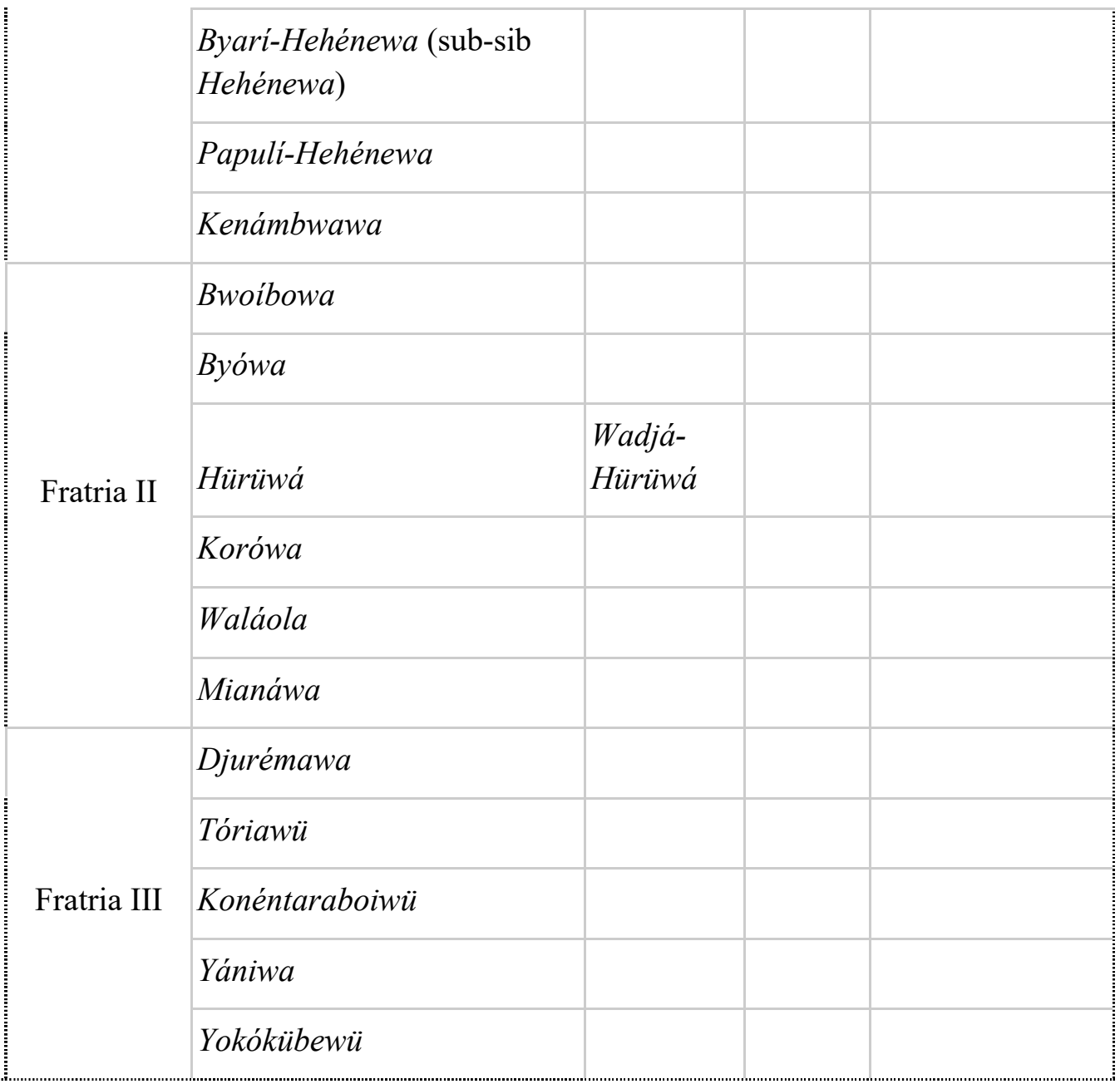

Tabela 7: Lista de clãs kubeo de Goldman (elaboração própria)

\begin{tabular}{|c|c|c|c|}
\hline \multicolumn{4}{|c|}{ A. Bruzzi Alves da Silva (1962) } \\
\hline Tribo & Divisões & Subdivisões & Localização \\
\hline \multirow{7}{*}{$\begin{array}{l}\text { Pamiwa ou } \\
\text { Kubewana }\end{array}$} & \multirow{7}{*}{$\begin{array}{l}1 \text { lista (nove nomes } \\
\text { fornecida em } \\
\text { novembro de } 1953 \text { pela } \\
\text { kubewana Heloisa, } \\
\text { residente em Caruru- } \\
\text { Cachoeira) }\end{array}$} & Órobakö & $\begin{array}{l}\text { Pindaiba-igarapé (perto de Mitú, } \\
\text { rio Uaupés) }\end{array}$ \\
\hline & & Awekö & Cabeceiras do Cuduiarí \\
\hline & & Wárarikö & Tatú-cachoeira (rio Uaupés) \\
\hline & & Hehénakö & Rio Cuduiarí \\
\hline & & Bahúkekö & Rio Cuduiarí \\
\hline & & Neábokö & Rio Cuduiarí \\
\hline & & Bareákö & $\begin{array}{l}\text { Pindaiba-igarapé (perto de Mitú, } \\
\text { rio Uaupés) }\end{array}$ \\
\hline
\end{tabular}




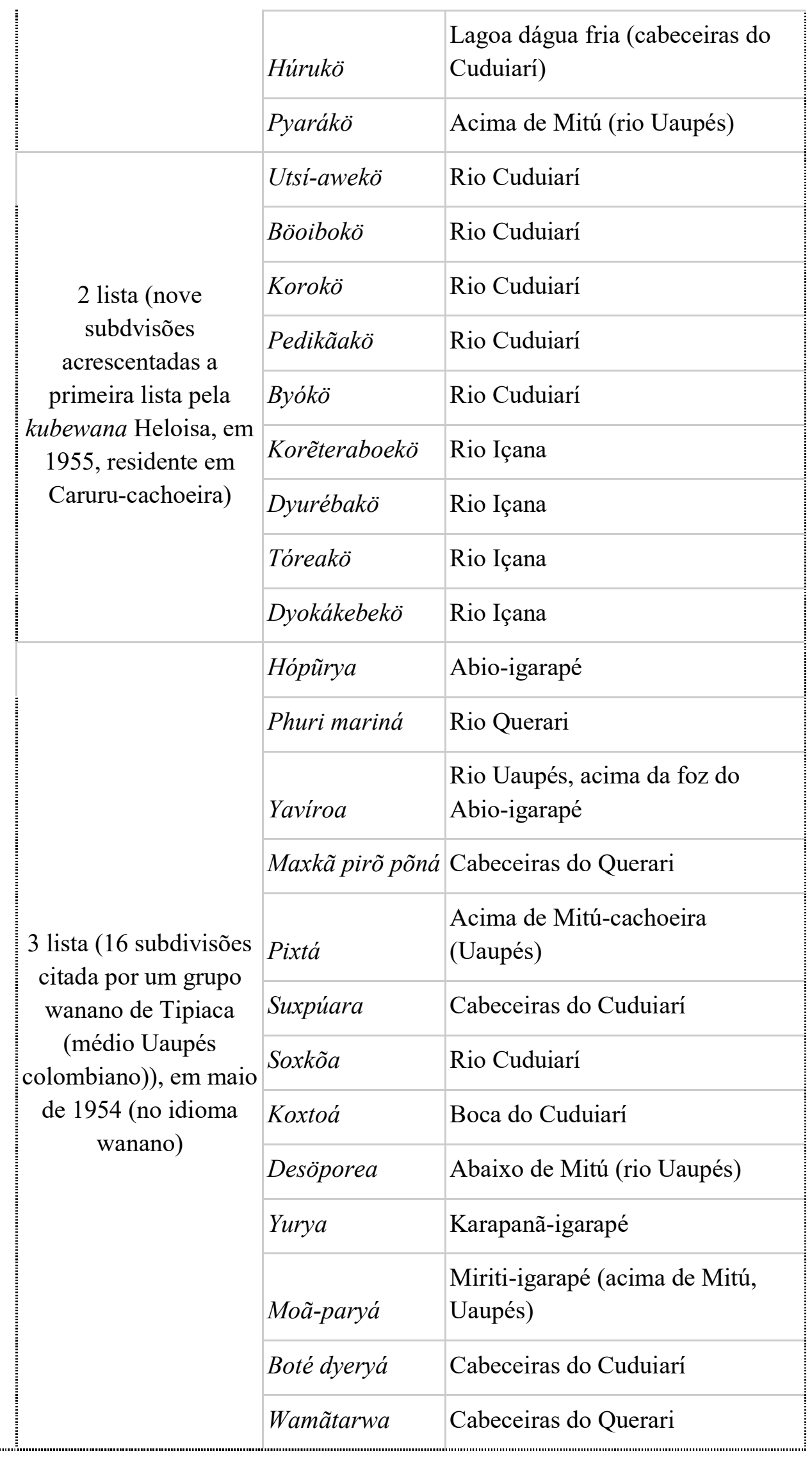




\begin{tabular}{|c|c|c|}
\hline & Yebákaroa & Rio Querari \\
\hline & Byêdero & $\begin{array}{l}\text { Em S. Cruz e Tatú-cachoeira } \\
\text { (Uaupés) }\end{array}$ \\
\hline & Wai wehekö & $\begin{array}{l}\text { Pacú-igarapé (acima de Mitú, } \\
\text { Uaupés) }\end{array}$ \\
\hline \multirow{21}{*}{$\begin{array}{l}4 \text { lista (citada em abril } \\
\text { de } 1957 \text { por duas } \\
\text { mulheres kubewana } \\
\text { provindas de Querari; } \\
\text { apresentaram-se como } \\
\text { da tribo koreteraböa) }\end{array}$} & Hehenawa & Tuí (rio Cuduiarí) \\
\hline & Padikawö & Itapinima (rio Cuduiarí) \\
\hline & Byawá & Pirá-Mutum (rio Querari) \\
\hline & Myarãwa & Sei-ma (rio Uaupés) \\
\hline & Bahúköwa & Uaracú-cachoeira (rio Cuduiarí) \\
\hline & Wararíwa & Macucú (rio Uaupés) \\
\hline & Korówa & Itapinima (rio Cuduiarí) \\
\hline & Pyaráwa & Pirá-mirim (rio Cuduiarí) \\
\hline & $\begin{array}{l}\text { Horóbora } \\
\text { paramera }\end{array}$ & Cupim-igarapé (rio Papuri) \\
\hline & Tídwa & Ti-igarapé (rio Uaupés) \\
\hline & Akeromöwa & Rio Pirá-Paraná \\
\hline & Táytö paramera & Rio Uaupés \\
\hline & Korébawa & $\begin{array}{l}\text { Iviarí-igarapé (afluente do } \\
\text { Querari) }\end{array}$ \\
\hline & Kopáyöwa & Miriti-paraná (rio Uaupés) \\
\hline & Barõáwa & Miriti-paraná (rio Uaupés) \\
\hline & Órobawa & Jacamin-cachoeira (rio Uaupés) \\
\hline & Yamitidöwa & Uaracapuri (rio Uaupés) \\
\hline & Wirowa & Tipiaka-cachoeira (rio Uaupés) \\
\hline & Tatíwa & Paca-igarapé (rio Uaupés) \\
\hline & Mõãkörawö & Iutica (rio Uaupés) \\
\hline & Betówa & Açaí (rio Uaupés) \\
\hline
\end{tabular}




\begin{tabular}{|l|l|l|}
\hline & Byákowa & Rio Içana \\
\hline Yamã paramera & Surubi-igarapé (rio Içana) \\
\hline & Máwa paramera & Cumari-igarapé (rio Içana) \\
\hline
\end{tabular}

Tabela 8: Lista de clãs kubeo de Bruzzi Alves da Silva (elaboração própria)

\section{Lista de sibs Hehénewa ${ }^{67}$ (GOLDMAN, 2004):}

a. Hehénewa que emergiram de Waracapurí no Uaupés ${ }^{68}$ :

1. Nome comum: Yavi-Hehénewa

Nomes próprios: (A) Uráhen, (B) Bümü, (C) Namáb, (D) Uménahodo

2. Nome comum: Yavícare-Hehénewa ou Namáboawu

Nomes próprios: (A) Uménahokü, (B) Emíharakaru, (C) Bedé-büküko - feminino, (D) Miáco-dhavi - feminino, (E) Pa-büküko

3. Nome comum: Macakü-Turu-Yahúbo

Nomes próprios: (A) Máku-Turu, (B) Namápodha - origem: Wahúya, (C) Piará-

Büküyo - Impananí-Papurí

4. Nome comum: Tuíbuawü ou Urádho-Yahúbo

Nomes próprios: (A) Bedé-podha, (B) Miánriwe-Tuibu, (C) Cowue-tuibu - vive no Timbo

5. Nome comum: Warin-Hehénewa ou Ihovedoawu

Nomes próprios: (A) Nahóru, (B) Uren-boricakü, (C) Namadho, todos vivem em Namocírba, Cuduiarí

6. Nome comum: Órobawa

Nomes próprios: (A) Uménaho-tucáru, (B) Aúnku mamákü, (C) Cowue - vive em Waracapurí

\footnotetext{
${ }^{67}$ Goldman lista aqui sete sibs segundo sua ordem de emergência (senioridade) em Waracapuri no Uaupés. Sobre essa lista nos diz o autor: "Except for my translation from the Spanish, the chart is just as it was compiled at my request by Pedro Rodriguez of Yavícare Hehénewa who consulted his grandfather, his father, and other sib elders" (2004, p. 77).

Também merece esclarecimento que o autor divide a lista com nome dos sibs ("Common name") e dos irmãos ancestrais que conformam cada sib ("Proper names").

${ }^{68}$ Goldman classifica os quatro primeiros sibs dessa lista como "seniores" e os outros três como "juniores" (2004, p. 79). Para comentários sobre a noção de "classe" operacionalizada por esse antropólogo remeto o leitor ao capítulo 2 de minha dissertação (PEDROSO, 2013).
} 
7. Nome comum: Wádhariwa

Nomes próprios: (A) Warímbükükuo, (B) Cuábe Hurebo - vive em Tatu, (C) Warín Wacurava, cachevera de Umarí

b. Hehénewa que se separaram do grupo geral:

1. Nome comum: Aumboawu (originário de Cuva-Havabo)

Nomes próprios: (A) Urapenaba, (B) Buturakü

2. Nome comum: Aunvewa (originário de Cuma-campi, Quevarí)

Nomes próprios: (A) Uracómoakü, (B) Buva, (C) Aunve, (D) Miarinkü-turebo

3. Nome comum: Abuhu-Hehénewa (origem: Macapimbo, cachevera de Waracu, Cuduiarí)

Nomes próprios: (A) Uramákuve, (B) Namakü-curanru (yaví, payé), (C) Miarinkü

4. Nome comum: Pedikuanwu (origem: Pediva, Toidibo, Cuduiarí)

Nomes próprios: (A) Pedido, (B) Cumau-bedebo

5. Nome comum: Pien-Hehénewa (origem: Piendo, cabeceira do Cuduiarí) ${ }^{69}$

Nomes próprios: (A) Pavakü-tarave, (B) Hiadhapi-macadho, (C) Hauvadho, (D)

Evadho

6. Nome comum: Piarava (origem: Puria-yuicun, morro próximo a Mitú)

Nomes próprios: (A) Piarachina, (B) Pavakü, (C) Piara-mamakü

7. Nome comum: Uchivaiwa (Uchivai-hoedu)

8. Nome comum: Baruawa (Baruaro, Yuruparí)

\section{Listas de Restrepo (2001):}

\section{Lista de grupos de fala cubeo (pamié):}

1. Hehéneva

2. Aúboa Hehénava

3. Aúveva

4. Oroba Hehénava

5. Vari $\sim$ Hehénava

6. Yavikareva ou papurí $\sim$ Hehénava

\footnotetext{
${ }^{69}$ Nota de Goldman: "Pien-Hehénewa were enemies of all Hehénewa and were almost completely eliminated in warfare with them" (2004, p. 79).
} 
7. Vadariva

8. Pedi Ktavit

9. Piédokavi

10. Uçivaiva

11. Bartáva

12. $\sim$ Maravá

13. Bahúkiva

14. Piaráva

15. Hehénartavi

16. Emihehénava

Grupos cubeo de origem diferente que falam a língua cubeo (pamié):

Lista $\mathbf{A}^{70}$ :

1. Yurémava

2. Tarábíavi

3. Yoká kibeví

4. Yúrivava

5. Betóva

6. Tortavi

\section{Lista B:}

1. Koróva

2. Bióvá

3. Bioibová

4. Miadáva

5. Hiriva

Lista dos "verdadeiros" Hehénava de nome tradicional e conhecidos por sua mitologia de origem (RESTREPO, 2001, p. 26) ${ }^{71}$ :

1. Kuábe

2. Henaki

3. Nahoki

4. Makaki Bikiyo

${ }^{70}$ Essa organização em "lista A" e "lista B” é minha, para fins de sistematização.

71 Restrepo (2001, p. 26) se refere a estes clãs como "grupo maior"; a lista seguinte diz respeito aos clãs do "grupo menor". 


\section{Lista do "grupo menor" (RESTREPO, 2001, p. 26):}

1. Hoéharabikiri

2. Paváki Yaví

3. Aukitiribi

Diante dessas listas de nomes o que podemos depreender? Qual a diferença entre nomes de grupos e de subgrupos? Podemos falar em ordem de grandeza dos nomes, isto é, nomes maiores e menores? Por que Yuremawa é constituído de outros nomes ao passo que Yúriwawa não? Tentemos avançar na análise dessas listas.

Nimuendajú adota como terminologia as noções de "tribo" e "clãs". Conta 24 nomes de clãs. Sua lista é próxima a de Goldman que em seu primeiro esforço de definição de categorias e sistematização dos dados kubeo conta 25 nomes de sibs, 13 nomes de "sub-sibs", e mais 3 nomes que considera "sem identificação", ou seja, não se enquadra em terminologia de fratrias. Vale notar que um desses nomes é Batóua, que penso ser uma variante de Betowa.

Bruzzi Alves da Silva coletou algumas listas de nomes kubeo. A primeira delas foi elencada por uma mulher kubeo em 1953, moradora da comunidade kotiria de CaruruCachoeira, e consistia em 9 nomes; dois anos depois, em 1955, essa mesma lista foi complementada com mais 9 nomes. A terceira lista foi fornecida em língua wanano por um Wanano. A quarta foi fornecida por duas mulheres de Querari em 1957 (trata-se do rio Querari, dado que a comunidade de mesmo nome onde desenvolvi minha pesquisa de campo ainda não existia). Já Restrepo lista 27 nomes de grupos kubeo, e 8 nomes hehénewa, número menor que lista de Goldman (2004), que apresenta 15 nomes.

Ao iniciar a análise das listas, uma primeira dificuldade que se apresenta diz respeito ao registro escrito feito pelos pesquisadores que, com exceção de Goldman e Restrepo, não comprendiam a língua kubeo. Outra dificuldade diz respeito a ausência de um padrão alfabético para grafia na língua indígena. Percebemos diferenças nas grafias e de uma quantidade grande de nomes não sabemos se de fato remetem a grupos e subgrupos ou se foram registrados incorretamente.

Em primeiro lugar, notamos que Yuremawa aparece na lista de Nimuendajú (1950) como "Dyuremawa/Dyuremaua". Esse nome também aparece na lista de Goldman (1963), "Djurémawa", como pertencente a fratria III. Aparece em Bruzzi Alves da Silva (1962) como 
"Dyurébakö". E por fim na lista de Restrepo (2001), como "Yurémava". Já o nome "Yúriwawa" aparece apenas na lista de Restrepo como "Yúrivava" sem nenhuma menção nas outras listas.

O nome "Dyaniwa" / "Yániwa", que aparece nas listas de Nimuendajú e de Goldman (1963) como “clãs", penso ser na verdade o nome de um subgrupo Yuremawa. Lembremos que, diferente dos Yúriwawa, os Yuremawa têm divisões internas e Yaniwa é o nome de uma delas. Vemos, portanto, na mesma lista, nomes com ordem de grandeza distintas, pois Yaniwa não seria um "clã", como indicam as listas, mas antes uma subdivisão do "clã" Yuremawa. Além desse nome, encontrei um segundo nome com ordem de grandeza díspar: Torzawz. Esse nome aparece na lista de Nimuendajú como clã Tóliawi e na de Goldman como clã Tóriawü. Nas conversas sobre nomes das subdivisões Yuremawa levantei algumas listas, como já exposto nesse capítulo, e a lista de Luiz Gilberto coloca Tortawz como irmão menor na escala de subdivisões yuremawa. Assim, vemos aqui novamente uma dificuldade com a escala na qual nomes são manejados, pois yahubo pode remeter aos Pamiwa, como também aos Yuremawa e Yúriwawa, como também a Yaniwa ou Tortawz.

Portanto, a questão do registro escrito torna a análise difícil. Há nomes na lista de Nimuendajú que parecem se repetir na lista de Goldman (1963), mas muitos deles não tenho certeza se seriam o mesmo nome. Importante destacar também as diferenças de registro entre as quatro listas que Bruzzi Alves da Silva (1962) apresenta. As duas primeiras, enunciadas por Heloisa, uma Kubeo, têm todos os nomes registrados na forma singular feminina. A terceira lista está registrada com nomes na língua kotiria, e a quarta é uma nova lista, com quase todos os nomes na forma plural, que repete alguns dos nomes das duas primeiras.

A tabela a seguir tenta estabelecer equivalência entre os termos que julgo se referirem ao mesmo nome, embora com registros diferentes de acordo com o pesquisador. Vejamos. 


\begin{tabular}{|c|c|c|c|}
\hline Nimuendajú (1950) & Goldman (1963) & Bruzzi Alves da Silva (1962) & Restrepo (2001) \\
\hline Tóliawi & Tóriawü & Tóreakö & Toriavi \\
\hline Walaliwa & Wathariwa & Wárarikö/Wararíwa & Vadariva \\
\hline Miaráwa & Mianáwa & Myarãwa & Miadáva/Miarikí \\
\hline Pialawa & Piaráwa & Pyarákö/Pyaráwa & Piaráva \\
\hline Kalówa & Korówa & Korokö/Korówa & Koróva \\
\hline Pedikwawi & $\begin{array}{r}\text { Pedikwa } \\
\text { (Sub-sib Hehénewa) }\end{array}$ & Pedikãakö/Padíkawö & Pedi $\sim$ Kiaví \\
\hline Aweea & $\begin{array}{r}\text { Aúnwewa } \\
\text { (Sub-sib Aúnbwawü) }\end{array}$ & Áwekö & Aúveva \\
\hline Ucuwaiwa & Utcíwaiwa & Utsí-awekö & Uçivaiva \\
\hline Buói- bowa & Bwoíbowa & Böoibokö & Bioibová \\
\hline & Konéntaraboiwü & Korẽteraboekö & \\
\hline
\end{tabular}

Tabela 9: equivalência entre nomes de grupos kubeo (elaboração própria)

De todas essas listas, os Yuremawa e Yúriwawa apontaram como nomes conhecidos: Hehénewa, Bahúkiwa, Biowa, Betowa, Yokókubewz, Uçiwaiwa, Tarábuawz. Vale notar o lugar do termo Betówa: aparece na lista de Bruzzi Alves da Silva (1962) como "Betówa", em Goldman como "sib não identificado" (grafado como "Batóua"), e reaparece na lista de Restrepo como "Betóva". Como vimos, o reconhecimento dos Betowa como Kubeo pelos Yúri Parãmena é fonte de muita controvérsia, que por vezes pode resultar em conflitos e violência ${ }^{72}$.

\footnotetext{
${ }^{72}$ No capítulo sete examinarei mais detidamente um desses episódios de conflito entre esses grupos.
} 
A primeira lista de Goldman, como vimos, apresenta listas de sibs, sub-sibs e uma lista de três "sibs não-identificados": "Batóua", "Ilhéadowa" e "Káua". Desses, "Batóua" reaparece em outras listas, como destacado acima, e é conhecido dos Yúri Parãmena. Já "Ilhéadowa" aparece apenas lista de Nimuendajú. Por fim, "Káua” não aparece em nenhuma outra lista. Em conversas com os Yúri Parãmena, afirmaram que conhecem a palavra kawá, que designa a ave urubu, e é usada como apelido (yahui amiya), o que nos indica outra dificuldade: considerar como nome de grupo o que seria nome de pessoa, no caso, um yahui amiya.

Merece atenção, por fim, o nome Wírowa, na quarta lista de Bruzzi Alves da Silva (1962) informada por duas mulheres Kubeo do rio Querari. Perguntei a alguns Yúri Parãmena sobre esse nome e ninguém conhecia. Na verdade, disseram-me tratar-se de um nome kotiria, informação confirmada na tese de Pedro Rocha (2012, p. 69), onde encontramos que Wirõa é nome de clã que se distribui nas comunidades de Ilha de Inambú, Caruru-Cachoeira, Jacaré e Poraquê-Ponta, todas no rio Uaupés. Aqui, portanto, identificamos outra dificuldade das listas: considerar como nome kubeo o que na verdade seria nome de outro grupo (Kotiria, no caso citado).

Como mencionei, em muitos momentos em campo apresentei essas listas aos meus interlocutores, perguntando sobre cada nome e o que ele indicava. Contei pouco mais de 7 nomes das listas apontados como conhecidos por alguns Yuremawa e Yúriwawa. Tal fato nos aponta que, diferentemente de outros grupos tukano, os Kubeo não parecem compartilhar de uma ideia de "todo", isto é, não temos uma lista exaustiva de "sibs" que compõem o grupo kubeo, como encontramos, para citar dois outros coletivos, no caso Tukano (ANDRELLO, 2006; 2016; MAIA \& ANDRELLO, 2018), e Desano (REICHEL-DOLMATOFF, 1971; BUCHILLET, 1983; RIBEIRO, 1995), onde, a despeito das dificuldades e disputas envolvidas na tentativa de ordenar os nomes, tem-se uma lista do conjunto dos nomes de grupos. Os Yúri Parãmena conhecem apenas alguns poucos nomes de grupos ditos Kubeo; muitos outros - quando citava as listas de Goldman em campo, por exemplo - eles nunca ouviram falar. São nomes que remetem a tradições de origem distintas, embora compartilhem a mesma língua kubeo. Avancemos nas análises.

No trecho de rio de minha pesquisa vivem Yuremawa, Yúriwawa e Betowa, como já é sabido do leitor, sendo que tanto Yuremawa quanto Betowa são nomes que se desdobram em outros nomes, o que significa dizer, nomes com distintas ordens de grandeza. O nome Yúriwawa, segundo Chacon (2012) remeteria a uma quarta fratria kubeo. Vejamos isso com 
mais detalhes.

Em primeiro lugar, recuperemos as formulações de Goldman acerca da noção de fratria. Chacon sintetiza o que diz esse antropólogo norte-americano nos seguintes termos

While most Tukanoan groups in the region are formed only by agnatic subgroups (sibs), the Kubeos are formed by affine groups, called phratries (Goldman 1963 and 2004). Each phratry is in turn formed by sibs. Each phratry acts as an exogamous group (comparable to other typical Tukanoan groups in the area), intermarrying with other Kubeo phratries as well as with other ethnic groups in the Vaupés, especially with Wananos (CHACON, 2012, p. 3, itálico meu).

Chacon prossegue afirmando que há quatro fratrias kubeo, "each formed by smaller groups called sibs, which in general share a common descent ideology and concept of territory (Goldman 1963, 2004, initially counted three, but research for this dissertation suggests that there are actually four in total)" (idem). Por fim, lembremos que, para Goldman, nos termos de Chacon, "the phratries were the real political bodies in Kubeo society and, although there is no centralized power, they are bound by relations of ritualistic, kinship, social/economic cooperation and solidarity among neighboring agnatic groups" (CHACON, 2012, p. 3).

Segundo a narrativa de origem contada pelo Yuremawa Henrique Rodrigues, Yúriwawa e Yuremawa compunham os Yúri Parãmena; são, portanto, provenientes de um mesmo grupo ancestral que em certo momento se divide. Segundo Goldman (1963) os Yuremawa ("Djuremawa" na grafia do autor) pertencem à terceira fratria; os Yúriwawa não aparecem na sua lista. Chacon (2012) aceita a categorização de Goldman que insere os Yuremawa como um sib da terceira fratria, mas sustenta que os Yúriwawa constituem uma fratria própria, quarta fratira em relação ao modelo de Goldman. Na nota quatro de sua tese, Chacon afirma: "The fourth group is composed of a single sib only, the Yúriwawa 'people of the Yúri deity' (inhabitants of Açaí village in the Brazilian Vaupés), which can intermarry with any other Kubeo sib, although mythlogically they were agnatically related to the sibs from another phratry" (2012, p. 3). Chacon afirma que a quarta fratria seria composta de apenas um sib, os Yúriwawa. Portanto, teríamos uma fratria de um sib apenas? Se é assim, qual a fronteira entre sib e fratria? De outro modo, poderíamos pensar em Yúriwawa como nome da quarta fratria? Por essa via, teríamos uma fratria nomeada, e estaríamos distantes da primeira formulação de Goldman (1963) segundo a qual qual fratrias não têm nomes, e próximos de sua segunda formulação (2004). Diante desse quadro outra questão desponta: 
Yúriwawa seria o nome de uma fratria que não se desdobra em outros nomes, ao passo que as fratrias reuniriam conjuntos de nomes sem um nome mais inclusivo?

O mesmo problema se coloca no caso dos Hehénewa. Como dito, se na primeira monografia (1963) Goldman afirma que as fratrias kubeo não são nomeadas, retifica essa afirmação na segunda monografia (2004), sugerindo Hehénewa como o nome da fratria I. Na nota três de sua tese Chacon diz: "Goldman (2004) has suggested that Hehenawa is the name for the entire Phratry-I. My impression is that this is not the case. What seems to be the case is that some groups within Phratry-I have the name Hehenawa added to their sib names, while some other sibs of the same phratry do not have Hehenawa in their ethnonyms" (2012, p. 2). Se consideramos a interpretação de Chacon as fratrias permanecem não nomeadas, o que parece contrariar a ideia onomástica compartilhada de modo geral no alto rio Negro segundo a qual tudo que existe e é conhecido tem nome. Além disso, Chacon apresenta uma solução para a multiplicação de nomes a partir de Hehénewa da qual discordo, pois parece-me mais adequado pensar que aqui também se passa aquilo que Andrello descreveu para a repetição de nomes tukano.

Segundo Andrello "a repetição de nomes é regra. No caso dos clãs, não poderia ser de outro modo, pois nomes são sete e clãs 47 [...]. Verificamos, assim, a existência de três, quatro, cinco ou mais clãs com o mesmo nome, diferenciando-se através de um apelido que o complementa" (2013, p. 7). Eis alguns exemplos citados:

Um exemplo: o nome Ye'pãra, que aparece pela primeira vez no clã 2 do esquema anexo reaparece ainda no clã 4 do primeiro bloco e em oito clãs dos demais blocos. Eles se diferenciam através de apelidos, tais como Oyé (gago), Oakapeá (falante, cochichador), Me'rú (oleoso), Nuhîro (achatado), Yamîro (espécie de formiga). Ou seja, características físicas, comportamento, semelhança com algum animal, aspectos de um episódio que protagonizou, todos esses elementos se prestam a qualificar uma pessoa e, assim, ao grupo que dá origem. $\mathrm{O}$ mesmo se passa com outros quatro nomes: para Ki'mâro há treze variações, para Akîto são quatro, e para Yu'ûpuri e Bu'û são três. Com isso chegamos a um conjunto de 32 nomes de clãs que combinam nome ancestral e apelido. Restam assim 15 clãs cuja designação corresponde exclusivamente a apelidos (2013, p. 7-8).

Assim, diferente do que diz Chacon, não se trata do termo Hehénewa acrescentado aos nomes de sib, mas antes apelidos unidos ao nome Hehénewa. 
Essas dificuldades no manejo de nomes e da categoria de fratria diz respeito também ao caráter compósito dos Kubeo, isto é, Goldman sustenta, e muitas das minhas conversas em campo confirmam sua tese, que os Kubeo resultariam da fusão de grupos de origem Tukano, "Makú" (nos termos de Goldman) e sobretudo Arawak. Nos termos de Chacon

The phratric organization and ethnic diversity among the Kubeos are the result of fusion of distinct ethnic groups from the Vaupés during the formation of the Kubeospeaking society (cf. Goldman 2004). Phratries III and IV proclaim that a few generations ago they used to speak an Arawakan language and are originally from the Aiyari River (i.e. not from their current location). Members of Phratry II are the original inhabitants of the area and there is a good amount of evidence that they were Arawakan speaking groups as well. Members of Phratry I are the original speakers of pre- Kubeo. In addition, several smaller groups from different ethnic backgrounds have been incorporated into one or another phratry, given that the up-river zone where the Kubeos live is historically a place where many groups came to seek refuge in times of regional instability (CHACON, 2012, p. 3- 4).

Chacon aponta que o substrato arawak pode ser encontrado em alguns aspectos da língua e cultura kubeo. Segundo esse linguista "the strong Arawakan substrate and adstrate in Kubeo society can be observed on their language and culture" (CHACON, 2012, p. 4). E cita como exemplo do que ele chama de hibridismo "the modification of Arawakan deities, such as Kúwai (in Phratry-I and II) and Yúri (in Phratry-III and IV) (Dzuliferi in Baniwa mythology, cf. Wright 2009) with Tukanoan symbolism” (ibidem). Já vimos isso nas falas sobre a língua original dos Yuremawa e Yúriwawa, uma versão do Baniwa-Kuripako. Em suma, eis que as formulações Yúri Parãmena nos mostram a inadequação da categoria de fratria.

Além dessas questões, merece atenção também o lugar do nome Betowa nas listas citadas. Lembremos que na lista de Goldman (1963) os Betówa (“Batóua”) aparecem como um sib não-identificado, isto é, que o autor não conseguiu encaixar no esquema de três fratrias. Os Yuremawa e Yúriwawa falam dos Hehénewa, os Kubeo ditos de mais alta hierarquia na formulação de Goldman, como os "verdadeiros" kubeo, como os "Kubeo originais", os Pamiwa, aqueles a partir dos quais os Yuremawa e Yúriwawa seriam apenas uma "cópia" ou "imitação", como dizem. Nas narrativas Hehénewa estudadas por Goldman é Kúwai, persongem responsável pela criação da humanidade na cachoeira de Waracapuri (Uaupés), que atribui nomes às pessoas e as reconhece como Pamiwa, função atribuída a Yúri e a avó Huredanaçu pelos Yuremawa e Yúriwawa, em Hapuí (rio Ayari). Além dessa 
diferença de origem, muitos outros grupos ditos "kubeo" são desconhecidos das narrativas Yuremawa e Yúriwawa, chegando mesmo a recusar o reconhecimento de alguns, como fazem com os Betowa. Quando falam dos Betowa, falam deles como "forasteiros", irmãos menores, como já dito anteriormente; falas sempre impregnadas de derrisão. Cito uma situação: em certa viagem de levantamento de nomes de lugares por conta da elaboração de plano de gestão ambiental para os Kubeo, ao pararmos em Puerto-Colômbia para uma visita rápida à comunidade, um indígena yuremawa de Querari, nosso prático no momento, fez uma piada dizendo que íamos visitar "makusitos", fala que ressoa aquela tese da origem "makú" dos Betowa apresentada por Goldman (1963). Outro motivo de críticas que os Yuremawa e Yúriwawa dirigem aos Betowa diz respeito ao fato desses se casarem com mulheres Hupd'äh, comumente um motivo de piadas e brincadeiras de tom ofensivo, que marcam um distanciamento entre esses grupos. Talvez o fato de Goldman ter listado o nome "Batóua" na categoria "sem identificação" possa ser entendida se levarmos em consideração esse quadro de tensões e conflitos.

Muitos nomes das listas foram apontados como desconhecidos por meus interlocutores kubeo. Esse desconhecimento foi explicado de duas maneiras: de um lado, diziam tratar-se de "outro grupo" e, portanto, "são eles que sabem", "tem que perguntar para eles, a origem é diferente", dizia José Bernardo. Outra explicação consistia em dizer que são nomes que possivelmente não existem mais, foram esquecidos. Comento a segunda explicação.

"O nome é o sib", afirmou Christine Hugh-Jones (1979). O apagamento do nome, o que significa a dissolução de coletivos, é um evento que se tenta evitar. Vejamos um caso examinado por Chernela (1993) no penúltimo capítulo de sua monografia onde nos oferece a descrição etnográfica de uma disputa em torno do acesso a certos recursos naturais envolvendo três sibs de Bucacopa $^{73}$. Segundo a descrição da autora, esse lugar era habitado na década de 1970 por três sibs: Biari Pona, um sib wanano dito de alta hierarquia, e detentor do acesso privilegiado aos recursos da região; esse sib era constituído por uma mulher Biari Pona

\footnotetext{
${ }^{73}$ Esse caso etnográfico também é recuperado e comentado por Raphael Rodrigues (2012, p. 85 e ss.), onde o autor o compara com a história da comunidade tukano de Ananás, no baixo Uaupés, e recupera as discussões em torno da relação entre disputas envolvendo grupos, legitimidade sobre territórios e hierarquia.
} 
(iro) chamada Nicho, seu marido desana e dois filhos. Simi Paro Pona constituía o sib desana ao qual pertencia o marido da mulher Biari Pona; esse sib era composto por dois irmãos, seus filhos (um deles era o marido de Nicho) e netos. O terceiro grupo, Wari Yuturia, dizia respeito a um sib relacionado agnaticamente ao Biari Pona (seus “irmãos menores"), e que vivia em relação de subordinação com o sib Biari; eram, portanto, os servos de Biari Pona. Montado o quadro social de Bucacopa, vejamos o conflito.

Nicho era casada com um Desana. Com a morte do último homem Biari, e sem a possibilidade de continuidade da descendência, instaura-se a crise envolvendo o controle sobre os recursos. O sib desana reclamava seus direitos com base na autoridade de Nicho, uma vez que ela era casada com um Desana. Contudo, os Desana não tinham nenhuma obrigação de generosidade e redistribuição dos recursos em relação aos Wari Yuturia (tal como acontecia entre estes e seus irmãos "mais velhos", os Biari Pona). Os Wari Yuturia, por outro lado, não estavam obrigados a aceitar a autoridade desana, os quais eram considerados, apesar do tempo de coresidência, como "visitantes". Diante desse conflito, a autoridade de Nicho se mostrava insuficiente, uma vez que não possuía a prerrogativa masculina de produzir descendência Biari Pona.

Se os Simi Paro Pona reclamavam seus direitos com base no fato de um membro do grupo ser casado com Nicho, os Wari Yuturia baseavam sua reivindicação no ranque (CHERNELA, 1993, p. 138). Eles reclamavam não apenas direitos de uso dos recursos, mas reconhecimento enquanto membros de um sub-grupo dos Biari Pona, isto é, "they state that their sib is, in terms of descent, one of the 'Firsts', rather than one of the 'Lasts'; in this way they lay claim to the rights associated with descent position. They have incorporated the Biari name into their own, becoming the Wari Yuturia Biari Pona" (CHERNELA, 1993, p. 138, itálico meu).

Eis, portanto, um caso etnográfico que nos mostra a articulação entre organização social, controle de recursos e sucessão legítima (posição hierárquica). Nessa situação, as relações de coresidência entre um sib chefe (os Bari), um sib servo (os Wari Yuturia), e um sib afim (os Desana Simi Paro) se desenvolvem na direção de um conflito quando o sib chefe se aproxima da dissolução. Esse caso exemplifica um fenômeno maior na região do Uaupés: o crescimento e a dissolução de grupos (no caso aqui citado, função das flutuações demográficas). Aqui, vale lembrar o que já dizia Goldman em sua primeira monografia sobre os Kubeo: 
From these observations it may be inferred that the history of Northwest Amazon has been one of constant formation and disruption of sociopolitical entities. What a tribe is at a time is a core of sib segments that may have preserved through time and then have drawn to them new sibs from people speaking the same as well as other language" (1963, p. 99-100).

Tal tese articula-se com a incorporação de nomes dado que os Wari Yuturia incorporaram o nome Biari. Aqui, como vimos, esse fenômeno envolve disputas em torno da ordem de senioridade, "a Junior sib may exploit the decline of a sênior descent line to usurp its position" (1993, p. 142). Como pensar esses movimentos e a incorporação de nomes?

Voltemos ao artigo de Stephen Hugh-Jones. “Através da nominação, o indivíduo adquire a identidade de grupo e uma parte da alma do grupo, enquanto a coletividade dos viventes é a continuação dos ancestrais e mantém vivos suas memórias, nomes e vitalidade" (2002, p. 51). Os nomes estão relacionados ao ancestral do grupo (cada grupo tem uma coleção de nomes provenientes de seu ancestral); denotam, portanto, posição cosmológica, ou, para usar um termo da literatura regional, hierarquia.

A literatura etnográfica dos povos do Uaupés tem formulado hierarquia, grosso modo, como uma escala de pessoas e coletivos baseada na ordem de nascimento dos ancestrais do grupo, como vimos. Christine Hugh-Jones, ao elaborar seu modelo de organização social para os Barasana, oferece a seguinte formulação sobre essa ordem de nascimento

Exogamous Groups are collections of sibs arranged in a hierarchical order, modeled on the birth sequence of an agnatic male sibling group. This principle of birth order, which I shall call "seniority", is found at every level of organization within an exogamous unit so that each individual, each subunit within each sib and each sib itself has a unique position in the order composed of similar units. Among sibs of an Exogamous Group there is a "first born", a "next born", a "next born" and so on to the "last born". Each sib is either an "older brother" or a "younger brother" from the point of view of any other sib (1979, p. 19, itálico meu).

Como tentei mostrar em minha dissertação de mestrado (PEDROSO, 2013), o que a etnologia regional tem chamado de hierarquia recobre uma grande quantidade de questões que não parecem se adequar as formulações dessa etnologia. Faz-se necessário encontrar termos mais adequados ao que dizem e fazem os indígenas do alto rio Negro e a aposta dessa pesquisa, como já enunciado, consiste em explorar o complexo de termos que os Kubeo usam para se 
referirem a si mesmos e a outros. Vejamos algumas pistas sobre o tema.

No alto Uaupés, notei que questão da senioridade entre os grupos yuremawa, yúriwawa e betowa é recorrente em conversas entre as pessoas e sobretudo nos contextos festivos, e que os irmãos menores devem "respeito" (pueđaino). No início de meu primeiro campo, Pedro Espitia (yuriwaku ex-morador de Açaí), explicou que a relação de senioridade diz respeito fundamentalmente a questão do "respeito" que o irmão mais novo deve ao mais velho; ouvi a mesma explicação em outros contextos e dita por outras pessoas. Assim, a noção de pueđaino ("respeito") merece atenção e maiores elaborações, assim como suas noções correlatas de pueđayz/pueđađo ("homem que respeita" / "mulher que respeita") e pueđabekt/pueđabeko ("mal-educado", “desrespeitoso" / "mal-educada”, “desrespeitosa”), pois me parece chave para entender o que temos chamado de "hierarquia". Os Yuremawa constituem o maior grupo, com o que consideraríamos subdvisões internas: Kapuareda, Wianawa, Benawikawa, e Yaniwa (esse, por sua vez, apresentaria três subdivisões não nomeadas, e escalonadas do irmão maior ao menor), Bia Tuçia Parãmena, e Tórławz; os Yúriwawa constituem um grupo menor, sem divisões internas, escalonando todos os irmãos como maiores e menores; e os Betowa, por sua vez, são considerados estrangeiros na região, como de baixa hierarquia, e apresentam divisão interna: Miawi, Pedikuriá, e Toreawz. Como lidar com essas formulações nativas? Como entender as categorias de irmãos maiores $e$ menores que ora designam relação entre pessoas, ora entre coletivos? Trata-se, parece-me, de relações de "respeito" e "consideração". Propor tais noções não resolve o problema da hierarquia, mas permite um afastamento de muitos pressupostos que tal categoria traz consigo $^{74}$, e uma maior aproximação dos entendimentos nativos.

\section{$* * *$}

A guisa de conclusão, a partir dessas considerações e como via para lidar com a questão dos grupos e subgrupos no alto Uaupés, parece-me adequada a sugestão de Roy Wagner (2010, p. 246) de considerar as distinções a partir de seu valor nominal, apenas como distinções e não como grupos. Os nomes em seu uso para estabelecer corte e diferenciações. Nas palavras de Saez

${ }^{74} \mathrm{O}$ leitor pode encontrar alguns dos tais pressupostos da categoria de hierarquia explicitados em minha dissertação de mestrado (PEDROSO, 2013). 
Mas há outro nível, opcional, porém, mais interessante, em que cabe se perguntar se os etnónimos, esses termos que nunca conseguimos levar muito a sério, mas que parecem ser de interesse para os nossos interlocutores indígenas, não podem ter um papel maior numa descrição etnográfica menos presa à grade classificatória, estabilizada pela etnologia, dos grupos indígenas. Trata-se, em poucas palavras, de ensaiar descrições radicadas nos sujeitos, e nas redes de relações que ensaiam cada vez que aplicam uma pauta de denominação nova. De levar em consideração que, se isso que nós chamamos de grupos são, como disse Wagner (apud Gordon 2006; pp. 117118), apenas nomes, eles são também nada menos que nomes, ou seja, são operadores que conseguem criar circuitos diferentes nessa realidade que estamos a estudar, e que não deveríamos considerar como um simples ruído, a perturbar uma ordem real obtida com tanto esforço de análise, ou de ação política (2011, p. 15).

O universo kubeo seria, desse modo, preenchido por nomes que se desdobram em outros nomes, e são operados em diferentes escalas e contextos. Um regime onomástico em transformação ou, como formulou apropriadamente Andrello "a dinâmica entre nomes e apelidos mais ou menos englobantes, bem como as formas de tratamento que implicam, são instrumentos fundamentais na conceituação de diferenças internas a esse grande conjunto multiétnico e multilinguístico [do noroeste amazônico]" (2014, p. 1). Se Christine Hugh-Jones (1979) afirmava que o "nome é o sib", os dados kubeo parecem nos indicar que o "nome faz o sib”. 
SEGUNDA PARTE - A PESSOA E SEUS NOMES 


\section{CAPÍTULO 3 - PUPUI AMIYA COMO MANEJO DE UMÉ}

Este capítulo desenvolverá o tema do pupui amiya yuremawa e yúriwawa, seus significados, contextos e práticas de atribuição. O termo kubeo pupui amiya é traduzido por "nome de benzimento". Essa tradução não é minha, mas antes diz respeito ao uso difundido no português da região do alto rio Negro. Os Yuremawa e Yúriwawa, quando usam o português, falam "nome de benzimento". O que refiro aqui como "nome de benzimento" recebe outras designações na literatura: "nome espiritual" (ARHEM, 1981; S. HUGHJONES, 2002), "nome sagrado", "native name" e "person's sib name" (GOLDMAN, 1963), "nome xamânico" (C. HUGH-JONES, 1979; S. HUGH-JONES, 1979). Os Tukano do médio Uaupés usam “nome de origem” (Raphael Rodrigues, Com. pes.).

Minha análise do pupui amiya pretende mostrar que há uma metafísica e uma política dos nomes entre os Kubeo: por um lado, há aqueles que aparentemente não se importam com os pupui amiya, o que é expresso por um aparente descaso e falta de interesse no assunto, sendo que alguns chegam a dizer que tais nomes, assim como outras práticas kubeo, pertencem à "era do indígena", isto é, ao passado, e que agora vivemos na "era do branco" onde o nome indígena não teria mais relevância, relegando-os ao esquecimento. Por outro lado, há aqueles que julgam o pupui amiya importante, mas têm compreensões distintas do que é o pupui amiya e o que ele faz: para alguns, o pupui amiya produz pessoas, isto é, sua vitalidade (expressa sobretudo, como veremos, na ideia de crescimento), afecções, disposições e qualidades na pessoa nomeada; tal via nos conduzirá a retomar questões relacionadas aos cuidados com a pessoa desde o nascimento, os benzimentos (pupuiye), os perigos na comunidade e na mata; o nome entendido desse modo está ligado ao manejo de “energias" e potências (LOLLI, 2010, p. 100 e ss.) $)^{75}$ e aponta para as narrativas de origem, os benzimentos e os conhecimentos antigos, o que supõe certa metafísica kubeo. Para outros, o pupui amiya é importante enquanto dispositivo de apresentação do indígena diante do Estado; trata-se do pupui amiya escrito em documentos, como exigência recente do Estado, da igreja, e da escola. Comecemos com o nome entendido como elemento constituinte e constitutivo da pessoa.

\footnotetext{
75 A noção de "manejo de potências" foi originalmente proposta por Andrello (2006) ao tratar das narrativas míticas tukano e da ação dos ancestrais da humanidade. Tal noção é recuperada e operacionalizada por Lolli (2010) ao desenvolver sua hipótese segundo a qual as ações terapêuticas dos benzimentos yuhupdeh são transformações das ações de manejo das potências primordiais. Tal expressão me parece adequada para designar o que pensam alguns Yuremawa e Yúriwawa acerca do que está envolvido no uso de pupui amiya.
} 


\section{O nascimento}

A vida dos Yuremawa e Yúriwawa é pautada por um complexto de cuidados, restrições e benzimentos sobretudo de proteção e para o crescimento da pessoa. Alguns momentos são tidos como de extrema vulnerabilidade ou de "crise", como formulava Goldman (1963), e exigem observação mais rigorosa de certos cuidados e a execução de benzimentos: o nascimento, a primeira menstruação e a realização do Jurupari, e em alguma medida também a morte. Antes, porém, de tratar desses momentos, perguntemos: como os Kubeo pensam a vida de uma pessoa? Segue o que Geraldo Edson apresentou como sendo as "fases da vida" da pessoa:

Mama poẽteyz (0 a 2-3 anos)

Recém-nascido

\section{Mama hikubuyz}

Quando começa a engordar

\section{Mama dobaku}

Quando começa a sentar

3. Mama papeyz

Começa a engatinhar

4. Mama waiwayz

Começa a dar os primeiros passos

5. Mama yawaribuyz

Começa as primeiras palavras

\section{Hiaðoku/hiaðowa}

Infância/criança (05-10 anos)

\section{Bohtyo}

Juventude (12-18 anos) 


\title{
Bukt bohtyo
}

Adulto (18-30 anos)

\section{Bukuku teyz}

Acima de 30 anos

\section{Bukuku}

Velho (acima de 60 anos)

Dito isso, acompanhemos alguns momentos da vida tidos com centrais pelos Yuremawa e Yúriwawa. O nascimento de uma criança é um evento de bastante importância para os Yúri Parãmena. O bebê, extremamente vulnerável, torna seus pais e outras crianças da comunidade também vulneráveis aos ataques dos espíritos da água e da mata. Por conta disso, há alguns cuidados que devem ser observados antes do parto, e sobretudo no momento do parto e algum tempo depois. Vejamos.

Antes do nascimento, durante a gravidez (mikakó) não há regras, mas há alguns cuidados. Gabriel Saldanha, Yúriwawa de Açaí, diz o seguinte:

\begin{abstract}
Mulher grávida tem que cuidar o corpo dela. [...]. Depois de nascer a criança aí sim, tem que ter muito cuidado. [...]. As mulheres falam quando está grávida, tem mulher que sentem preguiça, não tem vontade de trabalhar, tem sono, isso é. Antigamente os velhos não deixavam a mulher assim em casa, eles mandavam trabalhar, não muito não, tem que trabalhar em coisas leves. Porque o bebê eles dizem que nasce com preguiça já; aí a mulher não pode ficar parada não, tem que fazer as coisas, coisas leves, não muito pesadas. Depois que nascer aí sim, tem que benzer, proteger ela, o bebê.
\end{abstract}

Os pais podem afetar o bebê mesmo antes do nascimento; mulheres que não fazem nada durante a gravidez podem produzir filhos preguiçosos. Desse modo, as práticas e cuidados Yúri Parãmena parecem discordar das práticas yuhupdeh, tal como apresentada na interpretação de Lolli (2010), e Tuyuka, como formulado por Flora Cabalzar (2010), que fixam o benzimento de nominação como o "primeiro procedimento para construir uma pessoa" (LOLLI, 2010, p. 86); como vemos na fala do Yúriwawa Gabriel Saldanha, tal procedimento começa mesmo antes do nascimento da criança.

Dada a vulnerabilidade dos pais e do recém-nascido é preciso uma série de proteções (benzimentos) contra os seres da mata e água. Apresento a seguir uma breve descrição do nascimento de duas crianças que reúne práticas que comentarei a seguir. 
Marci, Yúriwako que vive em Querari, contou-me sobre o nascimento de suas duas filhas. O primeiro parto se deu na mata. Marci tinha viajado com Luiz Gilberto (seu marido), Martins (pai de Luiz Gilberto) e Gladis (sua sogra) para o igarapé Marãkãriya, pois os homens iam caçar e pescar. Uma vez lá, acampamento montado, Marci começou a sentir dores do parto. Luiz Gilberto tinha saído para caçar, e quem fez o parto foi Gladis com ajuda de Martins. Enquanto Gladis auxiliava Marci, Martins fazia benzimentos para afastar os animais da floresta que poderiam ser atraídos pelo cheiro do sangue. Logo em seguida, foi atrás de seu filho, para avisá-lo, com medo de que algo lhe tivesse acontecido. Por sorte, Luiz Gilberto não tinha achado nenhuma paca ou outro animal de caça, pois como explicou Marci, se ele atirasse no animal, a criança choraria no mesmo momento e sairia sangue de seu umbigo. Além desses cuidados, Marci também foi pintada com carajuru, que Martins tinha benzido. Em seguida, voltaram para Açaí, onde os pais fizeram quatro dias de resguardo, sem trabalhar, comendo apenas mingau. Nesse episódio, vemos a preocupação de Martins com seu filho no momento do parto, algo semelhante ao cuidado Bahúkiwa descrito por Goldman: “A woman about to give birth must alert her husband so that he will not leave the house or do anything strenuous that would interfere magically with the delivery and safety of the infant" (1963, p. 167).

No segundo caso, o nascimento de Liz, a segunda filha de Marci, foi Letícia (mãe de Luiz Gilberto) quem fez o parto em Querari, em casa mesmo. Foi um parto difícil e por isso Martins benzeu e deu água para Marci tomar, para ajudar a criança a sair. Letícia disse que isso acontecia porque Marci tinha o hábito de ficar parada na porta de casa, o que causava essa dificuldade na hora do parto. Depois que nasceu, Martins benzeu carajuru para proteger o bebê, como tinha feito no primeiro parto. Alguns dias depois, Marci teve dificuldades para amamentar, pois teve muito leite, que ficou duro em seu peito, e causava dor. Como Martins tinha viajado imediatamente após o parto, Luiz Gilberto mesmo fez benzimento em pente, que ele passou sobre o peito de sua esposa, fazendo movimentos para o leite sair. Após o parto de Liz, foram três dias de resguardo, nos quais não se podia comer, pescar, caçar, ou ir para roça. Apenas um mingau era permitido. Feita essa descrição, explicito algumas das "regras" e práticas que orientam momentos como os acima descritos.

Em primeiro lugar, os cuidados no nascimento. Conversando com o Yúriwawa José Bernardo, ouvi a seguinte explicação sobre nascimentos e cuidados:

Mulher não faz jejum, nada quando está grávida. Depois, quando ela tem filho, ela fica uma semana sem fazer nada; só cuidando da criança, e 
cuidando do corpo dela também. Fica assim, sem fazer nada, só o velho benze a ela, dá de comer; ele benze peixe também, beijú, o peixe assado, cozido, sal, tudo isso.

Mas as regras não devem ser observadas apenas pela mulher; cabe ao pai seguir certa conduta, como esclarece José Bernardo:

Marido e esposa têm que ficar uma semana em casa, por aí, 4 dias ou 5 dias. Só lavar a boca com água mesmo, sem tomar banho ainda. Sem comer peixe, sem comer carne, nada. Aí a gente benze para ele depois de 4 dias ou 5 dias né; ele benze com cigarro, com carajuru, e só isso né. Benze bem, depois dá cigarro para ela fumar, e marido também fumar, e até soprar no neném. Aí eles vão tomar banho. Ele, o velho mesmo leva; se ela tem sogra, eles vão cuidar do bebê enquanto ele está tomando banho. Aí ele fica tomando banho, segurando neném, banha o neném também, lava. Pronto, agora está livre. Depois de tomar banho, o pai, o velho, o sogro, eles vão pescar, ficam cozinhando aí, e está pronto aí. Depois de tomar banho, então saí da água, e entra na casa, troca roupa, e pronto. É hora de comer peixe para ele, peixe já benzido, sal misturado, já benzido e beijú. Depois de tomar banho eles já ficam comendo tranquilamente. E depois de tomar banho, comer peixe, ele fica ainda assim trabalhando 5 dias mais. Fica na casa. Se ele quer tomar banho ele vai, dá banho para o neném, e assim.

Vemos, a partir dessa fala, que logo após o nascimento deve-se ficar em casa, jejuando, evitando esforço físico, por aproximadamente cinco dias, até que os primeiros benzimentos tenham sido realizados, e a criança tenha tomado seu primeiro banho. A alimentação, durante esse período de resguardo, se resume a um mingau apenas. Somente depois de alguns dias os pais voltarão a comer comida com sal, peixe, beijú, sendo que cada um desses alimentos deve ser benzido antes. Mas por que esses benzimentos são importantes?

Perguntei a José Bernardo por que os benzimentos eram necessários. Sua resposta foi a seguinte:

Para não pegar essa doença, ou para não entrar micróbios, como diz o branco. E por isso ele não dá passeio no mato, ir trabalhar, e no rio também; às vezes fica doente aí. E para isso ele benze, para não pegar essa doença aí; benze tudinho, aí ele sai. Ir na roça, o homem também vai na pescaria.

José Bernardo tentou avançar uma explicação usando a noção de "micróbio" como analogia. Logo em seguida, diz que a mata e o rio são lugares onde a pessoa pode ficar doente. No caso do rio, José Bernardo atribui a causa de doenças ao ataque de peixes:

O peixe às vezes faz doença. Por exemplo, se tu vai pescar, depois de ter filho, o pai ou a mãe né, se ele mata peixe, ou às vezes cai e molha, aí as 
vezes fica apodrecendo aí, já começa a ter febre, fica doente. E para não ficar assim ele benze contra essa doença; a mulher também assim; e para neném também benze para não pegar essa doença, e assim; aí termina, aí tu pode andar normal.

O benzimentos é, portanto, condição para proteger a criança e os pais; como afirmou José Bernardo: "se vovô está aí, ele benze; se papai sabe, ele mesmo benze para o filho. Se ele não sabe, então manda benzer para outro, tio, irmão, pode ser parente, ele benze para ele"; mas é preciso benzer. Como vimos no caso contado por Marci, no primeiro nascimento foi o avô paterno da criança que fez os benzimentos; no segundo nascimento, esse mesmo avô fez parte dos benzimentos, mas dado que teve que viajar, o próprio pai da criança fez alguns benzimentos necessários, como o do pente para fazer o leite materno sair. Sem proteção, a criança e seus pais ficam vulneráveis ao ataque dos "seres espirituais" que habitam o espaço kubeo. Mas qual a noção kubeo de "ser espiritual" ou "seres da natureza"?

Os Kubeo de Açaí e Querari comumente falam de "seres invisíveis"76 ou "seres espirituais" que habitam as matas e rios. Estes seres são referidos quando se contam histórias de doenças, de caça e pesca, ou mesmo episódios durante trabalho na roça. Há dois termos gerais em Kubeo para designar tais seres: hoktww ("espíritos da mata"), usado para se referir aos seres que habitam o espaço da mata; e moawz ("espíritos da água"), aqueles que habitam o ambiente aquático. Geraldo Edson explicou da seguinte maneira:

Já esses que eu falei, esses hoktwz, moawz, são espíritos do mato, da água; são invisíveis. Tem os espíritos concretos e outros são abstratos, visível e não visível. Esses moawz e hokawz não dá para ver, a gente só vê quando aparece dor, doença, a gente diz "esse espírito que fez assim para a gente", a partir daí que a gente consegue descobrir; ver a gente não consegue ver, vamos sentir só as consequências. Aí precisa de benzimento para curar, pajé mesmo, todo isso aí. Tem o pajé para chupar isso aí, tem outro, o kumu, que faz cigarro. Tem que ir com o kumu, benzedor, já falando "a situação é assim", dali ele benze já.

Não se pode ver esses espíritos da mata e da água, contudo, pode-se saber da presença deles mediante alguns elementos como sons, cheiros e doenças. Os Kubeo me disseram muitas vezes que há vários tipos de hoktwz, e que é difícil precisar quantos tipos existem e quais são, uma vez que os mesmos não são vistos. Entre esses seres invisíveis, abuhuku (pl. abuhuwa) designa o mais conhecido. Tal termo é traduzido como "espírito", "demônio" e mesmo "diabo", termos esses provenientes do vocabulário cristão introduzido pelos

\footnotetext{
${ }^{76}$ Notei, no português nativo, o uso de um conjunto de termos para designar tais entidades: "seres invisíveis", "seres espirituais", "espíritos ou seres da natureza" ou apenas "espíritos".
} 
missionários; no dicionário kubeo organizado por Chacon $(\mathrm{s} / \mathrm{d})$ encontramos também a tradução "ser da floresta". Abuhuku é dito um "ser invisível", no sentido, se bem entendi as explicações que os Kubeo me forneceram, não de terem a invisibilidade como atributo de sua constituição, mas antes no sentido de que eles não se deixam ver; assim, poderíamos dizer de forma mais precisa que são "seres visíveis" que não se deixam ver. Caso a pessoa o veja, sofrerá as consequências disso, como a história do Yúriwawa Jaime Rodrigues de Açaí que Luiz Gilberto me contou certa vez.

Jaime é referido como abuhukt, seu apelido, e isso se deve à história do encontro entre ele e um abuhuku na mata. Conta-se que certa vez Jaime saiu para caçar. Achou um jacu, atirou e a ave caiu num lugar à sua frente. Quando chegou para ver, a ave já estava em outro lugar. Nesse momento, sentiu um abraço de algo como um "homem gigante", do qual ele não conseguiu ver o rosto, mas afirma que era um demônio. Acordou no dia seguinte, no mesmo lugar onde estava durante o encontro, sujo, arranhado. Voltou para casa nesse estado. Ficou um mês sem falar, "como se estivesse com o pensamento em outro lugar". Apenas depois desse tempo voltou a falar e então contou o episódio, mas não se não lembrava o que exatamente tinha acontecido. Eis um caso de encontro com abuhukt e suas consequências.

Mas isso não é tudo. Há muitos tipos de abuhuwa (makarõku abuhukü):

\section{Kuinaraðo abuhuku}

(“diabo de um pé”, “como um saci”, explicaram)

\section{Nũo abuhukt}

("diabo da raiz")

\section{Nama abuhukt}

(“diabo do veado")

Burucutu abuhukt

\section{Haruru abuhukt}

Awawakt/awawako ("curupira")

\footnotetext{
77 O dicionário kubeo de Chacon (s/d, p. 48) traduz makarõ como "floresta", e também como "terra/lugar"; assim, poderíamos traduzir makarõku abuhuku como "espírito da floresta" ou também "espírito da terra/lugar".
} 
Kuina opeko (feminino para curupira)

Kuina opekt (masculino para curupira)

Aqui, cabe lembrar que esses "espíritos da natureza" constituem categoria distinta dos "espíritos de mortos", os quais têm um lugar de destino: Abuhuñami, casa ou lugar onde vão os espíritos dos mortos ${ }^{78}$ que, segundo me indicaram os Yuremawa, fica numa serra próxima ao rio Querari, na Colômbia.

Os "espíritos de mortos" são designados em Kubeo pelo termo põe dekoku, que é comumente glosado em português também como "fantasma". Vale notar que o termo dekokt é também usado para designar sombra, fotografia e imagem de modo geral. Assim, ouvi algumas vezes os Kubeo usarem a expressão “dekokure hađomakõ pe ãrohãwi mu”, que pode ser traduzida como "parece que você viu fantasma".

Aqui, cabe esclarecer certa concepção da pessoa yuremawa e yúriwawa. Segundo esses, as pessoas são animadas por umé, um conceito de difícil tradução, que inclui "alma", "espírito", "energia" e "vitalidade". O corpo físico é chamado em Kubeo de bahu. Com a morte, esse corpo perece, e então a pessoa segue como põe dekokt, "espírito de morto", para Abuhuñami. A noção de umé, como vemos, é central, e recebeu elaborada atenção de Irving Goldman (2004).

Com efeito, Goldman busca formular uma "teoria dos poderes" kubeo. Destaca inicialmente que o termo umé é traduzido pelos próprios Kubeo como "espírito" ou "alma”. Segundo Goldman, acerca do modo de apreender corretamente tal noção:

It is more productive to follow the Cubean suggestion just cited and treat umé as part of a general notion of energy that expresses in Cubean thought a unified theory of cosmic action. It is not diverseness in itself that would lead us to regard umé as a form of energy. as a physicist might think of it; is also, as I shall try to show, that the manipulation or the management of this form of energy is governed by rules that constitute an elementary prime - a coherent corpus of seriously considered knowledge (2004, p. 347).

E continua, com uma tentativa de precisar mais a noção de umé:

Invisible and intangible like air or breath to all but the payé, umé is nevertheless a substance with mass that can be broken up and carried off. Imagined as air, it seems to be continuous and undifferentiated, a force filling all space evenly. But this is not the case. Like an Einsteinian conception of gravitational space, umé shapes itself to conform to the

\footnotetext{
${ }^{78}$ Chacon, no Dicionário Kubeo, registra como abuhuyami, e traduz por "casa dos espíritos” (s/d, p. 1).
} 
substances that it animates or suffuses with its vitalizing energy. In the human body, it is concentrated in the heart (uméndü) and flows outward to become the energizing force of each organ.[...] One can speak of umé of thought as well as of vision, speech, digestion, sexual function, and so on. It is the force that capacitates. [...] Like other tissues, blood is also activated by umé" (2004, p. 348, sublinhado meu).

Em Querari e Açaí os termos usados em português eram "energia", "força”. Luiz Gilberto certa vez explicou que cada grupo tem sua "força", que pode diminuir com o abandono de práticas como benzimentos, cuidados alimentares e corporais, respeito a certas "regras", realização de Jurupari e uso da língua, e aumentar com a manutenção de tais práticas $^{79}$. Essa fala de Luiz Gilberto se aproxima e corrobora a afirmação de Goldman segundo a qual "One merit of trying to represent Cubean culture from a perspective that is metaphysical and not sociological is that it comes closer to what Cubeo have in mind when they talk about themselves" (ibidem, p. 346). Dito isso, voltemos aos seres da natureza e seus modos de ação.

Geraldo Edson ofereceu a seguinte formulação sobre os seres da natureza e seus ataques:

Têm os seres visíveis e invisíveis. São os espíritos da natureza, seres que são invisíveis. Esse espírito pode possuir o próprio ser, se não é bem benzido. $\mathrm{O}$ pai depois de ter filho tem que ter aquele resguardo de 1 ou 2 semanas, antes de sair do resguardo tem que ser benzido, tem que fechar o corpo, de todo mundo, para que o ser invisível não possa atingir ele, para que não faço adoecer; se não vai ter várias consequências, aí quando for na água vai ter dor de ouvido, já sai aquele tumor, todo tipo acontece. Esses são Moawz que tão matando, peixe-gente que eles chamam. Já agora no mato, eles são hoktwz; esse hoktwzt também... até o cupim pode transformar em alguma coisa, para quem não for benzido, pode fazer que a pessoa fica doente, dor de coluna, várias coisas. Eles são espíritos, vivem dentro da água e na terra firme. Além desses, existem também aqueles animais, cobras que chamam, tem vários tipos de acontecimentos; essas coisas acontecem porque a pessoa não foi benzida, se foi benzida bem certinho, bem correto, se cumpriu o resguardo direitinho aí não faz nada. [...] O que afeta são aqueles seres invisíveis, que afeta para a própria criança e para os pais. Quando pai e mãe não cumpre aquele mandamento, que os velhos falam, no caso, questão do umbigo da criança, é proibido cortar aquele... como quando cortam a bananeira sai aquele broto dela... todo aquele que sai... aquela sororoca do mato, tem que ser benzido também, no caso para pegar terçado, todas essas

\footnotetext{
${ }^{79}$ Luiz Gillberto manifestava constantemente sua preocupação com o abandano de tais práticas e conhecimentos. O que se chama comumente de "perda da cultura", segundo Luiz Gilberto, é o "enfraquecimento do grupo", em sentido metafísico, ou seja, é a "força" e "vitalidade" do grupo que diminui, o que implica multiplicação de doenças - sinônimo de corpos frágeis, sem proteção - aumento dos conflitos e violência, e não crescimento da pessoa, no sentido corporal, nem da comunidade, no sentido de novas famílias. Insistirei nessas formulações de Luiz Gilberto, compartilhada por muitos outros Yuremawa e Yúriwawa, em outros momentos nesta tese.
} 
coisas. Senão faz que criança seja afetada no umbigo dele, começa a sangrar, chorar, se não benzer sangra e morre aí, chora, chora e morre. Por isso que é para evitar todas as coisas, tanto para pescar, tanto para pegar minhoca, tanto para pegar no fogo... todas essas coisas, tudo benzido; porque comparando esses são todos aqueles que têm espírito, seres da natureza, são envolvidos com esses materiais. São espíritos que fazem assim, quando a gente vê esse fenômeno aí.

Os malefícios advindos da não observância de regras pós-parto são ação dos moawa e hokuwa. Antes, porém, de detalhar o modo de ataque deles, vejamos com mais detalhes outro tipo de espírito da natureza. Na sequência dessa mesma fala, Geraldo Edson fornece a seguinte explicação sobre os abuhuwa:

Agora visível são aquelas pessoas que chamamos de diabo, que faz parte, já convive com a natureza, abuhukt; eles chamam também de põe dekokt, visagem, fantasma. Já abuhuku é palavra concreta; põe dekokt é palavra abstrata; não aparece, é um ser invisível, mas tem algum som, estrondo, que ele faz de longe, no caso chama de põe dekoku, fantasma; às vezes aparece para a gente, no formato de um ser, ou um animal, tem diversos tipos de ser; ou até mesmo aquela pessoa que faleceu, ele pode retornar, aparecer com um corpo, aparece antes de adoecer, se perder nosso parente próximo, isso acontece. Isso acontece, essa visagem. Agora em relação ao diabo tem vários tipos; tem aquele mihã abuhukt, dizem que esse é aquele tamanduá; dizem que é tamanduá que vira diabo, por isso que chama de mihã abuhukt. Os velhos têm história que ele vira diabo mesmo, o tamanduá. Agora o abuhukt a maior parte da gente não vê, escuta a palavra, mas a gente escuta dizer que outros viram, estiveram diante deles; ninguém sabe quantos tipos de abuhuku existem na natureza; aí no caso, o curupira, ele é um diabo também, um abuhukt, mas ele é um abuhukt que tem... como se diz... ele é igual a uma bomba atômica, quando começa a zuar ele já tira nossa força, já tira com aquele estrondo dele, aquela coisa que ele faz, nosso corpo já amolece, as pernas começam a tremer, nosso pensamento começa a sair do lugar, a gente já fica meio tonto, não consegue pensar mais, esse aí é um ser poderoso da natureza. Ele também tem aquele canto de diferentes de animais, imita animais, outro lado dizem que ele é o pai dos animais, o curupira, dizem que todos os animais que vivem na natureza são criação dele, igual um ser que cria aqui domesticado, como esse galo, tudinho, tem essa mesma coisa lá no mato, por isso que ele canta todas as línguas, o canto dos animais; ninguém sabe o formato dele, como ele aparece. Meu pai finado falava que ele parece uma...uma... não sei se ele viu uma mulher ou um homem, ele falou que viu esse curupira, aqui onde ele trabalhou, quando a gente morava lá em Pacú, ele viu o curupira comendo caranguejo, lá nesse igarapé. Ela tava sentada de costas, tinha cabelo até a cintura, a orelha dela tinha igual o formato de um cavalo, e já o rosto meio pintado, pintado de preto e amarelo, bem desenhado, dessa forma que ela aparecia, e a bunda bem larga, grandona, esse é o formato que ele disse que viu. Agora cada um conta, tem vários formatos que ele aparece... às vezes aparece naquele formato de centauro, que chama, cavalo meio ser humano... essa forma que ele aparece... esse Rafael me contou essa história também, quando ele foi pescar, ele tava faxeando, ele veio nadando no igapó, falou para mulher que pensou que era anta, ai cercou, pensando em atirar, cercou e focou, mas não 
era não, era um centauro, formato de um homem com traseira de um cavalo, agora já cabeça não tinha diferença não, orelha pontuda com cabelo para cá também. Esse formato de curupira, não sei outros. Agora, outro lado eles falam que tem pé virado para trás, pé grande, mas o pé dele não muda não, é grande mesmo, a gente já viu isso aí, acho que mede uns $30 \mathrm{~cm}$ a mais que o ser humano. Essa a parte do curupira, agora tem também outro diabo que zoa a noite, quando ele anda, ele zoa como estalando o dedo, o passo que ele anda, esse é outro tipo de abuhuku, esse chama de hokótará, esse outro diabo também; tem vários tipos de diabo. Tem esse hokótará, tem o "diabo do céu", «mษ kabuhukt, esse acho que é aquele quatá, é um filhote de orangotango; ele anda abaixo da copa das árvores, ele vai de uma copa para outra, dá para escutar de longe quando ele anda, não aparece não. [...] Jaime encontrou o diabo, aquele que tem cheiro ruim, ele falou, esse curupira também tem cheiro forte, cheiro estranho, mais que gambá, cada tipo de diabo tem cheiro estranho também, forte; com esse cheiro que ele mata a pessoa, dá para sentir de longe o cheiro dele. Já agora o curupira não, ele amolece o corpo do ser é com o barulho dele, com tiro dele. Antigamente dizem que ele fugiu da guerra, esse curupira, os velhos contavam; antes do começo do mundo, teve guerra, ele fugiu da guerra, roubando não sei se era espingarda, alguma coisa assim, quando ele fugiu não apareceu mais não, virou desse, a mãe natureza que ele virou já, por isso que ele zoa como se fosse atirando já, quando ele zoa no mato, é devido isso. Aqui perto que ele vive, esse curupira, vive, ao redor da roça. [...] Ele aparece, agora, o resto desse abuhukt, o resto, ninguém vê, ninguém escuta, agora esse curupira tem visto todo tempo, assim ele aparece, aparece não, ele zua, a gente escuta, ao redor da roça, dá para escutar som dele, agora resto a gente vê às vezes. Esse diabo fazem mal para pessoas, fazem devido cheiro dele, faz mal para pessoa, de tanto cheirar o cheiro ruim dele, a pessoa fica meio... como se diz... com dor de cabeça, dá mal estar, dá febre, dá tudo aí, isso aí, tem que benzer também, depois que a pessoa viu ou encontrou com esse diabo tem que ser benzida, com cigarro, com água, aí depois disso a pessoa começa a melhorar; se nao fizer isso a pessoa vai piorando, pode falecer também; aí dizem que o diabo já tá tirando a alma dele, melhor dizendo, quer dizer, a pessoa morre, mas a alma vai embora para lá, com ele, ou ele já substitui já com ele, assim que acontece; esses são os abuhuwa makãkawz.

Geraldo Edson classifica os abuhuwa como "seres visíveis", que podem ser encontrados na mata, como efetivamente aconteceu nos casos que ele cita: Jaime, Rafael e seu próprio pai. Esses encontros reais, que efetivamente aconteceram, permitem elencar alguns traços da aparência desses seres. Além disso, sabemos da presença deles, além do possível encontro direto, pelo som que alguns produzem e também pelo forte cheiro. Aqui, gostaria de chamar atenção para a questão do odor, pois assim como os abuhuwa têm cheiro muito forte, que pode causar mal a pessoa, os espíritos são atraídos pelo cheiro do sangue menstrual; o código olfativo é central aqui.

Portanto, a criança e seus pais estão no momento do nascimento vulneráveis ao ataque de moawz e hoktwz; mas como esses seres invisíveis da natureza atacam? Eis uma formulação do mesmo Geraldo Edson: 
A gente fala espíritos invisíveis, espíritos do mato, da água, todos esses aí, querem fazer mal a criança. É por isso que eles fecham todo o corpo, dos pais e das crianças, para não acontecer nada. Os espíritos percebem pelo cheiro; ele aparece de longe para o espírito, é mais fácil sofrer esse dano com o espírito, para evitar isso fecha todo o corpo dele, pai, criança.

Os benzimentos funcionam "fechando o corpo", tornando a pessoa invisível para os espíritos da mata e da água, uma vez que os mesmos são atraídos pelo cheiro do sangue do nascimento da criança. Tal explicação foi corroborada pelo Yuremawa Eduardo Rodrigues que, perguntado sobre o ataque dos seres da natureza, acrescentou mais uma forma de ação dos moawz e hokuwz:

Isso mesmo. Eles atacam. Por isso que a mulher na primeira menstruação tem que fechar o corpo, para não acontecer isso, os benzedores, os pais das meninas, tem que procurar com conhecedor, porque a primeira fase da menstruação é muito perigosa, a própria natureza, ele leva, pega espiritualmente, estrago, lugares sagrados. Por isso, para não acontecer, ele fecha o corpo, benze, é assim que eles fazem. [...] o espírito da natureza troca crianças, se a criança nasceu num lugar sem benzedor, se não fecha o corpo da criança, ele troca, dizem; criança nasceu normal, isso aí, demorado, a menos um mês, não é mais criança, transforma outro tipo de gente já. Como que chama... criança... tipo com defeito... criança nasceu normal, mas sem benzimento, de repente muda outro tipo, não fica como se fosse uma criança normal. Por isso que é muito perigoso para a criança, tem que benzer; a própria natureza troca, troca sapo, cobra, é assim, eles dizem, troca. Acontecia muito, por isso que os velhos, nesse primeiro parto, é bem benzido, para nao acontecer, para não ser trocado. [...] Carajuru benzido, alguns têm aqui, benzimentos. Como chama... aquele cheiroso... çipé, em português não sei como é... caranha em português, mistura com carajuru para pintar, são benzidos, aí o espírito da natureza, para não dominar naquela criança, para não pegar doença também, todo tipo de gripe, aí ele tem medo; por isso que ele é benzido esse carajuru e caranha. $\mathrm{O}$ caranha tem que ser benzido, porque antes de tomar banho é para jogar na água, para o espírito não encontrar você, não tocar em você. Aí o espírito não vê, ele tem medo. É só isso que a gente não pratica mais. [...] quando completa a criança já vai embora. Até quem encontra marido tem que ser uma festa também, tem que cuidar ainda, com um mês, com sogra dela, não pode tocar ela, depois que vai fazer gente aí; agora ninguém sabe o que está fazendo.

Segundo Eduardo, uma forma de ação dos espíritos da natureza é "trocar a criança", algo que os brancos referem como crianças "com defeito"; já se trata, nesses casos, de "outro tipo de gente". Certas práticas e cuidados devem ser observadas para evitar esse ataque. $\mathrm{O}$ benzimento com carajuru e çipé é indispensável. Aqui, obvservemos novamente a referência ao código olfativo: "Carajuru benzido, alguns têm aqui, benzimentos. Como chama... aquele cheiroso... çipé $[. .$.$] caranha em português, mistura com carajuru para pintar, são benzidos, aí$ 
o espírito da natureza, para não dominar naquela criança, para não pegar doença também, todo tipo de gripe, aí ele tem medo". Vemos, portanto, que há uma certa economia dos odores nessa relação com os seres espirituais. É o cheiro forte do sangue do parto que atrai esses espíritos, deixa a criança e os pais vulneráveis, assim como é o cheiro forte da primeira menstruação que deixa a menina vulnerável ao ataque desses seres. Para proteção, além do benzimento, pinta-se com carajuru misturado com çipé (caranha), substância essa com cheiro forte, que ajuda a afastar os espíritos da natureza. Vimos na descrição dos abuhuwa que esses têm cheiro forte, um dos elementos que faz mal aquele que encontra esses "demônios" na mata. Segue-se, portanto, que se determinados odores atraem os espíritos e fazem mal à pessoa, outros odores de certas substâncias benzidas funcionam afastando esses espíritos. Dito de outro modo, odores que aproximam, fazendo mal, e odores que afastam, protegendo a pessoa, "fechando o corpo". Dito isso sobre os seres espirituais, voltemos ao momento do parto.

Figura importante no momento do nascimento é aquela da parteira. Sobre quem faz o parto, José Bernardo disse:

Só a mulher, a mãe. Se ela tem sogra, a sogra cuida dela. O marido dela, se ele sabe benzer, ele benze, ajuda para ter assim normal, para ter filho, benze com água, manda ela tomar, benze com cigarro, manda ela fumar, tem tinta para pintar o corpo dela também, benze e dá para ela, então ela pinta na perna dela. Agora essa tinta não tem mais não. Agora dá um sabonete para benzer ela, para tomar banho, ele benze e dá para ela, com isso ela toma banho e lava o corpo dela. Também ele benze. Ajuda a benzer, o homem sempre fica na casa, e a mulher fica em outro quarto; por exemplo se ela não tem mais rápido o bebê, ele manda benzer para o velho, ele benze e benze, e nasce mais rápido; outro tem remédio, remédio caseiro que ele planta, dá para ela tomar, nasce rapidinho.

Em conversa com Eduardo Rodrigues, ele também destacou o papel da parteira:

Antiga cultura também tinha uma parteira, já existia dos índios também, dos povos indígenas, mãe, pode ser avó, uma senhora de outra comunidade, outra casa; experiente já, se a criança está em pé, ela já dá o jeito dela. Ou pode ser benzedor também; ele posiciona a criança certo. Isso que era a preocupação dos velhos, dos indígenas, que preocupavam com a criança. Tem certa etnia que não preocupa não, nem todos, por isso que criança nasce errado, na posição. A parteira esse pessoal leva, ou chama, se está também, ela é doutora, ela faz o serviço sozinho. Certo benzedor pode fazer só com benzimento a criança ficar na posição; isso que era a preocupação dos velhos. A mulher é mais delicada, os velhos diziam, não pode carregar peso, senão aborta. Hoje em dia a mulher sofre muito, tem certos homens indígenas que não ajudam nada, não têm pena da mulher, ela lá com aturazão, coitada, grávida ainda. Nossa etnia não existia isso, o homem é 
obrigado a trabalhar. [...] chama uma mulher mais velha para ajudar, sempre tem alguém para ajudar no parto. Minha mãe e meu pai, era antigamente. Minha tia, ela sempre ajudava. Quando não tem ninguém, a criança nasce aqui mesmo. A Letícia [mãe de Luiz Gilberto] sempre ajuda, ela é experiente, profissional. Por isso sempre que tem parto ela vai. [...] aquela mulher do seu Amós, Olivia, ela tem experiência também, sempre ela assiste assim quando criança nasce, faz parto, ajuda; o restante, esses jovens não preocupam não.

Pode acontecer do próprio marido fazer o parto. Geraldo Edson me contou certa vez:

Os pais seguem regras sim. Por isso que ele está em casa aí, esse Alexandre [Yuremawa vizinho de Geraldo Edson], nem para a escola ele está indo, está com 2 dias o filho dele; é menino. Acho que foi irmã da esposa que fez o parto, ou próprio ele, não sei. Meus filhos eu mesmo fiz o parto.

Mas, segundo Marci, isso não é comum; ela me explicou que homem não pode ver o parto:

Aqui para o indígena é proibido homem ver parto, para vocês no hospital é homem que faz parto, por isso que eu tinha vergonha de ir ao hospital; aqui é proibido. [Certa mulher kotiria] disse que [o marido] que fez o parto. Esse casal é esquisito. Para mim, minha regra, minha mãe falava é proibido homem fazer parto, aí sogra, que seja mulher que acompanha no parto, não homem, tem que ser alguém experiente.

Ainda sobre quem faz o parto, o Yúriwawa Gabriel Saldanha apresenta uma posição um pouco diferente da sustentada por Marci. Segundo ele, o pai deve ficar por perto no momento do nascimento, e ajudar seja com benzimentos ou remédios caseiros:

Quem faz o parto é pessoa mais velha, conhecida já, principalmente a sogra, tem que acompanhar ela, ou a mãe da mulher. O pai antigamente ficava longe, mas agora não, agora o pai tem que acompanhar também, ajudar benzer, procurar remédio, para nascer rápido o bebê. $\mathrm{O}$ marido tem que tá perto, ajudando ela, agora é assim, antigamente não, a mulher ficava sozinha, o marido ficava longe. Depois que nascia o bebê, aí ficava junto. O parto do filho de Paulo foi feito pela sogra dele, lá de Jaburu. (...) Parto de Cristian foi acompanhado pela mãe de Gabi; das meninas também, a mesma coisa, da Valdete foi a mãe de Gabi; da Tati foi a mãe de Tânia que acompanhou o parto.

Sobre o lugar adequado para o parto, o mesmo Gabriel Saldanha diz:

Hoje se prefere ter o filho em casa. Antigamente, a mulher não tinha assim, nascer dentro da casa; ela tinha a parte, longe, lá, daqui a $20 \mathrm{~m}$, tinha uma 
casinha para ela, para ter filho, separado da casa. Aquela que cuida do parto, ela vem, avisa, volta, depois ela avisa já nasceu, agora está livre, benzer de novo para ela ficar bem. Se as vezes depois de nascer ela fica sangrando, para ficar mais rápido, para acabar com esse sangramento, ele benze, acaba rapidinho. Hoje é na casa mesmo. Antigamente, somente os velhos viviam numa casa só, uma maloca, e por isso eles tinham uma casa em outra parte para ter filhos; e agora não, porque todo mundo tem casa assim separada; por exemplo, outro tem casa grande, se ela está no parto, fica em outro quarto, onde não tem gente, até nascer o neném. Agora é assim.

Lembremos que Goldman (1963; 2004), ao falar dos Kubeo Bahúkiwa e Hehénewa, descreve a roça como lugar apropriado para o parto, lugar esse que oferece grande rendimento para as análises do autor, ao desenvolver a relação entre mulher, nascimento e roça, chegando a formular paralelos entre "reprodução social" e "reprodução biológica". Entre os Yúri Paramena, a preferência é o espaço da casa. Mas há ainda o caso de muitas mulheres que dão à luz em hospitais, na cidade de São Gabriel da Cachoeira, situação facilitada com o transporte aéreo do exército; esse parto no hospital cria algumas dificuldades para os benzimentos e cuidados que devem ser observados. Contudo, ainda assim os benzimentos não deixam de ser feitos, como explica José Bernardo:

Agora nesse tempo, quando a mulher está grávida ou está com parto vai no hospital, não sei que, só procurando remédio dos brancos. Aí pessoal que benze, às vezes esse remédio do branco, e dá para ela; melhor ainda né. Tinha remédio também plantado para depois do parto ela tomar, por exemplo esse remédio, tomar e comer peixe para não ficar assim, não ter dor de barriga; se não fazer assim, se a gente come, fica com a dor de barriga, depois passa; para ela não ter, tomava esse remédio caseiro. Até homem também tomava; porque homem é principal, pai desse menino. Eles também faziam muitas coisas assim, os velhos. Depois quando o menino já cresce, querendo comer, benzia para ele também, para ele alimentar, depois ia normalmente, se não benzesse, as vezes ele ficava com diarreia; pra nao ficar assim, sempre ele benzia. Esses benzimentos para o homem não acaba, nós temos esse benzimento. Esses tukano, wanano, também tem esses benzimentos. Mesmo se ela foi lá no hospital, a gente benze.

Após o nascimento, como dito, uma série de práticas e cuidados cercam a criança e seus pais. O homem deve fazer certos resguardos, como evitar ter relações sexuais com a esposa, não fazer esforço físico e não trançar corda. Esses resguardos devem ser observados durante certo tempo após o nascimento do filho, tendo em vista preservar o umbigo do bebê (homuro) e consequentemente sua vida. O tempo ideal de resguardo é de um mês, mas atualmente costuma-se guardar por volta de cinco a sete dias. A mulher também não pode 
comer a maior parte dos alimentos, quando come, é preciso fazer benzimento. Cito alguns casos de consequências da não observância desses cuidados.

Maria (Kotiria), esposa de Geraldo Edson, falou que quando sua filha Kiane nasceu ela não observou a restrição alimentar completamente, e comeu carne de jacaré sem benzimento. Sua mãe a repreendeu duramente por isso, pois colocava a vida da filha em risco. Em outro episódio, Luiz Gilberto me contou que certa vez um homem Yúriwawa de Açaí ficou doente como consequência do ataque dos espíritos da água porque não tinha feito restrições quando sua esposa - uma Tariana - estava grávida, morando longe, em Iauaretê. Com efeito, seu corpo começou a manifestar alguns ferimentos na pele. Preocupado, o Yúriwawa procurou um pajé para benzimento e ouviu desse que ele estava se transformando em peixe, e que quando morresse por conta da doença se transformaria completamente em peixe e iria para casa dos espíritos-peixe (moawa). O citado Yúriwawa quase morreu, mas foi curado com benzimento. Portanto, concluía Luiz Gilberto, “esse momento do nascimento de uma criança é muito perigoso", estão todos vulneráveis ao ataque dos espíritos, "é preciso proteção, uma capa para proteger". Se os pais não seguem as "regras", as "restrições", eles e a criança podem ficar doentes e até morrer. Não adianta o pai adotivo fazer restrições, "os espíritos dão risada disso", explicou Luiz Gilberto certa vez, "o pai que gerou deve fazer as restrições"; lembremos aqui a afirmação feita mais acima de José Bernardo: "homem é principal, pai desse menino". Os mais jovens, segundo Luiz Gilberto, não observam essas restrições, "daí têm filhos fracos, sem fôlego, que ficam doentes com facilidade"; são, portanto, os mais afetados pelas doenças e consequências da falta de benzimentos e cuidados. Luiz Gilberto sempre insistia comigo na importância de observar essas "regras", pois elas "são verdade, a gente vê o que acontece quando alguém não respeita elas", e "alguns dizem que isso já é do passado, que a era dos indígenas já acabou, agora é a era dos brancos; mas a natureza não muda, os espíritos da natureza estão aí”.

Como Luiz Gilberto, sua esposa Marci também reclamava do fato de as pessoas de hoje não seguirem essas regras. Comentou o caso do Yuremawa Eduardo que, como parte dos cuidados de proteção durante o parto de uma de suas filhas, pegou çipé, preparou, benzeu e deu para ela, que deveria guardá-lo para usar sempre que preciso, tanto no próprio corpo como no corpo do seu bebê. Sua filha não usou o çipé e ainda, um tempo depois, jogou fora, pois dizia não gostar do cheiro forte da resina. Marci concluía o relato desse episódio afirmando que "por não observar essas regras, muitos jovens ficam doentes, sentem dores no corpo, e mais tarde virão consequências mais graves". Um exemplo de "consequência grave" foi dado em conversa com Luiz Gilberto sobre a situação física de um velho Yúriwawa que 
vive atualmente em São Gabriel da Cachoeira e que por conta de um acidente (uma queda) tem muita dificuldade para andar, necessitando sempre do apoio de muletas ou dos filhos. Luiz Gilberto comentou que “o velho está sendo castigado por não respeitar regras, os costumes", pois "ele teve muitos filhos e não fez resguardo, saia para beber caxiri, para pescar ou trabalhar, não respeitava as regras"; quando é assim, "os espíritos atacam a alma da pessoa com flechas invisíveis. Ela pode não sentir na hora, mas com o tempo esse ataque se manifestará”. É o caso do velho yúriwawa citado.

Outro caso de pais afetados por não observarem as regras no nascimento da criança me foi contado por Maria, esposa de Geraldo Edson. Ao ser perguntada se os pais ficavam doentes também, ela disse:

Fica; quando a criança vai crescendo, o pai vai ficando doente. Aquele Curió. Da primeira vez, falou que não era filha dele, foi tomar banho; tempo que passou, a menina foi crescendo, começou a sair tumor para ele; quase que ele morreu; ele foi tomar banho sem ser benzido, falou que não era filha dele.

Já o Yuremawa Eduardo dizia, sobre as consequências da não observância das regras:

Resguardo, uma semana. Antiga cultura era muito duro também, sem comer nada, ficar de resguardo uma semana mesmo, pai e mãe, era obrigado. Tem cerimônia no último dia, benzimento, algum caxirizinho, uma festa. Tomar banho, dia de comer peixe, era tudo benzido. Por isso antiga cultura era mais respeitado, para não acontecer o que está acontecendo, prevenção era muito duro, para não ter cabelo branco, não estragar dente, essas coisas que ele está prevenindo. A própria natureza dá o troco se não faz jejum. Hoje certa etnia faz resguardo, mas hoje está difícil. Ele prevenia para não criar cabelo branco. Quando a gente sai sem benzimento, o sol que dá castigo, cria cabelo branco. Hoje, quase não guarda resguardo. Aí pela idade com $40 \mathrm{ou}$ 45 anos que começa a aparecer isso aí, dor de dente, cabelo branco, dói minha costa. Só pai e mãe faz resguardo. Se o casal não respeitou o resguardo, muita gente sofre hoje em dia por causa disso. Não respeita o resguardo, o lugar sagrado, a mesma coisa. Aí paga. [...] depois que passou o resguardo já é normal.

Marci explicou que no caso de filho masculino o pai deve ter atenção redobrada e seguir rigorosamente as regras, reafirmando a ideia já apresentada da José Bernardo da importância do pai: 
O pai não pode fazer coisa pesada, tipo essa espingarda, não é para pegar coisa pesada, não pode ir para roça, até completar um mês; não é para trabalhar coisa pesada, senão criança chora; quando vai caçar fica perdido também. Não é que criança anda com pai? Se for menino tem que ter muito cuidado, a menina não é tanto, mas menino é perigoso, é sangue direto do homem; é mais perigoso, é homem, como se diz, ele já é direto corpo do homem, do pai, se o pai faz alguma coisa, criança já sente; mulher não é tanto, homem que tem que ter cuidado. Se for menino, tem que esperar um mês, obrigatório, se sabe benzer qualquer coisa ele já benze, parece que ele não faz nada, mas é benzimento que protege. Agora quem não sabe tem que esperar um mês. Depois já pode trabalhar, pegar espingarda e atirar.

Mais adiante, ainda nessa fala sobre benzimentos e cuidados Marci insistiu na importância de os pais seguirem as regras para se ter filhos saudáveis, o que é expresso pelo crescimento corporal, a saber, uma criança "gorda" é uma criança saudável:

Quando a gente benze bem, quando a gente cumpre regra, a gente vira saudável, se não cumpre regra vira igual [cita uma Yúriwawa], esqueleto já aí. Olha a mulher do Chico, ela deve ser bem benzida, nem parece que ela teve filha, ela é gorda, normal, corpo normal, isso que acontece quando a gente cumpre a regra. Quando a gente não cumpre, vai tudo, para o adulto ou criança, fica magrinho, come muito mas caga só diarreia [risos], passa direto, nem engorda mais, isso não é normal; mesma coisa para a criança, quando criança está bem saudável ele é gordo, normal, a criança doente chora todo dia, molezinho. [...] A mesma coisa aconteceu para aquela [cita filha pequena de um Yuremawa vizinho], porque eles não cuidam, o adulto não aguenta fome, aí sobra para a criança, ela que sofre consequência. Temos que cumprir a regra, senão a gente vai levar bronca dos velhos, a criança chora, adoece, quem vai ter culpa? Só a gente mesmo.

Além dos pais e do recém-nascido, outras crianças também podem ser afetadas durante um nascimento. Em uma visita a Geraldo Edson no ano de 2017 soube que seu filho pequeno, então com 2 anos de idade, estava muito doente, com febre e diarréia. Geraldo Edson explicou-me que achava que isso era porque o filho de Alexandre, seu vizinho, tinha nascido no dia anterior. Era preciso benzer seu filho para "fechar o corpo dele", protegê-lo dos "espíritos da natureza", os quais tinham sido "despertados pelo nascimento do filho de Alexandre".

Se os pais não agirem de modo adequado é o umbigo da criança que pode ser afetado, como explicou Geraldo Edson: 
Pais devem seguir as regras até a criança completar 3 meses, está bom já. 2 anos completa já, mas garantido é 1 ano. Já depois de 1 ano, ele já não consegue sofrer mais esses danos, assim quando os pais dele trabalham. [...] porque para criança o que acontece mais no caso é o umbigo dele, começa a sangrar já, caso se você fez coisa pesada, aí sofre é o umbigo da criança, começa a sangrar, atinge o umbigo da criança, o resto não atinge não. $\mathrm{O}$ pai faz, a criança é que sofre já, mesma coisa a mãe. Dizem que se a família teve a criança, menina ou menino, o que o pai faz, chega mais na criança, no caso o menino, mesmo caso a mulher, quando a mulher faz, atinge mais na criança, assim que eles falam. Mãe atinge a menina, o pai o menino. [...] qualquer descuido sai sangue do umbigo (homtro). Se tu seguir certinho, durante esses dois meses, já sara rápido. Só pai e mãe devem seguir as regras. Comida a gente come só depois de benzido, isso vale para o pai e a mãe; para não ficar sem comida a gente come um mingauzinho, um mingau de goma, isso resolve aí, um beiju seco, isso não precisa benzer para comer.

Também o Yúriwawa Gabriel Saldanha insistiu no cuidado com o umbigo:

Depois de um mês, aí a mãe e pai já podem trabalhar, não coisa pesada. Senão criança fica doente, dizem que o umbigo dele sai de novo; para não fazer isso, tem que ter cuidado; se a gente se esforçar, nosso esforço cai no corpo da criança, aí ele começa a chorar. Para não fazer isso tem que ter cuidado, tem que benzer de novo, vai indo até melhorar isso. Depois de um mês, o umbigo já está sarado. Temos que ter cuidado com a criança.

Certa vez, Luiz Gilberto explicou-me que o recém-nascido é "puro", ainda "não comeu alimento salgado ou doce”. Assim, cada novo alimento deve ser benzido. Sem os devidos cuidados e benzimentos, "a criança cresce desobediente", sem disposição para trabalhar, com saúde frágil. Aqui, vale notar que além dos cuidados para evitar doenças e produzir pessoas fortes e saudáveis, em outros termos, fazer crescer, há também um conjunto de práticas que operam no direcionamento e desenvolvimento de habilidades e capacidades na criança. Vejamos algumas.

Se os pais querem que o recém-nascido seja bom pescador podem colocar a penugem que fica sob a asa do gavião com carajuru sobre o umbigo do recém-nascido. Mas tal prática tem um efeito negativo, me contaram: a habilidade na pescaria implica falta de habilidade e disposição para outras atividades, como caça e trabalho na roça. Outra prática consiste em colocar mel na ponta da língua do recém-nascido para que ele não sinta dor se em algum momento for picado por cobra, isto é, desenvolva certa resistência corporal ao veneno da cobra. Se os pais querem despertar a inteligência, sobretudo habilidades para o conhecimento de línguas, o recém-nascido deve tomar água da folha de japim (kayuri).

Para encerrar essa descrição dos cuidados com recém-nascidos, cito mais duas práticas de proteção consideradas por muitos como imprescindíveis. Certa vez, num final de dia, 
quando voltava de Açaí para Querari, encontrei Mila - filha mais velha de Luiz Gilberto e Marci - com rosto e pernas pintadas com pequenas bolinhas feitas com tinta carajuru (mohá). Luiz Gilberto disse que era benzimento por conta de inflamação causada pelo dente dela. Em outra oportunidade, Marci me explicou que a pintura foi feita com carajuru benzido por Martins, avô paterno de Mila, e que ela tem esse carajuru desde pequena, guardado num pote, para ser usado sempre que preciso contra doenças e para proteção. Muitas vezes vi Marci voltar da roça com pintura de carajuru no corpo, no seu e de suas duas filhas pequenas. Esse carajuru benzido também protege dos animais do mato, como os insetos - pium, mutuca -, que picam e causam inflamações na pele. O pote com carajuru que Marci guardava para suas filhas consistia numa mistura de carajuru com çipé e óleo de piranha ${ }^{80}$, usado para impedir que a mistura de carajuru e çipé fique dura. O çipé faz com que o carajuru não saia logo do corpo.

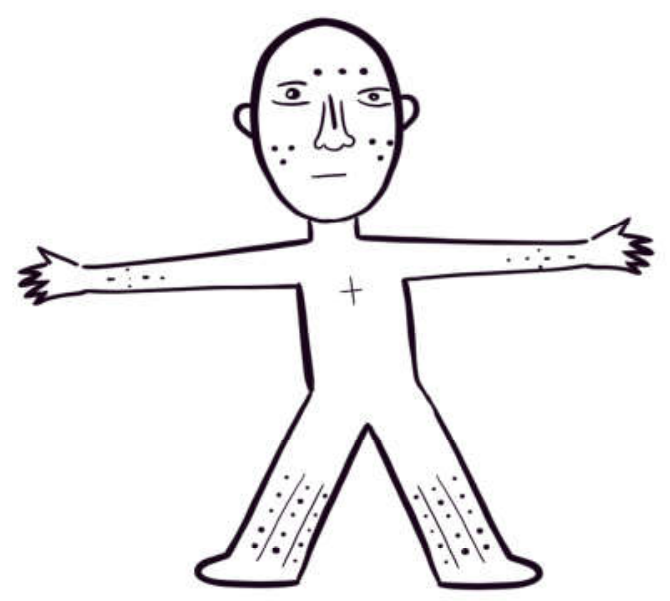

Figura 13: pintura corporal para proteção (desenho de Duane Mota, 2019)

Sobre o pote de carajuru, José Bernardo explica o seguinte:

Ele benze, pinta para o bebe. Com esse carajuru, ele pega esse pozinho, o umbigo dele deixa, para secar rapidinho; aí ela seca, e cai aquele pedaço, cai e fica normal. Aí guarda o carajuru, ele é guardado mesmo. Antigamente, todas as velhas tinham esse carajuru; antes de ir no trabalho, pintava no corpo dela, cara, perna; depois de voltar do trabalho ela tomava banho, limpava tudinho, ela ficava normal. Sempre o homem usava também essas

\footnotetext{
${ }^{80}$ Marci detalhou que o óleo da piranha é tirado da pele desse peixe com uma pena de galinha.
} 
coisas, antes de ir no trabalho, na roça, pintava ele também. Mistura carajuru com caranha (çipé) e passa na cara, perna; esse caranha tem cheiro diferente. Diz que esse bicho tem medo do cheiro dele. Antigamente, eles sempre usavam isso; até 8 anos eu lembro, que a minha mãe pintava essa coisa, caranha com essa mistura; bem vermelhinho, passava na cara, perna, às vezes passava aqui no nariz, onde respiramos, para não pegar gripe; passava nos filhos. Pinta todo esse corpo, cara, todo ele.

Além do uso da tinta carajuru, outra prática central que, como explicou muitas vezes Luiz Gilberto, deve ser observada para "o fortalecimento físico e espiritual do pai da criança e da criança" consiste no banho matinal no rio, preferencialmente em água muito fria. Aqui retomo brevemente análises de Pedro Rocha sobre importância do banho entre os Kotiria, que penso valer para os Kubeo.

Em sua pesquisa, Rocha (2012) concedeu lugar privilegiado à análise da importância da água para os Kotiria. Um dos elementos centrais da relação desses indígenas com a água consiste no banho. Desse modo, nos diz o antropólogo:

A primeira indicação dessa "aliança" a que me refiro é o banho matinal. O visitante recém-chegado à região do Alto Rio Negro, antropólogo ou não, não poderá deixar de notar que o banho matinal é uma instituição socialmente significativa ali. Isso porque, logo nas primeiras horas da manhã, as pessoas já estarão todas de cabelos molhados e penteados, enquanto ele, o visitante recém-chegado, provavelmente não estará. Ele será notado por isso, será inclusive questionado verbalmente por isso, e perceberá, rapidamente, que se quiser se adequar ao ritmo de vida da comunidade terá que se acostumar a banhar-se bem cedo no rio, todos os dias $(2012$, p. 80).

Logo após descrever os hábitos kotiria de banhos matinais e ao longo do dia, Rocha afirma que o banho não diz respeito apenas à higiene pessoal:

Além da higiene pessoal, ao banho matinal é reputada uma série de benefícios para a saúde do indivíduo, entre eles a fabricação de um corpo forte e robusto. Os Kotiria afirmam que os Baniwa do Rio Aiary possuem corpos mais fortes devido ao fato de este rio ser mais gelado que o Uaupés. Influi nesse processo o equilíbrio entre a temperatura do ambiente e da água. $\mathrm{O}$ choque brusco entre o quente e o frio é tido como causa de várias doenças, ao passo que o banho frio em um ambiente frio é visto como salutar (2012, p. 83).

Mais adiante, Rocha insere as práticas do banho no contexto do ritual Jurupari e da nominação, todos relacionados à criação de corpos fortes: 
Os banhos gelados na madrugada, os vomitórios, bem como as surras, são realizadas com o intuito de criar um corpo forte, um "corpo livre" (yzhari phakt), um corpo verdadeiramente humano (mahsa phakt). Também é esse um dos principais objetivos da nominação e dos cuidados durante o puerpério. Ou seja, conferir à pessoa os atributos e capacidades de que ela necessita para viver bem no mundo. Tudo isso faz a definição de Goldman muito oportuna: trata-se, em todos esses rituais, de casos particulares de "growth magic" [...] (2012, p. 120).

Tal como explicitado por Rocha para os Kotiria, também os Kubeo pensam o banho como uma prática relacionada à produção de corpos fortes e saudáveis, que contirbui para o "growth magic". Aqui, além de falar do banho, Rocha faz menção também a nominação. Eis que, feitas as descrições do momento do nascimento de uma criança e de algumas práticas envolvidas, é hora de voltarmos ao tema dos nomes; perguntemos então: onde se situa o pupui amiya (ou nome de benzimento) nessa fase inicial da vida?

O pupui amiya não parece ser atribuído no momento imediato de nascimento da criança. Diferentemente do que se passa com outros grupos tukano que nomeiam a criança pouco tempo após seu nascimento (ANDRELLO, 2006, p. 260; ROCHA, 2007, p. 75), os Kubeo o fazem dias, meses, ou mesmo anos depois ${ }^{81}$. Geraldo Edson, em 2014, tinha uma filha então com 2 meses e embora já tivesse escolhido o nome civil - ela se chamava Kiane -, ainda não tinha atribuído o pupui amiya; disse-me que precisava conversar com a avó ${ }^{82}$ sobre a escolha do nome e que ela mesmo faria o benzimento da criança. Além de Kiane, encontrei em campo outros casos de bebês sem pupui amiya definido. Irving Goldman em sua etnografia sobre os Bahúkiwa nos falava que "For the first year of its life the infant has no name (amyá) and is not fully a member if the sib" (1963, p. 171, itálico do autor). Restrepo, que escreveu sobre os Kubeo Hehénewa, informa que

Después de los ocho dias de nacimiento, los padres selebran en honor de su retoño una fiesta para beber a la cual asiste toda la parentela. En esta ocasión el abuelo (padre del padre), le da al niño el nombre de un antepasado. [...] El Payé en compañía del padre del niño se reune en la casa y hacen

\footnotetext{
${ }^{81}$ Também os Desana, segundo Reichel-Dolmatoff, não atribuem nome imediatamente ao nascimento. Segundo esse autor, a atribuição se dá quando a criança chega aos 3 anos de idade (REICHEL-DOLMATOFF, 1971, p. 140).

${ }^{82}$ O pai de Geraldo Edson, avô da criança, que seria a pessoa correta a ser consultada sobre a atribuição do pupui amiya, já havia falecido, vítima de picada de cobra. Vale notar que a avó é Tariana.
} 
invocaciones sobre él, fuman y rezan el tabaco y comen coca especialmente preparada (2001, p. 48).

Koch-Grünberg (2005), que visitou os Kubeo no início do século XX, nos deixou uma pequena preciosidade: a descrição de uma cerimônia de nominação de um recém-nascido. Vejamos.

Oito dias depois do nascimento, os pais preparam uma festa de bebida, em honra do seu recém-nascido, e nela se reune toda a parentela. Nesta ocasião, o avô (o pai do pai) dá o nome à criança. Os meninos quase sempre recebem dois nomes, e as meninas somente um.

Nomes masculinos:

Uëk = Anta
Yalkö = Capivara
Ollö = Morcego
Míaui = Gavião
Pupli = Coruja
Kdyu = Galinha
Umbo = Yapú
P'dú = Pequena ave
Bíohakö = Pequena ave
Paukö = Yandiá, peixe
Ualí = Acará, peixe
Bolíkakö = Aracú, peixe
Äb = Pequeno sapo
Naháukö = Camarão
Yamápola = Unha de veado
Yamáhäö = Barba de veado

Nomes femininos:

Kolko $=$ Pica-pau

Pauko $=$ Yandiá, peixe

Bolíkako $=$ Aracú, peixe

Tko = Mãe de entrecasca.

Auiyatá, que evidentemente está relacionado com "auiyá = sol", encontra-se como nome masculino e feminino.

Encontram-se nomes duplos:

Paukö Yaudö,

Ölhindo Yamáhäuö,

Äb Umnahokö (= sapo libélula), e outros.

Os nomes compostos quase sempre ficam abreviados.

Em vez de Öláhindo dizem Ölá; em vez de Yamápola ou Yamáhäuö dizem Yamá etc. Também aos meus Umáua Kaúlimu e Kauánamu, os Kobéua costumavam chamá-los de Kauí e Kauá. Do mesmo jeito, frequentemente abreviam os nomes cristãos. Em vez de Domingos, dizem Dómi. Em vez de Marcelino, os Tukáno no Tiquié diziam Massá.

Uma criança pequena, menino ou menina, é chamada pelos Kobéua com apelido carinhoso preferido, "tx'umí", que corresponde ao nosso "pequeno", "zinho".

Também aqui constatei o temor ao se mencionar o nome indígena (2005, p. 485-86). 
Notamos, nessa descrição, que Koch-Grünberg não nos oferece mais detalhes sobre a natureza do "nome" atribuído ao recém-nascido. Com efeito, trata-se de pupui amiya? Cruzando com outras etnografias e meus próprios dados podemos afirmar que sim, dado que não há registro de qualquer tipo de cerimônia para atribuição de apelidos, e o nome de branco, quando atribuído, se dava por meio do batismo.

Marco Sepulveda, que fez campo com os Kubeo Bahúkiwa em 1974, nos diz que "la ceremonia de la imposición del nombre tenía lugar hacia los cinco años, aunque no era forzoso hacerla a esta edad y podía demorarse hasta entrada la juventud" (1975, p. 128). Nessa "cerimônia" se dava a recitação de um "rezo"; nos termos de Sepulveda,

El "rezo" que acompaña la imposición del nombre está dentro de la narración de la historia, mejor, es la narración histórica con adición de las ideas apropiadas a la ceremonia. El relato comienza haciendo alusión al estado en que se encontraban los cubeo antes de emerger en Iparari (nos referimos al relato hehéneba). Aqui se enuncian las ideas centrales que se van repitiendo en todos los sitios históricos en un recorrido que incluye el rio Vaupés y el Cuduyarí hasta regresar a Iparari (1975, p. 128).

Além de Koch-Grünberg, encontramos uma descrição geral de cerimônia de nominação em Goldman (1963):

The naming ceremony (amindone hino: giving a name) is conducted by the paternal grandfather, whose privilege it is to give the name. Seated on a bench at the forward and ceremonial end of the house, with his son at his side holding the infant, the grandfather repeatedly recites a chant over a small calabash of milk. The father accompanies him. The milk has been drawn from the child's mother's breast but is referred to as milk from the father's sister, to emphasize the point that it is the child's own sib that will make it grow. The chant itself, as well as the blowing, are forms of growth magic. Each recitation begins with sustained loud whistles followed by the cries $h i$ i $i$ i $i$. At the conclusion of each recitation the grandfather blows into the milk, imparting to it his breath (umé), which is also his spirit. After several recitations a father's brother brings in mihi, in the proper ceremonial manner, tongue lolling and knees bent as though staggering under a great weight. All three drink the bitter brew and the recitation goes on" (1963, p. 171-172).

Em seguida, Goldman descreve uma cerimônia de nominação que teve a oportunidade de observar entre os Hehénewa:

A naming ceremony I observed among the Hehénewa lasted two hours, beginning an hour before noon. It took place on the day of a mourning 
ceremony but before guests had arrived. The choice of the morning hours, I believe, is to establish the naming as strictly an in-sib affair. In the Hehénewa case the mourning ceremony took the place of the drinking party. The ceremony concludes with bestowing the name, which is stated simply, "I give you the name__ which was the name of ". Then the grandfather blows into a small calabash of genipa with which the infant will be painted and into the calabash of milk. The child is induced to drink the milk. The grandfather now asks the child, "What name do you want?" Its father answers for it and the grandfather acknowledges it. The old man dips his index finger into the calabash of milk and presses it against the infant's heart "to make it grow". Then he asks the child, "What is your name?" The father answers for it. Finally, the old man touches the bridge of the child's nose and the ceremony is over. The bridge of the nose where it joins the forehead is the spot from which the soul will escape at death. By touching in the grandfather has left an opening for the soul to escape at the proper time (1963, p. 172).

Goldman observou essa cerimônia Hehénewa. Quanto aos Bahúkiwa, teve acesso apenas às descrições nativas. Contudo, afirma que as cerimônias são muito semelhantes, com diferença nos cantos. Vejamos primeiramente o canto de nominação Bahúkiwa (GOLDMAN, 1963, p. 172-173, itálico do autor):

People of our soil

The milk that is from this place that causes to grow

People who are our offspring

They are given milk

Milk of our soil

Milk that causes to grow

People who are being grown

People of our soil

People who are our younger sisters

Milk of the calabash

Milk that makes one grow quickly

Milk of our soil

People of our soil

People who are our younger brothers

The first one to grow fat

He [also] will grow fat 
Milk that is nourishing

Milk that is nourishing that will make [him] fat

People of our soil

Uráhana who was the first to grow fat

Milk that is nourishing

He will grow fat

Milk that is liquid

Milk that is nourishing

The manioc gruel that is nourishing

Milk of our land

People of our land

Uráhana was the first one

The manioc gruel that he ate

The milk that was given to him

Segue um canto de nominação Hehénewa (GOLDMAN, 1963, p. 173-174, itálico do autor):

Milk of our soil

That our offspring may grow

That we may all grow

Milk of the calabash

The offspring of Uráhana

The calabash of Djurédo

When she [Djurédo] saw the birth

Milk to make it grow, she gave it

Milk of the calabash it drank

A child was being born to Uráhana

The offspring of Uráhana

The calabash of Djurédo

When she [Djurédo] saw the birth

Milk to make it grow, she gave it 
Milk of our soil

She saw him grow

The son of hihédü

Her fat offspring

Milk of our soil

She saw them grow

Milk of the calabash

Children of our soil

She saw them grow

Son of Hihédü

Grew big and fat

Son of Uráhana

Grew big and fat

This milk of the calabash

He drank and grew

She saw it.

Uma primeira diferença notada por Goldman é que o canto Bahúkiwa insiste no crescimento, é uma forma de "crescimento mágico" (growth magic), ao passo que o canto Hehénewa é mais direcionado às referências aos "ancestrais do sib". Além disso, nota também que o canto Bahúkiwa faz referência a um único ancestral, que por sua vez é Hehénewa - Uráhana -, referência para a qual os interlocutores de Goldman não tinham explicação; o autor sugere como hipótese que o nome Uráhana em Kubeo tem uma conotação de crescimento, motivo de ser referenciado no canto citado.

Outro elemento que merece destaque é a referência constante nos dois cantos ao leite, substância também presente na cerimônia de nominação descrita por Goldman, e que parece ser central. Assim, Sepulveda comenta que todas as ideias desse benzimento de nominação giram em torno do leite (opekó) e da alma (umé) (1975, p. 128-129). Na descrição de Goldman "At the conclusion of each recitation the grandfather blows into the milk, imparting to it his breath (umé), which is also his spirit” (1963, p. 171). Qual a relação entre umé e nome (amiya)? Novamente, Goldman tem uma formulação bastante adequada ao que vimos até aqui: 
[...] human umé is not a free element. It is a differentiated entity associated with a personal name, with a kinship direction (from grandparent to grandchild), and with ritual performance supervised by the father and his brothers. Since it is the personal name (amiá) that gives umé its destination and identity, one may think of amindone (naming) rites as precautionary. Reliable persons certify the genealogical provenience of the name and direct it and its umé to the proper person. The name stabilizes the original umé that the infant acquired at conception, helping it to resist illness and the malice of fish that would steal its soul to hide it along the river, though they cannot use it for themselves [...].

Cubeo regard the substance of umé as differentiated, though not as fully as is the whole cosmos. The gap concerns a matter of personal names" (2004, p. 349-350, sublinhado meu).

O nome, portanto, ao estabilizar o umé que a criança adquire na concepção ajuda na defesa contra doenças e ataques de seres da natureza. Mas até agora retomei descrições da literatura sobre a atribuição de nome; como isso se dá entre os Yuremawa e Yúriwawa?

A escolha do nome é feita sem "cerimônias" ou qualquer tipo de "ritualização", como afirmou muitas vezes Luiz Gilberto. Mas não foi sempre assim. Ouvi relatos de alguns Kubeo mais velhos que lembravam ter visto quando criança ou escutado de seus pais e avós referências às festas que se faziam no momento da atribuição do pupui amiya. Assim, José Bernardo conta que antigamente se fazia festa:

Antigamente o velho benzia, fazia uma caxiroba, aí o velho ficava benzendo essa coisa. Aí diante de tudo, ele chamava, com cigarro, ele mesmo acendia, ele soprava para ele, aí dizia "agora esse homem ou essa mulher vai chamar assim, porque já benzi para ele"; e todo mundo sabia. [...] agora não tem mais benzimento para dar o nome; antigamente ele escolhia; o pai, o vovô dele perguntava... nossa tribo chamava assim, assim... qual o nome que você vai escolher, aí o velho fazia benzimento. Durante a festa, era cerimônia grande, todo mundo sabia os parentes, tios; tomando caxiri mesmo; por isso os velhos gostavam de benzer.

O velho Yúremawa Jaime também fala de festas que se faziam antigamente para dar nome e de como o benzimento feito no momento da atribuição não é mais lembrado:

Pai se tem, ou avô dá o nome. Antigamente, dizia que fazia ritual, festa grande com caxiri, danças, para dar benção desse, uma noite inteira, para dar benção. Tinha um "rezo", uma oração específica para dar benção. E uma cuia assim, com bebida, caxiri, assim, algo doce, para dar a criança que vai receber esse nome, como batismo, uma noite completa. Benzia a cuia, e dava para a criança beber. Ninguém mais sabe... meu pai finado dizia que sabia pouco também... não sabia completo. 
O Yúriwawa Paulo Espitia oferece a seguinte descrição a partir das memórias de seu

pai, o velho Simão:

Agora, hoje em dia... assim, o meu pai me falava que o nome de benzimento não se dava do nada; havia um ritual, que eles faziam para batizar, vamos dizer assim, como acontece no mundo religioso. E tinha um benzimento específico só para isso. Os indígenas batizavam quando, se fossemos contar nesse mundo contemporâneo, quando a criança atingia uns 12 ou 13 anos de idade, já adolescente. Então o chefão perguntava...essa coisa de pajé... existe essa versão também, se fala muito de pajé, e a gente acha que só o pajé fazia tudo, mas ele cuidava da parte de saúde do povo, ele fazia isso, era a área dele. Agora existia o sábio, o intelectual, que era responsável das cerimônias, então nesse caso o pajé não tem nada a ver com as cerimônias, nesse caso quem organiza isso é o chefão, o mais idoso, chefe da tribo, a gente chama de bađaku, então esse bađakt é... como dizer no mundo dos brancos... é... vamos dizer, "maestro", "maestro da orquestra", ele tem que saber benzer, tem que saber cantar, as danças, tudo, os passos, tudo, ele é isso, ele é tudo. Então o ritual do batismal se dava dessa forma, ele perguntava se havia crianças para se batizarem, tanto meninos e meninas também. Então quando tinha 2 ou 3 crianças nessa fase, crianças adolescentes, o pai pedia, "eu quero que os meus filhos sejam batizados"; então ele aceitava e organizava toda a cerimônia. Então eles começavam com benzimento, eram dois. Meu pai diz que ele participou de duas, as duas últimas que aconteceram quando ele era jovem, depois nunca mais, até hoje. Ele falava que eles começavam a benzer, se fosse no horário contado, pelo menos às $2 \mathrm{~h}$ da madrugada, antes que o galo cantasse, começavam a benzer. No meio da maloca sentavam os dois, e alguém, o discípulo dele, vamo dizer assim, alguém que era aprendiz disso, ele acompanhava. Então ele se posicionava bem no meio da maloca, bem no central mesmo, os dois, colocavam um banquinho, colocavam numa cuia pimenta, pelo menos três ou cinco pimentas, e uma cuia com pequeno caxiri, pouco, coberto com balaio, e começavam a benzer. A medida que eles iam benzendo, falando, iam batendo com uma varinha em cima do balaio, que cobria esse material; aquilo era longo, eu creio que ninguém mais conhece essa oração. Começando às $2 \mathrm{~h}$ da madrugada, aproximadamente, eles só terminavam meio-dia; benzimento longo, haja cérebro para gravar tudo isso [risos]. Eles só saíam do lugar quando iam fazer necessidades, e continuavam benzendo, falando tudo, desde a origem, os lugares aonde andavam, onde encontraram outros povos, tudo que aconteceu, tudo, tudo, até meio-dia. Então a medida que eles estavam benzendo, o resto do povo se juntava, se preparava, preparava os meninos que iam entrar no batismo, tomavam um pouco de caxiri, não era muito; até que terminassem o benzimento, aí sim, começava a cerimônia. Eles colocavam em fila, todos. Ele fica em pé, o chefão, e chamava pelo nome já, assim como o mundo religioso, ele dizia: "eu nomeio esse menino com esse nome", o pai dele já dava o nome do menino, "assim... assim...assim... por isso... respaldando o deus Yúri", e chamava o menino, e ele ia lá. O outro companheiro dele, com aquele bastão de comando, o behort, ele ficava tocando esse behort, muito lindo pelo que ele me contava. Então ele pedia que eles mordessem, mastigassem a pimenta, e então ele abria um buraquinho com aquela ponta do behort, e eles mandavam ele cuspir a pimenta nesse buraco, e a segunda parte era que ele tomasse um pouco da cuia de caxiri, só um pouco, porque todos aqueles batizados tinham que passar por essa cuia; então era assim que eles davam o 
nome, não era de qualquer maneira, isso tinha uma consagração, vamos dizer assim. [Perguntei sobre Jurupari] Não, Jurupari não acompanha, porque lá participava tanto as mulheres, era uma festa mais social, vamos dizer assim. Quando entra a questão do Jurupari é uma questão só para os homens, a mulher não participa. Jurupari tem os seus nomes específicos, mas não são atribuídos para as pessoas. Meu pai viu a última cerimônia, ele era novo, tinha uns 18 a 20 anos, nessa casa. Quem era o celebrador, vamos dizer assim, era o tal de Hiabu, que era um Yuremakt, ele era o celebrador, era único, só era ele. Outros lá, os Yuremawa, queriam fazer, chamavam ele. Quando os Betowa queriam fazer esse batismal tinham que convidar ele, só era ele; quando faleceu, não tem mais. Então hoje em dia já não existe mais isso, infelizmente, as pessoas vão nomeando de qualquer maneira [...].

O relato de Paulo Espitia, que por sua vez ouviu de seu pai, é a descrição mais detalhada que escutei ao longo de minhas interlocuções. Sentado no centro da maloca, diante de duas cuias, uma com pimenta e outra com caxiri, o velho conhecedor chefe do grupo (bađaku) fazia um longo benzimento que durava horas. Terminado o benzimento, os jovens a serem nominados faziam fila e um a um recebiam nome, ao mesmo tempo que tinham que mastigar pimenta e tomar um pouco de caxiri, ambos já benzidos. Se confrontarmos essa descrição de festa de nominação com as anteriores vemos que nas descrições de Sepulveda e de Goldman, além de outras diferenças, o leite ocupa papel de destaque. Já nos relatos que ouvi em campo dos Yúri Parãmena, não há referência a essa substância. Paulo diz que a criança nomeada devia tomar caxiri benzido. Muitas vezes perguntei se o leite materno tinha algum lugar no nascimento, se precisava ser benzido, e a resposta foi sempre negativa.

Após o nascimento, outro episódio de extrema vulnerabilidade da pessoa e que merece bastante cuidado diz respeito a primeira menstruação da menina e ao Jurupari dos meninos, sendo que, em certa chave de entendimento - aventada muitas vezes por Luiz Gilberto e alguns outros velhos - ambos eventos são entendidos como "confirmação" do pupui amiya. Vejamos.

\section{A primeira menstruação}

A primeira menstruação deve ser seguida de cuidados e restrições, segundo os Yuremawa e Yúriwawa. José Bernardo, a respeito do momento em que a menina menstrua pela primeira vez diz o seguinte:

Ela tem que ficar jejuando aí uma semana; comendo mingau, ela fica sem tomar banho, dois dias ou um dia; outra, depois de um dia já começa a tomar banho, aí ela fica dentro da casa, uma semana. Tem que benzer para ela, beijú, peixe, sal, ele benze de novo, para não ficar doente. Segunda menstruação também é mesma coisa, aí termina, pode menstruar sem 
problema, normal; aí termina para a mulher. Para homem não tem. Só que troca a voz, outro troca a voz, fala voz mais grossa, outros não trocam.

A menstrução da mulher pode atrair doenças, deixa a menina vulnerável. José Bernardo explica:

A primeira vez que ela fica menstruada, que os bichos, têm inimigo para fazer ficar doente a ela. Minhoca, por exemplo, qualquer bichinho pode chupar para ela, aí já começa a inflamar, ficar com pus, ferida, aí ela já começa a ficar doente; para ela não ficar assim ele benze, aí esse bicho não acerca ela.

E continua sua fala explicitando os cuidados que cercam o banho:

Às vezes, se a mulher é menstruada assim de primeira vez, se ela tomar banho, em seguida, se outro menino, velho, aí ele pega doença. Porque o cheiro dela, já vem outros micróbios, para fazer ela ficar doente, aí vem outro tomando banho, já entra nele. Para não ficar no porto esse bicho, ele acende cigarro, acende no porto, depois pega fumaça, e sopra para o rio. Aí eles vão embora, não fica esse micróbio no porto, aí qualquer um pode tomar banho.

Acrescenta que:

Antigamente, quando já velha, já adulta, tendo já marido, filho, algumas senhoras menstruam; quando elas menstruam não preparam nem beijú, nem mingau, ela não trabalha, só a moça, o filho dela, prepara mingau, quinhapira, beijú; aquela que está menstruada não trabalha, fica só dentro da casa, sem fazer nada, fica comendo, enquanto está menstruada, 4 ou 5 dias, depois ela anda, trabalha; só assim.

A mulher menstruada deve observar alguns dias de reclusão, contudo isso não siginifica ficar parada, pois nesse período de vulnerabilidade determinadas disposições podem afetar o corpo da mulher como fazer dela alguém preguiçosa. O Yúriwawa Gabriel Saldanha explica isso e lembra que antigamente meninas também levavam surra:

A menstruação da menina, ela não pode ficar parada, tem que ficar trabalhando, senão a menina que não gosta de trabalhar quando está menstruada vai ficar toda a vida assim. Agora se ela está a primeira vez menstruada, se quer trabalhar alguma coisa dentro da casa, ela não pode ficar todo o tempo sentada e deitada na rede não, tem que está em pé; porque eles dizem que ela está treinando para isso, para não ter preguiça. Depois disso, como eu falei, ela tem que ter benzido de novo tudo, caxiri, mingau, farinha, beijú, tudo, carne, peixe, sal, pimenta. Antigamente, os velhos, a 
primeira vez que elas menstruavam, eles davam surra, não surra de força, só para tirar a preguiça dela, no dia de bom dela, no banho dela. No primeiro dia que ela começou a menstruar fica em casa 4 a 5 dias, daí que ela vai banhar, depois do benzimento, aí eles preparam quinhapira para ela, faz caxiri, chamam os tios dela, parentes, faz festa. Aí nesse momento que eles faziam surra, aí na hora da quinhapira, eles pegavam os pratos de peixe, mandavam ela distribuir para todo mundo, para multiplicar a comida quando ela ficar adulta, para que nunca falte comida. Agora não tem mais isso, é só simples agora, benzeu, acabou. $\mathrm{O}$ resguardo elas fazem ainda, isso não acabou não, sempre tem. Cinco dias, depois já benzem com sal e pimenta, a partir daí já benze caxiri, frutas, carnes, assados, principalmente assado e frito. Quando ela come sem benzer frito e assado fica magra, nunca recupera a saúde dela. Agora mulher bem benzida nunca perde o corpo dela, tendo os filhos ela recupera, não fica magra não. Assim que eles dizem. Na segunda menstruação não precisa mais, é só uma vez. Aí é só quando ela tiver filho, aí sim. Se a gente não cuidar bem, pouco a pouco, com a idade, ela fica sentindo dores no corpo, dores de cabeça, isso acontece. Esse cabelo branco eles dizem também que é por motivo que a gente não cuida. No resguardo tem que ter um pano sobre a cabeça, da menina e do homem também. [...] aí desse tempo, tem que ter remédios caseiros para ela, pra nao sentir dores com picada de cobra, é muita coisa, aí nesse tempo que eles dão remédio. Tem gente que não sente dor com picada de cobra, nem sente.

Gabriel Saldanha elenca alguns cuidados necessários após a primeira menstruação. Chamo a atenção para a centralidade da saúde da mulher garantida pelos benzimentos e cuidados adequados; essa saúde se manifesta no corpo, isto é, "quando ela come sem benzer frito e assado fica magra, nunca recupera a saúde dela. Agora mulher bem benzida nunca perde o corpo dela, tendo os filhos ela recupera, não fica magra não". Vemos assim, a centralidade da noção de crescimento corporal; em outros termos, fazer corpos saudáveis é fazer crescer. Além desses cuidados, Marci dizia que na primeira menstruação também era o momento de se cortar o cabelo da menina pela primeira vez:

É obrigatório cortar cabelo. Tem gente que deixa para cortar quando menstrua primeira vez. Mas agora eu vejo para a menina que menstrua hoje, nem importa não. $O$ cabelo que corta joga fora, se não fizer isso diz que dá má sorte, se nao cortar, dá azar; a gente sonha só pesadelo quando fica com esse cabelo, dá má sorte.

Geraldo Edson também lembra tal prática:

Eles só cortam o cabelinho dela na primeira menstruação; cortam o cabelo da menina. Cortam e benzem, e ela toma banho e fica normal. Essa hora tem perigo também, desses seres invisíveis aí, espíritos, podem atacar também. Faz benzimento para proteger, alguns seres podem possuir ela, quando não está benzida, por isso tem que benzer ela. 
O Yuremawa Eduardo Rodrigues também insistiu na importância do benzimento na primeira menstruação, apontando um paralelo com o momento de nascimento de uma criança:

Na primeira menstruação, benzer só uma vez, mesma coisa. E também uma semana. A mesma coisa do parto, que ganhar uma criança. Ela já está iniciando assim, a menstruação é uma semana, sem comer nada. Porque cultura indígena diz que nesse período da primeira menstruação dela, é quase que ela vai preparar; só alimentando pimenta, cheirando pimenta, isso que ela está praticando, ela está transformando mulher; por causa disso é obrigatoriamente para ela. Tem que ficar em casa, não pode ser nem visitada, só a mãe, num lugar especial. Uma semana, aí a mesma coisa, ela tomar banho, corte de cabelo, isso chama já transformando uma mulher, a primeira menstruação. É uma festa também. Antigamente era uma festa também, cerimônia, convidava os parentes, primos, tios, avôs, mesma coisa. Dizia festa daquela menstruação, tomando caxiri, cultura, dançando por aí. Hoje não faz mais, não tem lei mais agora. Outra etnia tem, aqui não fizeram mais, só escuta "ah, já menstruou", só isso que a gente escuta; não tem mais como antigamente. Sabe aquela irmã, Amália, foi a última que vi meu pai fazer; ela fez menstruação tranquila, resguardo de uma semana, depois meu avô finado benzeu, fez cerimônia, festa; todo mundo bêbado saiu aí. Primeira festa da menstruação. Beber caxiri, benzendo. Porque esse dia tem certa pessoa que chama padrinho para cortar cabelo dela, é padrinho na cultura, ou madrinha. Para o homem é madrinha, para a mulher é o homem, para cortar cabelo.

Muitas vezes ouvi dos Yuremawa e Yúriwawa falas que colocavam em paralelo o Jurupari e a primeira menstruação como momentos importantes na vida do homem e da mulher, respectivamente. No que diz respeito ao nome, no caso da mulher, uma vez atribuído quando criança é confirmado na primeira menstruação, tal como, segundo alguns Kubeo como Luiz Gilberto e José Bernardo sustentam, acontece no Jurupari. Vejamos o que os Yuremawa e Yúriwawa pensam do Jurupari.

\section{O Jurupari}

Em meu campo não registrei nenhum Jurupari. As conversas que tive sobre esse evento faziam todas elas referência a um Jurupari ocorrido no início dos anos 1990, no qual participou um conjunto de jovens da geração de Luiz Gilberto, incluindo ele próprio. No ano de 2016, quando cheguei em campo pela segunda vez, na minha primeira visita a comunidade de Açaí notei chicotes de surra pendurados dentro da maloca e soube então que tinha acontecido um Jurupari. Contudo, parece que tal evento foi resultado da ação de um conjunto 
pequeno de pessoas; não consegui mais informações sobre ele ${ }^{83}$. O que segue, portanto, são memórias de Juruparis passados. José Bernardo descreve o Jurupari nos seguintes termos:

Para ver jurupari, também, se o homem já tem 10 anos, 8 anos, outro 11 anos, aí já começa a ver esse jurupari. O velhinho benze para o menino, depois benze a pimenta, manda morder ele, depois tem que cuspir na terra. Depois, porque ele se prepara para bater nele, benze, passa no corpo do menino com aquela tinta vermelha, carajuru, passa bem, depois começa a bater nele, devagar, devagar, um pouco forte; ai ele fica normal. Depois de velho também, antes de comer peixe ele benze, para comer assado também ele benze. E depois ele fica na festa normalmente, não tem para benzer, nada aí, ele vai comendo, vai faz festa, normal; é a primeira vez que ele vai ver esse Jurupari que ele benze.

Já Eduardo Rodrigues, sobre o Jurupari, diz:

Porque antigamente, quando completa 15 anos o homem também é obrigatório levar para surra, ele não menstrua nada, porque idade dele. Jurupari, benzimento de pimenta. Ele faz cerimônia de benzimento, primeiro para transformar um homem; todos que completavam 15 anos antigamente era cerimônia também, dabucuri, jurupari, comer pimenta, educação do pai, em geral, dos anciões da comunidade, assim, dando educação, da regra, como os jovens vão levar daqui para a frente; isso que eles estão fazendo para conhecer esse benzimento de 15 anos, dando um sermão, como diz o pessoal. Agora, só aqui que não tem, mas outras tribos têm, pratica tudo isso, faz essa cerimônia, essa etnia do desano, daqui do alto Uaupés, Kubeo também praticam, na Colômbia, continuam isso daí.

Não podemos deixar de notar nessas descrições as semelhanças com a festa de nominação descrita por Paulo Espitia anteriormente. Contudo, infelizmente, tenho poucos elementos para avançar mais na descrição e análise desse evento, constantemente apontado pelos Yuremawa e Yúriwawa como algo que não acontece mais, que "não preocupa mais os jovens", como disse certa vez José Bernardo. O que gostaria de chamar atenção aqui é para a ideia explicitada diversas vezes por Luiz Gilberto, também José Bernardo insistia nessa ideia, do Jurupari como momento de "confirmação" do pupui amiya, isto é, momento de reafirmação do nome atribuído quando criança. Também o Tukano João Paulo Barreto, em sua dissertação sobre os wai-mahsã, oferece interpretação semelhante:

\footnotetext{
83 Diante dos chicotes pendurados na maloca de Açaí passei a insistir em conversas sobre a assunto, mas não consegui avançar muito. Algum tempo depois compreendi a dificuldade para conversar sobre esse Jurupari: além das restrições que cercam tal prática, o episódio em questão remetia a uma "ritualização" (Luiz Gilberto) conduzida por determinada família em Açai, tendo em vista "iniciar" o filho de certo Yúriwawa; não envolveu, portanto, todos aqueles que deveriam participar de tal evento. Em suma, esse Jurupari remetia para uma questão delicada, pouco falada para evitar conflitos.
} 
Cada momento do desenvolvimento da criança, seja físico, psíquico, intelectual, moral ou social, era acompanhado, com especial atenção, por um especialista. A inserção na vida adulta era, inicialmente, marcada pela reafirmação do heri-porã, isto é, a recolocação do nome da pessoa na estrutura sócio-cosmológica, permitindo-lhe, a partir daí, sua participação na festa com o instrumento jurupari e a ingestão de kahpi $(2013$, p. 72).

Dito isso, passemos a outro momento também cercado de cuidados, a morte.

\section{A morte}

Há cuidados que devem ser observados até mesmo quando da morte de uma pessoa. Os Yuremawa e Yúriwawa têm fragmentos de memória da cerimônia de oino, a qual era feita quando alguém morria e tinham como destaque o uso de máscaras que cobriam todo o corpo de seu portador ${ }^{84}$. Tais máscaras não são mais usadas. Mesmo os mais velhos não chegaram a ver tal prática e têm esse conhecimento pelas descrições feitas por seus pais. Esses diziam que por meio das máscaras muitos personagens do momento da criação se faziam presente. De ornamento de apresentação de personagens das narrativas de criação, portanto, as máscaras se tornaram representação, isto é, passaram a ser artesanato nos dias atuais, comercializado nas cidades, como em São Gabriel da Cachoeira, ou Mitú, na Colômbia. Acontece com a máscara kubeo algo em parte semelhante ao banco tukano, de diacrítico dos Kubeo no noroeste amazônico à artesanato e memória compartilhada por alguns do passado.

Sobre cuidados com o morto, Gabriel Saldanha diz:

Mas tem benzimento quando a pessoa fica doente, só benzer para aquela doença que ele tem. Mas tem benzimento para aquele que morre, para o espírito dele não ficar perturbando para nós; faz um cigarro, protege. Em Kubeo fala põe dekoku, o espírito do morto. Aí tem benzimento para não voltar. Enterro faz oração, essa religião católica já pertence aqui, aí tem esse costume mesmo. [...] esse tempo que eles usavam a máscara, convidavam parentes, primos, para acompanhar lá; na época de meu pai tinha máscara ainda, quem foi o último que fez assim foi o pai de Bere, Angelico, ele que fez, aqui no Mureda, Oribu, foi o último que ele fez, daí nunca mais, tem mais não. Ele mesmo fez, convidou os parentes. Na última era, assim pela madrugada, dizem que eles queimam as coisas, queimam as máscaras; esse Bernardo, esse Dicá, sabe, mas não querem mais ensinar não; já perguntei, mas sempre responde com negativo, não ensinam. Aí já está tarde demais, eles tão ficando mais velho. Aí uma vez fui conversar com Roque, achei o canto muito bonito; porque tem vários tipos de máscaras feito, assim nomeado, chamado papagaio, chamado besouro, peixe, tem peixe aracú, tem

\footnotetext{
${ }^{84}$ Descrições detalhadas sobre essa antiga prática funerária Kubeo podem ser encontradas em Irving Goldman (1963, p. 219-252; 1964; 2004, p. 255-274).
} 
vários... como chama, aracú pinima, aí parecido tem aquele aracú um pouco amarelo, tem vários, tem muitos; até ele falou que tem essa máscara de borboleta, ele contava assim, eu imaginava; mas tem que ter dupla ele falava, de cada máscara é dupla, um desfilava cantando, aí quando acabava outro par de novo, até a noite inteira que eles faziam na maloca. Tinham caxiri, se tivesse mihi eles tomavam mihi; assim que eles usavam ele falou, eu achei muito bonito [...]. Daí parou, e nunca mais agora. Cada tipo de máscara tinha um desenho muito diferente. Eu fico falando com esse Jaime, cada vez mais estamos esquecendo.

Sobre o enterro, o Yuremawa Eduardo Rodrigues explica:

O enterro, depois da morte, tem cuidados assim, aí benze. Tem benzimento, porque certos lugares, sempre tem a sombra, como diz, sempre... o espírito, ele sempre dá um sinal, para não acontecer ele benze, para não voltar mais, ele benze. Para não acontecer isso ele tem que benzer de uma vez.

Os benzimentos são importantes no momento da morte, portanto, como proteção contra põe dekoku, os espíritos dos mortos. No que diz respeito ao nome do morto, não notei restrições ou cuidados especiais. O que as pessoas fazem, sempre que falam de alguém morto, é juntar o termo "falecido" ou "finado" ao nome do morto; desse modo, falam "finado João", "finada Maria" $" 55$. O nome do morto pode ser dito sem o qualificativo apenas quando usado como vocativo, no caso de invocação dos mortos, antiga prática descrita por Luiz Gilberto, levada adiante por uma "pessoa corajosa", e que consistia em, dentro de casa, diante do lugar onde o morto era usualmente enterrado e durante a noite, após construir em volta do túmulo uma pequena certa com madeira para manter a pessoa morta aprisionada a esses limites, chamá-la para uma conversação, com o propósito sobretudo de aprender conhecimentos que não foram ensinados antes da morte da pessoa em questão, invocação para obter ensinamentos dos mortos, portanto. Mas ouvi essa referência apenas de Luiz Gilberto e algumas poucas outras pessoas, unânimes em afirmar que isso não se faz mais, e mesmo no passado eram raras as histórias de pessoas que faziam.

Valencia, em sua monografia sobre os Kubeo Yuremawa, faz as seguintes considerações sobre o morto, muito próximas das que ouvi em campo:

Cuando una persona muere, dicen los Yuremava, que su alma /umé/, hace un largo recorrido hasta legar a su lugar de origen, allí se encuentra con sus

\footnotetext{
${ }^{85}$ Contudo, essa questão apenas surgiu para mim depois de realizados os trabalhos de campo. Assim, nas conversas sobre morte com os Kubeo não tive a oportunidade de desenvolver esse tema específico dos nomes dos mortos. O entendimento que tenho é aquele formulado acima.
} 
parientes cercanos y pertenecientes al mismo clan; este encuentro tiene lugar en una maloca espiritual llamada la casa de los muertos o / abuhu ñamí/.

Esta será la morada del espíritu después de que muera la persona y ocurre cuando la persona fue buena en esta vida.

Sin embargo, cuando una persona ha sido mala y ha cometido faltas en esta vida, al morir, tiene que pagar por sus males cometidos y es sometido a muchas pruebas; entre ellas es inmerso en un lago con breo hirviendo, ser convertido en un animal desagradable de acuerdo al mal hecho en esta vida. Si fue venenoso, será convertido en culebra, y si fue asesino, en tigre, y andará errante en la naturaleza, hasta que alguien lo mate y libere el espíritu; entonces, sí podrá reunirse con su gente en la casa de los espíritus.

En algunas ocasiones la persona que muere tiene un espíritu que molesta en la maloca y asusta a la gente. Este espíritu o/dekoki/, está pidiendo descanso porque algo en esta vida le ha quedado pendiente o porque la persona en vida fue mala y debe pagar su falta.

Este espíritu se aleja con un rezo o soplo que se hace con tabaco y también con resina o caraña, que se quema para alejarlo y darle descanso (VALENCIA, s/d, p. 97-98).

Aqui o destino da alma da pessoa que morreu (põe dekoku) é Abuhuñami. O espírito do morto que pode aparecer é dekokt, e quando acontece merece cuidados de benzimento para afastá-lo. Também os Yuremawa e Yúriwawa de Querari e Açaí compartilham tais ideias. Algo particular ao relato de Valencia, que não me recordo de ouvir de ninguém em campo, é a expiação que os mortos devem prestar por conta de conduta considerada má quando estava vivo.

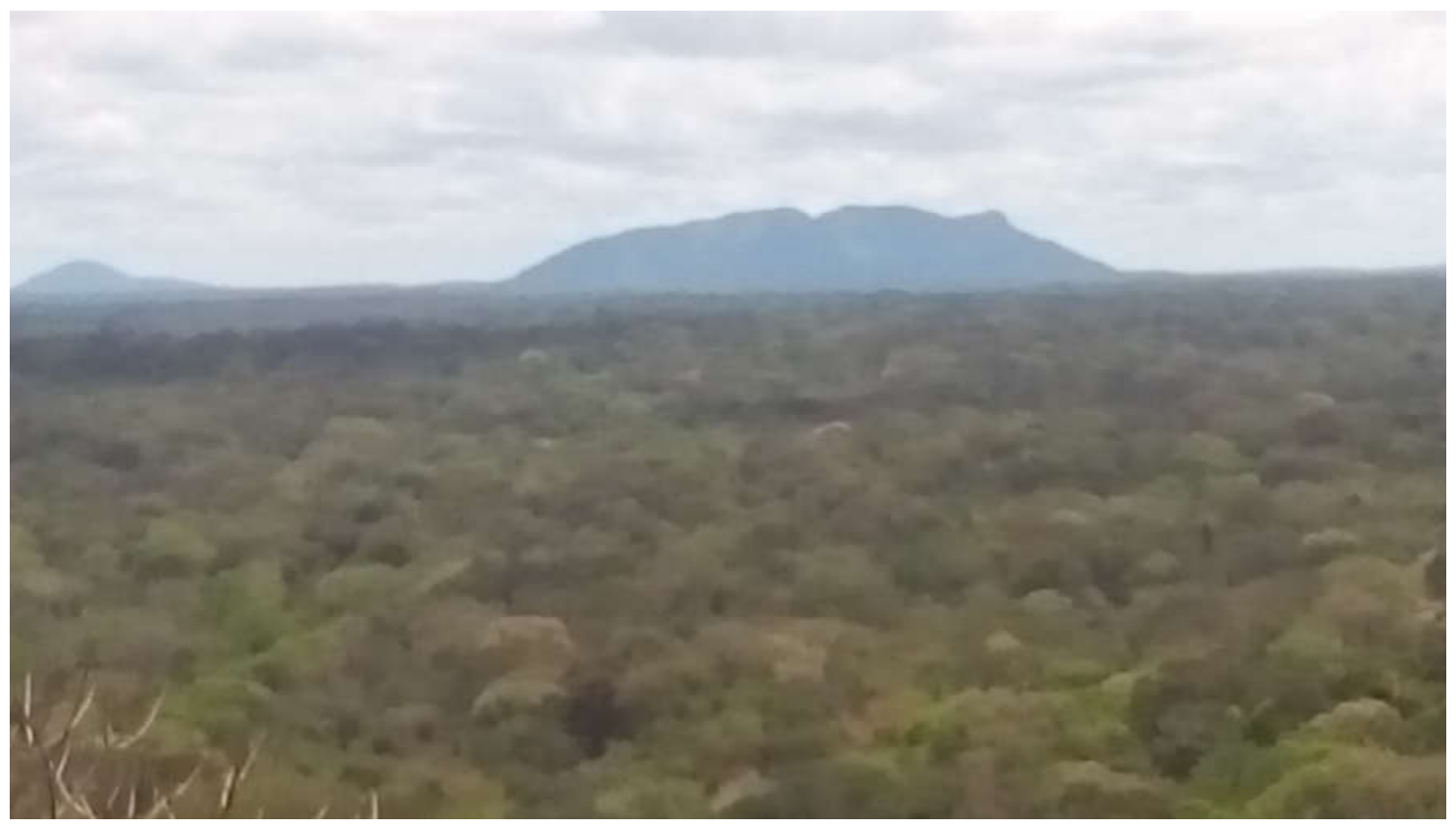

Figura 14: Serra de Abuhuñami (fotografia do autor, 2016). 
O que tentei mostrar ao leitor neste capítulo por meio da descrição de alguns dos cuidados que cercam o momento do nascimento, do Jurupari e da primeira menstruação, bem como a morte, é que a vida de um Yuremawa ou Yúriwawa é cercada de cuidados, os quais implicam no crescimento (ou não) da pessoa, elemento central para os Kubeo como já havia notado Goldman: "To appreciate the significance of growth magic it is necessary to understand the special relish the Cubeo have for body size, how much they appreciate heavy arms and bulging calves. Size is a vertue in itself' (GOLDMAN, 1963, p. 171, itálico meu). Tais cuidados com a pessoa visando sua proteção e crescimento supõe uma metafísica do manejo de umé. As práticas de nominação e "confirmação do nome" fazem parte desse complexo. No próximo capítulo examino as listas de pupui amiya e avanço mais algumas hipóteses sobre a atribuição desses nomes bem como um aparente "esquecimento" dos nomes enunciado por muitos Kubeo durante minhas interlocuções em campo.
\end{abstract}




\section{CAPÍTULO 4 - PUPUI AMIYA: METAFÍSICA E ESQUECIMENTO}

O pupui amiya é elemento constitutivo da pessoa kubeo; estabaliza o umé e faz crescer

(no sentido do "growth magic" de Goldman). Sobre os usos de pupui amiya, José Bernardo comentou o seguinte:

Essas pessoas, Tukano, Tariano, eles que chamam pelo nome de benzimento, quando vai benzer; qualquer coisa, tu está doente, ele fala o nome dele, aí vai benzendo, onde ele nasceu, onde ele tem sítio sagrado, aí vai benzendo; pra nós não tem essa coisa [...].

Eis uma primeira distinção entre pupui amiya kubeo e o que se chama de nome de benzimento para outros grupos tukano e tariano. O Yúriwawa Paulo Espitia, em conversa sobre pupui amiya, chamou a atenção para a tradução incorreta que se faz de tal noção por "nome de benzimento" e ofereceu a seguinte explicação:

[...] o que meu pai me falou, eram apenas 11 nomes yúriwawa; Yuremawa é outra coisa, não tem ligação, é deles. O que eu anotei eram 11 nomes, e esses nomes eram repetidos por várias pessoas; homens e mulheres têm nomes, e das mulheres também são muito poucos. Meu pai colocou da minha filhinha Karen de Marikó [...]. A outra pequena é Bedekó, "patinha", e tem a filhinha do meu irmão Jairo... não sei qual o nome que ele colocou. Então não tem muitos, só tem poucos, e esses nomes vêm se repetindo para as pessoas. O meu é Kuçiwida. Essa palavra levantou polêmica... eu falei meu nome no meu curso, e um colega Baniwa falou "espera aí, você disse que é Kubeo e tem nome com língua baniwa?!". Kuçi é um pássaro, wida é cabeça, então é cabeça desse passarinho. [...] Esse nome Kuçiwida é Baniwa, agora já em Kubeo traduzido significa "cabeça de mutum". Tem Huré, que também é nome de benzimento, são nomes tradicionais. [...] dizem que nós falávamos mais para Baniwa, assim, Kuripako. Então os nomes de benzimento sempre têm isso, relação muito próxima ao Baniwa, aí eles traduziram para o Kubeo. Cada nome de benzimento tem apelido. Em Kubeo a gente chama Pamie Amiya. Eu contesto essa questão de nome de benzimento, para mim não seria nome de benzimento, seria nome tradicional, porque nome de benzimento já não existe, na minha análise isso. O velho quando vai benzer não vai dizer Huré, ou Kuçiwida, ele vai simplesmente dizer Yúri paramekt, ou Yúri Paramekó, significa neto de Yúri, geração de Yúri, não se usa nome de benzimento, não se usa esses nomes das pessoas quando vai benzer, eu vim acompanhando meus finados tios benzendo, eles nunca falaram isso, quando eles benziam para gripe ou qualquer outra enfermidade, eles diziam... ou, por exemplo, resguardo de almas, essas coisas, eles sempre falam Yúri Parameku ou Yúri Paramekó, sempre; por isso eu contesto isso, por eles falam assim, não é nome de benzimento, é nome da pessoa, como se disse Diego, João... não se usa para benzer, em nenhum momento. Por isso, eu percebia, no caso, nós, quando fosse benzer para uma pessoa de outra etnia, outra tribo, ficava um pouco difícil, porque não tinha como ele respaldar aquilo, esse benzimento é 
direcionado especificamente para esse povo, para o grupo; como eu vou te dizer, no teu caso por exemplo, o senhor é branco, kariwa, na língua geral... como eu vou dizer? Você não é Neto de Yúri, aí não sei se o benzimento pega ou não pega; cada etnia tem seu benzimento [...] (sublinhado meu).

A fala é complementada por Pedro Espitia, irmão menor de Paulo, que acompanhava a conversa:

$\mathrm{Eu}$ acho que eles falavam esse nome de benzimento porque quando eles batizavam, eles benziam para poder dar o nome. Eu não sei quem colocou assim, essa versão. [...] O certo é nome tradicional, eu coloquei assim no meu memorial, para mim está errado isso de nome de benzimento. Quem sabe o nome de benzimento é o mais idoso, o avô (sublinhado meu).

Essas duas falas merecem nossa atenção. Em primeiro lugar, os nomes são poucos, tanto os de homens como os de mulheres. Segundo, Yuremawa têm seu conjunto de nomes, Yúriwawa têm os seus. Alguns nomes são em língua original, não Kubeo, como já apresentado em capítulo anterior, algo que causa espanto para um ouvinte Baniwa ou Kuripako, tal como a situação descrita por Paulo Espitia. Mais duas ideias são apresentadas na fala de Paulo: "Cada nome de benzimento tem apelido", e a contestação do uso da expressão "nome de benzimento". No sexto capítulo exploro a primeira ideia; atenhamo-nos à segunda.

"Eu contesto essa questão de nome de benzimento", afirma Paulo Espitia. Propõe em seu lugar o uso de "nome tradicional". Por que? "Nome de benzimento" sugere uma relação entre os nomes e os benzimentos. Contudo, tal relação não existe. $\mathrm{O}$ velho quando vai benzer "não vai dizer Huré, ou Kuçiwida, ele vai simplesmente dizer Yúri Paramekt, ou Yúri Paramekó", explica Paulo Espitia, o que "significa neto de Yúri, geração de Yúri, não se usa nome de benzimento, não se usa esses nomes das pessoas quando vai benzer”. Tal ideia é confirmada na fala de Pedro Espitia que sugere como explicação para esse equívoco o fato da atribuição do nome se dar por meio de benzimento. O que se chama "nome de benzimento" é, portanto, "nome da pessoa", e seria mais correto designá-lo como "nome tradicional" para suprimir confusões.

A argumentação de Paulo Espitia é bastante convincente. Luiz Gilberto, quando comentei essa fala, manifestou concordância ratificando que de fato "nome de benzimento" pode causar confusão, pois pode fazer entender que é nome usado em benzimento quando na verdade é nome atribuído por meio de benzimento. Feitas essas considerações sobre o termo, passemos aos nomes propriamente dito. 
Em campo levantei algumas listas de pupui amiya. Cada grupo, como vimos, tem o seu conjunto de pupui amiya. Vejamos primeiro uma lista de nomes Yuremawa masculinos que reuni, com comentários de Martins Gomes, grande conhecedor das tradições narrativas kubeo e que pacientemente se dispôs a analisar comigo as listas reunidas:

\begin{tabular}{|c|c|c|}
\hline Pupui amiya & $\begin{array}{l}\text { Tradução em português (com } \\
\text { comentários de Martins Gomes) }\end{array}$ & $\begin{array}{l}\text { Apelido } \\
\text { correspondente }\end{array}$ \\
\hline Pãrame & $\begin{array}{l}\text { Arraia (paramebó). Segundo } \\
\text { Martins, é apelido e não pupui } \\
\text { amiya }\end{array}$ & Pakoró (ucuqui) \\
\hline Мапиа̃ & $\begin{array}{l}\text { Martins conhece Manu como } \\
\text { pupui amiya; disse que Manuã } \\
\text { não tem sentido }\end{array}$ & \\
\hline Kã̃̃e & $\begin{array}{l}\text { Tipo de pássaro grande, parecido } \\
\text { com garça }\end{array}$ & \\
\hline Kuhé & Martins não conhecia o termo & $\begin{array}{l}\text { Wekó hĩdó (tipo de } \\
\text { pássaro, loro) }\end{array}$ \\
\hline Mená & $\begin{array}{l}\text { Pupui amiya, "nome próprio de } \\
\text { benzimento, não tem tradução" } \\
\text { (Martins) }\end{array}$ & $\begin{array}{l}\text { Warĩbihó (vômito do } \\
\text { porco) }\end{array}$ \\
\hline Yuré & Nome próprio, sem tradução & $\begin{array}{l}H u h t \text { (martim- } \\
\text { pescador) }\end{array}$ \\
\hline Kapai & $\begin{array}{l}\text { "Nome próprio de benzimento, } \\
\text { não tem tradução" (Martins) }\end{array}$ & Otaké/Kã̃̃e \\
\hline Tui & & \\
\hline Yuremaku & & \\
\hline Paidano & & \\
\hline
\end{tabular}




\begin{tabular}{|l|l|l|}
\hline Wekó & & \\
\hline Tekui & $\begin{array}{l}\text { "Nome próprio de benzimento, } \\
\text { não tem tradução" (Martins) }\end{array}$ & Kapai \\
\hline Kaiwariđa & & \\
\hline Wiá & & \\
\hline Wianá & & \\
\hline Horu & & Taitã/Tekui \\
\hline Tuipe & & \\
\hline Mandawá & & \\
\hline Menawika & & \\
\hline Kaparida & & \\
\hline
\end{tabular}

Tabela 10: pupui amiya Yuremawa masculinos (elaboração própria).

Segue lista com pupui amiya Yuremawa femininos:

\begin{tabular}{|l|l|l|}
\hline Pupui Amiya & $\begin{array}{l}\text { Tradução em português (com } \\
\text { comentários de Martins } \\
\text { Gomes) }\end{array}$ & $\begin{array}{l}\text { Apelido } \\
\text { correspondente }\end{array}$ \\
\hline Mayakó & $\begin{array}{l}\text { Jacamim, relacionado ao } \\
\text { jacamim }\end{array}$ & \\
\hline Mumũkó & $\begin{array}{l}\text { Borboleta, tipo de borboleta } \\
\text { pequena, que voa à noite }\end{array}$ & \\
\hline
\end{tabular}




\begin{tabular}{|c|c|c|}
\hline Moatoiko/Toiko & Pinta-peixe & \\
\hline $\begin{array}{l}\text { Nemikó (teve } \\
\text { discordância } \\
\text { entre alguns } \\
\text { velhos sobre ser } \\
\text { pupui amiya ou } \\
\text { apelido) }\end{array}$ & $\begin{array}{l}\text { Preta-mulher; refere-se a cor } \\
\text { preta }\end{array}$ & \\
\hline Kuraburikó & $\begin{array}{l}\text { Tipo de pássaro que permanece } \\
\text { na pedra, parecido com bacural, } \\
\text { de cor marrom }\end{array}$ & $\begin{array}{l}\text { Kõrekó (fêmea do } \\
\text { pica-pau) }\end{array}$ \\
\hline Wichukó & & \\
\hline Kawichukó & & \\
\hline $\begin{array}{l}\text { Kawawikó/Kawa } \\
-w i\end{array}$ & $\begin{array}{l}\text { Tipo de ave branca e com asas } \\
\text { pretas, rabo em forma de } \\
\text { tesoura, aparece entre } \\
\text { dezembro e abril }\end{array}$ & \\
\hline $\begin{array}{l}\text { Kãrakó ou } \\
\text { Kurãkó }\end{array}$ & Pedra-mulher, ou mulher-pedra & Wekó \\
\hline Enawia & $\begin{array}{l}\text { "Nome próprio de benzimento, } \\
\text { não tem tradução" (Martins) }\end{array}$ & \\
\hline Pađedikó & Grilo (tipo de grilo verde) & \\
\hline Pawakó & & \\
\hline Muri & & \\
\hline Hĩta & & \\
\hline Hoewekó & & \\
\hline
\end{tabular}


Tabela 11: Pupui amiya Yuremawa femininos (elaboração própria).

$\mathrm{Na}$ literatura etnográfica disponível encontramos também uma lista de pupui amiya yuremawa na monografia de Simon Valencia (s/d, p. 70-71). Ele divide a lista em duas: primeiro, aqueles nomes que podem ser traduzidos para o espanhol com algum sentido; depois, uma lista de nomes intraduzíveis que apenas têm sentido entre os Yuremawa. Seguem as listas:

\section{a) Primeira lista ${ }^{86}$ :}

Viyanari

Hipaidanari

Tuichidari

Menavikari

Viyanari-viya: Representación del Yuruparí mayor.

Bedebo: Representación del Yuruparí Huríkumada.

Vachu-Hipavacha: Representación del ancestro loro.

$\sim$ Kore'Toi: Representación de una variante de Yuruparí.

$\sim$ Kaiye $=\sim$ Makaiye: Sueño de la anaconda.

Tekui: Representación de la anaconda ancestral símbolo del chamanismo en los Yuremava.

Madava: Representación de variante de Yuruparí mayor.

Kapai: Lágrima de mochilero mayor.

Kaidapichua: Mujer tierra.

Vichuko: Mujer madera.

Mayako: Mujer sin puesto de radicación en la maloca.

Kavari: Representación variante del Yuruparí.

Veko: Representación variante de Yuruparí.

$\sim$ Koemu'Ko: Equivalente a Kapai representación del Yuruparí.

\section{b) Segunda lista:}

\section{Kaiva}

Yurema $=$ Yure

Pada

\footnotetext{
${ }^{86}$ Como estou citando o trabalho, deixei a grafia tal como adotada pelo autor.
} 
Hipaidanari

Vio

Mená

$\sim$ Enavia

$\sim$ Huni

$\sim$ Mataka

Padediko

$\sim$ Hita

Tendo listado os nomes Yuremawa, passemos aos nomes Yúriwawa. Segue lista de nomes Yúriwawa masculinos:

\begin{tabular}{|l|l|l|}
\hline Pupui amiya & $\begin{array}{l}\text { Tradução em português } \\
\text { (com comentários de } \\
\text { Martins Gomes) }\end{array}$ & $\begin{array}{l}\text { Apelido } \\
\text { correspondente }\end{array}$ \\
\hline Teã & $\begin{array}{l}\text { Tipo de pássaro grande, voa } \\
\text { no campo, come carrapato de } \\
\text { boi }\end{array}$ & \\
\hline $\begin{array}{l}\text { Manunđa } \text { (falaram } \\
\text { inicialmente } \\
\text { Manuđa, mas } \\
\text { corrigiram depois) } \\
\text { / Marruda }\end{array}$ & $\begin{array}{l}\text { Termo kuripako; nome de } \\
\text { instrumento de Jurupari. } \\
\text { Martins disse que o termo está } \\
\text { incorreto; o certo é manunda }\end{array}$ & \\
\hline $\begin{array}{l}\text { Murida } \text { (termo da } \\
\text { língua original) }\end{array}$ & $\begin{array}{l}\text { Termo kuripako, da língua } \\
\text { original dos Yúri Parãmena; } \\
\text { em Kubeo seria bedebo } \\
\text { (pato). }\end{array}$ & \\
\hline Kapiakani & $\begin{array}{l}\text { Termo kuripako, da língua } \\
\text { original dos Yúri Parãmena }\end{array}$ & \\
\hline Kura & Pedras & Yai (garça) \\
\hline Ñamahuã & Veado vermelho & Ođort (morcego) \\
\hline Yuriwakt & Singular de Yúriwawa & \\
\hline
\end{tabular}




\begin{tabular}{|c|c|c|}
\hline Hiabu kãtã & $\begin{array}{l}\text { Jacaré-Pedra; pedra localizada } \\
\text { no crânio e estômago do } \\
\text { jacaré. Kãtã: tipo de pedra, } \\
\text { amarela, parecido com piçarra }\end{array}$ & \\
\hline $\begin{array}{l}\text { Bede kiboba } \\
\text { (“Kumada } \\
\text { puwariku”, na } \\
\text { língua original) }\end{array}$ & Pata de pato (pé de pato) & \\
\hline Bedebó/Bede hoié & Pato/pato boiando na água & $\begin{array}{l}\text { Buetekart (tipo de } \\
\text { peixe, parecido com } \\
\text { sarapó) }\end{array}$ \\
\hline Huré & Pomba & $\begin{array}{l}\text { Wañáhemé (língua do } \\
\text { preguiça) / Wãiñart } \\
\text { (tipo de macaco } \\
\text { pequeno) }\end{array}$ \\
\hline Piađa kowzyó & $\begin{array}{l}\text { Segundo Martins, não existe } \\
\text { Piađa kowzyó, e sim apenas } \\
\text { Piađa }\end{array}$ & $\begin{array}{l}\text { Kawa } \\
\text { (urubu)/Waibowz (algo } \\
\text { como um conjunto de } \\
\text { cipós) }\end{array}$ \\
\hline Budi & $\begin{array}{l}\text { Animal grande, parecido com } \\
\text { veado (é um apelido segundo } \\
\text { Martins, sem tradução) }\end{array}$ & $\begin{array}{l}\text { Mató (massa de } \\
\text { mandioca) }\end{array}$ \\
\hline$\tilde{N} a m a$ & Veado & \\
\hline Yuriwart & $\begin{array}{l}\text { Relacionado aos Yúriwawa; } \\
\text { refere ao deus Yúri }\end{array}$ & $\begin{array}{l}\text { Dupu (animal pequeno, } \\
\text { fica sobre a água, um } \\
\text { tipo de buyokó: } \\
\text { tamancuaré) }\end{array}$ \\
\hline Pamurt & & \\
\hline $\begin{array}{l}\text { Manaká (língua } \\
\text { original; } \\
\text { "emimoé" em } \\
\text { Kubeo) }\end{array}$ & Açaí & \\
\hline
\end{tabular}




\begin{tabular}{|l|l|l|}
\hline $\begin{array}{l}\text { Kuçiwida (termo } \\
\text { na língua original; } \\
\text { em Kubeo: "Hztyzt } \\
\text { hipobü") }\end{array}$ & Cabeça de mutum & \\
\hline $\begin{array}{l}\text { Iaté (com língua } \\
\text { original, em } \\
\text { Kubeo: "hoewe") }\end{array}$ & Tukano & \\
\hline
\end{tabular}

Tabela 12: Pupui amiya Yúriwawa masculinos (elaboração própria).

Por fim, lista de nomes yúriwawa femininos:

\begin{tabular}{|l|l|}
\hline Pupui amiya & $\begin{array}{l}\text { Tradução em português (com comentários de } \\
\text { Martins Gomes) }\end{array}$ \\
\hline $\begin{array}{l}\text { Marikó (termo na língua } \\
\text { original; em kubeo seria } \\
\text { "Yaikó") }\end{array}$ & Termo kuripako segundo Martins; tipo de garça \\
\hline Yamata & $\begin{array}{l}\text { Martins não sabia o significado; disse que se fosse } \\
\text { Yamatakó seria um tipo de veado }\end{array}$ \\
\hline Upiarikó & Azeda-mulher \\
\hline Piađakó & $\begin{array}{l}\text { Sentido feminino de Piađa (que é um tipo de } \\
\text { pássaro roxo, com partes brancas, e também nome } \\
\text { do mestre de surras no Jurupari) }\end{array}$ \\
\hline Namatakó & $\begin{array}{l}\text { Martins não soube traduzir (ñama é veado) (José } \\
\text { Bernardo traduziu como veado nadando) }\end{array}$ \\
\hline Bedekó & Pata (fềmea do pato) \\
\hline Howewedut / Hoeweđo & \\
\hline
\end{tabular}




\begin{tabular}{|l|l|}
\hline Amehiyo & \\
\hline Hoeweñarebakó & Peito de tukano \\
\hline Yuriwakó & \\
\hline Namakó & \\
\hline
\end{tabular}

Tabela 13: Pupui amiya Yúriwawa femininos (elaboração própria).

Dessas listas, uma primeira observação é que alguns pupui amiya contam com apelidos correspondentes herdados junto com os nomes, e isso também acontece com alguns nomes femininos, fato que merece atenção, dado que apelidos são comumente usados entre homens. Tal dado parece apontar para uma diferença entre dois tipos de apelidos: aquele que acompanha o pupui amiya, fixo, dado junto com esse nome, e o apelido cotidianamente usado entre os Kubeo em brincadeiras. José Bernardo fala sobre pupui amiya e seus apelidos:

Esse benzimento? Porque antigamente ninguém sabia o nome dos brancos como agora, e por isso esse nome era o nome dele mesmo; só o nome dele era mesmo assim com nossa língua, chamava ele... se era homem dizia Yuriwart, se era mulher dizia Yuriwakó, ou se tem Namahuã, era o nome dele; depois que chegou esses nomes dos brancos. [...] repete isso, são poucos os nomes. Desde não sei quanto tempo os nossos avós... se por exemplo, se eu morrer, depois de tantos anos, já meus netos, assim... já vem repetindo o nome meu, isso não acaba. Esse meu filho Edson, tem o nome de meu pai; ele mesmo dizia esse nome: "você vai ficar com meu nome Huré"; ele mesmo chamou Osvaldo Ñamahua; esse Mailson que está em Manaus é Yuriwart; esse aqui [Marcelino] é Piađa. [...] esse é só de brincadeira, Odortu, apelido ["esse aí é igual segundo nome, apelido", intercalou Marcelino, que acompanhava a conversa]. Cada nome de benzimento tem apelido também. Apelido de Ñamahua é Yaí (garça) [risos]. De Bedebo nunca escutei, esse não tem brincadeira... nem pai... só nome mesmo. De Huré é Wãiñart [risos], é uma brincadeira; esse é um tipo de pássaro, aquele que come pupunha.

Notamos que José Bernardo insiste na afirmação já aventada por muitos outros de que os nomes são poucos, o que implica repetição de um mesmo nome para várias pessoas. Os 
nomes, idealmente, são transmitidos em geração alternada, de avô para neto ${ }^{87}$. Por fim, cada pupui amiya tem seu apelido correspondente. Tal distinção já foi elaborada por Stephen Hugh-Jones a partir do material tukano, ao falar que os apelidos "correm ao longo de um espectro. Em uma extremidade estão os nomes jocosos verdadeiros [...]. Na outra extremidade do espectro estão os nomes comuns, veneráveis, semi-sagrados [...] que agora formam par com nomes de espírito e são transmitidos com eles” (2002, p. 52, itálico meu). Sobre essa distinção e apelidos de modo geral tratarei em outro capítulo, como já anunciado. Sigo a análise dos pupui amiya. Aqui, insisto no pequeno número de nomes que se repetem ao longo das gerações. Isso coloca alguns problemas.

O pupui amiya marca a "consideração", o "respeito" (pueđaino) devido à pessoa em questão, explicou certa vez Luiz Gilberto; diversas vezes me disse: "o nome de benzimento marca a posição da pessoa, o lugar dela na ordem de consideração", "é o avô quem sabe indicar o nome de benzimento certo, ele escolhe o nome dentro da ordem de consideração, se é maior, do meio ou do final". Eis a dificuldade: como vimos, os nomes de benzimento são poucos, e os Yuremawa e Yúriwawa muitos. Os Yuremawa distinguem, como já detalhado no capítulo anterior, o que eles chamam "linhas de consideração"; assim, e em ordem de consideração, teríamos, em uma das listagens feitas: Kapuareda, Wianawa, Benawikawa e Yaniwa (essa com três subdivisões). Luiz Gilberto, que tem por pupui amiya Kapai, se identifica como Yaniwa. Geraldo Edson, por sua vez, se identifica como Benawikawa, contudo, tem o pupui amiya Kapai. Se o pupui amiya está relacionado à ideia de posição numa escala de consideração, como pensar esse tipo de situação?

Além disso, outras questões emergem da análise dessas listas. Como pensar certas “inconsistências" como a de pessoas com um pupui amiya, Kañe por exemplo, que é indicado por outras pessoas como yahui amiya de Kapai? Essas inconsistências são lapsos de memória, certa estratégia para evitar falar o nome, equívocos ao enunciar o nome? Vejamos.

Alguns nomes são apontados como "errados", resultado do descaso e desconhecimento dos conhecimentos relativos. O velho Yúriwawa Manuel diz o seguinte:

Agora minha mãe, Amélia, o apelido dela era Moatoiko... nome de benzimento de Amélia é Moatoiko, o grupo dela pertencia isso; Moatoiko, esse é próprio dela; porque às vezes a pessoa sem saber nada coloca o nome, por isso eu sempre dizia que tem que conversar com os pais. Por isso eu digo, eles perderam tudinho... coloca qualquer coisa... as vezes sem saber

\footnotetext{
${ }^{87}$ Digo "idealmente" pois, uma análise da distribuição dos pupui amiya nas gerações ascendentes e descendentes mostra muitos nomes da geração do avô que não aparecem na geração dos netos, e nomes de pais e seus irmãos repetidos para os filhos.
} 
coloca de outro grupo... Hori é wanano... Tuipe não é nome de benzimento, é da estrela, cada benzimento nasceu da própria origem... agora astronomia os velhos separavam, tal dia vai... conhecendo a estação do ano, tal dia Tuipe vai chover, aí vai preparar essa coisa para pegar o peixe.... Aí depois eles chamavam de $U c ̧ i w u$, esse grupo de estrelas... tal dia que vai chover... é uma estação do ano, não é nome de benzimento, tinha o grupo de estrelas.... [...]. Yuremawa e Yúriwawa têm nomes diferentes de benzimentos... eles devem saber...

Se nos atentarmos às listas de nomes vemos algumas inversões: Kã̃̃e aparece como pupui amiya, mas mais adiante na lista aparece com apelido de Kapai. Mas há outros casos de inversão: Kapai, pupui amiya, aparece como apelido do pupui amiya Tekui, que por sua vez aparece como apelido de Kaparida mais adiante na lista de nomes masculinos yuremawa. Além das inversões, há casos como o do nome Tuipe, apontado por Manuel na citação acima como nome de certa constelação, não sendo nem pupui amiya nem apelido; Manuel designou tal nome como equivocado, resultado do fato das pessoas colocarem "qualquer coisa" como nome. Não apenas colocam termos que não são propriamente nomes como por vezes usam nomes próprios de outros grupos, como o caso citado do nome Hori, que é apontado por Manuel como sendo Wanano (Kotiria) ${ }^{88}$.

Na lista de Simon Valencia dos nomes yuremawa, separada entre nomes com tradução possível e outros sem tradução para o espanhol - embora o autor apresente sem justificativa os quatro primeiros nomes da lista de traduzíveis (Viyanari, Hipaidanari, Tuichidari, Menavikari) sem tradução - vemos o pupui amiya Bedebo, que em minhas interlocuções foi apontado como sendo Yúriwawa. Ainda na lista de Valencia aparece "Veko", que Martins afirmou ser apelido (inclusive, vale destacar, é o apelido que me foi atribuído em campo, Wekó, nome da ave papagaio).

Luiz Gilberto conversando sobre nomes me falou que "há pessoas que valorizam os nomes de benzimento, e outras não; é importante conhecer os nomes" pois, ainda segundo ele, significa "saber quem se é, de onde vem, conhecer a própria história [...] é vergonha a pessoa não conhecer sua história, e outra de outro grupo conhece". Martins completou dizendo que "todo grupo tem sua história própria". Essas histórias falam da conformação do mundo e dos personagens responsáveis por tal conformação. É a esses personagens que se atribui também a origem dos pupui amiya.

O velho Jaime Rodrigues (Yúriwawa de Açaí) deu a seguinte explicação sobre pupui amiya:

\footnotetext{
${ }^{88}$ No próximo capítulo volto a esse tema do registro "errado" do pupui amiya, ao analisar a escrita dos nomes em documentos, particularmente o RANI, e apresento algumas explicações para isso.
} 
Esses são nomes do tempo antigo. É pouco nome. [...] Pupui amiya são nomes dos antigos, de nossos avôs, são nomes de nascimento, da criação; os primeiros já tinham esses nomes. [...] os velhos diziam que alguns nomes têm história. [...] Esse que chama Tekui, ele é mestre de pajé; como deus de sabedoria, de medicina, que o pajé utiliza para jogar água no doente, para tirar doenças; no começo foi o dono dessa sabedoria, o pajé, Tekui. [...] Kañe é como sonho, como sonhador. Kaparida é nome de nós.

O velho Jaime afirma o pupui amiya como sendo do "tempo antigo", "nome dos antigos, de nossos avôs" e menciona brevemente a história de alguns nomes: Tekui, Kañe e Kaparida. Tal fala nos remete à questão dos referentes desses nomes. Com efeito, "nome de benzimento é nome", como disse Luiz Gilberto certa vez, não se traduz; são nomes de personagens das narrativas antigas, como Kapai, Piađa e Tekui. Vejamos com mais detalhes alguns dos personagens das narrativas de origem, fontes dos nomes.

Sobre Tekui, o velho Yúriwawa Simão diz o seguinte:

Tekui é irmão do Kapai, da tribo Yuremawa, só que ele não morreu, ele voltou para o rio em forma de cobra. Ele é... a gente chama de moawz, na época de moawz, antes de se tornar humano... na forma de cobra na época... Yúri andava na forma de moawz, de cobra... então Tekui é irmão do Kapai, que não morreu, voltou para o rio em forma de cobra. Ele voltou num rio chamado Yawurađa, aqui no Ayari, um igarapé, um tal de Yawurađa. Tekui está lá, na forma de cobra. Já nós sabendo falar na nossa língua original, é só ir lá, com Tekui, se tiver doente; lá tem um lago, com uma pedra no meio, aí deixa o doente lá, com algumas coisas em forma de pagamento para o pajé, aí deixa o doente em cima da pedra, e espera, assim, um pouco distante. Aí Tekui sai, em forma de cobra grande, e ele tira as doenças, ele chupa onde está doendo, e a gente vai falando, na nossa língua, ele não entende mais o Kubeo, ele entende a língua original. Então ele sai, tira as doenças e a gente não morre, assim que funcionava antes, porque Tekui não morreu, ele está vivo, em forma de cobra, lá nesse rio que eu falei. Aí ele cura a pessoa, tem que pagar ele. Já agora, quase agora, no tempo do Huré, que era irmão do meu avô, no tempo de jovens eles foram; aí escutaram ele dançando com carriço, dançando com Jurupari, eles escutam pessoas morando lá, mas não tem ninguém morando lá. Aí eles chegaram lá, eles levaram faca, anzol, essas coisas que eles precisam lá, e deixaram lá, num lugar adequado, e ofereceram para ele, falando que eles trouxeram esse material em troca de zarabatana. Aí deixaram lá, e quando foram ver no outro dia, não tinha mais, tinha sumido. Aí apareceram três, no máximo tem que pedir três zarabatanas, ou dois; aí apareceu isso aí bonito, depois não aparece mais não. Se não pagar a gente não acha nada, lá onde Tekui está, tem que pagar alguma coisa. Funciona assim. Meu pai escutou essa história do irmão do pai dele, no tempo de criança. Ele me contou que realmente tinha gente lá, mas ninguém vê ele, mas a gente escuta ele, via as coisas que ele fazia. 
Tekui é um pajé e como tal pode fazer benzimentos de cura; ao contrário do que se passou com outros personagens, como o caso de Muriđa, que veremos adiante, Tekui não morreu, vive em certo igarapé do rio Ayari, e pode ser procurado para pedir cura para doenças. Simão lembra mesmo que quando jovem ouviu seu pai e tios contarem sobre certa viagem que fizeram ao local onde vive Tekui. Uma vez lá, deixaram faca e anzol como oferta para troca, e encontraram três zarabatanas no mesmo local no dia seguinte. Além da prova material dada por meio da troca, também ouviram sons que só podiam vir de Tekui, dado que não havia mais ninguém no lugar. Passemos a outro personagem.

O velho Simão contou a seguinte história de Muriđa (com tradução de seu filho Pedro Espitia):

Muriđa era um guerreiro forte, alto, com pernas enormes, tinha os soldados dele; ele comia a carne humana, não eram os soldados, era ele mesmo que comia a carne humana. Ele tinha equipe formada própria para guerra e para caça, tinha muitos soldados. Eles tinham tribo, chamada Biowa, e Muriđa ia eliminando essa tribo. O último, Biokt, ele veio, trouxe em forma de se humilhar, a tribo dele, para se oferecer para o Muriđa, aí que ele sentiu pena dele, não deixar matar ele. Tinha um menino, de outra tribo, servente dele. Muriđa sentiu fome, e mandou o menino pegar lenha, e levou o material completo para assar e comer; mas o menino sabia que ia ser comido e fugiu. Muriđa ficou chamando umas três vezes, como o menino não apareceu e Muriđa não aguentou a fome, cortou a própria batata da perna dele para comer, não conseguiu voltar e morreu no próprio local. Depois que Muriđa morreu, chegaram os soldados com a caça dele, e viram que ele estava morto. Aí perguntaram o que tinha acontecido para essa criança, que era servente do Muriđa, e ele contou tudinho que aconteceu; mas mesmo assim eles flecharam ele e comeram a carne, mataram o servente.

Aí depois disso, existia a tribo de Yokaktbekt, que era de outra tribo, que estava na frente de batalha, eles se revoltaram com ele, porque eles iam matando gente para trazer carne humana para o Muriđa comer, aí falaram: "nós estamos perdendo soldados por sua culpa"; aí respondeu "não, pode me matar então". Aí tiraram equipamento de proteção, escudo dele, e flecharam ele, esse Yokaktbekt; aí acabou a guerra, depois que Muriđa morreu. Aí, por esse motivo..., aí cortou essa linhagem... Yúriwawa não casa com Yokaktbekt. Depois que Muriđa morreu, quem tomou conta foi esse pessoal da tribo baniwa, esse do nheengatu, que é Baré... aí como Muriđa já tinha morrido, eles tomaram conta, passaram a pegar as crianças Yuremawa e Yúriwawa para serem escravos deles. Aí com o passar tempo, esse Yuremawa, o chefe deles, acabou matando esse itebu; aí começou conflito de novo. [...] O nome desse guerreiro é Kuenomo, que matou eles, guerreiro yuremaku, já para defender o povo dele, porque tanto yuremaku e yuriwakt estava se acabando; quem tomou a frente foi esse Kuenomo, que acabou matando esses baré, baniwa e outros tribos aqui do rio Negro. Então surgiu mais conflito, que chegou Nomi Paramekt, que são brancos, que veio de Portugal, quem comandava esse capitama é Nomi Parameku, branco. Aí se juntaram, e foram atrás para matar tanto Yuremawa, Yúriwawa, Hehénewa... todos que moram para lá. Já não suportavam mais esse pessoal, pois eram mais fortes... mas mesmo assim... na foz do rio Ayari tem um caminho que 
vara no Uaupés. Nesse caminho, ela que ia na frente, esse Nomi Paramekt, que tem forma de mulher; lá existem duas pedras, e o caminho passa no meio dessas duas pedras, enormes. Então um guerreiro ficou nesse lado e outro aqui; aí assobiavam, ela olhou para cima e flecharam na garganta dela... aí os soldados dela correram para trás; eles desceram, tiraram equipamento dela, e viram que era em forma de mulher, mas ela não tinha assim seios, peitos. Então recuaram para ver o que ia acontecer com ela. Aí os soldados dela voltaram... Aí o conflito da guerra termina [...].

Essa narrativa nos conta que Muriđa era o nome de um guerreiro que liderava um grupo de soldados e tinha por prática comer carne humana. A narrativa segue contando sobre a morte de Muriđa, e como isso implica no fim da guerra com outro grupo, Yokakubeku, e em uma reconfiguração da posição de comando: os Baniwa assumem essa posição por um tempo, são suplantados por Kuenomo, guerreiro yuremaku e, por fim, por Nomi Paramekt, comandante dos brancos, proveniente de Portugal segundo a narrativa. O relato se encerra com a morte de Nomi Parameku e o consequente fim da guerra.

Sobre Piađa, outro personagem das narrativas e fonte de pupui amiya yúriwawa, Simão diz:

Piađa é chefe da surra. No tempo das festividades... eles estavam fazendo festa de Jurupari lá no Wakaipani, de repente surgiu uma canção diferente da que eles tocavam... então eles se dividiram... "vocês tocam diferente, tem um som diferente, acho que vocês são de outra tribo", aí começaram a discutir. [...] Piađa é chefe da surra, ele surrou um da tribo yuremakt, e venceu ele na surra. Aí eles se separam... lá no Wakaipani, aí Piađa surge, da tribo dos Yúriwawa [...].

Na mesma conversa, Simão detalha a história de Piađa:

Estava acontecendo a festa, e apareceu Piađa, vinha cantando, e vinha surrando nas pernas. Ele entrou no grupo de Yúriwawa, não foi de Yuremawa, foi de Yúriwawa, aí se agradaram com a presença dele, e nomearam ele chefe da surra. $\mathrm{O}$ tal de Hurito veio enfrentar Piađa nesse momento, não se agradou, veio da tribo dos Yuremawa, enfrentar ele, e começaram a se surrar entre eles; e Piađa acabou vencendo. Então para a gente, dos Yúriwawa, Piađa é chefe de surra.

Piađa, chefe de surra, é figura central na narrativa de origem dos Yúri Parãmena, sendo um dos responsáveis por iniciar o conflito que resultará na divisão entre Yuremawa e Yúriwawa. Sobre esse episódio já falei no segundo capítulo, e voltarei ao tratar do Wakaipani, lugar de transformação dos Yúri Parãmena. Sigamos com as narrativas desses personagens do momento da criação. 
Sobre Toiko, Simão diz:

Ele tava dizendo que ela tinha aqui forma de mulher, e aqui era Toiko, a gente chama assim, pintado, então cobra pintada, jiboia no caso, referindo o corpo pintado dela, em forma de cobra, Toiko, então jiboia, uma forma de cobra com as pintas; aí surgiu esse nome de benzimento deles, Yuremawa, eles levam esse nome, ele já é dos Yuremawa.

Sobre Kapai, o mesmo Simão nos conta que:

Kapai é da tribo de Yuremawa, não é chefe de surra, é pajé da tribo yuremawa. O Kapai é pajé, aí ele se incorporou na forma de tatu, bem grande, tatu canastra como a gente chama aqui, e começou a cavar o Abuhukõ, a serra, porque, na época, quando nosso parente morria não tinha para onde ela ir, onde enterrar, a alma da pessoa, não tinha onde descansar, não tinha lugar. Então Kapai começou a cavar, já incorporado na forma de tatu. Então ele é pajé. Vai até Abuhuñami, para preparar o lugar para o pessoal morto. Então, nossa crença, quando alguém morre, ele vai direto para Abuhuñami. Eles chamam põe dekokt, essa alma que vai para lá. Antigamente, um senhor na idade do meu pai, quando tava doente, antes dele falecer ainda, o Abuhuñami já começava a estrondar, meu pai escutava ainda quando ele era criança. Então nossa crença é isso, a gente morre, é enterrado, e nossa alma vai para lá; e lá eles vivem normal, do jeito que a gente continua vivendo aqui; tem festas, tem as danças... na nossa crença, de nós indígenas; então a vida continua lá. [...] Kapai é o pajé.

Na mesma conversa, Simão complementa:

Kapai ficou lá no Abuhuñami, ficou lá, não morreu, se transformou em onça grande, e ficou lá, não voltou mais não, não morreu, ele tá vivo, tá lá.

Manuel, também Yúriwawa, relevante lembrar, conta a seguinte versão da história sobre Kapai:

O Henrique deve saber... o grupo dele se chama Kapai.... esse grupo de Kapai é o nome... origem principal, igual Yúri, porque ele ficou lá na cabeceira do Ayari, alí tinha uma igarapé... se chamava Yaurađa, yaura se chama uma gotinha de água, no sereno aparece, aí falamos Yaurađa para o igarapé... de lá na cabeceira tem um lago, aí que o chefe dele ficou... ele não ficou aqui, nessa terra, diz a história, porque ele viu que aqui nesse mundo não prestou, porque cheio de problemas, cheio de veneno, ele perdeu um filho, então disse, "não vou ficar nesse mundo, eu vou retornar outra vez"... então ele se transformou em cobra grande e ficou lá, até agora dizem que lá é dele... até hoje não sei como tá... muitas vezes eu fico perguntando para as pessoas do Ayari que estão vivendo... assim, eu tenho um primo, conhecido... assim dizem que vive lá, esse Kapai, quando a pessoa tá doente, iam lá; mas só que ele fala Baniwa. Quando a pessoa ia lá, ele 
perguntava "o que você quer?" ... só que, no sonho, "o que você quer? Eu vim atrás de você, a quem você pertence?", quando falava língua estranha, ele dizia "você não é meu grupo, você não é meu neto, você é outro", então eles diziam, precisando, "eu sou neto, eu falo minha língua" ... aí ele falava "então está bom, e o que você quer?", respondia "estou doente, me protege", e ele protegia, curava a doença. Tem um lago aí bem limpo, tem uma pedra no meio do igarapé, ele aparecia uma cobra, mas ele curava; já não sei como está; está limpo na beira desse lago, sempre fica limpando, porque ele fica lá, esse Kapai, avô dos Yuremawa, ele ficou alí. A história é assim, Ayari é cheio de história, quando passaram, quando procuraram um território para onde ficar, quando chegava lá já tinha outro grupo, aí separavam, passavam... e assim por diante.

Kapai é associado à figura do pajé, alguém com capacidade de curar. É um ser que em certo momento se retirou para um igarapé no rio Ayari e lá vive; pode, inclusive, ser procurado por aqueles que sabem de sua existência e conhecem sua língua. Aqui, Manuel indica uma associação entre "língua" e "grupo": "você não é meu grupo, você não é meu neto, você é outro", diz Kapai, ao que o visitante respondia "eu sou neto, eu falo minha língua"; dito de outro modo, a língua faz diferenciações, o que, parece-me, pode ser lido na chave da teoria do umé formulada por Irving Goldman (2004). A língua, enquanto voz, remete ao umé e é ao mesmo tempo manifestação da potência do grupo, dizia Goldman (2004, p. 345 e ss.), tal como ouvi diversas vezes de Luiz Gilberto, “a língua é a força da comunidade". Vimos também que Kapai é irmão de Tekui, outro personagem a quem se atribui capacidades de cura. Ambos estão vivos. Tal afirmação merece atenção, isto é, o fato de muitos dos seres ancestrais aos quais os nomes remetem estarem vivos. Os nomes remetem ao passado, ao momento da criação, é certo; contudo, é preciso estar vigilante para não supor um corte e um encerramento desses seres ancestrais no passado, uma vez que personagens como Tekui, Kapai etc. estão vivos, têm casas nas serras e igarapés, ao contrário do que afirma Viveiros de Castro quando diz "there is no doubt that the ancestors from which spirit names come are agnates not affines - but they are dead agnates" (2006, p. 94). Avancemos.

Vimos alguns dos personagens masculinos de onde provêm determinados pupui amiya. Contudo, tanto homens como mulheres recebem pupui amiya. Manuel, Yúriwawa, falou o seguinte sobre alguns nomes femininos:

[...] próprio Yúrí tinha esse nome, que se chama como se fosse avô da criação, da origem... deveria ser só para Yúri... Yúri é o principal seria... como se fosse criador dessa tribo... nós chamamos de nosso avô. Mas agora... irmão dele nasceram outro, e outro... aí colocaram cada apelido do irmão; não ficaram com cabeça. Aí colocaram assim... aí cabeça devia ser Yúri mesmo.... [...]. Nome de benzimento vem da origem, é próprio da origem. [...] Avís, que acompanhavam Yúri, que chamavam Namatakó, por 
isso minha filha chama ñamatakó bukuko, depois vem Hintaçu, Huredanaçu, o principal, são três que acompanhavam o Yúri... esses são os principais do grupo; aí esse benzimento sempre pega essa avó, o nome dela...Huredanaçu, Ñamatakó... tudo isso que ele pega. Ñamatakó era irmã do Yúri... eram essas três... o principal era Huredanaçu, depois Ñamatakó, depois vem Hintaçu... esse nome vai para grupo de Yuremawa, por isso que colocam na filha Hintaçu, Huredanaçu. Nós vivíamos em grupo com os Yuremawa, por isso que nós temos... assim... são nossos cunhados.

Tal como para os nomes masculinos, também os nomes femininos têm sua origem em personagens do momento da criação. Na fala de Manuel, vemos que Yúri tinha três irmãs: Huredanaçu, considerada a principal, que na narrativa de origem dos Yúri Parãmena que veremos com mais detalhes em outro momento é a responsável pela emergência dos primeiros grupos, Namatakó e Hintaçu.

Por fim, lembremos que as listas apresentam conjuntos de nomes diferentes para os Yuremawa e Yúriwawa. Contudo, o compartilhamento de nomes por dois grupos distintos não é algo impossível. Vimos Simon Valencia incluir em sua lista de nomes yuremawa um nome yúriwawa (Bedebo). José Bernardo diz que Yuremawa e Tarabuawz compartilham os mesmos nomes de benzimento:

Nome dos Yuremawa é diferente dos Yúriwawa; Yuremawa não pode colocar benzimento de Piađa, isso aí já é outra parte, eles já têm os nomes deles. Assim, Yuremawa, Tarabuawu têm os mesmos nomes... são a mesma tribo... só o nome está trocado... Tarabuawz é maior dos Yuremawa, é maior irmão deles... agora, qualquer Tarabuawz que chega ele chama de meu irmão, minha irmã, os filhos "tia"; entre eles não pode casar, Yuremawa e Tarabuawz; mas nome de benzimento é igual; entre eles não pode casar, são parentes mesmo, só que nome está mudado, Yuremawa e Tarabuawu.

Se compartilham os mesmos nomes, embora grupos diferentes, são parentes, "não pode casar". Avancemos.

Como já dito, o conjunto de pupui amiya é pequeno e tem importância central na vida da pessoa yuremawa e yúriwawa. Assim, Luiz Gilberto disse certa vez que "cada grupo tem o seu conjunto de nomes de benzimento, que vem dos antigos; a lista de nomes não é muito extensa, e os nomes se repetem muitas vezes". Explicou fazendo analogia com o batismo e a crisma que a criança recebe um "nome de benzimento" quando nasce (o "batismo") e que tal nome é confirmado com o Jurupari, no caso do homem, e com a primeira menstruação, no 
caso da mulher. Falou que tais "ritualizações" não são praticadas atualmente, o que implica "problemas de saúde, desnutrição e fraqueza para os jovens de hoje", ou seja, o não crescimento.

As consequências da não observância de certas práticas nos dias que correm também foram problematizadas por Eduardo Rodrigues, Yuremawa de Querari:

[...] tem que fazer, tomar banho de madrugada, cheirar pimenta. Hoje em dia, 9h vai tomar banho, como vai ter força?! Nem sabe pescar também [risos]. O quanto antes começar a praticar essas coisas, não acha dificuldade quando casar. [...] E por isso a cultura indígena, o crescimento do pessoal diminui muito, porque ele não obedece pela lei, começa a tratar a pessoa mais pelo sexo, por isso que antigamente não era autorizado usar sexo, porque não acaba de crescer, dizem. Nossa etnia tá aqui, nós era alto, gordo, não tinha baixinho gente não, agora já tá ficando parece criança, mais velhinho, porque não respeita o conselho do pai, não acaba crescendo, e pratica sexo já, não desenvolve.

Eduardo afirma o não crescimento como uma das principais consequências da falta de observância de certas práticas. Diz que em tempos atrás "Nossa etnia [...] era alto, gordo, não tinha baixinho", e que agora "já tá ficando parece criança, mais velhinho, porque não respeita o conselho do pai, não acaba crescendo, e pratica sexo já, não desenvolve”. Novamente, vemos a importância do crescimento corporal, entendido como parte do desenvolvimento da pessoa, importância essa, como já destaquei, formulada por Goldman ao descrever os Bahúkiwa (1963). Faz parte desse conjunto de práticas a atribuição de pupui amiya.

O pupui amiya diz respeito, portanto, fundamentalmente à produção da pessoa. Está, desse modo, relacionado ao manejo de vitalidades ou "energia", "força" (expressões usadas por Luiz Gilberto), ou, para usar o termo kubeo, manejo de umé. O nome articula-se ao crescimento corporal, é constitutivo do correto desenvolvimento da pessoa. Simon Valencia fala em "crescimento mágico" propiciado pelo nome: "Se decía que estos nombres eran importantes porque permitían el crecimiento como un atributo dado por los antiguos pero no era un crecimiento común sino que era un crecimiento mágico, un crecimiento en el poder espiritual de la persona" (s/d, p. 70, itálico meu).

Não apenas o crescimento é resultado do manejo de umé que se faz por meio da atribuição de pupui amiya. Aquilo que a pessoa virá a ser quando adulta pode ser moldado, dentro outros elementos, também pela atribuição de nomes. Aqui, para entender essa afirmação, retomemos em linhas gerais a teoria dos papéis especialistas, formulada por Christine Hugh-Jones a partir de seu trabalho com os Barasana (1979). 
Comecemos com duas advertências. Primeiro, apesar de partir dos dados Barasana, Christine Hugh-Jones sugere que tal teoria não se limita a esse grupo tukano e pode ser estendida para o contexto do Uaupés de modo geral (1979, p. 27). Segundo, ao elaborar seu modelo, Christine toma o cuidado de alertar o leitor que se trata da reconstituição de um sistema passado, pois a antropóloga encontrou entre os Barasana apenas fragmentos, mais especificamente apenas os papéis de xamã e cantor/dançador, referências ao que pode ter sido um sistema mais denso e forte no passado. Assim, segundo essa antropóloga,

The function of the specialist role system is more problematic. It is an ideological system and can be analysed as such whatever its practical functioning: it is this approach that the present-day anthropologist is bound to adopt. The content of the role categories can be drawn from the specialist individual roles existing in present-day society - there are dancers, chanters and shamans - and from idealized descriptions of the other roles of chief, warrior and servant. However, speculation about the past is inevitable (1979, p. 27-28, itálico meu).

A teoria dos papéis especializados de Christine Hugh-Jones sustenta que os Barasana estão arranjados em grupos exogâmicos simples, isto é, um conjunto de cinco sibs ordenados segundo uma escala hierárquica baseada na ordem de senioridade: chefe, cantor/dançador, guerreiro, xamã e servo. Contudo, ao apresentar em detalhes esse sistema, Christine é levada a considerar os papéis especializados em termos individuais:

First of all, the ideal behaviour associated with the roles must be presented in more detail. The difficulty with this, as suggested before, is that sib roles barely function at all at a practical level and therefore I am obliged to present a system, which above all applies to specialist groups, in terms of individual specialist roles (1979, p. 54, itálico meu).

Desses cinco papéis, a autora encontrou apenas três: xamã, cantor e dançador (sendo que cantor e dançador pertencem à mesma categoria). Os outros três papéis (chefe, guerreiro e servo) foram descritos a partir de fontes indiretas, implicando as já citadas especulações sobre o passado (1979, p. 54).

Por fim, Christine Hugh-Jones observa mais algumas particularidades do sistema em relação ao modo como devia ser no passado. Primeiro, em geral, "the specialist roles essential to a functioning of present-day society are performed in an individual capacity. Individual 
specialists are not confined to sibs of the same speciality" (1979, p. 28). Assim, a posse de um papel ritual não impede o indivíduo de possuir outro, e "for any specialist role there are degrees of competence and recognition" (1979, p. 28).

Christine Hugh-Jones chama esse sistema de "estrutura hierárquica" e isso acontece porque

the set of specialist roles are associated with the "hierarchical" birth order of the occupant siblings (groups or individuals). The birth order of these siblings may be understood as a political order, with the older sibling always having the superior power but, when we look at the specialist roles in isolation from sibling relations, it seems that this political order is only reflected in the outer roles of chief and servant. The position of these roles gives the entire set the appearance of a hierarchical order but, in fact, there is nothing obvious in the intrinsic nature of the middle three roles (dancer/chanter, warrior and shaman) to suggest why they should occur in this particular order $(1979$, p. 65 , itálico meu).

Aqui, para explicar a ordem hierárquica da sequência xamã, guerreiro, cantor/dançador (ordem crescente), Christine Hugh-Jones apresenta duas hipóteses (relacionadas): a primeira, uma hierarquia derivada da associação do conjunto de papéis com a ordem de nascimento (do primogênito ao último a nascer); isto é, "the first treats the set of roles as analogous to five stages in the passage of an individual male through a single descent-group generation” (1979, p. 75). Para essa primeira explicação, Hugh-Jones explora as seguintes analogias: servo/criança, xamã/iniciado, guerreiro/homem na fase do casamento, dançador-cantor/homem casado (fase da procriação), chefe/homem casado (fase do crescimento dos filhos) (1979, p. 65 e ss.).

A segunda hipótese consiste em afirmar uma organização bilateral simétrica baseada nas inter-relações de três domínios: o chefe e servo inserem-se no domínio políticoeconômico; o dançador/cantor e o xamã no domínio metafísico; e o guerreiro no domínio orientado para as relações com o fora, o que é externo à sociedade barasana. Assim, Christine Hugh-Jones "treats the set of roles as a model for relating the internal functioning of Exogamous Groups to the range of modes of communication with outside groups" (1979, p. 75). Essa segunda explicação mostra que todos os papéis especialistas são duais, isto é, possuem um aspecto externo e outro interno. Nessa explicação, do ponto de vista das relações com o exterior, teríamos o seguinte quadro (em ordem crescente de relação com o exterior): 
servos (sem nenhum contato com o exterior), xamã (responsável pelas agressões metafísicas aos outros grupos), guerreiro (agressão física direta aos outros grupos), dançador/cantor (contato semi-amigável, ambíguo), chefe (organiza e inicia todos os diferentes modos de contato) (ibid., p. 69 e ss.).

Eis, portanto, o modelo em seus traços essenciais. Voltemos aos Kubeo. Com efeito, Goldman tentou olhar os dados Hehénewa a partir da figura dos papéis especialistas. Tal como Christine Hugh-jones para os Barasana, não encontrou mais que fragmentos de tal sistema. Com efeito, Goldman $(1993 ; 2004)$ sistematiza as modalidades de relações ditas hierárquicas em três categorias: a) sistema de três classes: sênior, júnior e servos; b) sistema diádico de relações de parentesco (pai/filho; avô/neto; tio/sobrinho); e por fim, c) uma série ordenada de posições rituais que, nos termos desse antropólogo, embora não mais operativas, ainda são lembradas (1993, p. 146): chefes, líderes rituais, xamãs, guerreiros e servos ${ }^{89}$. Segundo Goldman, "it is unfortunate (for scholars only) that what appears to have been the most elaborate expression of hierarchy - namely, the organization of ritual ranks, or, as they have been called, 'specialist roles' (Hugh-Jones 1979) - no longer exists anywhere in the Vaupés" (1993, p. 148). Assim, Goldman compartilha da tese segundo a qual estaríamos diante de um sistema do qual restam apenas "fragmentos", isto é, "only a skeletal infrastructure of hierarchical relations now sustains what had been a total system. Cubeo recall the existence of the former system and so do the Barasana of the Río Pirá-Paraná" (1993, p. 148). Portanto, "neither the Cubeo nor the Barasana authorities could describe in substantial detail how the older system worked. But we can reconstruct it from proffered recollections, from the remaining forms of these ranks as they are today, and ultimately from our perception of the whole structure of rank that originally contained these ranks" (1993, p. 149). Voltemos aos meus dados e minha interlocução com os Yuremawa e Yúriwawa.

Em muitas oportunidades tive conversas sobre relações pretéritas entre grupos e possíveis especialidades. Algo que ouvi com certa frequência eram os relatos de guerra e a afirmação de que os Yuremawa e Yúriwawa eram guerreiros. O próprio nome do rio Querari, Kurá Huriya, que pode ser traduzido como "rio de sangue", remete à ideia de putrefação, apodrecimento, o que se refere aos cadáveres de guerreiros resultantes dos enfrentamentos no passado entre Kubeo e Tukano. Como especulação, poderíamos nos perguntar se tais falas do

\footnotetext{
${ }^{89}$ Curioso notar que a ordem apresentada por Goldman (1993) para os Cubeo difere daquela de Christine HughJones para os Barasana (1979) quanto à posição do xamã: em Goldman ele vem antes da posição de guerreiro, em Christine vem depois; lembremos que a própria autora já destacava que no caso da ordem desses papéis não é possível ter certeza sobre qual é maior ou menor.
} 
passado guerreiro desses grupos não poderiam ser ligadas à função guerreiro no sistema de Christine Hugh-Jones. Contudo, não tenho condições de desenvolver tal hipótese, fiquemos apenas com a sugestão.

Como a teoria dos papéis especialistas formulada por Christine Hugh-Jones e recuperada por Goldman para os dados kubeo se articula com os nomes? Muitos Yuremawa e Yúriwawa compartilham a ideia de que a atribuição de um nome afeta a pessoa, no sentido de propiciar o desenvolvimento de certas habilidades ou capacidades. Assim, alguém pode receber o nome de um poderoso pajé ou conhecedor, como o nome Kapai, por exemplo, na expectativa de que tal pessoa venha a ser um grande conhecedor. Pode-se receber, para citar mais um exemplo, o nome Piađa, mestre de surra durante o Jurupari, para que a pessoa venha a ser um habilidoso mestre de surras. Tal ideia não é formulada apenas pelos Yuremawa e Yúriwawa. Encontramos uma afirmação desse aspecto constituinte do nome nas análises de Flora Cabalzar do material tuyuka.

Com efeito, em conversa com Mandu, interlocutor tuyuka, Flora Cabalzar (2010) reproduz fala onde esse conhecedor explica como se dá a escolha do "nome de benzimento" a partir da expectativa do que a criança pode vir a ser:

Ele por meio da reza pensava, será que esse menino pode ser baya ou rezador? Concentrava e, se desse bem, rezava para ser baya.

O benzedor já sentia por meio da concentração na reza.

Para a menina a mesma coisa, será que ela vai ser yarige pako totalmente?

Se não desse certo, ele já rezava só um pouquinho.

Uma pessoa que não é tanto baya, ou tanto mãe dos alimentos...

Enquanto para ser baya mesmo, como vemos a pessoa dançando com todos aqueles adornos, mapua, ukaro, yutaro, kamoka, fazem o enfeite totalmente.

Assim é feito para ser baya, já com aquela dança.

Desde pequeno já tinha todos os enfeites completos.

Assim a criança é feita por meio da reza. 
Se a mãe dele não cuidar direito, os adornos dele vão molhar, estragar, tudo.

E a criança já vai ter doenças (wisire) e vai acabar morrendo. Era assim.

Para ser bom trabalhador, tem benzimento sim,

mas é diferente do benzimento para ser baya.

Ao invés de colocar adornos na cabeça,

já dão seus instrumentos de trabalho, como se já fosse trabalhar.

Dá o machado e o terçado para trabalhar (não para brigar).

Hoje pode também benzer para ser bom estudante.

Hoje em dia que é mais preciso agora, pode benzer também,

dão como se um aluno estivesse estudando,

dão um livro, lapiseira, todo tipo de lapiseira, cadernos.

Dão para ele, para ele pensar em estudar.

Se o cara fizer assim, ele não vai esquecer nada o negócio de livro, todo o tempo vai se lembrar de estudar com livro.

Bom, tem que rezar também quando ele está pequeno, os alimentos. (CABALZAR, 2010, p. 174-175, sublinhado meu).

Vemos, portanto, o nome produzindo pessoa; "a criança é feita por meio da reza", diz o interlocutor tuyuka de Flora Cabalzar. Devemos lembrar que, apesar de seu papel central, uma vez atribuído o nome, outras práticas devem ser observadas ao longo da vida para a produção da pessoa, como já esclarecido anteriormente, quando falamos dos cuidados que cercam o recém-nascido e a criança, ou seja, a atribuição de nome (pupui amiya) é constitutivo central da pessoa, mas não suficiente, outros elementos e cuidados são necessários.

Avançando nessa análise comparativa encontramos referência a essa capacidade do nome de benzimento atribuído afetar o que a criança virá a ser, ou os atributos e qualidades que ela virá a ter, na análise do material tukano feita por Rivelino Barreto. Com efeito, esse antropólogo nos diz:

Em prática, toda criança indígena, do noroeste amazônico, ao nascer recebe um nome do "benzimento de coração" (heripõra barséke), nesse caso as 
nominações dependem de cada etnia. No caso dos tukanos (as) (falante da língua) os nomes são: (homens) Dóe, Yuúpuri, Buú, Yeparã, Arkuto, tremiri, Seribihi, Sué, Wersemi... (mulheres) Pinroduhigo, Duhigo, Yepário, Diatho, Yusío... E são nomes hierarquizados, ou seja, são uma sequência de nomes se estabelecendo de irmãos maiores para irmãos menores, a princípio os irmãos menores não podem obter nomes de direito dos irmãos maiores. Lembrando que os nomes que apresentamos não estão em ordem, mas apenas para mostrar os nomes e esclarecer mais a questão. Em outras palavras, no dia em que o kumu benze "coração da criança" a criança recebe o nome que o kumu revela, e tradicionalmente era nesse dia que também acontecia a revelação que aquela criança seria futuramente, isso com inspiração do benzimento realizado pelo kumu. Mas complementando essa questão e trazendo exemplarmente os nomes em destaque, Dóe, por exemplo, tinha como função (vocação) a de ser chefe da maloca, e precisamente era um grande kumu, enquanto que Yuúpuri é o magnata de Uúkunse; Buú, por sua vez, é o mestre de música e muitas vezes também um grande kumu, enquanto que Yeparã se destaca como Yaí (pajé), claro outros nomes também trazem seus destaques de funções e domínios em vários aspectos do conhecimento tukano. Em termos precisos, vamos nos concentrar para dar exemplo mais claro destacando os integrantes tukano do sib Sararó Yuúpuri Búbera Põra de São Domingos Sávio, começando por Eremundo Buú (com isso podemos se estender a várias gerações da ancestralidade do referido sib) que era um magnata kumu. Seus filhos foram Dóe e Yarka Yaí, o primeiro era um renomado chefe da maloca, um kumu, e, portanto, um grande detentor de Uúkunse, enquanto que seu irmão Yarka Yai era um grande Yai (pajé), mas que não se destacava como detentor de Uúkunse. Os filhos de Dóe se chamaram Yuúpuri ( $1^{\circ}$ filho) e Yeparã $\left(2^{\circ}\right.$ filho). O primeiro filho tornou-se um kumu, enquanto que o segundo tornouse kumu (benzedor) e yai (pajé). Seguindo Yeparã. Os filhos de Yeparã (Manoel Kuriano) vamos citar apenas dois, se chamaram Dóe (José Barreto) e Yuúpuri (Luciano Barreto), o primeiro se tornou um grande Bayá (mestre de música) e o segundo se tornou um renomado Кити (benzedor), nesse caso existe desavença. É mais ou menos é esta dinâmica que ocorre seguindo a ordem do "benzimento do coração" da criança indígena, e vale ressaltar que a virtude de uma criança indígena em se tratar do "benzimento do coração" são variantes, portanto, não estão limitados a tornarem-se Yaí, Kити ou Bayá, a capacidade de ser tukano ou ser indígena varia muito, assim por exemplo, um tukano pode estar destinado através do "benzimento do coração" para ser um bom pescador, caçador, trabalhador, mulherengo, brincalhão, isolado, etc. Significa dizer que essa questão também é amplo e complexo, mas possível de ser compreendido (2012, p. 66, nota 29, sublinhado meu).

Vemos Rivelino Barreto afirmar a existência de certa ordem na distribuição dos nomes, "são hierarquizados, ou seja, são uma sequência de nomes se estabelecendo de irmãos maiores para irmãos menores". Tal afirmação coincide com o modo como Luiz Gilberto descreve os pupui amiya kubeo, os quais, como vimos, remeteriam a determinadas posições numa escala de irmão maior e menor, posições essas assentadas numa espécie de distribuição 
de potência ou "força" do nome. O nome, para Rivelino, tal como vimos no material Tuyuka analisado por Flora Cabalzar, faz a pessoa.

Contudo, apesar desse papel na produção de pessoas e capacidades e habilidades, a constatação geral nos dias de hoje, frequentemente enunciada pelos Yuremawa e Yúriwawa, parece ser que tal dimensão da atribuição dos nomes não é mais levada à sério pelas atuais gerações de modo geral. Aqui, vale lembrar que também entre os Tuyuka Flora Cabalzar notou algo semelhante no que diz respeito ao cálculo envolvido na escolha do nome a ser atribuído, implicando, nos termos da autora, em "reajustes cosmopolíticos":

Dentre tantas mudanças que os índios citam ao falar destes seus saberes ou cultura (entre "saberes maiores que ainda temos e aquilo que já perdemos"), uma segunda motivação deste capítulo é a idéia corrente entre alguns conhecedores, de que os benzedores de hoje, em comum acordo com as famílias, pais das crianças, têm preferido não mais fazer o benzimento da alma-nome da criança recém-nascida impregnando-a com intençãopensamento de ser e tornar-se grande conhecedor (como baya ou dançador, basegu ou benzedor, yuamu ou entoador cerimônia (também wederige higu); básegu ou protetor de doenças da Casa em Festa). Desse modo, dizem evitar os grandes riscos que se corre quando se possui saberes maiores sem, entretanto, dar seguimento ao conjunto de restrições associadas à sua produção, manutenção e incrementação. Agências nesse sentido, de reajustes na composição das almas, pensamentos, nomes, corpos, são aqui entendidas como reajustes cosmopolíticos no âmbito da hierarquia $e$ fabricação do corpo (CABALZAR, 2010, p. 80, itálico meu).

Se o pupui amiya produz pessoa, podemos avançar e sustentar que ele produz também a pessoa Yuremawa ou Yúriwawa, o que nos remete ao tema da patrilinearidade. Com efeito, segundo certa imagem tradicional da patrilinearidade os nomes dos ancestrais e o pertencimento ao grupo passam por linha paterna. Como formula Stephen Hugh-Jones (2002) a partir da análise do material tukano, os nomes constituem a essência imortal do clã, ao lado do sêmen do pai, responsável pelos ossos da pessoa, que carregariam capacidades subjetivas e espirituais; a atribuição de nome e a procriação constituem, portanto, aspectos da construção da pessoa como membro de um clã. Mas em meu trabalho com os Kubeo encontrei alguns casos de filhos de pais brancos que moram com mãe kubeo, e são considerados como Yuremawa ou Yúriwawa por terem recebido pupui amiya, em geral dado pelo avô materno. Há muitos casos também de filhos que não recebem o nome do pai, seja porque o mesmo 
faleceu, ou porque não foi reconhecido ou criado pelo pai. Contudo, o caso mais comum é aquele de filho de mulher indígena com homem branco.

Segundo Luiz Gilberto, quando uma mulher indígena tem filho com branco, o "nome de benzimento" é dado pelo avô materno, mas isso não é o "correto". Esse nome não tem a mesma "energia", para usar o termo de Luiz Gilberto, ou "potência", como vimos pensando a partir de sugestão de Lolli (2010), que tem o nome dado pelo avô de pai indígena; é antes uma “imitação", uma “cópia”, não é “original”. Esse é um assunto delicado, em geral envolve relações extra-conjugais, relações sobretudo com militares, que muitas vezes deixam a mãe sozinha etc. Mas cito um caso envolvendo tal tema, que penso não afetar negativamente meus interlocutores, e fundamenta o argumento que estou avançando aqui. Segue um diagrama que comentarei a seguir.

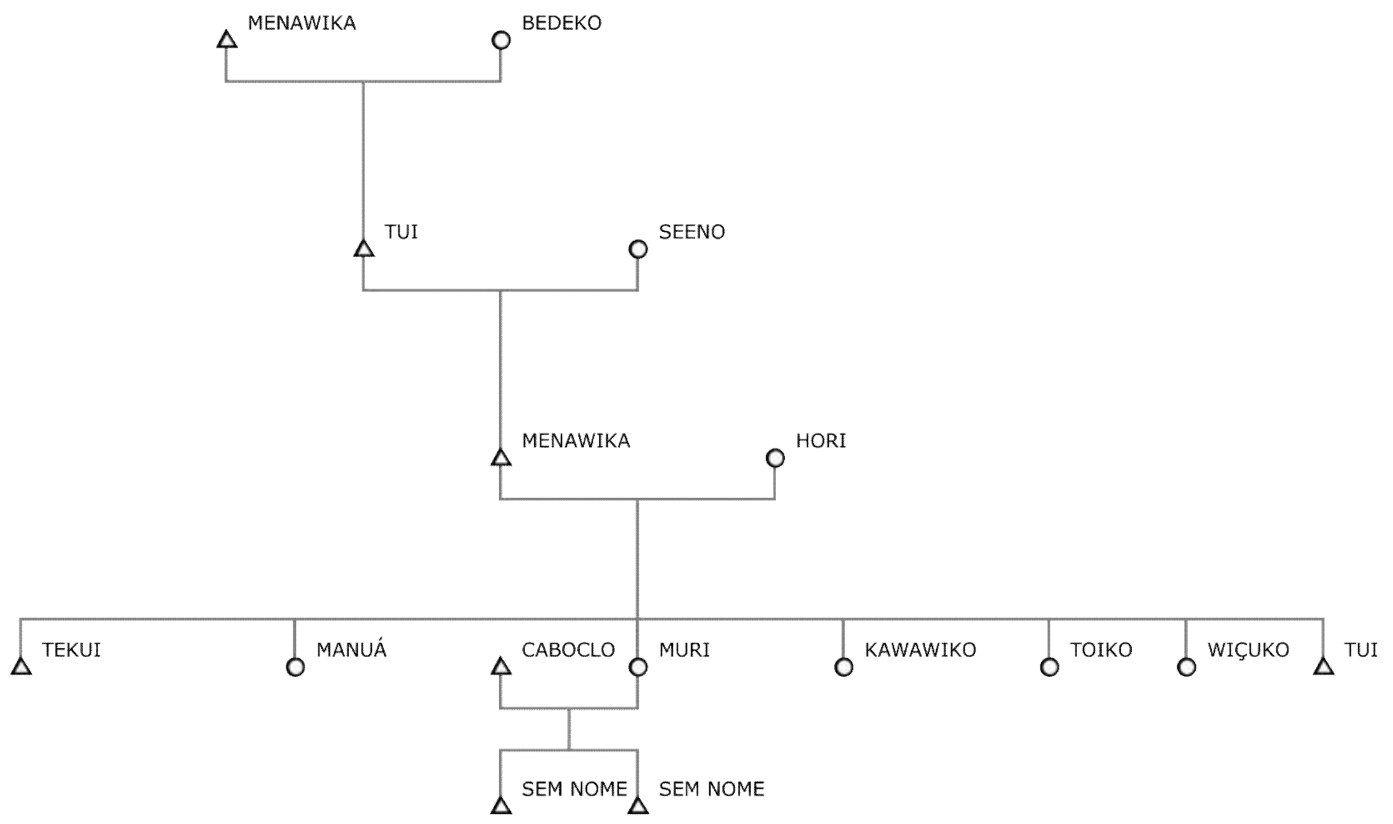

A terceira filha de Francisco (Menawika), Franciane (Muri), casou-se com um soldado proveniente de São Gabriel da Cachoeira, que prestava serviço temporário no PEF de Querari. Desse casamento tiveram dois filhos. Quando conversei com Francisco a respeito do pupui amiya dos filhos, ele me disse, em tom de brincadeira, "eles são filhos de caboclo, pai 
misturado"; e afirmou que as crianças seriam "consideradas" como Kubeo e, embora ainda não tivessem recebido pupui amiya, estava certo que seu pai e avô das crianças, o velho Henrique, daria os nomes.

Aqui, parece se confirmar a tese enunciada por Andrello (2014) segundo a qual "o caráter patri dos clãs não é assegurado automaticamente com a concepção ou o nascimento. Não se trata de um dado a priori, mas de uma qualidade propiciada por um processo de reciclagem de nomes ancestrais". Eis, portanto, que o nome, além de produzir qualidades/capacidades/habilidades, também faz da pessoa um(a) yuremaku/yuremakó, ou yuriwaku/yuriwakó.

Aqui, vale insistir novamente na comparação com outros materiais. Encontramos formulação próxima a de Andrello em Rivelino Barreto, que nos diz:

\begin{abstract}
Em outras palavras, é a descrição de uma linha de pensamento patrilinear, no caso a linha não é uma linha de sangue, não é uma linha de filiação nos termos dos antropólogos, é uma linha de barsesé, heripora barsesé; sendo que a vigência da patrilinearidade no noroeste amazônico não se condimenta como linha de sangue, mas sim da linha de fala, de nome $(2012$, p. 62, sublinhado meu).
\end{abstract}

Portanto, não estaríamos diante de "linhas de sangue" ou transmissão de substância, mas antes, na precisa formulação de Rivelino, "linhas de fala, de nome”. A expressão usada por Rivelino não poderia ser mais apropriada se lembrarmos da associação kubeo entre pupui amiya, língua e umé; ao se dar nome, atribui-se ("estabiliza-se", lembremos novamente de Goldman, 2004, p. 349) umé, a pessoa passa a compartilhar da "energia" ou "vitalidade" (nas traduções oferecidas por Luiz Gilberto para umé) do grupo, "energia" essa que do ponto de vista metafísico, segundo Goldman (2004, p. 345 e ss.), faz o grupo.

O pupui amiya se insere, portanto, num complexo de práticas e cuidados relacionados à produção da pessoa e manejo do umé que incluem variadas restrições - sobretudo alimentares -, participação em "ritualizações" (Jurupari), conhecimento das narrativas e dos benzimentos (pupuiye). 


\section{CAPÍTULO 5 - OS NOMES ESCRITOS: EQUÍVOCOS CONTROLADOS?}

Lévi-Strauss, em Tristes Tropiques (1955), ao falar de seu encontro com os Nambikwara e as dificuldades com a pesquisa, destaca, entre outras, aquelas que dizem respeito a questões de ordem linguística. Assim:

Si faciles que fussent les Nambikwara - indifférents à la présence de l'ethnographe, à son carnet de notes et à son appareil photographique - le travail se trouvait compliqué pour des raisons linguistiques. D'abord, l'emploi des noms propres est chez eux interdit; pour identifier les personnes, il fallait suivre l'usage des gens de la ligne, c'est-à-dire convenir avec les indigènes des noms d'emprunt par lesquels on les désignerait (1955, p. 326, itálico meu).

O esforço de Lévi-Strauss para arrolar os "nomes próprios” nambikwara apenas contornou essa interdição graças às circunstâncias que o autor descreve da seguinte maneira:

Un jour que je jouais avec un groupe d'enfants, une des fillettes fut frappée par une camarade; elle vint se réfugier auprès de moi, et se mit, en grand mystère, à me murmurer quelque chose à l'oreille, que je ne compris pas et que je fus obligé de lui faire répéter à plusieurs reprises, si bien que l'adversaire découvrit le manège, et, manifestement furieuse, arriva à son tour pour livrer ce qui parut être un secret solennel: après quelques hésitations et questions, l'interprétation de l'incident ne laissa pas de doute. La première fillette était venue, par vengeance, me donner le nom de son ennemie, et quand celle-ci s'en aperçut, elle communiqua le nom de l'autre en guise de représailles. A partir de ce moment, il fut très facile, bien que peux scrupuleux, d'exciter les enfants les uns contre les autres, et d'obtenir tous leurs noms. Après quoi, une petite complicité ainsi créée, ils me donnèrent, sans trop de difficulté, les noms des adultes. Lorsque ceux-ci comprirent nos conciliabules, les enfants furent réprimandés, et la source de mes informations tarie (1955, p. 326).

Os usos dos nomes nambiquara observavam rígidas restrições. Dada essa interdição, Lévi-Strauss apenas consegue obter alguns nomes junto às crianças, ainda que por meios, como o próprio antropólogo reconhece, pouco escrupulosos, beneficiando-se de uma situação de conflito. Recupero essa passagem de Lévi-Strauss apenas para colocar uma questão que desponta aos olhos de observadores atentos às práticas atuais de uso do nome de benzimento no alto rio Negro: os nomes de benzimento, afirmados na literatura regional como nomes de uso e conhecimento restrito tal como os nomes nabikwara, parecem ser manejados atualmente de outras maneiras. 
Hoje parece verificar-se um cuidado em tudo oposto com os nomes de benzimento, pois são encontrados em e-mail, capa de livros, são referenciados no batismo católico, estão presentes em documentos pessoais, nos registros da escola e universidade, e dos serviços de saúde. O que podemos depreender desse novo contexto que se nos apresenta? O que dizem os Yuremawa e Yúriwawa acerca desses novos registros e usos dos nomes de benzimento ${ }^{90}$

Não apenas os nomes de benzimento eram apontados como de uso restrito, também os termos de parentesco usados para se dirigir a alguém ou falar de alguém. Lembremos um caso contado por Janet Chernela logo na introdução de seu livro sobre os Wanano, em que comenta suas dificuldades ao registrar os usos de termos de parentesco entre os Wanano na comunidade de $W a p u$, no rio Uaupés. Conta a antropóloga:

My interest in the phenomenon of ranking was heightened by an incident that occurred early in my fieldwork. On arriving at the Wanano village of Wapu in 1978, I began to elicit terms of address in order to make sense of the relations among the 160 people in the village. I assumed that the terms themselves, such as "my father", would be neutral and public, even as they provided a key to the familial relationships of the members of the village. I had imagined this to be a sensible course and that my inquiry would be regarded as courteous and nonintrusive (1993, p. xi).

Após algum tempo observando os usos dos termos de parentesco, Chernela chega à seguinte conclusão:

I soon learned that address is the form of speech that carries information regarding status position. Individuals in a Wanano village are ranked, with no two individuals occupying the same position. In any dyad, one person is always the senior and the other the junior, indicated in speech by metaphors of relative age. These status positions are based upon inheritance from father to offspring. While thinking that I was making an innocent inquiry, I had unwittingly placed one family in a somewhat humiliating position. I later learned they were from a lower-ranked sib than the other villagers (1993, p. xii, itálico meu).

Contudo, os termos de parentesco também sofrem inflexões com o uso disseminado do português que se verifica atualmente nas comunidades kubeo, sobretudo em Querari.

\footnotetext{
90 Importante esclarecer: não trato aqui do tema da escrita e suas formas de modo geral, mas de um uso particular do nome de benzimento: seu registro em documentos. Interessa pensar as implicações de se ter o nome de benzimento registrado em documento do governo, visível para um amplo conjunto de pessoas, portanto.
} 
Assim, antes de analisar a escrita dos nomes de benzimento, vejamos brevemente ${ }^{91}$ os termos de parentesco comumente usados entre os Kubeo, termos esses apontados por Chernela e também Goldman como de uso restritivo.

\section{Os termos de parentesco}

A criança recebe, como vimos, dois nomes: nome de branco e pupui amiya ("nomes de benzimento"); além desses, o homem adulto recebe também apelidos. Também os termos de parentesco são muito usados nas conversações feitas em língua kubeo. Desenvolverei o tema dos apelidos no próximo capítulo. Aqui, faço algumas considerações sobre os usos dos termos de parentesco.

Goldman (2004, p. 114) já dizia que os termos de parentesco são um dos "modos de nomeação". O uso de tais termos não é desprovido de implicações. O mesmo autor afirmou que "The Cubeo are very sensitive to terms of address and so they use terms not merely to designate a precise degree of relationship, but diplomatically, to create a mood of closeness or of distance" (1963, p. 114). Assim, segundo esse antropólogo:

The use of European personal names offers another example of adaptation to the native cultural pattern. Among the Cubeo, personal names come from the traditional genealogy of the sib. They have a sacred character and are not used freely. Knowing a person's sib name is a sign of intimacy and such intimacy is not readily yielded up. [...] In common discourse kinship designations were used. The native name is not so much an appellation as it is sib identification [...]. (GOLDMAN, 1963, p. 19-20, itálico meu).

Com efeito, parece ser comum o uso de termos de parentesco no dia a dia, seguido de nomes de branco e apelidos. Os pupui amiya não são evocados. Vejamos alguns desses termos.

Os Kubeo usam os seguintes termos de parentesco vocativos:

\footnotetext{
${ }^{91}$ Digo "brevemente" pois, como sabemos, o parentesco é um dos domínios da antropologia cuja complexidade demandaria uma atenção especial para um tratamento adequado e que faça jus a literatura acumulada sobre o tema pela etnologia regional. Além disso, meu pouco conhecimento da língua durante os trabalhos de campo implicou poucos dados sobre o tema, o que não permite no momento uma elaboração mais aprofundada do assunto. Fica aqui uma exposição não exaustiva e inicial, de alguns usos que observei, e que, contudo, penso ser suficientes para avançar as hipóteses que se seguirão.
} 


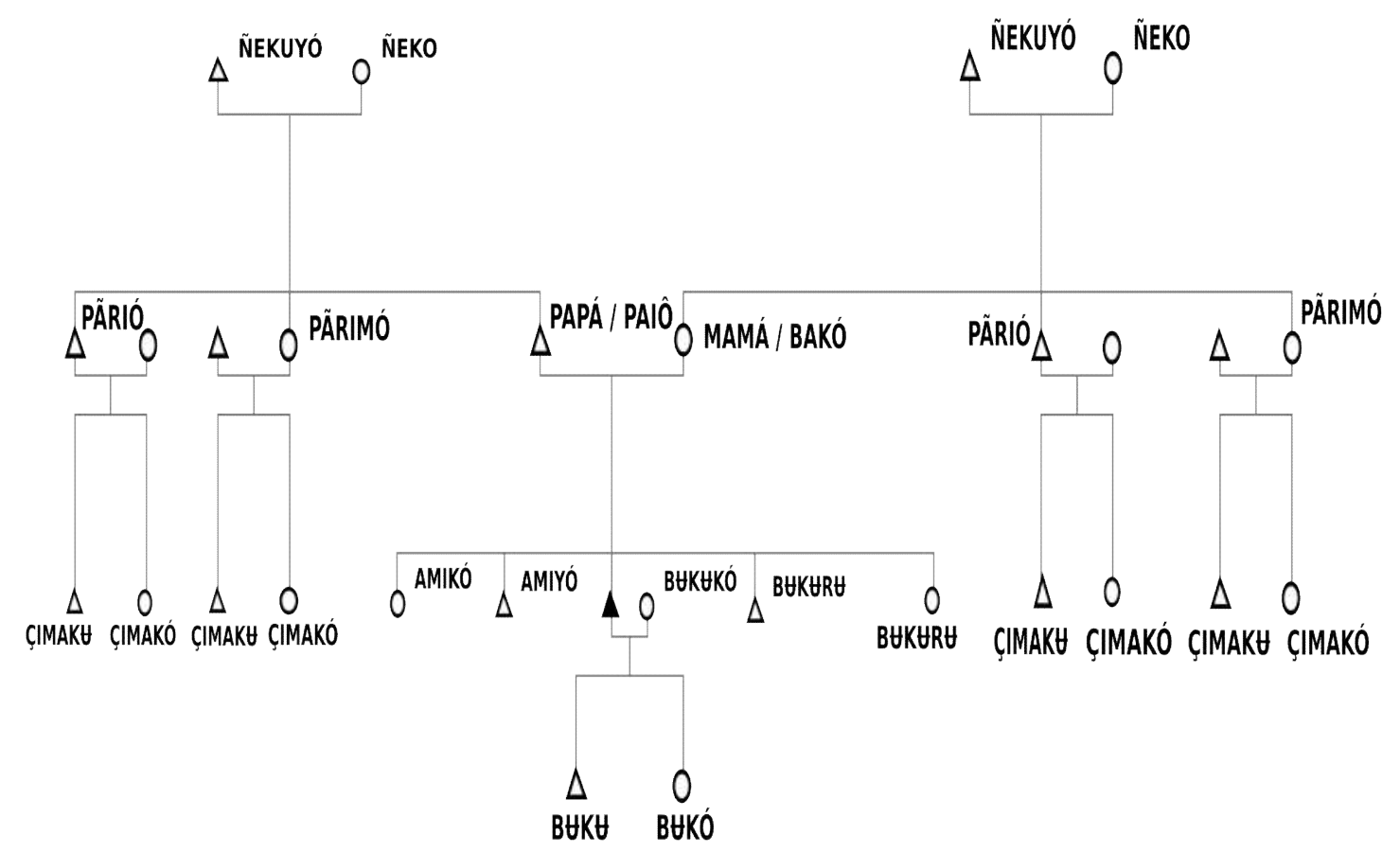

Algo para o qual chamo a atenção nesse diagrama é o uso que se faz do mesmo termo bukuru para irmão e irmã menor, sem distinção, ao passo que se distingue irmão e irmã maior $^{92}$. Uma expressão comum é ouvir alguém se referir a seus irmãos menores com o cumprimento: "aru bukurt" ("olá irmãos [menores]"). O marido pode usar com a esposa o vocativo bukukó (hapiakó na língua original ${ }^{93}$ ), termo que pode ser traduzido como "mulher", mas também tem o sentido de "velha"; a esposa dirige-se ao marido como bukuku (hapiaku na língua original).

No caso dos termos referenciais, notamos o seguinte para os irmãos:

Himamiku: meu irmão maior

Hiokt: meu irmão menor

Himamikó: minha irmã maior

\footnotetext{
${ }^{92} \mathrm{O}$ par irmão maior/irmão menor, lembremos, é central nas formulações kubeo acerca das relações sociais, e dos povos rionegrinos de modo geral. É uma díade manejada em variadas escalas: familiar, entre famílias, entre grupos etc. como discutido no segundo capítulo. Também em meu mestrado (PEDROSO, 2013) explorei os usos e sentidos de tais noções.

${ }^{93}$ Como já explicitado, os Yúri Parãmena afirmam que sua língua de origem é diferente da língua kubeo, falada atualmente. Contudo, embora perdida, muitos dos termos dessa língua ainda se fazem presentes nos pupui amiya, também em trechos de benzimentos e nos termos de parentesco. Nas conversações em campo não consegui um levantamento exaustivo dos termos na "língua de origem", o que explica o fato de aparecerem no texto as indicações de apenas alguns termos na "língua original".
} 
Hiokó: minha irmã menor

Para relações de afinidade, temos os seguintes termos vocativos:

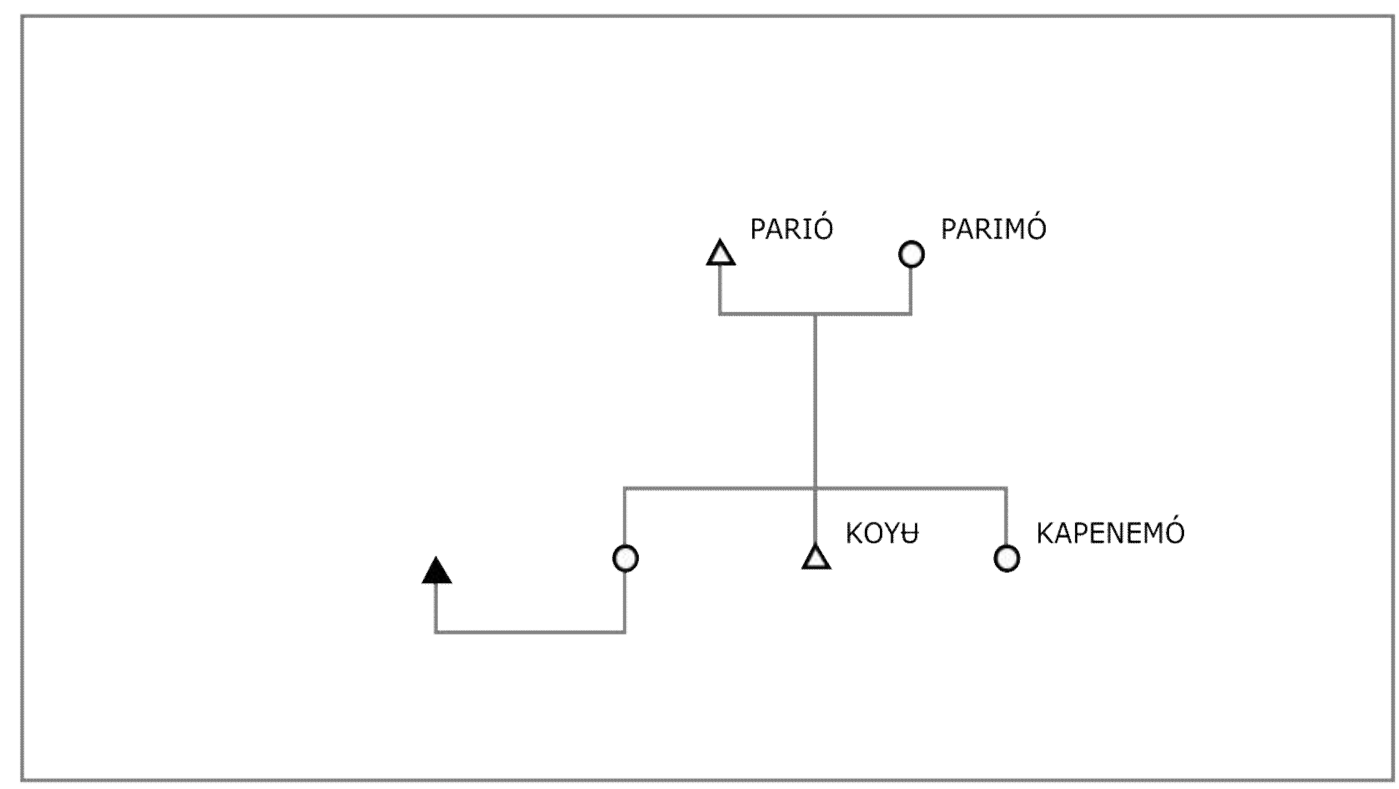

Para referir-se a pessoas de outros grupos com os quais não podem se casar, usam o termo pakomá, que traduzem comumente como "parente" ou também "primo-irmão". Assim, recordo-me de um episódio onde, durante uma festa de caxiri na casa de Martins, eu conversava com o velho José Bernardo (Yúriwawa) de Açaí, sendo que do meu lado também estava José, um velho kotiria de Jutica; em certo momento, José Bernardo se dirigiu a José chamando: "- Pakomá”. Lembremos que, como visto no segundo capítulo, os Yúriwawa não se casam com Kotiria, são "parentes”, o que explica o uso do termo por José Bernardo.

Como vimos em Chernela (1993) e Goldman (2004) os termos de parentesco, dentre as implicações de seus usos, marcam aproximações e distanciamentos. Contudo, tais termos são usados nas conversações que se dão com língua kubeo. Quando se conversa em português, é comum o uso dos nomes de branco como vocativos e referenciais, ou mesmo, em alguns contextos que analisarei no próximo capítulo, de apelidos. Termos de parentesco em português são poucos e parecem desfazer distinções e matizes que os termos em Kubeo projetam, pois perguntemos: como se expressam em português os usos marcados de buktru, amikó e amiyó (vocativos) e himamiku/hioku e himamikó/hiokó (referenciais) quando eles são subsumidos em português nas categorias de “irmão" e “irmã”? As noções de pakomá e çimá 
parecem ser subsumadas no uso de "parente", em sentido amplo, pois o termo pode referir-se a um indígena, qualquer que seja seu grupo; já ouvi, para citar um exemplo, a expressão “meus parentes guarani”. Esse uso dos termos na língua portuguesa merece atenção, dado o contexto linguístico atual nas comunidades kubeo do alto Uaupés.

Querari e Açaí apresentam dois contextos muito diferentes no que diz respeito ao uso da língua. Se em Açaí fala-se cotidianamente o Kubeo, com as crianças aprendendo a língua do pai, em Querari verifica-se uma situação oposta, a saber, fala-se muito pouco o Kubeo, sendo o português a língua dominante. Além do português, o Kotiria é também muito falado entre os Kubeo e entre um Kubeo e um Kotiria ${ }^{94}$, sobretudo na geração mais jovem. Uma consequência do não uso da língua, portanto, é o apagamento das relações implicadas nos usos dos termos de parentesco, algo formulado por alguns Yuremawa e Yúriwawa em falas como "os jovens de hoje não respeitam mais", "ninguém tem mais consideração pelos mais velhos e maiores", “não se sabe mais quem é irmão maior, ou menor, estão perdendo o respeito", falas que remetem a formulação de Luiz Gilberto sobre o "enfraquecimento do grupo"; deixar de falar a língua, segundo esse Yuremawa, implica perder "energia", "força”, potência o que, dentre outras consequências, não faz crescer nem as pessoas nem a comunidade. Feitas essas breves considerações sobre esse "modo de nomeação" (GOLDMAN, 2004, p. 114) que são os termos de parentesco, vejamos outro evento recente na vida dos Yuremawa e Yúriwawa relacionado aos nomes: a escrita do pupui amiya em papel.

\section{Escrevendo o pupui amiya}

Há quatro documentos de identificação pessoal importantes no alto rio Negro: o registro de nascimento, o registro civil ou $\mathrm{RG}$, o $\mathrm{CPF}$ e o registro expedido pela FUNAI, conhecido como Registro Administrativo de Nascimento de Indígena - RANI ${ }^{95}$.

\footnotetext{
${ }^{94}$ Uma análise detalhada da situação sociolinguística Kubeo e Kotiria no alto Uaupés pode ser encontrada no Plano de Gestão Territorial e Ambiental Kubeo e Kotiria (PEDROSO et al., no prelo).

${ }^{95}$ No site da FUNAI, encontramos a seguinte descrição: “O Registro Administrativo de Nascimento de Indígena (RANI) é um documento administrativo fornecido pela FUNAI, instituído pelo Estatuto do Índio, Lei n ${ }^{\circ} 6.001$ de 19 de dezembro de 1973: 'O registro administrativo constituirá, quando couber, documento hábil para proceder ao registro civil do ato correspondente, admitido, na falta deste, como meio subsidiário de prova.' Em outras palavras, o RANI pode servir como documento para solicitar o registro civil. O registro do RANI é realizado em livros próprios por funcionários da FUNAI, e para cada registro é emitido o documento correspondente, devidamente autenticado e assinado". In: http://www.funai.gov.br/index.php/docb/registroadministrativo-de-nascimento-de-indigena-rani (consultado em março de 2019).
} 
Algum tempo após o nascimento da criança na comunidade, os pais viajam até São Gabriel da Cachoeira com o propósito de fazer os documentos dela. Uma especificidade do RANI em relação aos outros documentos é que neste deve constar o dito "nome indígena" da criança, pais e avós. Eis que o conjunto de nomes de benzimento (pupui amiya kubeo) fica então registrado em papel, em documento oficial da FUNAI. Tal fato apresenta questões que merecem consideração, e dizem respeito ao registro propriamente dito dos nomes. Vejamos.

Em alguns momentos em campo, ao perguntar sobre o pupui amiya da pessoa, ou mesmo de seus filhos ou pais, não era raro vê-la consultar o RANI, para "ter certeza" do nome. Algumas vezes a pessoa olhava o RANI e confirmava o nome; outras, apontava que o registro no documento estava com grafia errada, ou tinha sido feito de modo equivocado, "errado", e que seria oportunamente "corrigido". Mas mesmo em alguns casos de nomes confirmados com auxílio do RANI, ao mostrar minha lista para alguns velhos de Querari ou Açaí, os mesmos apontavam um ou outro nome como "errado", seja por não existirem, por serem nomes de outros grupos ou mesmo apelidos. Explicito ao leitor alguns casos de registro "errado" de nomes, para em seguida tentar entender o que está em questão.

Começo com o caso da família de Gustavo, Yuremawa de Querari:

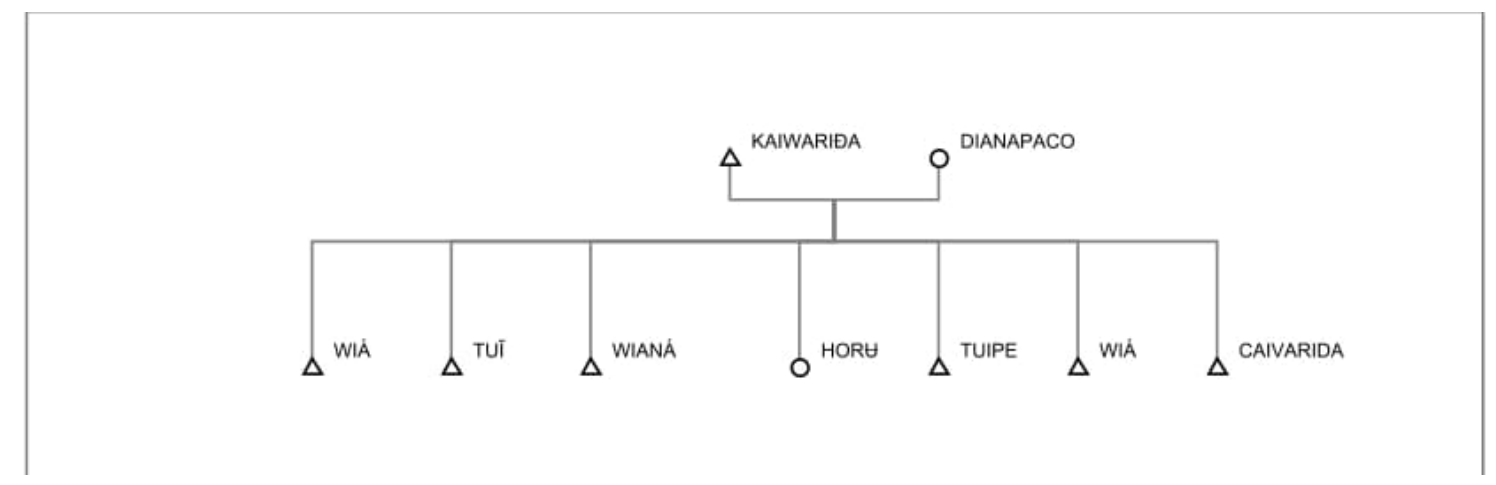

Gustavo é casado com uma mulher kotiria. Após fazer o registro da lista de pupui amiya de sua família, tive certo estranhamento, pois era a primeira que vez que ouvia certos nomes. Motivado por esse estranhamento, e com certo receio de parecer indelicado dirigindo perguntas sobre a correção dos nomes a Gustavo, fui logo em seguida consultar com Martins. De fato, ele apontou que o nome Hort, nome de uma das filhas de Gustavo, era Kotiria; Tuipe, por sua vez, era o nome de uma constelação kubeo, não sendo, portanto, pupui amiya Yuremawa. Notamos também que dois de seus filhos compartilham o mesmo pupui amiya: Wiá (primeiro e sexto filho), e o último filho compartilha o mesmo pupui amiya do pai 
(Kaiwariđa/Caivarida) que, como notamos, foi registrado no RANI com grafias diferentes, algo contrário a ideia, apresentada por, entre outros, José Bernardo, de que o nome deve ser transmitido de avô para neto. Além desse caso de nomes oriundos de outro grupo, que não seriam pupui amiya propriamente, temos os casos dos nomes registrados "errados" - e identificados como tais pelos próprios pais -, para usar o qualificativo que sempre escutava quando se referiam a essas situações. Vejamos o caso a seguir da família de Afonso, Yúriwawa de Açaí:

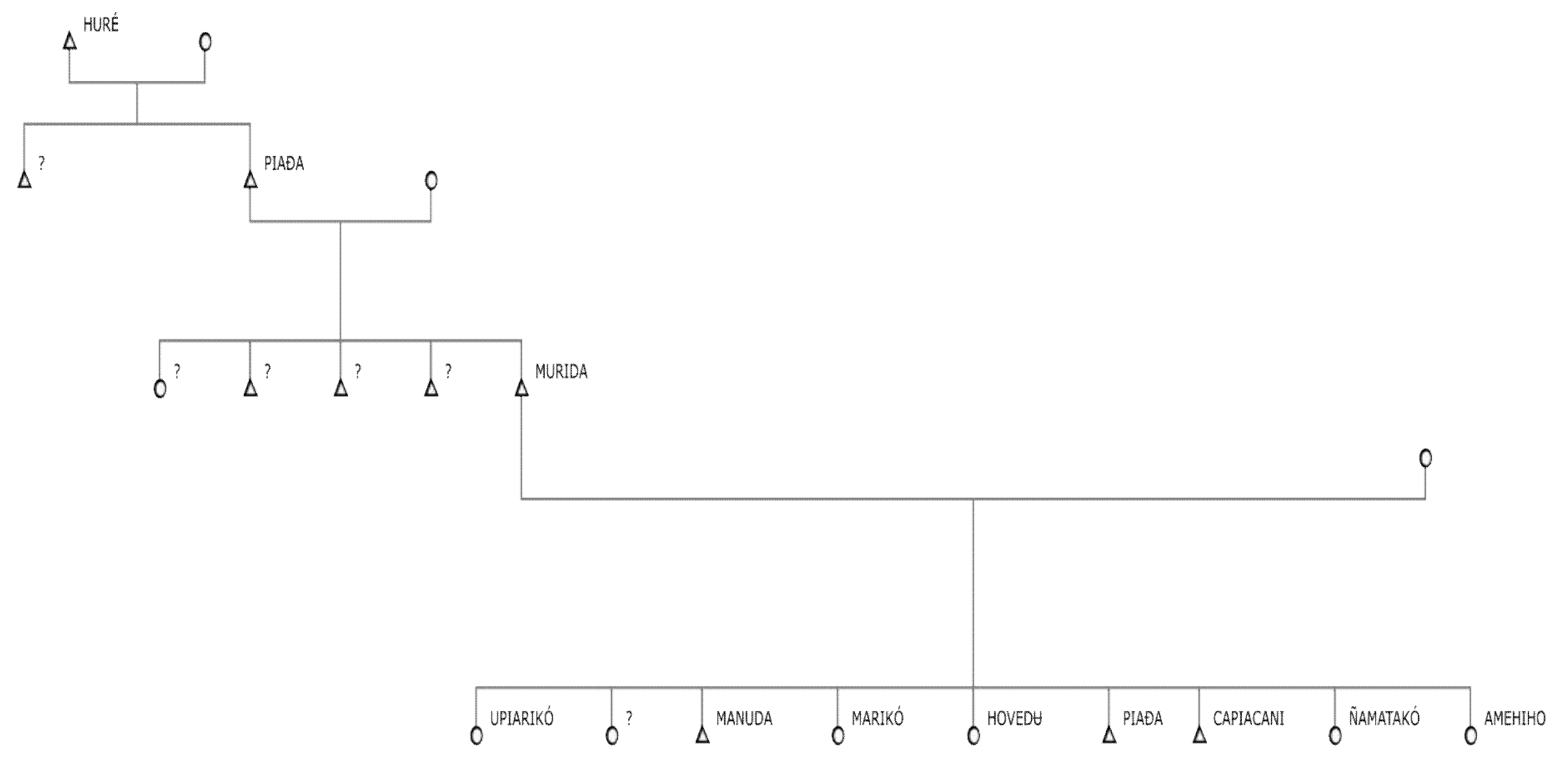

Afonso, Murida, lembrava o pupui amiya de seu pai e avô; contudo, quando perguntado sobre o pupui amiya de seus irmãos ele não lembrava, respondeu de modo evasivo dizendo "tem que perguntar para eles... eu não sei... eles que vão saber". Vale notar que, além dos irmãos, Afonso também não lembrava o pupui amiya de sua segunda filha mais velha, Lindalva, e respondeu com "tem que perguntar para ela; ela tem anotado no RANI, vai saber falar". Para os outros filhos, ele preferiu consultar o RANI de cada um antes de me dizer o pupui amiya, para "não falar errado o nome". Ainda assim, consultando o RANI, identificou alguns nomes como registrados "errados": Hovedt, nome de uma de suas filhas, estava "errado"; o correto seria Howewedt. A sua filha mais nova, que nasceu em 2014, está registrada com o nome Amehiho, quando o correto seria Amehiyo. Afonso apontou o erro e insistiu que o mesmo seria corrigido em momento oportuno. 
Presenciei outras cenas parecidas com essa descrita acima. Meu entendimento de tal situação - a pronta identificação do "erro" e disposição para "corrigir" -, é que se trata de uma forma de evitar possíveis críticas, pois registrar o nome "errado" pode ser considerado pelas pessoas como descuido e desconhecimento das tradições dos Yuremawa e Yúriwawa (no caso descrito se tratava de uma família Yúriwawa), indicativo de que a pessoa "não sabe mais a cultura indígena", como ouvi algumas vezes.

Vejamos outras situações envolvendo pupui amiya e seu registro no RANI.

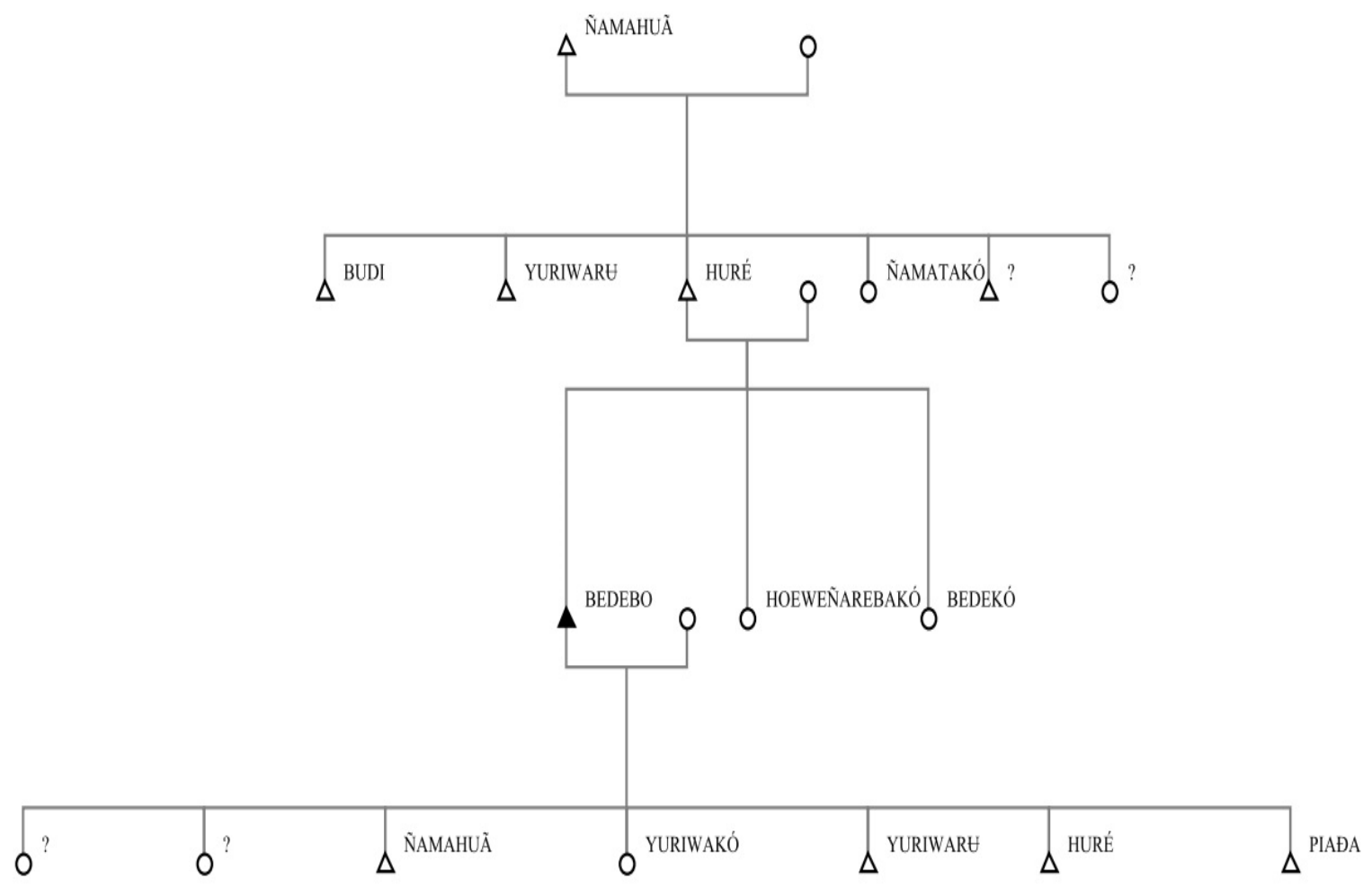

José Bernardo tinha memória dos pupui amiya de suas duas irmãs, e de seus pais e avós, bem como de alguns de seus tios (do total de cinco, lembrava o pupui amiya de três, não lembrando o de Simão e de Célia, tio e tia mais novos). No caso dos filhos, como podemos ver no diagrama acima, não lembrava o nome de Rosa e de Luz Endira, suas duas filhas mais velhas. Tal como Afonso, também respondeu dizendo "tem que perguntar para elas, tem no RANI”. Novamente, vemos a indicação do RANI como fonte para se saber o pupui amiya. 


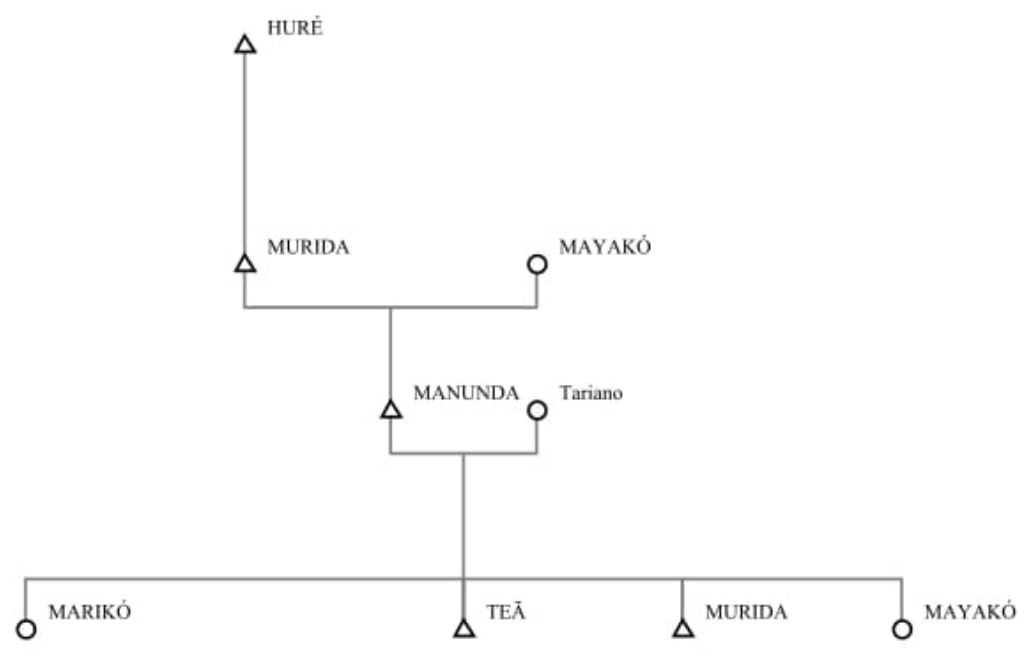

Quando sentei com Luiz - um Yúriwawa respeitado nas comunidades de Querari e Açaí, seja por seu conhecimento das "coisas dos brancos", resultado de anos circulando entre comunidade e cidade, participando de eventos políticos relacionados sobretudo a temas educacionais e a seu cargo de professor em Açaí e Querari, seja por ser considerado "irmão maior" entre os Yúriwawa, e ser filho de um grande conhecedor das práticas e "tradições" yúriwawa, o senhor Jaime - para falar sobre pupui amiya, ouvi que ele tinha certeza apenas sobre o seu pupui amiya e o de seu pai. Falou que seu segundo filho era Teã, e pediu que eu esperasse um tempo para que ele tivesse oportunidade de consultar o velho Jaime e também o RANI de seus filhos para ver o nome de cada um. Passada algumas semanas sem retorno sobre os nomes, decidi consultar o próprio Jaime, que contou o pupui amiya de cada neto. Vale destacar que, ao falar do pupui amiya do terceiro neto, Jaime fez uma pausa, pensou um pouco em silêncio, depois ouvi ele murmurar alguns nomes; percebi então que fazia um cálculo para decidir sobre o nome adequado do neto em questão. Sua resposta foi "vou deixar Murida para ele", que é o mesmo nome de Jaime. Tal cena chamou minha atenção, pois ao que tudo indica o nome foi escolhido no momento em que eu fiz a pergunta, o que explica o fato do próprio Luiz não saber dizer o nome do filho.

Outros dois pontos merecem destaque na análise do diagrama da família de Luiz. Em primeiro lugar, lembremos que para o segundo filho Luiz apontou como tendo por nome Teã, 
que seria o nome registrado no RANI, nome esse corrigido por Jaime, que disse tratar-se de um yahui amiya (apelido), e não pupui amiya. Teã seria o apelido próprio do pupui amiya Huré, que pertencia a Joanico, pai de Jaime, avô de Luiz. Por fim, a filha mais nova tem como pupui amiya Mayakó, o mesmo de sua avó paterna. Mas vale notar que a esposa de Jaime era Yuremakó, então temos um pupui amiya yuremakó atribuído por um avô yuriwaku a sua neta yúriwakó.

Outro caso de dificuldade na hora do registro observei ao levantar os nomes da família de Raimundo, Yúriwawa de Açaí.

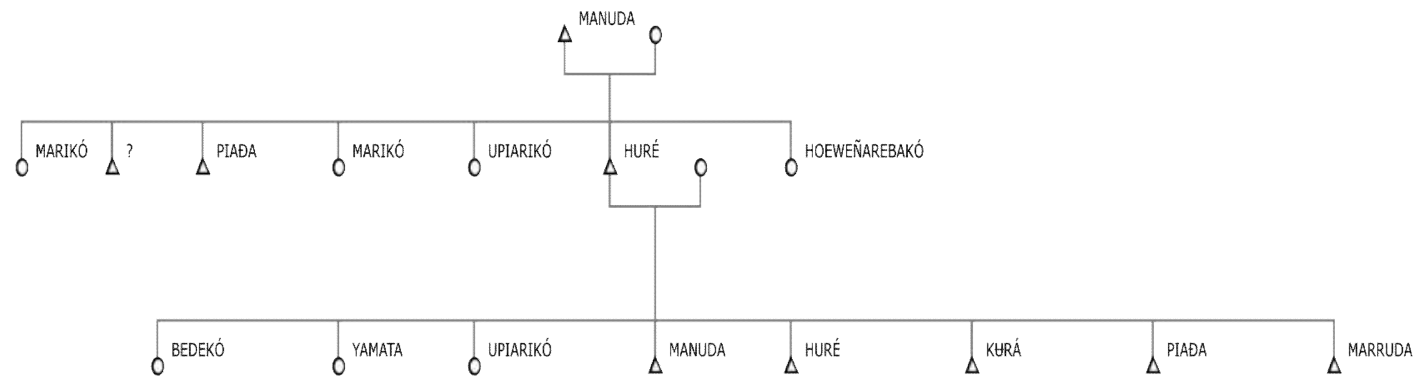

Quando perguntei sobre nomes, Raimundo disse não lembrar o pupui amiya de todos seus filhos (é pai de oito filhos). Para responder minhas perguntas teve que pegar uma pasta onde guardava os documentos da família: registro de nascimento, RG e RANI. Uma vez de posse desses documentos, para cada filho que eu perguntava, ele consultava o RANI e então me dizia qual era o pupui amiya. Destacou que, no caso do último filho, Luan Raimundo, quando foi fazer o registro em São Gabriel da Cachoeira, não tinha certeza do nome; registrou no RANI como Marruda e que o correto seria Manuda, o mesmo nome do avô paterno da criança. Outro ponto que chamou minha atenção: dos seis irmãos de Raimundo, ele não lembrava o nome de apenas um deles; curioso que todos os outros moravam então em São Gabriel da Cachoeira, e Raimundo afirmava não saber justamente o pupui amiya do irmão (Jaime) que então morava em Açaí, ou seja, estava mais próximo. 
Outro caso de registro de pupui amiya que merece atenção: família de Geraldo Edson.

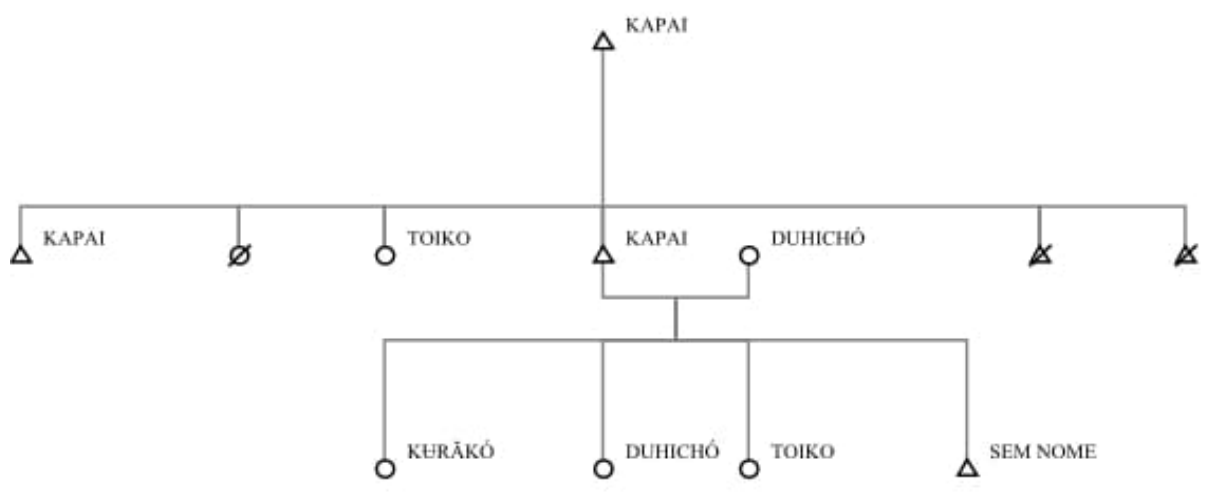

Geraldo Edson, Yuremawa, é casado com Maria, Kotiria de Jutica, no Uaupés. Quando conversei sobre os nomes da família, Geraldo Edson também pegou o RANI de cada um para consultar o pupui amiya registrado. Notamos no diagrama que sua segunda filha está registrada como Duhichó, o mesmo pupui amiya da mãe, nome kotiria portanto. Quando questionei sobre a atribuição de um nome kotiria, Maria explicou que no momento do registro em São Gabriel da Cachoeira estava sozinha, e como não conhecia os nomes kubeo decidiu registrar com nome kotiria. Segundo Geraldo Edson, o nome "correto" de Keila é Ñemikó. O filho mais novo, o pequeno Leonan, no meu último campo em 2017 ainda estava sem nome (contava então 2 anos de idade), e não tinha o RANI. Geraldo Edson comentou que ainda não tinha escolhido o nome da criança, o que deveria ser feito em breve, e que pensava em usar o nome do lado materno (o pai de Geraldo Edson tinha falecido fazia dois anos, vítima de picada de cobra), com o argumento de que era preciso "valorizar o lado da mãe; a gente dá nome do lado do pai sempre, e não valoriza o lado mãe".

Cito mais uma situação de pais que não lembravam o pupui amiya dos filhos, para mostrar que é algo relativamente frequente. É o caso da família de Carlos, Yúriwawa que vive em Querari. 


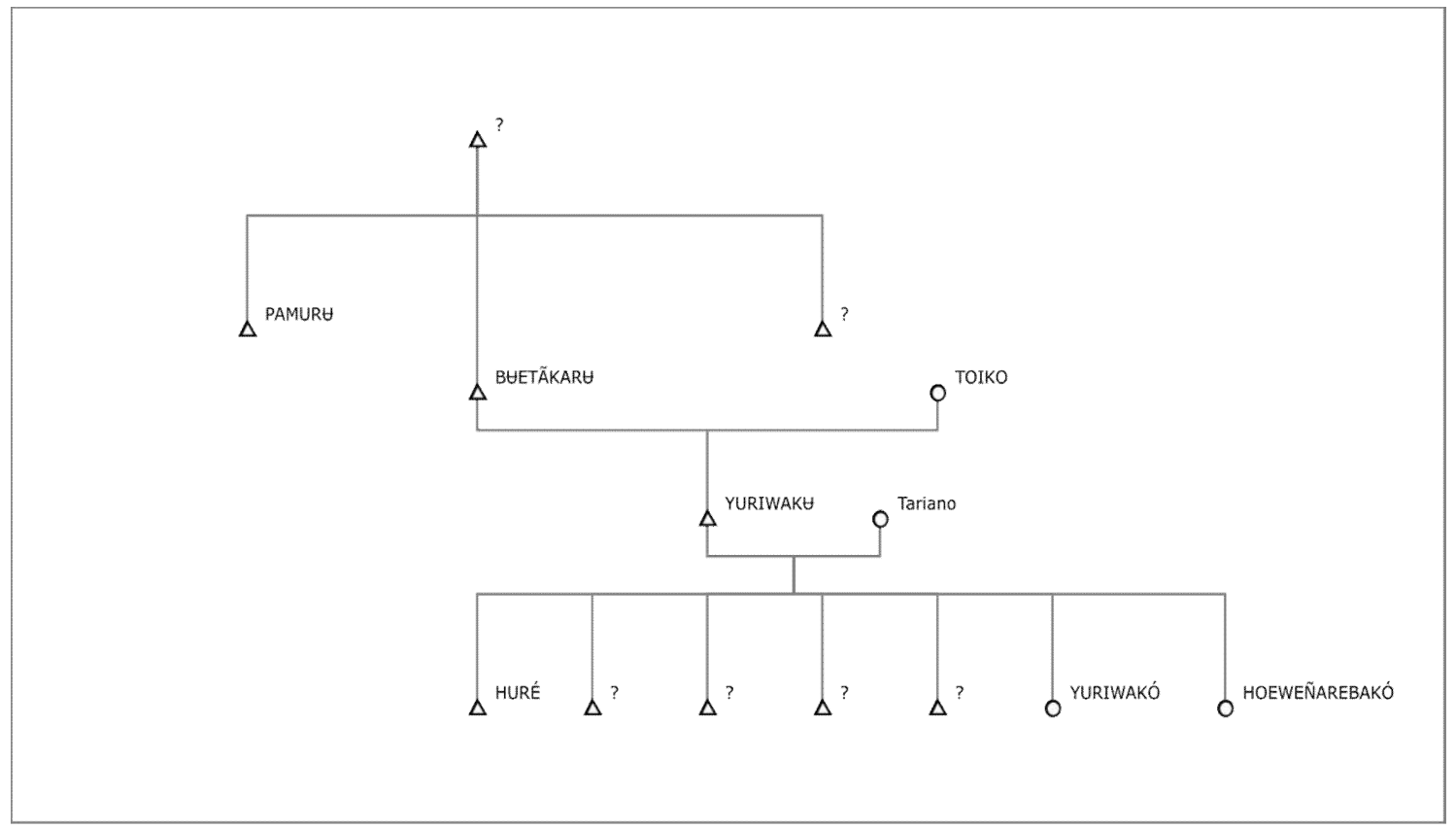

Carlos citou seu pupui amiya, o de seus pais e de um tio paterno; não lembrava o de seus avós, para o qual foi necessário consultar o RANI. No caso de seus sete filhos, sabia o pupui amiya do mais velho, Huré, que morava então em São Gabriel da Cachoeira, e de suas duas filhas mais novas, Yuriwakó e Hoeweñarebakó (ambas moradoras de Querari). No caso dos outros filhos (três deles então em São Gabriel da Cachoeira, e uma filha em Querari), não soube falar, disse "tem que perguntar para eles", não tinha certeza mesmo se tinham o RANI.

Por fim, outra situação de certo uso do RANI diz respeito aos casos de filhos de mães solteiras. Graciliano, respeitado conhecedor de benzimentos e das tradições narrativas em Querari, filho de Francisco, o fundador da comunidade de Querari e irmão de Henrique, o primeiro capitão de Querari, tem cinco filhas e nenhum filho, como vemos no diagrama abaixo:

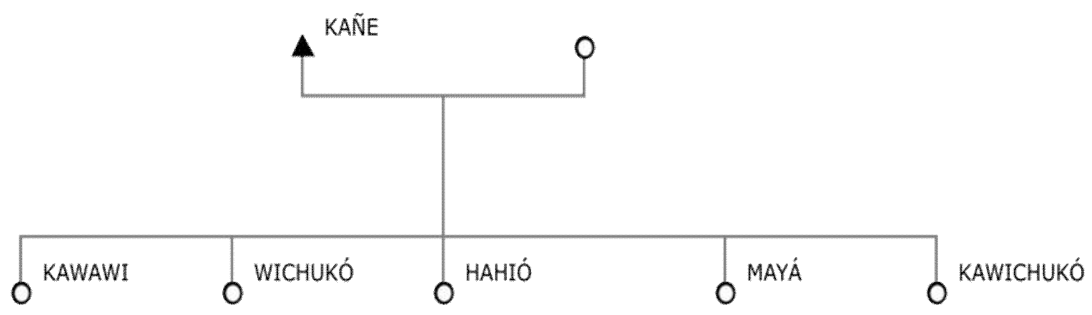


Sua primeira filha foi casada com um Desana, falecido, que deixou quatro filhos; a segunda filha também se casou com Desana, com o qual vivia, e teve também quatro filhos; tem uma filha solteira e as duas outras mães de filhos de pai kuripako. Perguntei o pupui amiya dos netos, e Graciliano foi categórico “eu não sei; pai que sabe. É outra etnia, pai que sabe". O único modo de acessar o pupui amiya, no caso dos filhos que viviam apenas com a mãe, era consultando o RANI, dado que as mães, Yuremawa, também não sabiam.

Por fim, gostaria de encerrar essa etnografia do levantamento de listas de nomes, por assim dizer, citando um caso de registro "errado" bastante peculiar, pois envolve alguns cruzamentos que me causaram certa confusão. Segue.

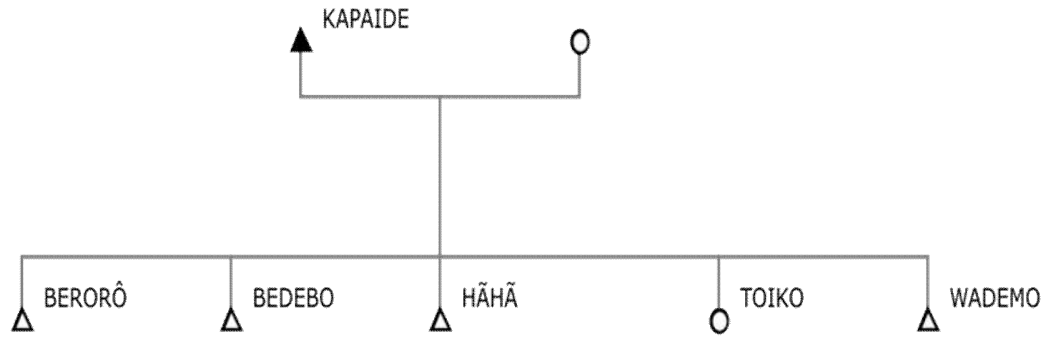

Alexandre, Yuremawa, tem como padrasto Maurício Lana, um Desana que vive em Querari. Contudo, foi criado por Henrique Rodrigues, a quem considera como avô, e de quem recebeu o pupui amiya de Kapaide. Não descobri quem era seu pai; quando perguntei, a resposta foi evasiva "um aí, já faleceu”. Sua esposa, Denise, é Betokó, filha de José Abelardo, ex-morador da antiga comunidade betowa de Yauaretê-Ponta (ela mesma nasceu em Yauaretê-Ponta). Seu primeiro filho tem como pupui amiya Berorô, um nome que nenhuma das pessoas a quem consultei soube dizer do que se tratava; contudo, todos foram unânimes em dizer que não era Yuremewa, nem Yúriwawa. O segundo filho, Josenaldo, tem o pupui amiya Bedebo que, como já vimos, é apontado como sendo Yúriwawa. Aqui, Alexadnre notou que o registro no documento estava "errado", pois consta Benebo. A segunda filha mais nova ainda não tinha RANI, mas já sabiam seu pupui amiya: Toiko. Por fim, perguntei o pupui amiya de Nadilson, filho mais novo, então com apenas três meses. O filho de Alexandre ainda não tinha recebido nome, e o pai não sabia dizer qual seria o nome da criança. Sua esposa Denise pediu que eu esperasse, e correu até a casa de seu pai José Abelardo, para perguntar 
qual seria o pupui amiya da criança. Voltou em alguns minutos com a resposta: Wademo. Note-se, não foi o avô paterno Henrique Rodrigues quem foi consultado sobre o pupui amiya da criança, foi antes o avô materno. Temos então uma família cujo pai tem pupui amiya yuremawa, um filho tem pupui amiya cuja origem é incerta, outro com nome yúriwawa, e por fim o filho mais novo com nome atribuído pelo avô materno, a despeito do avô paterno (adotivo) estar vivo e à disposição para ser consultado. Uma situação, como caracterizei acima, bastante peculiar.

Tais casos de registros "equivocados" de nomes não se restringem apenas ao pupui amiya, também o registro da "etnia" pode ser "errado". É comum encontrarmos no registro o termo "Kubeo" que, como vimos, cobre uma ampla gama de grupos falantes do Kubeo, com distintas tradições narrativas e lugares de origem, sendo inclusive matéria de disputa que em alguns momentos afloram entre Yúri Parãmena e Betowa. Tal fato é algo comum na região do alto rio Negro. Assim, Aline Iubel (2015) cita um caso de registro de nome de "etnia" que vale recuperar. Vejamos:

Presenciei o caso de uma senhora que foi à Funai solicitar o RANI de sua filha, que já tinha nove anos de idade. Quando indagada acerca da etnia da filha, informação que deve constar no documento, a senhora disse que ela e a filha eram Baré. No entanto, o funcionário notou que na Certidão de Nascimento de ambas, mãe e filha, constava que o local de nascimento era uma cidade no Pará. Informação à qual a senhora confirmou ser verdade. Porém, argumentou que mora em São Gabriel há bastante tempo, e que, sendo seu segundo marido Baré, ela e a filha já teriam virado Baré. Casos como esse não são incomuns (ibid., p. 196-97).

Diante dos casos examinados a partir dos diagramas e minhas conversas em campo, devemos perguntar: para que apontam esses casos de registro equivocado, "errado" como dizem, de nomes? Parece-me que podemos divisar algumas chaves interpretativas acerca do registro de nomes "errados". De um lando, estão aquelas assentadas na ideia de uma metafísica onomástica: em primeiro lugar, há os casos de manejo calculado dos nomes, relacionados a oportunidade de adotar um nome de mais potência, mais "energia", como o nome de um poderoso pajé (Kapai ou Tekui, por exemplo) ou habilidoso mestre de surras no Jurupari (Piađa). Em segundo lugar, os casos onde o desinteresse deliberado na correção do registro de nomes está assentado na ideia da palavra escrita como palavra sem potência; é comum ouvir as seguintes sentenças: "é importante que o velho e os pais saibam o nome da criança", "o nome escrito não tem força". Em terceiro lugar, o aparente desinteresse e descuido como forma de evitar explicitar o nome da criança, que deve ser de conhecimento 
restrito dos pais e avós, e mesmo como forma de proteção contra usos maléficos que possam vir a ser feitos ${ }^{96}$. Parece-me que há também certa reticência ao enunciar o pupui amiya de outra pessoa que não pais ou filhos, mesmo sendo casos muito próximos, como no caso citado de Raimundo que dizia não saber o nome de seu irmão Jaime (seu vinzinho em Açaí, lembremos). Em geral, vemos que há uma disposição para apontar o nome como "errado", mas não se diz qual seria o "certo"; quando eu perguntava, a resposta era: "não sei, tem que perguntar para ele”. Aqui, parece operar uma lógica oposta àquela dos apelidos, assunto do próximo capítulo, pois evita-se dizer o pupui amiya de outros, ao passo que o apelido sempre é o do outro, não se costuma falar o próprio apelido.

De outro lado, há aqueles casos que parecem ignorar a ideia de uma metafísica subjacente ao regime onomástico yuremawa e yúriwawa. Nessas situações, temos o registro equivocado como produção de distanciamento da pessoa da "cultura indígena", ou da "era dos indígenas", pois trata-se de novo momento na história, dominado pelo mundo dos brancos, a “era dos brancos". Também Restrepo (2001) em sua monografia sobre os Kubeo Hehénewa notou algo semelhante: "Estos nombres de la genealogía del Sib no son empleados hoy en día. Prefieren emplear nombres cristianos" (p. 90). Restrepo faz uma distinção entre "la vida anterior" ou "tradicional" e a "actual", que se assemelha aquela que os Yuremawa e Yúriwawa fazem entre "era dos indígenas" e "era dos brancos".

Por fim, há outro elemento explicativo dos registros "errados" dos nomes que não se relaciona a afirmação ou negação de uma metafísica do umé, mas diz respeito antes a uma situação, digamos, mais prática, a saber, o conhecimento precário da escrita e dificuldade do funcionário responsável pelo registro no órgão administrativo em São Gabriel da Cachoeira em entender a língua e grafar corretamente, acompanhada da ausência de uma grafia padronizada do Kubeo ${ }^{97}$.

\footnotetext{
${ }^{96}$ Aqui, outra questão delicada, a saber, os feitiços. Não avancei muito no entendimento desse tema ao longo de minhas interlocuções; mas parece ser consenso a ideia de que o pupui amiya pode ser usado, de algum modo, para fazer mal a determinada pessoa. Encontrei uma passagem esclarecedora sobre esse tema, e que parece concordar com as ideias Yuremawa e Yúriwawa, na fala de Luís Lana em sua interlocução com Samir Angelo; segue:

"Desde criança a pessoa é benzida. Recebe um nome. Saber o nome é importante na hora de fazer um estrago. Porque o nome contém a energia vital da pessoa. A força de vida está no nome. $\mathrm{O}$ estrago mexe com esta energia. É por isso que fazer estrago em branco não pega. Porque o nome do branco não carrega esta energia" (2016, p. 181).

97 Thiago Chacon (2012) iniciou em 2008 trabalhos de elaboração de descrição e documentação da língua kubeo, com o propósito de publicação de um dicionário Kubeo-Português (o dicionário existente, já de muitos anos, é Kubeo-Espanhol), e sistematização de uma gramática atualizada da língua, no que contou com apoio e
} 
Andrello, em investigação acerca da publicação de livros com narrativas de mitologias e histórias de grupos particulares do alto rio Negro, a coleção Narradores Indígenas do Rio Negro, mostra como, entre outras questões, nessas publicações "o uso da escrita e dos préstimos dos antropólogos para produzir livros vieram, de fato, a se prestar para a atualização de diferenças entre clãs tukano, desana, tariano e outros, ao longo de um processo histórico em que as práticas rituais que criavam as ocasiões para a reiteração das diferenças sociais a partir de falas e diálogos cerimoniais foram progressivamente abandonadas" (2010, p. 7). Penso que tal hipótese pode ser ampliada para o registro escrito dos nomes de benzimento no RANI. Também aqui notamos casos de produção deliberada de um distanciomanto do "mundo do índigena" e aproximação do "mundo do branco", para usar expressões que ouvi muitas vezes em Querari e Açaí, manifesta no aparente descaso em relação aos nomes de benzimento; vemos também o registro de nomes que, segundo algumas pessoas, não seria o "certo", pois estaria reservado a irmãos maiores, ou seja, certa manipulação de diferenças internas ao grupo.

Por fim, notamos também que o RANI se torna algo como depositário do conjunto de nomes do grupo; em caso de esquecimento, olha-se no RANI. O documento passa a ocupar um lugar anteriormente ocupado pelos velhos, ou seja, em geral, olha-se o documento, ao invés de questionar os mais velhos (procedimento que observei não poucas vezes). Dito de outro modo, a escrita parece ocupar o lugar da memória.

Além do RANI, o pupui amiya também se tornou uma exigência recente na escola. Em conversa com o então diretor da escola estadual de Querari Maurício Lana, no final de 2017, ouvi as seguintes considerações:

Aí é preciso já agora para cadastrar esses alunos tem que ter, na chamada tem que ser feito assim, o nome indígena; vamos supor, eu, Wari, Maurício, quer dizer, do convencional é Mauricio, na igreja católica, e do benzimento, que faz parte mais da origem, original mesmo, esse aí é Wari, quer dizer, duas coisas tem que ser chamado eu. Então por isso que tem que constar no SIGEAM cadastrado já. Essas coisas que eles estão exigindo, o SIGEAM, onde a gente faz matrícula, tudo é controlado por ele, o sistema. Isso tem que ter para esse ano já [2017]. [...] esses alunos que matriculei para esse ano, como estávamos na transição ainda, não preocupei mais, só preenchi e

interlocução de muitos jovens professores kubeo interessados no estudo da língua. Tal trabalho está em andamento, ainda sem previsão de conclusão e publicação. 
mandei para o secretário. Aí o secretário demorou a divulgar essas coisas. Quando cheguei, eu pensava que conhecia todos, os nomes do benzimento dos alunos, não conheço também. Então quando cheguei ele disse "está aqui para você preencher", "não sei, só sei o nome dos meus filhos", mas dos outros não sei não, mais ainda dos Kubeo, não sei como é o benzimento deles. Por exemplo, nosso Desano mesmo, nome do benzimento só vai sete [...], a mesma coisa as meninas também, quer dizer, nomes desana, tanto masculino e feminino, tem 14 nomes só. [...] antes RANI não era exigência, agora tem que tirar o RANI, o próprio cartório já pede. [...] antes para a matrícula na escola, precisa apenas da certidão de nascimento, agora cartório não dá mais certidão sem o RANI, tem que ter o RANI [...].

Maurício afirma a exigência do sistema de administração escolar do registro de nome de benzimento, do "nome indígena" como ele diz. Afirma ainda que o "nome indígena" deve estar registrado para a chamada feita em sala de aula. Outro problema explicitado por Maurício é aquele da exigência do RANI. Antes, diz Maurício, bastava a certidão de nascimento para efetuar a matrícula do aluno. Agora, além do registro de nascimento é preciso ter o RANI, o qual por sua vez pede o nome de benzimento da pessoa para registro. Independente de supor ou não certa metafísica do nome, todos devem ter "nome indígena".

Outra instituição que passou a pedir recentemente os nomes de benzimento na região é a igreja católica. Descrevo uma cena de crisma que mostra isso. No primeiro domingo do mês dezembro de 2017, o então bispo de São Gabriel da Cachoeira em visita à comunidade de Querari celebrou missa onde realizou batismos, primeira eucaristia e crisma. Na cerimônia de crisma, foram três os crismandos: Edson Torres, Yúriwawa de Açaí que vive atualmente em Querari; Marcelino Torres, Yúriwawa de Açaí, irmão de Edson; e Denise, Betowa que vive em Querari. Iniciada a cerimônia, os três fizeram fila, acompanhados dos padrinhos, para um a um receber a benção do bispo. Segue o diálogo entre bispo e crismandos:

Bispo: Vai dizer o nome de benzimento primeiro.

Edson: Meu nome, como todo mundo sabe, é Huré.

[Risos de alguns jovens sentados no primeiro banco]

Bispo: Edson, recebe por esse sinal o Espírito Santo, o dom de Deus, amém. A paz esteja contigo.

Edson: Contigo também.

[Edson volta a sentar-se. O próximo da fila é Marcelino. O bispo vira Marcelino de frente para os presentes na igreja]

Bispo: Fale a nome de benzimento bem alto.

Marcelino: Meu nome de benzimento é Piađa. Meu nome é Marcelino. [Alguns jovens sentados repetem em voz baixa o nome Piađa] 
Bispo: Marcelino, recebe por esse sinal o Espírito Santo, o dom de Deus, amém. A paz esteja contigo.

Marcelino: Contigo também.

[Marcelino volta a sentar-se; entra Denise]

Bispo: Diga o nome de benzimento.

Denise: Meu nome de benzimento é Makarepé. Meu nome de batismo é Denise.

[Alguns jovens sentados repetem em voz baixa o nome Makarepé]

Bispo: Denise, recebe por esse sinal o Espírito Santo, o dom de Deus, amém. A paz esteja contigo.

Denise: contigo também.

Notemos o pedido do bispo para falar em voz alta diante dos presentes na igreja o nome de benzimento ao lado do nome de batismo. O bispo pediu que o nome fosse enunciado não para ele apenas, mas para os presentes, o que se evidencia na orientação para o crismando ficar de frente para as pessoas no momento de falar o nome. Nos comentários da cena, disse que algumas pessoas riram quando Edson Torres disse seu pupui amiya. Por que essa reação diante de um nome que, como vimos em outro capítulo, deveria suscitar respeito e consideração? Não estou completamente certo de que seja isso, mas tenho uma intepretação: Edson é conhecido como Huré, termo que ouvi tanto pessoas mais próximas quanto alguns militares seus colegas usarem para designá-lo, nome muitas vezes tomado como apelido; lembremos que ele diz "meu nome, como todo mundo sabe, é Huré”. Esse é um dos poucos casos que um pupui amiya é usado para identificar, individualizar a pessoa, e se confunde com apelido (yahui amiya). Então há certa confusão nesse caso em distinguir nome de benzimento de apelido; prova disso, penso, é o fato do riso ter se dado sobretudo entre os mais jovens. Outro caso é o de Marcelino Torres, irmão de Edson, cujo pupui amiya é Piađa. Não poucas vezes ouvi Marcelino ser chamado pelo pai ou por alguns de seus irmãos por Piađa como vocativo ${ }^{98}$. O riso que se deu entre alguns jovens se deve, penso, a falta de conhecimento sobre o que é pupui amiya e o que é yahui amiya.

\footnotetext{
98 Esse episódio merece destaque, pois se trata de situação onde pai e irmãos usam o pupui amiya como vocativo; não observei outras situações semelhantes, o que não significa que não existam; antes, a falta de dados sobre tal tema pode ser resultado de minha dificuldade com a língua kubeo e também por tal uso se dar em âmbito familiar muito restritivo, mais íntimo.
} 
O pupui amiya também pode ser usado em capas de trabalhos escolares, como observei na escola de Querari, e mesmo na identificação em capas de monografias. Isso nos remete ao uso dos nomes de benzimento em capas de livros, algo bastante evidente no caso da Coleção Narradores Indígenas do Rio Negro ${ }^{99}$. Também vemos tal exibição do nome de benzimento em endereços eletrônicos e contas em redes sociais. Aqui, cabe-nos perguntar o que significam esses usos mais evidentes do nome de benzimento, pois diferente do que encontramos na literatura etnográfica regional, o nome de benzimento não parece mais ser cercado de restrições, seus usos adquiriram outros significados, outros contextos. Estamos, portanto, diante de uma transformação nas práticas de uso dos nomes de benzimento. Se se parte do reconhecimento da metafísica que conforma o lugar desses nomes nas práticas e conhecimentos kubeo, a ideia subjacente parece ser a de que tais nomes, quando escritos, perdem sua potência ou, como formulou Luiz Gilberto algumas vezes, “o nome escrito não tem energia, não tem força".

\section{Recebendo nomes e sobrenomes de branco}

O nome de branco, em geral, é escolhido pelos pais da criança algum tempo antes do nascimento, que pode variar de meses a dias. Contudo, a escolha após o nascimento não é incomum. Certa vez registrei um caso de bebê de quatro meses em Açaí que não tinha nome de branco, estava registrado no censo feito pelo agente de saúde local como "sem identificação". O nome de branco de uma pessoa yuremawa ou yúriwawa obedece a seguinte estrutura:

[nome escolhido pelos pais] [sobrenome da mãe] [sobrenome do pai]

Vejamos um exemplo:

\footnotetext{
${ }^{99}$ Uma análise dessa coleção com particular interesse nos nomes pode ser encontrada na tese de Samir Angelo (2016).
} 


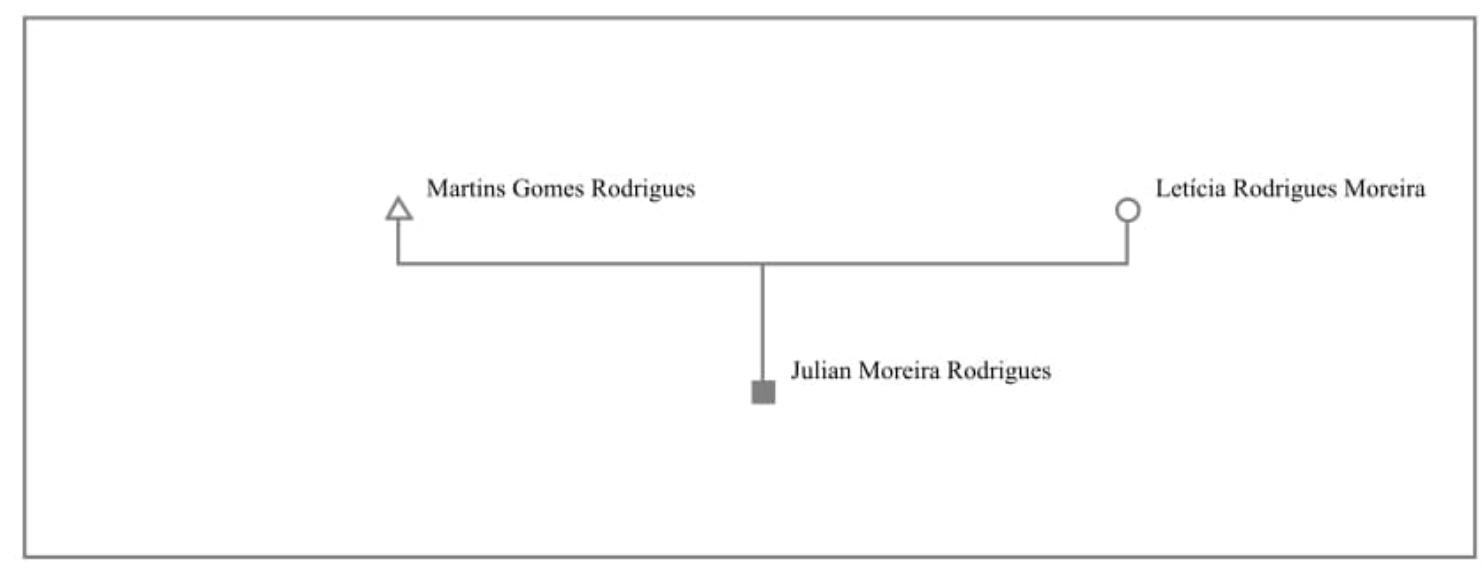

Não se sabe com precisão sobre como esses nomes foram introduzidos entre os Kubeo; sabemos que os brancos que passavam pela região, comerciantes colombianos em sua maioria, tiveram um papel de destaque; mas devemos enfatizar aqui o papel dos missionários, pois se não foram os primeiros nem os únicos a introduzirem o sistema de nomes de branco, certamente foram aqueles que formalizaram seu uso por meio do batismo católico.

Escolhido pelos pais, o nome de branco é confirmado na cerimônia do batismo católico. Sobre a origem desses nomes, Osvaldo, Yúriwawa, durante uma explicação de como se dava a atribuição de apelidos, comentou o seguinte:

Muitas pessoas inventam... as vezes a pessoa ali não tem apelido, aí inventam, já botam ali, e não sai mais não. A maioria já conhece com aqueles nomes que eles começaram a dar e vai indo. [...] quando tem grandes festas que não é brincadeira, aí eles utilizam o apelido tradicional. [...] Aquele do apelido... eu perguntei para o meu pai, "por que eles utilizaram isso?", era nome da pessoa mesmo, porque ninguém dava nome como os brancos usam hoje em dia, como nossos nomes agora, era desse jeito que eles colocavam ali. [...] Indígenas já tinham esses nomes, depois com os brancos com batismo que começou, antes não tinham esses nomes que a gente tem hoje em dia; era através da referência de um animal que eles colocavam aí. Interagiram ali com os brancos, aí começou esses nomes que hoje a gente tem.

Nessa fala, Osvaldo explicita a distinção entre dois tipos de apelidos: de brincadeira e tradicional (voltarei ao tema no próximo capítulo). O apelido parece ocupar o lugar mais próximo aquele que viria a ser do nome de branco; "era nome da pessoa mesmo, porque ninguém dava nome como os brancos usam hoje em dia, como nossos nomes agora, era desse jeito que eles colocavam ali”, assim fala Osvaldo sobre os apelidos. Mais adiante, "Indígenas 
já tinham esses nomes, depois com os brancos com batismo que começou, antes não tinham esses nomes que a gente tem hoje em dia [...]. Interagiram ali com os brancos, aí começou esses nomes que hoje a gente tem". Os nomes de branco foram introduzidos, portanto, de acordo com Osvaldo, com a prática do batismo, e passaram a ocupar o lugar de certo tipo de apelido. Introduzidos pelos brancos, esses nomes são atualmente de uso consolidado entre os Kubeo ao passo que nos citados apelidos parecem ter caído em desuso, "ninguém lembra mais", explicou certa vez Geraldo Edson ${ }^{100}$. Perguntemos: o que faz um nome de branco?

Stephen Hugh-Jones (2002), a partir do material tukano, aponta que os nomes de branco incorporam e carregam consigo os poderes externos dos estrangeiros; desse modo, diz o autor:

Em um nível mundano, esses nomes exóticos são uma alternativa conveniente aos nomes indígenas secretos e, junto com os patronímicos colombianos e brasileiros, compreendem partes desejadas e cada vez mais necessárias do processo de modernização. Mais esotericamente, esses nomes também incorporam os poderes exóticos e externos (ewa) dos estrangeiros (2002, p. 54).

O autor cita como caso mais óbvio desse uso dos nomes de branco "a adoção do nome Cristo pelos líderes dos movimentos messiânicos do século XIX, e o uso de nomes como Santiago e Poro (Paulo) pelos adeptos do culto" (2002, p. 54), e afirma que tal uso não foi relegado ao passado, pois, para alguns Tukano mais "tradicionais", "mas de modo mais difuso, essa apropriação de poderes dos estrangeiros incorporada em seus nomes continua até o presente" (ibidem).

Essa concepção do nome de branco (sobrenome, no caso) parece apontar para o tema da "hierarquia", e das noções nativas de "consideração" e "respeito". Com efeito, diferente do que se passa com o sobrenome materno, o sobrenome paterno se mantém ao longo das gerações. Aqui, gostaria de retomar uma formulação de Rivelino Barreto, Tukano do rio Tiquié que vive atualmente em Manaus, sobre a questão da atribuição de sobrenomes; esse antropólogo tukano nos conta o seguinte:

Quanto ao sobrenome Barreto que assinamos hoje, foi proposto também pelos missionários salesianos a partir da formação dos seus primeiros alunos. A dinâmica foi proposta para cada grupo, ou seja, escreveram vários sobrenomes na lousa e os meus tios escolherem então o sobrenome Barreto pelo qual somos conhecidos atualmente. Antes disso, o que equivalia nominalmente era a denominação tradicional de cada coletivo, isto é, nós

${ }^{100}$ Voltarei a essa fala de Geraldo Edson e o lugar dos apelidos no próximo capítulo. 
éramos conhecidos e até hoje somos conhecidos como Sararó Yuúpuri Búbera Põra (darsea). Em decorrência disso, muitos grupos no Alto Rio Tiquié e suas adjacências, são conhecidos pelo sobrenome que passou a equivaler como família Barreto, família Pena, família Bastos, família Nery, etc. Uma forma de reunir diferenças que se fez importante para todos, índios e não-indios (BARRETO, 2012, p. 26, sublinhado meu).

Nesse caso a escolha do sobrenome se deu, aparentemente, de modo aleatório, sem propósito aparente, sem motivação. A atribuição de sobrenomes, e eis o ponto que gostaria de destacar, é interpretada por Rivelino como uma "forma de reunir diferenças". Avancemos na análise da relação entre sobrenome e os grupos.

Tatiana Amaral, em sua pesquisa sobre a repatriação recente de um conjunto de ornamentos cerimoniais (basá busá) que estava guardado há décadas no Museu do Índio de Manaus, em certo momento, chama a atenção para a relação entre sobrenome e as relações entre irmãos maiores e menores. Diz a antropóloga:

[...] dentro de cada clã particular, as pessoas também são diferenciadas por meio de linhas de descendência paralelas. Geralmente, os clãs são nomeados a partir do nome do ancestral que dá origem ao grupo - por exemplo, o ancestral que deu origem ao clã Koivathe tinha exatamente este mesmo nome. O nascimento dos filhos deste ancestral fundador do grupo seria o ponto de partida das linhas de descendência. Isto é possível pela diferenciação relativa dos filhos do ancestral como irmãos maiores e irmãos menores. Os descendentes do irmão maior, o chefe, seriam considerados de primeira linha, já os descendentes do caçula seriam classificados como sendo de última linha. É interessante notar os paralelos entre os sobrenomes adotados pelas pessoas e as divisões dos clãs: os sobrenomes Alves e Galvão são usados por membros de um mesmo clã desana (Guahari Diputiro Porã), só que o sobrenome Alves indica membros de uma linha de descendência superior do que aquela a que pertencem os Galvão. Mas, em outros casos, os membros de um mesmo clã possuem um mesmo sobrenome, como é o caso do clã tukano Oyé, cujos membros adotaram o sobrenome Maia (AMARAL, 2014, p. 82).

A autora explicita que sobrenomes diferentes podem ser usados por membros de um mesmo "clã", destacando certa sobreposição entre determinados sobrenomes e o reconhecimento como irmão maior ou menor. Essa sobreposição me parece bastante comum. Assim, também os Yuremawa e Yúriwawa reconhecem com facilidade o sobrenome Rodrigues, por exemplo, como atribuído ao senhor Henrique Rodrigues, filho de Francisco Rodrigues, primeiro morador de Querari e, dentro das subdivisões desse grupo, considerado irmão maior. O sobrenome, portanto, ao contrário do pupui amiya que, segundo Luiz Gilberto possui diferenças de "força", potência, "reúne diferenças"; irmão maior ou menor, são todos 
"Rodrigues", para manter o exemplo. Mas isso não é tudo. Segundo Amaral, também se pode verificar outro uso do sobrenome: indicar "hierarquia" do grupo.

Em nota de pé página, Amaral desenvolve em detalhes esse uso explicando o caso do sobrenome Maia:

Segundo o livro da Coleção Narradores Indígenas do Rio Negro de autoria de homens tukano Oyé, a história da associação dos Oyé com o sobrenome Maia diria respeito à posição ocupada pelo grupo na escala hierárquica entre os Tukano. No começo do século XX, a Comissão de Limites liderada pelo Capitão Rondon averiguou que muitas crianças indígenas das malocas situadas no lado brasileiro estavam em uma Missão em Monfort, localizada no lado colombiano. Um menino chamado Benedito, nascido em 1913, estava estudando nesta missão. Chegando em Monfort, Rondon perguntou quem era o filho do chefe dos Ye 'pa-masa (Tukano) que estava estudando lá e os missionários apontaram o menino Benedito. Então, Rondon levou Benedito para a Missão de Iauaretê e, quando o menino foi entregue para o padre João Marchesi, o missionário logo pensou em qual sobrenome poderia dar para o menino. Nessa época, o governador do Amazonas se chamava Álvaro Maia e, por isso, Benedito recebeu o mesmo sobrenome. Anos depois, Benedito voltou para a comunidade do Pato, localizada no rio Papuri, e foi nesta época que os Oyé adotaram o sobrenome Maia - por iniciativa do próprio Benedito. Ainda que Benedito fosse descendente da última linha do clã, o sobrenome foi adotado por todos os Oyé (Maia \& Maia, 2004:123).

Ouvi esta história pessoalmente em Iauaretê. $\mathrm{Na}$ fala do meu interlocutor, um jovem tukano Oyé, parecia explícito que, para ele, a adesão ao sobrenome Maia fazia bastante sentido. Afinal, esse era o nome do "chefe" branco da região - por isso, provavelmente, todos os Oyé se apropriaram desse sobrenome, apesar de Benedito fazer parte da última linha desse clã. Devo dizer que esta história foi contada com evidente contentamento e com um tom que parecia denotar algo que poderíamos chamar de "orgulho". Nesse sentido, podemos considerar que esse distinto sobrenome não indígena (Maia) também parece compor um dos itens de "riqueza" que são acionados para revelar diferenciações hierárquicas estabelecidas entre os clãs dos Ye'pa Masa. Um fato ocorrido com o meu interlocutor tukano Oyé pode explicitar essa ideia: segundo Geraldo Andrello (comunicação pessoal), esse homem de sobrenome Maia, quando mais jovem, não tinha uma ideia clara sobre a posição de seu clã na escala hierárquica dos clãs tukano. Ele só foi ter noção de que fazia parte do grupo "chefe" tukano quando passou a viajar pela bacia do Uaupés e, quando se apresentava para as pessoas - dizendo que era da família Maia que vive em Iauaretê, depois de ter migrado da comunidade do Pato no rio Papuri -, essas reconheciam o sobrenome e afirmavam que esse é um nome de família usado por aqueles que ocupam o mais alto estrato da escala hierárquica dos Ye'pa Masa. (AMARAL, 2014, p. 82-83).

Aqui, Amaral explicita a origem do sobrenome Maia: Benedito, irmão menor dos Oyé, teve o sobrenome Maia atribuído por um padre missionário, que por sua vez retirou esse sobrenome do então governador do estado do Amazonas Álvaro Maia. Quando volta para sua 
comunidade no rio Papuri, todo o grupo Oyé adota esse sobrenome, visto então como nome do "chefe" branco da região e que, como indica a autora, passou a ser reconhecido como nome adequado ao clã $O y e ́$, que ocupava "o mais alto estrato da escala hierárquica dos $Y e$ 'pa Masa" (AMARAL, 2014, p. 82). Apresento dois comentários a essa descrição de Amaral.

Em primeiro lugar, vemos claramente neste episódio a ideia já discutida no capítulo anterior de que os nomes fazem coisas, atuam sobre pessoas e corpos. Como exposto, pode-se atribuir certos nomes com o propósito de produzir na pessoa determinadas habilidades ou capacidades, como ser um benzedor ou um mestre de surras no Jurupari, por exemplo. Desse modo, entendemos a observação de Amaral: "Ouvi esta história pessoalmente em Iauaretê. Na fala do meu interlocutor, um jovem tukano Oyé, parecia explícito que, para ele, a adesão ao sobrenome Maia fazia bastante sentido". De um grupo considerado como "chefe" é adequado, "faz sentido", que o sobrenome seja aquele de um chefe. Isso nos remete a afirmação de Andrello segundo a qual devemos estar sempre atentos, isto é, "trata-se de verificar em que medida a recusa em aceitar certos tratamentos ou tacitamente aprová-los corresponde à negação ou à afirmação de posições de status, isto é, em que medida adotar ou alterar um nome atribuído por outrem codificam disputas e transformações no interior de uma escala comum de pessoas e coletivos" (ANDRELLO, 2016, p. 60).

A autora avança ainda a seguinte interpretação do episódio: "Nesse sentido, podemos considerar que esse distinto sobrenome não indígena (Maia) também parece compor um dos itens de 'riqueza' que são acionados para revelar diferenciações hierárquicas estabelecidas entre os clãs dos Ye'pa Masa” (AMARAL, 2014, p. 82). Aqui, concordo com a autora, mas penso que podemos divisar dois e não apenas um uso do nome. É acionado para "revelar diferenciações hierárquicas estabelecidas entre os clãs dos Ye'pa Masa”, mas em outra escala parece ocultar "diferenciações hierárquicas", sem distinguir irmão maior ou menor; desse modo, Benedito Maia, mesmo sendo "descendente da última linha do clã", é um "Maia", o sobrenome, portanto, como formulou Rivelino Tukano, reúne diferenças. Eis que o sobrenome pode ser entendido nesse jogo de ocultar e revelar diferenças hierárquicas. Contudo, penso que o caso kubeo difere do material tukano.

Com efeito, se encontramos nas formulações apontadas de Stephen Hugh-Jones (2002) e Tatiana Amaral (2014) a noção de força incorporada ao nome, ao longo de meus trabalhos de campo e prolongada interlocução com os Yuremawa e Yúriwawa não encontrei nenhuma referência a nome de branco como dotado de "força" ou "poder", nem na memória do passado ou no presente. Também a literatura acerca dos Kubeo disponível não faz nenhuma menção a essa ideia comum aos Tukano. Tal constatação me leva a pensar que os 
nomes de branco para os Yuremawa e Yúriwawa, ao contrário da concepção tukano apresentada por Hugh-Jones e corroborada nas análises de Tatiana Amaral, são pensados como desprovidos de potência; se os nomes de branco apresentam alguma importância, devese antes a aproximação ao mundo dos brancos, num sentido pragmático-político, a participação no "processo de modernização" de que fala Hugh-Jones. "Força", "energia" ou potência é atributo dos pupui amiya ${ }^{101}$.

${ }^{101}$ Aline Iubel parece apontar para concepção semelhante em certo momento de sua pesquisa sobre a política em São Gabriel da Cachoeira. Com efeito, uma dificuldade que se colocou para a pesquisadora foi a de usar ou não os nomes de seus interlocutores. Assim, escreve Aline: "Além disso, a fala de Pedro Machado reivindica que seu nome e de seus familiares sejam colocados na história do movimento indígena e isso nos leva a uma questão com a qual os antropólogos quase sempre se deparam: usar ou não os 'verdadeiros' nomes de seus interlocutores. Questão que exige bastante cautela, já que os nomes indígenas são cercados de segredos, por serem necessários para a realização de feitiços, por exemplo. A opção por não omitir os nomes deve-se a diversos motivos: de um lado, como Pedro Machado demonstra, muitas vezes há uma vontade de ter seus nomes escritos em livros, teses, artigos, ou seja, 'colocados na história'; de outro lado, estamos escrevendo sobre eventos que envolvem pessoas públicas e conhecidas da cidade de São Gabriel, de nada adiantaria escrever 'o prefeito em vigor em determinado período' sem revelar seu nome, pois uma rápida busca na internet traria essa e tantas outras informações. Além disso, os nomes aos quais tive acesso, com os quais os índios com quem conversei se apresentavam a mim eram seus nomes de branco (em português), que 'não tem alma' (Pozzobon, 2013). Esses são os nomes que assumem uma face pública, e é isso que replico na opção metodológica aqui adotada" (IUBEL, 2015, p. 26). 


\section{CAPÍTULO 6 - BRINCANDO COM APELIDOS}

Em “De que riem os índios?” (2012 [1967]), Clastres chamou atenção para um traço que, embora frequentemente esquecido, é comum a muitos mitos: trata-se do humor, do riso, da capacidade do mito de "ao mesmo tempo falar de coisas solenes e fazer rir aqueles que o escutam" (ibid., p. 147). Esse ensaio de Clastres, a despeito de seu interesse, não parece ter sido levado a sério pela etnologia. Neste capítulo, portanto, proponho analisar o tema das brincadeiras com apelidos (yahui amiya), seus usos e contextos de atribuição, dando particular atenção ao que, ao meu ver, se apresenta como o seu contexto por excelência, a saber, a festa de caxiri.

\section{O yahui amiya kubeo}

Lembremos que Stephen Hugh-Jones (2002) sistematizou três categorias de nomes pessoais disseminadas nas etnografias tukano do noroeste amazônico, a saber: nomes de espírito, apelidos e nomes de estrangeiro. Acerca dos nomes de espírito, o autor nos oferece a seguinte formulação:

Cada grupo exogâmico possui um conjunto particular de nomes de espírito específicos quanto ao gênero (basere wame, bükü wame, "nome xamânico ou antigo"). Quando nasce uma criança, é dado a ela um nome pertencente a esse repertório e que foi previamente portado por uma pessoa morta do mesmo grupo, da segunda geração ascendente, um pai do pai (FF) real ou classificatório para meninos e uma irmã do pai do pai (FFZ) para meninas. Os indivíduos recebem, portanto, nomes de membros falecidos do grupo, tal como estes haviam recebido os seus nomes; os nomes dos vivos são logicamente os nomes dos ancestrais. Como o conjunto de nomes é restrito, dois ou mais indivíduos terão freqüentemente o mesmo nome (HUGHJONES, 2002, p. 50-51).

Hugh-Jones ainda nos diz que "através da nominação, o indivíduo adquire a identidade de grupo e uma parte da alma do grupo, enquanto a coletividade dos viventes é a continuação dos ancestrais e mantém vivos suas memórias, nomes e vitalidade” (2002, p. 51). Esses nomes de espírito são raramente usados em referência, "de modo que, para além do grupo de parentesco próximo, o nome de espírito de uma pessoa é geralmente conhecido apenas por ouvir falar" (2002, p. 52). 
Além do nome de espírito, a pessoa recebe um "nome de estrangeiro", isto é, nomes de brancos que "são conferidos logo após o nascimento, quase sempre pelos pais, mas, idealmente, por um agente externo e, melhor ainda, por um missionário em um rito de batismo" (2002, p. 53). Por fim, a terceira designação que uma pessoa recebe são os apelidos, ou "nomes jocosos" e os "nomes comuns", dois extremos de um mesmo espectro (2002, p. 52). É para esse tipo de nome que chamo a atenção do leitor nas páginas que seguem.

Antes de passar a análise dos apelidos e das brincadeiras propriamente, gostaria de fazer uma ressalva: há um conjunto de trabalhos na literatura antropológica sobre humor e relações ditas jocosas que destacam como central certo aspecto, a saber, aquele da relação entre uso de apelidos e parentesco. Essa orientação na tradição pode ser localizada nas formulações de Mauss (1928), Lowie (1920) e de Radcliffe-Brown (1949; 1952). Contudo, foi esse último autor quem mais enfatizou o papel do parentesco, pois Robert Lowie e Mauss, embora dêem considerável tratamento a esse plano de relações, afirmam a necessidade de considerar a relação de jocosidade propriamente dita, "no conjunto da cultura" (MAUSS, 1928). Parece-me que devemos levar a sério essa ideia inicial, pois penso que os dados kubeo apontam para uma apreensão mais adequada se consideramos a citada afirmação de Lowie e Mauss, embora as relações de parentesco não estejam excluídas das relações jocosas. Mais adequado que insistir na dimensão do parentesco, parece-me, é explorar o conteúdo humorístico das relações jocosas e suas implicações, é pensar a questão do que faz um apelido quando atribuído a uma pessoa e manejado em brincadeiras. Feita a ressalva, sigamos com as análises.

Em Kubeo apelido se diz yahui amiya, que pode ser traduzido como "nome de brincadeira" ou "nome de zombaria". O apelido comporta esses dois sentidos, brincar e zombar, causa de um riso positivo, alegre, e outro negativo, zombeteiro ${ }^{102}$. Com efeito, yahui amiya produz riso, brinca-se com o apelido do outro e isso faz rir. Mas pensemos: por que se

\footnotetext{
${ }^{102}$ Uso aqui os termos empregados pelo historiador George Minois quando analisa o lugar do cômico e do riso no texto bíblico (MINOIS, 2003, p. 120).
} 
usa yahui amiya? Quando se usa? Quais os yahui amiya comumente usados e suas histórias? Segue uma lista ${ }^{103}$ de yahui amiya dos Yúriwawa levantada no final do ano de 2016:

Kubuhuku (bicho de pé)

Piçana (gato), Emu (guariba)

Abuhuku (diabo/demônio)

Moaðo (bacural)

$\tilde{A} ð \tilde{a}$ (jararaca)

Wakort (cacau do mato) ${ }^{104}$

Koró (tipo de ave), Paipi (quati)

Okort (gota de água)

Hãhãbu (maraca)

Bedebo (pato), Kaparo (macaco prego)

Piaða (um dos chefes do Jurupari)

Mãtẽ (mucura)

Muchiva, Pikõku (tipo larva)

Em Querari, entre os Yuremawa, levantei a seguinte lista de yahui amiya também no final de 2016:

Aða kahé (coro de cobra)

Cabaré

Maruku (macaco da noite), Federal

Boé (mussum)

Wekt (boi)

$\tilde{A p e ̃ ~(p e r e r e c a) ~}$

Kõtẽ

Menorubo (tipo de besouro)

Kuнbo (jabuti)

Kamĩdu (caranguejo)

${ }^{103}$ Nas listas que seguem, decidi não citar nomes, indicando apenas os yahui amiya. Quando aparecer dois ou mais yahui amiya na mesma linha, significa que uma mesma pessoa é referida por eles; comentarei essa coleção de yahui amiya que algumas pessoas têm mais adiante no texto.

${ }^{104} \mathrm{Na}$ língua kubeo, wakoku a árvore de cacau do mato, e wakó a fruta de cacau. 
Waoko (macaco zogue zogue)

Nãpã (tucunaré)

Gegeba

Đoðe (traíra)

Wariro (ser mitológico)

Nama (veado), Uarĩarakakawé (canela de queixada)

Popay

Taĩtãre (jacamim)

Pollo (frango em espanhol)

Sokó (tipo de ave)

Lucho, Minhocão

Por fim, segue uma pequena lista de alguns yahui amiya atribuídos aos Betowa ${ }^{105}$ :

Kaparo (macaco prego)

Padre

Comandante, Carriçu, Terrorista

Weabo (Pacú)

Boi

Bia kahé (casca/couro de pimenta)

$U$ (preguiça)

O que podemos depreender dessas listas de yahui amiya? Em primeiro lugar, destaco que os a yahui amiya são de uso exclusivo dos homens, isto é, mulheres não têm e não usam yahui amiya entre elas ${ }^{106}$. Contudo, embora as mulheres não usem yahui amiya, é corrente que sejam elas as que atribuem yahui amiya aos homens, como veremos adiante. Os yahui amiya são próprios dos homens e usados entre eles. Lembremos que isso difere do caso do pupui amiya onde alguns nomes femininos são acompanhados de seus yahui amiya, o que nos

\footnotetext{
105 São Betowa que atualmente vivem em Querari; apenas um deles alterna entre Querari (para acompanhar filhos na escola) e sua comunidade, Puerto-Colombia, no lado colombiano do Uaupés. Outro vivia na época do levantamento em Yauaretê-Ponta, sítio logo abaixo de Açaí.

${ }^{106}$ Certa vez, em conversa num final de tarde em Querari sobre apelidos, ouvi referência a uma garota que dizia ter apelido, mas isso foi comentado como "coisa de jovem que não conhece as regras", e foi duramente repreendido pelos Kubeo presentes na conversa, que afirmavam enfaticamente que apelido é "coisa de homem".
} 
parece apontar para uma distinção entre dois tipos de yahui amiya, um que acompanha o pupui amiya e outro que consiste nesse de uso cotidiano, em brincadeiras, e que estamos analisando. Mais adiante voltarei a esse ponto, e mostrarei como os próprios kubeo formulam essa distinção.

Além dessa primeira circunscrição, temos outra relativa à idade: não é comum, embora eu tenha registrado alguns casos, homens jovens terem yahui amiya ${ }^{107}$; o mesmo acontece em relação aos mais velhos, pois se deve respeitá-los, não cabe referir-se a eles por yahui amiya. Geraldo Edson dizia:

Os velhos brincam. No caso esse o seu Martins, o seu Graciliano, o Jaime...esse outro aqui, entre os velhos eles bagunçam, não estranham não. Mas outros brincarem com eles é sem respeito já; mas a brincadeira entre eles é normal. Quando é muito velho não brincam mais não.

Apresento uma situação que evidencia essa ausência de brincadeiras quando se é muito velho. Certa vez, durante uma festa de caxiri, eu participava de uma conversa com três velhos: José Bernardo (Yúriwawa), Martins (Yuremawa), e Roque (Yúriwawa), sendo o terceiro o mais velho dos três. Eles brincavam com yahui amiya um do outro. Em certo momento, notei que Roque, embora acompanhando e rindo das brincadeiras, não tinha sido referido por nenhum yahui amiya; perguntei então qual era o yahui amiya desse senhor. "Não lembro mais", foi a resposta de Martins, reafirmada por José Bernardo. Quando, no dia seguinte, conversava com Martins, insisti no assunto, e foi então que ele me explicou que depois de certa idade, quando se já muito velho, deixa-se de "brincar" com a pessoa, tratandoa sempre respeitosamente. Tal episódio nos remete a uma formulação de Marcel Mauss, quando escreve

cette question [parentés à plaisanteries] se rattache à l'ensemble de celles que nous posons depuis de nombreuses années: des échanges et des hiérarchies entre les membres des clans et des familles entre eux et avec ceux des familles et clans alliés : phénomène social tout à fait humain $(1928$, p. 3 , itálico meu).

Vemos assim, como o tema das brincadeiras e relações jocosas remete aquele da ordem de senioridade, o que na literatura regional do noroeste amazônico tem sido chamado de hierarquia, e, no idioma local dos Kubeo, é referido pelas noções de "consideração" e

\footnotetext{
${ }^{107}$ Por "jovens" entenda-se o que os Yuremawa e Yúriwawa chamam de Bohtyo, termo que pode ser traduzido como "juventude", e diz respeito a faixa de idade entre 12 e 18 anos, como exposto no terceiro capítulo.
} 
"respeito"; não se usa apelido para os mais velhos, pois eles merecem respeito.

Outro aspecto a ser destacado das listas é que algumas pessoas têm mais de um yahui amiya, atribuídos em contextos distintos, isto é, são casos de pessoas que em certo sentido colecionam yahui amiya; o que significa ter muitos yahui amiya? Penso que isso está relacionado com a idade, e as relações que a pessoa vai estabelecendo ao longo da vida. Um senhor Betowa que vive atualmente em Querari, por exemplo, possui os seguintes yahui amiya: "Terrorista" (mais recente, porque certa vez ele disse, em brincadeira durante festa de caxiri, que era pior que terroristas, era "terrorista de terroristas"); "Carriçu" (yahui amiya mais antigo, que apenas seus conhecidos mais velhos usam com ele); e "Comandante" (não registrei os motivos desse yahui amiya; minha hipótese é que se deve ao modo como esse senhor comumente se veste para ir a roça, com roupa de militar). Nota-se, portanto, que ter mais de um yahui amiya é algo comum entre os mais velhos.

No caso yúriwawa minha lista compõe-se de 16 yahui amiya, dos quais a maior parte diz respeito a animais (Kubuhuku, Piçana, Emu, Moaðo, Ãðã, Koró, Paipi, Bedebo, Kaparo), um a plantas (Wakobu), dois a seres não-humanos (Abuhuku, Piaða), um a instrumentos musicais (Hãhãbu), e um último que se refere a um elemento da natureza (Okort). Em relação à lista yuremawa, disponho até o momento de 24 yahui amiya. Desses, também a maior parte deles se referem à animais (Maruku, Boé, Weku, Apẽ, Menortbo, Kułbo, Kamĩdu, Waoko, Ñããa, Đoðe, Ñama, Taĩtãre), dois a partes de animais (Aða Kahé, Uarĩarakakawé), um a ser não-humano (Wariro), um referente a personagem de desenho infantil (Popay), um como variação em torno do nome da pessoa ("Gegeba", a partir do nome Geraldo) e, por fim, um referente ao fato de certo assunto ser tema constante de conversa da pessoa designada com o yahui amiya (cabaré). No caso betowa, Kaparo (macaco prego), Weabo (Pacú), $U$ (preguiça), e Boi, referem-se a animais. Aqui, antes de continuar, dada a quantidade de yahui amiya que remetem aos animais, apresento alguns comentários sobre os nomes de animais.

\section{Nomes de animais}

Como vemos, os apelidos provêm em sua maioria de nomes de animais, seguido de nomes de seres não-humanos, plantas, partes de animais, e referências diversas como personagem de desenho animado, o próprio nome da pessoa, ou algo sobre o qual a pessoa fala com constância em suas conversações, e por isso passa a ser apelido da mesma. Antes de avançarmos no tema da atribuição de apelidos, faz-se oportuno nesse momento uma digressão sobre animais e nomes. Com efeito, os animais, fonte de muitos dos apelidos, têm nomes? 
Até agora falei de nomes atribuídos a pessoas. No caso dos animais, como já notava Irving Goldman "they have no personal names, only a species designation, for example, borícacü, fish, and forest animals" (2004, p. 349-350, itálico do autor). Contudo, é comum também encontrarmos animais que recebem nomes. O que faz um nome quando atribuído a um animal? O nome faz parte do movimento de familiarização do animal, de sua "domesticação", para usar um termo que ouvi em campo quando se referiam ao ato de criar animais, atribuindo nomes. O Yúriwawa Osvaldo chamou minha atenção para isso em conversa sobre uma paca que ele "domesticou". Vejamos esse caso em mais detalhes.

Certa vez, Osvaldo saiu para caçar em região próxima ao igarapé Marãkãriya. Passou a noite na mata. Já no final da noite avistou uma paca próxima ao igarapé e atirou. Quando foi recolher o animal morto, notou pelo volume de sua barriga que era uma fêmea e estava com filhote. Então decidiu cortar a barriga da paca para retirar o filhote. Para sua surpresa, o filhote de paca estava vivo. Osvaldo então o levou para casa com o propósito de criá-lo como "animal doméstico". A primeira ação, após a decisão de criar o animal em casa, foi atribuirlhe um nome, "Chico". Osvaldo explicou-me que "apenas animais domesticados recebem nomes, os selvagens não têm nomes próprios”. Osvaldo diz:

nome próprio dele [animal] não tem. Só em geral mesmo. Quando fala em kubeo yavi, serve em geral, depois vem especificando ali... [...]. Costuma dar nome para o cachorro, só quando a gente domestica ali que a gente bota o nome, só se for assim, se for do mato mesmo, não tem nome, só em geral; até passarinho se domestica dá nome, quando é domesticado recebe nome.

O cachorro é o animal mais comum criado como "doméstico". Todos têm nome. Afonso, de Açaí, tinha um cachorro que atendia pelo nome de "Chocolate", por conta da cor de seu pêlo (marrom). José Bernardo tinha um chamado "Bob", o que se devia a semelhança com cachorros de filmes, grandes e com farta quantidade de pêlos, que em geral atendiam pelo nome de "Bob", explicaram-me certa vez. Geraldo Edson tinha um cachorro com o nome "Pingo". A esposa de Geraldo Edson, numa referência a embriaguez do marido em festas de caxiri, chamava por vezes o cachorro de "Pinguço". Se o animal não é reconhecido por alguém da casa, não recebe nome. Na casa de Martins Gomes, em Querari, havia um cachorro já velho que, apesar de ser diariamente expulso, insistia em permanecer próxima a essa casa; tal animal não tinha nome, não era reconhecido como daquela família. 
Desses casos, vemos que o nome faz parte da familiarização do animal, estabelece uma diferenciação entre o "animal doméstico", criado por uma pessoa ou família e aquele "selvagem", "do mato", como dizia o Yúriwawa Osvaldo. Fechemos essa digressão sobre animais e nomes, e voltemos ao tema dos yahui amiya. Nossa questão no momento é: como se atribui yahui amiya? Qual sua origem?

\section{Origens dos yahui amiya}

O Yúriwawa Osvaldo tem como yahui amiya Mãtẽ (mucura) que, segundo ele mesmo me explicou, é a forma em Kubeo de waa, termo em Kotiria para mucura, que por sua vez deriva de uma semelhança sonora com o nome da pessoa portadora do yahui amiya: Osvaldo conta que costumava ser chamado "Ova" pelos mais velhos, uma forma abreviada de seu nome, daí "waa", donde Mãtẽ em Kubeo.

Jaime, senhor yúriwawa de Açaí, é referido como Abuhuku, e isso se deve à história do encontro entre ele e um abuhukut ${ }^{108}$ na mata. Conta-se que certa vez Jaime saiu para caçar. Achou um jacu, atirou e a ave caiu num lugar à sua frente. Quando chegou ao local para pegar a ave, ela tinha sumido, e já estava em outro lugar mais a frente. Neste momento, sentiu um abraço de algo como um "homem gigante", cujo rosto ele não conseguiu ver, mas tem certeza que era um "demônio". Acordou no dia seguinte, no mesmo lugar onde estava durante o encontro, sujo, arranhado. Voltou para casa nesse estado. Ficou um mês sem falar, "como se estivesse com o pensamento em outro lugar", explicou Luiz Gilberto quando comentei essa história com ele. Apenas depois desse tempo voltou a falar e então contou o episódio, mas não se não lembrava o que exatamente tinha acontecido.

O motivo da atribuição é mais claro no caso dos yahui amiya baseados em nomes de animais, pois em geral o nome se deve a algum tipo de semelhança - seja física ou de comportamento - presumida entre a pessoa e o animal que lhe empresta o nome. O yahui

\footnotetext{
${ }^{108}$ Como vimos, e retomo aqui brevemente, os Kubeo de Açaí e Querari comumente falam de "seres invisíveis" que habitam as matas e rios. Há dois termos gerais em Kubeo para designar tais seres: hoktwzt ("espíritos da mata"), usado para se referir aos seres que habitam o espaço da mata; e moawzt ("espíritos da água"), aqueles que habitam o ambiente aquático. Há vários tipos de hokttwa e moawa. Entre esses seres invisíveis, abuhukzt (pl. abuhuwa) designa o mais conhecido; tal termo é traduzido como "espírito", "demônio", "diabo" e "ser da floresta". Abuhukt é dito um "ser invisível", no sentido, se bem entendi as explicações que os Kubeo me forneceram, de que eles são não se deixam ver. Caso a pessoa o veja, sofrerá as consequências disso, como a história de Jaime a que me refiro acima.
} 
amiya mоaðo, traduzido por bacural ${ }^{109}$, foi dado à certo yuriwakt por sua esposa pois, dizia ela que no início do casamento ele não dormia a noite para namorar, tal como o bacurau, que tem o hábito de sair durante a noite para se alimentar. Mas esse mesmo yuriwaku também tinha um segundo yahui amiya; assim, segundo Osvaldo:

Do Gabi não sei... é bacural, não sei porque chamavam de bacural; mas parece que apelido dele mesmo é Hiabu, jácaré, não sei quem deu esse apelido para ele, acho que foram os próprios colegas.

Outro apelido referente a nome de animal, e também atribuído pela esposa é Paipi (quati ${ }^{110}$ ) que, segundo me explicaram, foi motivado pela observação da esposa de que seu marido agia sexualmente como o quati, referindo-se à disposição e vigor sexual dele. Mas ouvi de outra pessoa explicação diferente para esse yahui amiya. Osvaldo dizia: "Ricardo, Paipi, deve ser por causa dos dentes dele... o pessoal inventa, Paipi que tem aquele tipo de dente". Já Kubuhukt, apelido de um Yúriwawa de Açaí, se deve ao fato dele ter muitos filhos, tal como o bicho de pé tem muitos ovos. Osvaldo dizia: "você vê que o bicho de pé ali, quando ele tem ovo ali, tem muitos, devido isso, que ele tem monte de filhos. Assim que eles falam, não sei se é verdade. Bicho de pé só é um, mas tem bastante ovo”. Sobre o apelido "Minhocão" de um Yuremawa de Querari, Geraldo Edson conta o seguinte:

Minhocão vem lá de São Gabriel. A gente tava batendo bola, lá para o lado de Dom Bosco, com disputa de cocão, a gente montou um time, ele pegava a bola e jogava, mas não tinha força de jogar. "Você não tem osso nos dedos, não tem força, é minhoca já". Aí esse nome não acaba mais, até hoje.

Há também yahui amiya que se referem a outros elementos que não animais. É o caso de $H \tilde{h} h \tilde{a} b u$ (maraca), que foi dado porque aparentemente o pênis do portador desse apelido tinha uma forma que remetia a do maraca. Outro homem tinha como yahui amiya Okort (gota de água); segundo me explicaram, foi dado a pessoa pelo pai porque, quando criança, chorava muito, como acontece com a gota de água do orvalho, que cai apenas com um toque simples. Segundo Osvaldo:

\footnotetext{
${ }^{109} \mathrm{O}$ bacurau (Hydropsalis albicollis) é uma ave caprimulgiforme da família caprimulgidae. Conhecido também como curiango, curiango-comum, ju-jau, caribamba, amanhã-eu-vou (em Minas Gerais), ibijau, mede-léguas, acurana e a-ku-kú (nomes indígenas - Mato Grosso). Fonte: http://www.wikiaves.com.br/bacurau

${ }^{110}$ O quati (Nasua nasua) pertence ao Filo Chordata, à Classe Mammalia, à Ordem Carnívora e à Família Procyonidae. É um animal que pode medir $30,5 \mathrm{~cm}$ de altura, e o comprimento variar entre 43-66 cm, mais $22-$ $69 \mathrm{~cm}$ de cauda; pode atingir até $11 \mathrm{~kg}$ e obter uma ninhada por ano. Seu comportamento é diurno (FRANCIOLLI, 2007, p. 28).
} 
No caso, o Adelson alí, quando ele era bem pequeno, ele era chorão, ninguém podia tocar nele ou olhar ele, já começava a chorar. Aí o pai dele uma vez falou "não vai olhar ele não, não vai tocar nele não, que vai chorar, parece gota de água, quando você pega numa folha a gotinha de água já cai", desse jeito ele falou para o filho dele, Okort, aí olha aí, até hoje, o apelido verdadeiro não aparece mesmo.

Em conversa com José Bernardo sobre as histórias de yahui amiya, ouvi a seguinte explicação:

Apelido em Kubeo fala yahui amiya; apelido é nome de brincadeira. Avôs já tinham apelidos. Já é outro apelido, próprio, não é nome de benzimento. [...] nós também, Yuremawa, Tarabuwzt, têm nomes de benzimento; até Wanano tem; esse Wanano não aparece nome de benzimento, só de brincadeira ele chama. Esse nome de benzimento chama põe amiya, aí depois que vem yahui amiya. Nome de benzimento tem história, tem tudo. [Yahui amiya] alguns têm, outros não, nem todos. Ñamahuã tem história, porque meu avô, era o pai de meu pai, tinha esse nome, aí era namorador mesmo ele, aí se tu vai namorar, ele fala, vai ficar igual esse Yaí, vai ficar namorador, aí ele tem história. Esse Yai tem muita história, era namoradeiro ele. Uma mulher, parece que ela não tinha marido, ele namorava com ela. Quando ela ia lá na roça dela, ela ia nessa roça, ele falava para a mulher dele "vou pescar", aí escondido saia e pegava a mulher, agarrava e voltava. Outro filho, sobrinho dele, já sabia o que ele tava fazendo. A mulher foi na roça. Disseram "ele deve tá namorando, bora ver"; Mas ele tava aí, bem no meio da roça, fazendo... pegava um pedaço de pau, e jogavam nele. Depois ele tomava banho, subia na árvore, caia dentro. Quando ela voltou da roça, ele tava tomando banho, no mesmo porto. Aí ele subiu na árvore, aí caia na água. Outra história foi a mesma coisa, ele mesmo foi com ela mesmo. Ela ia tostar farinha. Ele saiu de manhã, falou para a mulher dele "vou pescar, vou voltar de tarde, 5 h ou 4h"; mas ele não foi, ficou atrás, escondeu canoa dele, ficou atrás olhando. Nesse tempo todos viviam na mesma maloca. Saiu todo mundo, na roça, outro na pescaria, e ela tostando farinha. Ele entrou e agarrou ela, e a farinha ficou queimando; queimou mesmo, já preto assim. Depois de fazer essa coisa ele foi pescar. Mesmo queimado ela tostou e deixou uma lata. Quando ele voltou, aí mesmo, essa farinha que ele fez queimar, já fazendo na cuia, ela disse "agora você tá com fome", "come essa farinha já preta mesmo". Durou quase 2 semanas essa farinha aí [risos].

Perguntei a José Bernardo, na mesma conversa, sobre a história de Wãiñarz:

Wãiñart não tem história. Waibowz não tem história, é um passarinho; com nossa língua, é atravessar o rio, aí, às vezes, brincando, dizia porque você chama esse nome de brincadeira Waibowz, "porque sou pescador e atravessava muito o rio para o outro lado". Odort também não tem história.

Aqui, José Bernardo distingue "nome de benzimento", que ele chama põe amiya, e apelido, yahui amiya. Logo em seguida conta a história do yahui amiya Yaí (garça) que, se 
olharmos a lista de pupui amiya apresentada no quarto capítulo, veremos se tratar de yahui amiya próprio do pupui amiya Ñamahuã. Uma diferença entre pupui amiya e yahui amiya é, segundo José Bernardo, que o primeiro tem história, isto é, parece não existir pupui amiya sem uma tradição narrativa; já no caso dos yahui amiya, "Alguns têm, outros não, nem todos".

Paulo Espitia explicou que os apelidos, em seu "uso correto", são associados aos nomes de benzimento, e que o uso que se faz hoje em dia "não respeita esse uso tradicional", distinguindo dois tipos de yahui amiya, algo que já apontamos em momento anterior de nossa análise. Assim, Paulo Espitia diz:

Esses apelidos, hoje em dia, eles estão dando apelidos de qualquer maneira. Por exemplo, geralmente eles davam, quando eu era adolescente, eles davam nome por conta das partes íntimas, então para mim isso já foi uma bagunça, uma brincadeira, então tem esses nomes. Agora, esses apelidos que eles têm geralmente é isso. Agora... boe... não sei se é nome típico, indígena, se deu por conta do pênis do cara... vai nomeando [risos]. Antes cada nome tradicional vinha acompanhando do apelido, não era para inventar; então, por exemplo, quem tivesse Mihakt, então eles chamam de Abuhukt; Miha Abuhuku eles chamam, é um bichinho, espécie de tamanduá. Não era inventado, cada nome tradicional era acompanhado com seu apelido, então era muito usado só apelido, as pessoas eram mais conhecidas pelo seu apelido; hoje é só brincadeira, e brincadeira de mal gosto até [...]. No caso, Ricardo, paipi, quati, não sei se esse é apelido que acompanha o nome tradicional... não sei... no meu ponto de vista é uma brincadeira... não tem nada ver com tradição, é contemporâneo já. [...] Às vezes eles combinam muito mais com nomes dos brancos. No caso, Raimundo, ao invés de dizer Raimundo, eles diziam "meu", daí deram o nome de "meu". Kubuhuku, Afonso, é a mesma coisa; na língua wanano eles falam dahpusu, que é bicho de pé, aí se assemelha o som, olha só, "Afonso, dahpusu", daí Kubuhukt, na língua kubeo "bicho de pé". Não são mais sérios, são brincadeiras, não são tradicionais. Gabriel, no caso, quando eu era jovem, chamavam ele Moakodohĩdo, "ovo de bacural", olha o saco dele, todo rajado, bem parecido com ovo do bacural.

Josefina, mãe de Paulo Espitia, que acompanhava a conversa, completa a fala do filho:

Antigamente, quando terminava caxiri, assim amanhecendo, eles ficavam brincando assim... tu é assim, tu é assim... brincando mesmo. Então nomes tradicionais mesmo são muito poucos, e são muito repetitivos para as pessoas.

Vemos nessa fala a formulação de dois tipos de yahui amiya: um que acompanhava o nome de benzimento, e outro que "não é sério", nome de "brincadeira". Também o Yuremawa Geraldo Edson avançou uma distinção entre dois tipos de apelidos: "apelido tradicional", que acompanha o nome de benzimento, e "apelido de brincadeira", comum nos dias de hoje e que 
não tem relação com o "apelido tradicional”. Segue sua explicação:

Aí em relação à esses apelidos, tem aqueles apelidos mesmo que não convém com aquele nome tradicional, ou seja, baseado por fora, que foi dado pelos colegas, pai ou mãe brincando. Aí tem aquele apelido que eles chamam com nome tradicional mesmo. Tem o apelido de brincadeira, mas tem o tradicional, assim, dessa forma. No meu caso, não é de brincadeira, é nome tradicional mesmo; aí varia em relação já como se fala em português, ou com outra língua, vão falando de acordo com a língua deles, em relação a esse nome aí. Tem vários significados também, cada língua. Porque o tradicional mesmo... esse Boé era o remédio dos velhos, dos antigos; quando eles faziam o dabucuri, eles comiam esse Boé, porque ele dava aquelas chicotadas, quando fazia aquele dabucuri com peixes, frutas, com cunhado dele ou concunhado, ou próximos dele. Então os velhos davam esse Boé para ele... quando ele corta, não machuca, no terçado também, ele é duro... é para evitar o corte para essas crianças, quando forem adultas, para fazer essas coisas... então eles davam ele, quem comia ele não se machucava, nem no corte, só ficava por cima aquela marca e sumia. Aí nessa questão... ele brincava assim... para comer esse, antes da chicotada. Ele falava "eu sou duro, não fere para mim não, eu sou Boé", por isso que deram esse nome para ele, porque cada vez que chicoteavam ele, não feria não, ele era duro, porque ele [avô de Geraldo Edson] comia isso quando era criança. Então dessa forma surgiu, deram esse nome de Boé, que não feria ele. Também a estatura, ele era baixinho. Aí dessa forma, o meu avô... o meu pai contando essa história, eles já me apelidaram com esse nome de benzimento, quando tava criança ainda, aí que surgiu esse nome. Aí quando fala com a língua dele. [...] tem às vezes aquele apelido que não combina com a pessoa, aí a pessoa fica revoltada já... antigamente não chamavam de apelido... esse apelido... ele concretizava como tradicional já... eles tinham aquele apelido já visado em alguma coisa, aves, animais da água... todas essas coisas. No caso, meu bisavô tinha o apelido de Hiabu, jacaré; ele era bravo, ele andava com patente, espada. Com ele era só duas palavras... gostava de dar lapada, amarrava mulher dele e batia. Ele era bravo. Deram o nome dele como Hiabu, jacaré. Agora não sei se era questão da mulher... ele tinha cinco mulheres, cada dia uma, que ia com ele no trabalho. Acho que foi questão das mulheres que deram para ele Hiabut. Agora outro era Huhtmakt, aquele martim-pescador, era meu avô também ele, esse era outro aí. Tinham vários aí... tinha esse Huhtmakt, tinha esse Ukupiãmakt... tinha vários aí... esse Boemakt, todos tinham nomes de animais, mas nomes, termos tradicionais deles já. O nome verdadeiro mesmo, de batismo do padre, não aparecia não, só aparecia mais o tradicional dele. Cada comunidade que ele parava, ele chamava só o apelido dele, o nome tradicional dele. Esse que era apelido transformou já tradicional para ele, não tinha mais como chamar o nome que o padre batizou não. A comunidade conhecia pelo benzimento, usou como tradicional dele já. Foi dessa forma. Mesma coisa as mulheres, elas tinham o nome deles, independente da língua que elas falavam, tinha o tradicional deles. Hoje em dia ninguém fala, fala mais questão do apelido, que não seja tradicional. Alguns têm aquele apelido tradicional mesmo, alguns não, levam só na brincadeira mesmo; o tradicional dele seria outro e eles chamam só de apelido normal mesmo. Aí essa a questão, hoje em dia... no caso aquele aluno, aquele Juan, cunhado do Raimundo, em português ele é Juan, já apelido que os colegas dele deram é Yiro, gafanhoto, não sei se é grilo ou não... Yiro é aquele que fica na roça, que canta aí; já tradicional dele é 
Wekó, seria nome tradicional dele... é dessa forma... aí fica, nome tradicional dele é esquecido, e aparece aquele apelido que deram os próprios colegas... tem essas coisas aí. [...] assim que acontece hoje em dia... a gente fala mais em apelidos que eles próprios deram aí. Mas uns falam e outros não, outros ficam com vergonha aí. [...]. Eduardo chamam de Maruko, macaco da noite, apelido de brincadeira... tradicional mesmo é diferente, não sei qual é [...] não sei porquê do nome, acho que não dorme a noite; foram as minhas tias que deram esse nome para ele. Toda a vez que minha tia, minha avó finada, quando ia para a roça, trazia abacaxi em casa, banana, algumas coisas; aí quando ele via alguns doces, aí ele não amanhecia na casa dele não; sempre amanhecia na casa da minha avó já. Ele viu que iam preparar algum mingau, então ele tinha que tomar junto lá na casa deles. Nesse tempo eles acordavam $5 \mathrm{~h}$ já, ir para o porto, tomar banho, trazer água para fazer mingau. Então quando eles faziam mingau, ele já entrava lá dentro de casa, entrava e sentava em cima da mesa, esperando eles. [...] Aí bagunçava com ele, chamava ele de Maruku, porque esse Maruku às vezes chora quando ele tá goirando, aí dessa palavra de goirar pegaram ele e colocaram já... "entrou esse animal para goirar pra gente", bagunçando já, "entrou esse macaco da noite para goirar a gente", daí deram o nome dele já; chegava no escurinho e ficava lá. Então daí deram o apelido e não acabou mais, continua até hoje. $\mathrm{O}$ tradicional ninguém chama mais... não sei qual o nome tradicional dele... chama mais em questão de brincadeira, chama Maruku, chama "Federal"...

Nesse momento, interrompi a fala de Geraldo Edson para peguntar porque chamava Eduardo de "Federal". Segue sua resposta:

Não sei, só mulher dele sabe, mulher que dá apelido para ele, não sei porque. Ele não dormia não, andava a noite inteira vistoriando quando ela bebia por aí, por isso que é "Federal". Mas até hoje isso não acaba não, o verdadeiro nome tradicional mesmo ninguém ouve falar dele, só brincadeira já.

O Yúriwawa Osvaldo, quando explica seu yahui amiya, também fez essa distinção entre dois tipos de apelidos:

Esse aí foi invenção dos outros... da minha própria pessoa é Yaí; esse de Mãtẽ é da própria comunidade, eles inventaram. Os indígenas não pronunciam o nome completo já não; aí os velhinhos chamavam de Ova, aí outro foi querer inventar que quando Wanano fala Ova tá referindo a Mãtẽ, "mucura", aí começou isso. O nome verdadeiro, o apelido verdadeiro, quase não aparece, só aparece esse aí agora.

Vemos, portanto, que os Yuremawa e Yúriwawa distinguem um "apelido tradicional", "verdadeiro", do "apelido de brincadeira", e que apontam o segundo tipo como de uso mais comum na comunidade, sendo o primeiro pouco usado e mesmo desconhecido para alguns, como afirmava mais acima Geraldo Edson: "O tradicional ninguém chama mais... não sei qual o nome tradicional dele...". Esclarecida a distinção, avancemos mais no tema da atribuição de yahui amiya. 
A atribuição de yahui amiya nem sempre é clara para aquele que o recebe, ou para aqueles que se referem à pessoa pelo yahui amiya; há muitos casos de yahui amiya que aparentemente não têm justificativas; digo "não têm justificativas" tal como muitos Kubeo dizem, isto é, não é um desconhecimento meu apenas, pois muitos não sabem porque determinada pessoa tem certo yahui amiya. Contudo, o fato de não ser claro a razão de alguém ter determinado yahui amiya não impede que ela seja foco de brincadeiras.

Uma vez atribuídos, os yahui amiya seguirão com a pessoa. Sobre atribuição de yahui amiya, Geraldo Edson tem a seguinte explicação:

Tem gente com mais de um apelido, Alexandre tem "preto", "Sokó", "Mico"; tinha um nosso colega que tinha o apelido de "Salsicha", outro era "Cachorrão", outro era "Noiado", e até outro era "calabresa", olha aí. Tem muito nome aí, como dizia meu pai, esse aí é nome de juventude, quando a pessoa faz juventude que o pessoal gosta de dar nome assim, aí não acaba mais não. No caso esse finado meu pai deram o nome de Curupira, Boraro, aí não acabava mais não; sempre brincavam com ele [...]. Quem dá apelido feio são aqueles Tukano, eles que dão apelido feio; até dão apelido da parte íntima do cara ou da parte íntima da mulher. No caso, não sei se já morreu, um velho lá do Papuri, apelidaram ele de Chinaka. Em Kubeo a maioria é nome de pássaros, de peixes, macacos, essas coisas... isso que falo, tem gente que tem mania de apelidar com nome de coisa feia mesmo. [...] quando a mãe ou o pai dão apelido para a criança, ela também não acaba mais, vai para o resto da vida.

Os yahui amiya são usados cotidianamente, em situações que indicam algum grau de proximidade. Apresento alguns casos etnográficos de brincadeiras que observei entre Yuremawa, Yúriwawa e mesmo Betowa, para sustentar essa hipótese.

Num dia do mês de junho de 2017, eu estava na casa de uma família kubeo comendo um pedaço de carne de boi assada. Amós, Yuremawa, chegou para falar comigo sobre uma demanda da escola local. Ofereceram um pouco de carne a ele. Nesse momento, Amós viu um dos filhos de José Abelardo passar e gritou:

- Comer carne de boi, Boi!

A fala era uma brincadeira com o yahui amiya dessa pessoa, "Boi", e a carne que se comia no momento. Aqui, vemos um Yuremawa dirigindo uma brincadeira com yahui amiya a um Betowa, ou seja, trata-se de grupos distintos, sendo os Betowa considerados menores, até mesmo "não Kubeo", como já destaquei em outro momento. Aqui, corroboro minha afirmação inicial de que o uso de yahui amiya não pode ser explicado adequadamente na 
chave do parentesco, pois parece antes que elementos como amizade e residência na mesma comunidade são fatores relavantes para entender com quem se brinca e porque se brinca. Vejamos mais um caso de uso de yahui amiya com Betowa.

Certo dia, Marci estava em casa limpando alguns peixes. Vi um que me parecia uma piranha, mas não tinha certeza, então perguntei a Marci:

\section{-É piranha?}

Nesse momento, Julian (jovem irmão de Luiz Gilberto, marido de Marci) apareceu e respondeu:

-É pacú.

Marci logo fez a brincadeira:

-É Rafael!

Ela se referia a um Betowa que tinha por apelido Weabo ("Pacú"), morador de comunidade do lado colombiano do Uaupés. Aqui, uma Yúriwawa brincava com o yahui amiya de um Betowa. Esse episódio e anterior remetem a questão da relação entre tais grupos.

Os Betowa são tidos pelos Yuremawa e Yúriwawa como outra gente, não Kubeo. Ouvi algumas vezes, em contexto de conflito e outras de zombaria em festas de caxiri, o uso da expressão "gente makú" para referir-se a eles, ou ainda "makusito", categorias essas, tal como as usaram os Yuremawa e Yúriwawa nesses contextos particulares, de diminuição do outro, de supressão de relações de consideração e respeito (na narrativa de origem, os Betowa são mencionados como o último grupo a ser nomeado pela avó Huredanaçu, e referidos como “criancinhas"). São considerados também como "forasteiros" nesse trecho do Uaupés, "estrangeiros", gente que chegou recentemente e, portanto, que não apareciam nas narrativas Yúri Parãmena como ocupantes legítimos daquele trecho de rio, mas antes pertenciam às cabeceiras, região, segundo o código hidrográfico compartilhado pelos povos tukano, dos grupos ditos de baixa hierarquia ${ }^{111}$; essa perspectiva é veementemente contestada pelos

${ }^{111}$ Lembremos que essa ideia, compartilhada pelos povos tukano de modo geral, consiste em afirmar que a ocupação do rio pelos ancestrais a medida que saem da cobra canoa se dá segundo a seguinte disposição: grupos de alta hierarquia/regiões próximas a foz; grupos de baixa hierarquia/regiões próximas à cabeceira. Esse código 
Betowa, que se consideram Kubeo e ocupantes legítimos do trecho onde vivem os Yúri Parãmena.

O que vemos, voltando aos dois episódios de brincadeira citados, é que, embora haja uma distância na ordem de consideração entre eles, e uma situação conflituosa acerca da legitimidade da ocupação betowa nesse trecho de rio, isso não impede que se brinque, o que nos faz pensar que tal relação parece ser possibilitada por outros fatores, como a convivência e amizade, fatores esses que se sobrepõem aquele do parentesco e da ordem de consideração, como já destaquei acima. Avancemos.

Outro episódio de uso de yahui amiya se deu numa manhã de domingo. Pousou na pista um avião do exército, que trazia material para o 2. PEF de Querari. Como acontece nessas ocasiões, muitas pessoas se reuniram no entorno da pista para observar o avião. Nesse momento, eu conversava com Maria, kotiria moradora de Querari e casada com Geraldo Edson. A alguns metros de distância notamos que Alexandre (Yuremawa de Querari) voltava para casa. Maria, assim que o viu passar, disse em voz alta:

\section{-Sokó, olha Sokó!}

Desse modo, fazia referência ao apelido de Alexandre. Segundo Maria, Sokó é um pássaro que come piaba, e tem o pescoço comprido, sendo que o apelido foi atribuído, segundo me explicou, por conta da semelhança física.

Há situações que a simples menção do apelido de alguém provoca o riso, mesmo que não seja a intenção. Lembro certa ocasião em que conversava com José Bernardo, em Açaí, sobre benzimentos e pessoas nas comunidades próximas que tinham conhecimentos para curas. José Bernardo citou o caso de uma mulher que tinha dor na perna e procurou benzimento; ao se referir a ela, não lembrava o nome de seu marido (Betowa, morador de Puerto-Colombia), então disse "a esposa de Bia Kahé". Tal menção ao yahui amiya, feita por conta do esquecimento momentâneo do nome de branco da pessoa em questão, fez com que os demais presentes na conversa (esposa e um dos filhos de José Bernardo) começassem a rir.

Em outra ocasião, estava conversando com Luiz Gilberto numa manhã. Notei que o tempo começava a fechar, indicando chuva. Nesse momento, Alexandre passava perto da casa de Luiz Gilberto, e então se deu a seguinte sequência de brincadeiras:

hidrográfico foi formulado por Goldman (1963) a partir do primeiro trabalho junto aos Bahúkiwa em 1939-40, e desenvolvido por Christine Hugh-Jones (1979) a partir de seu campo junto aos Barasana do Pirá-Paraná em 1968. 
Alexandre: Adriano!
Gilberto: Adriano!
Alexandre: pega tabacão e faz passar essa chuva!
Gilberto: está assim não porque você pegou aracu pela primeira vez né!

Todos riram. Alguns minutos depois, passou Elizeu, filho de José Abelardo, e Luiz Gilberto gritou:

- $U$ ! (Preguiça).

Esses episódios merecem alguns comentários. Em primeiro lugar, o uso do yahui amiya "Adriano" é uma referência, me explicou Luiz Gilberto, ao jogador de futebol conhecido como Adriano Imperador, pois durante os jogos de futebol pela tarde na comunidade Alexandre teria dito que jogava tão bem como Adriano. A referência ao tabaco para evitar a chuva é outro elemento muito comum em brincadeiras, pois parte do conhecimento de que alguns velhos podem evitar chuva soprando a fumaça de tabaco. Luiz Gilberto conclui a brincadeira fazendo referência ao aracu, que é considerado um bom peixe, liso, sem muito espinho, de carne boa, ou seja, a graça da brincadeira feita por Luiz Gilberto está em dizer que Alexandre não era bom pescador, e por supostamente pescar aracu pela primeira vez, ocasionou chuva. Já “ $U$ ” fazia referência a supostas semelhanças físicas da pessoa em questão com o animal preguiça.

Andrello, em comunicação acerca do tema dos nomes, faz as seguintes considerações sobre os apelidos:

Mas, ao facilitar a individualização, são sobretudo os apelidos e os episódios em que foram atribuídos que revelam algo das histórias e trajetórias particulares desses coletivos. Esses nomes jocosos, tal como mostra Stephen Hugh-Jones (2002), eram de uso cotidiano e atribuídos por cunhados ou cônjuges potenciais. Ainda que descorteses, pois se tratam de nomes de bichos e plantas ou características e hábitos corporais caricatos, não chegam a ser exatamente pejorativos, já que exibidos sem maiores constrangimentos. Do ponto de vista da pessoa, os apelidos caíram em quase absoluto desuso, tendo sido substituidos de modo bastante generalizado pelos nomes obtidos no batismo cristão. Mas, do ponto de vista dos clãs, os apelidos permanecem como o principal marcador de identidades: os membros de um clã costumam ser chamados de "filhos de X", sendo esse "X" o apelido do ancestral fundador (2013, p. 9-10, itálico meu). 
Vemos, portanto, que, ao contrário do que diz Andrello, o apelido não caiu em desuso; é muito usado e em muitos contextos. Mas aqui é preciso esclarecer: o apelido no sentido de "nome jocoso" permanece ativo e amplamente usado; no sentido de "nome comum" formulado por Hugh-Jones (2002), de fato, tudo indica que caiu em desuso. O que caiu em desuso, portanto, é o apelido ligado ao nome de benzimento, esse, lembrando por uns, esquecido por outros, não parece receber a atenção que o yahui amiya de uso cotidiano tem.

Diante dessa diversidade de usos e contextos, um leitor de Radcliffe-Brown (1949) pode inicialmente se perguntar sobre sobre as relações nas quais se permite e aquelas nas quais o uso de yahui amiya é interditado. Como já dito, os jovens comumente não recebem apelidos, e na velhice os apelidos são deliberadamente esquecidos; não se brinca com alguém muito velho. Mulheres, apesar de serem as principais atribuidoras de apelidos, não brincam, de modo geral. Também notamos ausência de brincadeiras com apelidos entre pais e filhos, e avôs e netos. Além dessas relações, não observei nenhum tipo de interdição para outras modalidades; sempre que julgava que determinada relação não era passível de brincadeiras, via no momento seguinte minha hipótese ser solapada pelo riso produzido entre pessoas envolvidas na citada relação, como as diversas brincadeiras entres Yuremawa, Yúriwawa e Betowa. Contudo, parece-me que melhor que pensar relações nas quais se usa ou não yahui amiya, interessa antes pensar a criatividade desses yahui amiya, ou seja, o que eles fazem? Minha hipótese é que os yahui amiya, por meio de aproximações, produzem alegria, o que significa dizer, produzem vitalidade, "força", o que implica no crescimento da comunidade, tal como o pupui amiya permite o "growth magic" da pessoa. Antes de avançar tal hipótese, contudo, devemos lembrar que as brincadeiras envolvendo essa categoria de nomes, embora de uso cotidiano, têm as festas de caxiri como seu contexto por excelência. Sendo assim, apresentarei brevemente $^{112}$ o complexo das festas entre os Kubeo, para em seguida analisarmos algumas situações de brincadeira com yahui amiya durante essas festas.

\section{Manejando vitalidades: as brincadeiras em festas de caxiri}

A festa ${ }^{113}$ se configura como o contexto por excelência do yahui amiya ${ }^{114}$. Os Kubeo usam o termo torohtri hãrãwz para se referir ao que chamamos de "festa"; termo que pode

\footnotetext{
112 Com efeito, as descrições que se seguiram serão "breves". Festas, tal como Beatriz Perrone-Moisés (2015) explicitou em seu trabalho de livre-docência, consistem em um dos eventos centrais da socialidade ameríndia e mereceria um tratamento mais detido.

113 O leitor já deve ter notado que opero com uma noção mais alargada de "festa", tomando-a como matriz relacional central da vida social indígena, tal como proposta por Beatriz Perrone-Moisés (2015): “A tradução é
} 
ser traduzido como "dia de alegria". As festas podem incluir dabucuri - prática de oferecimento de alimentos (carne de caça, farinha ou frutas) e/ou produtos artesanais entre pessoas e grupos -, e mesmo ser a conclusão de Jurupari. Contudo, o último Jurupari de que tive notícia em meu campo se deu início dos anos 1990. Já o dabucuri é mais frequente, embora não muito abundante, registrando-se poucos ao longo do ano.

As festas em Querari acontecem com frequência semanal. Em Açaí acontecem com menor frequência, em parte devido ao pequeno número de famílias que vivem nessa comunidade atualmente, e porque seus moradores por vezes frequentam festas em Querari. Nas comunidades colombianas que conheci mais próximas, a saber, Puerto-Playa e Montenegro, também há festas com certa regularidade ${ }^{115}$. Mas Querari ocupa certa posição central no que diz respeito às festas. Nesses momentos, há um elemento que não pode faltar: o caxiri $^{116}$.

As festas de caxiri podem ser feitas por diversos motivos. No geral, ela é feita como comemoração de um evento, seja aniversário de uma pessoa da comunidade, atividade da escola, alguma data comemorativa do calendário anual, festas religiosas, ou celebração da realização de trabalho comunitário, os chamados ayúris, onde a bebida de caxiri é oferecida como recompensa pelo trabalho.

Durante as festas de caxiri, os convidados bebem, dançam, conversam, e fazem muitas piadas e brincadeiras a partir de yahui amiya e histórias diversas. Antes de avançar na análise de alguns episódios de brincadeiras em festas de caxiri, faz-se necessário descrever como acontecem essas festas. Elas seguem certas linhas gerais. Apresento a seguir breve descrição de quatro festas, para depois proceder a análise.

precisa: trata-se de eventos coletivos que reúnem anfitriões e convidados em torno de fartura de comida e bebida, dança e canto, jogos... e têm o alegrar-se juntos como objetivo" (2015, p. 19).

114 É importante que tal afirmação não conduza a confusões: os apelidos são de uso cotidiano, em qualquer situação de coletividade ouvimos brincadeiras com apelidos. A festa é apenas um dos momentos onde seu uso é mais intenso.

115 Na comunidade colombiana de Puerto-Colômbia não aconteciam festas de caxiri por conta da orientação religiosa do capitão (evangélico); contudo, seus moradores participavam de festas em Açaí e Querari.

116 Os Kubeo usam o termo ũkũye para se referir a bebida em geral. No caso do caxiri, os termos variam de acordo o tipo de caxiri; por exemplo, caxiri de milho se diz weakoró. Há um termo para caxiri em geral, peçiakoró, mas, segundo conversa com alguns velhos de Querari, "peçia” não é um termo da língua kubeo; disseram que pode ser Baniwa ou Kuripako, e remete a dita "língua original” dos Yuremawa e Yúriwawa. 


\section{Primeira cena de festa (18 de junho de 2017)}

Geraldo Edson, então presidente da associação UNIARWA ${ }^{117}$, recebeu da FOIRN a doação de equipamento de radiofonia, e propôs a construção de uma casa para abrigar esse equipamento e funcionar como espécie de escritório da associação. Para isso, como meio de levantar recursos para compra de folhas de zinco para a cobertura dessa construção e combustível para o corte de madeira, a comunidade Querari decidiu organizar feiras nos bairros ou vilas para arrecadar dinheiro.

A primeira feira aconteceu no bairro São José. A segunda, a qual acompanhei e descrevo aqui, aconteceria no bairro Aparecida (em colaboração com a comunidade de Açaí). Para essa feira, Luiz Gilberto e Martins Gomes, moradores do bairro em questão, com o propósito de obter produtos para venda na feira, foram pescar e caçar no igarapé Marãkãriya, onde permaneceram por quatro dias. Ao mesmo tempo, suas respectivas esposas, Marci e Letícia, produziam caxiri de macaxeira.

O dia de feira começou com oração na igreja, logo pela manhã. Depois da oração deram início a feira da vila Aparecida no centro comunitário, com venda de produtos e oferecimento de caxiri, tudo acompanhado de música. Entre os produtos disponíveis para compra, havia peixe moqueado, pimenta, caxiri, carne de paca, banana, abacaxi, beiju. No final do dia, por volta das 16h, Luiz Gilberto, o coordenador do evento, encerrou a feira, e convidou os moradores da vila Aparecida a sua casa para prestação de contas do valor arrecadado, fazer avaliação da feira, e continuar bebendo caxiri.

Na reunião, Luiz Gilberto falou das pessoas que contribuíram com algum valor, e a quantia arrecadada. Dessa quantia, parte iria para a associação, e outra parte para constituir um fundo da vila Aparecida. Depois da reunião, Luiz Gilberto ofereceu caxiri as pessoas presentes e outras que foram chegando. Além do caxiri preparado por Letícia e Marci, haviam outras pessoas servindo caxiri também. A bebedeira foi acompanhada de música. Seguiram bebendo até tarde da noite.

No dia seguinte, algumas pessoas chegaram a casa de Luiz Gilberto logo pela manhã, em busca de mais bebida, e como havia caxiri, a bebedeira seguiu toda a manhã e parte da tarde, também acompanhada com música. Durante a festa, contavam piadas, muitas histórias 117 Criada em 2016, essa associação reúne as comunidades do trecho de rio entre comunidade de Querari e
comunidade de Jutica (Kotiria). 
engraçadas, e faziam brincadeiras entre si, sendo que maior parte delas envolvia temas sexuais e brincadeiras com as filhas um do outro.

\section{Segunda cena de festa (23-25 de junho de 2017)}

Com o propósito de construir a casa de radiofonia da UNIARWA, e dando continuidade a ideia das feiras nos bairros, foi a vez da vila São João. Maurício, Desana, morador de São João, na semana anterior, durante festa da vila Aparecida, havia dito em tom de desafio, e em estado de embriaguez, que sua vila iria arrecadar mais dinheiro que todas as outras. Afirmação que criou certa expectativa nas pessoas de modo geral.

A feira começou na sexta-feira no período da tarde. A construção de barracas no campo de futebol da vila e outros preparativos já tinham começado na quarta-feira. Havia cerca de oito barracas ao redor de parte do campo de futebol. Maurício montou uma barraca com venda de caxiri, vinho de açaí, refrigerante e san cocho. Geraldo Edson também tinha uma barraca com caxiri, bolo e banana. Alexandre, Yuremawa morador de São João, montou barraca com caxiri e produtos da cidade como salgadinhos industrializados, refrigerante, açúcar, arroz e bolacha. A despeito da diversidade de produtos a venda, todas as barracas tinham caxiri.

A feira ocupou todo o período da tarde. À noite, teve apresentação de quadrilha de moradores da comunidade em geral, travestidos os homens de mulheres e as mulheres de homens. A festa seguiu com caxiri e música até tarde da noite.

O sábado amanheceu com intensa chuva. Apenas no período da tarde a chuva parou e abriu o tempo. Teve comemoração de aniversário dos filhos de Cristo (um Tariano morador de Querari) na palhoça do bairro São José pela tarde, onde além de comida teve caxiri; essa segunda festa se desenvolveu por toda a tarde e noite.

Ao mesmo tempo, no período da noite, a festa de quadrilha continuou na vila São João. Primeiro teve apresentação de quadrilha das crianças, depois apresentação de quadrilha dos alunos da escola estadual, seguidos de apresentação de quadrilha de militares. Teve competição entre esses dois últimos, valendo como premiação um balde de caxiri e um fardo de refrigerante. Uma banca de jurados, composta por mim, Luiz Gilberto, Amós (Yuremawa), Luiz Rodrigues (Yúriwawa) e Geraldo Edson, julgou as apresentações. Depois da quadrilha a 
festa continuou com caxiri e música. No dia seguinte, a bebedeira de caxiri continuou em algumas casas e palhoças de bairros.

\section{Terceira cena de festa ( 09 de julho de 2017)}

Elinaldo, um Baré de São Gabriel da Cachoeira que veio morar em Querari acompanhando sua esposa (yuriwakó), filha do velho José Bernardo, organizou festa de aniversário para José Bernardo, seu sogro, que completava então 65 anos. Elinaldo estava sozinho, pois sua mulher ainda não havia retornado de São Gabriel da Cachoeira, onde foi para reunião de professores. Elinaldo preparou caxiri de arroz; além disso, ofereceu também arroz e carne de porco que havia adquirido no Pelotão do Exército de Fronteira como alimentos na festa. Katia, esposa de Edson Torres (um dos filhos do aniversariante), fez um bolo de comemoração.

As pessoas se reuniram na palhoça do bairro São José, onde mora Elinaldo, e a festa teve início por volta das $14 \mathrm{~h}$. Além dos familiares, estavam presentes alguns militares do PEF, e alguns amigos e conhecidos de outras comunidades. Primeiro Elinaldo comentou as circunstâncias e dificuldades para preparar a festa. Em seguida, convidou José Bernardo ao centro da palhoça, e todos cantaram parabéns. Por fim, Elinaldo convidou a todos para comerem. Fizeram uma fila, sendo que os familiares iam a frente, para receber arroz e carne. Depois de todos comerem, Elinaldo convidou para cortar o bolo, dizendo que era pequeno, e seria mais para as crianças comerem; para os adultos tinha caxiri. Com efeito, servido o bolo, a festa seguiu com muito caxiri e música no aparelho de som por toda a tarde.

\section{Quarta cena de festa (16 de setembro de 2017)}

Elizeu, Betoku de Querari, filho de José Abelardo, convidou Letícia e Martins (e toda a família) para comemorar aniversário de filho de Maria Estela, sua mulher e filha do Yuremawa Graciliano, na palhoça do Yuremawa Amós.

A palhoça foi enfeitada com bexigas rosas. No centro, duas mesas com panelas de arroz, feijão, frango assado e macarrão. Em outra mesa, um bolo, uma bandeja de salgados, e alguns refrigerantes. Elizeu pediu a palavra, disse que o motivo da festa era comemorar aniversário de 2 anos de filho de Maria Estela. Convidou os presentes a rezarem e agradecer a 
Deus pela data comemorativa. Depois, Maria Estela agradeceu aos presentes e convidou a todos para cantarem parabéns. Também convidou outros presentes que faziam aniversário no mês de setembro e ficarem na frente. Em seguida, serviram comida (além da comida citada, algumas pessoas convidadas trouxeram contribuições também, sobretudo beiju). Primeiro as crianças pegaram comida; depois os mais jovens, e por fim os adultos. Depois da comida, serviram bolo e algumas balas para os presentes. Então muitas pessoas retornaram a suas casas para guardar os pratos ou resto de alimento para comer depois. Em seguida, voltaram para a palhoça para tomar caxiri pelo resto da tarde e noite.

Nas cenas de festas que descrevi, vemos que algumas foram motivadas pelo propósito de levantar recursos para construção de casa de radiofonia para a associação Kubeo e Kotiria do alto Uaupés. Outras, e esse é um dos principais motivos de festas, pela data comemorativa de aniversários. Como já dito, os motivos de festas são vários.

Outro elemento importante que notamos nas descrições é que a preparação da festa demanda muito trabalho. Nas descrições das feiras notamos a presença de muitos produtos industrializados, como refrigerantes, salgadinhos, arroz, o que supõe viagens à São Gabriel da Cachoeira, Iauaretê ou Mitú (cidade na Colômbia) - os lugares mais próximos com comércio - para compra desses itens, ou seja, há esforço físico, econômico, de tempo, para produzir a festa. Mas o investimento de trabalho não se resume às viagens a cidade. Também supõe saídas para pescar e caçar, como Luiz Gilberto e Martins fizeram na primeira cena de festa descrita acima. Supõe o trabalho na roça para retirada de frutas, e sobretudo da maniva, matéria do caxiri, elemento central nas festas. Certa vez, visitei Geraldo Edson e o encontrei junto com esposa e sogro de seu irmão ralando mandioca com motor de rabeta. Estavam trabalhando para produzir caxiri para a festa de dia dos pais ${ }^{118}$. Geraldo Edson nesse dia falou que é comum o envolvimento da comunidade para produção de caxiri e carne de pesca e caça

\footnotetext{
118 Aqui, vale notar que essa festa foi feita depois da data comemorativa em questão. Isso aconteceu porque a comunidade recebeu a visita de padre salesiano no dia, e por consideração ao padre adiou a festa. Tão logo o padre voltou para São Gabriel da Cachoeira, os preparativos para festa tiveram início; vemos, portanto, que uma data comemorativa pode ser adiada, mas dificilmente deixa de ser comemorada com a realização da festa de caxiri.
} 
para as festas, o que toma em média dois dias de trabalho; "tem que trabalhar bastante", comentou.

As festas seguem uma rotina: dias antes escutamos os raladores de maniva na comunidade, é o início da preparação de caxiri. Quinta-feira em geral é o "dia de queimar beiju”, isto é, já começam a preparar a bebida. O dia após a bebedeira de caxiri é chamado de hũrãktru harawz (“dia da preguiça”), é dia em que as pessoas em geral não vão à roça, costumam ficar em casa, às voltas com afazeres locais, ou conversando na rede.

A festa pode ser no centro comunitário da comunidade ou nas palhoças particulares de cada bairro, como vimos acontecer em algumas das descrições acima. De qualquer modo, observamos que as grandes festas no centro comunitário sempre tendem a se fragmentar; desse modo, se há uma festa no centro, no final da noite as pessoas seguirão para as palhoças dos bairros ou casas de famílias onde tem caxiri, e continuarão bebendo lá. A medida que o caxiri acaba, muitas, querendo continuar a beber, seguem para outros lugares onde se diz ter caxiri, e a bebedeira continua. É comum no segundo ou terceiro dia de bebedeira ver pessoas, sobretudo grupo de jovens, andando pela comunidade embriagados em busca de mais de mais caxiri.

A organização das festas obedece certo código. Quando se trata de festa organizada por alguma família, por exemplo, na comemoração de um aniversário, os convidados recebem um convite formal, em geral escrito em papel. Uma vez convidado, é de bom tom levar um balde de caxiri para a festa. Luiz Gilberto disse certa vez que o convite é importante, alguém que não é convidado e chega numa roda de caxiri sem trazer seu balde não é bem aceito, e em alguns casos o dono da festa pode até pedir para a pessoa ir embora. Cabe destacar que os convites não se restringem apenas aos moradores da comunidade; festas intercomunitárias, sobretudo motivadas por torneios esportivos envolvendo disputas entre equipes de diversas comunidades do lado brasileiro e colombiano é algo muito comum na região.

Como já destacado, o caxiri é elemento central nas festas, sem ele a festa não existe. Os diversos tipos de caxiri garantem a festa. A centralidade da bebida é tal que muitas roças são mantidas exclusivamente para produção de manivas que serão usadas na preparação de caxiri. Certa vez, Luiz Gilberto fez caxiri de milho, o que é considerado um dos melhores tipos de caxiri que há, muito apreciado, e em conversa contou que é um dos poucos em Querari que tem roça de milho, sendo a finalidade principal dessa roça fazer caxiri de milho (weakoró). O caxiri reúne pessoas; o caxiri, como diz Luiz Gilberto, “é bebida para se beber 
com as pessoas, não é para ser consumida individualmente”. O mesmo Luiz Gilberto conta que o caxiri "abre a cabeça, a mente dos velhos para falar, contar histórias". Além disso, essa bebida é considera alimento, evidencia isso o fato que, no início das festas, costuma-se comer apenas uma quinhapira; depois, não se come mais nada, apenas caxiri é consumido. A festa começa com oferecimento de caxiri e termina quando o último balde fica vazio.

Certa vez, Luiz Gilberto apresentou uma leitura sobre o motivo de Querari ter tantas festas de caxiri semanalmente. Segundo ele, antigamente vivia apenas uma família em Querari, e um inspetor português de nome Godinho, responsável por vigiar a fronteira, se estabeleceu com essa família. As filhas desse português, segundo Luiz Gilberto, faziam festas de caxiri com frequência, e daí vem o motivo de Querari ter festas de caxiri toda semana. Luiz Gilberto ainda acrescenta, "as festas de caxiri de antes eram tranquilas, não haviam brigas e desentendimentos como hoje". Vejamos mais alguns traços das festas de caxiri.

No centro comunitário ou nas palhoças, é comum homens sentarem-se de um lado e mulheres do outro. A bebida é na maioria das vezes servida no sentido anti-horário. No geral, são mulheres que servem, e quase sempre casadas, o que supõe que a bebida foi preparada a partir das manivas cultivadas em roça aberta pelo marido. Mas tenho o cuidado de usar “quase”, pois isso não é regra; é comum jovens, homens e mulheres, servirem caxiri preparado pelos pais; muitas pessoas também compram caxiri para beber nas festas, como o caso de militares de outras regiões e que estão morando temporariamente na comunidade por conta do trabalho no Pelotão Especial de Fronteira, ou daquelas pessoas cujas roças não estão produzindo maniva, algo muito comum a muitos professores da comunidade, que por conta da dedicação quase sempre integral à escola não têm tempo para o trabalho na roça.

A pessoa que serve oferece uma cuia (algumas vezes canecas de plástico são usadas), e espera-se que aquele que recebeu a cuia tome todo o caxiri. Uma prática comum nesses momentos consiste na troca de bebida. Assim, Luiz Gilberto explica que quando alguém pede para beber toda a cuia, deve-se dar o "troco", oferecer caxiri para a pessoa, como se fosse um "diálogo"; preferencialmente, se a pessoa tem caxiri deve oferecer de seu próprio balde. Essa é uma forma de embriagar o outro também, se o caxiri for mais forte que o do outro. Um indicativo de que na festa se está servindo caxiri de boa qualidade é as pessoas ficarem embriagadas quase ao mesmo tempo; como ouvi certa vez de um velho em festa "o bom é quando todos ficam bêbados ao mesmo tempo". 
Há um modo considerado correto de se beber caxiri; tem que "saber beber, se beber além do limite vomita", explicou um dia Letícia. Dito de outro modo, o vômito é sinal de excesso, o que por sua vez indica alguém sem moderação, que não sabe beber. Além disso, há alguns tipos de caxiri que exigem mais moderação, como o caso de "caxiri doce", isto é, ainda com pouco tempo de fermentação, que não se pode beber muito, pois pode causar diarreia. Como disse Luiz Gilberto, "quando o caxiri é bom, não dá diarreia, nem dor de cabeça no dia seguinte".

Mas beber corretamente caxiri não diz respeito apenas a certa conduta considerada adequada. Mais importante, há cuidados na produção de pessoas para beber caxiri. Sobre prática para tomar muito caxiri, o Yúriwawa Gabriel Saldanha dizia o seguinte:

Dabucuri com Jurupari. Agora isso não tem mais também, só de vez em quando, se a gente quer a gente faz. Agora antigamente não, todo tempo fazia. Acordava às $2 \mathrm{~h}$ da madrugada para tomar banho, agora não tem mais não. Agora já é vida moderna, às $7 \mathrm{~h}$ com escova e toalha, aí quando está com 30 anos já vai dizer "poxa, estou sentindo dor no corpo, que isso". Por isso os velhos antigamente sempre tomavam banho; banhavam assim não à toa, pegavam qualquer coisa da mata e usavam, por isso viviam assim com saúde forte, saudável, não enfraqueciam, a cara não mudava também. Tem vários tipos de remédio que eles usavam [...]. Tem vários, para tomar uma cuia grande também; costumo brincar com meu filho, tenho uma cuia grande, costumo brincar com meu filho, "bora tomar essa cuia de mingau", ninguém consegue não, nem chega metade, a barriga enche. Uma vez chegou sogro dele, viu a cuia, falou "essa cuia sempre é assim, vou acabar essa cuia", pegou, encheu de mingau, deixou um pouco abaixo da metade. "Poxa, ele falou, essa cuia"; no outro dia, tomando caxiri, eu disse "você falou que ia acabar com essa cuia", e ele disse "se tomar essa cuia vou cair!". Antigamente pessoas preparavam para vomitar com canoa, bem cheia, ele vomitava no buraco da saúva; a gente derrama no buraco da saúva nunca enche, aí ele sempre vomitava aí, no buraco da saúva, aí sim, tomando caxiri, a nossa barriga nunca enche. Assim que eles faziam, esses sim, antigamente eles diziam que tinha uma cuia grande, eles davam pra ele, primos, parentes, quando chegavam em dia de caxiri, eles davam assim, uma fila, aí o que gostava de tomar caxiri tomava essa cuia sozinha. [...] finado pai de Jaime bebia, não ficava parado não, cantava capiwaiá, não parava não, ia toda a noite, bebia, conversava, cantava; até $9 \mathrm{~h}$ da manhã que ele parava, aí que ele começava a beber o resto.

Gabriel fala dos cuidados que se tinha para produzir corpos fortes e saudáveis, e também dos remédios da mata que eram usados com tais finalidades, diz "tem vários tipos de remédio que eles usavam [...]. Tem vários, para tomar uma cuia grande também”. Vemos que beber caxiri também se insere no complexo de práticas e cuidados, alguns dos quais já explicitamos no terceiro capítulo deste trabalho. 
Ofereço ao leitor essa breve descrição das festas de caxiri, contexto de muitas piadas e brincadeiras. Voltemos à análise do yahui amiya e seus usos.

Com quem se brinca? Geraldo Edson fornece a seguinte formulação:

A maioria entra na brincadeira com aquelas pessoas que gostam de brincar acho, não é com todo mundo. Eles falam que, no caso da juventude, a maioria dos outros eram bravos quando brincavam com eles, aí não gostavam, por isso não querem mais bagunçar com ele porque ele é bravo. Ele brinca com o cara que brinca. Mesma coisa a gente, a gente brinca com a pessoa que brinca com a gente, que tem a mania de brincar. É dessa forma. Às vezes ele não acha bom... fica assim. Pior ainda quando for na bebedeira, para brincar dá briga aí.

Durante uma festa no centro comunitário de Querari, ocorrida em junho de 2017, eu bebia caxiri e conversava com José Abelardo (Betowa). Nesse momento, Carlinhos (Yúriwawa que mora em Querari) entrou no centro comunitário. José Abelardo fez a seguinte brincadeira, usando o yahui amiya em português:

-Ele é cobra, cobra venenosa.

Tal prática, enunciar o yahui amiya de alguém que entra no centro comunitário, ou mesmo que se aproxima para conversar, é muito comum. Tal fala produz risos, e algumas vezes pode acionar uma resposta da outra pessoa, que também fará brincadeira com o yahui amiya daquele que brincou com seu apelido. Esse movimento de fazer a brincadeira, e receber uma brincadeira como resposta é constante durante a festa, e remete a ideia de disputa. Em geral, os mais velhos são aqueles que mais fazem brincadeiras, que dominam repertório amplo de histórias engraçadas e piadas. Os Kubeo costumam dizer: "ninguém pode com aquele velho" para referir-se a essa pessoa que sempre dá a última resposta nas brincadeiras. Vejamos outra situação.

Num final de semana do mês de setembro de 2016, eu participava de uma festa de caxiri em Querari. Em certo momento, quando conversava com o senhor Martins Gomes, sentou-se ao nosso lado Olando, Kubeo yúriwawa morador de Açaí. Dirigindo-se a mim, perguntava: 
Olando: - Você já viu jabuti (ku\#bo) correr mais que veado (ñama)?

Diego: - Nunca vi...

Olando: - Jabuti corre mais que veado, até pega mulher... nunca viu jabuti correr mais que veado?!

Diego: - não...

Olando dizia isso e ria, Martins também ria, respondendo que ku»bo é preferido das mulheres, "sempre pega as mulheres". Perguntei porque Olando falava que "jabuti corre mais que veado", e Martins respondeu que um dia me contaria a história de ku»bo e ñama. Só quando ouvi essa história pude entender o que fundamentava e tornava engraçada a brincadeira que Olando fazia com Martins. Segue a transcrição da história como contada por Luciene $(\text { Yúriwawa })^{119}$ :

O veado falava para o jabuti que o jabuti corria bem devagar, aí jabuti falou para ele:

- bora apostar.

Ai eles correram, aí o veado perguntou para o jabuti, e ele respondeu bem na direção dela 120 ainda. Ai depois ela correu, e perguntou novamente, ele respondeu bem na frente dela. Depois ela correu de novo, ai perguntou de novo, ele já chegou, ai ela desmaiou e morreu. Ele [o jabuti] ganhou.

O jabuti, considerado um animal lento, desafia o veado para uma corrida, em resposta à suas provocações. Durante a corrida, o veado dirige perguntas ao jabuti, que sempre responde a frente dele. $\mathrm{O}$ veado se esforça por alcançar o jabuti, mas sempre que pergunta o jabuti responde a frente dele. De tanto se esforçar o veado acaba morrendo, e o jabuti sai vitorioso da corrida ${ }^{121}$. Foi essa história que permitiu a Olando brincar com Martins, perguntando-me se já tinha visto veado correr mais que jabuti.

Em outra ocasião, em julho de 2017, eu e Martins fomos ao final do dia beber caxiri

\footnotetext{
${ }^{119}$ Essa narrativa foi contada a Thiago Chacon, durante suas pesquisas de campo para estudo da língua kubeo.

${ }^{120}$ A narradora usa o feminino para se referir a ñama (substantivo masculino em kubeo, como em português); mantive o uso da narradora.

${ }^{121}$ Conversei certa vez com Luiz Gilberto sobre a solução dessa história aparentemente impossível. Ele me explicou que o jabuti venceu a corrida recorrendo à inteligência, pois provavelmente quem respondia ao chamado do veado não era o mesmo jabuti, e sim outros, fazendo com que o veado acreditasse que estava perdendo a corrida.
} 
na casa de José Abelardo, onde estavam os filhos dele, e outras pessoas de Querari, um Kotiria de Taracuá-Ponta, e alguns militares. Quando cheguei, Geraldo Edson, que estava presente na festa, começou a me contar que havia armado cacuri para pegar peixe, e quando foi ver, tinha um jabuti (kuzbo) dentro. Até esse momento, a fala de Geraldo Edson parecia ser a de alguém contando um episódio ocorrido durante uma pesca, demorei para entender que era uma brincadeira contada a mim, tendo com alvo o senhor Martins, cujo yahui amiya, como vimos, é Ku»bo. Apenas percebi quando, logo após falar do jabuti dentro do cacuri, Geraldo Edson se dirigiu a Martins e perguntou como ele conseguiu entrar na armadilha; tratava-se, portanto, de uma brincadeira.

Getúlio (Kotiria de Taracuá-Ponta, comunidade logo abaixo de Açaí) emendou a brincadeira contando que seu filho, certa vez, chegou da escola e se dirigiu a ele:

-Pai, o senhor sabe como branco chama jabuti?

Getúlio: como meu filho?

-cagado!

Getúlio: não é cagado! (risos) É cágado! (risos)

As brincadeiras de Geraldo Edson e Getúlio produziam muitas risadas. Martins respondia dizendo que jabuti atrai as mulheres, que elas gostam do jabuti. Geraldo Edson insistia em perguntar a Martins como ele tinha entrado no cacuri; Getúlio ria e gritava: - Marroco! (termo em espanhol para jabuti) e todos riam. Usar o vocativo, referindo-se pelo yahui amiya, é uma forma muito comum de brincar e fazer rir.

Cito mais uma situação. Durante a festa de caxiri que descrevi anteriormente (primeira cena), Luiz Gilberto em certo momento brincava que Osvaldo certa vez comentou que nunca tinha visto boi vermelho, há boi preto, boi malhado, mas boi vermelho não. Isso fazia referência a "Boi" (Cláudio, Betowa, filho de José Abelardo), que, segundo Luiz Gilberto, ficava vermelho quando bebia, por isso "boi vermelho".

A partir desses casos, penso ser possível apresentar uma hipótese para o lugar desse tipo de fala, as brincadeiras com yahui amiya, nas festas e na comunidade de modo geral. Em primeiro lugar, lembremos que as festas ocupam um lugar central na vida social da comunidade, tal como sugerem Beatriz Perrone-Moisés (2015) e também Luis Cayón (2013). De acordo com Cayón, a partir de seu material sobre os Makuna do Pirá-Paraná, "el baile es la clave de las relaciones [...] al final, no hay mejor forma de capturar el alma del otro que bailando, no hay mejor forma de regalar el alma que bailando" (ibidem, itálico meu). Tal 
sugestão é destacada por Andrello em resenha recente do citado livro de Cayón, onde insiste sobre a importância dos "bailes ou festas de troca"122. Com efeito, Andrello nos diz: "Performances e comida seriam, assim, os itens que de fato circulam, promovendo alegria e vitalidade entre todos os envolvidos" (2017, p. 245). Se incluirmos na noção de performance as brincadeiras que circulam durante as festas, podemos afirmar que as brincadeiras com yahui amiya promovem "alegria e vitalidade".

Sempre se diz que uma comunidade "feliz", "animada", é onde tem muita gente, e onde tem festas de caxiri, o que significa muitas brincadeiras e, consequentemente, muita risada. Marci disse certa vez que dia sem caxiri é "triste" (oehiñz), "parado", "é triste ficar sem caxiri, sem festa". Comunidade sem festa, também costuma ser sinal de comunidade com poucos moradores; dito de outro modo, quando a comunidade esvazia, fica "triste"123. Tal como o caxiri reúne pessoas nas festas, os apelidos quando usados em brincadeiras também aproximam as pessoas, e essa aproximação produz alegria. Ouvi muitas vezes Martins dizer "essa semana está triste na comunidade", porque era semana sem festa. Aqui, gostaria de avançar um pouco mais no meu argumento; para isso, voltemos àquele que foi o primeiro antropólogo dos Kubeo, Irving Goldman.

Sugiro que podemos pensar a promoção "de alegria e vitalidade" como "manejo do ânimo"124 (mood management) da comunidade, noção essa proposta por Irving Goldman (1963), e que parece ter sido esquecida pela etnologia do noroeste amazônico, salvo em um artigo de Overing (1991) em que chama a atenção para o interesse das noções de comunidade e manejo do ânimo formuladas por Goldman. Com efeito, Goldman afirma em sua primeira monografia que os Kubeo Bahúkiwa não admitem o que ele chama de "desconforto psicológico"; em uma situação de conflito ou inimizade é comum que uma pessoa, casal ou mesmo família abandone a comunidade. Para evitar tais situações de desconforto que resultam em afastamentos ou rupturas, esvaziando a comunidade, os Bahúkiwa têm

\footnotetext{
122 Cayón (2013) e Andrello (2017) referem-se sobretudo as festas de dabucuri; contudo, para o argumento que proponho aqui, penso em festas de modo geral.

123 Tal lamento "está triste hoje" também é muito comum de se ouvir nas férias de julho e de final e início de ano, quando a comunidade fica esvaziada por conta do grande número de famílias que viajam sobretudo para a cidade de São Gabriel da Cachoeira e, portanto não tem mais as grandes festas comunitárias, ou bebedeiras de caxiri (uma ou outra casa faz caxiri, mas a bebedeira é em escala reduzida).

${ }^{124}$ Essa noção parece ter sido esquecida pela etnologia regional; penso que um dos motivos é a base psicológica que sustenta a interpretação montada por Irving Goldman em sua primeira monografia (1963), onde se percebe claramente a ressonância de algumas ideias de Ruth Benedict, tal como mostra Peter J. Wilson em seu prefácio ao segundo livro de Goldman (2004, p. xix e ss.). Tal viés psicologizante não fez fortuna no alto rio Negro, algo que o próprio Goldman de certa forma abandona em sua monografia sobre os Hehénewa (2004).
} 
mecanismos de manejo do ânimo. As festas, reunindo pessoas e promovendo alegria, são uma das formas desse manejo.

Em suma, duas chaves importantes das relações entre os Kubeo, e penso que podemos dizer no Uaupés, são as festas e as brincadeiras com yahui amiya, as histórias que sempre envolvem episódios engraçados, e que são trocadas durante as festas. Assim, Cayón está correto ao dizer que "Performances e comida seriam, assim, os itens que de fato circulam, promovendo alegria e vitalidade entre todos os envolvidos", se incluímos na noção de performance as piadas ou histórias engraçadas que são contadas e que, ao circularem, promovem alegria e vitalidade, realizando o "manejo do ânimo", o que significa mantendo a comunidade sem conflitos e rupturas, o que, em outros termos, pode ser formulado como fazer a comunidade crescer.

Concluamos, portanto. Os Kubeo fazem brincadeiras com yahui amiya, contam histórias cheias de humor, e essa circulação de falas engraçadas produz alegria, produz risos, promove, em suma, a vitalidade da comunidade, aproxima as pessoas. Mas a brincadeira pode virar zombaria, a aproximação pode ser substituída por afastamento.

\section{Quando a brincadeira vira zombaria}

Durante as festas de caxiri conversa-se, faz-se muitas piadas e brincadeiras a partir de yahui amiya e histórias diversas. Contudo, se o yahui amiya tem um uso que produz alegria e aproximação, pode também conduzir ao seu oposto, isto é, produzir brigas e violência, a brincadeira pode virar zombaria e terminar em troca de socos e pontapés. Se o yahui amiya produz aproximações, também pode produzir afastamentos; se ao reunir produz alegria e manejo da vitalidade, ao afastar produz rupturas, violência; a troca verbal de brincadeiras é substituída pela ofensa, o riso pelos socos e pontapés. Isso pode se dar simplesmente pela repetição em forma de grito do yahui amiya de alguém; se o alvo da brincadeira desaprova que determinada pessoa fale seu yahui amiya, passamos da brincadeira a zombaria e, em pouco tempo, possivelmente do riso aos socos. Numa expressão de Marci, "no dia de festa ganham almoço, e depois recebem socos de volta”. Por que se briga?

Luiz Gilberto explicou que as brigas no caxiri se devem a desavenças do cotidiano que se manifestam quando a pessoa está bêbada; uma ofensa sofrida permanece latente até o momento da embriaguez, quando então é potencializada pelo caxiri, e desemboca em violência. Marci, em conversa sobre brigas em festa de caxiri, falou-me que brigas por ciúmes e por desconfiança sobre paternidade dos filhos são motivos muito frequentes de desavenças; um terceiro motivo é a acusação de que alguém é o responsável por determinado 
comportamento na festa, pois ofereceu caxiri forte. Marci afirmava que o "os homens são o diabo quando bêbados"; uma expressão comum para se referir a violência nas festas. Letícia certa vez disse "quando está bom ele é boa pessoa, fala bem, é bonzinho; mas quando bebe vira o diabo. Ele é o diabo".

A explicação de Luiz Gilberto vai de encontro a certa explicação que encontramos na literatura etnológica. Danilo Ramos (2013), ao falar das brigas em festas de caxiri, retoma uma formulação do antropólogo Howard Reid, e que de certo modo constitui uma explicação partilhada pela literatura para os episódios de violência em festas de caxiri. Segundo Ramos "comentando sobre as brigas durante as festas de caxiri, Reid (1979) vê nos conflitos suscitados pelos eventos coletivos e pelo consumo da bebida um contexto de expressão das tensões, frustrações e ódios entre pessoas e grupos" (2013, p. 391). Esse antropólogo cita uma passagem de Reid que num primeiro momento parece se adequar ao contexto kubeo. Vejamos:

The Hupdu are calm, quiet, self-controlled people in everyday life, but as the party goes on, the household becomes more and more noisy. [...] In the later stages of the party serious fights do sometimes break out between residents, or between hosts and guests, and often end in deaths or serious injuries. [...] Except for occasional scraps between husbands and wives, fights only occur during drinking parties or rituals. [...] desires, frustrations, jealousies, personal likes and dislikes and other tensions that are bound to occur between small groups of people living in such intense intimacy find expression at drinking parties, whereas they are completely repressed in everyday life (REID, 1979, p. 135-136 apud RAMOS, 2013, p. 391).

Parece haver certo componente que seguiremos chamando "psicológico" a falta de termo mais adequado, uma irrupção de tensões acumuladas no cotidiano e catalisadas pelo caxiri.

Não apenas as brincadeiras e piadas podem ser feitas de modo zombeteiro, agressivo e conduzir a brigas, há também um forte conflito geracional, que vi se manifestou em muitos momentos, presente durante as festas na forma de disputa por formas musicais: os jovens gostam de cumbia, tocada em aparelhos eletrônicos. Os mais velhos querem tocar carriçú. Quando conseguem um espaço para tocar e dançar o carriçú, nota-se um aparente desinteresse e enfado dos mais jovens, que logo retomam o som de cumbia e o centro de dança se enche novamente de casais. Algumas vezes, isso pode levar a discussões, que podem terminar em brigas. Em outras situações, disputa-se o tipo de música ser tocada no aparelho de som, ou mesmo o lugar da pessoa que opera o som, o que mutias vezes também conduz a conflitos.

O Yúriwawa Gabriel Saldanha fala de como hoje as festas são dominadas pelo som, sem espaço para as práticas "tradicionais" de canto e dança: 
O que mais domina agora é o som, querem fazer festa com som, já procuram aí, o som. [...]. É muito bom quando tem japurutu, carriçu, é música boa mesmo, só falta aprender [...]. Aqui a gente sempre fazia com Muchiva, no primeiro dia "bora fazer só com nossa cultura", aí no outro dia, se sobrava caxiri, liberava o som.

Gabriel vê no interesse pelo som eletrônico um obstáculo à retomada de "práticas e conhecimentos tradicionais", como certas danças e cantos. Além disso, o som eletrônico também interfere nas conversas que se mantêm durante a festa, pois dificulta ser ouvido, algo diferente de uma festa ao som de carriçú por exemplo. Conversa-se menos com som eletrônico, segundo Gabriel.

Penso ter avançado nas descrições de festas e usos de yahui amiya, e mostrado como tal nome pode ser manejado para fazer crescer a comunidade ao produzir alegria e vitalidade. Para encerrar esse capítulo, gostaria de apresentar o que me parece constituir um terceiro tipo de apelido, a saber, o apelido de nomes de brancos.

\section{Apelidos de nomes de brancos entre os Yúri Parãmena}

A sistematização de Stephen Hugh-Jones (2002) para os nomes no noroeste amazônico, ao falar dos apelidos, faz referência a um "espectro" de designações. Contudo, essa solução de incluir um conjunto de tipos de nomes sob a ideia de um "espectro" não me parece satisfatória, e penso que já temos dados que nos permitem precisá-la. Relembremos o que diz o autor:

Além de um ou mais nomes de espírito, as pessoas têm regularmente pelo menos um apelido. Os apelidos (ahari wame, nome "jocoso") correm ao longo de um espectro. Em uma extremidade estão os nomes jocosos verdadeiros, a maioria dos quais se refere ao mundo dos mamíferos, pássaros e peixes: Maka Hino, "Jibóia", Yese Hoa, "Cabelo de Porco do Mato", Siru, "Japim/Xexéu/Rouxinol-do-Rio-Negro" e Wani Hiko, "Rabo de peixe-geográfico" são exemplos. Aqui, as palavras perdem seus referentes originais: aquele que é chamado Jibóia não é de modo algum uma cobra. Outros apelidos têm alguma referência direta ou oblíqua à vida, aos hábitos, à aparência física ou caráter do portador: como uma criança Riti, "Carvão", que estava sempre suja, e Güso Lise, "Boca de Jacaré", que fora mordido uma vez por um jacaré. Inventados e empregados por diversos Outros, esses nomes não transferíveis e biográficos servem para individualizar o portador. Na outra extremidade do espectro estão os nomes comuns, veneráveis, semisagrados, cujo conteúdo semântico é semelhante aos dos verdadeiros nomes jocosos dos quais, suspeito, eles podem derivar, mas que agora formam par com nomes de espírito e são transmitidos com eles (HUGH-JONES, 2002, p. 52 , sublinhado meu). 
O que Hugh-Jones chama de "apelido" corre ao longo de um espectro. Num extremo, os "verdadeiros nomes jocosos", que é o que os Kubeo chamam propriamente de apelidos (yahui amiya), nomes "não transferíveis e biográficos" que "servem para individualizar o portador"; no outro extremo os "nomes comuns", que o autor qualifica de modo pouco claro como "veneráveis, semi-sagrados", e que "formam par com nomes de espírito e são transmitidos com eles"; correspondem ao que alguns Kubeo propõem chamar de "nome tradicional", ou "apelido tradicional", aqueles que acompanham os nomes de benzimento, invariáveis. Contudo, ao longo do campo notei que outra forma de designação era muito usada; num primeiro momento pensei tratar-se de apelidos, mas não tinham o tom jocoso, de brincadeiras como acontece com os yahui amiya. Também não tinham relação com os pupui amiya. Com efeito, do que se tratava? Seria um terceiro sistema de designações dentro do espectro de Stephen Hugh-Jones? Vejamos do que se trata.

O Yúriwawa Osvaldo, em conversa disse que: "Maurício falam Mauro, Francisco falam Chico, Gilberto falam Xibé... Paulo falam Paú, é jeito de chamar, não some não". Em outro momento, o mesmo Yúriwawa Osvaldo explicou:

Apelido do Marcelino é Waibowz, um passarinho, Piađa é nome de benzimento. Masa é jeito de chamar ele, não é apelido, tem esse nome Marcelino, gosta de chamar de Masa; Bernardo chamam de Beré; Ricardo chama de José [com pronúncia em espanhol] para ele, porque ele é José Bernardo. Minha mãe que fala Beré para ele, mais direto. E para minha mãe também eles chamam de José [pronúncia espanhola] porque é Josefina. E assim vai indo... Ricardo falam Dicá (sublinhado meu).

Ouvi comumente o uso, sobretudo entre afins e irmãos, de tais termos, de tal "jeito de chamar", como define Osvaldo. Destaco que, embora Stephen Hugh-Jones não faça menção a esses usos em seu artigo (2002), já em Koch-Grünberg encontramos referência à esse tipo de nome "abreviado":

Os nomes compostos quase sempre ficam abreviados. Em vez de Öláhindo dizem Ölá; em vez de Yamápola ou Yamáhäuö dizem Yamá etc. Também aos meus Umáua Kaúlimu e Kauánamu, os Kobéua costumavam chamá-los de Kauí e Kauá. Do mesmo jeito, frequentemente abreviam os nomes cristãos. Em vez de Domingos, dizem Dómi. Em vez de Marcelino, os Tukáno no Tiquié diziam Massá. (2005, p. 485-86). 
Com efeito, muitos nomes são abreviações; contudo, nem todos são assim. Há nomes, como por exemplo, o uso de "Oliva" para Rosine que não parecem ser abreviações. Diante de tais nomes, podemos perguntar qual o seu lugar? Koch-Grünberg afirma que a abreviação de nomes acontece com o que parecem ser nomes de benzimento e também com "nomes cristãos". Em meu levantamento, encontrei esses nomes "abreviados" apenas em referência aos nomes de brancos. Minha explicação é que tais termos funcionam como apelidos associados à nomes de brancos. Tal como pupui amiya tem um apelido que o acompanha, fixo, invariável, também alguns nomes de branco seriam acompanhados de seu apelido, invariável. Segue uma lista:

\begin{tabular}{|l|l|}
\hline Nome de branco & Apelidos do nome de branco \\
\hline Gilberto & GibélXibé \\
\hline Bernardo & Beré \\
\hline Marcelino & Masa \\
\hline José & José (com pronúncia espanhola) \\
\hline Josefina & José (com pronúncia espanhola) \\
\hline Maurício & Mauro \\
\hline Paulo & \\
\hline Ricardo & Paú \\
\hline
\end{tabular}

Tabela 14: Apelidos de nomes de brancos kubeo (elaboração própria). 
Tais apelidos acompanham apenas alguns nomes. São de uso cotidiano tanto como vocativo ou referente. São usados comumente entre parentes e afins. Em suma, os apelidos parecem ser de três tipos. Tal como pupui amiya é acompanhado de apelidos, ou "nomes comuns", na terminologia de Stephen Hugh-Jones, nomes de branco também são acompanhados de apelidos, conformando certos pares de nomes. Por fim, o apelido de brincadeira, usado cotidianamente e sobretudo em contextos festivos, que produz risos, alegria. 
TERCEIRA PARTE - OS NOMES NOS LUGARES 


\section{CAPÍTULO 7 - OS NOMES FAZEM LUGARES}

Este capítulo propõe uma descrição e análise das conceitualizações kubeo do espaço e sua relação com os nomes, isto é, trata-se de pensar o que faz um nome quando atribuído a um lugar. Para isso, explicito as categorias kubeo de espaço. Em seguida, analisarei dois eventos recentes ligados ao tema dos nomes de lugar: uma viagem ao Wakaipani, realizada em 2013, e seus desdobramentos; e a participação kubeo na elaboração de um plano de gestão ambiental e territorial que começou a ser desenvolvido no ano de 2014. Penso que a análise desses eventos permitirá avançar algumas hipóteses sobre o tema em questão.

\section{As categorias kubeo de espaço}

Os Kubeo possuem categorias diversas para apreender o espaço, isto é, aquilo que na língua se diz hoborõ, termo que abrange as noções de "mundo", "terra", "espaço"; portanto, o termo inclui tanto uma ideia mais ampla de "mundo", quanto uma mais localizada de "terreno" - os Kubeo falam, por exemplo, para designar o espaço onde exercem algum tipo de atividade, "hi hoborõ" ("minha terra, meu terreno") -; o mesmo termo é usado para traduzir "território", como na expressão "Pamiwai hoborõ" ("território dos Kubeo"). Além desse termo, também se usa a palavra hãrãwz, que tanto significa "mundo", como também "dia", "estação" e "tempo", o que aponta para uma associação entre noções de espaço e tempo no pensamento kubeo. Certa vez, em oficina realizada em 2014 onde se discutia essas noções, alguns velhos Yuremawa e Yúriwawa esboçaram uma concepção de hoborõ, na qual o "mundo" era organizado em "camadas" (tukubu). 


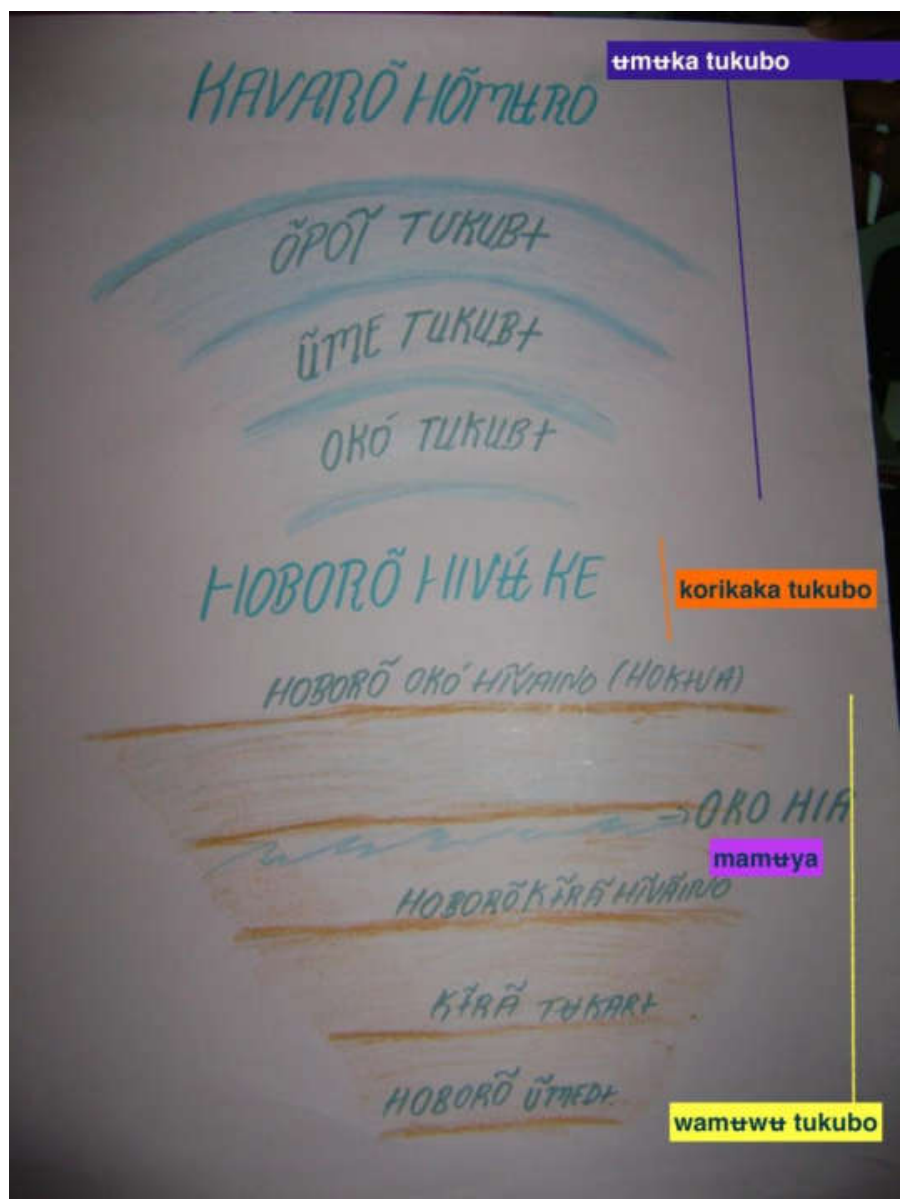

Figura 15: representação do mundo em camadas (autoria coletiva, 2014).

Nesta concepção sobre os planos do universo kubeo, temos: kawarõ hõmษrõ ("umbigo do céu”), õpõi tukubu (“camada do trovão"), ũme tukubu ("camada de ar, espírito, vitalidade"), oko tukubu (“camada de água”). Nesta representação, as linhas à direita foram usadas para indicar: umzka tukubo ("camada do alto"), korikaka tukubo (“camada média”), mamzya ("rio umarí"), mamuwz tukubo (“camada da gente umarí”). Embora alguns velhos tenham enunciado a concepção de hoborõ em camadas, quase não ouvi nas conversas em campo referência a essa concepção.

No "Pamiwai hoborõ" encontramos as seguintes categorias espaciais mais amplas: a comunidade, a mata, a roça e o rio. Vejamos como cada uma é entendida e sua respectiva importância.

O rio (ihtyá) com seus igarapés (htahıya) é uma categoria central na conceitualização kubeo do espaço. Recordemos que Goldman, já em sua primeira apresentação de dados do trabalho de campo junto aos Bahúkiwa, nos diz que "The Cubeo are a river people, and according to their traditions their ancestors first emerged from the rocks at river rapids; 
thereafter all the Cubeo lived along the Rivers" (1940, p. 242; grifo meu). E segue

A long saga chanted by the old men of the gens at ceremonial gatherings tells how the first ancestors, the Ancients, first emerged in the form of river anacondas in brother-sister pairs. The anacondas shed their skins and became people. The male of each pair founded a gens. In minute detail the saga narrates the journey of these first people seeking a permanent site, and mentions by name each bend of the river, each distinguishing geographic feature encountered by the Ancients in their wanderings (1940, p. 242-243, sublinhado meu).

As narrativas de origem falam de "jornadas" em busca de lugares para permanência. Nessa viagem, eventos vão sendo perpetrados - a constituição de alianças com outros povos, a conformação de novos lugares -, como a narrativa da transformação dos Yúri Parãmena, na qual o igarapé Marãkãriya é criado à medida que Marãkãriku avança em direção ao Wakaipani, como veremos. Esses eventos e feitos deixam signos ou marcas nos lugares, e todos esses lugares possuem nomes, os quais operam como indicativos de tais eventos conformados em tempos pretéritos; em outros termos, o nome condensa narrativas e, em certo sentido, o nome é o lugar. Os rios e seus elementos geográficos como praias, cachoeiras (kururõa), estirões, poços (kãinibua), ilhas (hiawza), pedras (kurãboa), e também elementos como areial (eparõ) e serras (ktrãkũa), canais (koarõa), pontas (kãpĩdoa), são lugares que possuem nome e história, isto é, lembrando Goldman, os "Ancestrais", em suas viagens, "mentions by name each bend of the river, each distinguishing geographic feature [...]" (ibidem). Nesse sentido, esses espaços constituem aquilo que Robin Wright propõe chamar mythscape ("mitagem" ou, numa tradução que me parece mais adequada, "paisagem mítica", WRIGHT, 2017, p. 609); nas palavras do antropólogo: “O termo 'mitagem' ('mythscape') refere-se à paisagem ('landscape') regional como uma coleção de sítios/lugares que estão todos relacionados com as tradições de criação" (s/d, p. 1), refere-se ao complexo total de lugares, "pois cada sítio estabelece a conexão entre Este Mundo e o Mundo-de-antes do passado primordial” (p. 9).

Os rios são marcados por corredeiras e cachoeiras ${ }^{125}$, as quais, comumente, indicam limites entre comunidades, ou mesmo pontos de residência, como era o caso de PacúCachoeira, comunidade localizada diante de cachoeira de mesmo nome. Também Goldman já

\footnotetext{
${ }^{125} \mathrm{Na}$ região, comumente se usa o termo "cachoeira" tanto para aquilo que nós designaríamos propriamente como cachoeira, tomando como critério a altura da queda d'água, como corredeiras.
} 
havia notado isso em sua etnografia dos Bahúkiwa. Com efeito, o antropólogo afirma que "the cataracts (cachiveras) are for the Indians focal points of residence. Traditional sites, they often mark tribal and sib boundaries. Every cataract has its petroglyphs that depict mythical figures still known to the Indians [...]" (1963, p. 8, grifo meu). O estabelecimento de residências próximas as cachoeiras é algo bastante difundido na região do Uaupés, como por exemplo as comunidades Kotiria de Jutica (CHERNELA, 1993), e Carurú-Cachoeira (ROCHA, 2007; 2012), próximas às cachoeiras de mesmo nome; as comunidades de Ipanoré e Urubuquara, próximas a cachoeira de Ipanoré; ou ainda, o povoado de Iauaretê, próximo a cachoeira de mesmo nome (ANDRELLO, 2006).

$\mathrm{O}$ rio conecta comunidades e lugares mais no interior da mata, bem como a comunidades com as cidades. Navegando o rio Uaupés (Ihiá) os Kubeo viajam até as cidades de Mitú, na Colômbia, ou São Gabriel da Cachoeira, no Brasil, passando pelos povoados (subdistritos) de Iauaretê e Taracuá. Tais deslocamentos são constantes, sobretudo para visitar parentes, participar de festas, receber salários e benefícios, e comprar produtos no comércio local.

Os rios e seus igarapés são também espaços para prática da pesca e da caça, atividade central para aquisição de alimentos, ao lado do trabalho na roça. Recentemente, tem-se tornado comum conflitos em torno de trechos de rio, sobretudo por conta da diminuição de peixes diagnosticada pelos Kubeo (e indígenas do Uaupés de modo geral), e pelo uso de malhadeiras, algo que causa certo incômodo, sobretudo quando se dá em regiões às quais o grupo não tem acesso legítimo. Esses conflitos, durante meu período de campo, se manifestaram durante a viagem ao Wakaipani e nas oficinas para elaborar planos de gestão, que serão analisadas mais adiante.

Outro elemento importante relacionado aos rios são os banhos. Ao acordar, deve-se iniciar o dia com um banho, de preferência nas águas geladas de igarapés. Segundo os Kubeo, os banhos são importantes na constituição do corpo, como vimos no terceiro capítulo. Uma pessoa que não toma banho pela manhã será vista como preguiçosa, e que muito provavelmente poderá ser vítima de doenças. Depois do nascimento e dos devidos benzimentos é importante o primeiro banho dos pais do recém-nascido no rio, junto com a criança. O banho, além de sua importância para corpos fortes e renovação da disposição pessoal, possui importância no conjunto de práticas ditas rituais, como, por exemplo, na preparação para o Jurupari. 
Rios e seus igarapés possuem nomes, e tais nomes são signos de eventos, da ação de personagens no tempo da criação, como mostrarei na análise da viagem feita pelo Marãkãriya com destino ao Wakaipani. Agora, detenhamo-nos na análise dos nomes propriamente dito de igarapés da região reconhecida como dos Yúri Parãmena.

Em 2013, durante os trabalhos de produção de mapas da região das comunidades yuremawa e yúriwawa, levantei uma lista de nomes de igarapés que tentei traduzir com a ajuda de alguns Kubeo de Querari. Meu interesse em traduzir os nomes recebeu mais de uma vez a advertência: "vai traduzir nome? Nome é nome, não se traduz”, comentou Luiz Gilberto ao me ver dirigindo perguntas sobre tradução desses nomes ao seu pai Martins. Contudo, penso que a tradução de nomes pode abrir vias de compreensão da lógica, supondo que há uma lógica, subjacente a esses termos. Iniciada a empreitada de tradução, acolhi sugestão de Luiz Gilberto, conhecedor do Kubeo e do português, já familiarizado com trabalhos de tradução ${ }^{126}$, de usar termos compostos, separados por hífen; explico o raciocínio de Luiz Gilberto. Traduzir, por exemplo, “Wekzya” como "Igarapé Anta”, pode dar a entender que se trata de um igarapé de anta, no sentido de frequentado por anta, ou também pode induzir a pensar que se trata de um igarapé pertencente a ela, ou seja, essa solução tradutória remete o leitor a uma atribuição imediata, o que, na leitura de Luiz Gilberto, pode causar confusões por parte do leitor; assim, a solução seria traduzir como "Anta-igarapé", pois essa "síntese atributiva" (CAMPOS, 2000, p. 28) permitiria manter o campo semântico do nome, sem induzir o leitor a ter uma interpretação equivocada de seu sentido. Segue lista:

\begin{tabular}{|l|l|}
\hline NOMES DE IGARAPE & TRADUÇÂOO \\
\hline Hiаðоða & Loiro-Igarapé \\
\hline Ktt Каһеða & Casca de Mandioca-Igarapé \\
\hline Warimuya & Apuzeira-Igarapé \\
\hline Mihiya & Ayahuasca-Igarapé \\
\hline Wekttya & Anta-Igarapé \\
\hline Maweða & Arara-Igarapé \\
\hline Tepaða & Tipo de árvore com folha grande; não consegui tradução
\end{tabular}

${ }^{126}$ O linguista Thiago Chacon iniciou em 2008 seus trabalhos de pesquisa junto aos Kubeo de Querari e Açaí; além de sua tese de doutorado (2012), uma descrição da língua Kubeo, Chacon realizou durante sua pesquisa atividades como treinamento de alguns Kubeo para trabalhar com documentação linguística, e oficinas visando elaboração de um dicionário kubeo. Luiz Gilberto foi um dos kubeo que recebeu treinamento linguístico e acompanhou tanto a pesquisa como as oficinas. 


\begin{tabular}{|c|c|}
\hline & exata \\
\hline Kõhãða & Ibacaba-Igarapé \\
\hline Hihekamu Uraða & Boca Grande-Igarapé \\
\hline Wahokaða & Sorva-Igarapé \\
\hline Ніmaða & Veneno-Igarapé \\
\hline Ñapãbuya & Tucunaré-Igarapé \\
\hline Кіреðа & Uirapixuna-Igarapé \\
\hline Epãku Koiya & "Igarapé onde praia afunda" \\
\hline Napã Hinuriya & "Igarapé onde tucunaré choca ovos" \\
\hline Mure Imariya & "Onde os carapanãs ficam dentro" \\
\hline Тети Тагаbнаðа & Arco-Igarapé \\
\hline Kurãya & Piracema-Igarapé \\
\hline Мureðа & Carapanã-Igarapé \\
\hline Wedaða & Acará Branco-Igarapé \\
\hline Maruku Tzaya & "Igarapé onde macaco da noite espia" \\
\hline Kahedoða & Tapuru-Igarapé \\
\hline Wãrĩtawaða & Acará-Igarapé \\
\hline Abuhuku Waiya & "Igarapé da travessia do diabo" \\
\hline Marãkãriya & Marãkãrikt-Igarapé \\
\hline Kuriaða & $\begin{array}{l}\text { Processo de fazer rapé com casca de árvore (kuria), e } \\
\text { também a casca de árvore (não consegui tradução precisa) }\end{array}$ \\
\hline Wahtzya & Tipo de coquinho do mato (não consegui especificar) \\
\hline Çinaða & Caranã-Igarapé \\
\hline Yawakari Koa & $\begin{array}{l}\text { Canal Yawakari (palavra da linguagem antiga, sem tradução } \\
\text { definitiva) }\end{array}$ \\
\hline Pamuma & "Caminho de tatu" \\
\hline Wawikoa & Jacundá-Canal \\
\hline Himiktriya & Mandi-Igarapé \\
\hline Оðа & Sororoca-Igarapé \\
\hline Huhษweða & Mucura-Igarapé \\
\hline Abiakoða & Estrela-Igarapé \\
\hline Hia Вetoða & Javari-Igarapé \\
\hline
\end{tabular}


Tabela 15: Nomes de igarapés (elaboração própria).

Apresentada a lista de nomes, passemos a sua análise. Merece atenção, em primeiro lugar, o referente dos nomes, pois vemos que alguns remetem a animais, outros a plantas, peixes, astros etc. Segue uma tabela com os referentes dos nomes organizados segundo determinadas categorias ${ }^{127}$ :

\section{Referentes dos nomes}

kubeo

\section{Categoria}

Plantas

Árvores

Aves

Peixes

Animais

Astros

Traços físicos

Substâncias

Palmeiras

Árvore frutífera

Características do lugar

\section{Número de nomes}

2

4

1

6

2

1

1

2

3

2

6

127 Sigo aqui como modelo a tabela usada por Roy Wagner em sua análise dos nomes Daribi, onde esse antropólogo analisa a recorrência de certas categorias de nomes: animais, plantas etc. (1972, p. 92-93). Que fique claro: as categorias usadas aqui são minhas, apenas a sugestão de análise retiro de Wagner. 
Evento relacionado aos

peixes

Insetos

Tipos de larva

Ancestrais míticos

Termos da língua antiga

Objetos

Analisando essa lista de frequência dos nomes segundo seu referente, vemos que dois tipos de nomes se destacam: nomes relacionados à peixes, como Ñapãbuya ("TucunaréIgarapé”), Himikuriya ("Mandi-Igarapé”) etc.; e nomes relacionados a características do lugar, como Ñapã Hinuriya, que pode ser glosado como "igarapé onde tucunaré choca ovos", ou Maruku Ttaya, "igarapé onde macaco da noite espia”, numa tradução livre. Em seguida, temos nomes relacionados a árvores, como Hiaðoða (“Loiro-Igarapé”), Тераða ${ }^{128}$ ou Kipeða (“Uirapixuna-Igarapé”). Próximo ao número de árvores como referentes, temos também palmeiras: Kõhãða ("Ibacaba-Igarapé”), Çinaða ("Caranã-Igarapé”), para citar algumas. Merece consideração mais dois fatos: em primeiro lugar, o nome do principal igarapé dos Yúri Parãmena, Marãkãriya, que pode ser traduzido como "Marãkãrikt-Igarapé", remete ao personagem ancestral Marãkãrikt, aquele que, ao se deslocar até o Wakaipani atraído pelo som produzido pelos Yúri Parãmena, foi dando forma ao igarapé, donde a explicação para a origem do nome desse igarapé. Em segundo lugar, o nome de um canal entre dois igarapés, Yawakari Koa ("Canal Yawakari”), foi apontado pelos Yuremawa e Yúriwawa, no momento da tradução, como termo da "língua antiga", isto é, língua originalmente falada pelos Yúri Parãmena antes de se apropriarem da língua dos Kubeo, e que eles não sabiam traduzir. Aqui, devemos notar que Yawakari Koa também designa lugar que foi antiga residência de algumas famílias Yúriwawa, antes de se deslocarem para próximo do rio Uaupés, onde hoje é a atual comunidade de Açaí, como vimos no primeiro capítulo.

Fazendo análise dos nomes de lugares vemos que os referentes remetem ao mundo sensível; os nomes de igarapés remetem a frutas, peixes, astros, plantas, insetos, animais em

${ }^{128}$ Não consegui traduzir esse termo em campo e identificar o tipo de árvore ao qual se refere. 
geral e antepassados míticos, o que nos remete a seguinte passagem de Cayon e Chacon (2014) onde falam sobre os topônimos:

En su gran mayoría, los topónimos son palabras con dos morfemas: el primero es un sustantivo que indica la identificación semántico-cultural más general de un lugar, como el nombre de una fruta silvestre o cultivada, un animal, un pez, un árbol, un personaje mítico, un objeto ritual o de la vida doméstica, entre otras cosas, que hacen referencia a los eventos ocurridos durante la creación del mundo. El segundo morfema puede ser u otro sustantivo, o un morfema clasificador o un adjetivo, que restringe el significado del primer morfema por especificarle una propiedad geográfica (por ejemplo, si es un río, un lago, un cerro, una piedra, etc.) o conceptual (por ejemplo, la maloca y partes de su estructura, objetos de poder ritual, partes del cuerpo de animales y vegetales, o cantidades) (CAYON \& CHACON, 2014, p. 220).

Mais adiante no mesmo texto os autores comentam as diferenças de referenciais dos topônimos de um grupo para outro:

No obstante, aunque existan patrones generales en la onomástica de los lugares, también se perciben diferencias importantes entre los grupos con relación a la selección de los nombres asociados, por ejemplo, a frutas silvestres y cultivadas en las narrativas usadas por los especialistas rituales en cada geografía chamánica [...]. Ya que los nombres de los lugares son centrales dentro de las geografías chamánicas, las especies citadas en las narrativas, cantos y curaciones chamánicas tienen un valor fundamental en cada sistema de manejo del mundo y demuestran preferencias culturales o énfasis en conocimientos, algunos generales y compartidos, otros exclusivos, que son centrales para la identidad de los grupos." (2014, p. 220-221).

Feitas essas considerações sobre nomes de rios e igarapés, passemos agora a outras categorias de espaço kubeo.

A floresta (makãrõ) é outro elemento importante para os Kubeo. A respeito dessa categoria, Goldman avançou formulações que contrariam muito do que observei em campo. Em primeiro lugar, Goldman nota o seguinte para os Bahúkiwa: "Except for an occasional crossing of a hairpin bend in the river the Cubeo never entered the forest. The rivers are known in minutest detail, but the forest (maqdno) is a deep, mysterious and undifferentiated wilderness. The country outside of the tribal limits is more or less unknown to the Cubeo" (1940, p. 242-243, grifo meu). Goldman faz uma diferenciação entre graus de conhecimentos 
do rio e da floresta com a qual não concordo, quando afirma que a floresta é um espaço indiferenciado e "misterioso". Ao fazer isso, o antropólogo norte-americano opera com uma dicotomia que atravessou boa parte da literatura regional, a saber, aquela entre "povos do rio" e "povos da mata ou floresta" (apontada, entre outros, por ATHIAS, 2008), sendo que a primeira categoria subsumiria os grupos tukano e arawak e a segundo os ditos "Makú". Penso que os Kubeo possuem conhecimentos profundos sobre ambos os lugares. Vejamos.

Alguns Yuremawa e Yúriwawa de Açaí e Querari praticam a caça, que se dá por meio de incursões noturnas na mata, às vezes incursões de muitos dias, por lugares muito distante das comunidades. Muitos lugares de pesca em igarapés, em determinadas épocas do ano, apenas são acessíveis por meio de caminhos na mata. Todo o processo de abertura e manutenção de roças também pressupõe conhecimento das matas: a escolha do local, a avaliação do que pode ou não ser cultivado no local, os percursos diários até a roça, os dias acampados em casas feitas na roça (ukũ é como os Yúri Parãmena chamam essas casas), algo que tem se tornado comum na região, sobretudo por conta das longas distâncias entre roça e comunidade, que toma horas de caminhada por trilhas na mata diariamente. Por fim, devemos lembrar que "os antigos", como dizem os Yuremawa e Yúriwawa, viviam no interior das matas, longe do rio Uaupés, e que a consolidação da vida segundo o padrão comunitário é recente e resultado em grande parte do esforço dos missionários salesianos.

Conversando sobre memórias de deslocamentos no passado, Jaime (Yúriwawa de Açaí) me contou que antigamente havia muitos caminhos que eram percorridos pelos mais velhos, e que muitos deles já não são mais conhecidos, se fecharam, dado que as pessoas pararam de percorrê-los; mencionou mesmo a existência de um caminho que, saindo de Açaí conduzia até o rio Ayari, um "varadouro" como tais caminhos são designados na região. Lembro-me que, em 2014, organizamos uma pequena expedição até uma serra chamada Iamawa ("Pedra do Veado"), local onde, segundo José Bernardo, os Kubeo antigamente iam caçar, pescar nos igarapés próximos e sobretudo pegar minhocas, pois sobre essa pedra há um certo tipo de vegetação cujas raízes escondem muitas minhocas; o próprio pai de José Bernardo era um dos que faziam esse percurso. Devo mencionar que nessa expedição saímos de Açaí bem cedo, caminhamos sem muitas paradas, e chegamos ao lugar apenas ao final do dia, quando já começava a escurecer. Esse é um exemplo, portanto, dos longos percursos dentro da mata feitos pelos Kubeo. Assim, a partir desses dados, mesmo que poucos, penso ser possível perceber a inadequação das categorias "povos do rio" e "povos da mata", de uma 
tipologia na qual os Kubeo e outros grupos tukano e Naduhup pudessem ser facilmente encaixados. Minhas análises subsequentes fortalecerão esse argumento.

Goldman diz que "The forest is a source of danger because of the Jaguar and the abuhuwa" (1949, p. 245). Com efeito, a floresta é uma fonte de perigos, mas o rio também é fonte de perigo, seja por conta das corredeiras e pedras que podem causar "alagamentos", muito comuns na região, seja por conta dos moawz, os seres da água. Se os Kubeo são "povo do rio", são também "povo da mata", no sentido que seu conhecimento da floresta não é menor, o que, novamente, mostra a inadequação de tal distinção. Falamos da floresta e do rio. Resta avançar considerações sobre duas outras categorias: a roça e a comunidade. Vejamos.

A roça (hioaino) $)^{129}$ constitui um dos centros da vida kubeo. Boa parte do dia se passa na roça. Vemos as famílias despertarem muito cedo na comunidade ${ }^{130}$, comer quinhapira e logo partir, retornando apenas ao final do dia, isso quando não dormem em palhoças na própria roça, para poupar tempo de caminhada e mesmo evitar carregar peso pelas longas trilhas na mata.

\footnotetext{
${ }^{129}$ Os Kubeo usam o termo tawa para designar um lugar, uma área limpa; assim, hió tawa se refere ao que chamamos de roça secundária, isto é, aquele descampado de lugares que já tiveram uma primeira plantação de manivas.

${ }^{130}$ Hoje é comum as pessoas começarem a sair para a roça a partir das $7 \mathrm{~h}$ da manhã; contudo, ouvi de alguns indígenas que seus pais e avós tinham o hábito de iniciar o dia ainda de madrugada, antes de amanhecer. Acordavam, banhavam e comiam algo antes do sol nascer. Explicaram-me que um dos motivos desse hábito, além de começar os trabalhos mais cedo na roça, era comer sem insetos ao redor dos alimentos.
} 


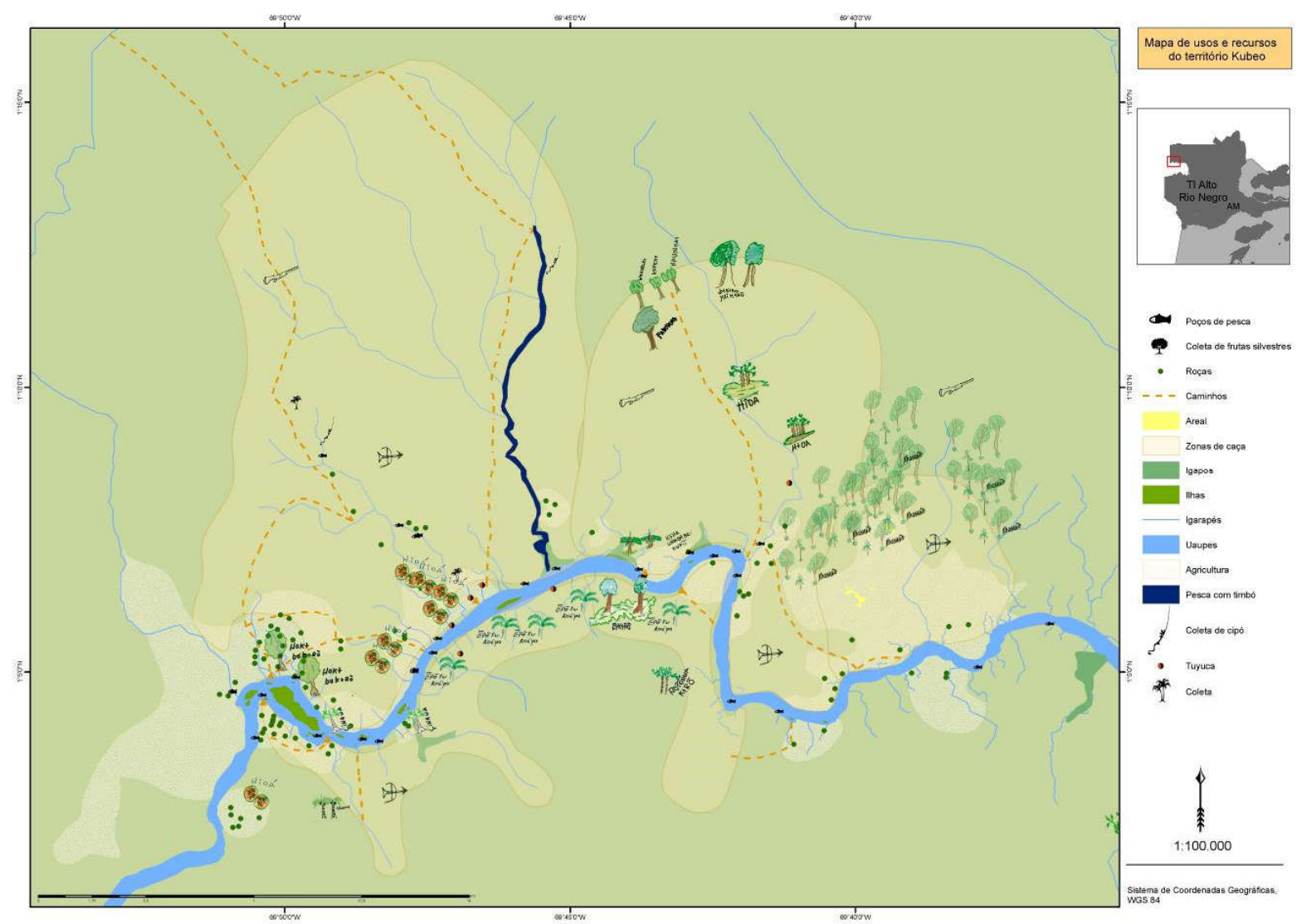

Figura 16: Mapa como representação kubeo de usos e recursos da região (Elaboração: Igor Richwin, 2019)

Há uma política subjacente a abertura de roças, isto é, quem pode abrir roças na comunidade, a escolha do lugar, e quem autoriza a abertura dessas roças. Alguns casos podem esclarecer esse ponto. Em primeiro lugar, o caso de Jaime, Yuremawa vindo de Jaburu ${ }^{131}$ que, quando chegou em Querari, teve que pedir autorização ao senhor Henrique Rodrigues - então chefe de Querari - para abrir roça, sendo que o mesmo senhor Henrique Rodrigues indicou a ele o lugar onde a roça deveria ser aberta. Se Jaime é Yuremawa, tal como Henrique, cito um segundo caso, a saber, o de José Abelardo, Betowa que, como já vimos, é ex-morador de Yauaretê-Ponta, que teve também de pedir autorização ao velho Henrique para abrir roça quando se mudou com a família para Querari. Por fim, um terceiro caso, aquele de um Baré vindo de São Gabriel da Cachoeira para morar com sua esposa, Yúriwawa de Açaí, que até minha última viagem a campo ainda não tinha conseguido espaço para abrir roça, sobretudo

\footnotetext{
131 Jaburu é uma comunidade kubeo (Yuremawa) no rio Querari; é a primeira comunidade a montante do rio, logo acima de Querari.
} 
devido a algumas críticas por ter vindo com a esposa quando o adequado, segundo os Kubeo, seria que a esposa fosse morar na comunidade do marido, não o inverso.

Tais casos aparentemente nos conduzem à noção de "posse", as quais, por sua vez, constituem um dos temas que tem gerado dificuldades de toda ordem para a etnologia regional. Com efeito, os Kubeo parecem estabelecer certas relações com alguns espaços que num primeiro momento parecem apontar para certa ideia de "posse", como no caso da relação da família com o espaço da roça, que difere da noção que se tem de outros espaços, como aqueles de caça, pesca, ou coleta de frutos e materiais vegetais diversos, tidos como de uso "comum" pelos moradores da comunidade. Sugiro explorar e matizar essas diferentes espacialidades por meio da categoria de "dono", bastante difundida na literatura, mas sistematizada sobretudo por Carlos Fausto (2008). Em Kubeo, "dono" é tradução de upaku, assim, por exemplo, "hiodoku upakt" (“dono de canoa").

Com efeito, Fausto sustenta a tese segundo a qual, a despeito de receber pouca atenção nas etnografias, a noção indígena de "dono" constitui uma categoria-chave para a compreensão da sociologia e da cosmologia indígenas; na definição desse antropólogo:

A categoria e seus recíprocos designam um modo generalizado de relação, que é constituinte da socialidade amazônica e caracteriza interações entre humanos, entre não-humanos, entre humanos e não-humanos e entre pessoas e coisas (FAUSTO, 2008, p. 329).

A noção de dono, portanto, não expressa apenas uma relação de propriedade ou domínio, mas é antes "uma noção cosmológica que inflete sobre o plano sociopolítico", afirma Sztutman, “remetendo, em termos muitos gerais, a essa capacidade de 'conter' apropriar-se ou dispor de — pessoas, coisas, propriedades e de constituir domínios, nichos, grupos" (SZTUTMAN apud FAUSTO, 2008, p. 335). Desse modo, Fausto sugere que o mundo ameríndio é um mundo de donos:

O mundo pós-mítico (...) é um mundo de múltiplos domínios. Esses domínios são constitutivos da estrutura do cosmos, de tal modo que um dos pressupostos a reger a ação humana sobre o que chamaríamos de mundo natural é o de que tudo tem ou pode ter um dono (2008, p. 339; grifo meu). 
O mundo ameríndio seria, portanto, dividido em diferentes espaços "de domesticidade pertencentes a humanos e a não-humanos" (FAUSTO, 2008, p. 339), isto é, domínios, com seus respectivos "donos-mestres". Voltemos agora à etnografia kubeo, pois tal como sugere Fausto para contexto etnográfico amazônico mais amplo, o espaço dos Yuremawa e Yúriwawa parece ser também ele habitado por donos. Seguem alguns dados que nos permitem sustentar tal tese.

Geraldo Edson em conversa sobre donos de lugar explicou-me o seguinte:

Dono de lugar, esses são espíritos também, próprio daquele lugar. Como eu falei, quando a gente não crê, o espírito desse lugar, ele vai demonstrar através de alguma coisa. No caso, se tem uma caverna, eles falam alguma coisa, aí tem dono, assim, verdadeiro nome dele não aparece não, mas através de alguma coisa ele aparece, através de alguma forma ele vai mostrando que realmente ele existe aí. Dessa forma que acontece essas coisas. O lugar é uma casa... assim... como se diz... aquela pessoa que nunca morreu, para ele é uma pedra, vamos dizer; aquele que não é pajé ou kumu vê como se fosse uma pedra, ou coisa normal; mas agora aquele que é pajé ou kumu sabe que é uma casa já, apenas tem formato de pedra, mas dentro é tudo casa. Eles vão vendo sonho deles, já mostra que isso é casa, tem algum ser lá dentro; ou até mesmo essa sucuri, todos esses tipos, esse é dono desse lugar. Hoje em dia quase ninguém acredita, mas os velhos falando, aqueles que conheciam mesmo, falavam que aquele lugar é sagrado, é uma casa mesmo, mas eles sabiam, eram conhecedores; hoje em dia está reduzindo mais esse conhecimento, a gente considera como lugar concreto já. Ninguém tem aquele respeito de considerar que aquele lugar é sagrado. Mas antigamente tinha respeito, considerava que aquele lugar era sagrado, para não acontecer alguma coisa, ele chegava, ele benzia, pedia para o dono do lugar que ia ficar um tempo, ficava pernoitando, aí ele deixa. [...] Esse ser, ele é invisível, sempre está com a gente; como a bíblia fala, Deus está em toda a parte, é a mesma coisa que eles sentiam, esse dono do lugar está em nosso meio também. Eles tinham que respeitar aquele lugar, por isso que eles faziam o cigarro, pediam primeiro. Antes de sair era a mesma coisa, agradecia e iam embora. Assim eles sabiam, tinham noção de quem era. Era o certo deles, dos passados, nossos avôs; todo lugar era sagrado deles. Agora não, todo lugar sagrado a gente já mergulha, ninguém tem mais medo. Dessa forma que acontece agora. Depois fica doente, acontece acidente, aí que a gente começa a pensar já aí.

Nesse momento da fala de Geraldo Edson fiz uma interrupção para perguntar se os donos de lugares têm nomes: 
Alguns lugares têm; no caso aqui o Wakaipani, ele tem nome, no caso esse Wakaipani é referente a um ser, onde originaram todos os grupos, vamos dizer, origem do grupo de gente, aí tinha que ter um ser deles, o maior deles, que fez com que todo mundo originasse. Então quer dizer que... Desse ser, então quem estava com inveja foi esse Aviá, ele que teve inveja dele, viu que estava saindo muitos grupos, aí fechou esse buraco da origem. Aviá é avô dos Wanano. [...] por isso que dizem, esse Marakãriku, ele é irmão maior do grupo dos Wanano. Por isso que falam, esse pedaço é todo dos Wanano, a gente é forasteiro. Viu que a gente... nosso grupo subiu lá do rio Ayari... viu que a gente não tinha onde morar, então deu filha dele para nosso primeiro grupo, cedeu esse terreno para ele ficar, como provisório, por isso que eles falam que Wanano é dono daqui. A partir dali que ele teve essa delimitação... tal lugar... tal lugar, a maior parte. Por isso que fala que esse lugar onde a gente caça, onde a gente pesca é lugar muito pobre, ele não foi escolhido pelo próprio Yuremakt, ele foi dado pelo Wanano, onde chegou e deixou ficar, não era o lugar onde queria; se tivesse o lugar deles acho que escolheria melhor que aqui; por isso que eles falam assim.

Novamente, interrompi a fala de Geraldo Edson para perguntar sobre determinada praia logo abaixo de Açaí, Ñapãku:

Napãku, "praia de tucunaré", tem dono, tem uma casa também lá, é uma casa. Esse formato de praia é formato de telhado já, da casa. No caso lá, essa Ilha de Tucunaré, acima de Jutica, o irmão do Cordeiro, tio dela, da Maria, ele estava contando, não sei se era tempo de páscoa, natal ou ano novo, subiu lá para pescar; foi pescar, cozinhou, comeu. Depois disso, ele estava deitado, aí de repente... lá para meia-noite, disse que começou a zoar um som de sino de catedral, zuou três vezes, primeiro zoou $9 \mathrm{~h}, 11 \mathrm{~h} 30$ e o último meia-noite. Aí a gente perguntou para ele "por que você não saiu e não olhou?"; ele pensou que essa ilha abriu todinha, e lá dentro era cidade; por isso que a gente falou "por que você não foi lá ver?", "não, deu medo já"; até por baixo, onde ficava esse casinha dele, já tinha um som estranho, parecia aquele canto do jabuti; por isso que falou, quando tocou esse sino abriu toda essa ilha de Tucunaré, era casa mesmo, casa de pirarucú.

Perguntei sobre Ñapãku a Geraldo Edson pela seguinte razão: certa feita, em janeiro de 2015, eu, João (outro antropólogo que estava em campo comigo), Luiz Gilberto e Geraldo Edson fomos até essa praia no rio Uaupés, Ñapãku (“Tucunaré-Praia”), logo acima de Açaí, para pescar. Geraldo Edson mostrou que, cavando a própria areia da praia, a gente podia encontrar minhocas para pescar. Eu e meu amigo antropólogo começamos a cavar e, animados e achando graça do que fazíamos rimos e falamos alto. Em determinado momento, uma parte da areia praia começou a desabar e a praia foi pouco a pouco sendo engolida pela água do rio. Era esperado que isso acontecesse dado que à medida que cavávamos o buraco feito ia sendo 
tomado pela água; mas o desabamento de areia foi tão grande e intenso que nos assustamos. Geraldo Edson imediatamente nos advertiu que "o dono do lugar estava bravo", pois eu e meu amigo estávamos fazendo muita bagunça em sua "casa". Geraldo Edson explicou que "a praia é o teto da casa do dono do lugar”. Luiz Gilberto complementou a advertência e explicação de Geraldo Edson dizendo que eu e João éramos desconhecidos, estranhos para o dono da praia, daí ele reagir à nossa presença no local. Segundo Geraldo Edson, é preciso pedir autorização ao dono do lugar para quem deseja frequentá-lo, fazer benzimentos, ter um comportamento respeitoso e agradecer sempre a estadia no lugar. Também explicou que o dono pode se manifestar de diversas formas para o visitante e listou três das formas mais comuns: pode aparecer na forma de uma sucuri, pode produzir algum tipo de som muito alto ou pode causar doenças à pessoa que chega sem os cuidados necessários.

Outro episódio que ouvi em campo diz respeito ao encontro de Jaime com um abuhukut ${ }^{132}$ : ele me contou que certa vez foi abrir roça perto do igarapé Muređa, bem dentro da mata, distante, portanto, da comunidade de Açaí. Em uma de suas idas ao lugar se deparou com "um ser parecido com um homem, mas muito grande, que tinha barriga grande, fazia som de onça, e com dentes grandes”. Esse ser passou por ele, não fez nada. Contudo, sua esposa ficou com medo e não quis mais abrir roça no local, abandonaram o lugar. Jaime disse que esse ser era o dono do lugar.

Um terceiro acontecimento se deu numa comunidade Kotiria do Uaupés; trata-se do alagamento de voadeira de militares em Carurú-Cachoeira, no final de 2014 ${ }^{133}$. Após perderem a embarcação e o equipamento tentando atravessar a cachoeira, os militares enviaram especialistas em mergulho para recuperar o material que afundou na água, como motor do bote e sobretudo as armas que os militares carregavam. Durante esse episódio, notei que muitas pessoas ficaram apreensivas com os mergulhadores perscrutando o fundo das cachoeiras. Luiz Gilberto, que me acompanhava, comentou que era perigoso tentar chegar ao fundo da cachoeira, pois podia despertar a reação do "dono do lugar", dos "espíritos sobrenaturais".

\footnotetext{
${ }^{132}$ Esse é outro episódio de encontro de Jaime com abuhukt, distinto daquele descrito no capítulo dedicado ao tema do yahui amiya.

${ }^{133}$ Eu voltava de uma viagem a São Gabriel da Cachoeira com Luiz Gilberto neste dia. Cheguei em CarurúCachoeira poucas horas depois do acidente com a embarcação dos militares.
} 
Os Kubeo de Açaí e Querari comumente falam de "seres invisíveis", "seres espirituais" ou apenas "espíritos" que habitam as matas e rios: hoktwz ("espírito da mata"), usado para se referir aos seres que habitam o espaço da mata; e moawz ("espírito da água"), aqueles que habitam o ambiente aquático, como já vimos. Estes seres são referidos quando se contam histórias de doenças, de caça e pesca, ou mesmo episódios durante trabalho na roça. Descrevo mais um evento que nos mostra o entrelaçamento entre lugares e esses espíritos: trata-se do caso da construção da pequena usina hidrelétrica de Querari, e a consequente incidência de malária na comunidade.

Segundo me contou Luiz Gilberto, durante a construção do Pelotão do Exército de Fronteira de Querari, nos anos 1980, decidiu-se aproveitar o potencial do igarapé Hiađođa (“Canoa-Igarapé") ${ }^{134}$ para gerar energia elétrica, e deu-se então início à obra de construção de uma barragem para uma mini usina hidrelétrica. Acontece que, próximo à foz do igarapé, havia um conjunto de "pedras" que precisavam ser removidas; dentre elas, haviam duas, "Pedra do Diabo" e "Cabeça da Onça", "pedras" essas que "tinham muita energia" e, juntas, "formavam uma panela". Sem as orientações e conhecimento desse poder, os militares explodiram as pedras, liberando assim doenças na comunidade, o que explica o primeiro surto de malária em Querari. Além da doença, a explosão das pedras, que abriu a "panela de malária", também liberou "diabos" que causavam outros tipos de doenças ou deixavam as pessoas que os encontravam mudas. Foi necessário benzimento para "fechar a panela de malária”. Geraldo Edson confirmou o relato de Luiz Gilberto, contou-me que esse trecho do igarapé era "casa do diabo", por isso também quando destruíram as pedras" o "diabo (abuhuku) ficou solto, sem casa. Foi preciso benzimento para que "diabo" fosse embora, encontrasse outra "casa".

Há também muitos lugares dos quais, mesmo não se tendo conhecimento empírico, sabe-se pelas narrativas e histórias que têm donos. Um exemplo é a serra de Bokómio, já no lado colombiano da fronteira. Segundo ouvi de alguns Kubeo, diz-se que no topo desta serra há ouro, mas a mesma tem uma "mãe" que a protege contra estranhos e invasores, sendo essa "mãe" dona do lugar. Para alguém chegar lá, é preciso "respeito" e observância de um conjunto de práticas, como benzimentos e interdições alimentares.

Por fim, cito a serra de $U k \tilde{u}$, próxima a comunidade de Puerto-Mauá, no rio Querari

\footnotetext{
${ }^{134}$ Esse igarapé separa a área militar do PEF da comunidade; tais espaços são ligados por uma ponte sobre a barragem da mini usina hidrelétrica.
} 
(Poẽ Poheia) e que visitei em 2016. Segundo Martins Gomes, que me guiou na visita, Ukũ tem dono, que se chama Tekui ${ }^{135}$ que, como me explicou, é uma pessoa, que se mostra com aparência de cobra para nós. Disse que Tekui vive atualmente em Yaurabu, uma serra que contém um poço no seu topo, e se localiza na cabeceira do rio Ayari. Segundo Martins, Tekui possui poderes de cura, e é um dos chefes dos Yuremawa. Alguém que quer visitar Ukũ deve pedir permissão à Tekui, ou então ele pode repreender com chuvas, trovões e doenças. Voltemos ao tema da "posse" de certos lugares, que sugiro apreendermos como domínios de determinados donos.

Parece haver diferentes escalas para se pensar certa noção de "posse" entre os Yuremawa e Yúriwawa: a escala familiar (roça, espaço da casa, isto é, “onde se mora”), da comunidade e aquela do grupo (espaço para caça, pesca e obtenção de recursos vegetais). Há certa noção compartilhada entre os Kubeo de "limite", de fim de um espaço e início de outro, e "regras" para uso desses espaços. Lembro-me de conversa com o Yúriwawa Luíz Rodrigues em 2013, quando ele disse que, para alguém que vai pescar ou caçar em áreas fora de sua comunidade, é preciso pedir autorização, ter o consentimento da comunidade "dona" do local da pesca ou caça. O não-consentimento pode implicar em conflitos, desentendimentos entre as pessoas. Os donos das roças, por sua vez, são as familias, e está relacionada a certa noção de patrilinearidade e de virilocalidade. Vejamos com mais atenção esse ponto.

Em conversa com Luiz Gilberto, ele me explicou que "cada família tem seu território", seu espaço para abrir roça. Tal espaço pertence a essa família e passa de pai para filho, é sempre o homem o responsável, o "dono" do lugar. Nesse sentido, quando se casam, o esperado é que a mulher vá morar junto com seu marido, isto é, na comunidade dele; “é uma vergonha o homem ir morar com a mulher. É sempre o homem que leva a mulher”, disse Luiz Gilberto. Citou o caso de certo indígena Baré de São Gabriel, que chegou em Querari acompanhando a esposa yúriwako, e estava com dificuldade para conseguir abrir roça em Querari e Açaí, pois “o correto seria ele levar a esposa para viver na sua comunidade”, explicou Luiz Gilberto. O conhecimento dos espaços onde cada um pode trabalhar, e a qual família pertence cada local, é compartilhado por todos, segundo Luiz Gilberto.

Roça e "trabalhar na roça" são tidos por muitos Kubeo como atributos do "indígena". Um "indígena propriamente tem roça”, afirmava Luiz Gilberto, e despende parte de seu dia realizando trabalhos nesse espaço. É ainda Luiz Gilberto que, durante uma conversa sobre

${ }^{135}$ Tekui, como analisei, é também pupui amiya ("nome de benzimento"). 
diferenças entre brancos e indígenas, me disse que "vocês brancos têm um lugar onde guardam a riqueza de vocês, o banco; o nosso 'banco' é a roça”, isto é, tal como o dinheiro do branco está depositado em bancos, a "riqueza do índio está na roça". A roça é vista como riqueza da família pois é fonte de alimentos; os itens da roça também produzem circulação de mercadorias por meio da troca ou venda; por fim, as roças também garantem as manivas indispensáveis para o caxiri das festas, inclusive muitas roças são mantidas exclusivamente para produção de caxiri, e portanto de alegria para a comunidade. Avancemos na nossa análise das categorias de espaço kubeo.

A comunidade, noção que os Kubeo não parecem ter um termo apropriado na língua, mas que me foi traduzido como kohi hininektrõ, expressão que pode ser entendida como "lugar onde moram pessoas", localiza-se próximo ao rio Uaupés, tanto no caso de Açaí como de Querari. Isso merece destaque porque, como mostrei no primeiro capítulo, no passado os Yúriwawa viviam próximos a igarapés no interior da mata. Foi sobretudo por conta do trabalho missionário salesiano que passaram a viver em casas próximas uma das outras, no padrão de comunidade tão comum ao alto rio Negro de modo geral. Também ouvi o termo kuritawa, designando espaço compartilhado ou habitado por parentes, por "gente da região". Explicaram-me que esse termo remetia a ideia de comunidade, por oposição a imarõ ("cidade"), e envolve a noção de pessoas que se reúnem para beber caxiri e comer quinhapira.

$\mathrm{Na}$ comunidade de Açaí, além das casas, que os Kubeo dizem ser ñaranawi kurãmi, termo que pode ser glosado como "casa copiada dos brancos", há uma maloca, pami kurãmi. As ñaranawi kurãmi são em sua maioria feitas de madeira, tanto a estrutura como as paredes (tábuas serradas); também é comum estrutura de madeira com paredes de certo tipo de plástico; o chão é de terra batida, e os telhados são feitos com folhas de zinco. No geral, as casas têm a cozinha separada, sendo esta com estrutura de madeira e paredes de casca de árvore, chão de terra batida e a cobertura feita de palha de buriti ou caranã. Já a pami kurãmi não é mais usada como faziam os antigos, isto é, como moradia ${ }^{136}$, mas antes como espaço para reuniões, festas de caxiri e outras atividades coletivas; eventualmente, viajantes podem usar a maloca para pernoitar ${ }^{137}$.

\footnotetext{
${ }^{136}$ O leitor encontrará uma descrição detalhada da ocupação tradicional da maloca em, entre outros, Stephen Hugh-Jones (1979; 1993; 1995), e Beksta (1984).

${ }^{137}$ Uso esse também destacado nas etnografias de Aline Caetano da Silva (2012, p. 43-50), para os Waikhana do rio Papuri; e Pedro Rocha (2012, p. 97-104), para os Kotiria de Caruru-Cachoeira, no rio Uaupés.
} 


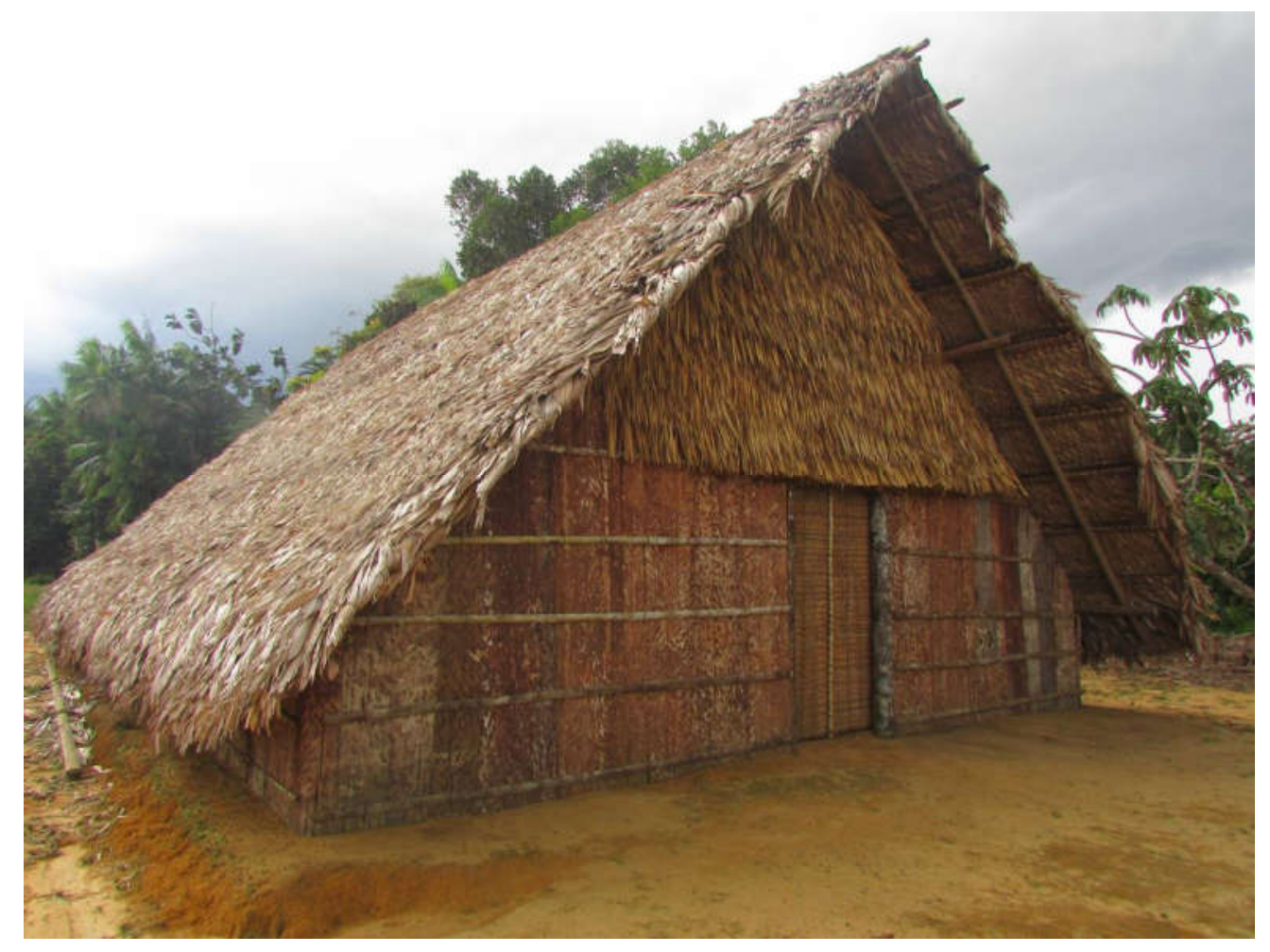

Figura 17: Maloca da comunidade de Açaí (fotografia do autor, 2014).

José Bernardo assim lembrava das malocas:

No Oributinha maloca, maloca grande. Muitas famílias moravam lá, cinco famílias. Os jovens, sempre eles ficavam no meio da maloca, tinha rede deles; os velhos que ficavam noutra bera, parede, da maloca, com as mulheres, criançada, os jovens sempre ficavam no meio, tinham a rede dele. Quando eu nasci cada família já tinha casa, já era separado, os missionários já tinham chegado. Outro não querendo viver na maloca grande, fazia casa separada da maloca, uma maloquinha, vivia com a mulher dele, a filha, afastado. Aí chegaram os missionários e fizeram a casa assim, casa da cultura dos brancos, aí a gente já fica acostumando agora, até agora. 
As malocas constituíam, além de moradias, espaços de realização de festas e cerimônias rituais, como dabucuri (bedeino) e Jurupari. Nesse sentido, era considerada "mãe e pai” dos Kubeo, segundo Luiz Gilberto. Ainda segundo esse Yuremawa, "maloca é pessoa, é mãe e pai", o que nos remete ao tema já bastante explorado na literatura regional (HughJones 1993 ; 1995) da androginia da maloca. Luiz Gilberto também sustenta que "a maloca é o universo, uma pessoa, ou também uma mãe", falas essas que remetem para concepções mais amplas e difundidas entre muitos grupos tukano, como Stephen Hugh-Jones mostrou em alguns de seus trabalhos (1993; 1995). Vejamos uma longa fala de Luiz Gilberto, onde descreve a maloca:

[...] é uma pessoa [maloca] para nós. Nessa comunidade [Açaí] eles sempre mantêm ainda isso, porque para nós é uso. Para quem faz eventos de ritualizações, sem essa casa, não tem como a gente fazer ritualizações. Para manter vivo as ritualizações, tu tens que ter um espaço específico, que isso é parte disso. Então a gente não tem maloca, não tem como. Isso faz parte do dentro da maloca, não fora, já é tradição. Então, pelo menos na comunidade, a gente tem uma maloca. Mas hoje em dia não é exatamente a maloca, como era né, grande, que cabe muita gente; agora não, é mini-maloca. [...] Nossa maloca era de $50 \mathrm{~m}$ de comprimento por $20 \mathrm{~m}$ de largura; altura era mais ou menos uns $25 \mathrm{~m}$, porque depende do comprimento da casa né, se a casa é mais comprida, a altura também vai, se ela reduz... Mas sempre alto, sempre na forma de um triângulo. [...] A gente acredita e a gente valora que ela é nossa mãe, a mãe que cuida de seus filhos, então todos os seus filhos estão lá dentro. Então é a mãe protegendo a gente. Então para nós é uma pessoa que cuida, é pai e mãe, como um todo. Nesse sentido, todos os materiais que ela contém, tudo tudo, a gente não usa como qualquer coisa. Por exemplo, tem uma regra que a gente valora, em que nenhum momento nós de nosso grupo vamos pegar uma madeira que foi montada, e que depois foi tirada, nenhuma pessoa vai pegar e queimar ela. Isso a gente não faz, porque é mesma coisa que você pegar os restos da sua mãe e queimar. E não se usa para fazer o fogo assim porque, tipo lenha, a gente não faz isso. Porque a gente acredita que toda essa madeira que está lá dentro, que na verdade são ossos, costelas, tudo. Como a maloca tem um tempo que ela é capaz de chegar a 20 anos sem ser removida. Então durante 20 anos, quantos tipos de rituais foram feitos, quantas potencialidades foram usadas lá dentro. Então toda essa madeira está cheio de energia, cheio, cheio. Então o que acontece, na hora que ela é removida, alguma coisa ali, se pegar um pedaço dela e queimar, é a mesma coisa que a gente pegar um pano, botar na gasolina, e jogar no fogo; o que acontece? Uma explosão. Pode ser fatal, mas nesse sentido da potencialidade não do fogo, mas energia, que para muitos pode se tornar, que geralmente se torna, energia negativa, que faz mal para a saúde, a gente pode acabar matando muita gente, mesma coisa que a gente detonar uma bomba dentro da casa. Então isso a gente valora muito, então tudo é descartado normalmente, sem ser queimado, tem que ser destinado a um certo lugar e pronto; mas em nenhum momento a gente queima isso. [...] O que a gente sente é que isso são ossos de nossa mãe. Então é por isso também que 
quando a gente constrói uma maloca, a gente tem de fazer do jeito como ela é, quer dizer certinho, nenhum parafuso a menos, quer dizer, nenhum cipó a menos. Porque se deixou de fazer ou colocar o material necessário, aí não é mais maloca, seria nova criação, e como é nova criação não é mais maloca, vai deixar de ser maloca. Então são esses cuidados que a gente tem. Então toda madeira que está composta, ela sempre tem nome. Então são as partes de valores na construção de maloca; não é maloca você chegar e pronto, fiz uma maloca. [...] A gente, geralmente, todo homem tem esse conhecimento [sobre construção de maloca], mas sempre tem um chefe, sempre tem um chefe maior, e sempre tem os seus seguidores; até os mais novos cabe, é no sentido obrigatório para quem é homem. Tem que ter esses conhecimentos. Então isso é hereditariedade né, que ninguém é eterno na vida, então o primeiro foi, então depois dele substitui outro, e assim vai. Tem que saber tudo isso. A maloca que a gente tem atualmente, ela é pequena, mas tem toda essa estrutura, completinha, é miniatura, mas está completinha. Se alguém chegar lá, que muitas vezes já fizeram isso, um não-indígena passando por aí, falar "isso aqui é maloca?", "claro, é maloca". Então, ele começa a perguntar: "esse aqui tem nome?", "tem"; "aqui tem nome?", "tem".

\section{Luiz Gilberto segue sua explicação dizendo que "a maloca é uma pessoa”, possui porta}

de entrada masculina e feminina, está disposta segundo o nascer e pôr do sol, e em seu interior há espaços reservados para cada tipo de pessoa:

Então a gente vai explicando até completar uma pessoa completa, isso aqui é costela, direita, esquerda, os esteios são as pernas, as portas, uma porta para os homens, outra porta para as mulheres, então porta de entrada e saída. Os bancos para as mulheres, para os homens, para os cantores, para os benzedores, e o centro como base de tudo isso, o núcleo de toda essa energia. Então a maloca sempre tem a parte, tem o local específico para cada tipo de pessoa. Então são coisas valiosas que a gente acredita, a gente tem. Porque em nenhum momento, por exemplo, um homem pode sentar no lado que corresponde às mulheres, seria falta de respeito; quem é mulher, senta mulheres, aí vai, as mais velhas, as mais novas, tudo que tem a ver com isso. Os jovens sempre são os jovens, os mais adultos, são os mais adultos. Os benzedores têm uma parte específica para eles. E para aqueles que fazem conversa, que a gente chama de conversas cantadas. Tem outros banquinhos, tudo completinho, mas cada um no seu espaço específico. Então, portanto, que a gente considera que a maloca é a nossa mãe, ela sustenta tudo isso, guarda tudo isso lá dentro. Ninguém pode ficar fora. [...] A posição no terreno, da maloca, ela nunca deve ficar ao inverso do nascer do sol e do pôr do sol. Sempre todas malocas vão ficar nessa direção, a entrada e a saída, que é o início do dia e o término do dia.

Mais adiante, na mesma conversa, Luiz Gilberto fala do uso do interior da maloca para enterrar os mortos: 
Então nesse sentido também já falando dos defuntos nossos, a gente nunca faz um enterro do defunto olhando no pôr do sol, sempre tem que estar na nascente, porque tem luz, e nesse outro lado é escuro. Então sempre os defuntos nessa posição. Portanto, nossos defuntos sempre foram enterrados dentro das malocas, então portanto que ela é a mãe de todos: é cemitério, e onde as famílias vivem, então é uma mãe que cuida de tudo, é vida [...], é um templo, o que eu quero dizer, lá é centro de aprendizagem, é escola, é faculdade, é cemitério, é um todo, é um universo.

E desenvolve a seguir mais algumas considerações sobre a maloca, destacando que todas as suas partes têm nomes:

Portanto que a gente considera que é a nossa mãe e pai, é o centro da vida nossa. [...] O centro [da maloca] é vazio, e é um espaço retangular, sempre tem fileiras, são quatro colunas, duas no outro lateral, duas no outro lateral. São quatro colunas, total. Então tudo, todas essas partes têm nome específico. [...] A parede já é outra coluna, fora da coluna tem um, além dela tem outro, que é a base principal. Então sempre um lado da parede é aberto, ele é um corredor livre, para as pessoas rodarem fácil, nunca é fechado. É, portanto, quando eles colocaram maloca, isso saiu muito ofensivo, que maloca. Depois quando eles começaram a me explicar "por que é maloca?", "do mãe louca". Isso não cabe com a gente. [...] mas quando a gente não entendeu essas coisas, tudo bem; mas quando eles mesmos, não-indígenas, começaram a ensinar, a esclarecer tudo, bom, aí que pegou. Mas são com coisas que foram colocadas sem querer, ou as vezes com intenção. Mas eu mesmo fico muito ofendido com isso. Então graças aos outros, os mais recentes, já começaram a colocar, do que ser "mau oca", "casa tradicional", aí sim, "casa tradicional" eu concordo. [...] para nós é Pamiami, que significa kurãmi, centro de viver; na nossa língua não tem maloca, não tem, mas na outra linguagem saiu. [...] Então comparando com hoje é muito preocupante, porque muitas crianças dizem "maloca", "maloca"; então são coisas que as crianças têm que saber que não é exatamente isso. Muitas aparecem nos caderninhos deles "maloca", o que significa: "mau oca".

Acima, ao descrever os usos do espaço da maloca, mencionei que antigamente seu interior era usado como cemitério; tal pratica continuou com enterramentos feitos no interior das casas. Depois da chegada dos salesianos, tornou-se comum a criação de um espaço próprio para enterrar os mortos, afastado do lugar de moradia, isto é, os cemitérios. Vale mencionar que tal termo não tem correspondente na língua, pois não existe no pensamento kubeo a ideia de um espaço circunscrito e afastado do lugar de moradia para enterrar os mortos, tal noção é pós-salesiana. Interessante notar que, como já vimos, a despeito da 
ausência desse lugar à parte para enterro dos mortos, há elaborações quanto ao lugar dos espíritos dos mortos, fato que aponta para uma teoria do pós-morte kubeo. Os Yúri Parãmena falam de Abuhuñami, isto é, trata-se de serra localizada no lado colombiano da fronteira, próxima ao rio Querari, onde se localiza a "casa dos mortos", ou "casa dos espíritos", lugar para onde se dirigem os espíritos daqueles que morreram, como vimos no terceiro capítulo. Durante uma viagem com Martins a Puerto-Mauá, comunidade kubeo no médio rio Querari, onde Martins passou parte de sua infância e onde atualmente vive um irmão seu, ele explicoume que o porto dessa comunidade é também "porto dos espíritos", que se dirigem a serra de Ukũ ("tapiri dos espíritos", ou "barraco dos espíritos", lembrando que esse mesmo termo também é usado para se referir às moradias provisórias construídas nas roças), localizada atrás de Puerto-Mauá, e de Abuhuñami. Nessa mesma conversa Martins também explicitou que o trecho do rio Querari até as proximidades de Puerto-Mauá era "território dos Yuremawa", sendo o trecho mais acima território dos "próprios Kubeo", a saber, Biowa e Hehénewa.

Goldman (1940) apresentou uma versão da teoria pós-morte bahúkiwa onde fala do lugar dos mortos, localizado geograficamente - como para os Yúri Parãmena - o qual é perigoso e deve ser evitado durante a noite. Segue:

According to them, the dead of each gens go to live in a gens house situated only a short distance back of the river not far from the actual gens residence. This site is dangerous and must be avoided at night, because at dusk one can heart the spirits of the dead talking and singing. At the head of each household of spirits of the dead is a chief who was the first ancestor of the gens. All the gentes of the same phratry have their separate gens house at the same site, thus forming a phratric village. The Cubeo add that persons who have violated their obligations in reciprocal gift-giving friendships will be challenged by their creditor upon arrival at the village and refused entrance. The spirits of the dead make the journey to the site by canoe and then walk a short distance overland. For this reason the dead are buried in their canoes and given a walking staff. The dead are also provided with a hammock and a calabash (1940, p. 243).

Vemos que diferente do que se passa para os Yuremewa e Yúriwawa, cuja serra dos mortos, Abuhuñami, localiza-se próxima ao rio Querari acima, o lugar dos mortos para os Bahúkiwa é uma casa localizada não muito longe de onde habitam os Kubeo vivos. Voltemos ao tema da comunidade e, mais especificamente, a Querari, que possui uma configuração espacial que merece mais atenção. 
A comunidade de Querari possui uma igreja católica e duas escolas - municipal e estadual -, instituições de grande importância para a comunidade e para os Kubeo de modo geral. A escola é a responsável por boa parte da movimentação entre comunidade e cidades. Além da escola, o pelotão do exército também possui grande importância para os Kubeo da região, e encontra-se em área afastada da comunidade, do outro lado do igarapé Hiađođa. A despeito de não ser muito grande, Querari está organizada em "vilas" ou "bairros": bairro São José, bairro Nossa Senhora Imaculada, Vila Poupex, Bairro da Aparecida, bairro São João, e bairro da Paz. Diante dessa espacialização, parece-me adequado pensar a comunidade de Querari como uma espécie de modelo reduzido da cidade de São Gabriel da Cachoeira, com seus bairros, ruas etc; Querari também encontra paralelos com a configuração de bairros, ou vilas, de Iauaretê. Algumas comunidades, a medida que vão ficando muito grandes tendem a se dividir internamente segundo o modelo de bairros. Aqui, meu interesse dirige-se para a questão dos nomes atribuídos a esses bairros.

Como se pode notar a partir da relação de nomes dos bairros, a maioria deles é de ordem religiosa, remetendo a nomes de santos. Assim, temos: bairro São José, bairro da Aparecida, bairro Nossa Senhora Imaculada Conceição (sendo essa a padroeira da comunidade de Querari) e bairro São João. Outro nome, Vila Poupex, designa o bairro onde vivem militares do PEF, e tem paralelo com o lugar de moradia de militares em São Gabriel da Cachoeira.

No que diz respeito a origem desses nomes de bairros merece menção o fato de que muitos deles começaram como brincadeira, algo semelhante aos apelidos, e apenas depois adotaram a divisão com nomes relativos a santos, nomes "de verdade", isto é, nomes provenientes do mundo dos brancos. $\mathrm{O}$ que estou sugerindo aqui é um paralelo entre os dois tipos de nomes de bairros - nome de brincadeira e nome "de verdade" - e certos nomes de pessoas, a saber, apelidos e nomes de branco. Vejamos com mais atenção a nomeação dos bairros de Querari. 


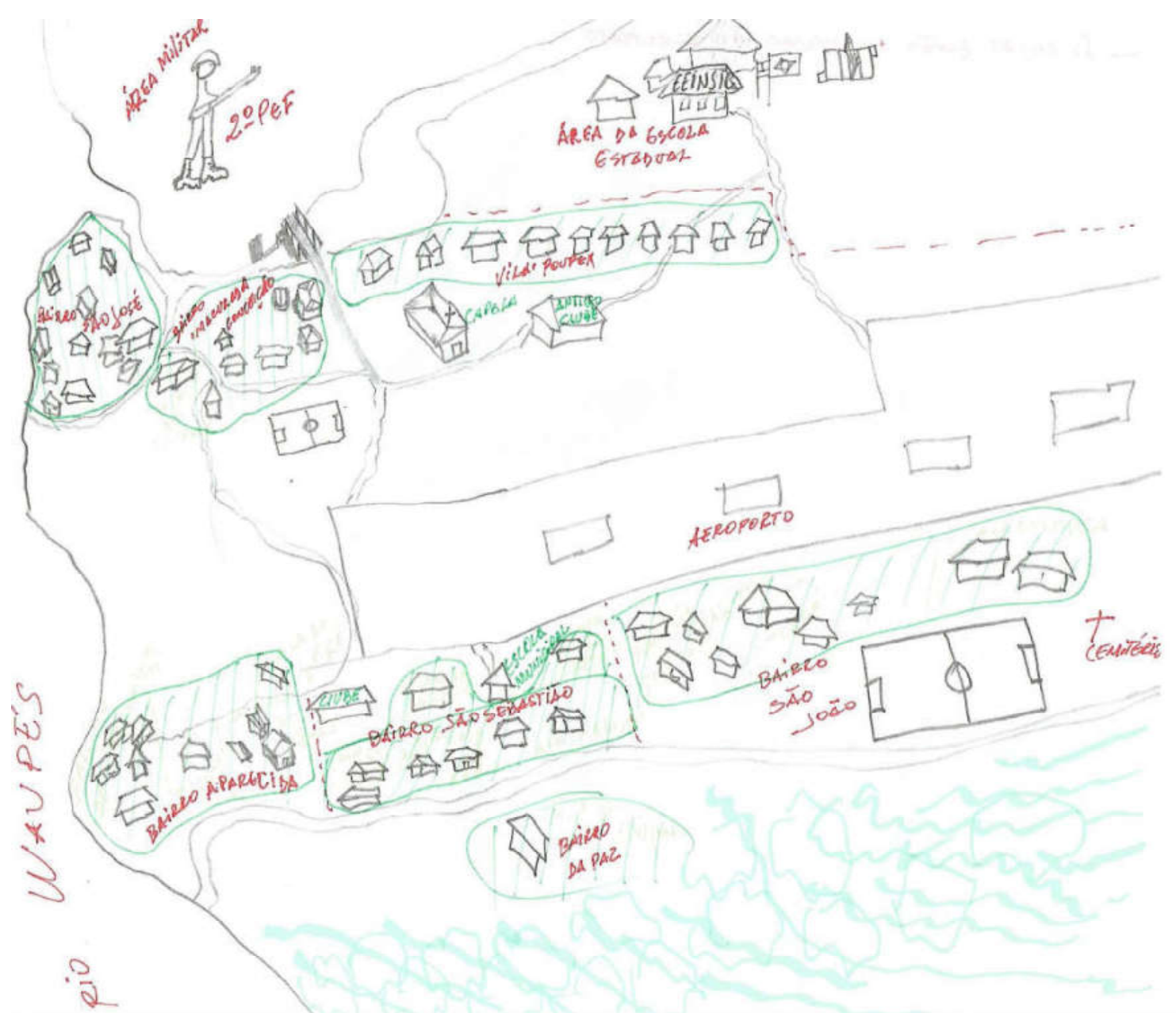

Figura 18: desenho dos bairros de Querari (desenho feito por Osvaldo Torres, 2014).

Em setembro de 2017, durante uma conversa com o Yuremawa de Querari Geraldo Edson, ele me contou como se chamavam os bairros, e qual o motivo de terem recebido nomes de santo. Segue trecho da conversa:

Diego: Quem inventou essa história de dividir a comunidade aqui em bairros?

\section{- Foi Maurício.}

Diego: O Maurício? Ele que começou com essa história?

- Aham, foi ele que começou. Começaram já apelidando, com nome de brincadeira; aí depois de um tempo que apareceu já então né, aí mudaram já para outro nome já aí. Nomes de alguns santos. Antes era tudo brincadeira. Viram que não estava dando certo, por isso mudaram para o nome 
verdadeiro, próprio.

Diego: qual era o nome daqui antes?

- Daqui? Era Vila Cauim. E aqui era bairro Camanaus, onde é Aparecida.

Diego: Bairro Camanaus, é? Por causa do porto ali embaixo?

- É, por causa do porto. Já a ilha do São José era Ilha do Jararacal, porque quando eles bebiam eram bravos lá o pessoal, aí botaram Jararaca. Aí no Sagrado Coração, ali era São Paulo ainda. E ali era vila militar ainda, por isso que botaram Poupex, era vila militar. Daí mudaram; viam que não dava certo, brigavam todo o tempo quando bebiam, por causa do bairro. Começa a brincar e dava briga. Aí depois tiveram que batizar com nome próprio, mudaram para outro nome.

Diego: mas porque aqui chamava vila cauim?

- Hum? Vila Cauim? Porque o pessoal bebia só aqui, nessa vila.

Diego: aí depois resolveu dar o nome certo para cada bairro?

-É. Aí começaram a mudar já aí.

Essa conversa merece alguns comentários. Em primeiro lugar, temos a lista de nomes de brincadeira dos bairros, algo como os apelidos de pessoas: vila Cauim, bairro Jararacal, São Paulo, Poupex e Camanaus. Desses, três são referências a outros lugares: São Paulo, referência à cidade de mesmo nome no estado de São Paulo; Poupex, mesmo nome para vila militar que aquele usado em São Gabriel da Cachoeira; e Camanus, nome do bairro em São Gabriel da Cachoeira onde se localiza o principal porto da cidade. Vila Cauim faz referência à bebida, e ao fato do bairro que recebeu esse nome ser lugar onde se diz que as pessoas vão para beber. No caso do bairro Jararacal, há mais de um sentido para o termo. Vejamos.

O bairro São José é conhecido como "bairro Jararaca", ou "Jararacal”, e tal designação tem dois sentidos. O primeiro ouvi do Baré Elinaldo, morador desse bairro, e que comentou ter matado algumas jararacas em São José no mês de julho (época de chuvas e cheia do rio, quando é comum encontrar cobras na comunidade), fato que o fez afirmar "agora entendo porque o bairro São José se chama "bairro Jararaca"'; seu entendimento foi confirmado por Jaime (Yuremawa), que disse ser São José "lugar onde jararaca faz piracema", "lugar de jararaca" e "paranã de jararaca". Em conversa com Geraldo Edson sobre tal explicação, ele me disse que São José é uma ilha; o igarapé que o contorna se chama Aĩktma ("caminho da sucuri”), a ilha se chama Moami ("casa de peixe"), e é o lugar onde a sucuri, considerada "pai 
dos peixes", faz piracema ${ }^{138}$, o que explica a quantidade de cobras no bairro em época de chuvas.

O segundo sentido diz respeito ao fato de nesse bairro acontecerem muitas brigas e desentendimentos durante festas de caxiri, o que fez as pessoas de Querari associarem seus moradores a jararacas, isto é, são pessoas bravas e agressivas tais como a cobra jararaca.

Outro elemento que deve ser considerado nesse trecho de conversa diz respeito à afirmação segundo a qual quem começou com as brincadeiras foi Maurício. Ora, Maurício, morador de Querari, é considerado "estrangeiro", isto é, ele é um indígena desano, cujo lugar legítimo é indicado como sendo o rio Tiquié. Como mostrei no capítulo anterior, os apelidos de pessoas são, em geral, atribuídos por esposas, ou seja, uma pessoa de certa forma de fora do grupo. O paralelo entre os dois contextos de atribuição de nomes de brincadeira (para bairros e para pessoas) é evidente.

Por fim, há o espaço da "cidade", que os Kubeo traduzem em sua língua como imarõ. Perguntei certa vez sobre o significado desse termo, e ouvi que tal palavra podia ser entendida como "onde tem alguma coisa" ou "onde tem coisas", remetendo ao fato de a cidade ser o lugar onde se encontram itens industrializados (as tais "coisas"). Citaram São Gabriel da Cachoeira e Iauaretê como exemplos de imarõ. Nessa mesma conversa, explicitaram que imarõ também remete a ideia de um lugar onde há pessoas de diversos grupos convivendo, e onde não há práticas de se reunir para beber ou comer, como acontece nas comunidades. É importante, quando se fala da cidade, mencionar a questão dos constantes deslocamentos. $\mathrm{O}$ calendário escolar e as viagens para a cidade de certa forma moldam a rotina da comunidade. Nas férias de julho, e de final e início de ano, a comunidade fica esvaziada, não tem mais as grandes festas comunitárias ou bebedeiras de caxiri.

Por fim, outra importante questão para os Kubeo acerca de seu espaço, e que não desenvolverei aqui, apenas menciono brevemente, diz respeito ao fato de viverem em região de fronteira entre Brasil e Colômbia, situação com muitas implicações. Nota-se uma coexistência de duas conceitualizações do espaço no pensamento kubeo: de um lado, o entendimento do espaço tal como delineado nas narrativas de origem e transformação da humanidade, isto é, o mythscape kubeo; de outro, o entendimento do espaço como dividido pela fronteira, distinguindo "brasileiros" de "colombianos", categorias operacionalizadas em

138 Portanto, não “onde jararaca faz piracema”, como tinha dito Elinaldo. 
muitos contextos, sobretudo naqueles de acesso ao sistema de educação, e a certos benefícios do governo.

Feita essa apresentação de algumas das principais categorias de espaço kubeo, descreverei e analisarei em seguida dois episódios de campo que oferecem elementos para pensar o tema que nos interessa aqui, a saber, aquele dos nomes de lugar: uma viagem feita em 2013 ao Wakaipani, lugar de transformação dos Yúri Parãmena, e o contexto de elaboração de mapas como material subsidiário de um plano de gestão da região onde vivem os Kubeo e seus vizinhos Kotiria.

\section{Episódio da viagem ao Wakaipani}

Em maio de 2013, fui a campo fazer minha primeira pesquisa entre os Kubeo e assessorar o projeto "Lugares Sagrados", concebido com recursos do Museu do Índio - RJ, e que consistia na realização de oficinas de capacitação para uso de aparelhos como gravadores de áudio, máquinas fotográficas e filmadora, com o propósito de registrar as narrativas de origem dos Yúri Parãmena, bem como visitar o seu lugar de transformação, o Wakaipani. O projeto, coordenado por um linguista e assessorado por dois antropólogos, foi desenvolvido pelos alunos do então terceiro ano do ensino médio da escola estadual de Querari, como trabalho de conclusão de curso, e teve ampla participação da comunidade e demais interessados, inclusive moradores de comunidades vizinhas do lado brasileiro e colombiano do Uaupés.

Terminada as oficinas, e orientados por alguns velhos Yuremawa, Yúriwawa e Betowa, fizemos uma viagem pelo Igarapé Marãkãriya (afluente do rio Uaupés, no lado brasileiro) até o Wakaipani, onde os Yúri Parãmena, contam alguns velhos, teriam deixado a forma peixe para assumir a forma humana. O propósito geral da viagem era refazer parte do percurso da Cobra Canoa $^{139}$ e registrar os seus locais de parada, bem como parte das histórias associadas a esses lugares.

\footnotetext{
${ }^{139}$ O motivo da Cobra Canoa Ancestral é manejado com mais de um sentido pelos Kubeo. Assim, ouvi alguns velhos afirmar que se tratava mesmo de uma "cobra gigante", no sentido literal, que carregava os Yúri Parãmena; mas já ouvi também outros dizerem não se tratar literalmente de uma cobra, mas sim que a primeira humanidade viajou na forma peixe "como se fosse uma cobra", isto é, dispostos como tal; dizendo ao mesmo tempo que a Cobra Canoa é algo "dos Tukano". Eis um tema que aguarda análises comparativas mais detalhadas.
} 
Segundo uma narrativa contada pelo velho senhor Henrique Rodrigues ${ }^{140}$, filho mais velho do primeiro morador da comunidade de Querari, como vimos, os Kubeo surgem na cachoeira de Hapuí (Hípana ${ }^{141}$ ), no rio Aiary. Seguem viagem reunidos como anaconda até o Içana, depois descem pelo rio Negro até São Gabriel da Cachoeira, lugar já pertencente aos Baré; e, por conta disso, onde não era possível permanecer. Então seguem viagem subindo o Uaupés, e passando pelos territórios dos Desana, Tukano e Pira-tapuya. Chegam a Iauaretê, que também já tinha dono. Seguem viagem até a cachoeira de Santa Cruz, no Uaupés colombiano, cujo território pertencia ao grupo Pamiwa, os "Kubeo originais". Voltam pelo Uaupés e entram no igarapé Marãkãriya (próximo a atual comunidade de Açaí), seguindo pelo igarapé Wahtya até sua cabeceira, conhecido como Wakaipani, onde se fixam, conformando o lugar sua "maloca de surgimento".

É em Wakaipani que a avó Huredanaçu passa a nomear os grupos, oito grupos no total: Meaçiwida, Kahetaremi, Kaporedo, Makawedo, Wiana mamaramu, Kaiwarido, Takari e Betokt, sendo Meaçiwida o irmão maior de todos, e Betowa o último da série; os Yuremawa, nessa versão, ocupam uma posição intermediária. Em seguida, esses grupos se dispersam, ocupando lugares específicos ao longo do Uaupés, sendo que os grupos dos irmãos mais velhos ocupam posições a jusante, e os irmãos mais novos ocupam posições a montante do rio. Segue a narrativa de origem contada pelo senhor Henrique Rodrigues:

Nós nascemos na cachoeira de Hípana (Hapuí). Aiary se chama este rio. Lá nós surgimos, todos éramos peixes. Ali estava aquele que nos estava puxando para fora. Também existia nossa avó, chamada Huredanaçu. Ela estava pensando na gente, e atrás dela estava o Yúri. Existe uma pedra muito parecida a uma pessoa (representa o Yúri). Ele tinha um tabaco sagrado, estava fumando. Puxava os peixes pelas mãos para que se transformassem em gente. Tem uma laje de pedra bonita ali, onde os peixes estavam para se

\footnotetext{
${ }^{140}$ Henrique Rodrigues é um senhor de vasto conhecimento das tradições narrativas kubeo e muito respeitado na comunidade e por comunidades vizinhas, reconhecido, como explicitado no primeiro capítulo, como "tuchaua". Essa narrativa foi contada durante a oficina de 2013, em Kubeo. Apresento aqui uma tradução preliminar, feita em grande parte por um conjunto e alunos kubeo que participaram das oficinas. É importante lembrar ao leitor que se trata de uma versão condensada, pois como o próprio senhor Henrique sempre lembrava "a história dos Yúri Parãmena é muito grande". Aproveito para registrar aqui meus agradecimentos e reconhecimento da bondade e gentileza de Henrique Rodrigues, sempre disposto a ensinar e conversar sobre as narrativas kubeo.

${ }^{141}$ Hípana é um termo que designa, para os povos arawak, o "centro do mundo". Robin Wright nos diz que: "A noção de 'centro' é de importância fundamental no cosmos. Podem existir múltiplos 'centros' do mundo, em lugares físicos diferentes dentro de um mapa geográfico, porém todos têm o mesmo nome, que significa 'centro do mundo', que é o nome Hípana. Assim, o Hípana do Rio Aiary é conhecido entre todos os Hohodene como o 'centro do mundo', tanto no sentido vertical como no horizontal; no entanto, as cachoeiras têm um outro nome, Kupikwam, que diz respeito a um tipo de videira silvestre que se encontra pendendo das árvores na redondeza das cachoeiras. Essa vinha silvestre passou a existir em certo momento no mito de Kuwai. Na região do norte amazônico de língua Aruaque, há vários outros lugares sagrados com o nome de Hípana” (s/d, p. 4).
} 
transformar. "Pronto, já os fiz como peixes", disse Yúri para a gente. Depois de haver terminado soprou com tabaco. Pronto, já havia feito a criação, "agora vamos olhar este rio", disse. Baixaram pelo rio até o "rio Caba" (Içana), onde desemboca o rio Aiary. Baixaram pelo rio Caba, subimos e depois baixamos novamente para ir para São Gabriel. Aí apareceu a canoa de peixes, a canoa dos Yuremawa, que era a canoa que nos estava guiando. Então o dono desta terra nos disse: "não é assim, eu sou dono deste território, este território é meu", disse o Baré, aquele que é propriamente de São Gabriel. "Está bem, então!" Dissemos e regressamos. Vimos subindo por este rio (Uaupés). Havia muitas pessoas nesta parte do território. Vimos muitas pessoas: Desanos, Tucanos, Pira-tapuyos... O território era deles.

Continuaram subindo e bateram em Iauaretê. Lá também já havia dono. Passaram subindo por Iauaretê, essa canoa de peixes subindo, sendo guiados pelo Jirau de Turi de Jibóia. Olha, Waracapuri (Santa Cruz) se chama cachoeira de Hĩparari. Ali chegamos batendo na cachoeira. Era território do grupo Pamiwa (os Kubeo originais). Não nos aceitou o de aí, "este território é meu" nos disse.

Voltamos baixando, olhe, este igarapé Açaí é grande. Aí entrou a canoa de transformação. Agora foram subindo, até o igarapé Wahtya, entrando até sua cabeceira. Aí neste lugar nos fixamos. Lá está nossa maloca de surgimento. Aí nós nos dispersamos. Nossa avó Huredanaçu nos disse "já os tenho guiado até aqui". Então ela passou a nomear os grupos. Nós fomos chamados de Yueremawa. Havia nosso irmão mais velho, chamado de Meaçiwida. Abaixo dele veio o Kấhetaremi. Depois veio o Káporedo. Abaixo dele vem o Mákãwedo. Meus irmãos mais velhos, que estão acima da gente. Depois vem a gente, Wiana mamaramu. Depois vem Kaiwarido. Por último vem o Tákari, ele é o neto do Pato (Bedebo), nosso irmão mais novo. Tem ainda este que era uma criancinha, o Betokt. Assim somos nós. O Yúriwaku é um grupo do meio. Um dia dissemos: "Não temos nosso cunhado, que há com vocês? Hoje nós vamos nos encontrar (vamos ser cunhados)", disse. Este é o Yúriwaku.

Eles já haviam surgido e voltamos à mesma casa no rio Aiary. Então nos deixaram em lugares específicos e vieram: "Você vai ficar aqui, você vai ficar ali..." até na cabeceira onde fomos ficar. Ficamos em três grupos: Yawakabo (parte de baixo da ilha), acima está o lugar chamado Pedra de Quati, lá onde nos estabelecemos. Nós somos o grupo do meio, nossos irmãos mais velhos ficaram abaixo de nós.

Depois da criação viveram muito bem por um tempo. Quando começaram as guerras nos perseguiram até a selva. Agora já descemos para viver em nosso território. Em Pacú, havia o Marakãriku, o chamado Wanano. Ele nos deu este território, Pacú-Cachoeira. Já havíamos nos encontrado com a filha do Banano. Nos deram a filha (nos tornamos cunhados) e depois nos deram o território, nossa terra saborosa, com seus igarapés, onde pescamos, e fazemos quantas outras coisas mais!

Até Poço Tucunaré, acima da comunidade de Açaí, onde está a ponta da praia. Até aí nos limitaram. Ficamos com este pedacinho, então voltou até aqui (foz do rio Querari), onde começa o território dos Biówa. Porém, eles não têm território. Os meus parentes se encontraram com eles e vivem agora na área dos Biówa como se fosse território nosso. Assim é, este é o correto. Isto foi como aconteceu antigamente, assim falaram nossos antepassados. 
Os Yuremawa ocupam um território originalmente pertencente aos Kotiria (Wanano). Marakãriku, um personagem das narrativas de criação kotiria ${ }^{142}$, e considerado chefe desse povo $^{143}$, deixou que os Yúri Parãmena se estabelecessem no lugar, tornando-se cunhado dos Yuremawa. Essa, em linhas gerais, uma versão da história de surgimento dos Yuremawa e Yúriwawa ${ }^{144}$. Voltemos ao contexto da viagem ao Wakaipani.

Antes da viagem, reunimos parte dos moradores de Querari e Açaí para produzir mapas da região, com interesse sobretudo no igarapé Marãkãriya. Osvaldo, um Yúriwawa que vive atualmente em Querari, mas ex-morador de Açaí, e um caçador reconhecidamente habilidoso, que faz constantes incursões para caça e pesca no igarapé Marãkãriya, assumiu a frente na elaboração do mapa desse igarapé, por suas habilidades de desenho e conhecimento dos igarapés da região, mas foi todo o tempo auxiliado e guiado por velhos yuremawa, yúriwawa e betowa. A oficina resultou assim em mapas com grandes detalhes de igarapés, seus nomes em Kubeo e indicação de lugares considerados importantes. Dois pontos merecem destaque acerca do período de oficinas. Em primeiro lugar, os mapas foram desenhados por jovens indígenas, orientados pelos mais velhos; mas merece menção o fato de que algumas mulheres mais velhas também se manifestavam sobre a localização dos lugares, os contornos dos igarapés, e seus nomes. Além disso, durante os preparativos para viagem, uma das questões que foi discutida era se as mulheres iriam ou não na viagem até o Wakaipani, pois tratava-se de visitar o lugar de transformação dos Yúri Parãmena, isto é, de rememorar um conhecimento manejado pelos homens. A decisão foi de que as mulheres também iriam, mas tomariam todos os cuidados necessários como fazer os benzimentos de proteção e observar as restrições indicadas pelos mais velhos.

\footnotetext{
142 Para os Kotiria, este herói é conhecido pelo nome Kené, e sua "casa" fica próxima a comunidade de JacaréCachoeira, no rio Uaupés. O nome do "igarapé sagrado dos Yúri", como em explicaram, deriva do nome deste ancestral, pois o próprio igarapé teria se formado quando Marãkãriku adentrou a floresta em direção ao Wakaipani, remetendo àquela dialética conteúdo-continente destacada por Stephen Hugh-Jones (2014), onde o conteúdo forma o continente.

143 Certa vez, conversando com Gabriel Saldanha, Yúriwawa de Açaí, ouvi a expressão "Marãkãriku é chefão dos Wanano".

${ }^{144}$ Lembro ao leitor que citei outras versões dessa história de surgimento no segundo capítulo da tese. Aqui, analiso a versão que norteu a realização da viagem descrita acima.
} 


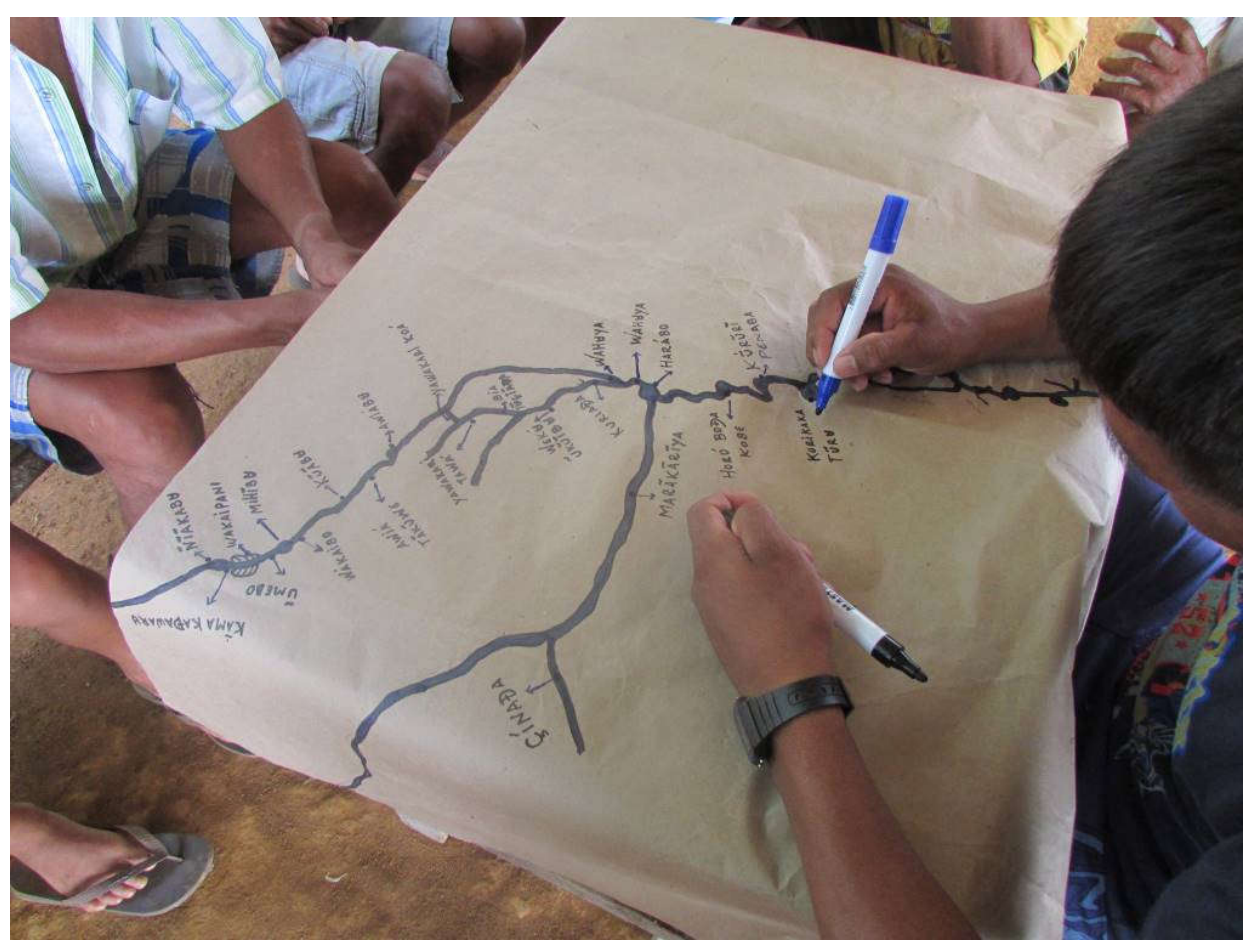

Figura 19: Oficina de elaboração de etnomapas (Fotografia do autor, 2014).

Depois das oficinas, durante a preparação dos materiais para a viagem, eu e os outros dois participantes não indígenas (outro antropólogo e um linguista) fomos protegidos com benzimento por meio de buçibu (tabaco) benzido, e pintura com muhã (carajuru) misturado com çipe, um tipo de resina, desenhando uma pequena cruz no peito, e outras duas na sola dos pés. Tal proteção era contra possível ataque de animais, tais como cobras, e dos hoktwwt (“espíritos da mata”), risco ao qual nós, não indígenas, por sermos estranhos e não termos passado pelos cuidados que um Kubeo passa ao longo da vida, estávamos particularmente expostos. Em seguida, partimos para o lugar de transformação, designado Wakaipani.

Seguimos de canoa pelo rio Uaupés, até a foz do igarapé Marãkãriya, onde entramos. A medida que adentramos o igarapé, a viagem se tornava mais difícil, pois havia muitos troncos de árvores caídos no meio do rio e galhos boiando, que podiam quebrar os motores dos botes; além disso, em muitos trechos e curvas do igarapé o nível da água era muito baixo, tendo que passar com cuidado, até mesmo empurrar as embarcações.

Dada a crescente dificuldade para avançar pelos igarapés, em determinado momento da viagem encostamos os botes e seguimos por trilhas na mata. Importante mencionar que, quando interrompemos a viagem pelo igarapé para seguir caminhando, Marcela (Yuremawa de Querari) pediu que eu passasse levemente as folhas de uma planta (pinu pinu) na perna e nos pés, com os olhos fechados, para proteção contra picada de cobra. 
Caminhando por aproximadamente cinco horas até chegar ao Wakaipani, viagem prolongada por pausas para descanso, onde tomávamos chibé, a bebida feita a partir da mistura de água e farinha, e alguns momentos de dificuldade para encontrar o caminho, dado que, por conta de não ser mais um caminho frequentado pelos Kubeo, o mesmo se perdeu na mata, estava fechado, e exigiu um trabalho tanto para ser encontrado, como para ser aberto a golpes de terçado.

Ao longo do percurso, o velho Jaime, Yúriwawa de Açaí e respeitado conhecedor das narrativas de origem e "ritualizações", como dizia Luiz Gilberto, tomou a frente da pequena expedição, mostrando os lugares de parada, enunciando seues nomes e contando as histórias associadas a esses lugares. Além de respeitado conhecedor, Jaime era reconhecido como morador legítimo da região, filho dos Yúriwawa que viviam no interior da mata, antes de se reunirem em Açaí. O reconhecimento tácito da consideração e respeito que lhe eram devidos se mostrou no fato de Jaime assumir a frente da pequena expedição. Notei também que Jaime, considerado o irmão mais velho, falava e apontava, e os outros velhos que nos acompanhavam se limitavam a fazer gestos confirmando a história e repetindo fragmentos dessas falas em voz baixa.

Ao chegar ao lugar de transformação, Wakaipani, uma imensa laje de pedra coberta por petroglifos, Jaime iniciou uma apresentação formal com os "donos" e "cuidadores do local". Seu objetivo era anunciar a nossa chegada da maneira correta, para que tudo corresse bem durante a nossa estadia. Como mostrou Cayón (2010) em sua pesquisa com os Makuna, os lugares sagrados dos povos tukano são locais de poder muito importantes, constituem a base do trabalho xamânico. Cada sítio ou lugar tem sua própria história de formação que fundamenta seus poderes, bem como possuem espíritos cuidadores ou animais protetores que podem fazer muito mal a pessoas indesejadas que adentrem o local se certa ética não for observada pelo visitante. Sendo assim, como já apontei ao discutir a categoria de dono, para realizar atividades em Wakaipani, era necessária uma mediação com estes "espíritos donos"; foi o que Jaime fez.

Ao lado de outros dois velhos, Pedro (Yuremawa) e José Abelardo (Betowa), com voz alta, numa fala formal, o Yúriwawa Jaime apresentou as pessoas que estavam chegando ao lugar, dizendo que era ele, Jaime, junto com seus parentes. Elencou um a um o nome de cada velho presente, isto é, o pupui amiya, e se referiu aos mais jovens como sendo os seus netos. Apresentou os três membros não-indígenas da comitiva ${ }^{145}$ pelo nome que nos foi dado em

${ }^{145}$ Um linguista e dois antropólogos (eu e João), assessores do projeto. 
eventos anteriores e disse: "eles vieram subindo junto com a gente, ver nosso território. Amanhã, juntos, veremos tudo da melhor maneira". Depois de apresentar quem estava chegando, Jaime ressaltou que não iríamos perturbar o local ficando nele por muito tempo e que até a metade do dia seguinte já teríamos partido. Segue a fala de Jaime:

Aqui na casa de criação, vieram estas pessoas e eu, com meus filhos e netos, Manunda e Kapiakani. Agora estes, meus parentes: Manua, seu irmão Kaiwarida... Yuré, todo o grupo. Esses nossos filhos e este aqui, o Páturi, todos nós aqui chegamos, porém não vamos perturbar esse lugar ficando aqui por muito tempo. Amanhã, por volta do meio-dia, já estará tudo terminado. Por isso pedimos para que não chova aqui na tua casa. Piada, Kawa, Wekó... todos que estão chegando; eles vieram subindo, junto com a gente, ver nosso território. Amanhã, juntos, veremos tudo da melhor maneira. Isso é tudo por agora ${ }^{146}$.

Além dessa fala de apresentação, outras restrições foram explicitadas por Jaime: certo trecho da cachoeira não podia ser pisado por mulheres; alguns lugares no Wakaipani e em suas proximidades deveriam ser evitados por pessoas estranhas, no caso, os três brancos que acompanhavam a viagem, pois o dono do lugar ou os espíritos da mata podiam nos agredir, dado que não nos conheciam. Também não era permitido fazer muito barulho, isto é, o comportamento tinha que ser moderado. Outra restrição foi a de não derramar sangue na laje do Wakaipani, e essa restrição foi enunciada quando um dos indígenas que seguiam na viagem conseguiu caçar um jacaré na cachoeira, para comermos. Ao jogar o corpo do animal no chão, com o sangue de seu ferimento escorrendo, foi imediatamente advertido pelos mais velhos que isso não era permitido. Retirou imediatamente o animal do lugar para ser preparado para o cozimento e limpou o chão jogando água, para tirar o sangue. Em certo momento, no final do dia, já acampados no lugar, os mais velhos circularam um cigarro benzido, para proteção.

\footnotetext{
${ }^{146}$ Essa fala foi gravada em Kubeo e traduzida por alunos Kubeo do terceiro ano da Escola de Querari. Registro aqui o devido reconhecimento ao trabalho desses alunos, assim como a tradução da narrativa feita por Henrique Rodrigues e já citada.
} 


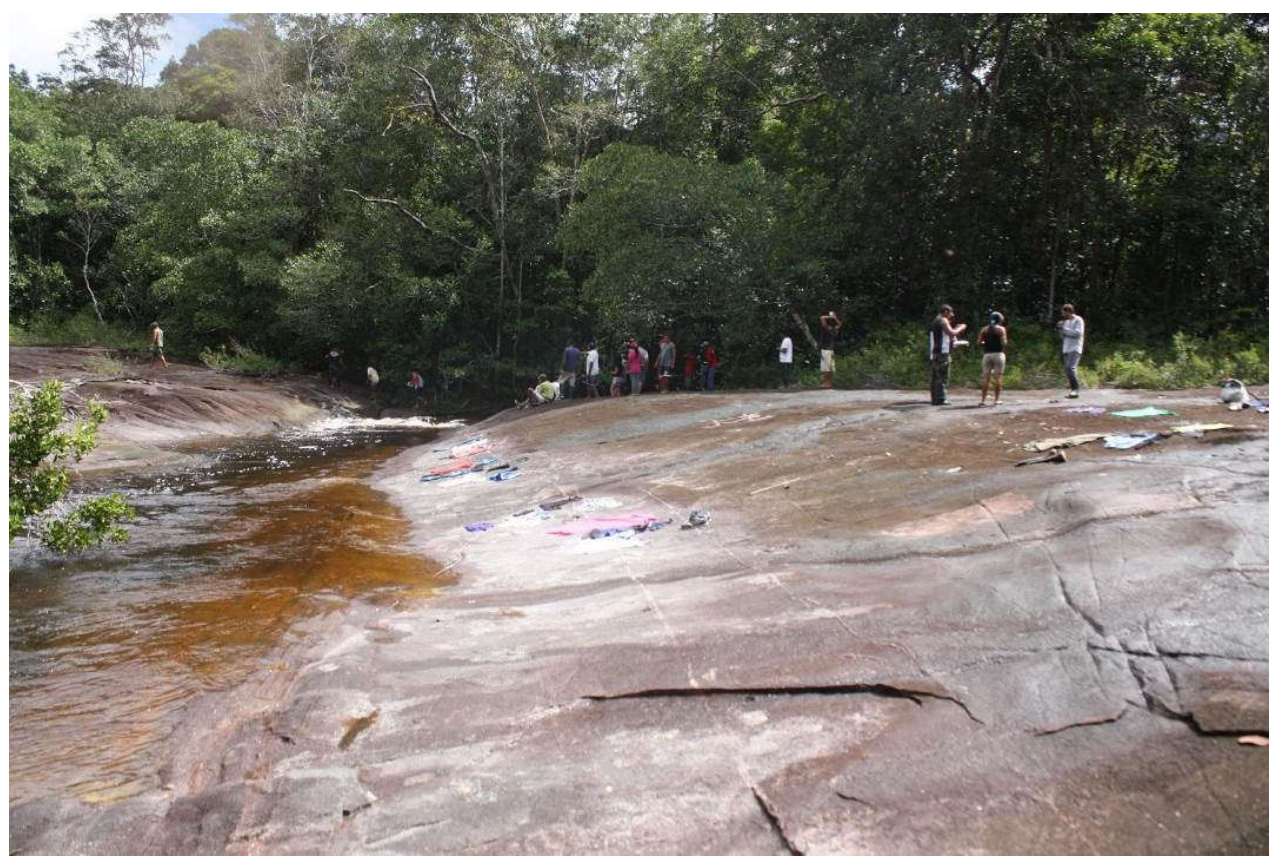

Figura 20: Wakaipani, maloca ancestral kubeo (fotografia de autor não registrado, 2013)

Alguns dias após o retorno, a viagem foi comemorada com a realização de uma festa de caxiri na maloca da comunidade de Açaí com a presença de moradores das três comunidades envolvidas, ou seja, além de Açaí, os Yuremawa de Querari e os Betowa de Puerto-Colombia. A certa altura da festa, alguns velhos betowa e seus filhos iniciaram uma discussão com velhos Yuremawa acerca da necessidade de se fazer outra expedição, mas dessa vez para contar a história “verdadeira”, e não aquela versão, segundo eles "errada”, da chegada dos Kubeo ao Wakaipani. Alguns Yúriwawa, considerados irmãos menores daqueles que tomaram a frente na viagem, também manifestaram interesse em outra viagem, na qual pretendiam expor a versão "verdadeira" da narrativa de origem, o que implicava refazer os mapas desenhados nas oficinas antes da expedição. Lembro que durante a discussão, um Betowa batia no peito com violência e afirmava "sou betokt, sou betokt", afirmando ser merecedor de respeito, e como tal dizia conhecer a "verdade", dizia que embora muitos nomes de lugares estivessem corretos no relato Yúri Parãmena, as histórias associadas não estavam todas corretas, isto é, questionava o conhecimento narrativo condensado nos nomes de lugares.

Feita a descrição do episódio, passemos a sua análise. Em primeiro lugar, lembremos que a chegada ao Wakaipani foi precedida de uma fala do velho Jaime dirigida ao "dono" do lugar. Essa fala tinha como objetivo esclarecer os motivos de nossa presença ali e pedir permissão para pernoitar no referido trecho de igarapé. Para isso, a primeira etapa consistiu 
em nos tornar conhecidos, isto é, fomos apresentados ao dono do Wakaipani por meio dos nomes, da enunciação do pupui amiya de cada um. Mesmo os não indígenas presentes foram apresentados por meio dos respectivos nomes ${ }^{147}$. Eis que o pupui amiya opera certa aproximação entre visitante e anfitrião, e penso em não estar equivocado ao usar tal matriz relacional ${ }^{148}$, sobretudo pelo evidente paralelo que podemos estabelecer com o início de uma festa na comunidade, que iniciava com a chegada dos convidados, e sua apresentação diante do anfitrião (S. HUGH-JONES, 1979). Tal enunciação do pupui amiya opera também como proteção, um modo de garantir que o dono do lugar não ataque os visitantes por serem desconhecidos $^{149}$. Aqui, vemos operar certo jogo onomástico kubeo de enunciação e ocultamento: se em outros momentos o pupui amiya não é enunciado, por ser de conhecimento pessoal e restrito, e como evitação de um possível uso maléfico do nome, como vimos em capítulo anterior, aqui se passa justamente o contrário, é a enunciação do pupui amiya que garante a proteção ${ }^{150}$. Sigamos com a análise.

Notamos que durante a viagem os Betowa e outros velhos repetiam e confirmavam a todo momento a fala do velho Yúriwawa, não houve discordância em nenhum momento. Mas na festa de caxiri, já embriagados, a disposição era outra, tratava-se de reclamar um conhecimento "verdadeiro" acerca dos lugares e suas histórias, bem como inscrever os Betowa na narrativa do Wakaipani, reclamação essa que foi expressa pela afirmação repetida do nome "Betowa", "sou betoku, sou betoku", repetia a referida pessoa que havia iniciado o conflito. Vemos nesse gesto uma diferenciação que se dá por meio do nome, aqui criando agrupamentos, em operação semelhante à descrita por Roy Wagner (2010) em sua análise dos nomes na Nova Guiné.

\footnotetext{
${ }^{147}$ No meu caso, fui apresentado como Wekó (papagaio). O motivo de tal escolha nunca ficou claro para mim; o nome me foi atribuído sem mais explicações. O senhor Abelardo foi quem escolheu o nome para mim. Nesse sentido, penso que se passou comigo algo muito comum entre os Kubeo, isto é, o apelido é assunto dos outros, não daquele que o recebe. Meu amigo também antropólogo foi apresentado como Kawá (urubu). Ambos os nomes eram yahui amiya, portanto.

${ }^{148}$ Uso tal termo no sentido que lhe é dado por Beatriz Perrone-Moisés (2015), em sua análise da festa como chave para a socialidade ameríndia.

149 Também Rosilene Pereira (2013) destaca esse aspecto protetivo do nome diante de donos de lugares ao falar do benzimento de nominação em sua dissertação sobre a produção de pessoas waikhana: "É através do nome recebido no nascimento que um indivíduo é protegido. $O$ nome é de fundamental importância para quando formos viajar para lugares fora de nosso ambiente, porque as viagens são consideradas deslocamentos para outras casas e elas têm donos, por isso é preciso apresentar-se aos donos da casa para que não ocorra estranhamento, ou seja, é através dos nossos nomes que recebemos proteção para a vida toda" (ibidem, p. 55, itálico meu).

${ }^{150}$ Agradeço a Renato Sztutman por chamar minha atenção aqui para esse ponto, que num primeiro momento de redação de minhas análises passou despercebido.
} 
Lembremos que ss Betowa são tidos pelos Yuremawa e Yúriwawa como outra gente, não Kubeo. Ouvi algumas vezes, em contexto de conflito e outras de zombaria em festas de caxiri, o uso da expressão "gente makú" para referir-se a eles, ou ainda "makusito", categorias essas, tal como as usaram os Yuremawa e Yúriwawa nesses contextos particulares, de diminuição do outro, de supressão de relações de consideração e respeito. Lembremos também que na narrativa de origem citada acima, os Betowa são mencionados como o último grupo a ser nomeado pela avó Huredanaçu, e referidos como "criancinhas". São considerados pelos Yúriwawa e Yuremawa como "forasteiros" nesse trecho do Uaupés, "estrangeiros", gente que chegou recentemente e, portanto, que não apareciam nas narrativas dos Yúri Parãmena como ocupantes legítimos daquele trecho de rio, mas antes pertenciam às cabeceiras, região, segundo o código hidrográfico compartilhado pelos povos tukano, dos grupos ditos de baixa hierarquia ${ }^{151}$; essa perspectiva é veementemente contestada pelos Betowa, que se consideram Kubeo e ocupantes legítimos do trecho onde vivem os Yúriwawa e Yuremawa. Portanto, retomando o episódio da festa de caxiri evocado acima, vemos que afirmar o nome Betowa, tornando assim o agrupamento betowa visível ${ }^{152}$, distinguindo-se dos Yúri Parãmena ao mesmo tempo que reclamavam um conhecimento "verdadeiro" da narrativa de origem insere-se, sobretudo, nessa disputa pelo reconhecimento de sua presença nesse trecho de rio, reconhecimento esse que pareceu aos Betowa possível de ser obtido por meio da participação na elaboração de mapas da região, algo que pode ser observado, por exemplo, no fato de que o capitão e membros de Puerto-Colombia voluntariamente participaram das oficinas de elaboração de tais mapas, com grande interesse e empenho; tratava-se de colocar sua comunidade no mapa, de afirmar o reconhecimento do trecho onde vivem os Betowa como pertencentes a ele; dito de outro modo, tratava-se de afirmar e escrever o nome no papel.

Devo acrescentar que nesta região não há apenas um conflito entre os Yúri Parãmena e os Betowa, mas também entre Betowa e Kotiria. Segundo as narrativas de origem, como

\footnotetext{
${ }^{151}$ Essa ideia, compartilhada pelos povos tukano de modo geral, consiste em afirmar que a ocupação do rio pelos ancestrais a medida que saem da cobra canoa se dá segundo a seguinte disposição: grupos de alta hierarquia/regiões próximas a foz; grupos de baixa hierarquia/regiões próximas à cabeceira. Esse código hidrográfico foi formulado por Goldman (1963) a partir do primeiro trabalho junto aos Bahúkiwa em 1939, e desenvolvido por Christine Hugh-Jones (1979) a partir de seu campo junto aos Barasana do Pirá-Paraná em 1968.

152 "Os termos são nomes, não são as coisas nomeadas. Eles diferenciam ao dizer: 'Estes são os do rio; aqueles são os da montanha', ou 'Estes são provenientes de Weriai; aqueles, de Daie', e são significativos não por causa da forma como descrevem algo, mas por causa da forma como o contrastam com os outros" (WAGNER, 2010, p. 246); mais adiante, o mesmo autor nos diz: "[...] um nome, não um grupo; é uma forma de distinguir, de incluir e excluir; é, pois, meramente um dispositivo para estabelecer fronteiras" (ibid., p. 247).
} 
vimos, o trecho ocupado pelos Yúri foi cedido por Marãkãriku, chefe dos Kotiria. Contudo, os Betowa, segundo a versão contada pelos Yúri, não receberam o espaço cedido por Marakarikt. Vou detalhar um pouco mais esse episódio para esclarecer esse ponto.

Jaime ao longo da viagem foi nos guiando e mostrando que o grupo de Marãkãriku, atraído pelo som que escutou vindo do interior da mata, foi subindo através do curso do igarapé Marãkãriya e adentrou a área de Wakaipani. Jaime aponta uma pedra no curso do rio como sendo o herói kotiria, isto é, ela marca a primeira posição de Marãkãriku destacada na narrativa. A história prossegue com o velho Jaime mostrando um pouco mais acima outra pedra, signo do local do primeiro encontro entre Marãkãrikt e os Yúri Parãmena. A partir desse momento, a medida que Marãkãriku vai realizando a sua subida em direção a Wakaipani, Jaime narra uma série de bloqueios que os Yúri Parãmena fizeram para tentar conter o avanço de Marãkãriku,

Eles não queriam que Marãkãriku subisse o rio e chegasse a maloca ancestral de seu povo, erigida em Wakaipani. Marãkãriku era um desconhecido com o qual os Yuri Parãmena não haviam estabelecido alianças e portanto, era um possível inimigo. Vários sítios pelos quais passou Marãkãriku e seu grupo têm nomes próprios que marcam a trama que se desenvolveu no local (VEIGA NETO, 2014, p. 79).

Marãkãriku vai, contudo, vencendo todas as tentativas de bloqueio dos Yúri Parãmena. João Veiga Neto, que também acompanhou a viagem como assessor e pesquisador, analisando esse momento da narrativa, sustenta que

A subida de Marãkãriku segue os passos de um ritual de Jurupari. Desde o início, os Yuremawa e os Yúriwawa explicam que o que motivou a ida de Marãkãriku até o local foi o fato de que este escutou o som de flautas de Jurupari vindo do interior da floresta. Ao chegar o local, o invasor ${ }^{153}$ wanano é recebido pelos ancestrais Yúri Parãmena e inicia a participação no ritual que estava em curso. É por isso que Marãkãriku recebe doses de ayahuasca e depois precisa se preparar para a disputa de surra. Estas disputas são realizadas dentro de uma maloca com dois homens travando um combate armados com longos chicotes. É importante ressaltar que o local em que Marãkãriku parou para se recuperar se chama Umebo, este termo possui um significado relacionado a vitalidade, a respiração. [...]. Já no fim do avanço final, muito próximo da grande laje rochosa de Wakaipani, existem diversas marcas de rasgos esculpidos nas rochas que formam o leito do curso do igarapé, "foi assim que fizeram com o corpo dele, deixando as marcas das chicotadas do Jurupari. Estes são os lugares sagrados, onde está a nossa

\footnotetext{
153 Aqui, é necessário um comentário à análise de Veiga: Marãkãriku não é propriamente um “invasor", dado que é dono do território; ao contrário, são os Yúri Parãmena que, em outro momento da narrativa, receberão autorização dos Kotiria para permanecer na região.
} 
origem, como diziam nossos anciãos que já se foram com todo o seu conhecimento" (VEIGA NETO, 2014, p. 81, itálico do autor).

Em certo momento da festa, acontece um desentendimento entre alguns de seus participantes, o que conduzirá à uma divisão do grupo ancestral dos Yúri Parãmena em dois: os Yúriwawa e os Yuremawa. Marãkãriku, ao final do processo de separação, estabelece relações distintas com cada grupo: irmão dos Yúriwawa e cunhado dos Yuremawa (VEIGA NETO, 2014, p. 88-89).

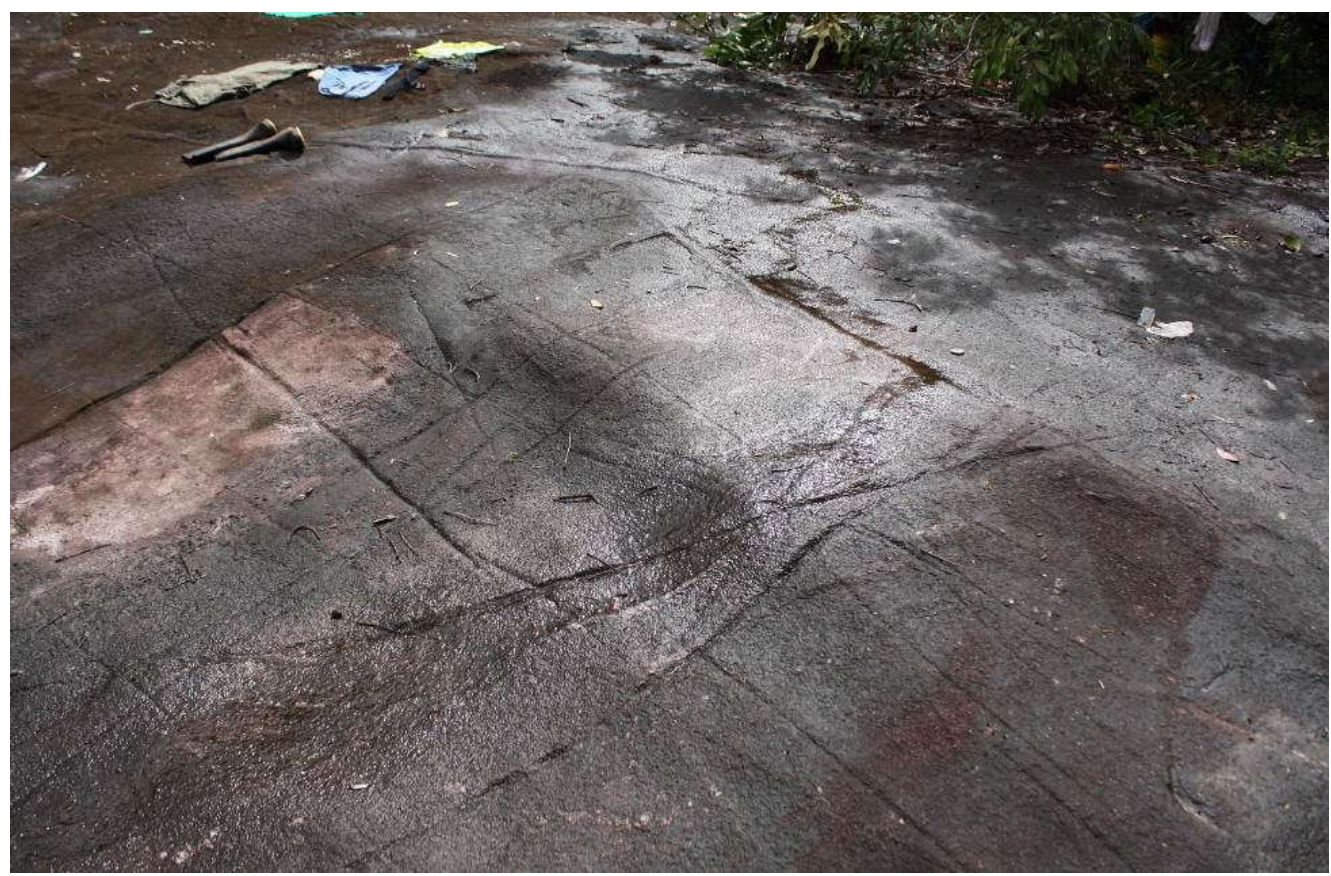

Figura 21: Marcas da surra no Marãkãriku durante o Jurupari (fotografia de autor desconhecido, 2013)

Luis Cayón, que desenvolveu pesquisas sobre a noção de lugar entre os Makuna do Pirá-paraná, indica que “o espaço funciona, em alguma medida, como uma grande matriz epistemológica, que, ainda que fixado a terra, também pode transportar-se conceitualmente a espaços desconhecidos, [...]. O espaço é uma espécie de livro do conhecimento" (CAYON, 2010, p. 189). Essas formulações de Cayon se mostram bastante adequadas para o modo como os Kubeo pensam o espaço. O autor chega mesmo a propor a noção de "geografia xamânica", definida "como um aspecto que fundamenta a estrutura da realidade, vincula as pessoas com o espaço em que vivem, dá-lhes um lugar no cosmos e as relaciona com outros seres, humanos e não humanos, que povoam o universo" (CAYON, 2010, p. 210). Contudo, 
tenho algumas restrições com a ideia de "geografia xamânica" operacionalizada no Uaupés, pois, se essa noção se mostra bastante pertinente para o Pirá-Paraná - região "preservada", como apresenta Cayón (2010, p. 32) -, penso que o Uaupés apresenta um contexto um pouco diferente no que diz respeito ao xamanismo. Outra noção, a de "mythscape" - "paisagens míticas" - proposta por Robin Wright, me parece mais adequada, mais ainda não completamente satisfatória.

Voltemos agora ao tema dos conflitos entre Yúri Parãmena e Kotiria. É comum ouvir em brigas acusações de "você não é daqui", "volte para sua comunidade". "Ser de outro lugar" aparece, portanto, como categoria de acusação. Segue um episódio que corrobora tal interpretação: o Yúriwawa Osvaldo me contou que, certa vez, durante preparativos para um jogo de futebol, ouviu de Edimar, Yuremawa filho de Pedro (irmão do velho Henrique Rodrigues), que ele não podia ocupar a posição de capitão do time de futebol, ou mesmo se comportar como tal, pois não era de Querari (lugar do jogo), “próprio de Querari”, e sim de Açaí, portanto devia jogar futebol em Açaí. Osvaldo ficou muito bravo, mas se controlou, não cedeu à acusação, e assim o conflito não terminou em briga. O lugar é, portanto, uma categoria de acusação em disputas; ao longo de meus campos registrei muitas situações de acusações ou conflitos - como a descrita - baseados nas noções de "ser do lugar" e "não ser do lugar". Os Betowa, desse modo, são considerados como "estrangeiros" pelos Yúri Parãmena e também pelos Kotiria, que constantemente afirmam que no episódio acima narrado por Jaime Marãkãriku permite que os Yúri Parãmena se estabeleçam na região, não os Betowa. Disputam mesmo o nome Pamiwa pois, como vimos, se os Yuremawa e Yúriwawa são Pamiwa, mas não verdadeiros Pamiwa, "Kubeo próprios", como eles dizem, mas antes "imitações", "cópias" dos "Kubeo verdadeiros" - recordemos que, em certo momento da narrativa de origem contada pelo senhor Henrique Rodrigues, os Yúri Parãmena seguem viagem até a cachoeira de Santa Cruz, no Uaupés colombiano, cujo território pertencia ao grupo Pamiwa, os "Kubeo originais"; voltam então pelo Uaupés até o igarapé Marãkãriya -, os Betowa, por sua vez, da perspectiva Yúri Parãmena, não seriam nem "Kubeo próprio" nem "imitações", mas antes outra gente, outro "clã" ou "etnia", para usar o vocabulário nativo corrente; um "clã" que se estabeleceu no trecho do Uaupés onde vivem os Yúri Parãmena tempos depois da chegada desses. Aqui, lembremos o que dizia Stephen Hugh-Jones:

A mito-história do alto rio Negro é uma história política em um duplo sentido. Por um lado, fazendo referência a estrangeiros, as narrativas de 
todos os grupos da região remetem uma longa história de resistência à dominação externa e servem para legitimar reivindicações indígenas pelo território. Por outro lado, histórias particulares servem também para legitimar reivindicações pelo território, bem como o status de um grupo particular em face aos demais (2012, p. 162-163).

Esse conflito virá à tona novamente em um segundo episódio relacionado à elaboração de mapas e discussão de territórios no contexto do movimento recente de elaboração de planos de gestão ambiental e territorial no alto rio Negro, os chamados PGTA's, elemento novo que se insere nessa teia de conflitos descrita a partir do caso da viagem ao Wakaipani. Vejamos.

\title{
Produzir consenso com nomes no papel: os Yúri Parãmena fazem planos de gestão ambiental e territorial
}

A partir de uma série de discussões conduzidas por associações indígenas, membros do movimento indígena e instituições como a FUNAI e Ministério do Meio Ambiente acerca de novos problemas relacionados aos usos do território em terra indígena, foi assinado em 2012, pela então presidente Dilma Roussef, um decreto que instituiu a Política Nacional de Gestão Territorial e Ambiental de Terras Indígenas - PNGATI, a qual é definida, em seu artigo primeiro, como tendo por objetivo

\begin{abstract}
garantir e promover a proteção, a recuperação, a conservação e o uso sustentável dos recursos naturais das terras e territórios indígenas, assegurando a integridade do patrimônio indígena, a melhoria da qualidade de vida e as condições plenas de reprodução física e cultural das atuais e futuras gerações dos povos indígenas, respeitando sua autonomia sociocultural, nos termos da legislação vigente ${ }^{154}$.
\end{abstract}

Dentre as possibilidades de implementação de tal decreto nas terras indígenas, tem se difundido no Brasil a elaboração de Planos de Gestão Territorial e Ambiental, os conhecidos PGTA's, como instrumentos de diagnóstico e proposição de soluções, seja na escala intercomunitária, por meio de acordos, seja na relação com o Estado, através da sugestão de políticas públicas. No contexto nacional, é bastante desigual a estágio da elaboração de PGTA's pelas populações indígenas. Há desde grupos que já contam com plano de gestão elaborado e publicado, até aqueles que estão se familiarizando recentemente com a PNGATI e seus instrumentos. No caso do alto rio Negro, há registros de oficinas e discussões sobre

\footnotetext{
${ }^{154}$ Decreto disponível em: http://www.planalto.gov.br/ccivil_03/_ato2011-2014/2012/decreto/d7747.htm
} 
tema desde o ano da assinatura do decreto. Recentemente, encontra-se em fase de elaboração um plano de gestão para as terras indígenas do alto rio Negro, fruto de uma parceria entre ISA, FUNAI e FOIRN ${ }^{155}$. No caso dos Kubeo, além da participação nesse plano recente, já tinham iniciado em 2014 o trabalho de discussão e elaboração de um PGTA menor, englobando apenas os Kubeo e Kotiria do Uaupés brasileiro, com recursos do PDPI ${ }^{156}$. Detenho-me brevemente nesse primeiro PGTA Kubeo e Kotiria.

Tal trabalho, conduzido por uma equipe de pesquisadores indígenas kubeo e kotiria ao longo de um ano, consistiu na realização de diversas tarefas: oficinas de discussões sobre território e elaboração de mapas, registros fotográficos de lugares, bem como de seus nomes e algumas histórias relacionadas a cada lugar; mapeamento de roças, lugares de pesca e caça e história das comunidades. Duas questões se manifestaram com frequência nessas oficinas. Vamos a elas.

Um primeiro problema que se colocou nesse trabalho de PGTA, sobretudo no momento da elaboração de mapas, foi aquele da fronteira nacional. Dado que as comunidades no rio Uaupés estão arranjadas de outra maneira que não segundo uma divisão do Estado brasileiro, isto é, com relações de parentesco e significação dos lugares que abarcam comunidades dos dois lados do rio, Brasil e Colômbia, se coloca a questão de como representar esses elementos em mapa; dado que o PGTA é um instrumento da PNGATI, a qual por sua vez diz respeito ao Brasil apenas, qual noção de fronteira deve ser observada, a local ou a do Estado?

Além dessa questão, durante as oficinas para desenhar os mapas foi muito enfatizado o tema dos limites de território de cada comunidade. Assim, perguntavam-se até onde se estenderia o trecho Yuremawa, o trecho Yúriwawa, e onde começava o trecho kotiria. Os Betowa presentes reclamavam também a delimitação do trecho pertencente a eles. Nesse momento, o desenho dos mapas era conduzido pela explicação dada pelos Yuremawa e Yúriwawa mais velhos, respeitados conhecedores das narrativas de origem e deslocamentos, bem como dos limites de cada comunidade. Esse interesse e as discussões que suscitava parece apontar para algumas hipóteses de apreensão do envolvimento recente dos Kubeo na

\footnotetext{
${ }^{155}$ Fruto da parceria entre ISA, FUNAI e FOIRN, o PGTA alto rio Negro teve início no segundo semestre de 2016, com previsão de conclusão em 2019. Mais informações podem ser obtidas em: https://www.socioambiental.org/pt-br/tags/plano-de-gestao-territorial-e-ambiental-pgta

${ }^{156}$ O Projeto Demonstrativo de Povos Indígenas - PDPI, que funcionou durante anos como importante fonte de recursos para realização de projetos por comunidades indígenas, cessou em 2013. O leitor interessado pode encontrar um histórico do PDPI, bem como enunciação de seus objetivos no site do Ministério do Meio Ambiente: http://www.mma.gov.br/apoio-a-projetos/povos-ind\%C3\%ADgenas
} 
elaboração de mapas. Vejamos.

O mapa parece ser entendido, de modo geral, como espécie de panaceia, isto é, uma solução definitiva dos conflitos, um modo de representar os limites das comunidades fundamentado num decreto do Estado e, portanto, que deve ser observado por todos, dados seu caráter "oficial". Em outros termos, a inscrição do nome do lugar no papel produziria consenso. Lembro-me que, durante uma das oficinas realizadas em Querari, um morador Kotiria de Taracuá-Ponta fez o seguinte comentário: "agora sim, com o mapa cada um vai saber seu território, e respeitar"; e desenvolveu lembrando que os Yuremawa e Yúriwawa têm o espaço deles, fundamentado na narrativa de origem, segundo a qual, como já mencionado, os Kotiria, legítimos moradores da região, cederam parte dela aos Yúri Parãmena. Mas o Betowa são "forasteiros" na região, daí a importância dos mapas para esclarecer "de vez" a quem pertence o lugar ${ }^{157}$. Assim, os etnomapas parecem ser vistos como a cristalização e resolução de um conflito que nas narrativas de origem permanecem em constante disputa.

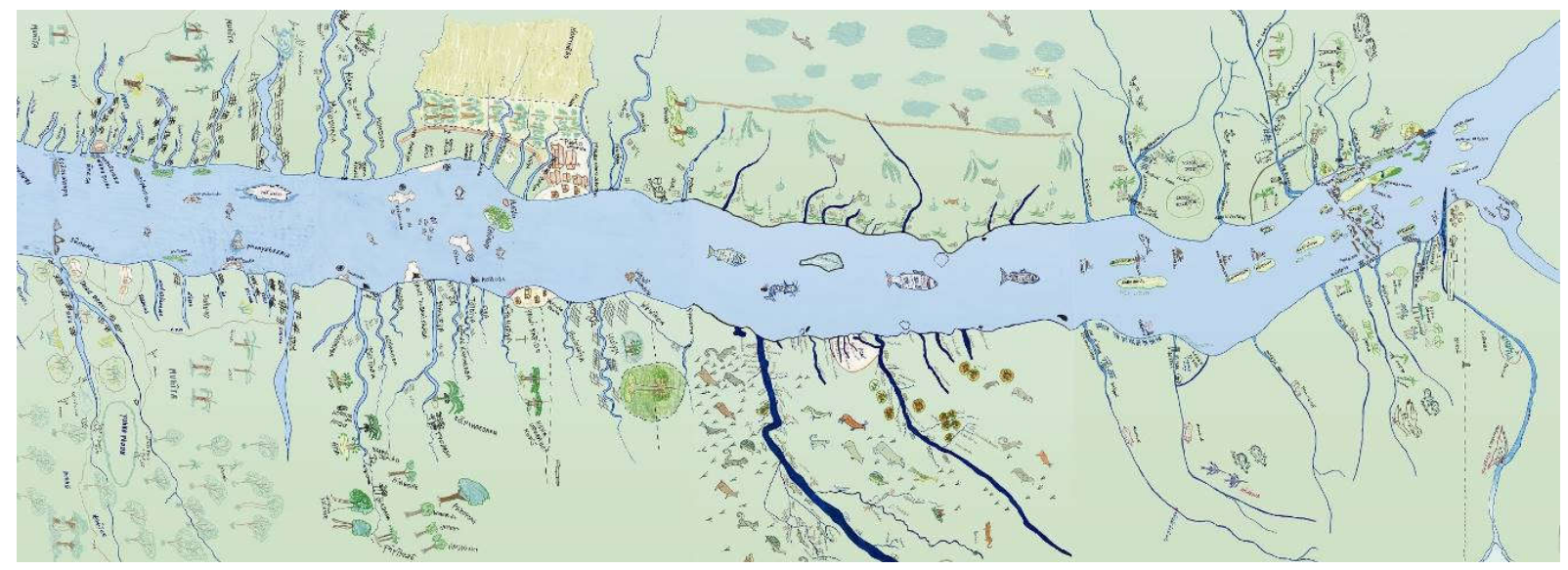

Figura 22: mapa mental do trecho de Querari (Kubeo) até Taína (Kotiria) (2016).

Cito uma situação que evidencia esse conflito entre os Yúri Parãmena e os Betowa: certa vez, durante um levantamento de dados familiares para a composição do PGTA alto rio Negro, visitei, acompanhado de um Yuremawa pesquisador, que estava na condição de pesquisador indígena do PGTA, o sítio de Yauaretê-Ponta, para entrevistar a família que vivia nesse lugar. Uma das perguntas consistia na identificação da "etnia" do entrevistado. Nesse momento, notei que o pesquisador yuremawa me perguntou como proceder, pois no questionário a ser preenchido não constava "Betowa"; contudo, havia "Kubeo", ou seja, o

\footnotetext{
${ }^{157}$ Embora o foco de minhas análises aqui sejam os Kubeo, em comunidades tariano acima de Iauaretê também ouvi a mesma ideia, bem como em Iauaretê.
} 
pesquisador reconhecia ali que aquela família betowa não era kubeo.

Contudo, se conflitos entre grupos são constantemente atualizados nas narrativas de origem, em sua enunciação, plástica e performática, como isso acontece no mapa que parece produzir certa cristalização gráfica? Estamos diante de dois regimes distintos de codificação dos conflitos: regime das narrativas de origem, com seus códigos já estabelecidos, e o regime dos mapas, novo, com seus códigos ainda sendo apreendidos pelos Kubeo. Os códigos do regime das narrativas, tais como conhecemos pela literatura etnográfica, são fundamentalmente: pessoa do velho que narra, as relações de consideração (a dita hierarquia), o parentesco, os nomes e os lugares. Como sabemos, as versões das narrativas não parecem passíveis de solução. Nesse sentido, o termo "versão", comum em etnografias, necessita de alguns esclarecimentos quanto ao seu uso, pois pode dar margem a pensar que há uma verdade substancial: tal termo deve ser usado tal como Lévi-Strauss ${ }^{158}$ fala em "versões" ou "variantes" ao se referir aos mitos, isto é, como transformações uns dos outros.

Aqui, um leitor da literatura etnológica rio negrina poderia objetar que se daria com os mapas o mesmo que com as narrativas: proliferação de versões. Tal como um volume da coleção Narradores do rio Negro estimulou a publicação de outros volumes, poderíamos nos perguntar se não teríamos a produção de muitos mapas, versões cartográficas distintas. Contudo, penso ser justamente essa a novidade dos mapas: aos olhos dos Kubeo, não permitiriam a existência de outras versões, seriam resultado de trabalho coletivo e de consenso ${ }^{159}$.

Se o conhecimento do espaço está codificado numa forma de conhecimento que tem as narrativas de origem como elemento central, condensadas por sua vez nos nomes de lugares, qual seria o lugar dos mapas nesse regime de conhecimento? Minha hipótese, já anunciada, é que os mapas têm sido apreendidos como potenciais produtores de consenso, como algo que cessaria discussões em torno dos limites de território, condensando assim as versões das narrativas de origem em uma única versão, "oficial”, respaldada pelo Estado brasileiro. São, portanto, tecnologias manejadas no conflito entre narrativas e grupos. Uma vez que o nome do lugar foi inscrito no papel (mapa), não há mais controvérsia ou disputa possível.

\footnotetext{
${ }^{158}$ Remeto o leitor à "Abertura" de "O cru e o cozido" (2004).

159 Com efeito, minha interpretação pode estar equivocada e se passar com os mapas algo semelhante ao que aconteceu com os livros de narrativas de origem dos grupos. É necessário mais tempo para avaliar como tais iniciativas de produção de mapas serão manejadas e conduzidas na região. O que me parece, como sustentei acima, é que se passa com os mapas algo diverso.
} 
À guisa de conclusão, me parece apropriado citar um episódio referente ao conhecimento dos lugares, apresentado por Aline Iubel em sua tese (2015): José Ribamar Bessa Freire, num texto escrito em homenagem ao Padre Casimiro Béksta por ocasião de seu falecimento em 2015, fala de certo episódio que remete à importância das rotas percorridas pelas anacondas ancestrais e do território. Escreve Aline:

O cronista narrou uma história vivida por Casimiro e alguns indigenistas no alto Uaupés em 1978. Consta que, na ocasião, presenciaram uma criança ser mordida por uma cobra. A criança precisava ser transportada para um hospital em São Gabriel da Cachoeira, em uma viagem que custaria três dias de navegação em trechos encachoeirados, onde eram frequentes naufrágios e mortes. Havia um pequeno barco disponível, mas não havia quem o pilotasse, pois os índios especialistas estavam ausentes. Um jovem tukano se ofereceu para conduzir o barco. Casimiro então lhe perguntou se ele já havia feito essa viagem. E o jovem respondeu: "Eu nunca, mas meus primeiros ancestrais fizeram este trajeto na cobra-canoa e eu conheço oswametisé - os lugares por onde a cobra-grande passou, meu avô me contou a história das casas de transformação". Ocorreu que, a partir da narrativa mítica, que registra as referências geográficas, as marcas e os sinais nas pedras, praias, serras e ilhas, o jovem passou por todas as cachoeiras e guiou o barco até São Gabriel (2015, p. 33).

Cayon, ao descrever uma viagem entre Manaus e São Gabriel da Cachoeira também destaca sua admiração com o conhecimento de lugares demonstrando por indígenas que nunca estiveram nos ditos lugares:

Enquanto avançavamos na viagem, eu ficava perplexo com o resto dos acompanhantes da expedição com o fato de que os pajés sabiam tantas coisas sobre lugares que nunca tinham visitado, ao menos físicamente, e que todos estavamos vendo pela primeira vez. Lembro especialmente de uma bela praia antes de chegar a Santa Isabel chamada Sẽme da wi (Maloca de paca), onde os pajés nos avisaram com pelo menos um dia de antecedencia que o próximo lugar importante que encontraríamos era a praia que era a maloca dos botos. Efetivamente, quando chegamos à praia encontramos uma grande quantidade de botos (2010, p. 10).

Desses episódios, e de tudo que foi dito até aqui, vemos que "narrar é conhecer", como ouvi de alguns velhos Yuremawa durante as oficinas de PGTA; mapear é, da 
perspectiva Kubeo, antes uma forma de validar certa versão da narrativa de origem, uma tentativa de cristalizar graficamente algo que é plástico e objeto de disputas. A escrita estabiliza, condensa versões em consenso. Mapear é, em suma, tomado pelos Kubeo como uma possibilidade de produzir consenso ${ }^{160}$.

Parece acontecer com os mapas algo que vimos acontecer com registro de pupui amiya: também os mapas são manejados na atualização de conflitos entre grupos e famílias, como espaços onde a inscrição do nome é uma forma de delimitar a qual família ou grupo pertence determinado espaço, mas com respaldo do governo.

Em suma, os nomes condesam um conhecimento narrativo acerca dos lugares. Tal como os pupui amiya, são provenientes da cena de criação da humanidade e de parte do espaço $^{161}$. Esse conhecimento, como vimos, é matéria de disputas, como aquela entre Yúri Parãmena e Betowa descritas no episódio da viagem ao Wakaipani e que voltaram à cena no momento da elaboração de mapas visando um plano de gestão para a região. Tal como o pupui amiya pode ser manejado no momento do registro escrito no RANI, também o nome do lugar escrito no papel (mapa) é entendido como evento importante, como possível dispositivo de produção de consenso no estabelecimento de fronteiras e usos legítimos do lugar onde se vive, passível, portanto - também ele e a narrativa que condensa - de ser manejado.

\footnotetext{
${ }^{160}$ Como destaca Aline Iubel: “Consenso, aliás, é um princípio bastante valorizado nas tomadas de decisões no alto rio Negro. Tanto em esferas ditas tradicionais quanto no movimento indígena, em geral, busca-se o 'consenso'”' (2015, p. 173).

161 Digo parte pois, se muitos lugares são criados quando certos eventos são perpetrados, como o igarapé Marãkãriya que surge a medida que Marãkãriku faz o percurso até o Wakaipani, outros já estão conformados, como o rio Uaupés ou os lugares que a narrativa de Henrique Rodrigues aponta como já tendo donos: São Gabriel da Cachoeira, Iauretê ou Santa Cruz, no Uaupés colombiano.
} 


\title{
CONSIDERAÇÕES FINAIS
}

\begin{abstract}
Assaz o senhor sabe: a gente quer passar um rio a nado, e passa; mas vai dar na outra banda é num ponto muito mais em baixo, bem diverso do que em primeiro se pensou. Viver não é muito perigoso? Guimarães Rosa
\end{abstract}

Iniciei meu trabalho com os Kubeo no já distante ano de 2013. Desde lá, foram muitas as tentativas de avançar no entendimento das práticas e falas dos Yúri Parãmena. Esta tese constitui, tal como a epígrafe já anuncia, parte de uma investigação em curso, inconclusa. Recupero a seguir meu ponto de partida, e apresento em linhas gerais os principais argumentos e hipóteses da tese, destacando alguns de seus ganhos em relação às formulações da literatura etnológica regional.

A pesquisa seguiu, poderíamos dizer, um roteiro wagneriano. Partindo de uma questão geral sobre a constituição, dissolução e atualização de unidades e subunidades sociais kubeo, sugeri como chave para conduzir a investigação uma etnografia do regime de nomes kubeo, isto é, descrever os contextos nos quais nomes são atribuídos, seus distintos usos e o modo como são pensandos pelos Yuremawa e Yúriwawa, com interesse sobretudo nos nomes de pessoas, mas sem descuidar do fato de que, no alto rio Negro de modo geral, pessoa, coletivo e lugar são indissociáveis, como afirmou Luiz Gilberto em fala que citei na introdução e recupero nessas considerações finais: "Nas conversas com cigarro [conversas longas] se começa perguntando: ‘quem é você?', e ‘de onde você é?’”, ou seja, as coordenadas que definem uma pessoa passam pelo grupo (“quem é você?”) e pelo lugar (“de onde você é?”). A pesquisa tentou, em suma, responder às questões o que faz um nome? O que um nome ativa e produz? O nome, como vimos, faz pessoas, lugares e grupos.

Os nomes de lugares são signos de feitos e eventos perpetrados no passado, quando da criação das pessoas e dos lugares. Eles condensam conhecimento narrativo, que por sua vez é matéria de disputa, de discussões sobre a legitimidade da existência de um grupo em determinado local. Elemento novo nesse cenário é a inscrição dos nomes em mapas, por conta da elaboração de um plano de gestão do território (PGTAs), visto como possível definição e cristalização da legitimidade de determinado grupo ocupar a região. Se o nome de lugar condensa conhecimento narrativo ao mesmo tempo que se inscreve em tradições narrativas e isso produz dissenso, o nome inscrito no papel (mapa), por sua vez, é visto como potencial produtor de consenso. 
Os nomes de grupos, por sua vez, como apontou Roy Wagner nos anos 1980, são apenas nomes mas, como destaca Saez, "eles são também nada menos que nomes" (2011, p. 15). Não existem grupos sem nomes, numa indissociabilidade entre existência e nome tal como a ontologia projetada pelo regime onomástico kubeo indica, isto é, tudo o que existe e é conhecido tem nome. Os nomes produzem grupos ao operarem certas diferenciações, que podem ser dar segundo determinados códigos, tal como Roy Wagner apontou para o material das Terras Altas da Nova Guiné.

No que diz respeito à pessoa, a tese buscou complexificar certa sistematização de Stephen Hugh-Jones acerca dos nomes onde o antropólogo britânico distinguia três tipos de nomes: de espírito, de branco e apelidos. Vimos, com os Yuremawa e Yúriwiwa, que toda pessoa tem um nome de branco e um pupui amiya (nome de benzimento). Além desse nome, as pessoas têm também apelidos (yahui amiya), e esses apelidos se distinguem em três tipos: os primeiros são os "apelidos tradicionais" que formam par com o pupui amiya e tal como esses são provenientes do momento de origem; tanto homens como mulheres têm esse tipo de apelido. O segundo tipo são os apelidos de brincadeira (ou “jocosos"), usados no cotidiano, os yahui amiya propriamente ditos, originários em sua maioria de animais, suas partes e hábitos; apenas homens recebem yahui amiya. Por fim, os apelidos de nomes de brancos, formas aparentemente abreviadas do nome de branco na formulação de Koch-Grünberg (2005), usados tanto para homens como para mulheres.

Diante desse quadro parece ser possível divisar certa lógica onomástica onde os nomes se apresentam comumente como par: assim, Pamiwa e Kubeo (tal como Ye’pá Mahsa e Tukano; cf. ANDRELLO, 2016), para nomes de coletividades; pupui amiya e seu "apelido tradicional", nome de branco e seu apelido, para nomes de pessoas; "nome de verdade" e "nome de brincadeira" para alguns lugares, como vimos na nomeação dos bairros de Querari.

O nome, como se vê, se diz de várias maneiras. Não podemos, portanto, colocar todos no mesmo plano. O pupui amiya é sempre de conhecimento restrito, de seu portador ou de pessoas mais próximas, como cônjuge, pais, filhos e avós; é o inverso do apelido de brincadeira, que é sempre do outro, evita-se falar do próprio apelido. Nomes de branco, ao contrário do pupui amiya, não observam nenhuma restrição de uso, e parecem ser tomados como desprovidos de potência, "energia". Contudo, o mesmo pupui amiya, por sua vez, parece ser tomado par alguns Yuremawa e Yúriwawa como sem potência quando escrito, seria, para usar um par de noções muito manejado nas falas desses Kubeo, "cópias", “imitações” do pupui amiya.

Vimos também, a partir do material kubeo, que os pupui amiya não são nomes dos 
mortos (ancestrais) sendo reciclados - "transmitidos", nos termos de Viveiros de Castro (2006, p. 92) - entre os vivos, tal como formulou Stephen Hugh-Jones (2002) e reafirmou Viveiros de Castro (2006), pois quase todos os seres da origem estão vivos: Kapai está vivo, Tekui está vivo, para citar alguns. Esses seres têm o seu lugar e podem inclusive ser consultados, como nos casos que descrevemos no quarto capítulo. Aqui, vale lembrar um trecho da etnografia dos lugares baniwa no rio Içana conduzida por Carlos Xavier. Em certo momento, Xavier narra uma conversa com um interlocutor baniwa onde pergunta sobre Napirikoli:

Havia, de minha parte e também dos meninos da Pamáali, grande curiosidade em relação à origem de Napirikoli. Seu Antonio disse que Napirikoli teve origem "aqui mesmo, na Cidade Grande". Disse ainda que ele é um homem e que vive ainda nesse mundo, ninguém sabe onde. "Ñapirikoli não morreu", disse ele, "porque não existe nenhuma história sobre a morte dele". Segundo ele, a morte começou com Maawerikoli, e por isso até hoje as pessoas morrem. "Por isso existe a morte. Se o irmão de Naapirikoli não tivesse morrido, ninguém morreria, até hoje", diz (XAVIER, 2008, p. 87).

Do mesmo modo quase todos os personagens da criação Yúri Parãmena estão vivos, até que se conte a história da morte deles.

Por fim, o exame do sistema de nomes Yuremawa e Yúriwawa nos mostrou como certa metafísica está subjacente, assentada na noção de umé e seu manejo. Pupui amiya é um modo de manejar o umé e, em conjunto com outras práticas, fazer crescer seu portador. O mesmo pupui amiya é manejado quando se trata de movimentar-se pelos distintos domínios com seus donos, o que pressupõe também ciência do conhecimento narrativo condensado nos nomes de lugares. Também o yahui amiya ao produzir alegria e aproximar as pessoas faz a comunidade crescer. Eis nos, portanto, diante de uma metafísica que toma como central o manejo de umé para crescimento da pessoa e da comunidade.

Em suma, esta tese tentou, através da descrição de algumas falas e práticas de atribuição de nomes kubeo, explicitar um conjunto de noções Yúri Parãmana acerca da nominação, e apontar algumas direções para se pensar a questão o que pode fazer um nome? Terá cumprido seu papel se as questões e hipóteses levantadas aqui se apresentarem ao leitor não como soluções ou formulações conclusivas, mas antes como estímulo a novos investimentos etnográficos e ao prolongamento da interlocução e reflexão a partir do que dizem, falam e nos esinam os Yúri Parãmena.

Kenora yz mahiwz (“É só isso que eu sei”). 


\section{REFERÊNCIAS}

ABU-LUGHOD, Lila. A escrita contra a cultura. Equatorial, v. 5, n. 8, p. 193-226, 2018.

ALVES DA SILVA, Alcionilio Bruzzi. Crenças e lendas do Uaupés. Quito: Ediciones Abya-Yala, 1994.

ALVES DA SILVA, Alcionilio Bruzzi. A civilização indígena do Uaupés. Roma: LAS, 1962.

ANDRELLO, Geraldo. Cidade do Índio: Transformações e cotidiano em Iauaretê. São Paulo: Editora UNESP: ISA; Rio de Janeiro: NUTI, 2006.

ANDRELLO, Geraldo. Falas, objetos e corpos: autores indígenas no alto rio Negro. Revista Brasileira de Ciências Sociais, vol. 25, n. 73, 2010.

ANDRELLO, Geraldo (coord.). Repensando a estrutura social do Uaupés (Noroeste amazônico). Projeto de Auxílio à Pesquisa - FAPESP, 2012 (concluído em 2015), Ms.

ANDRELLO, Geraldo. Peixes e pessoas: problemas cosmopolíticos no Uaupés. Comunicação ANPOCS, 2013, Ms.

ANDRELLO, Geraldo. Nomes, posições e (contra) hierarquia. Coletivos em transformação no alto rio Negro. Ilha - Revista de Antropologia, v. 18, p. 57-97, 2016.

ANDRELlO, Geraldo \& LOLLI, Pedro (coord.). Nominações: pessoas, objetos, hierarquia e parentesco no Alto Rio Negro (AM). Projeto de Auxílio à Pesquisa - FAPESP, 2016 (concluído em 2018), Ms.

ANGELO, Samir R. F. de. Transmissão e Circulação de Conhecimentos e Políticas de Publicação dos Kumua do Noroeste Amazônico. Doutorado (Doutorado em Antropologia Social) - São Paulo, Faculdade de Filosofia, Letras e Ciências Humanas, Universidade de São Paulo, São Paulo, 2016.

ARHEM, Kaj. Makuna social organization: a study in descent, alliance, and the formation of corporate groups in the North-Western Amazon. Uppsala Studies in Cultural Anthropology. Stockholm: Almqvist \& Wiksell, 1981. 
ARHEM, Kaj; CAYÓN, Luis; ANGULO, Gladys e GARCIA, Maximiliano. Etnografía Makuna: tradiciones, relatos y saberes de la gente de agua. Bogotá: Acta Universitatis Gothenburgensis e Instituto Colombiano de Antropología e Historia, 2004.

ATHIAS, Renato. Hupd'äh/Tukano: les relations inégales entre deux sociétés du Uaupés amazonien (Brésil). Recife: Livro Rápido, 2008.

AZEVEDO, Dagoberto Lima. Forma e conteúdo do bahsese Ye'pamahsã (Tukano): fragmentos do espaço Di’ta Nuhku (terra-floresta). Dissertação (Mestrado em Antropologia Social) - Universidade Federal do Amazonas, Manaus, 2013.

BARRETO, João Rivelino Rezende. Formação e transformação de coletivos indígenas no Noroeste Amazônico: do mito à sociologia das Comunidades. 199 f. Dissertação (Mestrado em Antropologia Social) - Universidade Federal do Amazonas, Manaus, 2013.

BARRETO, João Paulo Lima. Wai-mahsã Peixes e Humanos: um ensaio de antropologia indígena. Dissertação (Mestrado em Antropologia Social) - Universidade Federal do Amazonas, Manaus, 2012.

BEKSTA, Casimiro J. A maloca Tukano-Dessana e seu simbolismo. Manaus: Secretaria de Educação e Cultura, 1984.

BRANDÃO, Iolanda Bezerra dos Santos. Psicologia no Brasil: a presença dos salesianos. 201 f. Tese (Doutorado em Psicologia Social) - São Paulo, Pontifícia Universidade Católica de São Paulo, 2006.

BUCHILLET, D. Maladie et mémoire des origines chez les Desana du Uaupés (Brésil). Paris (tese de doutorado), 1983.

CABAlZAR, Aloisio. Filhos da Cobra de Pedra: organização social e trajetórias tuyuka no rio Tiquié (noroeste amazônico). São Paulo: UNESP, 2009.

CABAlZAR, Aloisio (org.). Manejo do Mundo: conhecimentos e práticas dos povos indígenas do rio Negro, noroeste amazônico. São Paulo: ISA; São Gabriel da Cachoeira, AM: FOIRN, 2010. 
CABAlZAR, Flora F. S. D. Até Manaus, até Bogotá. Os Tuyuka vestem seus nomes como ornamentos: Geração e Transformação de conhecimentos a partir do alto rio Tiquié (noroeste Amazônico). São Paulo, PPGAS/USP (tese de doutorado), 2010.

CAMPOS, Haroldo de. Bere'shith: a cena da origem. São Paulo: Perspectiva, 2000

CAYÓN, Luis. Penso, logo crio. A teoria makuna do mundo. Tese (Doutorado em Antropologia Social), Universidade de Brasília, Brasília, 2010.

CAYÓN, Luís. Etnografía compartida: algunas reflexiones sobre el trabajo de campo con los makuna en la Amazonia colombiana. Anales de Antropología, v. 52-1, p. 35-43, 2018.

CAETANO DA SILVA, Aline Scolfaro. Falas Waikhana: conhecimento e transformações no alto rio Negro (rio Papuri). São Carlos, PPGAS/UFSCar (dissertação de mestrado), 2012.

CASCUDO, Luís da Câmara. Em Memória de Stradelli. Manaus: Editora Valer e Governo do Estado do Amazonas, 2001.

CHACON, Thiago Costa. Dicionário Enciclopédico Kubeo Multilingue. (Versão de trabalho, 1. rascunho), s/d.

CHACON, Thiago Costa. The phonology and morphology of Kubeo: the documentation, theory, and description of an Amazonian language. University of Hawai'i: Phd thesis, 2012.

CHACON, Thiago Costa. Kubeo: linguistics and cultural interactions in the Upper Rio Negro. In: EPPS, P. \& STENZEL, K. (eds.). Upper Rio Negro: Cultural and linguistic interaction in Northwestern Amazonia. Rio de Janeiro: Museu Nacional; Museu do Índio FUNAI, 2013.

CHACON, Thiago \& CAYÓN, Luis. Considerações sobre a exogamia linguística no Noroeste Amazônico. Revista de Letras da Universidade Católica de Brasília, Volume 6, Números 1/2, Ano VI, 2013.

CHERNELA, Janet. The Wanano Indians of the Brasilian Amazon: a sense of space. Austin: University of Texas Press, 1993. 
CORREA, Francois. Los Kuwaiwa: Creadores del universo, la sociedad y la cultura. Quito: Ediciones Abya-Yala, 1997.

CLASTRES, Pierre. De que riem os índios? In: CLASTRES, Pierre. A sociedade contra o Estado: pesquisas de antropologia política. São Paulo: Cosac Naify, 2012.

DIAKARA, Jaime. GAAPI - Elemento fundamental de acesso aos conhecimentos sobre esse mundo e outros mundos. Dissertação (Mestrado em Antropologia Social) Universidade Federal do Amazonas, Manaus, 2018.

DOSSIÊ: A serpente do corpo cheio de nomes: Etnonimia na Amazônia. Ilha Revista de Antropologia, v. 18, p. 57-97, 2016.

DRAGO, André. Formas políticas ameríndias: Etnologia jê. São Paulo, PPGAS/USP (dissertação de mestrado), 2012.

EPPS, Patience \& STENZEL, Kristine (eds.). Upper Rio Negro: Cultural and linguistic interaction in Northwestern Amazonia. Rio de Janeiro: Museu Nacional; Museu do Índio - FUNAI, 2013.

FRANCIOLLI, A. L. R. et al. Morfologia dos órgãos genitais masculinos de quati (Nasua nasua, Linnaeus 1766). Revista Biotemas, 20 (1), 2007.

GARCIA NOGUEIRA, Silvia; FERREIRA PIRES, Flávia. Antropologia Pós-Social, perspectivas e dilemas contemporâneos: entrevista com Marcio Goldman. Campos - Revista de Antropologia, [S.1.], v. 13, n. 1, jun. 2012.

GIACONE, Padre Antônio. Os Tucanos e outras tribus do Rio Uaupés afluente do Negro Amazonas. São Paulo: Imprensa Oficial, 1949.

GOLDMAN, Irving. Cosmological beliefs of the Cubeo Indians. In: The Journal of American Folklore, vol. 53, n. 210, 1940, p. 242-247.

GOLDMAN, Irving. Tribes of the Uaupés-Caquetá region. In: STEWARD, J. H. (Ed). Handbook of South American Indians. V. III. Washington: Smithsonian Institution, 1948.

GOLDMAN, Irving. The Cubeo: Indians of the Northwest Amazon. Urbana: The University of Illinois Press, 1963.

GOLDMAN, I. The structure of Ritual in the Northwest Amazon. In: MANNERS, R. A. (editor). Process and Pattern in Culture: Essays in Honor of Julian Steward. Chicago, Aldine, 1964. 
GOLDMAN, Irving. Perceptions of Nature and the Structure of Society: The Question of Cubeo Descent. In: Dialectical Anthropology, 1, 1976, p. 287-292.

GOLDMAN, Irving. Time, Space and Descent: the Cubeo exemple. In: Actes du XLII Congrès International des Américanistes. vol. 2, 1977, Paris, p. 175-183.

GOLDMAN, Irving. Reflections of Nature in Vaupés Cultures. Reviews of From the Milk River (Christine Hugh-Jones) and The Palm and the Pleides (Stephen Hugh-Jones). American Ethnologist, 8, 1981, p. 383-389.

GOLDMAN, Irving. Hierarchy and Power in the Tropical Forest. In: HENDERSON, J. S.; NETHERLY, P. J. Configurations of Power: Holistic Anthropology in Theory and Practice. Ithaca: Cornell University Press, 1993.

GOLDMAN, Irving. Cubeo Hehénewa Religious Thought: Metaphysics of a Northwestern Amazonian People. New York: Columbia University Press, 2004.

GOLDMAN, Marcio. Como funciona a democracia: uma teoria etnográfica da política. Rio de Janeiro: Sette Letras, 2006a.

GOLDMAN, Marcio. Alteridade e experiência: Antropologia e teoria etnográfica. Etnográfica [online]. 2006b, vol.10, n.1, pp.161-173.

GOW, Peter. Of Mixed Blood: Kinship and History in Peruvian Amazonia. Oxford: Clarendon Press, 1991.

GOW, Peter. An Amazonian Myth and its History. Oxford: Oxford University Press, 2001.

HOLGUIN, Álvaro Solto. Mitos de los Cubeo. In: Actes of the Thirty-ninth International Congress of Americanists, VI, 1972, p. 59-65.

HUGH-JONES, Christine. From the Milk River: Spatial and Temporal Processes in Northwest Amazonia. Cambridge: Cambridge University Press, 1979.

HUGH-JONES, Stephen. The Palm and the Plêiades: Initiation and cosmology in Northwest Amazonia. Cambridge: Cambridge University Press, 1979.

HUGH-JONES, Stephen et al. Historia del Vaupes. Maguaré, Número 1, 1981. 
HUGH-JONES, Stephen. Clear descent or ambiguous houses? A re-examination of Tukanoan social organization. In: L’Homme, 126-128, XXXIII (2-4), 1993, p. 95-120.

HUGH-JONES, Stephen. Inside-out and back-to-front: the androgynous house in Northwest Amazonia. In: CARSTEN, Janet \& HUGH-JONES, Stephen. About the house: LéviStrauss and beyond. Cambridge: Cambridge University Press, 1995.

HUGH-JONES, Stephen. Nomes secretos e riqueza visível: nominação no noroeste amazônico. Mana, 2002, vol.8, n.2, pp.45-68.

HUGH-JONES, Stephen. Caixa de Pandora: estilo alto-rio-negrino. R@U - Revista de Antropologia da UFSCar, 6 (1), jan. /jun. 2014, p. 155-173.

HUGH-JONES, Stephen. Escrever na pedra, escrever no papel. In: ANDRELLO, G. (org.) Rotas de criação e transformação: Narrativas de origem dos povos indígenas do Rio Negro. São Paulo: Instituto Socioambiental/FOIRN, 2012.

IUBEL, Aline. Transformações políticas e indígenas: movimento e prefeitura no alto rio Negro. São Carlos, Tese (Doutorado), Universidade Federal de São Carlos, 2015.

KOCH-GRÜNBERG, Theodor. Dois anos entre os indígenas: viagens ao noroeste do Brasil (1903-1905). Manaus: EDUA/FSDB, 2005.

LASMAR, C. De volta ao Lago do Leite: Gênero e transformação no Alto Rio Negro. São Paulo: Editora UNESP/ISA; Rio de Janeiro/NuTI, 2005.

LEBRUN, Gerard. O que é poder? São Paulo: Brasiliense, 1981.

LÉVI-STRAUSS, Claude. O cru e o cozido. São Paulo: Cosac \& Naify, 2004.

LÉVI-STRAUSS, Claude. La Pensée Sauvage. Paris: Plon, 1962.

LIMA, Tânia Stolze. (Resenha) An Amazonian Myth and its History. Mana, Rio de Janeiro, v. 8, n. 2, p. 198-202, 2002.

LOLLI, Pedro. As redes de trocas rituais dos Yuhupdeh no igarapé Castanha, através dos benzimentos (mihdiid) e das flautas Jurupari (Tí). São Paulo: FFLCH/USP, 2010. 
LOLLI, Pedro. Sopros de vida e destruição: composição e decomposição de pessoas. Revista de Antropologia, São Paulo, USP, 2013, v. 56, n. 2.

LOLLI, Pedro. A plasticidade makú. ILHA - Revista de Antropologia, Florianópolis, v. 18, p. 177-198, 2016.

LOWIE, Robert H. Primitive Society. New York: Boni and Liveright, 1920.

MAIA, Gabriel Sodré. Bahsamori: o tempo, as estações, e as etiquetas sociais dos Yepamahsá (tukano). Dissertação (Mestrado em Antropologia Social) - Universidade Federal do Amazonas, Manaus, 2016.

MAIA, Arlindo \& ANDRELLO, Geraldo. Ye'pâ-Di'iro-Mahsã, gente de carne da terra: os Tukano do rio Uaupés, 2018, no prelo.

MARQUES, Adriana Aparecida. 2007. Amazônia: pensamento e presença militar. 233 f. Tese (Doutorado em Ciência Política) - São Paulo, Faculdade de Filosofia, Letras e Ciências Humanas, Universidade de São Paulo, São Paulo, 2007.

MARQUÉZ, Juan Carlos. Mitu Vaupes: a participação dos índios na construção do urbano na Amazônia. 262 f. Tese (doutorado) - Universidade Estadual de Campinas, Instituto de Filosofia e Ciencias Humanas, Campinas, 2008.

MAUSS, Marcel. Parentés à Plaisanteries. Annuaire de l'École Pratique des Hautes Études, Section des Sciences Religieuses, Paris, 1928.

MEIRA, Marcio A. F. de. A persistência do aviamento: colonialismo e história indígena no noroeste amazônico. 322 f. Tese (Doutorado em Memória Social) - Universidade Federal do Estado do Rio de Janeiro, Rio de Janeiro, 2017.

MELO, Joaquim Rodrigues de. A política indigenista no Amazonas e o Serviço de Proteção aos Índios: 1910-1932. 212 f. Dissertação (Mestrado) - Manaus, Instituto de Ciências Humanas e Letras, Universidade Federal do Amazonas, Manaus, 2007.

MINOIS, George. História do riso e do escárnio. São Paulo: Editora UNESP, 2003.

MORGAN, John H. Ancient Law. London: J.M. Dent \& Sons, Ltd. New York: E.P. Dutton \& Co., 1936. 
MORSE, Nancy L. Cubeo kinship. In: MERRIFIELD, William R. (Ed.). South American kinship: eight kinship systems from Brazil and Colombia. Dallas: The International Museum of Cultures, 1985. p. 79-92.

NEVES, Eduardo G. Paths in dark waters: Archaeology as indigenous history in the Upper Rio Negro Basin, Northwest Amazon. Phd dissertation, Indiana University, 1998.

NIMUENDAJÚ, Curt. Reconhecimento dos rios Içána, Ayarí e Uaupés. Journal de la Société des Américanistes. Tome 39, p. 125-182, 1950.

PEDROSO, Diego Rosa. “Quem veio primeiro? ”: Imagens da hierarquia no Uaupés (Noroeste Amazônico). 156 f. Dissertação (Mestrado em Antropologia Social) - São Paulo, Faculdade de Filosofia, Letras e Ciências Humanas, Universidade de São Paulo, São Paulo, 2013 .

PEDROSO, Diego Rosa; RAMOS, Danilo Paiva. Diálogos Uaupesianos: Notas sobre diferentes olhares para os povos do Uaupés. ILHA - Revista de Antropologia, Florianópolis, v. 16, n. 1, p. 69-104, 2014.

PEDROSO, Diego Rosa. Verbete Irving Goldman. Enciclopédia de Antropologia, 2016. Disponível online em: http://ea.fflch.usp.br/home

PEDROSO, Diego Rosa et al. (orgs.). Plano de Gestão Territorial e Ambiental Kubeo e Kotiria. Brasília, no prelo.

PEREIRA, Rosilene Fonseca. Criando gente no alto rio Negro: Um olhar Waíkhana. Dissertação (Mestrado em Antropologia Social) - Universidade Federal do Amazonas, Manaus, 2013.

PERRONE-MOISÉS, Beatriz. Festa e guerra. Tese de livre-docência (livre-docência em Antropologia Social) - São Paulo, Faculdade de Filosofia, Letras e Ciências Humanas, Universidade de São Paulo, São Paulo, 2015.

QUEIROZ, Ruben Caixeta de. Urupere: eis que a história (re)surge da mitologia (ou seria o contrário?). In: 28. Encontro Anual da ANPOCS, Caxambu, 2004.

RADCLIFFE-BROWN, Alfred R. A further note on joking relationships. Africa: Journal of the International African Institute, 19(2):133-140, 1949. 
RADCLIFFE-BROWN, Alfred R. Structure and Function in Primitive Society. London: Cohen and West, 1952.

RAMOS, Danilo Paiva. Círculos de coca e fumaça: Encontros noturnos e caminhos vividos pelos Hupd'ah (Maku). São Paulo, FFLCH/USP (tese de doutorado), 2013.

REICHEL-DOLMATOFF, Gerardo. Amazonian Cosmos: The Sexual and Religious Symbolism of the Tukano Indians. Chicago: The University of Chicago Press, 1971.

RESTREPO, Miguel López. Los Cubeos: su historia, su tradición, sus pensamientos. Mitú, 2001. Ms.

RIBEIRO, Berta G. Os Índios das Águas Pretas: Modo de Produção e Equipamento Produtivo. São Paulo: Companhia das Letras. 1995.

ROCHA, Pedro. Bahsare Wamã. Parentesco e onomástica na Bacia do Uaupés. Rio de Janeiro, PPGAS - MN/UFRJ (dissertação de mestrado), 2007.

ROCHA, Pedro. Antes os brancos não existiam: corporalidade e política entre os Kotiria do Alto Uaupés (AM). Rio de Janeiro, PPGAS - MN/UFRJ (tese de doutorado), 2012.

RODRIGUES, Raphael. Relatos, trajetórias e imagens: uma etnografia em construção sobre os Ye'pâ-masa do baixo Uaupés. São Carlos: PPGAS/UFSCar (dissertação de mestrado), 2012.

SAEZ, Oscar Calavia. Nomes, pronomes e categorias: repensando os "subgrupos" numa etnologia pós-social. Antropologia em primeira mão. Programa de Pós-Graduação em Antropologia Social, Universidade Federal de Santa Catarina. Florianópolis: UFSC, Programa de Pós-Graduação em Antropologia Social, 2011, v. 138.

SALSER, J. K. Cubeo Phonemics. Linguistics, 75, 1971, p. 74-79.

SALSER, J. K. Cubeo. In: Aspectos de la Cultura Material de Grupos Etnicos de Colômbia. Lomalinda, Editorial Townsend, 51-69. ILV, 1978.

SEPULVEDA, Marco Aurelio Zambrano. Los Cubeo: algunos aspectos de su cultura. Bogotá: Univ. de los Andes, 1975.

SORENSEN, Arthur. Multilingualism in the Northwest Amazon. In: American Anthropologist. Vol. 69, No. 6, 1967, p. 670-684. 
STEWARD, Julian H. South American Cultures: An interpretative Summary. In: STEWARD, Julian H. Handbook of South American Indians. New York, vol. 5, 1949, pp 669-772.

STRATHERN, Marilyn. O Gênero da Dádiva: Problemas com as mulheres e problemas com a sociedade na Melanésia. Campinas, SP: Editora da UNICAMP, 2006.

SZTUTMAN, Renato. O Profeta e o Principal: A ação política ameríndia e seus personagens. São Paulo: EDUSP, Fapesp, 2012.

SZTUTMAN, Renato (coord.). Diplomacias cosmopolíticas nas terras baixas sulamericanas: exercícios de comparação etnográfica. Projeto de Auxílio à Pesquisa FAPESP, 2016 (concluído em 2018), Ms.

TEIXEIRA-PINTO, Márnio. Com o "outro" nos olhos: Alguns aspectos da alteridade na etnologia amazônica. Anuário Antropológico, Brasília, UNB, v. 43, n. 2, p. 229-260, 2018.

VALENCIA, Simon. Los Yuremawa. Mitú, s/d. Ms.

VANZOLINI, Marina. Notas sobre os nomes aweti: O que faz um nome herdado? 2018a. Ms.

VANZOLINI, Marina. O que um nome pode fazer? 2018b. Ms.

VEIGA NETO, João Pimenta. Wakaipani, a grande Maloca Ancestral: Processos de diferenciação entre os Yúriwawa e Yuremawa dentro do conjunto Kubeo no Uaupés brasileiro. Trabalho de Conclusão de Curso (Graduação em Ciências Sociais), Universidade de Brasília, 2014.

VIVEIROS DE CASTRO, Eduardo. A inconstância da alma selvagem - e outros ensaios. São Paulo: Cosac Naify, 2002.

VIVEIROS DE CASTRO, Eduardo. Appendix to chapter 4: On Tukanoan Onomastics: four remarks and a diagram. In: VOM BRUCK, Gabriele and BODENHORN, Bodenhorn. The Anthropology of Names and Naming. Cambridge: Cambridge University Press, 2006.

ZAPATA, Nelson Berrío. Análisis del sistema fonológico de la lengua Cubeo del Vaupés. Bogotá, Universidad de Los Andes, 1982. 
WAGNER, Roy. Existem grupos sociais nas terras altas da Nova Guiné? Cadernos de Campo - Revista dos alunos de pós-graduação em antropologia social da USP, São Paulo, n. 19, p. 1-384, 2010.

WALLACE, Alfred Russel. A narrative of travels on the Amazon and Rio Negro: with an account of the native tribes, and observations of the climate, geology, and natural history of the Amazon Valley. London, 1870.

WRIGHT, Robin. M. História indígena do noroeste amazônico: Hipóteses, questões e perspectivas. In: CUNHA, Manuela Carneiro da. História dos índios no Brasil. São Paulo: Companhia das Letras/FAPESP, 1992, p. 253-266.

WRIGHT, Robin. As tradições sagradas de Kuwai entre os povos aruaque setentrionais: estruturas, movimentos e variações. Mana vol. 23, no.3, Rio de Janeiro, Sept./Dec. 2017.

WRIGHT, Robin. Mitagens e seus significados no noroeste amazônico. Ms. s/d. 